\title{
TÉCNICA E CONSTRUÇÃO EM RAMOS DE AZEVEDO - A CONSTRUÇÃO CIVIL EM CAMPINAS
}

\begin{abstract}
Dissertação apresentada como parte dos requisitos para obtenção do Título de Mestre em Arquitetura, Urbanismo e Tecnologia ao Programa de PósGraduação em Arquitetura e Urbanismo da Escola de Engenharia de São Carlos - USP.
\end{abstract}

Orientador: Prof. Dr. João Marcos de Almeida Lopes 


\section{FOLHA DE JULGAMENTO}

\section{Candidato(a): Arquiteto e Urbanista THAIS CARNEIRO DE MENDONÇA.}

Dissertação defendida e julgada em 06/04/2010 perante a Comissão Julgadora:

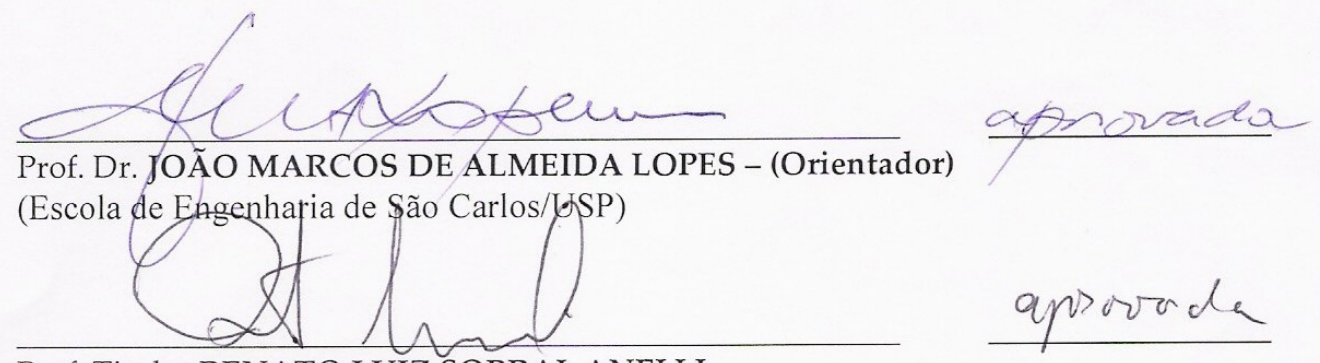

Prof. Titular RENATO LUIZ SOBRAL ANELLI

(Escola de Engenharia de São Carlos/USP)
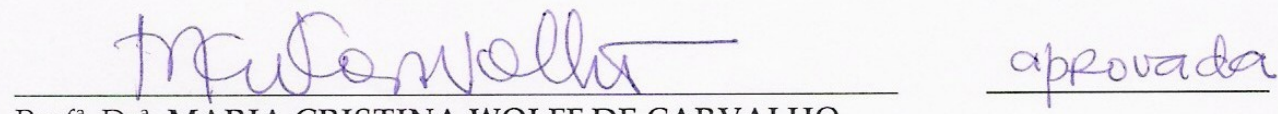

Prof ${ }^{\mathrm{a}}$. Dr ${ }^{\mathrm{a}}$. MARIA CRISTINA WOLFF DE CARVALHO

(Fundação Armando Álvares Penteado/FAAP)

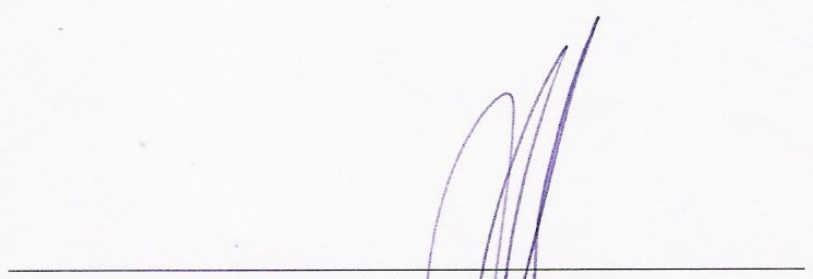

Prof $^{\mathrm{a}}$. Associada AKEMI INO

Vice - Coordenadora do Programa de Pós-Graduação em Arquitetura e Urbanismo, em exercício

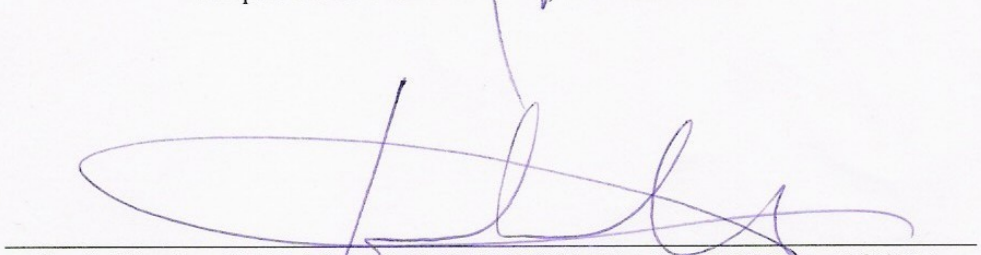

Prof. Titular GERALDO ROBERTO MARTINS DA COSTA

Presidente da Comissão da Pós-Graduação da EESC 
A Deus, que dá o dom da vida. 


\section{AGRADECIMENTOS}

Em primeiro lugar, agradeço a minha família, meus pais e meu irmão, pelo apoio a esta pesquisa, no qual não teria chegado até aqui.

Em especial aos meus pais, que mais que me incentivar, me levaram onde fosse preciso, gastando seu precioso tempo.

A minha avó, com quem desde que eu era pequena compartilha do tema comigo.

A Jolivan, companheiro que nunca desiste de me ensinar.

Aos queridos amigos, que entenderam a minha ausência.

Aos chefes e colegas da EMDEC, pela compreensão.

A Profa. Jane, minha primeira orientadora, que me estimulou a seguir nesta jornada.

A Julie, que tanto se empenhou nesta jornada histórica da Fazenda Pau d' Alho comigo, e a sua equipe.

Ao arquiteto Ricardo Leite, pela sua preciosa contribuição com os documentos da Catedral Metropolitana de Campinas.

Aos funcionários dos acervos e bibliotecas: Museu de Imagem e Som, Biblioteca Pública Municipal de Campinas, Biblioteca do Liceu de Artes e Ofícios de São Paulo, Biblioteca Central da PUCC, Biblioteca Central da Unicamp, Biblioteca Central e FAU-Maranhão da USP e Biblioteca Adir Gigliotti.

A Rita (CSPC), Maria (Fundação Energia) e Adriana (Sistema Ligdoc de Informação).

Aos arquitetos João Camargo, Lucas, Bárbara di Mônaco, Aldomar Caprini e Eleusina,

Aos Profs. Maria Cristina e Anelli, da banca, que muito me auxiliaram no direcionamento da pesquisa.

Por fim, esta pesquisa não teria chegado até aqui sem a persistência do meu orientador: ao Prof. João Marcos, pelas orientações, cuidado, dedicação, questionamentos e comentários. 
"Há alguma coisa de que se possa dizer: Vê, isto é novo? Já foi nos séculos passados, que foram antes de nós.

Já não há lembrança das coisas que precederam, e das coisas que hão de ser também delas não haverá lembrança, entre os que hão de vir depois." 


\section{RESUMO}

Mendonça, Thaís Carneiro de. Técnica e Construção em Ramos de Azevedo - A Construção Civil em Campinas. São Carlos, 2010. 281f. Dissertação (Mestrado) - Curso de Pós-Gradação em Arquitetura, Urbanismo e Tecnologia, Universidade de São Paulo, Escola de Engenharia de São Carlos. São Carlos, 2010.

O objetivo principal desta dissertação é analisar as técnicas construtivas na produção do engenheiro-arquiteto Francisco de Paula Ramos de Azevedo, a partir do momento de sua chegada da Bélgica a Campinas, em 1879, quando termina seus estudos na faculdade e inicia sua carreira profissional, abordando também o estudo da construção civil campineira no último quartel do século XIX. Primeiramente, foi feito um levantamento histórico do período citado e também um estudo teórico de componentes que envolvem esse aparato tecnológico para compreensão do emprego dessas técnicas construtivas no contexto envolvido. Em seguida, foram relacionadas as implicações que envolvem esse assunto, buscando formular questões que levaram ao grande sucesso do engenheiroarquiteto na produção de suas obras e no empreendimento de seus negócios futuros relacionados com o ramo da construção. Mais especificamente, foram investigados os contextos histórico, político e econômico, explicitando os materiais e indústrias disponíveis, relação com casas bancárias, mão de obra, eventos relacionados e outros fatores essenciais para a compreensão do desenvolvimento da construção civil campineira. Posteriormente, foi feito um levantamento de campo sobre a reforma da sede da fazenda Pau d' Alho, atribuída ao engenheiro-arquiteto. Esse levantamento constitui tanto um instrumento para o estudo dos processos construtivos anteriores e posteriores à reforma quanto uma base para o estudo da aplicação dessas técnicas construtivas. Com o estudo de campo, novas formulações relativas às técnicas construtivas locais, assim como a questão da preservação do patrimônio histórico e o papel desempenhado por Ramos de Azevedo nesse âmbito foram levantados, buscando entender uma parte da história que foi construída não por uma, mas por várias mãos.

Palavras-chave: Técnicas Construtivas, Construção Civil, Ramos de Azevedo, Patrimônio Histórico, Campinas 


\section{ABSTRACT}

Mendonça, Thaís Carneiro de. Constructive Techniques by Ramos de Azevedo - Civil Work in Campinas. São Carlos, 2010. 281f. Essay (MSC) - Post-graduate Course in Architecture, Urbanism and Technology, Universidade de São Paulo, Escola de Engenharia de São Carlos. São Carlos, 2010.

Main purpose of this essay is to go through the work of engineer-architect Francisco de Paula Ramos de Azevedo and to analyze his constructive techniques, upon his arrival in Campinas coming from Belgium in 1879, when he finished his university degree and started his professional career, including a study on the civil construction in Campinas through the last quarter of the $19^{\text {th }}$ century. Initially a historical survey was done covering above period and also a theoretical study of components involving the technological apparatus in order to understand their contextual use. Next the implications of the subject were listed, formulating questions on what led to the large success of the engineerarchitect in his production and established his future business in the civil work. More specifically, the historical, political and economic context were investigated, explicating available materials and industries related to banking houses, hand labor, related events and other essential factors required to understand the development of civil work in Campinas. Lastly a field survey was done on the renovation of the main house of Fazenda Pau d'Alho, which is credited to the engineer-architect. This survey is both instrumental for the study of constructive processes before and after the renovation, and a base for the study on the application of those constructive techniques. With the field survey, new formulations were done related to the local constructive techniques, as well as questions about preservation of the historical assets and the role played by Ramos de Azevedo in this regard, in an attempt to understand part of a history that was written not by one, but by many hands.

Key words: Constructive Techniques, Civil Work, Ramos de Azevedo, Historical Assets, Campinas 


\section{SUMÁRIO}

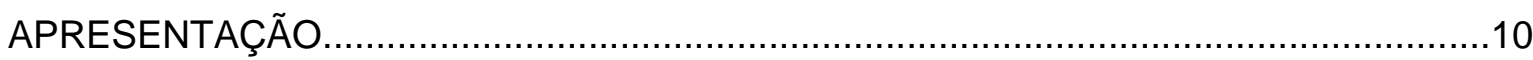

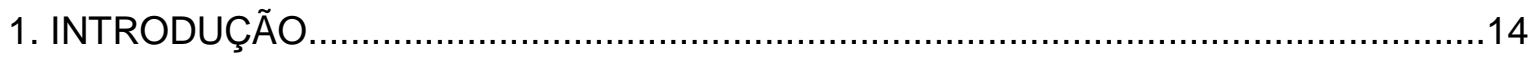

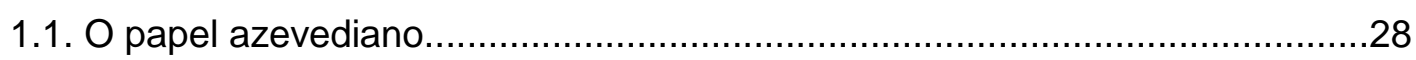

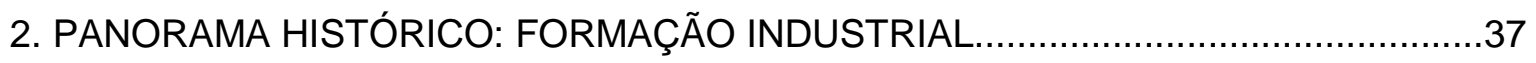

2.1. Economia do Café: da Manufatura à Indústria...............................................37

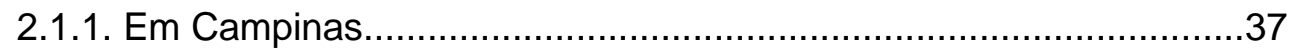

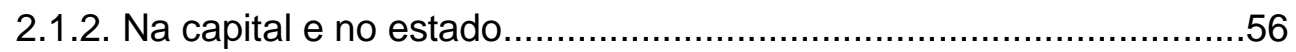

2.1.3. No Brasil: exposições, feiras e eventos........................................65

2.1.4. Os fatores da industrialização.....................................................71

2.2. Sobre a indústria da Construção Civil.........................................................72

2.3. O papel das escolas profissionais no processo industrial..............................75

2.4. Financiamento: relação com casas bancárias e importadoras.......................79

2.5. Materiais e processos construtivos no contexto paulista................................81

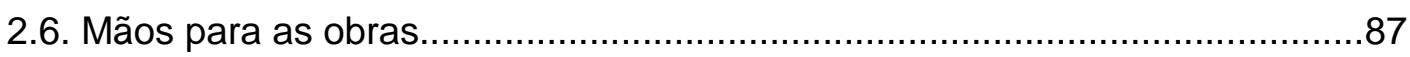

2.6.1. Escravos: no Brasil e em Campinas............................................87

2.6.2. Imigrantes: no Brasil, no estado de São Paulo e em Campinas.......92

2.6.2.1. Atuação da mão de obra livre na indústria da edificação...95

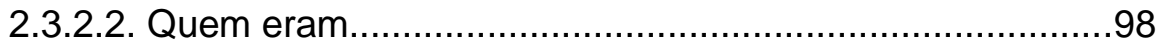

2.7. Construção e linguagem de estilo no contexto campineiro e azevediano.....103

3. O PROCESSO E A TÉCNICA .................................................................... 123

3.1. Uma sede, um partido arquitetônico novo: a Fazenda Pau d' Alho...............123

3.1.1. Agenciamento do café ......................................................................123

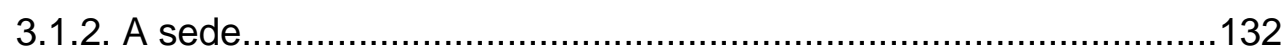

3.2. Técnicas construtivas na fazenda Pau d' Alho............................................146

3.2.1. Fundação e alicerces................................................................146

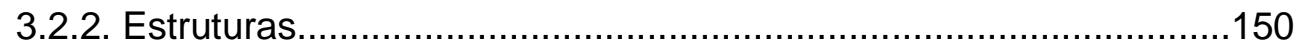

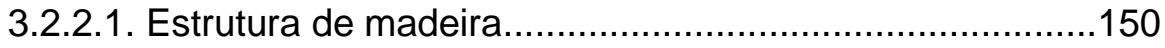

3.2.2.2. Alvenaria de tijolo....................................................153

3.2.2.3. Alvenaria de pedra.................................................... 161

3.2.2.4. Estrutura metálica........................................................163

3.2.3. Argamassas................................................................... 165

3.2.3.1. Cal.......................................................................... 165

3.2.3.2. Cimento.................................................................... 166

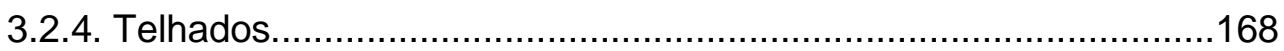


3.2.4.1. Estrutura de madeira 170

3.2.4.2. Estrutura metálica.....................................................171

3.2.4.3. Telhas cerâmicas......................................................172

3.2.4.4. Cobertura metálica...................................................172

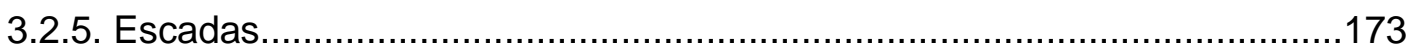

3.2.5.1. Escadas de pedra e tijolo.................................................173

3.2.5.2. Escadas de madeira.............................................................. 174

3.2.5.3. Escadas de ferro........................................................ 175

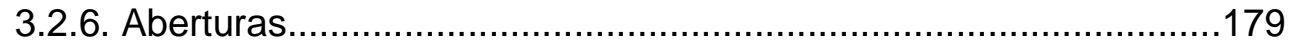

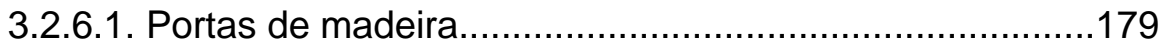

3.2.6.2. Portas de ferro...........................................................184

3.2.6.3. Janelas de madeira.....................................................184

3.2.6.4. Caixilhos de ferro........................................................186

3.2.7. Acabamentos........................................................................ 192

3.2.7.1. Decoração arquitetônica..............................................192

3.2.7.2. Argamassa, rebocos e estuques....................................201

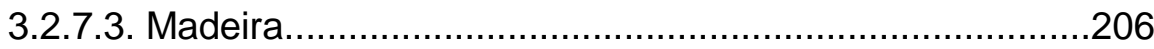

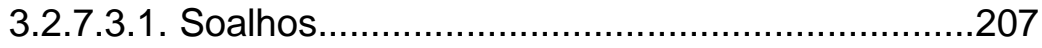

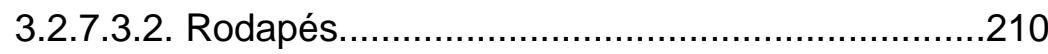

3.2.7.3.3. Forros e vigamentos....................................210

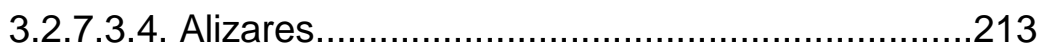

3.2.7.3.5. Ornamentos.................................................214

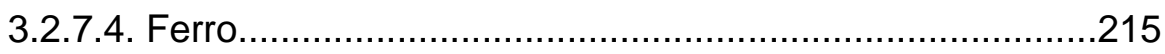

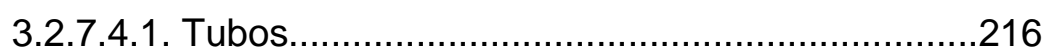

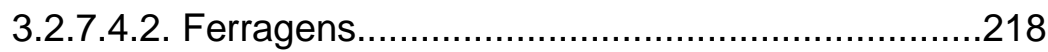

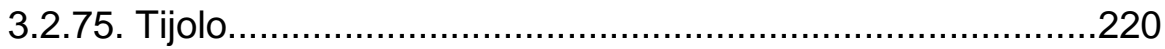

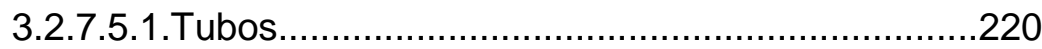

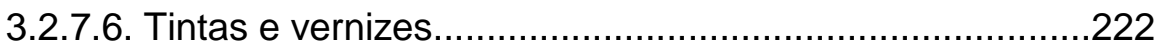

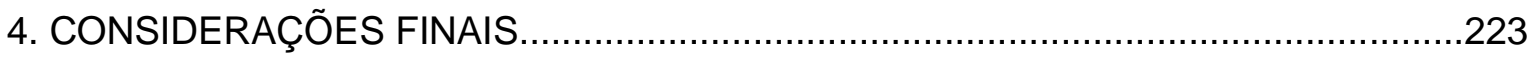

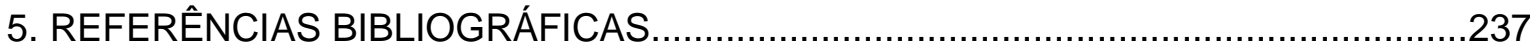

6. ANEXOS

Anexo 1: Quadros de indústrias e mão-de-obra por ano em Campinas..............248

Anexo 2: Quadros de indústrias e mão-de-obra por ano em São Paulo...............253

Anexo 3: Fazenda Pau d' Alho - Planta e elevações.........................................254

Anexo 4: Fazenda Pau d' Alho - Imagens.................................................270 


\section{APRESENTAÇÃO}

A presente dissertação aborda a construção e as técnicas construtivas nas obras do engenheiro-arquiteto Francisco de Paula Ramos de Azevedo, procurando avançar para além dos limites da análise formal e histórica já consagrada: o estudo do contexto acadêmico europeu, assim como o dos novos programas, tipologias e linguagens introduzidas no país no período de atuação de Ramos, além daquele que se dedica às questões de higiene e salubridade das construções e à influência do engenheiro-arquiteto no processo de formação de mão de obra especializada e tecnológica paulista - um âmbito em que Ramos de Azevedo se destacou. Tais estudos servem, contudo, como guia e referência para o rumo pretendido para esta pesquisa, procurando compreender como tais aspectos dialogam com o contexto empresarial e tecnológico da época, mais especificamente a indústria da construção civil no qual o engenheiro-arquiteto estava inserido inicialmente, antes da formação de seu império na capital: o campo tecnológico e industrial da cidade de Campinas. Assim foram observados uma parte desse aparato que então se estruturava, a mão de obra ali aplicada, as indústrias existentes, a relação com as casas bancárias e importadoras, a cultura construtiva vigente na época e os eventos relacionados que ocorreram no período, em busca de uma tipologia arquitetônica. $A$ reforma da sede da fazenda Pau d'Alho, obra atribuída ao engenheiro-arquiteto, comparece como o fio condutor da presente dissertação, ao apontar aos diferentes subtemas relacionados ao tema central, no que se refere à construção civil campineira. $A$ sede foi escolhida em detrimento de outras duas obras - inclusas na proposta inicial do estudo (sede da Fazenda Jambeiro e residência de Azurem Costa - atual capela do Hospital Vera Cruz) - em virtude do curto tempo de pesquisa frente ao volume de informações que a ampliação do número de estudos de caso geraria; e em virtude de seu bom estado de conservação - ainda que algumas partes da construção tenham sido descaracterizadas, antes da ação de tombamento promovida pela administração municipal através do CONDEPACC, em dezembro de 2008. Outro motivo que nos levou optar pela sua escolha foi o fato de a sede da fazenda envolver diferentes épocas e culturas construtivas, servindo como referência temporal para o estudo das técnicas construtivas locais ali aplicadas e a dinâmica da mão de obra ali investida - em visível processo de transição, essencial para a compreensão deste estudo.

O contexto que retrata todo o conjunto cafezista no qual a fazenda está inserida naquele momento da atuação de Ramos, diante de todo o complexo que envolve a cultura e o beneficiamento do café, não poderia, nesta investigação, ser aprofundado como gostaríamos - trata-se de um estudo à parte e objeto de um esforço coletivo e bem mais amplo. Um breve esboço, contudo, serve de pano de fundo para o objetivo da 
pesquisa aqui dissertada, procurando manter o foco, antes de tudo, nas técnicas aplicadas na sede da fazenda.

São dois os principais livros que abordam a produção arquitetônica do engenheiro-arquiteto Ramos de Azevedo: o primeiro, do consagrado professor Carlos Lemos, Ramos de Azevedo e seu Escritório, destaca sua carreira já consolidada na capital paulistana; o segundo - editado posteriormente, mas voltado para o contexto que precede sua atuação em São Paulo - de autoria da professora e pesquisadora Maria Cristina Wolff de Carvalho, Ramos de Azevedo, aborda especialmente a vida acadêmica de Ramos, além de dar continuidade à historiografia de sua atuação na capital. Foram, com certeza, o solo sobre o qual esta dissertação lança seus fundamentos. Outro trabalho, não menos importante e que contribuiu significativamente para a realização deste trabalho, é a dissertação de Ana Maria Reis de Góes Monteiro, a qual investiga a atuação do engenheiro-arquiteto em Campinas, no período em que viveu e trabalhou na cidade: Ramos de Azevedo: Presença e atuação profissional em Campinas: 1879 a 1886. É a partir deste referencial que elaborei o capítulo 1, lidando com algumas informações introdutórias e comentando alguns aspectos do papel azevediano no processo de construção de uma abordagem que se pode chamar de 'nacional' do processo de produção em arquitetura e urbanismo.

Estes trabalhos foram parcialmente consultados anteriormente, num programa de Iniciação Científica, num estudo de levantamento das obras campineiras do engenheiroarquiteto. Foi a partir desse momento que fui incentivada a circunscrever a pesquisa, abordando especialmente as técnicas construtivas operadas por Ramos em seus projetos campineiros, estendendo a investigação para o contexto do aparato de produção do edifício e da cidade naquele momento, bem como a dinâmica da nascente indústria de construção civil na cidade.

No capítulo 2, procurei aprofundar o estudo do contexto de todo o aparato tecnológico estruturado no tempo e no espaço onde Ramos de Azevedo viveu e atuou, desde sua formação escolar até sua volta da Europa à Campinas, já formado engenheiroarquiteto, onde iniciou sua carreira: a transição da base manufatureira para a industrial, o papel da cultura do café neste processo de transição, o mercado de serviços e a indústria de materiais construtivos, a transição da mão de obra escrava para a mão de obra assalariada, a presença dos imigrantes etc. Diversos e variados livros de história do período, econômica, social e política, e seu contexto em São Paulo e Campinas, foram consultados, cujo destaque fica por conta do Campinas, seu berço e juventude, do professor Celso Maria de Mello Pupo e a monografia História do Município de Campinas, de 1952. 
Ainda compondo este capítulo, estruturei um levantamento das indústrias na região de Campinas no período em questão, sempre em paralelo com a vida de Ramos de Azevedo e os principais acontecimentos do período. Foram pesquisados principalmente os livros: Guia Histórico da Indústria Nascente em Campinas (1850-1887), de Ema Elisabete Camillo; a monografia de graduação em Economia de Juliana Borges Araújo: A indústria da Construção Civil em São Paulo e a Indústria da Tecnologia de Concreto: da experiência do Gabinete de Resistência dos Materiais ao Laboratório de Ensaios dos Materiais, 1899-1934; e os almanaques periódicos de Campinas: de José Maria Lisboa para o início da década de 1870 e de Hypólito da Silva no final da década de 1870. Para o estado de São Paulo, consultei os almanaques de Jorge Seckler: Almanach Administrativo, Commercial e Industrial da Província de São Paulo para o anno de 1886, assim como para o ano de 1891. Para o levantamento da mão de obra local e de profissionais como engenheiros, arquitetos, agrimensores e os industriais, também foram usados essa mesma importante ferramenta, os almanaques.

$\mathrm{Na}$ parte central da dissertação, no capítulo 3, foram estudadas as técnicas construtivas mais comumente utilizadas no período, analisadas através da sede da fazenda Pau d'Alho. Tais processos construtivos estão razoavelmente bem registrados nos antigos manuais de construção, particularmente aqueles publicados no final do século XIX e no início do século XX. Cabe ressaltar o Vinhola Brasileiro, de Cesar Rainville, publicado no Rio de Janeiro em 1880 e os manuais de João Emílio dos Santos Segurado, publicado provavelmente em 1908, tanto em Portugal como no Brasil, em vários volumes ${ }^{1}$. Também foi consultado outro livro mais recente, que poderia ser considerado um manual, de 1986, também publicado em Portugal: Curso Elementar de Construções, de Luiz Augusto Leitão. Estes livros citados retratam todas as etapas da construção civil na época, desde a descrição de serviços de terraplenagem e os competentes equipamentos necessários, às alvenarias mais usadas, tipos de coberturas e materiais indicados para os acabamentos, dos moldes às molduras. Outro livro importante que de igual modo serviu de referência foi o de Sylvio Vasconcellos: Arquitetura do Brasil - Sistemas Construtivos, de Belo Horizonte, publicado em 1958. Contudo, o principal esteio desta empreitada e o mais apropriado para o estudo pretendido foi, sem dúvida, o livro "compêndio" do engenheiro-arquiteto, Alexandre Albuquerque, Construções Civis, de 1938. Albuquerque fora aluno de Ramos de Azevedo, tornando-se posteriormente professor e seu companheiro na Escola Politécnica.

\footnotetext{
${ }^{1}$ São eles: Materiais de Construção; Alvenaria e Cantaria; Construção Civil em Edificações; Construção Civil em Acabamento de Construções: estuques, pinturas, etc.; Construção Civil em Terraplanagens e Alicerces; Trabalho de Carpintaria Civil; e Trabalho de Serralharia Civil.
} 
Nesse sentido, o estudo da técnica construtiva na obra de Ramos justifica-se na medida em que se compromete, de forma geral, trazer à luz aspectos importantes da influência dos sistemas construtivos - e de todo o aparato empregado para a sua consecução - sobre a definição estilística no período e o quanto alguns comprometimentos técnicos, organizacionais e econômicos estão envolvidos nesta definição. Mais especificamente e de forma lateral, o estudo pretendido também contribui para compreender alguns aspectos do padrão de expansão urbana campineira em um de seus períodos mais proeminentes, inclusive enquanto decorrência das relações que articulam a produção arquitetural do período e os vetores de produção imobiliária. Muitos acervos não puderam ser consultados devido à extensão da pesquisa e alguns livros indicados na bibliografia original e outras referências - apesar de indicadas - não foram consultadas, pela impossibilidade de acesso ou porque estão esgotados. Contudo, o material levantado e aqui disposto pretende, a partir desta dissertação, servir como referência inicial para uma análise mais profunda sobre as técnicas construtivas do engenheiro-arquiteto mais conhecido do município campineiro no período aqui abrangido. 


\section{INTRODUÇÃO}

Os escravos estavam todos alvoroçados, mas não porque se tratava de uma rebelião contra o seu senhor ou alguma reclamação por eventuais maus tratos. A Lei do Ventre Livre já vigorava há treze anos - desde 28 de agosto de 1872 - e a Lei dos Sexagenários acabara de ser aprovada (28 de setembro de 1885). O motivo de tal alvoroço foi noticiado no "Diário de Campinas", de 11/12/1885, no qual o Comendador Aranha - mais tarde promovido a Barão de Anhumas - acabava de contratar professor para seus escravos menores ${ }^{1}$. A produção cafeeira campineira estava no seu auge e esse novo contexto de prosperidade econômica não apenas substituía a antiga ordem produtiva precedente, como também introduzia novos costumes que acabariam reordenando toda a vida cotidiana naquele fim de século: a vida requintada dos fazendeiros - sempre candidatos aos títulos nobiliárquicos como os de barões e condes não dispensava a presença dos escravos, agora ampliada para dentro do ambiente familiar, ainda mais lapidada por alguma instrução fundamental².

Ao requinte dos escravos educados, juntava-se aquele que se explicitava nos detalhes da construção que o Comendador Aranha resolvera reformar e estabelecer como sede de sua fazenda e residência para a família: nas salas, o piso frio ganhava maior distinção quando substituído pelo tabuado; as janelas agora exibiam maior sofisticação, com o vidro em detalhe azul que lhe encimava a parte curva; o ferro trabalhado, compondo adereços, adornava grades e portões. Os dormitórios eram arejados, ostentando altos pés-direitos, e a bela varanda, com as seis colunas neoclássicas e entradas laterais, refrescava a casa agora assobradada. Frisos e detalhes neoclássicos emolduravam todas as aberturas: não se achavam vestígios da singela vida de outrora.

Tido como homem de "elevado sentimento de solidariedade humana e sensível à propaganda abolicionista"3, o Comendador Manuel Carlos Aranha ofereceu cartas de alforria aos seus numerosos escravos quando ainda se verificava, entre os senhores, muita resistência no cumprimento das leis abolicionistas que precederam a Lei Áurea de 1888. A alforria, contudo, não era tida como novidade: instados pelo governo imperial, muitos senhores libertaram seus escravos para servirem na Guerra do Paraguai (18641870) - inclusive o próprio Comendador ${ }^{4}$, Capitão da Guarda Nacional, proprietário

\footnotetext{
${ }_{1}^{1}$ PUPO, Celso Maria de Mello. Campinas, Município no Império: fundação e constituição, usos familiares, a morada, sesmarias, engenhos e fazendas. São Paulo: Imprensa Oficial do Estado, 1983, p. 186.

${ }^{2}$ LEMOS, Carlos. Casa Paulista - história das moradias anteriores ao ecletismo trazido pelo café. São Paulo, EDUSP, 1999, p. 77.

${ }^{3}$ SERVIÇO GRÁFICO BRASILEIRO DE GEOGRAFIA E ESTATístICA, Monografia História do Município de Campinas. Rio de Janeiro, 1952, p. 265.

${ }^{4}$ Ibid., p. 265.
} 
também das fazendas Santa Maria, Santa Clara e Jaguari e, portanto, senhor de muitos escravos $^{5}$. Contudo, mantenha-se claro que, tanto a condição de alforriado como a de negro aculturado e minimamente educado, com acesso à intimidade da aristocracia rural, não significava que passaram a ser tratados com alguma permissividade ao trânsito e à igualdade social ${ }^{6}$.

O Comendador tornara-se proprietário da Fazenda Pau d'Alho desde o referido ano de 1885, nove anos depois das terras da antiga sesmaria à qual pertencia serem fracionadas. A história da Fazenda Pau d'Alho remonta à divisão de terras de Pedro José Batista, de Antônio Bicudo e de Ana Teles Moreira, sesmaria sobre a qual Antônio de Cerqueira César adquiriu direitos de posse em 1788, fundando seu engenho na estrada de Goiás, então chamada Estrada de Anhumas (atual Campinas - Mogi-Mirim). Falecido em 1822, deixou a sesmaria para o filho, o tenente Antonio Benedito Cerqueira Leite que, casado com a escrava Maria Zelinda da Conceição, teve dez filhos ${ }^{7}$ - uma situação conjugal que, apesar de nos parecer incomum para a época, era assim assumida ainda em tempos não muito francos. Falecido em 1861, sua viúva vendeu o engenho ao parente Manuel Leite de Barros, cuja esposa, Cândida da Rocha Ferraz - ou Cândida Maria Ferraz de Barros -, também após ficar viúva, dividiu a sesmaria em três fazendas: Anhumas, Santa Cândida e a Pau d'Alho - que, após esse périplo genealógico, passou a pertencer ao Comendador Aranha ${ }^{8}$.

Ao adquirir a fazenda, o Comendador - então em franca ascensão econômica, política e social - promoveu ali significativas reformas, atribuindo à sede da propriedade principalmente - ares mais sofisticados, alinhavados pelas mãos de um recém-chegado engenheiro-arquiteto que se ausentara da cidade por seis anos para se dedicar aos estudos que o introduziram no ofício. Aquela reforma agregou e sintetizou mudanças construtivas que se tornaram muito comuns no último quartel do século XIX, evidenciando as novas técnicas que entrariam em voga no século seguinte e as inúmeras

\footnotetext{
${ }^{5}$ Processo de Inventário do ano de 1894 (Cartório do 3o Ofício - Caixa 388 - Processo no 7686), importante levantamento feito por Pedro Abate (ABATE, 1998) para seu estudo da Fazenda, contendo cópias dos processos obtidos em fontes primárias.

${ }^{6}$ Por outro lado, também a mudança de condição da presença do negro na economia agrária demandava alternativas no arranjo produtivo: outros proprietários tentavam seus primeiros passos no Sistema de Parceira, sistema de imigração estrangeira que viria, aos poucos, propiciar a substituição da mão de obra escrava nas lavouras - plenamente efetivada com o Regime de Colonato (para melhor compreensão do Regime de Colonato, ver: A Presença Italiana no Brasil, organizado por Luis Alberto de Boni (DE BONI, 1990). Essa nova situação da presença do negro na economia significava, via de regra, uma não-presença, isto é, o negro não deixou de existir, ele não sumiu, mas foi substituído em boa medida, enquanto força de trabalho, pelos trabalhadores imigrantes assalariados.

${ }^{7}$ Alguns deles destacaram-se no cenário nacional - a maioria através de sua atuação política -, como o senador Francisco Glicério (empresta hoje seu nome a importante avenida no centro de Campinas), Jorge Miranda, Coronel Julio César de Leão Cerqueira e Eloi Cerqueira, entre outros.

${ }^{8}$ Referência na História de Campinas, Correio Popular, Campinas, 31 out. 2004.
} 
decorrências nos processos de produção da arquitetura e da cidade que por aqui se instalaram, tanto no âmbito regional como até mesmo no nacional.

Francisco de Paula Ramos de Azevedo é o engenheiro-arquiteto que está por trás dessa reforma: a história de sua formação mistura-se com a história da cidade onde cresceu e atuou nos primeiros anos de exercício de sua profissão - história amarrada a outras histórias e fatos que estão ligados entre si que, ao enunciarmos o caráter do percurso aqui iniciado, não poderiam ser relevados ou esfumados, obstruindo a pretensão de contrastarmos o histórico das atividades profissionais realizadas pelo engenheiro-arquiteto e todo o aparato produtivo - aqui compreendido como 'técnicas construtivas'9 - que se articulava enquanto meio de produção do edifício e da cidade, em um determinado período da história do país.

Ao nos aproximarmos do contexto de época no qual Ramos de Azevedo nasceu, constatamos que mesmo as maiores cidades do interior do estado de São Paulo, na metade do século XIX, ainda mantinham seu aspecto bucólico, delineadas por um casario baixo e simplório, acessado por arruamentos ainda sem calçamento. Porém, aos poucos, as portas estreitas e janelas quadradas, os largos telhados de duas águas com suas cumeeiras paralelas à rua, as sacadas recuadas do muro poucos centímetros e as grossas paredes de taipa deixaram de fazer parte do cenário urbano, assim cotidianamente construído desde três séculos antes ${ }^{10}$. Com o advento do tijolo - cujo uso difundiu-se amplamente com a chegada dos imigrantes europeus - a forma edificada da cidade transformar-se-ia irrevogavelmente.

Campinas, ao aproximar-se a virada do século, já experimentava algum apogeu urbano com a inauguração da Companhia Paulista e da Companhia Mogiana de Estradas de Ferro - importantes escoadouros da produção interiorana paulista ${ }^{11}$, com acesso direto ao porto de Santos - e com a transição do ciclo do açúcar para o do café, principal evento econômico que contribuiria decisivamente para a prosperidade da cidade. Assim, a construção das estradas de ferro na década de 1870 assume papel decisivo no desenvolvimento de uma economia que agora se impunha determinada pelo capital agrocafeeiro, bem como as instalações e equipamentos para beneficiamento do café -

\footnotetext{
9 Tendo como referência uma abordagem específica de técnica e tecnologia, o professor Álvaro Vieira Pinto sugere que a ideia de tecnologia deve aparecer associada à ideia de forças produtivas. Ver PINTO, Álvaro Vieira. O conceito de tecnologia. Rio de Janeiro: Contraponto, 2005, p. 49 ss.

${ }_{10}$ LOUREIRO, Maria Amélia Salgado. A Evolução da casa Paulistana e a Arquitetura de Ramos de Azevedo. São Paulo, Voz do Oeste e secretaria do Estado da Cultura, 1981, p. 21.

${ }^{11}$ REIS FILHO, Nestor Goulart. "Campinas e suas estações: de onde partia o progresso", in: São Paulo e outras cidades: produção social e degradação dos espaços urbanos. 1994, p. 46.
} 
reconfigurando estruturalmente o aparato industrial da época colonial. Juntamente com outros modernos recursos técnicos - como o telégrafo, a iluminação a gás e o sistema de bondes com tração animal -, as vias férreas afetaram toda a estrutura urbana, naquele momento também em processo de transformação profunda - não só com as vantagens das instalações prediais de água encanada, já em fase de acabamento, mas, também, em virtude da intensa reordenação produtiva de todos os seus componentes, pretendendo suprir as necessidades da crescente população - neste momento com 80 mil habitantes na totalidade do município ${ }^{12}$.

A ascensão da economia cafeeira teve papel fundamental e interferiu diretamente na oferta da mão de obra urbana, especialmente na composição étnica da classe operária em formação: essencialmente estrangeira, chegou a superar, em determinado momento, os contingentes de trabalhadores mais conformados pelo que se poderia chamar de "identidade nacional"13. Durante o período, a cidade recebeu uma quantidade significativa de imigrantes - primeiro os alemães e, posteriormente, os italianos atendendo às necessidades de mão de obra exigidas pelas novas configurações produtivas, agora redesenhadas pelo fim do regime escravista e pela lavoura de café. A introdução do tijolo cozido e do sistema de alvenaria de tijolos também contribuiu para maior absorção da mão de obra imigrante, especializada na manipulação da nova técnica que passou a ser intensamente utilizada na construção civil ${ }^{14}$.

Nesse período, a atividade industrial já era intensa, e foram formados os primeiros partidos operários no Rio de Janeiro, quando ocorreram as primeiras greves em busca de melhores condições de trabalho, salários e moradia digna, pois cada categoria de cada setor econômico instituía seu salário, com o provimento mínimo para subsistência, e não existia um valor mínimo estabelecido por lei. Após a proclamação da República, muitos dos direitos (horas, salários, férias, etc.) dos operários foram assegurados a partir da movimentação e reivindicações das classes laborais, assim como também com a ajuda dos positivistas, que perpetravam um certo lustro europeu para as relações entre capital e trabalho. O sindicato do ramo da construção civil era mais forte que os de outros ramos, com um salário médio para um adulto relativamente superior ao pago em outros setores. Os canteiros de São Paulo ganharam todas as greves de 1907 a 1913, conseguindo fazer atender reivindicações importantes, especialmente as dos operários das ferrovias do estado (Jundiaí, São Paulo, Santos, Rio Claro e Campinas). Segundo Boris Fausto, o êxito se explica pela qualificação dos empresários de São Paulo (pequenos empreiteiros)

\footnotetext{
12 Badaró, Ricardo Sousa Campos. Campinas, o Despontar da Modernidade. Campinas, UNICAMP/ CMU, 1996, p. 30.

13 FAUSTO, Boris. Trabalho urbano e conflito social (1890-1920). Rio de Janeiro, Bertrand Brasil, 2000, pp. 25 a 33.

${ }^{14}$ Sobre este aspecto, ver particularmente XAVIER, P. C. P., 2004.
} 
e também devido aos cuidados extras e direitos necessários para um ramo de trabalho pesado ${ }^{15}$.

Junto à nova técnica de construção utilizando tijolos, também se incorporava lentamente um novo estilo, o ecletismo. Ramos de Azevedo demonstrou muita habilidade e perspicácia, articulando com muito apuro técnico o novo processo construtivo, aprendido na Bélgica, e a linguagem da composição eclética, adotando um padrão construtivo que the era intrinsecamente mais adequado. Por outro lado, a compatibilização entre o processo de produção e a linguagem arquitetônica impunha a necessidade de formular e desenvolver novas tecnologias construtivas, sistemas de produção já com identificável caráter fabril e até mesmo a introdução de novos materiais - como veremos mais adiante -, atendendo às demandas da elite campineira, alçada a essa categoria pela riqueza produzida pelo café ${ }^{16}$.

Terminado o estudo básico na cidade, em $1869^{17}$ o campineiro Ramos de Azevedo (como se considerava, apesar de ter nascido em São Paulo - no dia 08 de dezembro de 1851 -, por acaso, quando a mãe foi visitar a irmã doente) foi cursar o nível secundário na Escola Politécnica do Rio de Janeiro, numa época em que o curso era voltado para a formação de militares, dedicado ao "ensino das matemáticas e ciências físicas naturais e também às doutrinas próprias da Engenharia Civil” ${ }^{18}$. Porém não pôde completar os estudos, ficando apenas três dos sete anos do curso ${ }^{19}$.

Voltando para Campinas em 1872 - já então com 20 anos -, Ramos trabalhou como ajudante de engenheiro-chefe e desenhista na Cia. Paulista de Estradas de Ferro e

\footnotetext{
${ }^{15}$ FAUSTO, Boris. Trabalho urbano e conflito social (1890-1920). Rio de Janeiro, Bertrand Brasil, 2000, p. 48.

16 Arquivo Histórico Municipal Washington Luis, Site Informativo Número 1, Julho - Agosto de 2005.

17 Algumas fontes datam a ida de Ramos à Escola Politécnica do Rio de Janeiro no ano de 1869, então com 18 anos (FARAH, A.P.), porém outras fontes dizem que foi aos 15 anos - o que não corrobora a contabilidade das efemérides.

18 TELLES, Pedro Cardoso da Silva. História da engenharia no Brasil (Séc. XVI a XIX). Rio de Janeiro, Livros Técnicos e Científicos, editora SA, 1984.

19 Enquanto Monteiro, em seus relatos, não explicita claramente os motivos da interrupção das aulas na Escola Politécnica do Rio de Janeiro (MONTEIRO, Ana Maria Reis de Góes. Ramos de Azevedo: Presença e atuação profissional em Campinas: 1879-1886. Dissertação apresentada à Faculdade de Arquitetura e Urbanismo da PUC-Campinas para a obtenção do grau de Mestre, 2000, p. 14), Pelágio Lobo, em fonte buscada por Farah (FARAH, Ana Paula. A produção do Engenheiro Arquiteto Francisco de Paula Ramos de Azevedo na Província de São Paulo. Tese de Mestrado, Escola de Engenharia de São Carlos, 2003, p. 23), aponta que o curso fora interrompido devido a uma decisão do Imperador, autorizando, quem quisesse, abandoná-lo, permitindo a reintegração de seus antigos alunos e militares, que retornavam após o fim da Guerra do Paraguai. Tendo em vista que, segundo Lemos, Pelágio Lobo era "amigo pessoal do Dr. Ramos, com quem convivera nos escritórios da diretoria da Companhia Mogiana de Estrada de Ferro", podemos inferir que a informação sobre a interrupção do curso deve ser procedente (LOBO, Pelágio. Velhas Figuras de São Paulo. São Paulo, Academia Paulista de Letras, 1977, p.251. apud LEMOS, Carlos A. C. Ramos de Azevedo e seu escritório. São Paulo, Pini, 1993, p.4).
} 
Cia. Mogiana de Estradas de Ferro ${ }^{20}$ - onde conquistaria as graças de seu presidente, Antonio de Queirós Telles - o Barão de Parnaíba -, que viria apoiá-lo na profissão anos mais tarde e a quem Ramos seria eternamente grato ${ }^{21}$.

Carlos Lemos, em sua importante pesquisa sobre a vida e obra de Ramos de Azevedo, relata o relacionamento da família do engenheiro-arquiteto com uma tradicional família local, os Cerqueira Leite - os citados antigos proprietários da fazenda Pau d'Alho: três filhos de Antonio Benedito com a escrava Maria Zelinda da Conceição casaram-se com três irmãs de Ramos, e outro filho do tenente, o general Francisco Glicério, conhecido político nacional, fora seu amigo e também companheiro de maçonaria ${ }^{22}$. Essa ligação de Ramos com a maçonaria, conforme afirmado por Lemos, é decorrência de sua aproximação - como a de tantos da aristocracia paulista da época - com as sociedades secretas dos estudantes da Faculdade de Direito de São Paulo ${ }^{23}$ e da futura Escola Politécnica, uma tradição trazida por aqueles que estudaram na Europa e que fundavam suas ações no pressuposto da ajuda mútua "na vida profissional mesmo depois de formados"24. Essa ligação de Ramos, conforme documento do Dr. Paulo Piratininga Pinto, membro da Academia Campinense Maçônica de Letras - citada por Farah ${ }^{25}$ em sua dissertação de mestrado sobre a atuação do engenheiro-arquiteto na província de São Paulo -, teria um outro introdutor: Bento Quirino dos Santos que, além de formalizar a entrada daquele jovem de 22 anos na maçonaria em outubro de 1873, teria the pedido um projeto da fachada da Loja Maçônica. Não se sabe se esse projeto foi realizado. É bastante certo, contudo, que esse envolvimento com a maçonaria também contribuiria para a formação de Ramos, tanto quanto para o agenciamento de suas relações profissionais (são inúmeros os integrantes da maçonaria que, no futuro, atuarão ombro a ombro com Ramos de Azevedo), como quanto para a composição de um rol bastante poderoso de clientes.

Logo depois, com 23 anos, foi estudar na Universidade de Gante, na Bélgica, onde ingressou na Escola Preparatória para o curso de Engenharia Civil. Contudo, não chegou a completar o curso de dois anos, sendo aprovado ao fim de um ano letivo no curso Especial de Engenharia e Arquitetura ${ }^{26}$. Juntamente com esse curso, para complementar sua formação e por sugestão da Universidade, entrou para o curso

20 LEMOS, Carlos A. C. Casa Paulista - história das moradias anteriores ao ecletismo trazido pelo café. São Paulo, EDU USP, 1999, p. 109.

21 LEMOS, Carlos A. C.. Ramos de Azevedo e seu escritório. São Paulo, Pini, 1993, p.5 a 9.

22 Idem, p.4.

23 BANDECHI, Brasil. A Bucha, a Maçonaria e o Espírito Liberal. São Paulo, Editora Parma, 1982, p.101.

24 LEMOS, Carlos A. C.. op.cit. 1993, p.4.

25 FARAH, Ana Paula. A produção do Engenheiro Arquiteto Francisco de Paula Ramos de Azevedo na Província de São Paulo. Tese de Mestrado, Escola de Engenharia de São Carlos, 2003, p.22.

26 CARVALHO, Maria Cristina Wolff de. Ramos de Azevedo. São Paulo, Editora da Universidade de São Paulo, 2000, p. 71. 
noturno da Academia de Belas Artes, a "Primeira Classe de Arquitetura", sendo ali o único aluno a cursar o ensino superior, dentre outros quatorze profissionais que se dedicavam às artes aplicadas (como vidraceiros, estucadores, vitralistas, carpinteiros e serralheiros) ${ }^{27}$.

Sua formação foi especialmente influenciada pelo contexto da Bélgica - um dos primeiros países a demonstrar um consistente processo de industrialização depois da Grã Bretanha, em medos do século XIX, duplicando rapidamente sua rede de ferrovias e a quantidade de máquinas a vapor empregadas na base industrial ali nascente ${ }^{28}$. Essa industrialização acelerada alterou completamente a estrutura social do país, com a formação de uma vigorosa classe operária que, composta por contingentes populacionais expulsos dos campos, via-se obrigada a vender sua força de trabalho na cidade. Instituíase, assim, pelo assalariamento e pela nova ordem técnica da divisão do trabalho, uma inédita categoria social e econômica que se impunha como um poderoso agente de interesses que se imiscuíam nas entranhas da nascente cidade industrial. Enquanto, no Brasil, a manufatura começou a prosperar devido à crise do trabalho artesanal e de base escravista, na Europa, o trabalho industrial já havia se consolidado e a manufatura não mais predominava - pelo menos nos moldes das oficinas de corporações medievais. $A$ manufatura, para cá trazida por meio da importação de produtos e equipamentos, ganha, a partir desse momento, outro componente determinante para a estruturação do modelo de substituição de importações e mão de obra escrava: a mão de obra imigrante, a qual contribuiu sobremaneira para a constituição de uma nova força de trabalho, mais condizente com a formação econômico-social em curso $^{29}$.

Em outubro de 1878, então com 27 anos incompletos, Ramos de Azevedo obteve o título de Engenheiro Arquiteto, formando-se com "grande distinção"30 e, depois de seis meses na Europa, voltou ao Brasil, à cidade onde crescera, expondo seus trabalhos acadêmicos no mesmo endereço da loja de tecidos e armarinhos do seu pai, o Major Martins, à Rua Barreto Leme, $\mathrm{n}^{0} 1^{31}$. Carlos Lemos, que traz alguma referência sobre essa exposição, apresenta um anúncio de jornal que destacava os inovadores desenhos e plantas de Ramos para a cidade. Podemos daí inferir que esse foi o começo da sua carreira profissional e, por que não, o início do seu escritório.

A Campinas que Ramos encontrou quando retornou da Europa apresentava uma mancha urbana razoavelmente bem definida. Com o aparecimento das pequenas

27 Ibid., p.73.

28 lbid., p.39.

${ }^{29}$ CUNHA, Luiz Antônio. O ensino profissional na irradiação do industrialismo. São Paulo, 2000.

30 CARVALHO, Maria Cristina Wolff de. Ramos de Azevedo. São Paulo, Editora da Universidade de São Paulo, 2000, p. 76.

31 LEMOS, Carlos A. C.. Ramos de Azevedo e seu escritório. São Paulo, Pini, 1993, p.5, 8. 
indústrias, essa mancha compunha-se de bairros que abrigavam, além de moradia 'proletária' - se nos permitirmos utilizar o termo -, também algumas instalações voltadas para atividades de fundição, além de pequenas indústrias dedicadas ao desenvolvimento da produção cafeeira, incentivadas pela recém instalada linha férrea (1872). Com efeito, a construção da estação acabou promovendo a instalação de centenas de famílias operárias ao seu redor, reforçando a tendência industrial e proletária daquela parte da cidade. Ao norte da região central - que compreendia os principais edifícios públicos, como a Matriz Nova e Velha, a Cadeia, o Passeio Público (já iniciado em 1876), escolas e hospitais - instalavam-se os bairros residenciais de classes mais abastadas. Assim foi formado o Frontão (Cambuí) e o bairro Guanabara, ainda constituído por chácaras, tendo aos fundos o já existente bairro do Fundão (atual Ponte Preta) ${ }^{32}$.

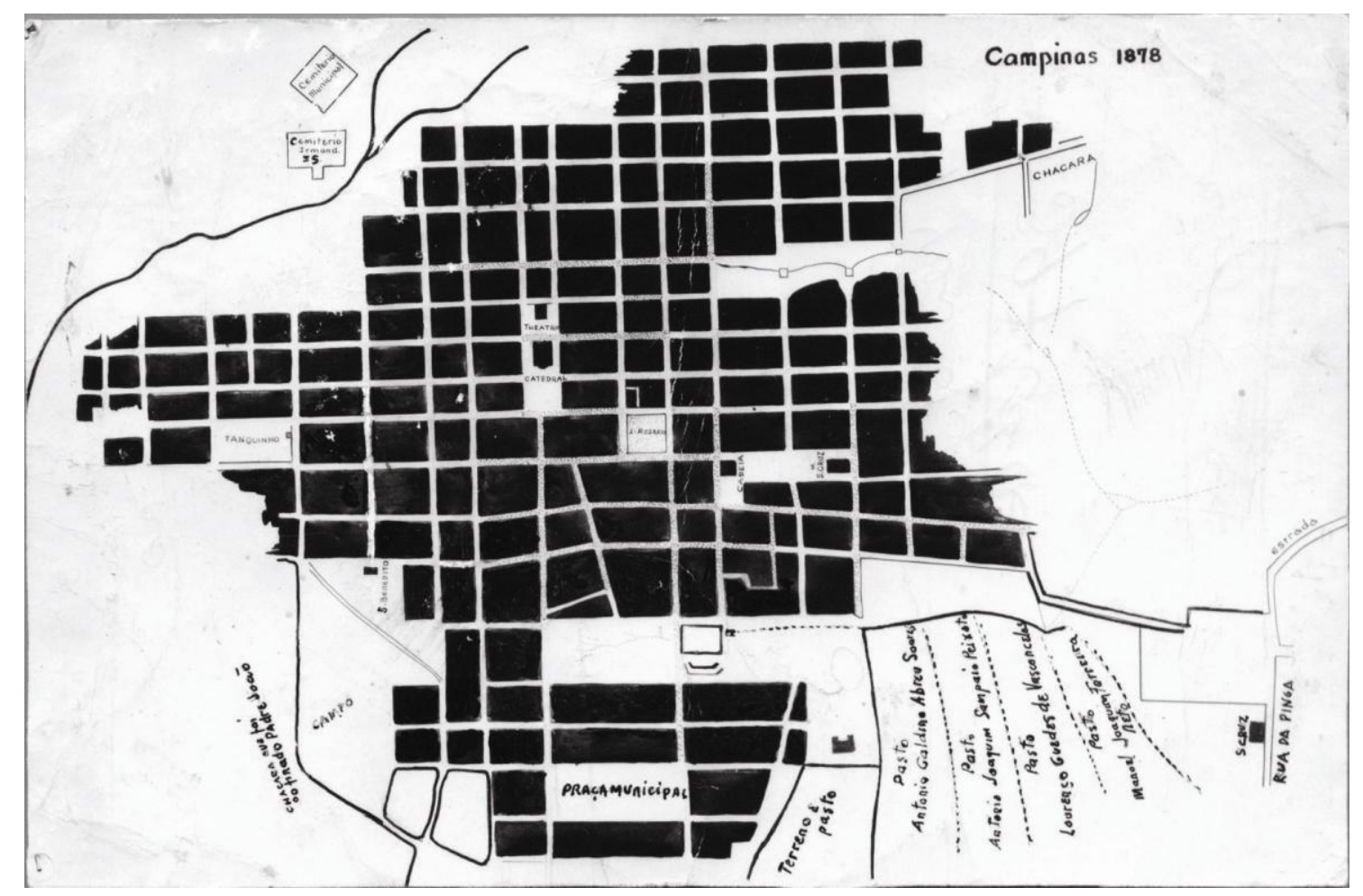

Figura 01: Mancha urbana de Campinas em 1878, tendo ao centro o antigo Teatro Municipal ${ }^{33}$

Ramos certamente voltara da Europa com a intenção de aplicar as novidades que aprendera, isto é, pôr em prática, em projetos públicos, as idéias urbanísticas e sanitaristas que vinham, sistematicamente, sendo praticadas no exterior. Tendo como pressuposto essa preocupação de sanear e higienizar os espaços, edificações e áreas urbanas, Ramos de Azevedo projetou para a cidade de Campinas, em 1882, o Matadouro

\footnotetext{
32 Badaró, Ricardo de Souza Campos. Campinas, o despontar da modernidade. Campinas, CMU/ UNICAMP, 1996, p.28.

${ }_{33}$ PESSOA, Ângelo E. da S. (Org.). Conhecer Campinas numa perspectiva histórica. Campinas: Secretaria Municipal de Educação, 2004 - CD-ROM.
} 
Municipal, com galerias para escoamento do sangue dos animais abatidos, boxes azulejados e ambientes internos providos de boa ventilação. É onde se percebe a grande influência dos conceitos sanitaristas do Tratado Cloquet $^{34}$. Até então, o abatimento se fazia a céu aberto, com péssimas condições de higiene, causando mau cheiro, poluição das águas e, certamente, problemas de saúde pública ${ }^{35}$.

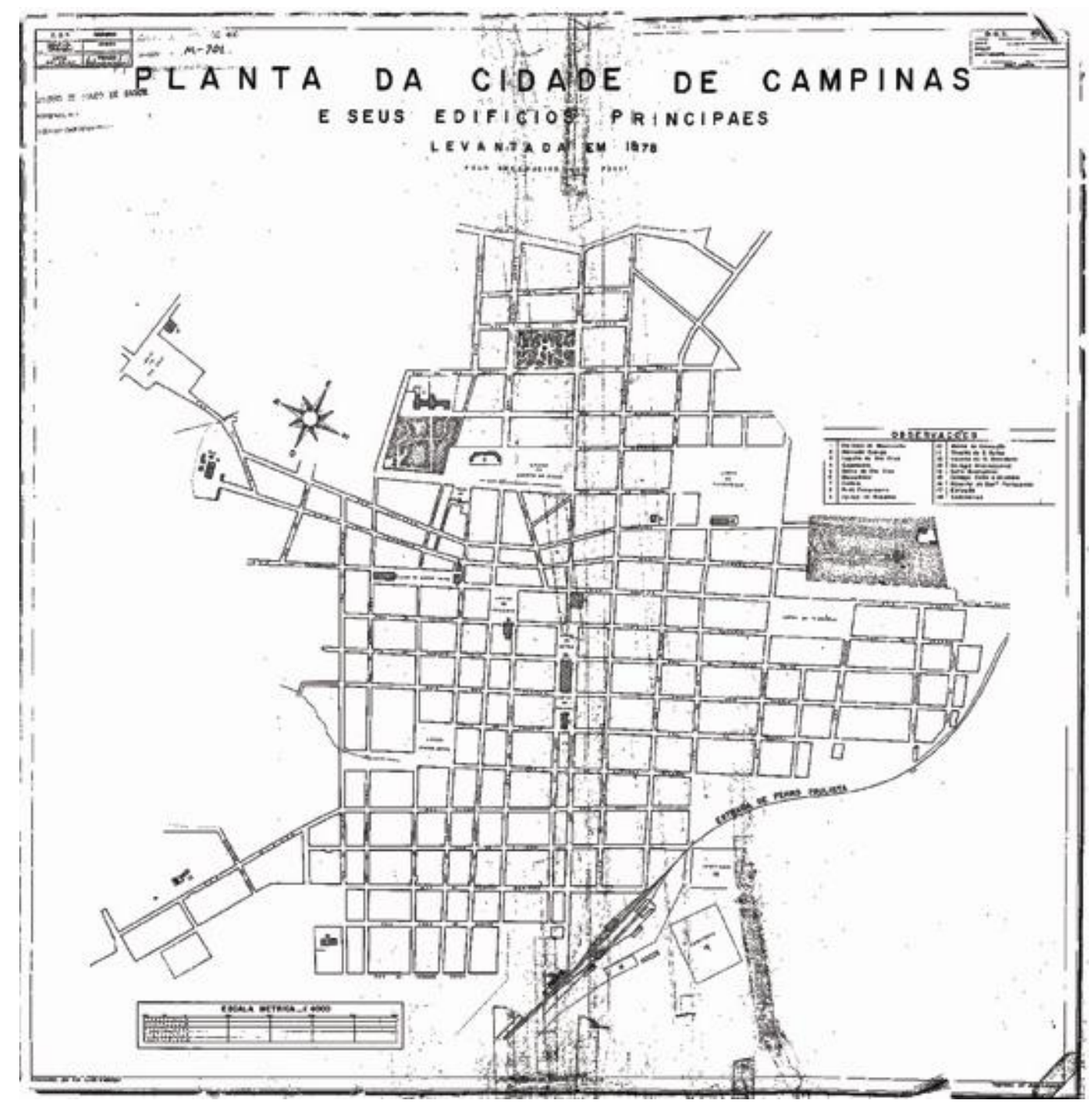

Figura 02: Mapa de Campinas com os principais edifícios em 1879, antes da inauguração da primeira obra de Ramos de Azevedo ${ }^{36}$

34 O Tratado Cloquet não é muito conhecido por autores internacionais. É citado por Maria Cristina Wolff de Carvalho em sua tese sobre Ramos de Azevedo - na qual estudou a vida acadêmica de Ramos na Bélgica -, de onde extraímos essa referência. Segundo a autora, Louis Cloquet deu aulas na Universidade de Gante, influenciando fortemente o aprendiz - a ponto de Ramos indicar, anos depois, um exemplar do seu tratado como parte da Biblioteca da Escola Politécnica de São Paulo. O tratado consiste num importante e minucioso estudo teórico dividido em quatro partes: "Os elementos da arquitetura", "Higiene, aquecimento e ventilação", "Tipos de edifícios" e "Estética e Composição" (CARVALHO 2000:122).

35 CARVALHO, Maria Cristina Wolff de. Ramos de Azevedo. São Paulo, Editora da Universidade de São Paulo, 2000, p. 247.

${ }^{36}$ PESSOA, Ângelo E. da S. (Org.). Conhecer Campinas numa perspectiva histórica. Campinas: Secretaria Municipal de Educação, 2004 - CD-Room. 
Além dos projetos ocupados com o saneamento público da cidade ${ }^{37}$, são diversos aqueles destinados à construção ou reforma de edificações, totalizando pelo menos vinte e seis obras - projetadas ou construídas, tanto no período em que viveu em Campinas como quando já estava instalado na capital paulistana.

Sua primeira e grande tarefa como arquiteto de edificações resultou de um convite do seu antigo chefe na Cia. Mogiana, o Barão de Parnaíba - aquele a quem Ramos seria "eternamente grato", como diz Lemos. Tratava-se de acompanhar as obras de conclusão da fachada da Igreja Matriz, iniciadas em 1879. Efetivamente, as obras de construção da igreja já haviam começado décadas antes, em 1807. Devido a erros técnicos, conflitos políticos e a má qualidade do solo local - que havia sido aplicado na elevação dos muros de taipa que compunham o corpo da edificação -, as obras arrastaram-se durante esse longo período, redundando numa série de patologias que impediam a conclusão do projeto. Em meados de 1879, após inúmeras tentativas de equacionamento dos problemas construtivos, propostas e projetos de alguns construtores e diferentes administrações das obras, o encargo foi passado a Ramos de Azevedo, então um promissor engenheiro-arquiteto com 28 anos, que preferiu dar continuidade ao projeto de seu antecessor, o engenheiro italiano Cristovam Bonini, que solucionara o problema da fachada com um encamisamento de tijolos, revestindo e

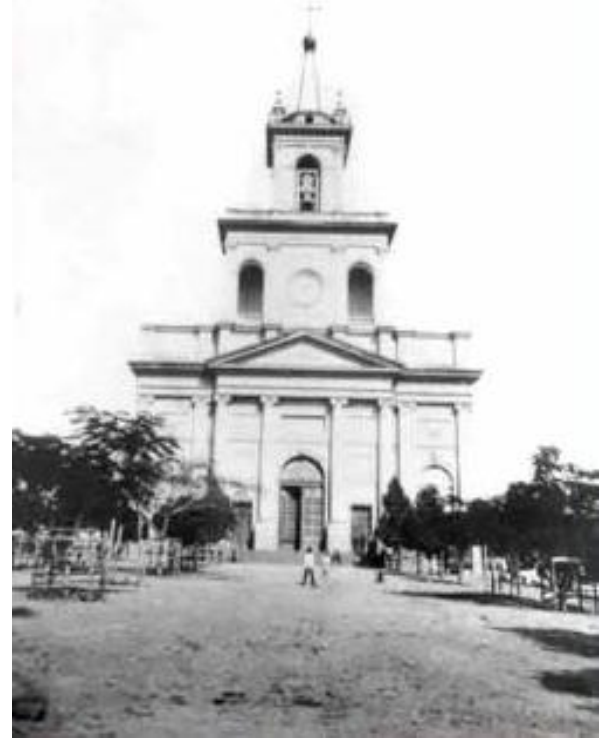

Figura 03: Igreja Matriz Nossa Senhora da Conceição de Campinas ${ }^{38}$

a antiga parede de taipa original ${ }^{39}$. A inauguração da obra aconteceu em 1883, com uma bela festa promovida pelo Barão de Anhumas - umas das mais ativas personagens na história da construção da Igreja Matriz, participando do Diretório das obras entre 1848 e 1961. Seria para ele que Ramos de Azevedo iria trabalhar, reformando a sede da fazenda Pau d' Alho, após sua aquisição em 1885, e aplicando ali soluções construtivas muito semelhantes àquelas adotadas na reforma da Matriz.

\footnotetext{
37 Ana Maria Reis de Góes Monteiro, em sua tese sobre a atuação de Ramos em Campinas, dedica um capítulo inteiro aos projetos de saneamento do engenheiro-arquiteto: Projeto de Posturas para uma nova cidade, p. 155 ss. Ver MONTEIRO, Ana Maria Reis de Góes. Ramos de Azevedo: Presença e atuação profissional em Campinas: 1879-1886. Dissertação apresentada à Faculdade de Arquitetura e Urbanismo da PUC-Campinas para a obtenção do grau de Mestre, 2000.

${ }^{38}$ Campinas, SP, 1883. Coleção Geraldo Sesso Júnior.

39 Idem, p. 93. Este assunto será tratado mais adiante, estruturado como argumento para algumas considerações importantes para esta dissertação (ver capítulo 3, no item 3.2. Técnicas Construtivas na fazenda Pau d' Alho).
} 
Dentre tantas outras obras de Ramos em Campinas, uma em particular ganhou bastante destaque: trata-se do projeto para o edifício do Circolo Italiani Uniti, de 1886 uma instituição fundada por um comerciante italiano com o intuito de prestar assistência aos conterrâneos pobres. Cabe aqui o destaque para essa obra, justamente em virtude da participação do engenheiro italiano Samuel Malfatti na elaboração de seu projeto. Malfatti havia auxiliado Ramos na finalização da Igreja Matriz, quando se tornaram mais próximos: teria sido ele o responsável pela conclusão da cúpula da catedral campineira ${ }^{40}$. Como afirma Lemos, podemos dizer que Malfatti foi um dos principais colaboradores de Ramos em Campinas, assim como os engenheiros Guilherme e Jorge Krug - este, cunhado do engenheiro italiano. Jorge Krug teria um escritório na cidade - como aparece nos registros dos almanaques locais - e mais tarde seria presença constante nas obras paulistanas de Ramos.

Essa foi, provavelmente, a última obra de Ramos antes de sua mudança para a capital paulistana, ocorrida em 1886, a convite do Visconde de Paranaíba, para ser arquiteto oficial do Estado de São Paulo agora já chegado aos seus 35 anos e trazendo, na bagagem, sete anos de experiência acumulada com seu escritório em Campinas.

Antes de sua partida, Campinas começava a ultrapassar os limites da ferrovia, eixo físico que definira o "fim" da cidade por um curto período de tempo. Com a região central mais adensada, a diminuição das chácaras em seu entorno e o aumento de loteamentos nos arrabaldes populares, a cidade estava em pleno processo de expansão: Ramos não veria todo o caos que ali se instalaria, decorrente de um processo de crescimento urbanístico desordenado e relativamente violento. Com a abolição da escravidão, em 1888, um grande número de negros mudou-se para a cidade sem que, obviamente, qualquer iniciativa para alojá-los, pública ou privada, fosse sequer imaginada. Além disso, três surtos de febre amarela consecutivos assolaram o município entre os anos de 1889 e 1897.

Contudo, mesmo não residindo mais em Campinas, Ramos continuou com diversos projetos naquela cidade. Um breve inventário das obras do engenheiro-arquiteto em Campinas pode ser visualizado no mapeamento preparado por Ana Maria Reis de Góes Monteiro (Figura 04).

40 LEMOS, Carlos A. C.. Ramos de Azevedo e seu escritório. São Paulo, Pini, 1993, p.5, 8. 


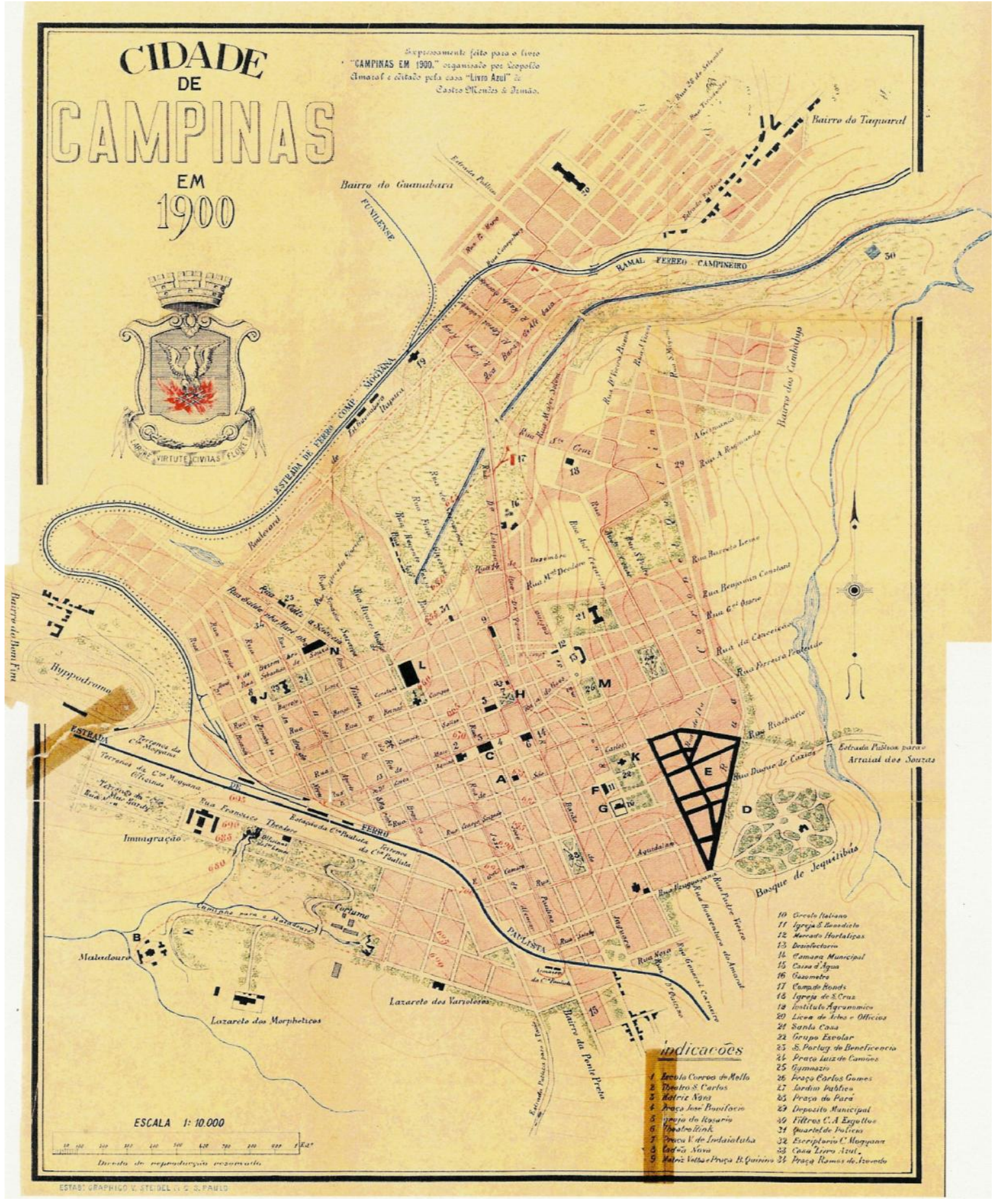

Figura 04: Mapa de Campinas em 1900 com a localização das obras de Ramos de Azevedo feito por Monteiro: Escola Ferreira Penteado (A), Matadouro Municipal (B), Matriz Nova (C), Bosque dos Jequitibás (D), Campo das Caneleiras (E), Capela de São Benedito (F), Circolo Italiani Uniti (G), Chalé dos Construtores $(\mathrm{H})$, Cadeia Nova $(\mathrm{J})$, 1ำ Grupo Escolar (K), Mercado Municipal (L), Praça Carlos Gomes (M), Instituo Profissional Bento Quirino $(\mathrm{N})^{41}$

${ }^{41}$ MONTEIRO, Ana Maria R. de G. Ramos de Azevedo: Presença e atuação profissional Campinas: 18791886. Dissertação de Mestrado PUC C, 2000, p. 271. 
Em 1896, Ramos de Azevedo finalizou o projeto para a Cadeia Pública, substituindo a antiga e bastante simplória edificação que a abrigava, situada onde atualmente se encontra a Praça Bento Quirino. As inovações ficaram por conta, novamente, da preocupação com a higiene da construção: uma cuidadosa adequação do programa, com cômodos bem distribuídos e arejados, tanto na parte dos prisioneiros como nas salas do Fórum ${ }^{42}$.

Tais aspectos também comparecem como preocupação de projeto para a produção de construções escolares: em 1897, novas medidas e leis, destinadas a estender o novo padrão de ensino escolar republicano, foram decretadas. Os novos Grupos Escolares haveriam de expressar o projeto republicano de educação popular, associada à "disciplinarização, civilização e intectualização, além da formação moral, e não mais os valores religiosos do Império"43. E o prédio que abrigaria esses novos Grupos Escolares deveria expressar tal ideia através da sua arquitetura e monumentalidade. O projeto de Ramos de Azevedo para o Primeiro Grupo Escolar em Campinas - atual EEPG Francisco Glicério - seguia os padrões da Escola Modelo, instituídos em $1890^{44}$. Bastante suntuoso para os padrões da época, o edifício destacavase em meio às residências e lojas vizinhas. Internamente, a construção era composta de ambientes amplos, com pés-direitos mais altos que os costumeiros - 0 andar térreo deveria ter 5,00 metros, o primeiro, 4,80m e o segundo, $4,50 \mathrm{~m}$. As portas deveriam medir $3,20 \times 1,20 \mathrm{~m}$ e as janelas $2,20 \times 1,10 \mathrm{~m}$, agora equipadas com folhas venezianas. As paredes, muros que assumiam ao mesmo tempo função estrutural e de vedação, deveriam alcançar 30 centímetros de espessura ${ }^{45}$.

Mais tarde, nas duas primeiras décadas do século $X X$, quando começaram a ser criadas escolas voltadas para a formação profissional para atender a expansão industrial experimentada pelo Estado de São Paulo, Ramos de Azevedo projetou Escola Profissional Bento Quirino. Inaugurada em 1918, foi uma de suas últimas obras em Campinas $^{46}$. O projeto pretendia atender a um desejo registrado no testamento de Bento Quirino - o introdutor de Ramos na maçonaria, vereador pelo Partido Republicano na

${ }^{42}$ CARVALHO, Maria Cristina Wolff de. Ramos de Azevedo. São Paulo, Editora da Universidade de São Paulo, 2000, p. 159.

${ }^{43}$ MONTEIRO, Ana Maria Reis de Góes. Ramos de Azevedo: Presença e atuação profissional Campinas: 1879-1886. Dissertação de Mestrado PUC C, 2000, p. 224.

44 Após a Proclamação da República, o ensino escolar foi totalmente reformado, constituindo um novo padrão, a Escola Modelo. Estruturada a partir de novas práticas pedagógicas, tais práticas foram rigorosamente seguidas pela Primeira Escola Modelo, em São Paulo, implicando significativo impacto no programa arquitetônico do edifício que a abrigava. Seu conceito foi primeiramente aplicado à Escola Normal, do jardim de infância aos quatorze anos, sendo posteriormente estendido a todo ensino público do Estado de São Paulo.

45 LOUREIRO, Maria Amélia Salgado. A Evolução da casa Paulistana e a Arquitetura de Ramos de Azevedo. São Paulo, Voz do Oeste e Secretaria do Estado da Cultura, 1981, p. 33.

${ }^{46}$ PRÉDIO do Colégio Bento Quirino. Folha de São Paulo, São Paulo, 17 jul. 1987 (Artigo encontrado na Biblioteca do Centro de Memórias da Unicamp). 
época da Monarquia, um homem intimamente envolvido em muitos projetos campineiros. Bento Quirino - um dos fundadores do Colégio Culto à Ciência e da Companhia Campineira de Água, além de presidente da Cia. Mogiana - deixara manifesto, em seu testamento, que desejava a construção de uma escola profissional, masculina e gratuita, dedicada aos pobres.

Também já no início do século XX, Ramos de Azevedo teve a oportunidade de atuar como paisagista e interveio de forma bastante significativa em um dos pontos que se tornaria referencial em Campinas: remodelou o que era então o Largo Correia de Melo, um local tomado pelo capinzal e por brejos, com lixo amontoado por todos os lados, dividindo espaço com as lavadeiras que por lá estendiam suas roupas em varais improvisados. A partir dessa intervenção paisagística, a praça passou a ser chamada de Praça Carlos Gomes, em homenagem ao maestro campineiro, ganhando monumentos e as palmeiras imperiais que anelam seu interior ${ }^{47}$.

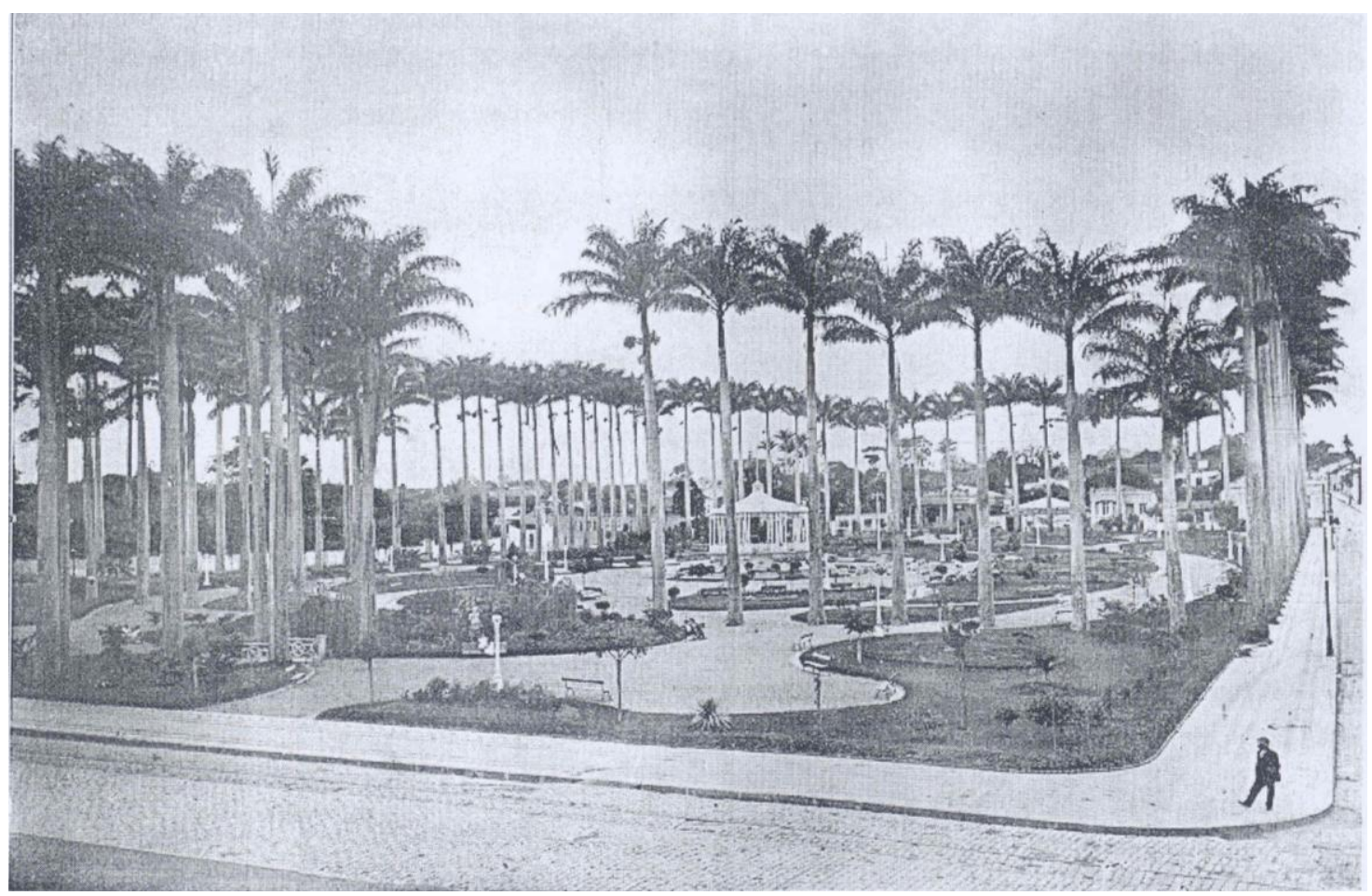

Figura 05: Vista da Praça Carlos Gomes remodelada ${ }^{48}$

\footnotetext{
${ }^{47}$ Site da Prefeitura Municipal de Campinas:

http://www.campinas.sp.gov.br/portal_2003_sites/conheca_campinas

${ }^{48}$ MONTEIRO, Ana M. R. de Góes. Ramos de Azevedo: Presença e atual profissional em Campinas: 18791886. Dissertação apresentada à Faculdade de Arquitetura e Urbanismo da PUC-Campinas para a obtenção do grau de Mestre, 2000, p. 250.
} 


\subsection{O papel azevediano}

Ainda no final do século XIX, algumas novas tendências para as construções urbanas foram se impondo - como a inutilização da alcova, dando lugar a quartos que se abriam para a luz natural, bem como a adoção do corredor lateral para aeração dos ambientes. Ramos de Azevedo seguiu à risca tais tendências, ao mesmo tempo adotando-as e promovendo-as, além de frequentemente lançar mão do recurso de recuar a casa em relação ao alinhamento da rua - além do recuo lateral - dando espaço para a formação de jardins, ainda que pequenos, entre o edifício e a calçada ${ }^{49}$. A questão da salubridade e da higiene das edificações, então atendida com recursos de arejamento e iluminação - até então relativamente ignorada nas tradições construtivas do Brasil tornou-se presente em quase todas as obras do arquiteto - como é possível constatar na Escola Francisco Glicério e na Cadeia Pública em Campinas. A mesma atitude projetual também valeu para residências das classes de menor poder aquisitivo e para as casas de aluguel, construídas pelos italianos. Essas casas tinham porão alto e entradas laterais com portões de ferro que davam para o novo corredor que surgia com a adoção do recuo lateral - e sempre reproduziam o mesmo estilo ${ }^{50}$. Os edifícios, que até então não atendiam a nenhum rigor formal sistematicamente instituído, passaram a ganhar aplicações ecléticas, conciliando diversos elementos de estilos históricos como o Neoclássico e o Neogótico - mesmo que este último, em estado puro, não fosse muito valorizado no Brasil. Esses ornamentos ecléticos trouxeram movimento e uma razoável variedade para as fachadas, mas, ao mesmo tempo e paradoxalmente, asseguravam uma certa homogeneidade ${ }^{51}$, pois acabavam respeitando os novos padrões de composição, articulando platibandas, frisos e gabaritos aos novos modos de se produzir a construção $^{52}$. A utilização de vestíbulos - uma espécie de hall de distribuição na entrada das residências, um recurso bastante presente na Europa daquela época - foi outra importante inovação que, segundo Lemos ${ }^{53}$, foi trazida por Ramos para o Brasil. Até então e seguindo a herança colonial, as casas eram providas apenas de varandas que, pela sua condição de área externa, não propiciava a mesma funcionalidade dos vestíbulos europeus. Essa nova área, destinada à locomoção de um cômodo para outro e

49 LEMOS, Carlos. A. C. Alvenaria Burguesa: Breve história da arquitetura residencial de tijolos em São Paulo a partir do ciclo econômico liderado pelo café. São Paulo, Nobel, 1985, p.55.

50 REIS FILHO, Nestor Goulart. Quadro Arquitetura do Brasil. São Paulo, Perspectiva, 1970 p. 46.

${ }^{51}$ FABRIS, Annateresa. Ecletismo na Arquitetura Brasileira. São Paulo: Nobel, Editora da Universidade de São Paulo, 1987, p.70.

${ }^{52}$ A Lei no 43 de 1895 estabelecia normas de higiene para as construções dentro do perímetro urbano, definindo a porcentagem máxima de ocupação dos lotes e as medidas dos pés direitos. Ramos de Azevedo deixou um manuscrito que completa essas legislações, em parceria com Luiz Augusto Pinto, intitulado "Projeto de Código de Posturas, arruamento, nomenclatura, construções, etc.".

53 LEMOS, Carlos. A. C. Alvenaria Burguesa: Breve história da arquitetura residencial de tijolos em São Paulo a partir do ciclo econômico liderado pelo café. São Paulo, Nobel, 1985, p.55. 
à distribuição de fluxos, propiciava um recurso muito útil para o conforto da moradia e foi, para além de mero apetrecho de ostentação, rapidamente assimilada pelas classes médias.

Entre os palacetes que passaram a concorrer com os sobrados antigos, estão algumas residências projetadas por Ramos de Azevedo, como a Residência Azurem Costa - adornada com rica ornamentação em ferro fundido e com pilares de sustentação da varanda feitos com o mesmo material; a Residência Horácio Antônio da Costa; e a Casa Lafayete Álvaro de Sousa, todas em Campinas. Nesse momento, Ramos de Azevedo já era conhecido como o arquiteto dos "projetos chave-na-mão", pela rapidez com que respondia a suas demandas e o curto período dispensado entre a contratação do projeto e o final da obra.

Essa mudança dos métodos construtivos e nos decorrentes modos de organização da mão de obra - além de uma relativa facilidade para importação de componentes construtivos - permitiu novos partidos e programas arquitetônicos. Ramos de Azevedo, usufruindo de suas habilidades e do círculo social do qual fazia parte, praticamente construía as obras que quisesse e conseguia promover vários empreendimentos ao mesmo tempo. Como gerenciador de projetos e obras, Ramos de Azevedo

"conseguiu a proeza de comandar os técnicos de fora, e isso era, para os conterrâneos, um fato sobrenatural. Foi o agente cultural que mostrou aos patrícios a nova ordem, a outra concepção de vida moderna dentro do novo modelo arquitetônico. Quis varrer das cidades a melancólica fisionomia caipira decorrente da taipa de pilão" ${ }^{24}$.

Ramos de Azevedo nutria uma indiscutível paixão pelos materiais e técnicas, a qual o levou a aplicar os conhecimentos que aprendera com os arquitetos do velho mundo com o cuidado de quem introduz 'ideias estranhas em terra estranha', compatibilizando, com muito rigor, linguagem arquitetônica e técnica construtiva, incorporando as tradições europeias numa 'arquitetura brasileira', que agora se pretendia não mais colonial. Apesar da falsa impressão que muitas vezes fica, quando os discursos esbarram num certo tom laudatório sobre o real alcance da prodigalidade de Ramos de Azevedo, é certo, contudo, que a adoção do ecletismo demandava recursos técnicos e materiais até então inexistentes no Brasil: tratava-se de aqui instaurar um processo civilizatório, de emoldurar com fachadas mais condizentes o espírito liberal que se queria fazer prevalecer e de contribuir para a composição de uma arquitetura que rompesse

${ }^{54}$ CAMARGO, João Batista Araújo: extraído de texto cedido pelo próprio autor em entrevista concedida em Setembro de 2005. 
com o pesado lastro de nosso passado colonial. No entanto, essa arquitetura inaugurava a aplicação de novos materiais e de novas técnicas e, consequentemente, aprofundava a dependência do setor de construção civil ao mercado externo. De certa forma, tal fato não constituía nenhuma novidade: os poucos arquitetos - na verdade a maioria engenheiros estrangeiros - que atuavam no Brasil naquele período, limitavam-se a simplesmente copiar os modelos ecléticos, em sua maioria, expressões de linguagem clássica. Ramos de Azevedo, por sua vez, praticava uma arquitetura que tinha como referência a experiência adquirida na Bélgica. No período que passou em Gante, Ramos conviveu com uma cidade que passava por uma grande expansão urbanística, sendo que um dos principais responsáveis pelos projetos da municipalidade era seu professor na Escola Especial de Engenharia, Adolphe Pauli. Por outro lado, os projetos de inspiração neogótica que o engenheiro-arquiteto plantou no cenário nacional também traziam o traço da construção aprendida com Louis Cloquet - que substituiu Pauli na Escola Especial. Foram essas influências que acabariam levando Ramos de Azevedo a experimentar o Art Nouveau ${ }^{55}$, agora traduzido num modo eclético e utilizando uma grande variedade de novos materiais e técnicas.

Numa sociedade que passava a reverenciar "as principais virtudes burguesas: o espírito de iniciativa, a determinação, a larga capacidade administrativa, o prestígio social e o sucesso financeiro" ${ }^{56}$, Ramos soube corresponder ao imaginário do "grande empreendedor', - além de, muito provavelmente, poder contar com um círculo de amizades bastante poderoso, como já procuramos enunciar. Tido como um "idealista", Ramos apresentava muita desenvoltura e habilidade para lidar com as ideias novas e ampla capacidade de colocá-las em prática, superando de modo astucioso as limitações de seu tempo e acumulando a experiência que lhe assegurava uma aguçada visão de oportunidade. Num contexto que se alinhava a partir de novos pressupostos para a sustentação política do poder econômico que se consolidava, sua obra sabia corresponder às demandas por um corolário "civilizatório" que estruturava uma nova estilística construtiva: cuidado com a composição, novidade e qualidade no desenho de implantação e aprimoramento na distribuição e articulação dos espaços e massas do edifício. O grande conhecimento que acumulara sobre técnicas construtivas articulava-se

\footnotetext{
55 Segundo Maria Amélia Salgado Loureiro, todas as edificações, na arquitetura colonial, independente das classes sociais, eram construídas com os mesmos materiais, apenas com distinção quanto à área construída. As casas dos ricos e dos pobres eram rigorosamente iguais, com os mesmos materiais e estilos, só mudando o número de cômodos das edificações destinadas a mais dos ricos. A arquitetura brasileira, que se mantinha fiel às tradições coloniais, passou a se modificar só no final do século XIX, com o aparecimento do Art Nouveau que passou a ser muito utilizado em São Paulo, representando a transição entre o revival Clássico e o Modernismo. Utilizando de forma vigorosa o artesanato e as artes aplicadas, Ramos de Azevedo incorporou este estilo em muitas das suas obras.

${ }^{56}$ Site do Arquivo Histórico Municipal de São Paulo: http://www.fotoplus.com/dph/info01/index.html.
} 
com as ordens de uma concepção de beleza que dava forma às expectativas da elite que agora assumia posto com a economia cafeeira.

Para que o ecletismo fosse possível por aqui, Ramos percebeu a necessidade de promover alguma industrialização no setor da construção, sem o que a equação que articula práticas construtivas, materiais aplicados e processos de organização da força de trabalho não sustentará o que enunciamos aqui como tecnologia da arquitetura e do urbanismo $^{57}$. Dessa forma, o ecletismo aparece como um processo facilitador e até mesmo promotor das transformações tecnológicas no campo das construções, assimilando essas inovações em território nacional ${ }^{58}$.

Outro aspecto que merece destaque no âmbito da sua produção profissional é o seu desempenho como adepto do urbanismo sanitarista: reverberando as concepções dos positivistas sobre modernidade, ciência e o novo status da vida urbana, os princípios que recomendava foram de grande relevância no processo de modernização da cidade que precisava ser reorganizada a partir dos novos pressupostos, dispondo de espaços diferenciados e funcionalmente especializados para atividades como escolas, matadouros, cadeias etc. Compartilhando o discurso republicano, ajudou a difundir novas concepções para as instituições de ensino, hospitais e edifícios públicos, contribuindo para a consolidação dos argumentos que justificavam a nova ordem republicana.

As análises das obras de Ramos frequentemente observam a sua importância, tanto para o período em que o engenheiro-arquiteto viveu e atuou como quanto para períodos posteriores. Considerando o seu legado histórico, suas obras registram os fenômenos arquitetônicos de época, bem como o contexto econômico, político, social e os arranjos práticos dos processos produtivos daquele momento e que formataram, sob certos aspectos, a gênese de diversos ramos de produção de materiais construtivos e componentes para a construção civil. Dessa forma, sua importância transcende a discussão dos estilos arquitetônicos, como sugere Wolff de Carvalho ${ }^{59}$ : para além da abordagem das tradições culturais que marcaram a composição arquitetônica de Ramos de Azevedo e de seus colaboradores, também o cotidiano da produção material de sua arquitetura deve ser iluminado com a devida intensidade e cuidado. Sua prática profissional e o modelo de empresariamento que viabilizou a extensão de sua atuação exigiram a capacitação de mão de obra e o incentivo à implantação de um parque industrial mínimo para a produção de matéria-prima. Para atender às demandas da

\footnotetext{
57 LOPES, João Marcos de A. Em memória das mãos: o desencantamento da técnica na arquitetura e no urbanismo. Tese de Doutorado apresentada ao Departamento de Filosofia do Centro de Educação e Ciências Humanas da Universidade Federal de São Carlos - UFSCar, abril 2006.

${ }^{58}$ REIS FILHO, Nestor Goulart. Quadro da Arquitetura do Brasil. São Paulo, Perspectiva, 1970, p. 185 e 186.

59 CARVALHO, Maria Cristina Wolff de. Ramos de Azevedo. São Paulo, Editora da Universidade de São Paulo, 2000, p. 15.
} 
arquitetura que realizava - uma arquitetura profundamente comprometida com os pressupostos estéticos e construtivos de além-mar - tornava-se necessária a importação de materiais de origem europeia, exigindo, além de um criterioso e cuidadoso planejamento comercial, também uma sólida estrutura administrativa. Para tanto, Ramos passou a atuar no comércio de materiais como madeira, cal, mármore e granito, ou seja, na promoção de empreendimentos comerciais relacionados ao fornecimento de materiais para construção civil. Também empresariou empreendimentos de grande e pequeno porte, ligados a bancos, serraria e cerâmica, entre outros, abrindo caminho para que a matéria prima fosse produzida aqui mesmo no Brasil, reduzindo os tempos e os custos despendidos com os serviços de importação.

Quanto à formação da mão de obra que atuava nas obras que empresariava, Ramos de Azevedo parece ter compreendido como aproveitar as vantagens de articular organicamente o conhecimento promovido pela formação acadêmica e aquele adquirido com a prática dos ofícios. Por um lado, fundou com Paula Souza, juntamente com outros cinco professores, a Escola Politécnica de São Paulo. Ali, ministrava aulas em duas matérias: Arquitetura Civil - Higiene das Habitações e Elementos de Edifícios - e Composição Geral. Concomitantemente, em 1895 assumiu a direção do Liceu de Artes e Ofícios de São Paulo - que já existia desde 1873, criado por um grupo de aristocratas pertencentes à elite cafeeira nacional, e promoveu uma radical remodelação do curso, agora instalado em um novo prédio (atual Pinacoteca do Estado, junto ao Parque da Luz, centro da capital paulistana), cujo projeto era de sua autoria. Segundo Maria Cristina Wolff de Carvalho, Ramos de Azevedo, no comando de seu escritório em São Paulo, conciliava a diversidade de concepções de seus colaboradores e aplicava a mesma postura no ensino da Politécnica e de Artes e Ofícios. É exatamente essa atuação sincrônica, que solidarizava as atividades como empresário e construtor com aquelas que conduzia como diretor e professor - ainda que essa realização fosse menos conhecida, segundo Marcovitch ${ }^{60}$ - que não pode ser compreendida sem pensá-la dessa forma. É incontestável - até mesmo pelo tanto que a herança da Politécnica ainda persiste - o quanto essa articulação sincrônica abrangia mais que a arquitetura em si, estendendo-se para diversos aspectos da construção civil e de processos de produção do edifício e da cidade. Dessa forma, tanto o Liceu como a Escola Politécnica parecem essenciais para a cidade de São Paulo que, como já comentado, vivia profundas transformações com a abolição da escravatura e a concentração da renda cafeeira - além da intensificação da entrada de trabalhadores livres europeus. Era assim que se ia formando o ainda incipiente mercado consumidor e se preparava terreno para a "modernidade urbana": o

${ }^{60}$ MARCOVITCH, Jacques. Pioneiros \& Empreendedores - A Saga do Desenvolvimento no Brasil. Volume 1. São Paulo, EDUSP 2003, p.137. 
processo de industrialização, que transformou São Paulo e cidades como Campinas em polos urbanos, intensamente industrializados ${ }^{61}$.

Muito do que se atribui como o papel do arquiteto nos dias de hoje certamente encontra fundamentos no período em que Ramos de Azevedo viveu na Europa. A Universidade de Gante, na Bélgica, promoveu a criação da Écoles du Génie Civil et Arts et Manufactures, em 1838. O curso era voltado para a construção, hidráulica, mecânica e matemática, além de também se ocupar com as "leis de harmonia e origem e estudo das ordens gregas e romanas e suas aplicações", tornando o seu ensino de Arquitetura mais completo que o da Academia de Belas Artes. Consolidando o ensino de arquitetura, o curso passa por uma série de reformulações no período entre 1863 e 1869, que vigoraram justamente na época em que Ramos de Azevedo ali se encontrava ${ }^{62}$. Até então, o ensino de arquitetura dava-se principalmente na Academia de Belas Artes (pautada pela École de Beaux-Arts de Paris). O curso, contudo, não gozava de autonomia em relação ao ensino das demais belas artes (pintura e escultura) e por muito tempo o real sistema de aprendizado de arquitetura deu-se junto às "lojas" ${ }^{63}$ e nos canteiros de obras. Apenas no final do século XVIII é que os arquitetos de ofício começaram a se preocupar com aspectos ligados à estrutura e materiais de construção. A Escola Especial - que nascera junto com independência do país, ao se desmembrar da região norte (atual Holanda), provocara a reestruturação do sistema de ensino, no qual após alguns anos uniu as três antigas universidades estatais de Gante e Liège, fundadas em 1816 por iniciativa do Rei Guilherme I em uma só universidade ${ }^{64}$ - manifestava uma grande empolgação com as novas possibilidades que surgiam com o emprego do ferro na arquitetura e apontava para, além do uso de uma nova técnica, a liberdade de adequar a forma mais aos materiais e às necessidades correspondentes.

A Universidade de Gante também seguia o modelo francês, influenciada pelos preceitos positivistas que circulavam pelos ambientes acadêmicos da época - como o culto à razão e à ciência - e priorizava a metodologia projetual que se pautava pela geometrização e, muitas vezes, pela repetição, como defendia o Professor Jean Nicolas Louis Duran. Também aparecia, como conteúdo de ensino, preceitos de proporção e de sua articulação com forma, técnica e materiais, destacando sua aplicação nas artes decorativas, nas aulas dadas pelo Professor Adolphe Pauli. Nos estudos das tipologias, e

${ }^{61}$ FISCHER, Sylvia. Ensino e Profissão: O Curso de Engenheiro Arquiteto da Escola Politécnica de São Paulo. 1989, São Paulo, p. 28.

62 CARVALHO, Maria Cristina Wolff de. Ramos de Azevedo. São Paulo, Editora da Universidade de São Paulo, 2000, p. 65.

${ }^{63} \mathrm{Na}$ Bélgica, segundo Maria Cristina W. de Carvalho, as lojas maçônicas ainda não tinham desaparecido totalmente em meio ao crescimento das academias de arquitetura, muitos ainda se formavam mestres com o aprendizado secreto, nos ateliês e nos canteiros de obras (Idem, p. 80).

64 Ibidem, p. 67. 
também nos tratados da concepção formal de projetos (como Vignola, Alberti, François Mansard, Delorme), podemos reconhecer as fontes da "arte de construir" de Ramos de Azevedo, só que agora aplicadas nos novos programas: a mesma composição formal repete-se, abrigando funções diversas (tipologias diferentes). Nesse período, tal expediente de projeto não constituía mais um dogma intransponível, preconizava-se até mesmo uma ampla liberdade ao se projetar a articulação entre forma e função, quebrando uma regra clara dos períodos passados. Mas, por outro lado, parece-nos que as relações entre estilo arquitetônico e os aspectos técnicos funcionais do edifício aprendidas na Universidade de Gante - que basearam e fundamentaram solidamente a formação do engenheiro-arquiteto - este é sim um aspecto diferenciador que se destaca na atuação profissional de Ramos de Azevedo, que demanda apurada capacidade técnica e criativa, deixando transparecer uma indefectível exigência por detalhes e alto nível de qualidade nas obras (tanto na concepção quanto na execução), baseados nas recomendações de higiene e na mais alta tecnologia da época ${ }^{65}$.

No Brasil, a criação das escolas politécnicas foi igualmente vinculada ao movimento positivista, com ênfase no ensino aplicado de geometria e de aritmética. $O$ modelo da Politécnica paulista foi baseado nas Technische Hochschule, "no ensino prático, porém baseado em ciências aplicadas às artes e indústrias" ${ }^{66}$. As aulas pela manhã eram teóricas e a tarde era reservada para projetos, laboratórios e trabalhos manuais nas oficinas. Isso, segundo Milton Vargas, levou à valorização da pesquisa tecnológica, sendo uma das origens, no Brasil, do Gabinete de Resistência dos Materiais, fundada pelo engenheiro e amigo de Ramos, Antônio Francisco de Paula Souza, em 1899, tendo como referência o projeto da Escola Politécnica de Zurique, onde estudara. No ano anterior, o Gabinete de Arquitetura teria sido organizado e dirigido por Ramos de Azevedo, que formou uma notável coleção de modelos dos principais sistemas construtivos. Segundo o mesmo autor, com Ramos na diretoria da Poli - que assumiu por ocasião da morte do seu amigo Paula Souza - e o seu papel de construtor, o campo da indústria da construção civil teria prosperado significativamente, originando daí a possível síntese entre engenharia civil e arquitetura que predomina até hoje em São Paulo ${ }^{67}$.

O positivismo na Europa, ainda no início do século XIX, ao mesmo tempo em que ia ao encontro dos interesses da nova classe burguesa-industrial em ascensão, também dali emanava e dali retirava seus pressupostos. A necessidade de uma "ideologia", que articulasse os seus interesses e lhes atribuísse a aparência de suporte legal naturalizado,

65 FARAH, Ana Paula. A produção do Engenheiro Arquiteto Francisco de Paula Ramos de Azevedo na Província de São Paulo. Tese de Mestrado, Escola de Engenharia de São Carlos, 2003, p. 66.

${ }^{66}$ VARGAS, Milton (coord.). Contribuições para a História da Engenharia no Brasil. São Paulo: EPUSP, 1994, p. 18.

7 Ibid., p. 19. 
era essencial para o enfrentamento dos problemas sociais e as diversas manifestações da luta de classes. Seu princípio fundamentava-se no progresso do homem e tinha como base preceitos emprestados do corolário cristão: o amor, a fraternidade e o respeito ao próximo. Divulgar o conhecimento científico, objetivo, racional e em obediência às leis imutáveis da natureza era tarefa fundamental da nova categoria social que se instalava como elite política e econômica no país. Por aqui, penetrou primeiro nas Escolas Militares e em algumas Academias de Direito - pois, nessa época, era onde se localizavam os principais centros de reprodução de conhecimento. E por aqui fincou raízes profundas, influenciando até mesmo no dístico da bandeira nacional, com o lema "Ordem e Progresso".

Por outro lado, a maçonaria também serviu, por essas bandas, como veículo para a propagação dos anseios iluministas de liberdade de pensamento e do lema adotado pela revolução francesa - "Liberdade, Igualdade e Fraternidade", os epígonos de um discurso considerado fundamental para a consolidação da independência brasileira. Como anunciavam - e anunciam - seus defensores, "o lluminismo e a maçonaria encontram-se nas raízes da libertação do novo mundo"68. Além disso, a maçonaria também teria contribuído para a formação da nova "elite liberal", que se auto-destinaria a definir os novos rumos republicanos do país ${ }^{69}$, desde os inconfidentes como José Joaquim da Silva Xavier, conhecido como Tiradentes, assim como José Bonifácio, o próprio Marechal Deodoro da Fonseca, Francisco Glicério e Prudente de Moraes, entre outros. São personagens da nossa história que iriam levar seus compromissos, interesses ou convicções até a Proclamação da República, sendo os dois últimos reconhecidos amigos de Ramos de Azevedo. Nesse período, a capital paulistana já contava com quatro lojas maçônicas, todas voltadas às práticas filantrópicas, articuladas numa espécie de sociedade de socorros mútuos ${ }^{70}$. Ao lado dos republicanos, professando os pressupostos positivistas - e ligado à maçonaria -, Ramos de Azevedo circulava com facilidade entre diversos grupos de poder - o que, certamente, correspondia a uma destacada capacidade de articular-se em ambientes diversos com tolerância e, por vezes, em oposição ${ }^{71}$.

\footnotetext{
68 BANDECCHI, Brasil. A Bucha, a Maçonaria e o Espírito Liberal. São Paulo: Editora Parma, 1982, p. 14.

${ }^{69}$ CASTELLANI, José. A maçonaria e o movimento republicano brasileiro. Traço Editora, 1989, p. 45.

70 Em sua origem, a maçonaria está ligada a uma elite artesã e manufatureira, desde o início da Idade Média, em que seus integrantes são admitidos a compartilhar dos segredos de uma 'arte liberal' (como pedreiros e fundidores), cujo ensino se dava nas oficinas e "lojas" de ofícios e que tinha como objetivo a ajuda mútua e a defesa do grupo. Com o advento da Modernidade, a organização prevalece, também de forma corporativa, mas agora como elite política e propugnadora de condutas ético-morais: mais importante para os maçons era - e ainda seriam, no período em questão - a irrestrita conduta, de honra, respeito e civilidade.

${ }^{71}$ MARCOVITCH, Jacques. Pioneiros \& Empreendedores - A Saga do Desenvolvimento no Brasil. Volume 1. São Paulo, EDUSP 2003, p.134.
} 
Após esta breve exposição sobre a obra de Ramos de Azevedo e algumas de suas implicações, acreditamos possível atestar como se faz necessário um amplo estudo do processo histórico no qual ela se insere para um conhecimento mais apurado das técnicas utilizadas na arquitetura daquele período e suas variações: a técnica construtiva de um determinado contexto corresponde à totalidade do aparato tecnológico empregado na configuração material e cultural daquele contexto ${ }^{72}$.

Nesse sentido, este trabalho propõe colocar aspectos deste contexto em evidência para que sirvam de parâmetro de comparação e contraste no estudo das técnicas utilizadas por Ramos de Azevedo. Além de se tratar de uma abordagem no próprio campo tecnológico e de assim situar suas diferentes práticas, este estudo se propõe a chamar a atenção para uma necessária inter-relação entre esses diferentes campos: Ramos de Azevedo destacou-se pelo conhecimento aprofundado e pelo estudo apurado das relações entre forma e função, mas no sentido de perscrutar as relações entre a "ciência da construção" e a "ciência da história"73. Reconhecidamente complementares para o exercício de projeto, praticamente inexiste, por outro lado, o tratamento combinado desses dois campos de conhecimento na literatura arquitetônica nos dias de hoje.

A análise da obra de Ramos de Azevedo aqui proposta pretende, portanto, contribuir para a melhor compreensão das implicações entre técnicas construtivas utilizadas no período e pelo engenheiro-arquiteto - e aspectos do contexto histórico, econômico, político, social e cultural local - pensado, inclusive, como fenômeno urbano -, tendo no horizonte o papel azevediano de precursor do Modernismo e da Modernidade principalmente em terras paulistas e paulistanas - e como agente importante para a instalação de uma modalidade de capitalismo industrial em terras brasileiras.

\footnotetext{
72 MARCUSE, Herbert. "Algumas implicações sociais da tecnologia moderna" in Praga - revista de estudos marxistas. São Paulo, Jinkings Editores Associados, 1997 ( $\mathrm{n}^{\circ} 1$ set/dez 1996 - original de 1941).

${ }^{73}$ CARVALHO, Maria Cristina Wolff de. Ramos de Azevedo. São Paulo, Editora da Universidade de São Paulo, 2000, p. 101.
} 


\section{PANORAMA HISTÓRICO: FORMAÇÃO INDUSTRIAL}

\subsection{Economia do café: da manufatura à indústria}

A fazenda Pau d'Alho, como visto no primeiro capítulo, antes de pertencer ao Comendador Manuel Aranha, fazia parte de uma extensa área que compreendia ainda duas outras fazendas, a Santa Cândida e a Anhumas. Situadas na região onde se concentravam inúmeros engenhos campineiros - como relata Silvia Palazzi Zakia na pesquisa histórica que instrui o processo de tombamento da fazenda ${ }^{1}$-, aquela região correspondia plenamente ao comentário do engenheiro português Luiz D’ Alincourt, de passagem pela cidade no início do século XIX: "Todo o terreno de Campinas é ótimo para a plantação de cana... O lugar chamado Anhumas tem primazia entre os mais para dita plantação...”.

Ainda que não seja comprovado que a fazenda produzira açúcar, por falta de dados iconográficos e documentos ou mesmo resquícios da atividade que atestem a prática da lavoura de cana em algum período naquela propriedade, é certo que sua infraestrutura produtiva sofreu, ao longo de um curto período de tempo, profundas transformações, decorrentes das alterações econômicas da época que implicaram o estabelecimento de uma nova base técnica de produção. Esse aparato produtivo estruturava-se, então - com a proclamação da República - , com o advento da lavoura de café, com a abolição da escravatura e com a entrada do trabalhador assalariado e imigrante - sobre novos padrões de mecanização, outras matrizes de geração e transmissão de força motriz, outros arranjos de financiamento e securitização da produção etc. Ora, seria esse processo, de profunda transformação da estrutura de produção, que arrastaria todo o arcabouço superestrutural também em direção ao turbilhão de mudanças experimentadas no período, estabelecendo novas configurações para as dinâmicas sociais e culturais até então definidas pela lógica colonial. Com o intuito de compreendermos as mudanças na cultura construtiva, ocorridas na cidade de Campinas e no Estado de São Paulo, no período de atuação de Ramos de Azevedo, aprofundaremos o estudo dessa reacomodação da base produtiva, para então adentraremos propriamente no universo da Fazenda Pau d'Alho.

\subsubsection{Em Campinas}

A Fazenda Pau d'Alho vinculava-se a uma cidade de fortes relações comerciais. Atendendo às regiões mais remotas do Estado, Campinas movimentava uma ampla

\footnotetext{
${ }^{1}$ Condepacc: Processo de Tombamento no 042, data de abertura 16 de dezembro de 2004.
} 
diversidade de mercadorias, recebendo algodão, toucinho, feijão, queijo, etc., em troca de sal, ferramentas e artigos importados ${ }^{2}$. Essa posição de pólo comercial e entreposto regional reafirmou-se na década de 1850 , quando a província foi atingida pelo avanço dos cafezais vindos do Vale do Paraíba - apesar de vir mantendo uma produção de café significativa desde 1835, paulatinamente substituindo o cultivo da cana de açúcar. 0 preço internacional do café, a disponibilidade de terra e a força de trabalho sem qualificação - antes apenas empregada no corte da cana e nos afazeres da produção de açúcar - levaram os senhores de engenho a investirem definitivamente no plantio do café.

Nesse período, a cidade era um dos maiores núcleos de população de escravos, a qual sobrepujava a população branca e protagonizaria diversos conflitos, deflagrados ou não. Há vários registros sobre as atividades dos escravos, relatadas por Julio Mariano $^{3}$, na maior parte traduzidas em conflitos, como o levante de negros em 1830; a agitação dos escravos de Indaiatuba - que poderia influenciar no comportamento dos escravos de Campinas - que em 1848 fugiram para Itu; além do versado conflito entre escravos e seu feitor em 1853, num cafezal em Valinhos denominado Capuava - daí o incidente conhecido como o "Crime de Capuava". Os negros continuavam sendo a maioria mesmo depois do fim do tráfico negreiro, em 1850, e até a década de 1870, quando Campinas contava com 20 mil escravos dentre 33 mil habitantes ${ }^{4}$. Muitos deles competiam com a mão de obra livre, ainda antes do fim do tráfico negreiro, na década de 1840: "o negro cativo que não labutava nas fazendas costumava ser cedido em aluguel pelo dono ao preço de 300 a 400 réis por dia", segundo Júlio Mariano, enquanto ao trabalhador livre pagava-se, em média, 600 réis pela mesma jornada de trabalho Entre eles havia bons pedreiros, ferreiros, calceteiros e sapateiros ${ }^{5}$.

Mas o negro haveria de, por sua vez, compartilhar afazeres, no campo e na cidade, com uma nova categoria de trabalhadores livres: os imigrantes. Os primeiros colonos estrangeiros, entretanto, destacavam-se pela sua formação industrial, principalmente os alemães, que eram habilidosos técnicos e artesãos. Instalando-se pelos bairros da cidade, foram ele que montaram as primeiras oficinas de consertos de veículos, chapelaria, sapataria e comércio em geral, segundo dados das indústrias

\footnotetext{
2 PUPO, Celso Maria de Mello. Campinas, seu berço e juventude, Campinas: Publicações da Academia campinense de Letras, 1969, p. 20.

3 MARIANO, Júlio. Campinas de ontem e ante-ontem; quadros históricos menos conhecidos da Cidade Princesa, que se traçaram tendo por base documentos inéditos do Arquivo da Câmera Municipal de Campinas. Campinas, Editora Maranata, 1970, p. 57.

${ }^{4}$ Badaró, Ricardo de Souza Campos. Campinas, o despontar da modernidade. Campinas, CMU/ UNICAMP, 1996, p. 26.

5 Idem, p. 11.
} 
campineiras de Silvério Godói ${ }^{6}$. Esse processo de transformação econômica foi bastante sensível, tendo em vista o rápido crescimento da cidade, materializado por novas ruas, construção de novos prédios e criação de novos espaços culturais.

Já na década de 1850, quando se instalavam as primeiras indústrias na cidade, foi inaugurada a Indústria de Chapéu Santa Cruz Bierrenbach (em 1857) e a Fundição Farber (no Bonfim, em 1858) ${ }^{7}$. No que se refere a alguma ainda insipiente 'indústria de componentes para a construção civil', em 1860, foi aberta a primeira olaria mecanizada, conforme mencionada em registros, a olaria Sampainho ${ }^{8}$ (ver Figuras 01 e 01A). Nessa década, os engenhos da região já eram equipados com modernos equipamentos de serrar e máquinas agrícolas importadas da Lidgerwood MFG Co., instalada na cidade em 1862. A par dessa vigorosa intensificação nos processos de mecanização da produção, a cidade foi assolada por uma das primeiras de muitas epidemias que viriam a seguir: a "peste das bexigas", considerada como casos esporádicos de varíola benigna?

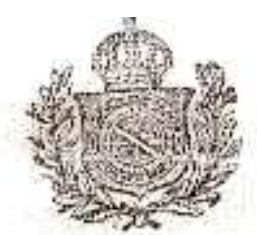

Na Imperial Ferraria e Olticina mechanica de A. C. Stompaio Peixoto, incumbe-se Itc mandar fazer oplimos separadores de wate a 5005000 cada um, e bem assim vende-se chapas de zinco para os mesmos a $50 \div 000$ cada ume, e se ellas lorem de ferro ou cołre eustarão um pouco mais.

Campinas 18 de Feveruto fie 1870 ti-1

Figura 01: Propaganda da Olaria Sampainho na Gazeta de Campinas, de $1871^{10}$

\footnotetext{
${ }^{6}$ SERVIÇO GRÁfICO BRASILEIRO DE GEOGRAFIA E ESTATístiCA, Monografia História do Município de Campinas. Rio de Janeiro, 1952, p. 525.

7 CAMILLO, Ema Elisabete Rodrigues. Guia Histórico da Indústria Nascente em Campinas (1850-1887). Campinas, CMU/Mercado de Letras, 1998, p. 22.

8 LEMOS, Carlos. Alvenaria Burguesa; Breve história da arquitetura residencial de tijolos em São Paulo a partir do ciclo econômico liderado pelo café. São Paulo, Nobel, 1985, p. 41.

9 MARIANO, Júlio. Campinas de ontem e ante-ontem; quadros históricos menos conhecidos da Cidade Princesa, que se traçaram tendo por base documentos inéditos do Arquivo da Câmera Municipal de Campinas. Campinas, Editora Maranata, 1970, p. 72.

${ }^{10}$ Figura 01 e Figura 01A: CAMILLO, Ema E. R. Guia Histórico da Indústria Nascente em Campinas (1850-1887). Campinas, CMU /Mercado de Letras, 1998, p. 71.
} 


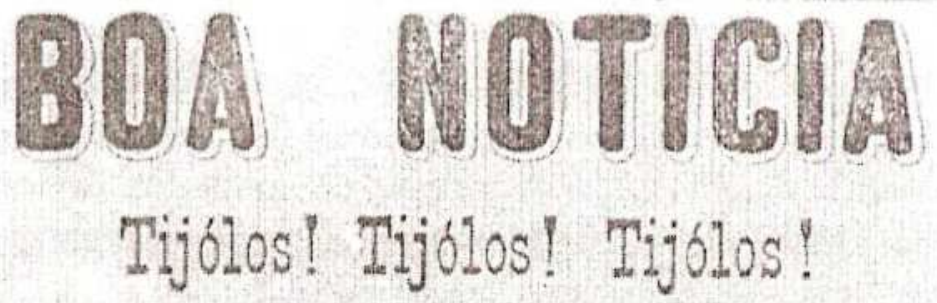

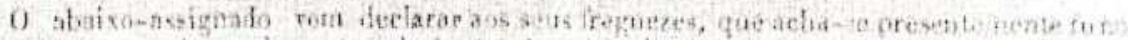

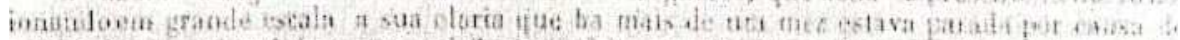

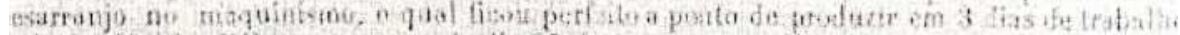

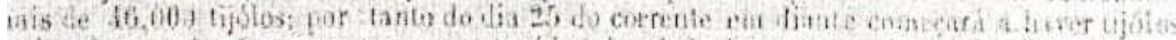

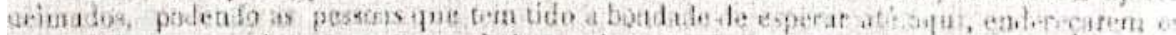

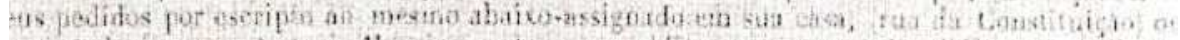

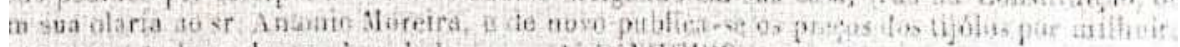

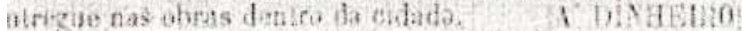

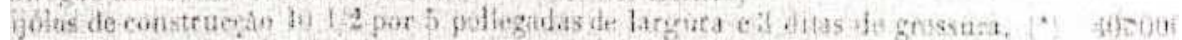

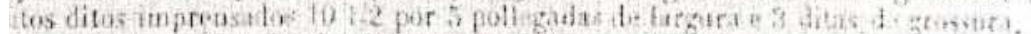

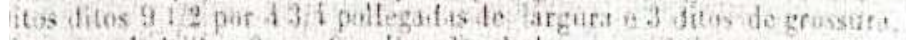

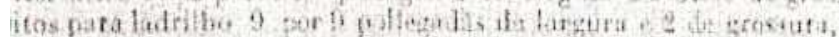

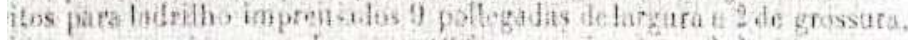

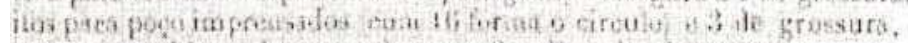

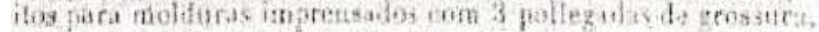

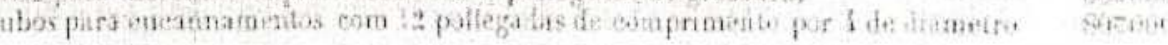

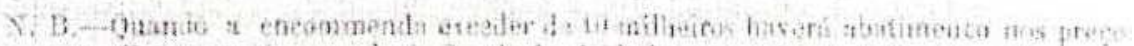

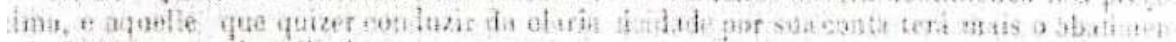

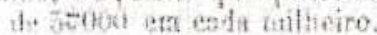

* Eata medina é ingleza.

Figura 01A: Propaganda da Olaria Sampainho na Gazeta de Campinas, de 1877

A significativa ampliação do número de novas indústrias e o avanço da economia cafeeira fizeram a antiga tradição construtiva sucumbir frente às novidades que se impunham naquele período. Até meados do século XIX, essa tradição baseava-se na técnica de paredes de taipa socada ou de mão, cobertas com estruturas de madeira e com telhas de barro do tipo capa e canal. O trabalho com a madeira também experimentou um significativo desenvolvimento, deixando as técnicas mais artesanais para bem equipados engenhos de serrar. A região de Campinas concentrava o maior número dessas unidades industriais em meados de $1860^{11}$. A infra-estrutura que se instalava, contudo, ainda era de muito pequeno porte para atender ao mercado da construção civil local, que importava materiais e até mesmo mão de obra de outras regiões. Além de lutar para perder seu ar interiorano, emoldurado pela tipicidade da construção com taipa de pilão, agora, com o incremento na produção do tijolo de barro cozido e com o advento das tipologias assobradadas, Campinas também suspirava pela adoção das linhas neoclássicas em suas edificações, mais condizente com as aparências que pretendia afirmar. Mas, para tanto, era necessário também o incremento da produção de materiais de construção e da oferta de mão de obra, tanto para a construção como para as atividades correlatas (engenharia, agrimensura e arquitetura, por exemplo).

\footnotetext{
${ }^{11}$ Telles, H. Apud SAIA (1989:138).
} 
Em 1870, segundo os registros do Almanak de Campinas para $1871^{12}$, podemos identificar, na cidade, duas olarias, dois depósitos de cal, dois depósitos de ferro e zinco, seis depósitos de madeira, três ferrarias, duas fundições de ferro e 14 lojas de ferragens (ver Quadro 1B do Anexo 1). O referido almanaque registra apenas um arquiteto, Manoel Gonçalves da Silva Cantarino (ver Quadro 1A do Anexo 1). Quanto à mão de obra para construção civil, a cidade contava, segundo o almanaque, com dezessete carpinteiros e mestres de obras (provavelmente, mestres carpinteiros), dois entalhadores, quatro ferradores, dez ferreiros e serralheiros, três fundidores, treze marceneiros, cinco pedreiros e mestres de obra (provavelmente, mestres pedreiros), cinco pintores, três torneiros de ferro e metais, cinco torneiros de madeira e três vidraceiros. $O$ destaque ficou por conta da Fundição Bierrembach \& Irmão, uma das mais antigas fábricas da cidade - que, como vimos, instalou-se na cidade para, inicialmente, produzir chapéus (ver Figura 02). Já em 1871, segundo Almanak de Campinas para $1872^{13}$, vemos que os engenheiros são ainda muito poucos e ainda são os mesmos do ano anterior, como o arquiteto que consta nesse registro, Manoel Gonçalves da Silva Cantarino, assim como o engenheiro agrimensor João Gonçalves Pimenta. O número de artesãos, contudo, principalmente mestres de obras, pedreiros, marceneiros e pintores, aumentou significativamente, constando trinta e dois carpinteiros e mestres de obras, dezessete marceneiros, dois entalhadores, dois fundidores de metais, seis ferradores, treze ferreiros e serralheiros, dez pedreiros e mestres de obras, oito pintores, três torneiros em ferro e metais, quatro torneiros em madeira, três vidraceiros (ver Quadro 2B do Anexo 1) - uma ampliação de 70 para 100 profissionais, quase $40 \%$ de incremento no contingente de oficiais dedicados ao ramo da construção civil.

Quanto às indústrias e instalações comerciais voltadas para o setor das construções, podemos ver que houve, nesse ano, um pequeno aumento no número de unidades, especialmente olarias (de 2 para 7), lojas de ferragens (de 14 para 17) e depósitos de madeira (de 6 para 7); no restante, continuam sendo dois depósitos de cal, dois depósitos de ferro e zinco, duas fundições de ferro e bronze. Aparece, então, referência a oito casas de importação e comissões (ver Quadro 2A do Anexo). De modo geral, Campinas seguia os passos da capital paulista em relação à abertura de novas indústrias. A quantidade de mão de obra, porém, era mais reduzida, por conta de um contingente ainda pequeno de imigrantes. Em número, foram as casas de importações as instalações comerciais que mais cresceram no período. Nesse mesmo ano, foi criado o

\footnotetext{
12 LISBOA, José Maria. Almanak de Campinas para 1871. Campinas: Typographia da Gazeta de Campinas, 1870.

${ }^{13}$ LISBOA, José Maria. Almanak de Campinas para 1872. Campinas: Typographia da Gazeta de Campinas, 1871.
} 
Banco Colonial do Estado de São Paulo, voltado para o incentivo ao crescimento industrial.

\section{Oflicina de Machinas para lavoura FLVDIÇÃO DE FERRO B BRONZE}

A VAPOR

Do IBIerrembach \& Irmão

Fabricam machinas de beneficiar café, solidas, simples e bem acabadas, custam de 1:000\$000 a $3 ; 000=000$.

Tambem fabricam brunidores, e elevadores de café, engenhos de mandioca, parafusos e prensas de mandioca, e de enfardar algodão, engenhos de serrar madeira com serra vertical ou circular, engenhos de moer canna, moinho vertical ou horisontal, transmissóes, polias de todos os tamanhos, arados, cultivadores, debulhadores, rodas hydraulicas de todos os tamanhos, etc.

Concertam toda e qualquer machina, inclusive machinas a vapor.

Fundem em ferro e bronze toda e qualquer obra.

Fabricam carroças, carros de $\mathbf{4}$ rodas, trolls ou qualquer outro vehiculo.

Tem sempre promptos: manivellas, dentaduras, trilhos, roldanas, etc., para engenhos de serra, pescocos, mancaes, etc.

Mandam vir da Europa ou Estados-Unidos, qualquer machina, mediante rasoavel commissào.

\section{CAMPINAS}

Figura 02: Propaganda da Fundição Bierrembach \& Irmão, de $1871^{14}$

Em 1872, quando a Cia. Paulista passou a fazer a ligação de Campinas com o porto de Santos, o jovem Ramos de Azevedo passou a trabalhar na ferrovia, envolvendose com a área de engenharia e auxiliando o engenheiro-chefe. Logo em seguida, começou a trabalhar na Companhia Férrea Mogiana, que acabara de ser instalada e que logo passaria a ser uma das oficinas mais completas do país, na Vila Industrial, juntamente com a Cia. McHardy, de máquinas agrícolas. Com ela foi construída a Estação Ferroviária de Campinas, em um estilo novo, o gótico-vitoriano, seguindo os padrões arquitetônicos ingleses do século XIX.

\footnotetext{
${ }^{14}$ Figura 02 e Figura 03: PESSOA, Ângelo E. da S. (Org.). Conhecer Campinas numa perspectiva histórica. Campinas: Secretaria Municipal de Educação, 2004.
} 
É nesse período que se iniciam efetivos melhoramentos urbanos e que proliferam agitações culturais na cidade. Nessa época, Campinas não parava de crescer, passava por mais transformações, ganhando novas indústrias - de couro, sabão, cerveja e alimentos - e expandindo ainda mais sua malha urbana. $O$ transporte era feito a cavalo, liteira e trole. A cidade ganhava seus primeiros bancos, enquanto no estado já existiam alguns bancos como o Banco Mercantil de Santos e London and Brazilian Bank, Banco Comércio e Indústria, Banco União de São Paulo, Banco dos Lavradores, Banco do Brasil e Banco da Província (todos fundados até 1883) ${ }^{15}$.

Essa vigorosa expansão ferroviária e industrial, acompanhada pela equivalente expansão urbana, criou novas demandas para a construção civil, exigindo a presença de profissionais qualificados para o setor. O pai de Ramos de Azevedo, o major João Martins de Azevedo, percebendo esta tendência no mercado, depois do filho trabalhar nas obras da Cia. Paulista como desenhista em 1874, incentivou-o a ingressar na engenharia civil, encorajando-o a estudar na Bélgica. É para onde Ramos, com apoio da família e amigos - inclusive políticos - viajou em 1875, rumo à Universidade de Gante.

Apesar dos avanços industriais significativos experimentados no início da década de 1870, o seu final não apresenta o mesmo ritmo de desenvolvimento: a mão de obra ainda era rara e inexperiente, sendo em sua maioria imigrantes. Segundo o Almanach Popular para o anno de $1878^{16}$, a cidade tinha ainda apenas um engenheiro agrimensor, dois torneiros, um marmorarista, dois ferradores, com duas olarias, duas fundições, seis depósitos de madeira, onze lojas de ferragens e sete marcenarias (ver Quadro 3 do Anexo 1). Esses números indicam o fechamento de alguns estabelecimentos, como o caso das olarias, que caíram de 7 para $3-$ e, portanto, com reflexos no contingente de mão de obra empregada no setor. No ano seguinte, segundo podemos ver no Almanach Popular para o anno de $1879^{17}$, a cidade registrava duas oficinas de carpinteiros e mestre de obras, onze oficinas de ferreiros e serralheiros, onze fundições de ferro, bronze e galvanizadores de metais, quatro oficinas de funileiros e latoeiros, doze fábricas de móveis, três olarias e duas serrarias a vapor. Quanto à mão de obra, havia dois marmoristas, três pintores, decoradores de casas, taboleiros, letreiros e forradores de papel (ver Quadro 4 do Anexo 1). Na recém inagurada Capela de Nossa Senhora da Boa Morte, construída pelo padre J. J. Vieira, juntamente com o Passeio Público (atual Praça Fluminense), é possível observar, na construção, materiais de diversas origens, também

\footnotetext{
${ }^{15}$ LAPA, José Roberto do Amaral. A Cidade: os Cantos e os Antros; Campinas 1850 - 1900, EDUSP, 1996, p. 38.

16 SILVA, Hypolito da. Almanach Popular para o anno de 1878. Campinas: Typographia da Gazeta de Campinas, Primeiro anno, 1877.

17 FERREIRA, Carlos, e SILVA, Hypolito da. Almanach Popular para o anno de 1879. Campinas: Typographia da Gazeta de Campinas, segundo anno.
} 
com a provável "importação" de mão de obra de outras cidades. Por exemplo, as grades ali instaladas foram fabricadas pelos irmãos Bierrenbach, de Campinas, enquanto o altar e estatuária foram confeccionados em mármore de Carrara, por Blás Crespo Garcia, do Rio de Janeiro ${ }^{18}$.

Um acontecimento significativo - que interessa particularmente para esta dissertação e que não aparece registrado nos almanaques periódicos locais - é a contratação, na década de 1870, de aproximadamente cinquenta operários italianos para o término da construção da catedral campineira, pelo engenheiro também italiano Cristovam Bonini. Como já relatado na Introdução deste trabalho, as obras de construção da Igreja Matriz arrastavam-se desde 1807, e foi com a contratação do arquiteto italiano e desse grupo de imigrantes que as obras tomaram algum rumo efetivo, até sua conclusão em 1883, já sob a condução de Ramos de Azevedo. O grupo de imigrantes era formado de carpinteiros, ferreiros, mestres, pedreiros, serventes, entalhadores, canteiros, ajudantes e aprendizes. Esse poderia ser considerado o primeiro contingente imigrante a trabalhar na construção civil campineira.

Em 1881 a cidade experimentou uma nova expansão das instalações fabris, voltadas principalmente para a produção de maquinário para lavoura, com fundição de ferro e bronze, além daquelas dedicadas à fabricação de cerveja e gelo, sabão, chapéus. Também aparecem, no período, curtumes, marcenarias e carpintarias a vapor. Segundo nos informa Godoi, a cidade entrou no século XX com quarenta e sete fábricas (entre elas uma refinação de açúcar, uma fábrica de chapéus, cinco de máquinas para lavoura, dez de móveis, duas caldeirarias, um curtume e onze olarias) - tudo isso numa cidade com cinquenta e cinco ruas e dezessete praças $^{19}$.

Em termos de infra-estrutura, vimos que a cidade já apresentava condições urbanísticas já bastante adequadas: a iluminação pública a gás, que só se viabilizou com empenho e persistência dos republicanos, tinha os bicos de gás "plantados enviesadamente nas calçadas" ${ }^{\text {"20 }}$. O grupo de Joaquim Egídio Sousa Aranha, que venceu a concorrência para implantação do sistema - e, para tanto, fundou a Companhia Campineira de lluminação a Gás em 1872 -, construiu o gasômetro (ver Figura 03), e a cidade ganhou tubos para canalização de ferro fundido até os combustores, instalados em vários pontos. Os lampiões a gás, que foram inaugurados em 1875, ficavam em

\footnotetext{
${ }^{18}$ A edificação possui ,na fachada, três belas estátuas, simbolizando a fé, a esperança e a caridade e, no interior, o coro é decorado com pintura mural.

${ }_{19}$ CONDEPHAAT, Relatórios de Processo de Tombamento. Colégio Técnico de Campinas, agosto/1983 (Centro de Memória Unicamp), p. 40.

20 SERVIÇO GRÁFICO BRASILEIRO DE GEOGRAFIA E ESTATístICA, Monografia História do Município de Campinas. Rio de Janeiro, 1952, pp. 32 e 33.
} 
colunas e arandelas de ferro. Já haviam sido instalados os sistemas de abastecimento de água encanada e os chafarizes públicos.

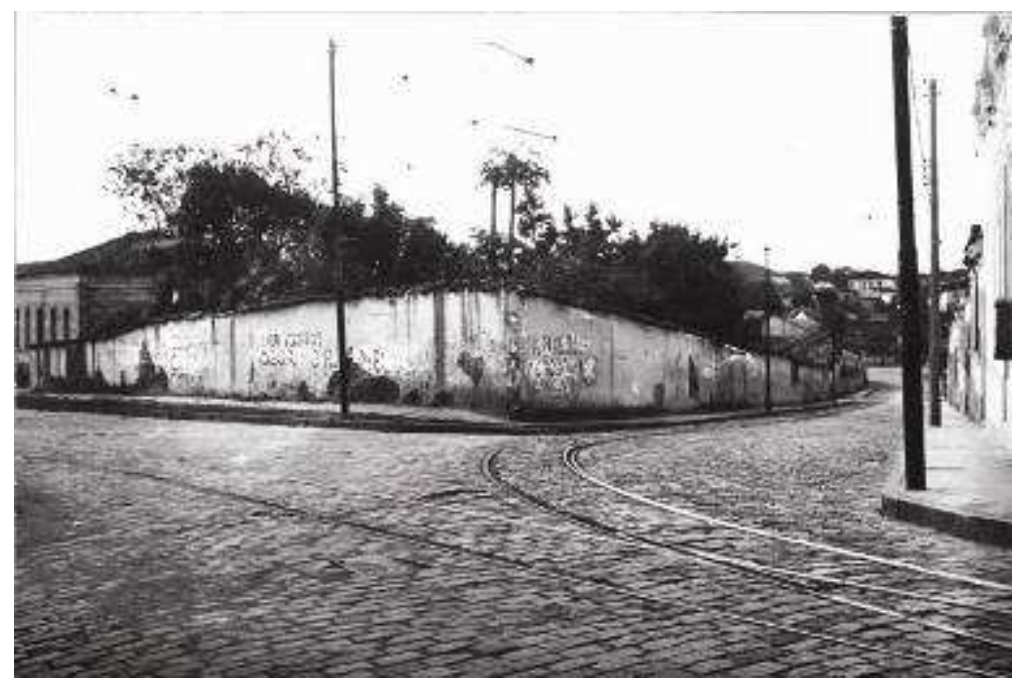

Figura 03: Fundos do antigo gasômetro

A vida cultural era intensa: é dessa época a criação de diversas associações culturais e a instalação do comércio varejista na Rua São José (atual Rua Treze de Maio). $\mathrm{E}$ a fisionomia da cidade também ganhava novas feições: nas residências e comércio, era muito comum a camarinha ${ }^{21}$ e, mais tarde, a chamada água-furtada herança colonial que influenciaria significativamente o partido dos pequenos prédios urbanos neoclássicos.

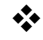

É nesse contexto que Ramos de Azevedo - de volta à cidade, já formado engenheiro-arquiteto e com escritório recém instalado - inaugura sua primeira obra, a Escola Ferreira Penteado, em 1880. De pequenas dimensões, a construção da Escola não deve ter exigido importação de materiais construtivos em muito grande escala. Porém, para a execução dos serviços, deve ter exigido muito preparo técnico da mão de obra local, para que ela conseguisse executar a contento as linhas neoclássicas propostas pelo projeto.

\footnotetext{
21 Segundo o Dicionário llustrado de Arquitetura, camarinha se designa como um pavimento superior reduzido, em relação à planta baixa, com um ou dois compartimentos, usualmente com duas águas, independentes do telhado principal (ALBERNAZ, Maria Paula e LIMA, Cecília Modesto de. Dicionário Ilustrado de Arquitetura. 2 ${ }^{\mathrm{a}}$ edição, São Paulo, ProEditores, 2000).
} 
Nesse período, Ramos já estava envolvido em diversos projetos como o do Cemitério "Do Amparo", em Campinas, em parceria com o engenheiro Antônio Francisco Paula Souza; o do Bosque dos Jequitibás (1ํ- Parque de Campinas); a reforma da sede da fazenda Pau d'Alho e a Casa de Saúde; as Escolas Ferreira Penteado e Correia de Mello; e o Cemitério do Fundão (atual Saudade), de novo, juntamente com seu amigo Paula Souza.

Entre os anos de 1880 e 1885 - a maior parte do período em que o engenheiroarquiteto atuou em Campinas -, não foi possível identificar, nos acervos pesquisados, os registros de almanaques sobre a indústria local. Pelos dados obtidos em outras referências bibliográficas, parece-nos possível afirmar que poucas mudanças foram implantadas na indústria e no mercado de construção civil. Mas é em 1885 que ocorre um importante evento industrial, digno de nota, tanto pela sua repercussão como pela participação de Ramos: a 1를 Exposição Regional de Campinas, reconhecida como um grande marco para o desenvolvimento industrial da cidade e região, pelo fato de ali ter sido possível exibir progressos no setor agrícola e sediar uma exposição de produtos de uma nascente indústria mecânica, afirmando e consolidando a cidade não só como importante entreposto comercial, mas também como um verdadeiro polo de desenvolvimento regional. No evento, situado no Largo do Rosário, foram construídos o Pavilhão Municipal, projeto de Luis Augusto Pinto, o Pavilhão de Indústrias e o Chalé de Construções, projeto de Ramos de Azevedo - que também participou da comissão julgadora da exposição -, formando-se assim a praça da "indústria e arte", nos dizeres de Monteiro $^{22}$, que buscou nos jornais locais da época tais informações. O Chalé das Construções era um pavilhão desmontável de madeira, nos moldes de um chalé suíço, com 53,00m2 no centro de uma área de $225,00 \mathrm{~m} 2$ do Largo do Rosário. Com embasamento de tijolos, cobertura de folhas de ferro galvanizado e revestimento interno de bambu, sua fachada ficava voltada para a Rua do Rosário. Foi inaugurado em meio a muita festividade - tanto que Carlos Gomes compôs, para o evento, uma peça para grande orquestra, coro, banda e fanfarra, concluída em 22 de março de 1885 e que foi executada, pela primeira vez, em 25 de dezembro desse mesmo $a^{23}{ }^{23}$.

Nesse período, os imigrantes, agora em grande número e com o relativo apoio do governo, buscavam se organizar em sociedades de ajuda mútua, escolas e oficinas. $\mathrm{O}$ Almanach do Correio de Campinas para $1886^{24}$ anunciava duas sociedades: a Sociedade

\footnotetext{
${ }^{22}$ MONTEIRO, Ana Maria Reis de Góes. Ramos de Azevedo: Presença e atuação profissional em Campinas: 1879-1886. Dissertação apresentada à Faculdade de Arquitetura e Urbanismo da PUC-Campinas para a obtenção do grau de Mestre, 2000, p. 149.

${ }^{23}$ Site Prefeitura de Campinas: www.campinas.sp.gov.br/cultura/bibliotecas/hinos/historia.

${ }^{24}$ BARCELLOS, Henrique. Almanach do Correio de Campinas para 1886. Campinas: Typographia da Gazeta de Campinas, 1886.
} 
Portuguesa Beneficente, mais antiga, existente desde 1873 e com 800 sócios, e a Sociedade Italiana Confederata, existente desde 1884. Esse fato, importante para nós, e a atuação vigorosa destas sociedades - marca a presença expressiva dos imigrantes na vida educacional e cultural da cidade, além de sua intensa participação no setor de comércio e serviços.

Esse mesmo almanaque anunciava ainda o registro de quatro engenheiros, sendo um militar, o capitão João Gonçalves Pimenta e três doutores, entre eles Ramos de Azevedo, seu amigo Antonio Francisco de Paula Souza, além de Luiz Pinto (ver Figura 04). Os números de estabelecimentos industriais e comerciais, bem como o número de operários (ver Figura 05), respectivamente, se mantiveram quase os mesmos de seis anos antes: três olarias, oito ferragens, três fundições, quatro depósitos de madeira, sete marcenarias e oficinas de móveis, três depósitos de móveis (ver Figura 06), três estabelecimentos de papéis pintados e vidros (ver Figura 07). Quanto à mão de obra, o referido almanaque registrava três marmoristas (ver Figura 08), nove ferreiros, dois ferradores, quatro marceneiros e um mestre de obras. Nesse momento, ganham destaque os comerciantes importadores de ferragens, como Santos, Irmão \& Nogueira e de mármore, como Manoel Poceiro Fontan (ver Quadro 5 do Anexo 1). 
Salvador Geraldo, rua General Osorio n. 80.

José Pano, rua do General Osorio 11.96.

\section{DENTISTAS}

José Ramos Cordeiro, rua Formosa, n. 36.

Jorge Reinhardt, rua Formosa n. 30 .

Joào Pedro 11 . Ferreira, rua Barreto Leme n. $2^{n}$

Joaquim d'Almeida. Barbosa, rua do Imperador n. 16.

\section{ENGE.THEIROS}

Capitão João Gonçalves Pimenta, rua da Ponte, n. 28.

Dr. Francisco Paula Ramos de Azevedo, rua 11 de Agosto a.

Dr. Antonio Francisco de Paula Souza, rua do General Osorio.

Dr. Luiz Pinto, rua do Commercio.

\section{ESPINGARDEIROS}

Salvador Geraldo, rua do General Osorio n. 80.

Jose Pano, rua do General Osorio n. 96.

Nicolao Vignone, rua Luzitana n. $10 \%$.

FiRIVHA DE TRIGO, (leposito) de

Franciseo Krug \& Comp., rua do (iros n. 19.

$$
\text { FARIVHA DE TRIGO, (moinho) de }
$$

.. Romano Lippi, rua do Senalor Saraiva.

$$
\text { FERRAGENS }
$$

Antonio José Machado, rua do Rosario n. 2:3.

Alexandre Antonio Pires \& Comp.. rua do General Osorio n.2.

Antonio Franciaco de Andrade Couto, rua Direita n. 17 e i9.

Souza, Silva \& Comp., rua Direita n. 25

Santos, Irmào \& Nozueira, rua do Sacramento n。 $23 \mathrm{~A}$.

Gomes Pinto, Gardozo \& Comp. rua do C. mmercio n. 55.

José Rodrigues dos Santos Calhelha, rua do Comenereio n. 万̄.

Pedro A. Anderson is Comp. rua du Rosirio n. 2 A.

$$
\text { FERREIROS }
$$

Miguel Alborto, ria do Commercio n. 105.

Guilherme Leonard, rua do Regente Feijo n. 1:3 1.

Cassiano Durin, rua Onzo de Arosto n. $2: 3$.

Rodrigo de Moura Dias, rua do Bum Jesus n. 2.

José Francisco Alvos, rua de S. Jose n. 20

Lembri Angelo, rua da Constituicào n. 8.

José de lloura Dias, rua de S'. Carlos 11.89 A.

Miguel Closel, rua de S. Carlos n. 81.

Nanoel Lopes Ferreira, rua do Regente Feijo $1,37$.

$$
\text { FUNDICÕES }
$$

Ilac Hardy \& Comp., rua Andrade Neves.

Lid gerwood Manufacturing \& Comp, rua Anirade Neves.

Viuva Faber \& Filhos, rua Duque de Caxias.

Figura 04: Relação de engenheiros na cidade do ano de $1886^{25}$

\footnotetext{
${ }^{25}$ Figuras 04 a 08: BARCELLOS, H. Almanach do Correio de Campinas para 1886. Campinas: Typographia da Gazeta de Campinas, 1886, pp. 94 a 97.
} 
Henrique Deutsch \& Irmão, rua Direi!a n. 15. José Gerin, rua do Sacratnento n. 35, i! arles Devienne, rua do Góes.

LIVRARIAS E EYCADERYACOOES

Antonio B. An Castro Nendes, rua Direita n. 18. Alfredo Gentini \& Comb., rua Direita n. 3\%. Correio de Cumpinas, rua Direita n. 58 .

C̈rmino Tamandaré de Toleilo \& Conp., rua Direila n. ju. Eloy Cerupeira, rua Direita n. 16.

Ianoel dia Costa Velho Sammio, pua Direita n. 23.

Jotta \& Comp, rua Direitio ne 4 .

Souza comp, rua do lincario.

(i) :nes Pinto \& Corap, rua Lizitana n. 91 LOCCADE $3318130($ fabriea de

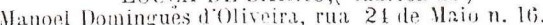
Jo:lquim Domingues d'olivirat, rua de S, José n. :3ti.

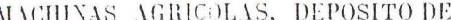

Joño Bierrenbach, rua da Ponte o. 39)

Pedio A. Inderson, rua José de liencar n. 31

Ariale Veves 11.15

Lisigerwood, Manufacturing \& C., rma S. José n. $82 \mathrm{~A}$

MACHISAS DE COSTURA. DEPOSITOS DE

André Reinhardt. rua Dirita n. 38 A.

francise kru tik G, rla do Goes n. 19

Gomes Pinto \& Barros, rua do Commercio n. 71

$$
\text { IIAIDEIRIS. DEPOSITO DE }
$$

Francisco José dos Reis, rua da Constituicão n. 2.

Toacto carlos in. 101.

Joà Fellippe Vacier la silva, rua do Sallanha llarioho 41

Almeida \& Santos, rua do Regente Feijio n. 50.

din e satos.

Lourenco simes, rul to liommercio n. $105 \mathrm{~A}$

Jose Chicorelli, rua Amerima n. 2.

Antonio Exel, rua S. Josi 11.16 .

Paulino Biancolino.

Puãu Perrin \& Rachou, rua lo Bom Jesus.

Luiz de Tulio it Irmão, ria lo Rosario n. 51.

Silya \& L. rua Direita, n. 27

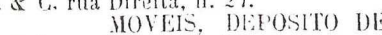

Mireita $n, 2$ \%

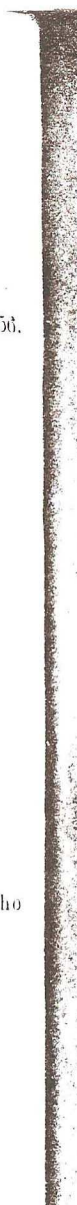

Liviz de Tulio \& Irmão, rua do Rosario n. 54

Ferreira da Silva \& Armbrust. rua Direita n. 4it. MACAS, FABRICAS DE

Garibaldi del Vecchio, rua da Conceir:ão n. 91 A.

Garibaciseo Romani, rua do General ozorio n. 13 MARMORISTAS

ManoeI Pocero Pontan, rua do Rosario n. 41.

José Marlinelli, rua de S. José n. 88. CONCERTADOR DE IYSTRUMEYTOS

Joaiquim José Caetano.

Dr. Thomaz Alves Fillıo, rua do Commercio n. 12.

Dr. Braulio Gomes, rua do Gives.

Dr. Virgilio de Arajas, sua do Commercia n. 27.

Dr. Ataliba Florence rua Direita n. 20 .

Dr. Diogo Pupo rua do Rosario n. 9.

Dr. Bento f. de Souza, rua do Rosario n. 31.

Dr. Ricardo (r. Daunt, ruz do Imperador n. 6.

-Dr. Guilherme da Silva, rua do Constituição n 23.

Dr. Antenor Angusto Ribeiro Guimarảes, rua 24 de Maio.

Dr. Germano Melchert, rua José de Alencar n. 10.

Dr. Cassiano B, de N. Gonzaga, rua do Regente Feijú.

Dr. Francisco Augusto Pereira Lima, rua do Regente Feijo a. 24.

r. Caetano Monfort, rua do General Ozorio.

Di: Sergio F. de Paiva Meira, rua do Bom Jesus n. $1 \mathrm{l}$ A: OURIVES, FABRICA VTES

José Gerin, rua do Saeramento n. 35.

Francisco Assis Fragoso, rua Direita, n. 18 A

Emilio Decourt, rua do Rosario n. 35

$$
\text { OLARIAS }
$$

Pedro delPuchito, rua lde Santa Cruz.

Jusé Martella, rua da Ponte.

Jose Martella, rua da Ponte.

OFFICIYAS DE CARROS E CAHROCAS

Camps \& Irmãos, rua do Bom Jesus a. 12.

Ernesto IVare, rua da Constituicado.

Franciaco Krug, rua de S. Carlos.

Arlindo Teixeira Norueira, Bairro d'Atilsaia.

Francisco Vieira, rua da Constituiçào.

PADEIROS

Joฐo de Lueca, rua Luzitsa n. 115.

Figura 05: Relação de marcenarias, marmoristas e olarias do ano de 1886 


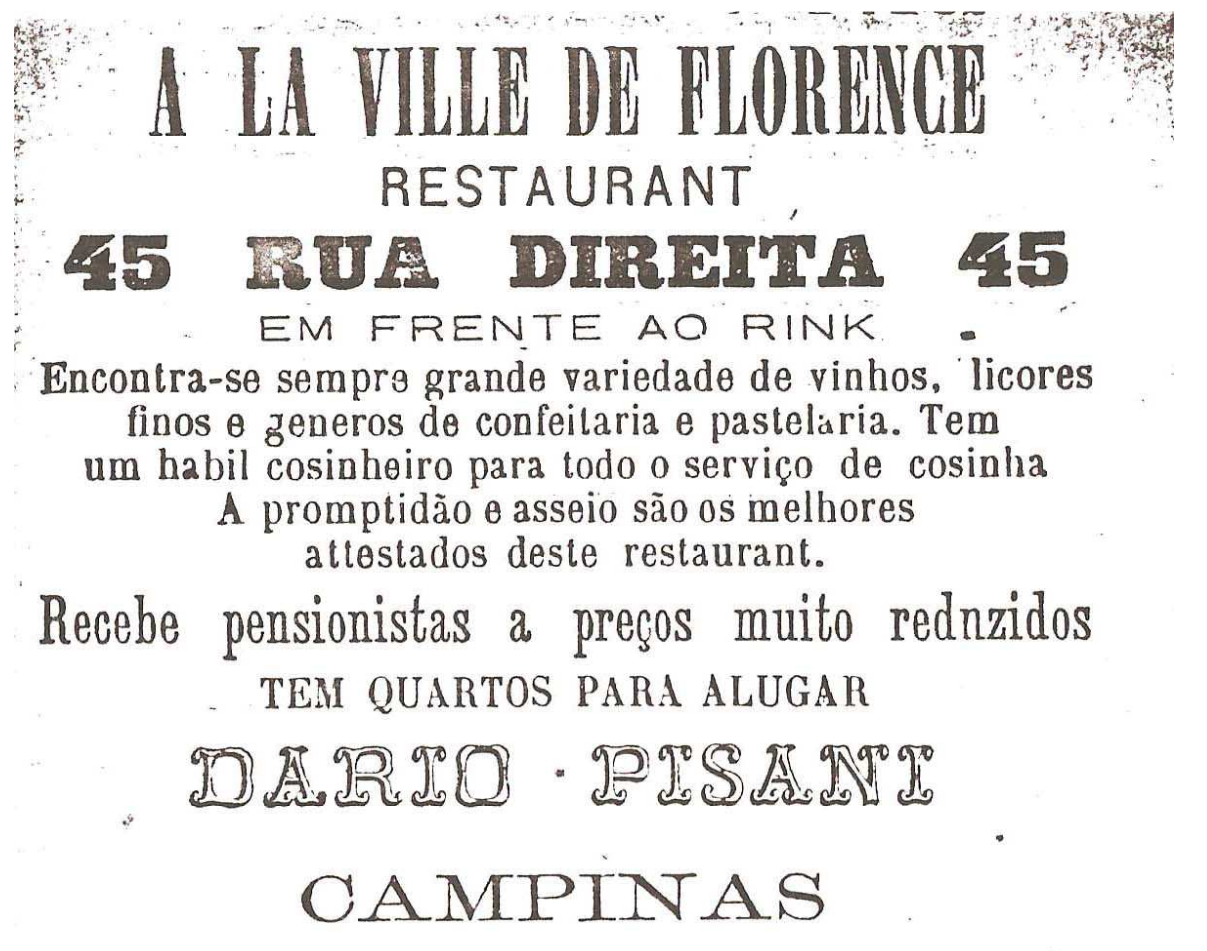$$
\text { GRANDE OFFICINA }
$$$$
\text { E }
$$

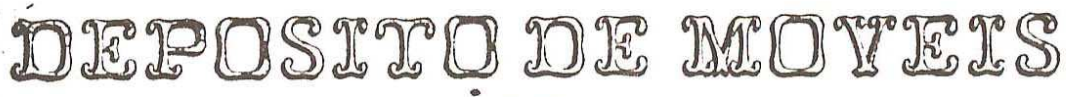$$
\text { DE }
$$

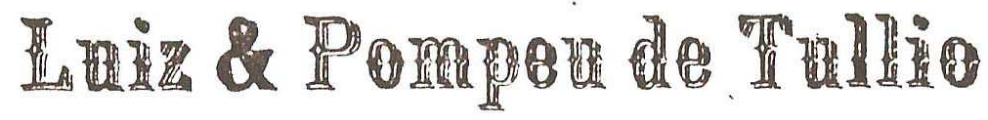$$
\text { 54-RUA DO ROSARIO-54 }
$$
Fazem toda e qualquer obra de torno. Colchoaria e armações para cortinados.
Fazem toda e qualquer obra com brevidade. Ro melte-se para qualquer ponto da e-trada de firro. musica.

Nesta casa trata-se tambem qualquer serviço de

\section{CAMPINAS}

Figura 06: Propaganda de um dos depósitos de móveis 


\section{VIUKUN HE PAPEIS PINTADOS}

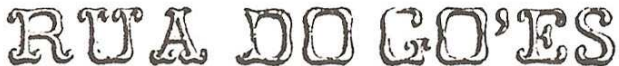

\section{ESQUINA DA DO COMMERCIO \\ ENCARREGA-SE DE PINTURAS DE CASAS E FORRAÇAOO \\ A PAPEL POR MODICOS PREÇOS}

Grande sortimento de vidros para vidraças, espelcos lavrados $\theta$ de cores, molduras para quadros venesianas para janellas, lampeòes para kerosene, elc. elc. Variado sortimento de papeis pintados nacionaes e estrangeiros. Espelhos para todos os tamanhos, chaminès para lampeões, oleographias e linagens, etc. elc.

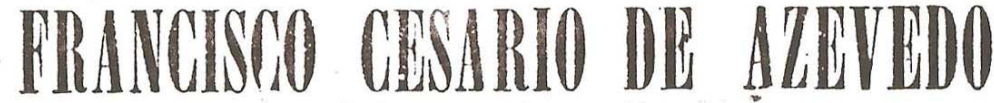

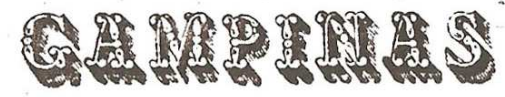

Figura 07: Propaganda de estabelecimentos de vidros 


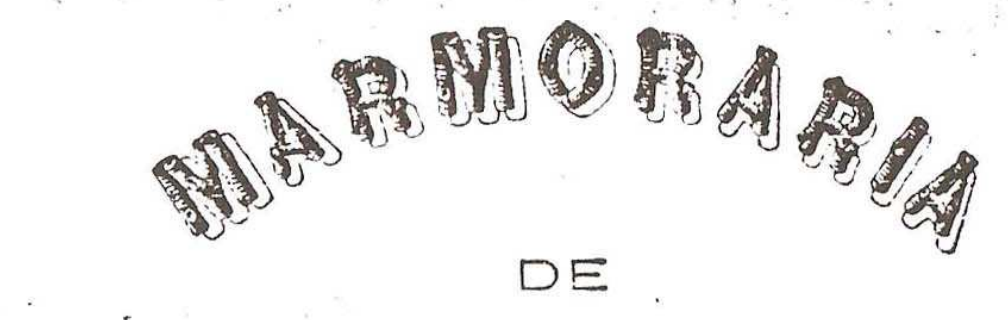

JOSE MARTINISLII

88--Rua de S. José--88

Especialidade em generos de Italia. Commissòes e expedições dinheiro para Europa.

\section{BANDEIRA \& QUIRINO $\mathrm{COM}$}

Casa de comnissões e consignacões

\section{RECEBEMI A COMMIS̄SÃO}

Para expedir ou vender café e generos da lerra. Teem deposito de sal, assucar, cal e outros generos do paiz e estrangeiros.

\section{Compram Café

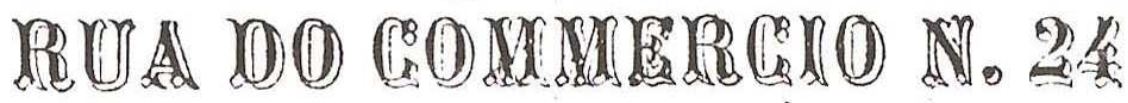 GAMPINAS}

Figura 08: Propaganda de um dos marmoristas 
Acompanhando aquele inequívoco crescimento econômico, a cidade experimentou, no final dos anos 1880, também um vigoroso crescimento populacional, somando mais de vinte mil habitantes na área urbana e cinquenta mil em todo o município. Cresceria ainda mais com a instalação da rede pública de coleta de esgotos e com a fundação, em 1887, da Companhia Campineira de Águas e Esgotos - que passou a abastecer cada prédio da cidade com águas do riacho Iguatemi e Bom Jardim, na Vila Rocinha (hoje Vinhedo). É também, desse período, a fundação do Hipódromo Campineiro, no Bonfim, e da Estação Agronômica. Alguns anos mais tarde, em 1891, foram concluídos os serviços de instalação da rede de água encanada e de calçamento de ruas com paralelepípedo e macadame, substituindo o antigo calçamento pé-demoleque.

Por outro lado - e na esteira desse processo de intensa expansão urbana, experimentado nessas duas últimas décadas do século - a cidade foi assolada por três epidemias de febre amarela, entre outras implicações de saúde pública, decorrentes do descompasso inicial entre infra-estrutura de saneamento e crescimento urbano. Apesar de contar com menos habitantes - que fugiram das epidemias - os investimentos se mantiveram e o ramo industrial não chegou a ser prejudicado. Vemos que as olarias seguiram a tendência do crescimento da cidade: em 1892, segundo o Almanhach de Campinas (literário e estatístico) $1892^{26}$, a cidade ganhou mais cinco olarias - agora contava com oito no total. Além das olarias, contava também, entre outros estabelecimentos, com a marcenaria e a carpintaria de José Seccarelli, a oficina de marcenaria e depósito de móveis de Attilo Pesfetti \& Comp., além de um armazém de vidros, cristais, louças e outros, de Firmino Tamandaré de Toledo. Quanto aos trabalhadores, encontramos apenas o registro de três marmoristas (ver Quadro 6 no Anexo 1).

Ainda no século XIX, cabe ressaltar uma característica distintiva das primeiras indústrias na região de Campinas, que se localizavam junto aos rios e córregos da região, geralmente distantes do centro urbano, com o objetivo de utilizar a energia hidráulica como força-motriz. É claro que se trata de um expediente prático bastante óbvio, muito comum na história europeia nesse período de transição entre a manufatura e o sistema fabril moderno. Mas parece-nos relevante salientar o quanto importa, em termos de evolução urbana, a transição entre distintos processos técnicos de produção e transmissão de força motriz. A partir do século XX, as novas indústrias, já equipadas com maquinário a vapor, foram sistematicamente instaladas próximas aos centros urbanos, procurando alcançar maior disponibilidade e oferta de mão de obra - além de maior

${ }^{26}$ CARDONA, Francisco, e ROCHA, José. Almanhach de Campinas (literário e estatístico) 1892. Campinas: Typographia Cadorna, primeiro ano, 1892. 
proximidade do mercado consumidor e da facilidade de transporte oferecida pela malha ferroviária. As fábricas, então, não dependiam mais dos cursos d'água para gerar energia: muitas já utilizavam a energia a vapor e algumas iniciavam o uso da energia elétrica ${ }^{27}$.

Nos primeiros dez anos do século, em período que se avizinhava à Primeira Guerra Mundial, o café estava perdendo o seu valor e as importações começavam a cair. $\mathrm{Na}$ contramão desse processo - e até mesmo em decorrência dele -, vemos que é justamente nesse momento que a cidade começa a experimentar um desenvolvimento industrial de fato. Também é nesse momento que as indústrias locais começaram a atender, de modo mais sistemático, o mercado da construção civil. Campinas sentia os efeitos dessa industrialização com ares de um polo urbano: em 1908, tinha cinco mil casas, oitenta e uma ruas e dezesseis praças, e o número de empreiteiros construtores já era bem significativo: segundo o Almanach de Campinas para $1908^{28}$, a cidade contava com vinte e nove empreiteiros construtores, vinte e um ferreiros, quatorze marceneiros e carpinteiros (ver Figura 09), além de três marmoristas.

${ }^{27}$ TELLES, Henrique Vichnewski. As indústrias Matarazzo no interior paulista: arquitetura fabril e patrimônio industrial (1920-1960). Dissertação de Mestrado, Departamento de História do Instituto de Filosofia e Ciências Humanas da Unicamp, p. 45.

${ }^{28}$ LADEIRA, José M. e OCTAVIO, B. Almanach de Campinas para 1908. Campinas; Typhographia e Stereotyp. da Casa Mascotte, 1908. 
Vicente Canecchio, rua 13 de Miso 6.5. Vieira dos Santos \& Irmão, estação.

\section{COSTUREIRAS}

D. Cesira Pedrazzoli, rua F. Glycerio 66

D. Emma Hempel, rua Campos Salles 37.

D. Filomena Mosca Nucci, rua Irmã Serafina 1.

D. Julia Fabrini, rua Moraes Salles 118.

D. Maria Luiza Longhi, rua Barão de Jaguara 3í.

D. C'rsula Costa, rua Francisco, Glycerio 2-2.

\section{CASAS DE CALCYAOAS}

Antonio Magorno, rua Moraes Salles 118

Angelo de Tullio, rua Barīo de Jaguara 18

Caetano Biondi, rua 13 de Mraio 27.

Donato Cordone, rua do Cióes (6.

Francisco Matallo, rua Barão de Jaguara 69

Felippe Lancellotti, rua Costa Aguiar 62.

" D rua 13 de Miaio 37.

Herculano Penteado, rua Bario de Jaguara $4:$.

João Perrella, rua Campos Salles 20.

João Monteiro, rua 13 de Maio 19.

João Ziggialti, rua José Paulino 135

José Nueci, rua Dr. Quirino 67.

Miguel Rola, rua 13 de Maio 8.8 .

Nicolau Aquilino, rua 13 de Maio 60.

\section{('ALCADOS (.MBCLLANTE)}

Nicolau Ferrinho.

\section{CONSTRTCTORES, EMPREITEIROS}

Antonio Dias de Oliveira, rua Ferreira Penteado.

Alexandre de Concilis, rua 13 de Maio 106.

Adolpho Mendes, ria. Tisconde Rio Branco 4s.

Domingos de Oliveira, rua $B$. de Campos 47 .

Eusebio Carlos Dias, rua Francisco Gircerio

\section{$-203-$}

Frnesto Layorini, Ponte Preta.

Fortini \& Mazzini, rua Barão de Jaguara 45.

Francisco 'Tanck, rua Alvares Machado.

Francisco Pilsen, rua J. de Alencar 45.

Frederico Pedro Somnesen, rua Alvares Machado 12

Hercole Bonetti, rua Bernardino de Campos 57 A.

Joaquim Alves Dias, rua Boaventura do Amaral 7 B.

Joaquim Alves Dermardino de Campos.

Joaquim Silva Junior, rua Bernardisco Glycerio 122.

José Leite de Oliveira, rua General Osorio 111

José Tartari, rua Barão de Jaguara 82.

José Pinheiro Junior, rua Alvăres Nachado 83.

Josó Piffer, rua Ferreira Penteado.

Jose Piffer, Carralho, rua Dr. Ricardo 75.

Mazzini \& Comp., Botafogo.

Paschoal Laloni, rua Costa Aguiar 31

Raphael Mauro, rua Irmã Seraphina 1.

Ricardo Hartinamn, rua General Osorio 111.

Ur. Tito Vartins Ferreira, rua Bernardino de Campos $12 \mathrm{~B}$.

Victorino Simōes, rua Dr. Ricardo 79.

Vicente Farinelli, Frontão.

Vicente Gigliotti, rua Dr. Quirino 12t.

\section{CHARUTARIAS}

J. Ladeira (Casa Mascotte) Rua Barño de Jaguara 19 Lafayette Roso, rua Barão de Jaguara 31

Silva Guimarães \& Comp., rua Campos Salles 3.

CASAS DE JOIAS, OURIVES

Iain 4 .

Antonio Dauria, rua 13 de Main $4 \mathrm{~A}$.

Augusto Hack, rua Barão de Jaguara 5t.

Emilio Decourt, (herança) rua Francisco Gly

José Gerin, rua Barão de Jaguara 62.

Julio Ernesto Hack, rua 13 de Maio 18

Ladislau Kirschemberg, rua 13 de Maio 60 A., /, ।

\section{CARPINTEIROS, MARCINEIROS}

Antonio Teixeira, rus Ferreira Penteado $147 \mathrm{~A}$.

Figura 09: Relação dos construtores empreiteiros ${ }^{29}$

Comparadas com o que vimos antes, as olarias não eram tantas, contavam-se sete instalações. Quanto à indústria moveleira, registravam-se duas lojas de móveis na cidade (ver Quadro 7 do Anexo 1); mas, pelo detalhamento dos equipamentos citados nos registros dos almanaques, podemos ver que suas fábricas eram maiores e mais bem equipadas, contando com grande número de funcionários. Em 1910 foi aberta a Companhia Curtidora de Campinas ${ }^{30}$, que protagonizou papel importante nesse processo de crescimento industrial. Em 1912, a cidade já contava com oitenta e três estabelecimentos industriais, assumindo um inconfundível aspecto fabril e ares de cidade operária.

Da Primeira Guerra Mundial até 1921, nenhuma fábrica foi instalada, talvez porque as leis municipais - além dos efeitos da Guerra - não incentivavam a instalação de novas indústrias; as existentes mantiveram-se e cresceram. É apenas a partir de 1921

\footnotetext{
${ }^{29}$ LADEIRA, J. M. e OCTAVIO, B. Almanach de Campinas para 1908. Campinas; Typhographia e Stereotyp. da Casa Mascotte, 1908, pp. 202 e 203.

30 OCTAVIO, Benedito e MELILLO, Vicente. Almanach Histórico e Estatístico de Campinas 1912. Typhographia Casa Mascotte, 1911.
} 
que tem início uma nova era de implantação de novas indústrias em Campinas. É desse período a abertura da fábrica de Tecidos Elásticos de Godoy e Valbert (primeira da América - até então produtos similares eram importados da Inglaterra, Suíça e Itália), da Chapéus Cury, da Seda Nacional (Matarazzo), da Indústria Brasileira de Artefatos de Ferro (fabricação em ferro maleável, também a primeira na América do Sul), dentre outras.

\subsubsection{Na capital e no estado}

Na cidade São Paulo, as primeiras fábricas datam do início do século XIX. Uma das primeiras que se tem notícia é uma tecelagem, instalada em 1810, que possuía dez teares e produzia diferentes tipos de tecidos de algodão. Nesse mesmo ano, noticia-se o início da produção siderúrgica na região, com a instalação da fábrica de ferro São João de Ipanema, em Iperó (SP), próxima à Sorocaba ${ }^{31}$. Mais tarde, em 1818, surgiram, na capital paulista, mais duas tecelagens. Uma delas já exibia porte bastante razoável, empregando dez mestres e sessenta operários, quase todos negros e mulatos. Sua existência, contudo, soma um curto período. Depois delas, São Paulo ficou muito tempo sem a instalação de novas fábricas, surgindo apenas oficinas artesanais ou pequenos estabelecimentos fabris. É bom lembrar que, no período colonial, era proibida a instalação de forjas de grande porte, além da realização de diversas outras atividades industriais. Tal situação só viria se alterar com a chegada da família real ${ }^{32}$.

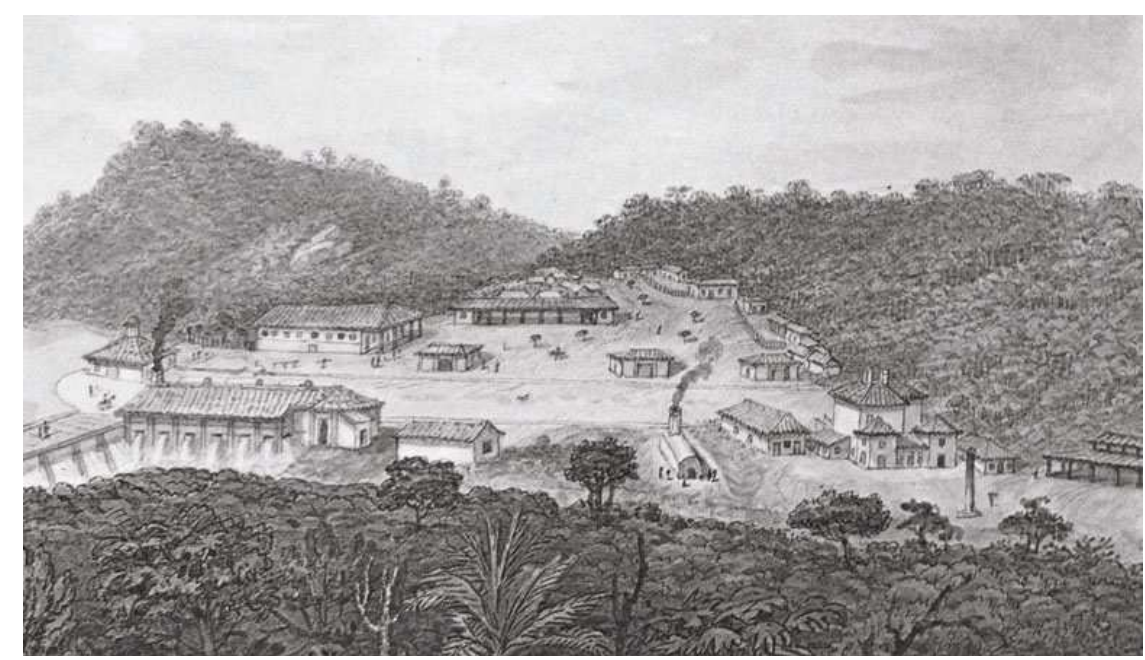

Figura 10: Real Fábrica de Ferro São João de Ipanema, Iperó, Século XIX, gravura de J. B. Debret. ${ }^{33}$

\footnotetext{
${ }^{31}$ Para efeito de comparação, em 1813, surgiram no Brasil duas siderúrgicas importantes, ambas em Minas Gerais: a Fábrica Patriótica (próximo a Congonhas do Campo) e Fábrica de Gaspar Soares (em Morro do Pilar), além da Fábrica de Armas, já instalada desde 1810 no Rio de Janeiro.

32 Telles, H. Apud SIMONSEN (1973:09).

${ }^{33}$ Figura 10 e Figura 11: PESSOA, Ângelo E. da S. (Org.). Conhecer Campinas numa perspectiva histórica. Campinas: Secretaria Municipal de Educação, 2004.
} 
Até a década de 1840 não havia como reunir condições para implantar, aqui, qualquer manufatura que conseguisse competir, no preço e na qualidade, com os artigos produzidos pela indústria inglesa. Mas é nesse período, em 1836, com a construção da refinaria de açúcar de Santos - possivelmente a primeira usina de açúcar movida a vapor -, e com o decreto de 1846 - que concedia diversos privilégios às fábricas de algodão -, que começaram a ser criadas as condicionantes tecnológicas - aparato composto por recursos técnicos, operacionais, legais e infra-estruturais - para o futuro crescimento industrial.

Em 1850, quando foi criada em São Paulo a Companhia Cantareira de Água e Esgoto $^{34}$, podemos verificar que ainda era muito pequeno 0 número de estabelecimentos comerciais instalados na capital. Mesmo com a promulgação da Lei Eusébio de Queirós - que proibia o tráfico negreiro e que, teoricamente, contribuiria para a reestruturação da base econômica e infra-estrutural de produção e abastecimento -, o substrato do trabalho permaneceria composto por mão de obra escrava ainda por um bom tempo.

Nesse momento, o país contava com cerca de cinquenta estabelecimentos industriais (dois de tecidos, dez de alimentação, cinco de pequena metalurgia, entre outras). Mas as principais fábricas aqui instaladas eram indústrias têxteis: até 1860, o número dessas fábricas, aqui no

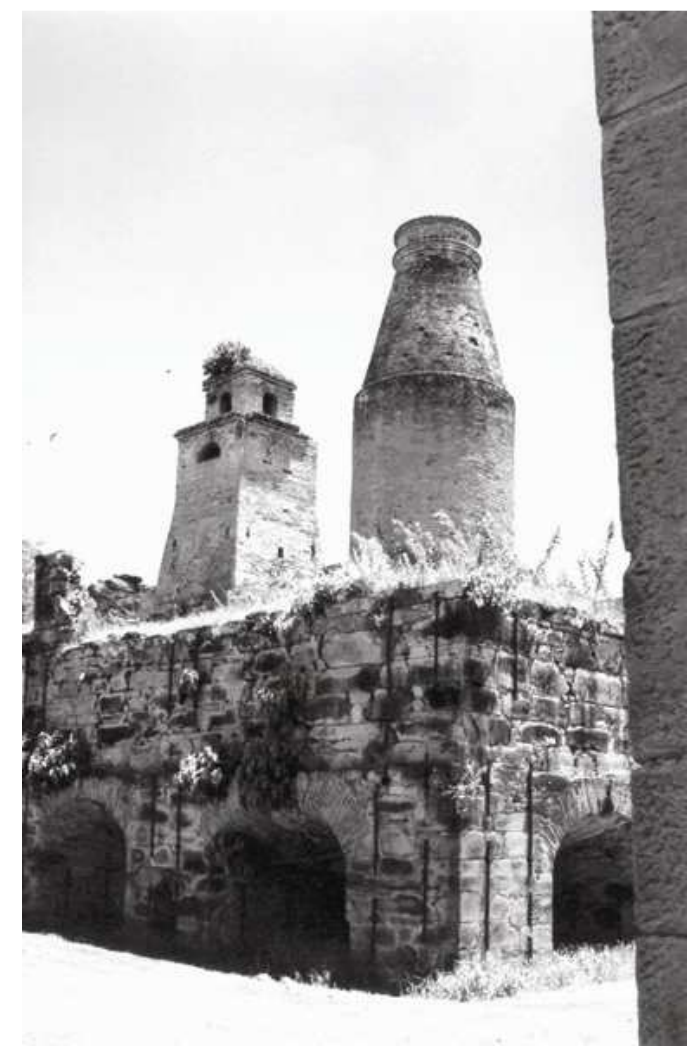

Figura 11: Altos fornos da Real Fábrica de Ferro São João de Ipanema, Iperó. Brasil - nove estabelecimentos -, era relativamente muito pequeno - se comparado ao dos EUA, que tinha mais de mil tecelagens nessa época. Em cidades como Campinas, nesse período, ainda inexistiam fábricas de tecidos. A produção - mesmo a manufatureira - limitava-se ao atendimento de subsistência das fazendas de café, produzindo congêneres para alimentação, vestuário e apoio à produção cafeeira. Além disso, a parca produção fabril restringia-se àquela promovida por uma meia dúzia de pequenas oficinas instaladas nas cidades.

\footnotetext{
${ }^{34}$ Articulando um sistema ainda pouco eficiente, a empresa captava água do Rio Ipiranga e da Serra da Cantareira para distribuí-la e atender as necessidades da cidade.
} 
De qualquer forma, a indústria manufatureira ${ }^{35}$ que aqui se instalava compreendia, basicamente, três segmentos: primeiro, a fabricação de máquinas e implementos para a atividade agrícola e para o beneficiamento do café; segundo, a tecelagem para a produção de sacarias de juta para a embalagem do café; e terceiro, a produção dos bens de consumo corrente. Isto é, fica claro porque a instalação da maior parte das indústrias nascentes foi, principalmente, promovida por ricos fazendeiros. Mas também os imigrantes estrangeiros e os comerciantes importadores tiveram papel relevante na estruturação de uma economia manufatureira por essas bandas: diversificando as aplicações de seus capitais e investindo na indústria, esses agentes acabariam tornandose figuras importantes no processo de composição de uma economia industrial, tanto ou mais que a velha aristocracia cafeeira. Foi o caso do imigrante italiano Francisco Matarazzo, que chegou ao Brasil trazendo algumas economias para formar seu primeiro estabelecimento no ramo de importações e, posteriormente, na fabricação dos produtos que antes importava, tornando-se uma liderança relevante na história da indústria paulistana. É claro, contudo, que essa situação diferia muito daquela dos imigrantes que não tinham capital e que trabalhavam duro no campo, nas oficinas urbanas e nas indústrias nascentes.

Com a ligação ferroviária entre Santos, São Paulo, Jundiaí e Campinas, em $1872^{36}$, a cidade portuária que constituía o ponto final da ferrovia tornou-se o principal escoadouro da produção cafeeira, roubando a hegemonia da então capital federal do Brasil. Foi a partir desse momento que as pequenas indústrias paulistanas começaram a crescer. Nesse período, é possível verificarmos, através de diversos anúncios publicados na época, um significativo crescimento do número de artífices e artesãos especializados na cidade, como aqueles que se encarregavam de trabalhos de instalação de molduras em quadros, decoração de ambientes em alto relevo, pintura de tabuletas sobre vidro, pintura a óleo em salas de jantar e cenografias para a decoração de ambientes diversos. $\mathrm{Na}$ oficina de pintura de Francisco Tornotti, à Rua Boa Vista, $n^{\circ} 50$, muitas vezes extrapolava-se o campo de competências tradicionais de uma 'oficina de pintura', uma vez que se encarregavam de desenhos lineares, plantas de casas, planos de implantação de estradas de ferro e outros serviços de engenharia. Em 1871, com o advento da presença da mão de obra imigrante na construção civil, começa a se tornar perceptível seu peso numérico - como explicitam os anúncios da Associação Auxiliadora da Colonização e Imigração, que recrutavam carpinteiros, marceneiros, serralheiros,

\footnotetext{
${ }^{35}$ Cabe salientar que caracterizamos aqui essa "indústria manufatureira" como a base técnica e operacional que viria sustentar um ramo industrial que, nesse momento, dava seus primeiros passos.

${ }^{36}$ Convém relembrar, tratava-se da primeira ferrovia em território paulista, instalada pela companhia inglesa São Paulo Railway Co. para transportar o café produzido no interior do Estado até o porto santista.
} 
ferreiros, canteiros, pedreiros e operários para trabalhar nas estradas de ferro que iam sendo construídas ${ }^{37}$. Mesmo assim, ainda é significativa a presença do escravo negro na construção civil, correspondendo, em 1872, a 31,7\% do total de trabalhadores, nesse ramo, na cidade de São Paulo ${ }^{38}$.

É nesse contexto que o tijolo de barro cozido alcança o papel de protagonista notório na construção - e reconstrução - da cidade. Não que o tijolo fosse um ilustre desconhecido nos canteiros paulistas: conforme Paulo Cesar Xavier, há uma cidade no extremo noroeste paulista - cuja origem corresponde a uma espécie de instalação militar e naval destinada a dar retaguarda às colônias instaladas no sul do Mato Grosso, quando a província passou a ser ameaçada por Solano Lopes, nos prelúdios da Guerra do Paraguai (1864-1870) - que teria sido construída, já em 1858, inteiramente com alvenaria de tijolos: às margens da foz do Rio Tietê, a cidade de Itapura, que abriga o Forte de Itapura - ou, mais conhecido como Palácio do Imperador (hoje em ruínas) ${ }^{39}$.

Carlos Lemos, em seu livro Alvenaria Burguesa, afirma que Campinas foi a primeira cidade a ser provida de uma olaria com produção mecanizada de tijolos cerâmicos (a olaria Sampaio Peixoto) em 1860, antes mesmo da capital paulistana ${ }^{40}$. Segundo Eudes Campos $^{41}$, há registros, datados de 1861, que comprovam a existência de uma olaria no bairro paulistano do Pary, recrutando escravos para trabalhar na chácara onde se instalava. Também há anúncio pedindo oficiais telheiros, um para tomar conta do forno e outro para queimar telhas e tijolos numa chácara do Pacaembu de Cima. Em 1872, há registro de outra olaria, no Bom Retiro, que solicitava abertura de vala para atracar o vaporzinho "Progresso" (abastecimento de combustíveis). Nesse período foi criada a olaria Santa Cruz, em Santos, de Martins \& Irmãos, que atendia a capital e o interior. No final da década, as olarias multiplicaram-se: só no Bom Retiro, instalaram-se grandes olarias como a Ribeiro \& Clavel, de Manfred Meyer \& Paiva e outras, passando a capital, apesar da tardia instalação de olarias, a apresentar significativa ampliação desse setor produtivo. Mas é importante lembrar que, até então, a operação destas olarias era essencialmente sustentada por trabalho manual.

Demandando uma linha de produção específica, uma técnica já bastante disseminada era a utilização do tijolo de revestimento, desde as décadas de 1850 e 1860,

\footnotetext{
37 D'ALAMBERT, Clara Correia. Tijolo nas construções paulistanas do século XIX. São Paulo: s.n., 1993, pp. 185 e 186.

${ }^{38}$ PEREIRA, Paulo C. X. São Paulo - a construção da cidade - 1872-1914. São Carlos: Rima, 2004, pp. 24 e 25. Ainda segundo o autor, um dos motivos que levou o governo brasileiro importar mão de obra seria a necessidade de forçar o rebaixamento dos valores cobrados pelos serviços realizados pelos "escravos de ganho".

39 Idem, p. 28.

40 LEMOS, Carlos A. C. Alvenaria Burguesa: Breve história da arquitetura residencial de tijolos em São Paulo a partir do ciclo econômico liderado pelo café. São Paulo, Nobel, 1985, p. 41.

${ }^{41}$ D'Alambert Apud CAMPOS (1993:189).
} 
aplicados nos campanários das igrejas, como as torres da Igreja São Pedro dos Clérigos e de São Bento. Os primeiros a empregar o tijolo nu (sem revestimento) em São Paulo podem ter sido o pedreiro alemão Christiano Siechrist ${ }^{42}$, os ingleses - ou então os americanos - no Galpão da Inglesa, em 1867. Na década de 1870, tornou-se muito comum aplicar o tijolo na arquitetura industrial e também na arquitetura escolar - como nas escolas Americana e do Arouche. Até mesmo em pontes, o tijolo de barro cozido assumiria a condição de material construtivo - como na ponte Miguel Carlos na capital paulistana. Já na década de 1880, o uso de tijolo sem revestimento passou a ser menos frequente, mas ainda aparecia em circunstâncias específicas: foi utilizado em algumas construções como no Hospital Misericórdia (1882), na Hospedaria do Imigrante (1886) e no Matadouro de Vila Mariana $(1886)^{43}$. O uso da alvenaria de tijolo de diferentes cores passou a ser mais utilizado, uma técnica trazida pelos ingleses. De qualquer forma, é surpreendente o crescimento da indústria oleira na cidade: em 1878, o almanaque da capital já anunciava um total de 27 olarias $^{44}$.

Embora popularizada pela mão de obra imigrante, a técnica tijoleira já era relativamente dominada pelos escravos, em sua maioria libertos, no final da década de 1870 - fato este reafirmado por D' Alambert, que destaca em sua tese que esse momento foi anterior à chegada das primeiras levas de imigrantes italianos ${ }^{45}$.

O ano de 1872 é o ano da chegada dos primeiros imigrantes que, em massa, desembarcavam na capital paulistana. $O$ auge desse primeiro movimento migratório é o ano de 1878. Período curto, de qualquer forma: o fluxo vai se reduzindo ao longo dos anos de 1880, até que em 1888 praticamente se esgota. Provavelmente, o pico no fluxo migratório pode ser reflexo do decreto de 1881, quando novamente proibiu-se o emprego de trabalho escravo em serviços municipais (o decreto anterior, de 1869, fora suspenso por falta de trabalhadores livres) ${ }^{46}$.

Nesse momento, duas instituições de ensino, a Sociedade Propagadora (futuro Liceu de Artes e Ofícios) e a Sociedade Sagrado Coração de Jesus, contribuíram de modo relevante para o desenvolvimento técnico dos artesãos ${ }^{47}$. É plausível afirmar que

\footnotetext{
42 Que aparece no Almanak Administrativo, Mercantil e Industrial da Província de São Paulo para o anno de 1858, com endereço no Piques.

43 D'Alambert Apud CAMPOS (1993: 401).

${ }^{44}$ Enquanto Campinas contava com apenas três olarias neste mesmo ano, só para mantermos sob atenção o contexto que referencia esta dissertação.

45 Já em Campinas, não podemos afirmar o mesmo: embora a técnica fosse bem conhecida nessa época, com o reduzido número de olarias e a mão de obra escrava liberta investida em outros ramos de produção, podemos afirmar com alguma segurança que foi com a primeira leva de imigrantes, anos mais tarde, que a técnica tijoleira seria popularizada no município campineiro.

46 D'ALAMBERT, Clara Correia. Tijolo nas construções paulistanas do século XIX. São Paulo: s.n., 1993, pp. 186 a 190.

47 A contribuição das escolas profissionais na indústria da construção civil será abordada em capítulo posterior.
} 
esse desenvolvimento técnico também se refletia nos processos de produção de componentes para a construção civil, inclusive no que se refere à sua conformação geométrica e material. Era comum a rivalidade entre engenheiros e mestres de obras, como aquela decorrente do uso do tijolo tubular, material que os mestres de obras hesitavam utilizar, talvez por ignorar suas reais características ${ }^{48}$.

Com a mecanização dos processos produtivos aplicados nas olarias, passaram a ser produzidos tijolos com três tipos de máquinas: aquelas que amassavam o barro e formavam tijolos em forma de fita ininterrupta, sendo necessário apenas cortar a fita no comprimento desejado; aquelas que lançam barro para dentro de fôrmas; e aquelas que extrudavam barro por uma peça com orifícios (maromba), estrategicamente desenhados, de maneira semelhante ao que se usava para fabricação de tubos de chumbo. Segundo o engenheiro César de Rainville ${ }^{49}$, os tijolos feitos nessas máquinas não eram consistentes, resistentes e bonitos, como os artesanais. É certo, porém, que os novos processos ocasionaram o aparecimento de diversos tipos de tijolos, até então não utilizados, como o ladrilho e os porosos e ocos, especialmente criados para construções leves, abóbadas e arcos. A Martins \& Irmãos, proprietária da olaria Santa Cruz, em Santos, encarregava-se de fornecer tijolos cheios e furados, de dois, três e seis furos, de cimalha ou ladrilho, além de telhas francesas, cimento e materiais diversos para seu assentamento ${ }^{50}$.

Como já vimos, ao longo da década de 1870 e início da de 1880, outro fator que contribuiu para o desenvolvimento das indústrias foi a introdução das máquinas a vapor. Num primeiro momento, as indústrias que começaram a se instalar no interior do Estado - como a fiação e tecelagem Jundiaiana, de 1874, em Jundiaí - eram movidas, inicialmente, por força-motriz hidráulica. No caso da tecelagem de Jundiaí, em 1886, o aparato motriz hidráulico é substituído por uma caldeira a vapor. De modo geral, porém, até 1875 , a maior parte do parque fabril instalado no estado utilizava a força-motriz hidráulica, principalmente as tecelagens: Santo Antônio, de São Luís de Paraitinga; Santa Francisca, de Piracicaba, instalada junto ao rio da cidade, com 100 teares e 180 operários; Fábrica Carioba, em Campinas, com 26 teares; e, por fim, em Salto, a Fábrica Júpiter, instalada junto à queda-d'água do Rio Tietê. A Júpiter utilizava, como tantas outras, a força d'água para movimentar seus 50 teares, mas, em vez das grandes e desajeitadas rodas d'água, ela tinha uma moderníssima turbina hidráulica, mais econômica, que ocupava menos espaço que as máquinas a vapor ${ }^{51}$.

\footnotetext{
48 REDONDO, Garcia. Revista de Engenharia, 1880, p. 203.

49 RAINVILLE, Cesar O Vinhola Brasileiro. Eduardo e Henrique Larmmert, Rio de Janeiro, 1880, p. 236.

50 D'ALAMBERT, Clara Correa. Tijolo nas construções paulistanas do século XIX. São Paulo: sn, 1993, p. 78.

51 Telles, H. Apud RIBEIRO (1988:33-36).
} 
Citado em Ribeiro, para Henrique Telles $^{52}$ - em sua análise das indústrias Matarazzo no interior paulista -, esse seria o momento chave para o desenvolvimento das modernas indústrias paulistas, decorrente de uma conjunção de fatores e do surgimento de um novo mercado que lhe é correlato:

\begin{abstract}
Na década de 1870 estavam assentadas as condições para o surgimento da indústria algodoeira; a abundância de matéria-prima (algodão) a preços acessíveis, a facilidade no recrutamento de força de trabalho especializada e em importar maquinismos, a melhoria nos transportes, a disponibilidade de mão de obra e a presença de um crescente mercado consumidor ${ }^{53}$.
\end{abstract}

Essas primeiras fábricas tinham todas as suas máquinas importadas dos Estados Unidos pela firma Lidgerwood - que, por sinal, mantinha sua sede em Campinas. Telles faz referência a uma das primeiras fábricas modernas ${ }^{54}$, com mão de obra livre e maquinário importado, a tecelagem São Luiz, de Itu, fundada em 1869. Instalada no centro da cidade, com 24 teares e 62 máquinas, era acionada por duas bombas d'água que captavam água de um riacho vizinho à fábrica. Seu idealizador foi o Tenente Coronel Luiz Antônio Anhaia, farmacêutico daquela cidade. O técnico que projetou o edifício da fábrica São Luiz foi William Putney Raston, empregado de William Van Vlek Lidgerwood. Raston também foi aos Estados Unidos comprar as máquinas e contratar mão de obra especializada ${ }^{55}$ e adotou um sistema construtivo mais moderno, com paredes portantes e divisórias feitas com alvenaria de tijolos revestida. A caixilharia de madeira, com vidros, também foi executada com o auxílio de maquinaria e toda a cobertura do prédio foi executada com telhas de barro do tipo capa e canal.

Embora em menor escala que nos estabelecimentos têxteis, a utilização do maquinário a vapor nas olarias era igual àquela realizada nas oficinas de linhas férreas. $A$ introdução de máquinas era estimulada naqueles ramos de produção que não geravam concorrência com o produto importado, como o calçamento de ruas e extração das areias do Tietê $^{56}$. Como parâmetro da presença de maquinário nas olarias, sabe-se que o

\footnotetext{
52 TELLES, Henrique. V. As indústrias Matarazzo no interior paulista: arquitetura fabril e patrimônio industrial (1920-1960). Dissertação de Mestrado, Departamento de História do Instituto de Filosofia e Ciências Humanas da Unicamp.

53 Telles, H. Apud RIBEIRO (1988:27).

54 BRUNO, Ernani. S. História e Tradições da Cidade de São Paulo. José Olympio Editora, São Paulo, 1954, p. 1133.

55 SAIA, Luis. Morada Paulista. São Paulo, Perspectiva, 1989, pp. 144 e 151.

56 PEREIRA, Paulo C. X. Espaço, técnica e construção. São Paulo: Nobel, 1988, pp. 86 e 87 . Outro exemplo de setor que não oferecia concorrência significativa, mesmo após este período de nascimento industrial - e que, portanto, atraia o investimento em instalações industriais - era o vidraceiro: é notória a presença da fábrica Santa Marina, na Água Branca, fundada em 1897 por Antonio Prado e Elias Pacheco Jordão, com 200 trabalhadores italianos e franceses.
} 
número de trabalhadores nesse ramo de produção representava $15 \%$ do total de trabalhadores dos estabelecimentos que utilizavam motor movido a vapor.

Outro fator que contribuiu para o desenvolvimento econômico de São Paulo foi o fato de muitos fazendeiros de café fixarem residência na capital, explicando, inclusive, o aumento demográfico na cidade entre 1872 e 1886. "Novos bairros se abrem para os dois lados da Avenida Liberdade em direção ao Santo Amaro. Chácaras são loteadas e novas áreas urbanizadas, nos campos Elíseos e em Higienópolis" ${ }^{57}$. Por essa época, já era possível encontrar muitas marcenarias e depósitos de móveis que ofereciam produtos compatíveis com as novas ordens vigentes de referências para 'bom gosto' e 'valor'.

Em 1885, juntamente com a grande expansão industrial experimentada pela capital, também o setor de produção oleira acompanharia o ritmo do crescimento econômico paulistano: são quarenta e duas olarias só nos bairros de Tatuapé, Catumbi, Barra Funda e Água Branca. No ano de 1887, já se registravam na capital três tecelagens, uma cerâmica, cinco grandes fundições, quatro fábricas de artefatos de madeira e uma de mobília, uma de produtos suínos, uma de fósforos, duas de chapéus e algumas dezenas de pequenas fábricas e oficinas de artesãos, na maioria de imigrantes. Mas esse vigoroso desenvolvimento também é, ao mesmo tempo, tributário e promotor do desenvolvimento do interior do Estado. Em 1886, são inúmeras as novas instalações para beneficiamento do café, situadas na cidade de São Paulo ou em sua proximidade, fazendo-a tornar-se a maior produtora de café do país.

Entretanto, a capital não poderia ser a maior produtora de café sem 0 desenvolvimento ferroviário. A malha ferroviária expandia-se por todo o interior: em 1872 , deu-se a concessão da Estrada de Ferro São Paulo-Rio, alcançando Mogi das Cruzes em 1875; Jacareí, São José dos Campos, Caçapava e Taubaté em 1876; e Guaratinguetá e Cachoeira em 1877, entroncando, nesta última cidade, com a Estrada de Ferro Central do Brasil. A Cia. Paulista de Estrada de Ferro, partindo de Jundiaí, atingiu Campinas em 1872, Rio Claro em 1876, Araras em 1877, completando, em 1880, o ramal Mogi-Guaçu. A Sorocabana abriu linha de São Paulo a Sorocaba em 1875, Ipanema em 1876, Boituva em 1882, Tietê em 1883, Laranjal em 1886, Conchas em 1887, Pirambóia em 1888 e Botucatu em 1889. Em 1873, a Companhia Ituana inaugurou a linha Jundiaí até Itu, alcançando Piracicaba em 1879 e São Miguel em 1888. A Companhia Mogiana de Estrada de Ferro, partindo de Campinas, atingiu Mogi-Mirim em 1875, Casa Branca em 1878, Ribeirão Preto em 1883, Batatais em 1886, Franca em 1887, e nos anos seguintes alcançou o Triângulo Mineiro. A Cia. Rio Claro, partindo dessa cidade, alcançou São Carlos em 1884, Araraquara em 1885, Jaú em 1887. Em 1884, a Estrada

${ }^{57}$ D'ALAMBERT, Clara Correia. Tijolo nas construções paulistanas do século XIX. São Paulo: s.n., 1993, p. 11. 
de Ferro Bragantina inaugurou suas linhas, interligando a capital com Atibaia e Bragança $^{58}$.

O crescimento ferroviário foi acompanhado pela ampliação da rede de iluminação pública que, em 1872, passou a ser feita a gás. Nesse mesmo ano, deu-se o início do serviço de bonde com tração animal, operado pela Viação Paulista. Anos mais tarde foi inaugurado o serviço telefônico na cidade (em 1884) e a The São Paulo Tranway Light and Power Company assumiu a Viação Paulista.

Nas últimas décadas do século, foram realizados múltiplos investimentos industriais, comerciais e também imobiliários. A província deixou de apresentar o caráter rural que marcou sua existência colonial, com a formação de pequenos e novos núcleos de urbanidade mais citadina e a introdução de melhoramentos urbanísticos no tradicional Triângulo Central. Nessa época, a cidade delimitava-se pelos extremos da várzea do rio Tietê, da Barra Funda até Belenzinho. As populações mais pobres e os operários distribuíam-se por bairros distintos daqueles ocupados pelas elites da cidade - muito embora, com a instalação de bondes elétricos pela Light, a integração desses distintos bairros passa a configurar tramas de circulação mais fluidas. À medida que o capital e a economia cafeeira se desenvolviam, os acúmulos desse capital transcenderam as fronteiras das fazendas de café, passando a ser aplicado também em atividades tipicamente urbanas, como a bancária, os escritórios, armazéns e oficinas de estrada de ferro, comércio atacadista, comércio de exportação e importação e a indústria. Com o processo de urbanização, também se desenvolveram o comércio varejista, os transportes urbanos, comunicações, energia elétrica, construção civil e os equipamentos urbanos ${ }^{59}$. Outros fatores, também relacionados à produção do café, contribuíram para a implantação da indústria no final do século XIX - como, por exemplo, a baixa de preços internacionais do café, em 1896/97, que fez diminuir a lucratividade das antigas plantações. As novas plantações, já no intuito de assegurar a lucratividade de seus ativos, aplicavam parte desses lucros em capital industrial, acabando por criar meios que foram a base para a constituição do nascedouro da indústria paulista, como descreve Wilson Cano:

...foi o capital cafeeiro quem promoveu essa primeira expansão industrial. Os próprios fazendeiros investiam seus lucros em indústrias (...). As evidências históricas demonstram que também comerciantes, bancos, imigrantes, importadores e outros agentes do complexo cafeeiro fundaram ou adquiriram empresas industriais... (CANO 1998: 143.)

\footnotetext{
58 ARAÚJO, Juliana B. de. A indústria da Construção Civil em São Paulo e a indústria da tecnologia de concreto: da experiência do gabinete de resistência dos materiais ao laboratório de ensaios dos materiais, 1899-1934. Monografia para Graduação em Economia, PUCCAMP 1992, p. 39.

${ }^{59}$ CANO, Wilson. Raízes da concentração industrial em São Paulo. Rio de Janeiro, Difel, 1998, p. 80.
} 
Um reflexo desse processo de crescimento industrial foi a criação das vilas operárias. Em todo o Estado de São Paulo estabeleceram-se grandes indústrias, contando quase que invariavelmente com alguma infra-estrutura específica para atender seus operários, como a de Nicolau Scarpa, que começou trabalhando como operário e formou, em 1919, a Sociedade Anonyma Scarpa, com a Fábrica de Fiação, Tecidos e Malharia, em São Bernardo; a Fábrica de Fiação e Tecidos Nossa Senhora da Ponte; e a Fábrica de Óleo e Sabão, em Sorocaba. Em 1912, Jorge Street instalou a Fábrica de Fiação e Estamparia Maria Zélia, no bairro do Belenzinho, à qual se agregava uma vila operária com mais de 600 casas, creche, grupos escolares (masculino e feminino), escolas profissionais, farmácia, médico, dentista, açougue, armazém, igreja, jardim e restaurante. Rodolfo Crespi, imigrante italiano, fundou um importante estabelecimento, o Cotonifício Crespi S.A., na Moóca. Antonio Proost Rodovalho, Egidio Pinotti Gamba e os irmãos Jaffet também foram importantes industriais paulistanos, protagonistas desse intenso processo de crescimento industrial ${ }^{60}$.

Por fim, outro ramo de grande importância para o setor da construção civil que cresceu, a partir desse desenvolvimento técnico e industrial acelerado, foi o de produção de componentes para a construção de estruturas de concreto armado. No início do século $X X$, o concreto passou a ser utilizado na construção civil, inicialmente na construção pesada. Mas já em 1913 foi realizado o ensaio dos materiais para a construção do primeiro edifício de concreto armado erigido em São Paulo, o edifício Leônidas Moreira, antigo palacete Guinle. Nas vésperas da Primeira Guerra, quem teria importante papel na contribuição para a produção de tecnologia nacional seria a Escola Politécnica: contava com laboratórios comparáveis aos melhores do velho continente e, apesar da função inicial do Gabinete de Resistência dos Materiais ser didática, as pesquisas realizadas pelos alunos eram sistematicamente empregadas na construção civil na cidade.

\subsubsection{No Brasil: Exposições, feiras e eventos}

Para melhor compreensão da dinâmica econômica do período e como índice do grau de importância do processo de industrialização vivido pelo país, é de grande valia considerarmos os principais eventos, feiras e exposições ocorridos na época, tanto locais quanto nacionais. Inicialmente, a ocorrência de pequenas feiras nacionais incentivou a

60 Telles, H. Apud CARONE (2001:131). 
criação de novas indústrias, bem como a realização de eventos de grande porte para a disseminação dessa 'cultura industrial' no Brasil ${ }^{61}$.

Com efeito, a partir do último quartel do século, com a expansão da lavoura de café, esses eventos passam a ganhar destaque cada vez maior: a "Primeira Exposição de Café do Brasil", ocorrida de 14 a 24 de novembro de 1881, reuniu e mostrou 1145 amostras pertencentes a 924 expositores. Estavam ali representadas as províncias do Rio de Janeiro e Minas Gerais e, em diminuta parte, as províncias de São Paulo e Espírito Santo. Basicamente, a exposição trazia apenas tipos e modelos de máquinas para beneficiamento de café. No entanto, o sucesso do evento ensejou a realização da "Segunda Exposição de Café do Brasil", realizada no período de 22 de outubro a 6 de novembro de 1882. É a partir desse momento que eventos regionais e nacionais contaram com a presença de Ramos de Azevedo.

Como visto, uma feira de importância regional ocorreu em Campinas no ano de 1885, com a presença de Ramos, um ano antes de sua mudança para a capital paulistana. Mais tarde, um grande evento movimentou a cidade: a "Exposição Continental", em 1890. Iniciada em outubro, a exposição trazia produtos naturais e artefatos da indústria nacional, além de maquinismo americano e europeu. A Exposição estava prevista para 1892, com preparativos iniciados já em 1890. O projeto seria realizado na Várzea do Carmo, por Ramos de Azevedo, assim como o acompanhamento de sua execução, a cargo do Banco União. O projeto era composto de um conjunto de pavilhões, palácios, jardins, bosques, lagos, canais, chafarizes, pontes e rochedos. Entre eles, pavilhões para cada um dos estados, expondo temas ligados ao comércio, às artes e às indústrias, além de cafés e restaurantes e, nas extremidades, áreas para hotéis, teatros e hipódromos, bem como uma área com cabanas rústicas para divertimento de adultos e crianças (tiro ao alvo, ateliês fotográficos e buffets). No projeto constava também a ligação do Ipiranga com a Várzea do Carmo, através de um boulevard: a Avenida Ipiranga ${ }^{62}$.

Também foi cogitado, pela comissão da "Exposição Continental", o uso do edifício Monumento Ipiranga, construído pelo arquiteto italiano Tommasio Gaudenzio Bezzi,

61 O primeiro grande evento internacional "A Grande Exposição dos Trabalhos da Indústria de Todas as Nações", mais conhecido como Exposição Universal de 1851, reuniu pela primeira vez, em Londres, homens das Artes, Ciência e Comércio, com grande destaque para a estrutura desmontável de ferro, o Palácio de Cristal. Seu êxito incentivou a realização da Exposição Internacional em Paris em 1855, inaugurando o calendário de sucessivas exposições internacionais, cujo ápice foi a Exposição Universal de Paris de 1900 (FRAMPTON, Kenneth. História Crítica da Arquitetura Moderna. São Paulo, Martins Fontes, 1997).

62 SEGAWA, Hugo. Prelúdio da Metrópole - Arquitetura e Urbanismo em São Paulo na passagem do século XIX ao XX. São Paulo, Ateliê Editorial, 2000, pp. 16 e 17. 
finalizado em abril de 1890, mesmo contra a sua vontade ${ }^{63}$. A exposição, contudo, por inúmeras razões, não aconteceria.

No início do século $X X$, uma exposição tentava igualar-se às maiores exposições do mundo, a "Exposição Nacional" de 1908 no Rio de Janeiro, que celebrava os 100 anos da abertura dos portos. Com a República já em vigor há um bom tempo, tentava-se deixar para trás a imagem monarquista do país, evidenciando os sinais de progresso e modernidade que explicitariam essas mudanças - como a reforma promovida por Pereira Passos, que alargou ruas e remodelou todo o centro da capital federal.

A "Exposição Nacional" foi montada na orla do bairro da Urca, com pavilhões monumentais, representando os principais estados, e estava dividida em quatro seções: Agricultura, Indústria Pastoril, Indústrias e Artes Liberais. Em cada uma delas eram exibidos produtos naturais, típicos de cada estado, assim como artigos manufaturados, que não estavam à venda, mas podiam ser negociados futuramente. A localização dos pavilhões indicava a situação política do momento: São Paulo e Minas Gerais, por exemplo, estavam lado a lado, refletindo a política "café-com-leite" - que já orientava a disputa pela hegemonia na condução da República. Os pavilhões eram construídos em estilo eclético e, apesar da monumentalidade aparente, sua estrutura era bastante frágil suficientemente estável para subsistir apenas o período da exposição. Além disso, nem todos os pavilhões eram novos: algumas edificações foram aproveitadas ou reformadas a partir de estruturas existentes, como uma construção que abrigava atividades da Escola Militar. Algumas instituições tinham pavilhões exclusivos, como o Correio e Telégrafos, o

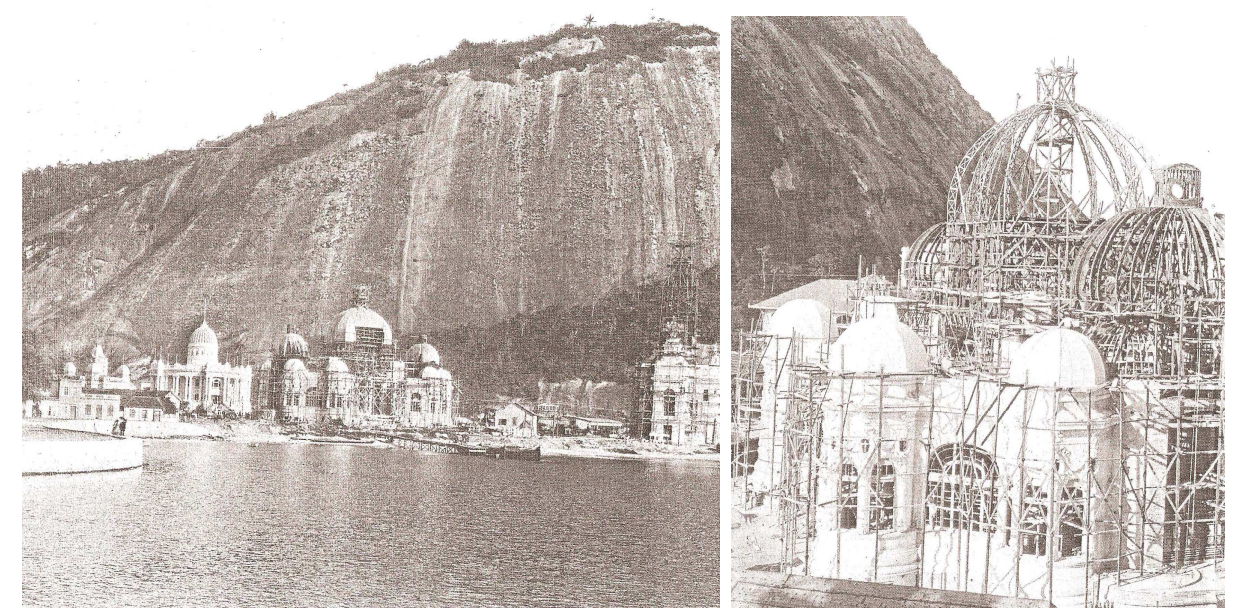

Figura 12: Vista aérea da Exposição Nacional em 1908 no Rio de Janeiro e pavilhão em construção ${ }^{64}$

${ }^{63}$ BARBUY, Heloísa. Museu Paulista: um monumento no Ipiranga, história de um edifício centenário e de sua recuperação. São Paulo, Imprensa Oficial, 1999. 
Corpo de Bombeiros e o Jardim Botânico, enquanto que em outros pavilhões funcionavam restaurantes e realizavam-se atividades de lazer. A "Exposição Nacional", com $182.000 \mathrm{~m} 2$, foi a maior já realizada no país até aquele ano, ultrapassando, inclusive, as Exposições Internacionais que a antecederam. Ramos de Azevedo também participou da exposição do Rio de Janeiro, projetando o Pavilhão de São Paulo - além de expor seu já significativo álbum de construções. Os alunos da Escola Politécnica paulistana também participaram do evento, expondo uma síntese de seus trabalhos e realizando uma mostra fotográfica.

Os pavilhões foram construídos para uma existência provisória, poucos permanecem até hoje. A maioria foi levantada com estruturas de madeira preenchida com estuque, concebida para durar no máximo dez anos. Os únicos que se mantêm de pé são o Pavilhão das Máquinas, hoje parte do campus da Universidade Federal do Rio de Janeiro, parte do Pavilhão de Minas Gerais, atual Escola Municipal Minas Gerais, e o Pavilhão dos Estados, que abriga a Companhia de Pesquisas e Recursos Minerais. $\mathrm{O}$ Pavilhão de São Paulo, projetado por Ramos, e o Pavilhão da Fábrica Bangu, projetado por Sampaio Correa, permaneceram de pé só até 1909.

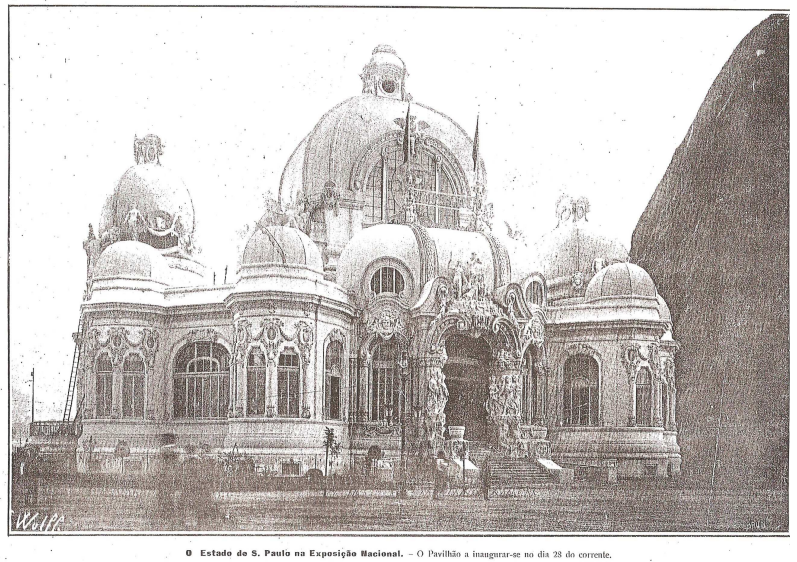

Figura 13: Pavilhão de São Paulo, projetado por Ramos de Azevedo e sua maquete ${ }^{65}$

Nesse momento, como já vimos, o processo inicial de industrialização do país já se efetivara, principalmente na região que se beneficiava com a renda do café.

64 Site: http://omundopreepostorreeiffel.blogspot.com/ e LEMOS, C. A. C. Arquitetura Brasileira. São Paulo: Melhoramentos: Editora da Universidade de São Paulo, 1979, p. 64.

65 Imagens gentilmente cedidas por Luisa Videssot. 
$\mathrm{Na}$ capital paulista, o Palácio das Indústrias tornar-se-ia o grande palco dos eventos que promoviam aquela 'cultura industrial' a que nos referimos: eventos como a Feira de Agricultura e outras, ocorridas a partir de 1917. O Palácio das Indústrias teve sua pedra fundamental lançada em maio de 1911 e foi oficialmente inaugurado em abril de 1924. Durante o período de sua construção, contudo, já abrigava eventos relacionado às indústrias e um "Centro de Artes" provisório, concebido por Ramos de Azevedo, que incentivou a abertura de ateliês para os artistas, que ali executavam tanto esculturas para o próprio palácio como para outras localidades. Entre os artistas estavam Oreste Mantovani, Nicola Rollo, Victor Brecheret, Adolfo Rollo, Van Emelen e Rigoletto Mattei, reunindo um grande número de discípulos a seu redor - os quais, posteriormente, formar-se-iam escultores de prestígio, muitas vezes premiados em salões de artes plásticas ${ }^{66}$.

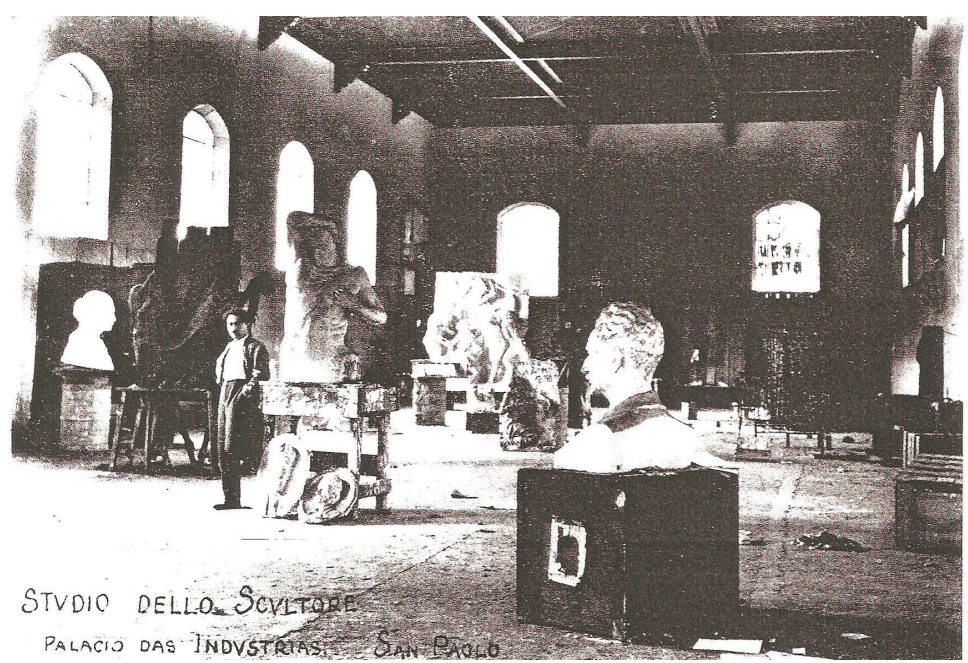

Figura 14: Ateliê do escultor Rigoletto Mattei no Palácio e "Exposição Industrial da Cidade de São Paulo" de $1917^{67}$

Ainda inacabado, o Palácio das Indústrias abrigou, em 1917, a "I Exposição Industrial da Cidade de São Paulo", com a participação das principais indústrias do município, que experimentaram grande desenvolvimento no período da Primeira Guerra Mundial. Contudo, a primeira exposição, realizada após a inauguração do Palácio das Indústrias, foi a "Exposição de Maquetes para o Monumento do Ipiranga", concurso que causou grande impacto e repercussão na cidade, com a vitória de Ettore Ximenes, em março de1920. Também em 1920, abrigou a "III Exposição Industrial de São Paulo" com a presença de empresas como Matarazzo, Vitaliano Michelini, Lacta, Falchi \& Papini, Casa Alemã, Mappin Stores, Máquinas Singer, Cotonifício Rodolfo Crespi, Antarctica Paulista, Casa Nathan, Salus, Instituto Butantã, entre outros, e registrou uma visitação superior a 100 mil pessoas, inaugurando iluminação elétrica interna e externa do prédio,

\footnotetext{
66 PREFEITURA Municipal de São Paulo. Palácio das Indústrias Memória e Cidadania - O restauro para a nova Prefeitura Municipal de São Paulo. São Paulo, Método, 1992, pp. 36 e 37.

${ }^{67}$ Figura 14 e Figura 15: PREFEITURA Municipal de São Paulo. Palácio das Indústrias Memória e Cidadania - O restauro para a nova Prefeitura Municipal de São Paulo. São Paulo, Método, 1992, pp. 36 e 37.
} 
anteriormente iluminado por lampiões a gás. Em 1922, o palácio abrigou também "I Exposição Geral de Belas Artes". Entre 1923 e 1927, aconteceram cinco exposições no Palácio, sendo que a "Il Exposição de Automobilismo e Rodoviação do Brasil" ocorreu ali, em 1924.

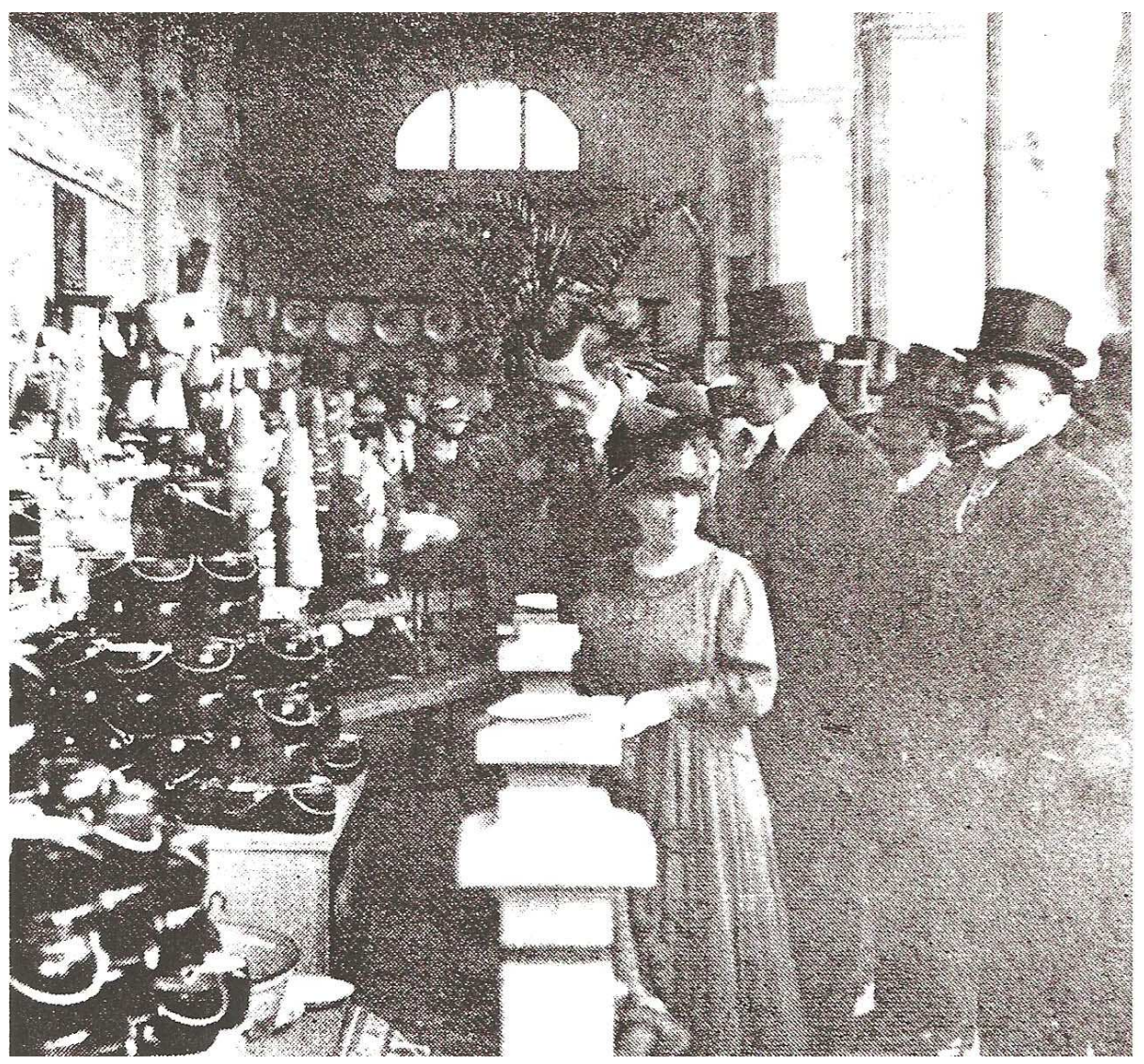

Figura 15: Primeira Exposição Industrial da Cidade de São Paulo 


\subsubsection{Os fatores da industrialização}

Até 1913 o valor de embarque do café experimentou incrementos constantes, chegando a triplicar, nesse ano, em relação aos primeiros anos do século. As condições de comércio melhoraram quando as fábricas foram ampliadas e reequipadas. As importações de máquinas e produtos de ferro e aço experimentaram seu auge no período de 1909 e 1913. São Paulo já não dependia mais do Rio de Janeiro e, como um índice do desenvolvimento do setor de serviços, as companhias de conserto nascidas durante a guerra mantiveram-se e até prosperaram após o final do litígio - como o caso do imigrante inglês Pirie, que consertava máquinas e elevadores e, alguns anos mais tarde, em sociedade, passou a fabricar os elevadores por aqui utilizados. De 1900 a 1920, o parque industrial de São Paulo expandiu-se rapidamente, principalmente se compararmos com as duas décadas seguintes, quando o ritmo foi mais lento ${ }^{68}$.

As razões para tal expansão econômica são motivo de debate.

Alguns autores apontam, como fatores determinantes para a industrialização do país, a política econômica tarifária, que impunha altos tributos às importações; a relativa abundância de matéria prima local, como algodão, couro, madeira, cana-de-açúcar e matérias primas minerais não metálicas, como argila e areia; além da integração ferroviária entre os estados de São Paulo, Rio de Janeiro e Minas Gerais. A produção, em termos brutos, passou de 60 mil para 200 mil toneladas em 1927.

Para outros o país já estava industrializado antes da I Guerra Mundial. Alguns autores consideram que a própria crise do café acabou promovendo o crescimento da indústria interna. Outros consideram o contrário, pois as indústrias, com a crise do café, acabavam arcando com custos muito mais altos, com a importação de matérias-primas, combustíveis e máquinas, onerando seus recursos de investimento e limitando seu crescimento $^{69}$. Mas foi no ano de 1917 que começou a verdadeira crise, com a suspensão das importações de café por parte dos ingleses. Apesar de um indiscutível crescimento limitado, a indústria se diversificou: novas fábricas, que produziam ferro gusa e cimento, motores elétricos, máquinas, ferramentas e peças de automóveis, foram instaladas. Por outro lado, a capacidade de investimento em infra-estrutura havia sido bastante afetada: a construção de estradas de ferro experimentou um lento crescimento

${ }^{68}$ PEREIRA, Paulo C. X. São Paulo - a construção da cidade - 1872-1914. São Carlos: Rima, 2004, pp. 33 a 35. Segundo Pereira, até a Segunda Guerra houve apenas surtos industriais, não contínuos.

69 É importante ressaltar que, nesse período que precedeu a primeira grande guerra, as importações pesavam mais que a própria indústria nacional: essa relação se inverteria, registrando um saldo favorável para as exportações, apenas durante a guerra. 
até o final da década de 1930, e as estradas boas eram poucas, pois a maioria ainda era de terra ${ }^{70}$.

De qualquer forma, é plausível afirmar que, de uma forma ou de outra, devido à guerra ou não, o capital nacional necessário para a industrialização do país foi, inicialmente, fornecido por fazendeiros. Mas também é provável que os investimentos dos fazendeiros e importadores fossem menos importantes para o desenvolvimento da indústria - no período imediatamente seguinte à instalação das primeiras indústrias - que o reinvestimento feito pelos próprios industriais ${ }^{71}$.

\subsection{Sobre a indústria da construção civil}

A indústria da construção civil - que na época era nomeada de indústria de edificação - foi, desde sua origem, marcada por uma grande rotatividade de mão de obra. A admissão e a dispensa de seus trabalhadores dependiam do andamento das obras e da sazonalidade dos empreendimentos - daí o pequeno número de grandes empresas e a grande quantidade de pequenas. Essa indústria interferia em variados setores da economia e diversos ramos de produção, justamente porque utilizava tecnologias mais rudimentares articuladas a processos tecnológicos mais complexos. Assim, esse setor produtivo antecede o crescimento industrial em geral, tanto por ser responsável pela execução de toda a infra-estrutura necessária como pelo fato de propiciar a movimentação de todo um amplo segmento econômico ${ }^{72}$.

No Brasil, as empresas com maior número de estabelecimentos eram as de produção e comercialização de cimento e cal, seguidas daquelas envolvidas com a produção e comercialização de portas, esquadrias e escadas. A maioria desses estabelecimentos eram firmas individuais. Até 0 ano de 1889, do total de estabelecimentos de indústrias de edificação instalados, 75\% pertenciam a fábricas de cimento e cal, $12,5 \%$ a marmorarias, $8,93 \%$ a fábricas de esquadrias, portas e escadas e $3,57 \%$ a fábricas de papéis pintados. Vale lembrar que, quanto ao pessoal empregado na indústria de edificação brasileira, o ramo era ainda predominantemente dominado por homens: num total de 4.279 operários, 41 eram mulheres e, nessas indústrias, de 401

\footnotetext{
${ }^{70}$ DEAN, W. A industrialização de São Paulo (1880-1945). São Paulo: Difusão Européia do Livro, 1971, pp. 120 a 123.

71 Idem, pp. 94 a 98.

72 Araújo ApudWERNEK (1978:12).
} 
proprietários, seis eram mulheres. Quanto aos administradores, engenheiros e empregados técnicos, de 143, apenas uma era mulher ${ }^{73}$.

Nos últimos anos do século XIX, o setor já estava estruturado na cidade de São Paulo. Essa indústria abrangia a fabricação de cal e cimento - que produziam a cal hidráulica, cal virgem, cal de marisco, cal de pedra e os cimentos; as marmorarias - que produziam túmulos, mausoléus, escadas, figuras, soleiras, balcões, pedras para lavatórios, estátuas, monumentos, ornamentos para sepulturas, louças, jazigos, altares, bustos e móveis; as fabricas de ornatos de cimento e gesso - que produziam esculturas, estuque, artigos de ornamentação, imagens diversas, estátuas de gesso e que prestavam serviços de galvanoplastia. Abrangia também as fábricas de esquadrias, portas e escadas, que produziam também esquadrias de ferro e madeira, portas, janelas e grades de ferro, além de assoalhos, divisões para escritórios, balcões, armações, corrimãos, bandeiras e até artefatos de cimento armado (como balaustradas, por exemplo). As fábricas de papéis pintados, que produziam papel estampado, papel pintado e guarnições, além de confetes e serpentinas, também compunham a indústria de edificação que então se estruturava. Como se pode perceber, tratava-se de produtos basicamente artesanais e que não demandavam, necessariamente, altos investimentos e grande complexidade tecnológica ${ }^{74}$.

Como já ressaltamos, era grande a quantidade de pequenos estabelecimentos, denunciando um reduzido volume de capital fixo investido. Tais estabelecimentos, além de, consequentemente, absorver um também reduzido número de operários, concorriam, através de suas políticas de preços, em grau bastante acentuado.

Nos primeiros 20 anos do século $X X$, esse número de estabelecimentos quintuplicou, a maioria em São Paulo e Distrito Federal, devido ao intenso processo de urbanização que essas cidades experimentavam. Nesse período, havia 275 estabelecimentos instalados no país, ainda predominando as fábricas de cimento e cal, seguidas das fábricas de esquadrias $(31,64 \%)$, marmorarias $(13,45 \%)$, fábricas de ornatos, cimento e gesso $(2,91 \%)$ e, com apenas $1,09 \%$ do total de estabelecimentos, fábricas de papéis pintados ${ }^{75}$.

No Estado de São Paulo, no total, concentravam-se 20 desses estabelecimentos. No entanto, segundo Araújo, no setor industrial paulista, o ramo de edificação não tinha peso significativo: apenas $1,33 \%$ do total de estabelecimentos existentes no Estado: eram 55 dos 4145 estabelecimentos, sendo 40 firmas individuais, 10 sociedades em

\footnotetext{
${ }^{73}$ ARAÚJO, Juliana B. de. A indústria da Construção Civil em São Paulo e a indústria da tecnologia de concreto: da experiência do gabinete de resistência dos materiais ao laboratório de ensaios dos materiais, 1899-1934. Monografia para Graduação em Economia, PUCCAMP 1992, p. 49.

${ }_{75}^{74}$ Censo de 1921, Ibid., p. 42.

75 Ibid., p. 43.
} 
nome coletivo, três sociedades em comanditas simples, uma sociedade anônima, uma sociedade em comanditas por ações. Até 1899, haviam sido fundados cinco estabelecimentos industriais no setor de edificação. De 1889 a 1914, esse número passou para 110 estabelecimentos. De 1915 a 1919, passou para $75^{76}$.

Essa indústria absorvia um total de 2.030 empregados, sendo muitos deles menores de 14 anos. Na medida em que aumentava o número de funcionários, o número de estabelecimentos diminuía. Quanto ao capital investido, a indústria de edificação apresentava volume relativamente baixo, se comparado a outros setores da indústria paulista. Também a composição orgânica do capital investido já demonstrava a congênita discrepância entre capital fixo e capital variável, uma característica própria do setor: os gastos com matéria-prima representavam 53,1\%; enquanto os salários consumiam 40,1\%; os transportes, $2,9 \%$; e os combustíveis, $2,5 \%{ }^{77}$.

Finalmente, reaproximando-nos do contexto mais específico desta dissertação: quanto ao desenvolvimento industrial de Campinas, este superaria a produção cafeeira apenas nas primeiras décadas do século XX. Dessa forma, podemos afirmar que Ramos de Azevedo atuou numa cidade ainda sem infra-estrutura industrial plenamente instalada, sustentada pelo capital auferido com a lavoura do café e envolvida pelo requintado estilo de vida da aristocracia cafeeira. A mão de obra local ainda não se especializara e, invariavelmente, recorria-se aos materiais importados e mão de obra estrangeira. Por outro lado, era preciso algum conhecimento ilustrado para lidar com essa mão de obra. Ao que parece, Ramos de Azevedo não teria tido problemas nesse sentido, aproveitando o conhecimento adquirido nas artes decorativas, fruto de sua estadia em Gante. Por outro lado, parece possível afirmar que a plena conjugação dos recursos (infra-estruturais, industriais e tecnológicos) para a realização da arquitetura e da engenharia que aprendera na Bélgica aconteceria apenas após sua permanência em Campinas.

\footnotetext{
${ }^{76}$ A sociedade em comandita simples é caracterizada pela existência de dois tipos de sócios: os sócios comanditários, que contribuem apenas com o capital, ficando alheios à administração, e os comanditados, que contribuem com capital e trabalho, além de serem responsáveis pela administração da empresa (http://pt.wikipedia.org/wiki/Sociedade em comandita simples).

77 ARAÚJO, Juliana B. de. A indústria da Construção Civil em São Paulo e a indústria da tecnologia de concreto: da experiência do gabinete de resistência dos materiais ao laboratório de ensaios dos materiais, 1899-1934. Monografia para Graduação em Economia, PUCCAMP 1992, p. 46.
} 


\subsection{O papel das escolas profissionais no processo industrial}

Uma classe emergente, que aparecia com a renda do café investida na indústria, levou à formação de um grupo político muito forte, constituído por fazendeiros, bacharéis, comerciantes, militares e intelectuais muito ativos, que buscava, conforme os ideais positivistas e os preceitos maçons, um novo ideário e uma nova prática para a educação pública, mais ajustada com as concepções republicanas de existência civil. As novas escolas e seus prédios compõem um eloquente exemplo das inovações pretendidas, além de introduzirem novas tipologias arquitetônicas e construtivas ${ }^{78}$. Mas as motivações explícitas - benemerência, solidariedade, formação e educação para todas as classes sociais - não demarcavam nenhuma reserva à manifestação, também explícita, da necessidade objetiva de formação de um contingente operário, tecnologicamente apto, para atendimento da nova demanda industrial.

A tradicional formação técnica profissional - que deu origem à mão de obra especializada que se dedicaria à construção civil - deu-se a partir das antigas corporações de ofícios, organizadas à moda da colônia, conhecidas, em algumas partes, como "Bandeiras de Ofícios" "'. Em muitos casos, o agrupamento profissional acontecia a partir de uma organização nos moldes de uma confraria religiosa. Daí surgiram os oleiros, telheiros, carpinteiros, entalhadores, pedreiros, pintores, ferreiros, serralheiros e decoradores de interiores de igrejas. Estes, para terem sua própria oficina e mudarem de categoria, deveriam obter uma licença da Câmara Municipal, submetendo-se a um exame supervisionado pelo "juiz de ofício". Todo o processo, contudo, não era conduzido lá com

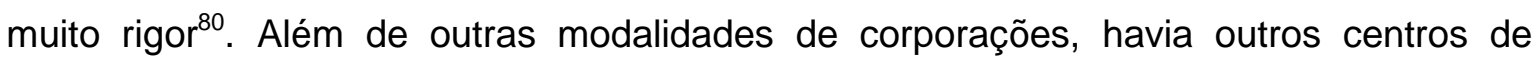
aprendizagem, como as oficinas dos engenhos das fazendas, onde os conhecimentos técnicos práticos eram ensinados aos escravos negros, ainda que de modo assistemático. Como já fizemos referência no início deste capítulo, era comum, até a

\footnotetext{
78 Tomando como referência o contexto campineiro, o edifício do Colégio Culto à Ciência, de autoria do engenheiro e empreiteiro Guilherme Krug - que, como vimos no capítulo anterior, viria a trabalhar com Ramos, anos mais tarde - segundo os dados da escola na época, inova ao trazer aspectos da arquitetura europeia, com janelas de mansardas e o tijolo à vista. A escola, idealizada em 1869 pelos republicanos e positivistas Campos Sales, Francisco Glicério, Américo Brasiliense, Prudente de Moraes e outros membros da Sociedade Culto à Ciência, foi fundada a partir de iniciativa particular, sem intenção de lucros. Mesmo com as dificuldades financeiras que já imaginavam, a proposta pedagógica que se pretendida implementar visava à capacitação profissional de todas as classes sociais. O Colégio Internacional, fundado pelos americanos sulistas, fiéis da Igreja Presbiteriana americana, foi outra edificação que tipificou claramente a influência da arquitetura estrangeira. A seguir, o crescimento do número de escolas seria constante nos anúncios de jornais. Em evidência, o Colégio São Benedito, o Liceu de Artes e Ofícios (atual Liceu Nossa Senhora Auxiliadora), a Associação Culto a Ciência, a Creche Bento Quirino, a Escola Noturna da Loja Maçônica e a Associação Artística Beneficente de Campinas, entre muitas outras. Até 1871, eram em número de quinhentos e setenta; dois anos depois, subiu para setecentos o número de escolas urbanas (LISBOA, José Maria. Almanak de Campinas para 1872. Campinas: Typographia da Gazeta de Campinas, 1871).

${ }^{79}$ CONDEPHAAT, Relatórios de Processo de Tombamento. Colégio Técnico de Campinas, agosto/1983 (Centro de Memória Unicamp), p. 45.

80 FONSECA, Celso Suckow da. História do ensino industrial no Brasil, Rio de Janeiro, 1962, p. 3.
} 
abolição da escravidão, o senhor de escravos adquiri-los, ensiná-los ofícios e alugá-los, constituindo uma segura alternativa de renda, além de valorizar o capital investido na aquisição do cativo ${ }^{81}$. Em termos de formação técnica do trabalho livre, ainda no século XVII, a Casa de Fundição e Moeda passou a ensinar, de forma sistemática, como examinar metais, lavrar minas e fundir o ouro. Outro destaque, nesse sentido, foi a iniciativa dos Arsenais da Marinha, em que eram ministrados conhecimentos sobre a construção naval ${ }^{82}$.

Quando D. João VI liberou a instalação de estabelecimentos industriais em 1809, foi criado, no Rio de Janeiro, o Colégio das Fábricas, destinado à formação dos artistas e aprendizes vindos de Portugal, com o objetivo de fornecer mão de obra para atender o Arsenal Real Império ${ }^{83}$. Em 1819 foi instituído o Seminário de Órfãos, onde se ensinavam ofícios para órfãos. Porém, em 1824, a primeira Constituição brasileira, outorgada por D. Pedro I, proibiu as corporações de ofícios, abrindo uma grande lacuna no aprendizado profissional. Em seu lugar, privilegiou-se a cultura intelectual que, por sua natureza, acabava depreciando o trabalho manual e condenando os ofícios como atividade desprestigiada. Esta situação manteve-se durante todo o Império, caracterizado pela formação de doutores, bacharéis e letrados. Até a proclamação da República, para uma formação tecnológica mais ilustrada, o país contava apenas com a Academia Militar do Rio de Janeiro: fundada em 1810, foi dividida, mais tarde - em 1845 - em Escola Militar e Escola Central - que, em virtude de sua localização, contribuiu decisivamente para a fundação da primeira ferrovia brasileira, a Estrada de Ferro Mauá ${ }^{84}$.

Apenas com o advento da República é que ressurgiu a preocupação com o ensino de ofícios, mas a partir de iniciativas privadas e de sociedades civis organizadas com objetivos filantrópicos, já no final do século. De tais iniciativas, só seriam sentidos os impactos décadas mais tarde. Em São Paulo, um exemplo é a fundação da Sociedade Propagadora da Instrução Popular, como já mencionado anteriormente, o futuro Liceu de Artes e Ofícios. Outros exemplos na capital são o Instituto D. Rosa (1885) e o Liceu de Artes e Ofícios do Sagrado Coração de Jesus, criado por iniciativa de padres salesianos.

Além da necessidade de escolas técnicas e instâncias formalmente constituídas de ensino profissional - decorrente da antiga proibição do governo colonial e imperial -, também o grande aumento de estabelecimentos industriais no país exigiu a criação de novas escolas de ofícios. Em 1906, o presidente Afonso Pena, em seu discurso de

\footnotetext{
81 PEREIRA, Paulo César Xavier. São Paulo, a construção da cidade, 1872-1914. São Carlos, Rima Editora, 2004, pp. 24 a 26.

82 Ibid., pp. 71.

83 CONDEPHAAT, Relatórios de Processo de Tombamento. Colégio Técnico de Campinas, agosto/1983 (Centro de Memória Unicamp), p. 46.

${ }^{84}$ Em 1854, com a implantação de um pequeno trecho de $15 \mathrm{~km}$, a ferrovia fazia a ligação entre o porto de Mauá e Petrópolis.
} 
posse, chamava a atenção para a "criação e a multiplicação de institutos de ensino técnico profissional, contribuindo também para o progresso das indústrias, proporcionando-Ihes mestres e operários instruídos e hábeis". A partir desse compromisso de posse, Pena sancionou um decreto que mandava criar o Ministério dos Negócios de Agricultura, Indústria e Comércio, para propor, entre outros assuntos, ações voltadas para o ensino profissional. Nesse mesmo ano, o engenheiro José Joaquim da Silva Freire criava, nas instalações da Estrada de Ferro Central do Brasil, a Escola Prática de Aprendizes de Oficinas ${ }^{85}$. Três anos depois, a Câmara dos Deputados propôs a habilitação do poder público para implementar escolas profissionais de âmbito federal. No caso de já existir uma escola desse tipo, o governo auxiliaria o estabelecimento estadual com subvenção igual à cota destinada ao custeio da escola. Esse decreto, na opinião de Suckow da Fonseca, é o marco inicial das atividades do governo federal no campo de ensino de ofícios. Em 1910, foi inaugurada uma rede de estabelecimentos, mantida pelo governo federal, congregando as escolas de aprendizes artífices: a Escola Técnica Getúlio Vargas (masculina), em 1911, em São Paulo; a Escola Técnica Carlos de Campos (feminina), também em 1911 e também em São Paulo; a Escola Técnica João Belarmino, em Amparo; e Escola Técnica de Jundiaí (fechada logo em seguida).

Tais escolas, contudo, funcionavam em condições precárias, com um quadro profissional inadequado, dado que o corpo docente era composto por professores do ensino primário. Além disso, os edifícios eram inapropriados, dificultando o funcionamento das oficinas. Para melhorar a situação, Hermes da Fonseca regulamentou um decreto - Decreto n 9070, de 25/10/1911 - separando o curso primário dos cursos de ofícios, reservando o primeiro exclusivamente para aqueles que não sabiam ler, escrever e contar, e assegurando, inclusive, o ensino de "desenho para todos". Já os cursos de ofícios, agregava-os nas Oficinas, com quatro horas por dia para os primeiros e segundos anos e seis horas por dia para os terceiros e quartos anos. O ensino ali incluía aulas teóricas e práticas, concretizando a proposta de educação profissional vigente à época, o "aprender fazendo": os alunos poderiam, através da escola, receber encomendas e utilizar suas instalações para realizá-las. O regulamento de 1911 também se preocupou em atentar para as questões edilícias, relativas às instalações de ensino, melhorando as condições de iluminação, de insolação, ventilação e de abastecimento de água potável.

É importante ressaltar que a pretensão das escolas técnico-profissionais não era apenas fornecer mão de obra especializada, arvorando-se igualmente como promotora de benefícios sociais. Nesse sentido, é eloquente a frase de Francisco Joaquim

\footnotetext{
${ }^{85}$ FONSECA, Celso Suckow da. História do ensino industrial no Brasil, Rio de Janeiro, 1962, p. 158.
} 
Béthencourt, o criador da Sociedade Propagadora das Belas Artes, no Rio de Janeiro: "Combater a ignorância é defender a liberdade" ${ }^{86}$. Também relevante é a manifestação do presidente Venceslau Brás Pereira Gomes, quando ressaltou a necessidade de se dar maior atenção às escolas primárias, com o objetivo de combater a "criminalidade, vagabundagem e o alcoolismo". Para tanto, propunha a criação de escolas industriais de eletricidade, mecânica, química e comércio. O governo, porém, não se encontrava em condições econômicas adequadas para incrementar o ensino profissional, pois as exportações de café haviam decaído com a Primeira Guerra Mundial, gerando grandes dificuldades nas contas públicas.

A quantidade de pequenas indústrias, entretanto, não deixou de crescer paulatinamente, contribuindo para a ampliação da variedade de conhecimentos e especialidades profissionais exigidas, resultado da diversidade de problemas de ordem técnica demandados por esse nascente parque industrial. A falta de mão de obra para atender a demanda exigiu a criação de um maior número de escolas profissionais, além de melhorias nos métodos de aprendizagem ${ }^{87}$. No estado de São Paulo, foram criadas as seguintes escolas: em 1918, a Escola Profissional Masculina de Rio Claro; em 1924, a Escola Profissional Dr. Julio Cardos, em Franca; em 1927, o Instituto Borges de Artes e Ofícios, em Itu; em 1929, a Escola Profissional Fernando Prestes, em Sorocaba; em 1931, a Escola Profissional Mista Coronel Francisco Garcia, em Mococa; e em 1933, a Escola Profissional Mista de São Carlos ${ }^{88}$. Nesse período, foram aprovados diversos decretos no sentido de melhorar, sistematizar e legalizar essa modalidade de ensino. Nessa fase inicial de incremento de escolas profissionais, o governo aprovou, através do Ministério da Agricultura, com João Gonçalves Pereira Lima à sua frente, um novo regulamento para as escolas de Aprendizes e Artífices que exigia, entre outros requisitos, o curso primário obrigatório e idade mínima de 10 anos (lei oํ 3454 de 06/01/1918).

Foi nesse contexto, depois de muitos anos de luta para a consolidação de uma rede de escolas profissionais no Estado que, finalmente, foi criada em Campinas a Associação do Instituto Profissional Bento Quirino, em 25 de junho de 1915 - cujo edifício, projetado por Ramos de Azevedo, fora inaugurado em 1918.

\footnotetext{
${ }^{86}$ Conforme o site www. educacional.com.br/revista/0408/pdf/02 Parceria.pdf

87 CONDEPHAAT, Relatórios de Processo de Tombamento. Colégio Técnico de Campinas, agosto/1983 (Centro de Memória Unicamp), p. 52.

${ }^{88}$ Suckow da Fonseca, Celso. História do Ensino Industrial no Brasil, Rio de Janeiro, 1962, p. 327.
} 


\subsection{Financiamento: relação com casas bancárias e importadoras}

Com o acúmulo e desenvolvimento do capital cafeeiro, também os sistemas de importação, seu financiamento e sua securitização foram se desenvolvendo. Essa dinâmica foi essencial para, entre outros resultados, viabilizar o levantamento de edifícios de grande porte no Brasil, para a intensificação dos processos de expansão urbana e para a ampliação do processo de industrialização do país. Esse capital acabaria trazendo novos costumes e uma nova arquitetura.

Como já afirmamos anteriormente, enquanto para alguns autores tal dinâmica foi determinante para o abastecimento e o consequente desenvolvimento da indústria nacional, para outros foi razão de obstrução e postergação de um processo de industrialização mais acelerado. No entanto, seja esse um processo mais ou menos veloz, o que aqui nos interessa são as suas consequências e seus reflexos na construção civil. Para tanto, parece-nos importante uma leitura - ainda que superficial - do modo como se estabeleceram as relações entre o capital agro-cafeeiro e o capital industrial.

A relação entre banqueiros, fazendeiros de café e importadores foi ficando cada vez mais intensa: quanto mais crescia a demanda pelo fruto e seu derivado, mais os fazendeiros necessitavam de créditos para abrir novos cafezais. A lavoura de café, quanto mais se expandia, mais exigia grandes investimentos, pelo fato de se tratar de uma planta perene e de ciclo lento, demorando de cinco a seis anos para dar frutos após o plantio ${ }^{89}$. Isso significava, necessariamente, vínculos com ciclos lentos e comprometimentos também perenes, compromissando o mercado de créditos bancários e o da lavoura cafeeira. Por outro lado, os investimentos não se restringiam ao financiamento de recursos para ampliar as lavouras: fazia-se necessário, também, a aquisição de mais e mais implementos agrícolas e máquinas para o processamento do café - equipamentos, até então, apenas adquiridos no exterior.

Em 1873, em São Paulo, havia apenas quatro estabelecimentos bancários: duas agências de bancos maiores e duas casas bancárias. Em 1889, houve um pequeno aumento no número dessas agências: agora eram cinco bancos, além de duas sucursais de bancos estrangeiros ${ }^{90}$. Os bancos nacionais eram os grandes mediadores dos negócios de importação, pois tinham como função amparar o intermediário que

\footnotetext{
${ }^{89}$ ARAÚJO, J. B. A indústria da Construção Civil em São Paulo e a indústria da tecnologia de concreto: da experiência do gabinete de resistência dos materiais ao laboratório de ensaios dos materiais, 1899-1934. Monografia para Graduação em Economia, Pontifícia Universidade Católica de Campinas, 1992, pp. 10 a 12.

${ }^{90}$ Araujo Apud SINGER (1966:33).
} 
financiava, assegurando-lhe alguma solvência frente a instabilidades devido à variabilidade da oferta e instabilidades de mercado decorrentes de efeitos sazonais e climáticos (pragas e geadas) ${ }^{91}$. Os comissários do café e as Casas Comissárias, que ficavam no porto de Santos, passaram a ter filiais em Campinas ${ }^{92}$. Segundo Ernani Silva Bruno $^{93}$, houve sim um desenvolvimento sensível da indústria até 1880 , mas a multiplicação das casas importadoras foi maior, principalmente daquelas envolvidas com a importação de máquinas para a lavoura, o que demonstra o quanto a economia cafeeira dependia dessa tríplice aliança: fazendas, bancos e casas importadoras.

À medida que aumentava a demanda mundial pelo café, os fazendeiros sentiamse incentivados a realizar novos investimentos, ampliando as alternativas de aplicação de seus capitais, pois estas se mostravam cada vez mais lucrativas. Essa movimentação do mercado financeiro atravessou a virada do século, com as importações atingindo seu auge entre 1909 e 1913. Contudo, com o crescimento e nascimento de novas indústrias em meio a pequenos surtos de crise financeira - é bem provável que, nesse período, o reinvestimento feito pelos industriais fosse mais importante que os investimentos dos fazendeiros e importadores - como já considerado em 2.1.4, entre os fatores que implicaram diretamente no processo de industrialização do país.

O reflexo dessa dinâmica de investimentos no processo de produção da capital paulista - novas edificações e urbanização - tem impacto importante no seu processo de expansão: ao longo dos anos de 1890, a cidade expandiu sua área central, urbanizandose ao redor e intensificando o mercado de locação - mas ainda não necessariamente a produção imobiliária. Antes, na contratação de serviços de construção - num chamado primeiro estágio -, utilizavam-se os próprios recursos auferidos com investimentos imobiliários, construindo as casas de vilas e os condomínios horizontais. Elaboravam-se projetos e contratavam-se construtores com recursos gerados pela própria produção imobiliária. Só no final do século XIX é que surgiriam as incorporadoras e instituições financeiras dedicadas aos financiamentos imobiliários, como Banco Hipotecário Lar Brasileiro $^{94}$.

Num âmbito mais restrito - por força do recorte pretendido por este trabalho - a situação de Campinas seguia a dinâmica do contexto geral estabelecido pela economia

\footnotetext{
${ }^{91}$ Araujo Apud SINGER (1966:33).

92 Badaró, Ricardo de Souza Campos. Campinas, o despontar da modernidade. Campinas, CMU/ UNICAMP, 1996, p. 29.

93 BRUNO, E. S. História e Tradições da Cidade de São Paulo. José Olympio Editora, São Paulo, 1954, p. 1133.

${ }^{94}$ Araujo Apud VASCONCELLOS (1985: 39).
} 
cafeeira. Já no final do século, os fazendeiros e investidores - que eram chamados de "capitalistas" - socorriam a Intendência Municipal para atendimento de despesas geradas pelas obras públicas, através da comissão de títulos denominados "Acções da Cidade", oferecidos a juros de 8 e 9\% ao ano, segundo o relatório da Câmara. Quando a Câmara achava necessário, recorria-se também à venda de terrenos do município. A cidade tinha algumas casas bancárias que garantiam os investimentos da iniciativa privada, tanto de empresários do comércio como da lavoura - como uma filial da Mauá \& Cia, a casa bancária do Dr. Theodoro Reichert, que oferecia e recebia dinheiro a prêmio, emitindo títulos hipotecários, cauções, apólices da dívida pública, ações do Banco do Brasil, ações das estradas de ferro, depósito em conta corrente e depósitos a prazo fixo ${ }^{95}$.

\subsection{Materiais e processos construtivos no contexto paulista}

É entre os meandros do contexto histórico, social e econômico explicitado anteriormente que pretendemos ressaltar, ainda que de forma ampla, o que por aqui existia em termos de materiais e sistemas para aplicação na construção civil, particularmente na situação regional que nos interessa, o Estado de São Paulo ${ }^{96}$.

Inicialmente, os materiais básicos, encontrados ou produzidos no estado, eram a areia, a cal e o tijolo, além de alguns componentes semiprocessados. Havia inúmeras fundições e serrarias, mas a maioria dos materiais de ferro era importada, assim como boa parte da madeira e papéis de parede. Nesse período, como já vimos, surgiram inúmeras pequenas oficinas, já a partir de 1880, quando a técnica tijoleira já estava consolidada.

Segundo Carlos Lemos, os materiais de acabamento, em sua maioria, eram importados: os vidros (lisos, lapidados, fosqueados, coloridos ou espelhados), vitrais para aplicação em igrejas e palacetes -, as ferragens em geral, os arames e pregos galvanizados, as chapas de cobre para condutores de calhas e chapas de zinco e de ferro zincado (chapas lisas ou onduladas), os papéis de parede (lisos ou decorados em relevo estampado), as telhas de cerâmica vindas de Marselha, o cimento em barricas, os ornatos

\footnotetext{
95 MARIANO, Júlio. Campinas de ontem e ante-ontem; quadros históricos menos conhecidos da Cidade Princesa, que se traçaram tendo por base documentos inéditos do Arquivo da Câmera Municipal de Campinas. Campinas, Editora Maranata, 1970, pp. 35 a 38.

${ }^{96}$ Para complementar a dissertação sobre algumas especificidades desse setor produtivo e suas implicações objetivas na composição de uma abordagem arquitetônica e construtiva - a de Ramos de Azevedo -, materiais, técnicas e processos serão analisados com maior profundidade e circunscrição já no contexto de sua efetiva aplicação, tendo como referência o estudo de caso escolhido (ver o Capítulo 3: O processo e a técnica).
} 
e moldes de gesso, ingredientes para a composição de massa para revestimento, de betumes para impermeabilização, as tintas a óleo, manilhas vidradas, mármores variados - especialmente os de Carrara -, mosaicos, ladrilhos e azulejos (brancos ou decorados), aparelhos sanitários, tubos e canos para instalações hidráulicas, grimpas, grades, guarda-corpos, colunas de ferro (forjado ou fundido) e o ainda hoje cobiçado pinho-deriga.

A madeira nacional, chamada madeira "de lei", era considerada boa, pois resistia à umidade e possuía grande resistência à flexão, ao contrário das que vinham de fora. Mas, segundo Lemos, a madeira nacional era inadvertidamente desperdiçada ${ }^{96}$ e as que eram consideradas de qualidade acabavam sendo exageradamente dimensionadas, para efeito de garantia, quando de sua aplicação em estruturas. O transporte era bastante complicado, feito em juntas de bois, com o auxílio de cordas e correntes. Boa parte, porém, da madeira que se comercializava era mais para a execução de navios do que destinada à construção de edifícios - o que implicava cortes de madeira exclusivos, mais indicados para construção de mastros e vergas de embarcações. Por fim, era comum dizer que as madeiras eram 'maltratadas', muitas vezes, já nas serrarias. A madeira tirada da Serra do Mar era considerada ruim, servindo para obras provisórias, como andaimes, caixas de açúcar etc. Assim, era natural a importação do pinho-de-riga, o qual apresentava grande resistência ao ataque de cupins e à flexão, era de talhe fácil e passível de aplicação em diversas situações construtivas (estruturas, esquadrias, mobiliário etc.), predominando no mercado madeireiro até por volta de 1914. Ressalte-se que, em Portugal, era comum a utilização do pinho-de-riga para a construção de escadas $^{97}$. Mas seria somente nas marcenarias dedicadas à fabricação de mobiliário que se observavam cuidados maiores na aplicação do pinho-de-riga e na valorização dos seus veios. Pouco tempo mais tarde, já era possível encontrar, espalhadas na cidade, uma infinidade de fabricantes de móveis, até mesmo produzidos com maior cuidado que os importados e não só com madeiras de outras paragens, mas também com espécies nacionais. A par da nascente indústria moveleira, também ia surgindo uma importante cadeia de produção que lhe era associada, como por exemplo as fábricas de espelhos.

Já alguns materiais eram mais fáceis de se obter, como a areia - atendendo a todo o processo de construção, das fundações ao revestimento - que era tirada do fundo dos rios que cortavam a cidade, principalmente das margens do rio Tietê ${ }^{98}$. Lemos afirma que antes, para a confecção da taipa e, mais tarde, para a fabricação de tijolos, os

\footnotetext{
${ }^{96}$ LEMOS, Carlos A. C. Alvenaria Burguesa: Breve história da arquitetura residencial de tijolos em São Paulo a partir do ciclo econômico liderado pelo café. São Paulo, Nobel, 1985, pp. 36 a 38.

97 SEGURADO, João Emílio dos Santos. Acabamento de construções: estuques, pinturas, etc. Lisboa: Bertrand, 19-?, Cap. 9, p. 294.

${ }^{98}$ LEMOS, Carlos A. C. Alvenaria Burguesa: Breve história da arquitetura residencial de tijolos em São Paulo a partir do ciclo econômico liderado pelo café. São Paulo, Nobel, 1985, p. 39.
} 
socovões de terra, saibro e tabatinga eram retirados dos barrancos da Tabatinguera - a ilustre ladeira que hoje liga a várzea do Tamanduateí ao promontório onde se originou a cidade de São Paulo.

O tijolo, a princípio, chegou a ser importado ${ }^{99}$, mas logo surgiram diversas olarias e instalações destinadas à sua fabricação, ao lado das fabriquetas de telhas tipo capa e canal. Porém os tijolos já eram bem antes conhecidos por aqui, em terras paulistanas: desde 1610, quando foi construído um pelourinho na cidade, utilizando o material; mais tarde, em 1767, há registros de Morgado de Mateus fazendo referência aos índios oleiros; e, em 1808, encontramos registros sobre o uso do tijolo em construções da província, nos documentos da Câmara Municipal ${ }^{100}$. Também em São Paulo, o Diário Popular de 1810 noticiava o progresso do uso do tijolo em Pinheiros, mas que logo se difundiria por toda a cidade. No entanto, podemos afirmar, como diz Lemos, que a maioria das obras executadas com alvenaria de tijolos, até esse período, foi abastecida pelas pequenas olarias, operadas manualmente. Como comentado introdutoriamente, foi no período áureo da economia cafeeira que o tijolo acabou sendo popularizado, particularmente a partir de sua aplicação em instalações e construções ligadas à produção do café, como os terreiros de secagem e as tulhas para estocagem dos grãos. Por outro lado, apesar de já conhecido e difundido como material construtivo - isso por volta de 1860 -, a produção de tijolo devia ser cara, pois na metade do século cogitou-se a importação de instalações industriais do Reino Unido - de Londres - com uma capacidade de produção de 20 a 25 mil tijolos - o que, segundo os defensores da ideia, baratearia os custos do componente. Em Campinas, a primeira olaria mecanizada, destinada a uma grande produção mensal, foi instalada em 1860, fornecendo tijolo a inúmeras cidades. A olaria, a primeira conhecida no estado, trazia o mesmo nome de seu proprietário, Sampaio Peixoto. Era considerada "moderna", com sistema importado, Clayton \& Comp., merecendo a visita de D. Pedro II, que concedeu a honra de estampar no tijolo as armas do Império. A Sampaio Peixoto produzia "tijolos em relevo", tijolos para "construções sólidas", tijolos tubulares de "três qualidades"101, ladrilhos, (prensados ou não), dutos para poços, tubos para sistemas de drenagem etc. Muitas vezes, sua capacidade de produção não atendia toda a demanda que lhe era encaminhada.

A produção da cal, até final do século XVII, era restrita ao litoral ${ }^{102}$ - a cal produzida a partir da calcinação de ostras, conchas e restos de crustáceos. Sua

\footnotetext{
99 Idem, pp. 39 a 43.

100 D'ALAMBERT, Clara C. Tijolo nas construções paulistanas do século XIX. São Paulo: s.n., 1993.

101 LISBOA, José Maria. Almanak de Campinas para 1872. Campinas: Typographia da Gazeta de Campinas, 1871, p. 41.

102 LEMOS, Carlos A. C. Alvenaria Burguesa: Breve história da arquitetura residencial de tijolos em São Paulo a partir do ciclo econômico liderado pelo café. São Paulo, Nobel, 1985, pp. 43 a 48.
} 
utilização restringia-se, nesse período, às regiões litorâneas, sendo pouco difundida no altiplano, devido à dificuldade de transposição da Serra do Mar. A cal utilizada em terras de Piratininga era retirada dos sambaquis - um equipamento funerário dos primitivos habitantes locais que, com o tempo e a partir do processo de calcinação, transformava-se em blocos de carbonato de cálcio. A cal foi primeiramente levada pelos índios - já a partir de 1606 - para o Ibirapuera, mas sua utilização não era tão comum. A cal era aplicada, inicialmente, na composição da taipa, participando como agregante. Posteriormente, passou a ser utilizada também no assentamento de alvenarias, em revestimentos e na composição de tintas para as pinturas de acabamento, como constata L. L. Vauthier ${ }^{103}$. Como relata esse engenheiro francês - em visita ao país a serviço da prefeitura do Recife - a cal era assim utilizada em sua brancura original ou colorida com pigmentos vegetais, principalmente quando destinada à pintura das construções mais ricas, como igrejas. De modo geral, a pintura a cal, pela sua condição de material inerte, era principalmente aplicada como desinfetante e usada na higienização de edifícios, como hospitais, até os inícios do século XIX.

Já a cal de ostra era considerada material de má qualidade, pois suas características higroscópicas contribuíam para a manutenção da umidade nas paredes. A cal preferida era aquela produzida a partir de rochas calcárias que, proveniente de Santos, só começou a ser mais intensamente utilizada em fins do século XVII. Só no começo do século XIX a cal passaria a ser produzida na região de Sorocaba, próximo à zona hoje ocupada pelo município de Votorantim. As instalações ali implantadas já exibiam porte considerável, com grandes fornos que atingiam capacidade de até 10 toneladas cada um, integralmente dedicados à produção industrial de cal. Outro produtor ficava em Santana de Parnaíba, às margens do Tietê, fornecendo cal para as obras paulistanas. Em 1887, entre Santana de Parnaíba e Juqueri, nas proximidades da estação Caieiras (daí o nome da estação e do município), foram construídos os fornos de cal do Coronel Rodovalho (ou Comendador Antonio Proost), já equipados com rede de energia elétrica. Mais tarde as indústrias do Coronel Rodovalho passariam a produzir cerâmica e, posteriormente, papel.

A primeira tentativa de produção de Cimento Portland no Brasil foi patrocinada pelo mesmo Antonio Proost Rodovalho, que em 1888 instalou uma fábrica em sua fazenda, mas que não chegou a produzir regularmente (ver Figura 23). Há notícias de outras tentativas, na Paraíba e no Espírito Santo, mas que também não alcançaram

${ }_{103}$ VAUTHIER, L. L. Casas de residências no Brasil. In Arquitetura Civil I, FAUUSP e MEC-IPHAN, São Paulo, 1975, p. 54. 
sucesso. A primeira fábrica a produzir normalmente foi a Cia. Brasileira de Cimento Portland Perus, no ano de 1926. A fábrica foi fechada e, em seguida, vendida para o imigrante português Antônio Pereira Ignácio, que continuou com a fabricação de cimento. Como o negócio era rentável, em 1935 Ignácio resolveu construir uma grande fábrica de cimento no bairro de Santa Helena, em Votorantim. Com a inauguração dessa fábrica, em 1936, o cimento ali produzido passou a se chamar "Cimento Votoran", permanecendo com esse nome até os dias de hoje. Nessa época, a fazenda que se chamava Fazenda Santo Antônio passou à condição de bairro do Município de Mairinque e a chamar-se Rodovalho - em homenagem ao Comendador -, mantendo-se lá somente a indústria de cal hidráulica, as olarias e instalações para extração de pedras e para a exploração de lenha.

Em termos de materiais e técnicas para a execução de estruturas metálicas - algo já bastante desenvolvido na Europa, particularmente na Inglaterra -, pode-se dizer que não encontraram grande receptividade na construção dos edifícios de São Paulo no fim do século ${ }^{104}$, apesar das reconhecidas vantagens identificadas nas rotinas de execução. Em virtude da inexistência de uma cadeia produtiva que permitisse a vulgarização do sistema construtivo (mineração intensiva, parque siderúrgico desenvolvido, processos de laminação instalados etc.), São Paulo tinha, nesta época, alguns poucos exemplares de edifícios construídos com estrutura metálica: o Mercado da Rua São João e a estrutura de grandes arcos treliçados da estação da Luz - que havia sido importada da Inglaterra.

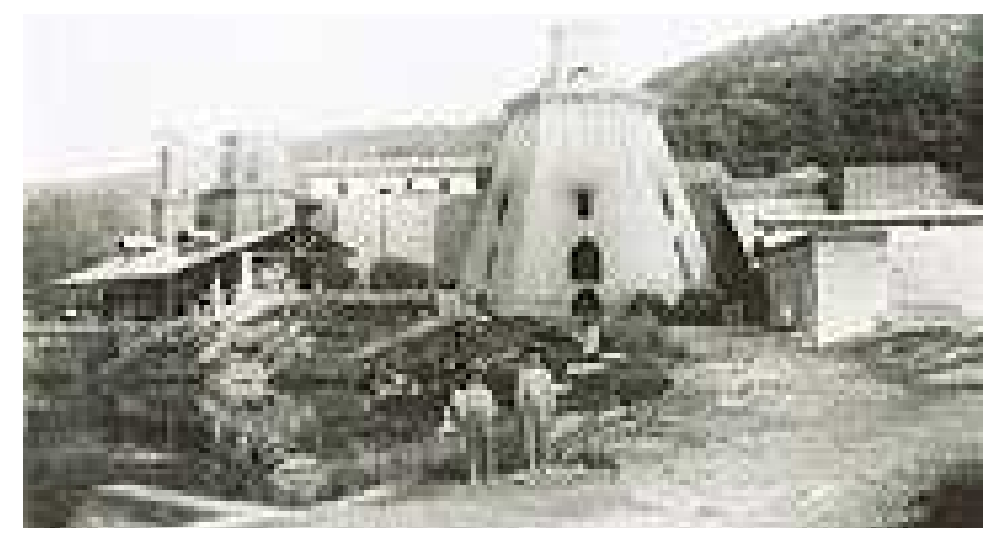

Figura 16: A fabrica de cal em Caieiras, pertencente ao Coronel Rodovalho, com seus funcionários, em pose de $1900^{105}$

Era mais comum o uso do metal como ornamento, na maioria ferro fundido importado, aplicado nos coretos de praças públicas e em componentes construtivos como escadas em caracol desmontáveis, estruturas de claraboias, marquises envidraçadas, gradis, guarda-corpos e colunas ornamentadas. O máximo de disseminação da aplicação

\footnotetext{
104 LEMOS, Carlos A. C. Alvenaria Burguesa: Breve história da arquitetura residencial de tijolos em São Paulo a partir do ciclo econômico liderado pelo café. São Paulo, Nobel, 1985, p. 48.

${ }^{105}$ Site: http://www.dcomercio.com.br/especiais/outros/acsp110anos/ofuturo.htm.
} 
de metal em estruturas era a aplicação de perfis de ferro para a sustentação de abobadilhas, nas estruturas dos pisos, fazendo as casas ganharem porões mais altos.

Quanto aos mármores e pedras naturais para revestimento e pisos, o Banco União de São Paulo era o detentor do direito de lavra do mármore das jazidas de Ituparanga, que ficavam próximas à represa e abasteciam Ibiúna e cidades vizinhas. Pela variedade de cores, o mármore dali extraído rivalizava com os importados (eram pouco conhecidos, apesar da qualidade - não lascavam com facilidade) ${ }^{106}$.

Quanto à pedra artificial, há notícias em A Província de São Paulo ${ }^{107}$ sobre a fundação, junto à olaria Bom Retiro, de uma fábrica de pedra artificial denominada "beton agglomeré, systema Coignet": uma mistura de areia fina e cimento, conformada em moldes, compondo colunas, pilastras, capitéis, degraus, balaústres ou simples tijolos. Há notícias da tentativa de substituir o tijolo pela pedra artificial, mas não se obteve sucesso, principalmente por ser muito mais cara que o tijolo de barro queimado, tendo em vista o fato de o cimento ser importado. Porém, quanto às moldagens decorativas, utilizadas nas ornamentações externas, pela resistência às intempéries e pela maleabilidade de formas, as pedras artificiais ofereceram concorrência significativa aos estuques executados com pó de mármore, gesso e cal.

As envasaduras e coberturas ${ }^{108}$ ganharam novas dimensões e formatos: os telhados de geometria mais simples, com apenas duas águas, assumiram desenhos mais complicados, com vários recortes e movimentos complexos, apenas possíveis com a aplicação de calhas internas nas águas-furtadas. Quanto ao revestimento dos telhados, a indústria de cerâmica, nessa época, alcançava produzir material superior aos similares estrangeiros - como a telha produzida em Marseille, por exemplo -, tanto pela qualidade da argila como pela de fabricação.

\footnotetext{
${ }^{106}$ DEAN, W. A industrialização de São Paulo (1880-1945). São Paulo: Difusão Européia do Livro, 1971, p. XIX.

${ }_{107}$ Idem, p. 49.

108 Ibidem, p. 50.
} 


\subsection{Mãos para as obras}

\subsubsection{Escravos: no Brasil e em Campinas}

Aqueles escravos que alvoroçavam a fazenda, comentando as últimas providências do comendador Aranha - que pretendia lhes trazer alfabetização e algum ensino fundamental -, não estavam todos, necessariamente, envolvidos com a lavoura de café. Pelo contrário, muitos deles dedicavam a maior parte de seu tempo servindo a sede, não só em serviços gerais (cozinha, limpeza, jardinagem etc.) como também consertando telhados, recuperando o revestimentos de paredes, fazendo a manutenção de móveis e utensílios, trabalhando nas oficinas contíguas à casa-sede.

$\mathrm{Na}$ maior parte das vezes, o senso comum associa o negro escravo no Brasil exclusivamente ao trabalho braçal nas lavouras, muito em virtude do fato de a categoria o escravo - acabar diluindo a diversidade de circunstâncias que o negro, como força de trabalho, acabava sujeito. Antes da abolição da escravidão, em 1880 a maioria da mão de obra aplicada na construção civil era majoritariamente composta por escravos, principalmente os cativos que não trabalhavam nas fazendas.

Mesmo dispondo de ampla bibliografia sobre o trabalho escravo no meio urbano ainda que menos abordado que o seu trabalho nas fazendas e na lavoura -, são poucas as referências sobre o envolvimento deles na construção civil. Pelo papel de seus ofícios praticados na cidade, seja em forma de aluguel, como artesãos e mesmo pela sua atuação nas indústrias, é certo, contudo, que o escravo tem papel fundamental na construção da cidade - particularmente se considerarmos sua maciça presença no meio urbano, como no caso de Campinas: a população escrava chegou, em dado momento, a superar a população branca, quando a cidade registrou um dos maiores índices de população escrava no interior do país ${ }^{109}$. Assim, parece-nos possível presumir que todo esse contingente negro não se dedicava, exclusivamente, a atividades agropastoris.

No entanto, há uma linha importante da historiografia que discute a incompatibilidade do escravo com o meio urbano nesse período: ao mesmo tempo em que se trata de uma força de trabalho necessária para sustentar todo o processo de urbanização em curso, questiona-se sua presença na cidade, tendo em vista o tipo de qualificação que essa mão de obra apresentava. Além disso, há todo um conjunto de mecanismos adjacentes, decorrentes de sua presença na cidade que, necessariamente, tem de ser ajustado permanentemente. Por exemplo, a presença do escravo no meio urbano envolvia altos custos com segurança, uma vez que era cotidiano o temor de

\footnotetext{
${ }^{109}$ Em 1872, Campinas contava com trinta e três mil habitantes, sendo treze mil brancos e vinte mil negros e mulatos (BADARÓ 1996:26).
} 
insurreições. Um outro argumento para justificar essa incompatibilidade era a demanda de trabalho maior na zona rural que na urbana. Essa questão foi amplamente debatida por Sidney Chaloub, que enfocou a importância da violência e crimes envolvendo escravos na cidade e suas implicações ${ }^{110}$. Alguns autores americanos questionaram a incompatibilidade do escravo com o meio urbano, como Richard Wade ${ }^{111}$ e Claudia Goldin $^{112}$, e essa questão foi igualmente discutida no Brasil, por autores posteriores aos primeiros que retrataram o assunto, como Gylberto Freire ${ }^{113}$ e Emilia Viotti da Costa ${ }^{114}$.

De qualquer forma, Mario Danieli Neto defende essa historiografia a respeito do escravo como crucial para o entendimento de sua atuação no meio urbano - no caso, abordando a cidade de Campinas, na sua pesquisa intitulada "O escravo urbano em Campinas Imperial (1850-1888)"115:

Pois o escravo urbano desfrutava de uma maior liberdade de movimento dentro da cidade e, por vezes, seu trabalho chocava-se com o trabalho de artesãos e comerciantes livres, gerando conflito dentro desse espaço, onde a competição por serviços era muito acirrada"116

Danieli relata como a formação de Campinas influenciou na atuação dos escravos. Na década de 1870, a cidade ainda era dividida em duas freguesias - a Freguesia Nossa Senhora da Conceição e a Freguesia Santa Cruz ${ }^{117}$. Na primeira, ficavam as principais ruas e era onde se concentrava a maior parte da população urbana. $\mathrm{Na}$ segunda, menos populosa, concentrava-se o comércio, principalmente de escravos e bebidas - o que trazia má reputação para aquela freguesia. Os escravos também se concentravam nas proximidades do mercado, mercadejando produtos fabricados em casa ou coletados em pomares e hortas - doces e frutas, principalmente ${ }^{118}$. Também atuavam no comércio ambulante e vendendo nas casas. Como eram produtos básicos, eram muito procurados pela população que, ao mesmo tempo, se preocupava quanto à sua segurança. Leis eram criadas para conter atos de rebeldia: eram proibidos de jogar e,

\footnotetext{
110 Ver CHALOUB, Sidney. Cidade Febril: cortiços e epidemias na cidade imperial. São Paulo: Companhia das Letras, 1996.

${ }^{111}$ WADE, Richard. Slavery in the cities 1820-1860. Londres, Nova York, Oxford Unoversity Press, 1967.

112 GOLDIN, Claudia Dale. Urban slavery in the american south - 1829-1860: a Quantitative History. Chicago, The University Chicago Press, 1976.

${ }^{113}$ FREYRE, Gilberto. Sobrados e Mocambos. Rio de Janeiro, Record, 1961.

114 COSTA, Emília Viotti da. Da Senzala à Colônia. São Paulo, Livraria Editora Ciências Humanas Ltda, 1982.

115 NETO, Mario Danieli, "O escravo urbano em Campinas Imperial (1850-1888)". In MEDRANO, Lilia Inês Zanotti de e GODOY, João Miguel Teixeira de (org). Campinas - Visões de sua história. Campinas: Editora Átomo, 2006, Capítulo 2, p. 41.

116 Idem, p. 45.

117 Ibidem, p. 55

${ }^{118}$ Segundo as normas locais, os negros só não podiam vender aos domingos e dias santos, exceto farinha, feijão, milho, arroz e toucinho.
} 
até mesmo, com as pessoas livres. Além disso, os senhores eram estritamente responsabilizados pelos seus cativos, quando estes circulavam pela área urbana.

$\mathrm{Na}$ primeira metade do século XIX, a atividade comercial era ainda bastante reduzida no núcleo urbano campineiro. Com isso, a maior parte dos escravos, nesse período, concentrava-se na lavoura. No entanto, paulatinamente, essa relação vai se invertendo e, já a partir de meados do século, uma parte cada vez maior de escravos passou a atuar no comércio e em outras atividades urbanas. Segundo Danieli, o comércio talvez tenha sido o setor mais dinâmico em que os escravos atuaram - entre muitos outros, como serviços domésticos, transporte de bagagem, indústria, serviços especializados, etc. E a construção civil teria sido, talvez, o segundo setor mais dinâmico da economia campineira. Badaró ${ }^{119}$, autor do livro Campinas, o Despontar da Modernidade, citando BERGó (1944:659), nos informa que

quase metade (dos negros e mulatos) compunha a população urbana, dedicando-se às obras de edificações, abertura de ruas, implantação de estradas de ferro e serviços domésticos das famílias abastadas.

A cidade crescia e a demanda por serviços na construção civil era grande. Muitos escravos já estavam nas pequenas indústrias do setor - como a Olaria Sampaio, que em 1873 anunciava a contratação de escravos de aluguel ${ }^{120}$. Os serviços dos escravos de aluguel no setor da construção civil também já se mostravam especializados. Lemos cita a segmentação de ofícios entre o escravo carpinteiro e o escravo pedreiro ${ }^{121}$, mas considera que tal segmentação não implicava, necessariamente, em valorização da mão de obra escrava em relação à livre - ainda que esta se apresentasse em menor número:

Eram pedreiros, ferreiros e sapateiros, que costumavam serem cedidos em aluguel ao preço de 300 a 400 réis por dia - os "jornais" - muito mais barato e vantajoso que o trabalhador livre, que ganhava em média 600 réis $^{122}$

No final da década de 1870, o sistema escravagista entrou em declínio, tanto por causa da concorrência industrial e da necessidade de circular produtos industrializados numa escala mais ampla -, como por outras questões diversas, com alcance mais

119 Badaró, Ricardo de Souza Campos. Campinas, o despontar da modernidade. Campinas: CMU/ UNICAMP, 1996.

${ }_{120}$ MEDRANO, Lilia Inês Zanotti de e GODOY, João Miguel Teixeira de (org). Campinas - Visões de sua história. Campinas: Editora Átomo, 2006, Capítulo 2, p. 66.

${ }^{121}$ LEMOS, Carlos. Casa Paulista - história das moradias anteriores ao ecletismo trazido pelo café. São Paulo: EDU USP, 1999, p. 221.

${ }_{122}$ MARIANO, J. Campinas de ontem e ante-ontem; quadros históricos menos conhecidos da Cidade Princesa, que se traçaram tendo por base documentos inéditos do Arquivo da Câmera Municipal de Campinas. Campinas: Editora Maranata, 1970, p. 11. 
restrito: alguns autores afirmam que esse declínio ocorreu por questões econômicas, não mencionando a concorrência oferecida pela mão de obra livre estrangeira, que ganhava vigor com as novas leis e incentivos promovidos pelo governo, trazendo imigrantes para atuar no Brasil. Outros autores apontam que o expediente de importação de mão de obra decorre dos elevados preços dos serviços - tanto daqueles oferecidos pelos jornaleiros e escravos de ganho como pela mão de obra livre existente -, promovendo um sistemático rebaixamento do valor de custeio dos serviços na medida em que se ampliava sua oferta $^{123}$.

No caso de Campinas, as sucessivas epidemias que viriam assolar a cidade, no final do século XIX, teriam contribuído ainda mais para a redução da oferta de mão de obra escrava - e mesmo da livre. Mesmo assim, pelos registros da época - ainda que não específicos sobre o assunto -, podemos afirmar, com alguma segurança, que a mão de obra escrava atuou de forma determinante na construção civil da cidade campineira.

Ao contrário da capital paulistana, parece que a mão de obra escrava conviveu por muito tempo com os imigrantes, em sua maioria italianos, devido ao pequeno número destes registrados nos almanaques locais. E não poucos ex-escravos, por falta de oportunidade, permaneceram junto aos seus antigos donos, exercendo suas antigas funções. Algumas fotos de 1909, encontradas no acervo da fazenda Pau d'Alho - objeto de estudo desta pesquisa -, mostram filhos de escravos e ex-escravos que permaneceram na fazenda, servindo a seus antigos senhores.

\footnotetext{
123 PEREIRA, Paulo César Xavier. São Paulo, a construção da cidade, 1872-1914. São Carlos, Rima Editora, 2004.
} 


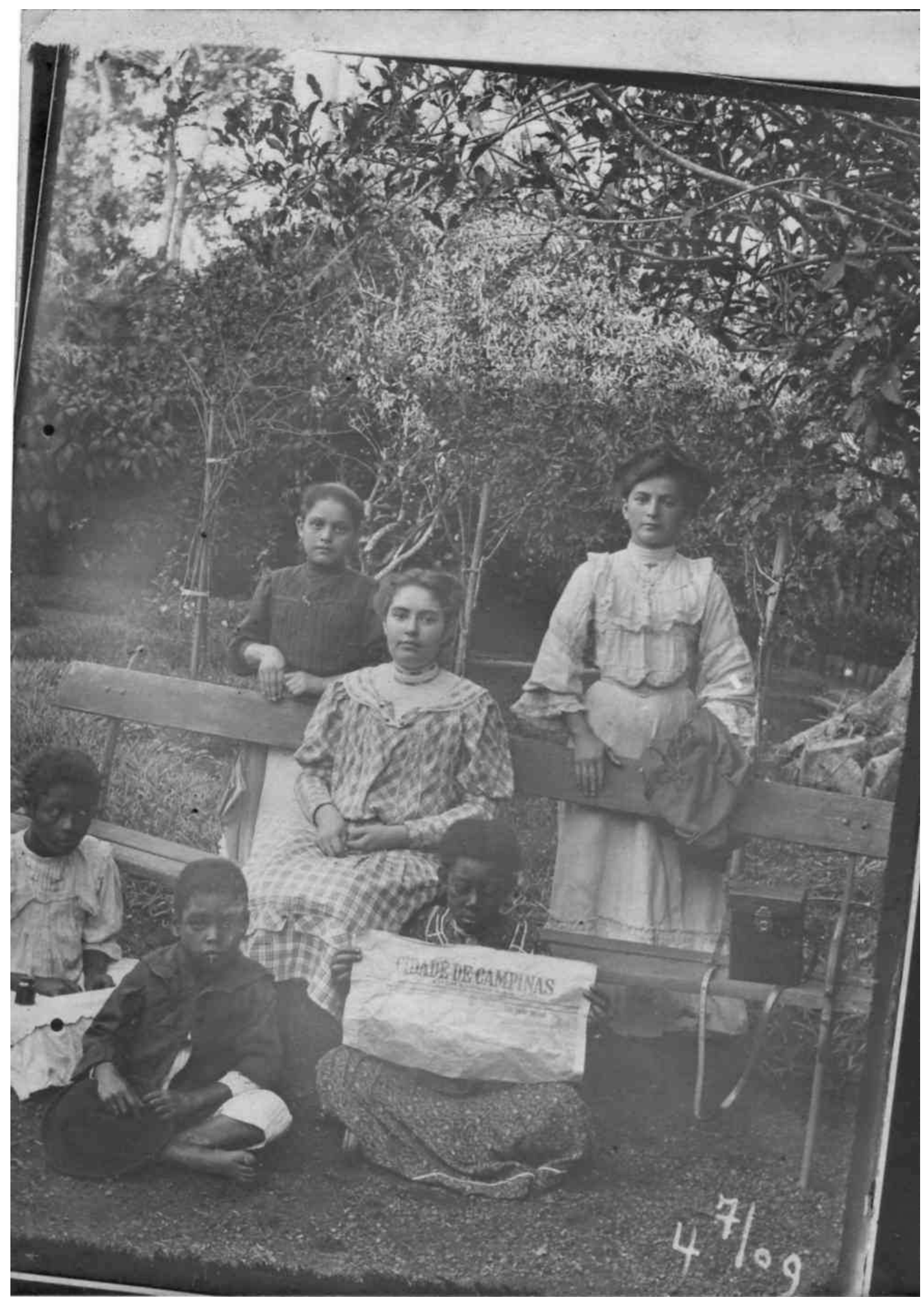

Figura 17: No primeiro plano, filhos de ex-escravos, sentados no chão, exibindo a primeira página do "Cidade de Campinas"; no segundo plano, dona da fazenda sentada no banco ${ }^{124}$

124 Figura 17 e Figura 18: Fotos cedidas por Julie Dutilh. 


\subsubsection{Imigrantes: no Brasil, no estado de São Paulo e em Campinas}

No período de transição entre o ciclo da cana-de-açúcar e o advento das grandes lavouras de café e o fim da escravidão, a imigração européia passou a ser incentivada por D. Pedro II através do financiamento de viagens e da veiculação de propaganda no exterior. Essa imigração subvencionada trouxe profundas alterações, não só no modo de vida brasileiro - definindo novos costumes e comportamentos ao modo europeu - como também em diversas áreas da economia e setores produtivos, principalmente naqueles nos quais esse novo contingente de trabalhadores encontrava colocação profissional ${ }^{125}$.

Em outubro de 1880, chegou no porto de Santos uma grande leva de imigrantes da Península Itálica de uma só vez. Daí em diante, o número de trabalhadores desembarcados, em boa parte oriundos da zona rural do país de origem, só fez crescer. Em 1884, uma lei provincial em São Paulo autorizou o governo local a assumir as viagens e instalar imigrantes do Norte da Itália no interior paulista, desde que contratados pelos fazendeiros de café. O governo central, por sua vez, reforçou em 1885 as verbas de auxílio aos imigrantes, facilitando-lhes a amortização de suas obrigações com o trabalho nas fazendas ${ }^{126}$. A intenção inicial era vir para cá para trabalhar no campo, nas lavouras de café. Mas, aos poucos - muito em virtude de suas tradições citadinas -, retornavam às cidades, fixando-se em setores urbanos dispersos, propiciando o crescimento de bairros operários e direcionando algumas tendências urbanas. No início de 1900 chegaram novas levas de imigrantes que se fixaram diretamente nos centros urbanos, tanto os imigrantes detentores de algum capital como comerciantes e profissionais diversos (carpinteiros, mecânicos, pedreiros, mestres de obras, encanadores, gráficos e artesãos em geral, além daqueles que simplesmente assumiriam a condição de operários das indústrias nascentes). A capital paulista foi crescendo em população e se tornou a cidade que mais acolheu imigrantes, chegando a abrigar uma população italiana, por vezes, maior que a população nacional. Em 1920 falava-se mais a língua italiana que o português em São Paulo. Mesmo assim, também cresceram, nesse período, as camadas médias da população paulistana.

O principal fator que contribuiu para a vinda em massa de imigrantes do Veneto para o Estado - entre 1882 e 1890 - foi a péssima situação socioeconômica dessa província da Itália, devido às tentativas de integração política que vinham se realizando no país. Além disso, em 1887 houve uma grande seca, greves dos trabalhadores rurais,

\footnotetext{
125 D'ALAMBERT, Clara Correia. Tijolo nas construções paulistanas do século XIX. São Paulo: s.n., 1993, p.11.

126 STAHLBERG, Altino. A presença dos imigrantes italianos em Limeira. Limeira: Memória Limeirense, 1998, p.18.
} 
miséria e desemprego. O mesmo ocorria com os trabalhadores do campo que viviam no Sul da Itália, na região da Campania (província de Nápoles, Avelino, Benevento e Salerno), na região da Puglia, Basilicata, Calábria e na região da Sicília ${ }^{127}$.

Em 1886, um grupo de fazendeiros paulistas criou uma associação para incentivar a imigração de famílias européias para o Estado de São Paulo, nascendo assim a Sociedade Promotora de Imigração, sob liderança de Antonio de Queiroz Telles, o Visconde de Parnaíba - que, na condição de governador provincial, promovera, entre 1886 e 1888, a construção da Hospedaria dos Imigrantes, junto das Estradas de Ferro do Norte e São Paulo Railway, no bairro do Brás. A Sociedade Promotora de Imigração funcionou, porém, só até $1896^{128}$.

Em termos gerais, a recepção dos imigrantes não era compatível com a propaganda que ajudava a seduzi-los a se transferirem para o Brasil. A situação de acomodação na capital paulistana era triste, havia muitas denúncias de maus-tratos e as condições de instalação eram péssimas. Os alemães foram os primeiros a reclamar; em seguida os italianos. Para resolver essa situação, foi criado, em 1911, o Patronato Agrícola, órgão do governo estadual responsável pela fiscalização das condições de trabalho nas fazendas. Uma espécie de consulado do Estado de São Paulo na Europa tratava da imigração como um "assunto comercial": toda a operação era planejada com um certo cuidado, desde a escolha das companhias de navegação até a infra-estrutura para receber os imigrantes, na Hospedaria dos Imigrantes - o que não significava qualidade na acolhida. A norma estabelecida pelo governo era a concessão de passagem gratuita só para famílias que viessem de terceira classe e, quando chegavam no porto de Santos, iam de trem, que saia do próprio porto, direto para a Hospedaria. Ficavam ali por até 8 dias, com acomodação e refeições gratuitas, prazo considerado suficiente para acertar os contratos de trabalho.

Já em Campinas, assim como em Jundiaí - que, apesar de compor a mesma região, gozava de uma certa autonomia em relação à cidade campineira, por estar mais próxima a São Paulo - a maioria dos imigrantes, vindos com apoio do governo, chegaram entre 1892 e 1918 - nesse último período, fugindo da guerra ou, ainda que tardiamente, para atender às demandas da lavoura da região (Figura 18). Contudo, afirma-se, recorrentemente, que esses imigrantes eram profissionais mais preparados que os de outras levas, artífices com habilidades definidas, comerciantes e pequenos industriais ${ }^{129}$. Há outras falas contrárias, que defendem o prestígio do imigrante como uma construção

\footnotetext{
127 Idem, p.19.

128 CARNIER Junior, Plínio. A imigração para São Paulo - a viagem, o trabalho, as contribuições. São Paulo,1999, p.19.

${ }^{129}$ BOTACINI, Vicente. História de Campinas e história da Imigração Italiana. Campinas: Hortograph Produções Gráficas, p. 62.
} 
discursiva interessada, necessária no processo de substituição do nacional no nascente mercado de mão de obra ${ }^{130}$.

É necessário fazer um recorte - local e temporal - e relembrar que, em Campinas, como já vimos, instalara-se na cidade, na década de 1870, um grupo - por volta de 80 operários italianos - contratado para trabalhar nas obras da Catedral Metropolitana de Campinas - a Igreja Matriz -, muito provavelmente incentivados pelo engenheiro italiano Cristovam Bonini, contratado, no momento, para dirigir a reforma e a conclusão do edifício. Esse estágio das obras requeria uma mão de obra bastante especializada, envolvendo habilidades para o encamisamento de tijolos em volta da construção de taipa de pilão, além de execução de frisos, relevos e acabamentos de madeira. Esse grupo de artistas, chamado de "corpo de artífices", foi provavelmente o primeiro grupo de operários imigrantes na cidade - como já mencionado anteriormente.

De qualquer forma, a chegada dos imigrantes contribuiu para a expansão do comércio e para o surgimento de pequenas indústrias, principalmente no Estado de São Paulo. Dessas pequenas indústrias, as mais comuns eram aquelas que fabricavam produtos cerâmicos - como tijolos, telhas e ladrilhos - papel, tecido e materiais para construção em geral.

É comum afirmar-se que o grande legado dos imigrantes em termos de "cultura industrial", foi o alto nível técnico que trouxeram na bagagem, apesar de serem, em grande parte, analfabetos. Paradoxalmente, sua valorização como artífices qualificados, ganhando prestígio, particularmente na atividade da construção - como também defende Paulo César Xavier -, fez com que o trabalho manual voltasse a ser valorizado ${ }^{131}$ :

Foi também o imigrante responsável pela quebra do preconceito que, durante séculos havia estigmatizado as atividades manuais, relegada ao escravo. Através da sua habilidade e sensibilidade, a atividade artesanal voltou a ser respeitada e colocada em seu lugar de destaque, enquanto forma de invenção e de expressão humana ${ }^{132}$.

A técnica construtiva que se consagrou em suas mãos foi a alvenaria de tijolos revestida, popularizada nos estilos neoclássico e eclético. Além de se destacarem pelo domínio dessa técnica, atuando como pedreiros, telheiros, oleiros e mestres-de-obras, os imigrantes italianos destacaram-se também como gráficos, artesãos, frentistas, modeladores e moldadores de ornatos, entalhadores, cenógrafos, decoradores de

\footnotetext{
130 PEREIRA, Paulo César Xavier. São Paulo, a construção da cidade, 1872-1914. São Carlos: Rima Editora, 2004, p. 57.

$131 \quad$ Idem, p. 58.

132 MACAMBIRA, Yvoty de Macedo Pereira. Os Mestres da fachada: artistas-artesãos. São Paulo, Brasil: Centro Cultural São Paulo, Divisão de Pesquisas, 1985, p. 10.
} 
interiores e escultores: teriam sido eles os principais propagadores das construções neoclássicas em terras paulistas ${ }^{133}$.

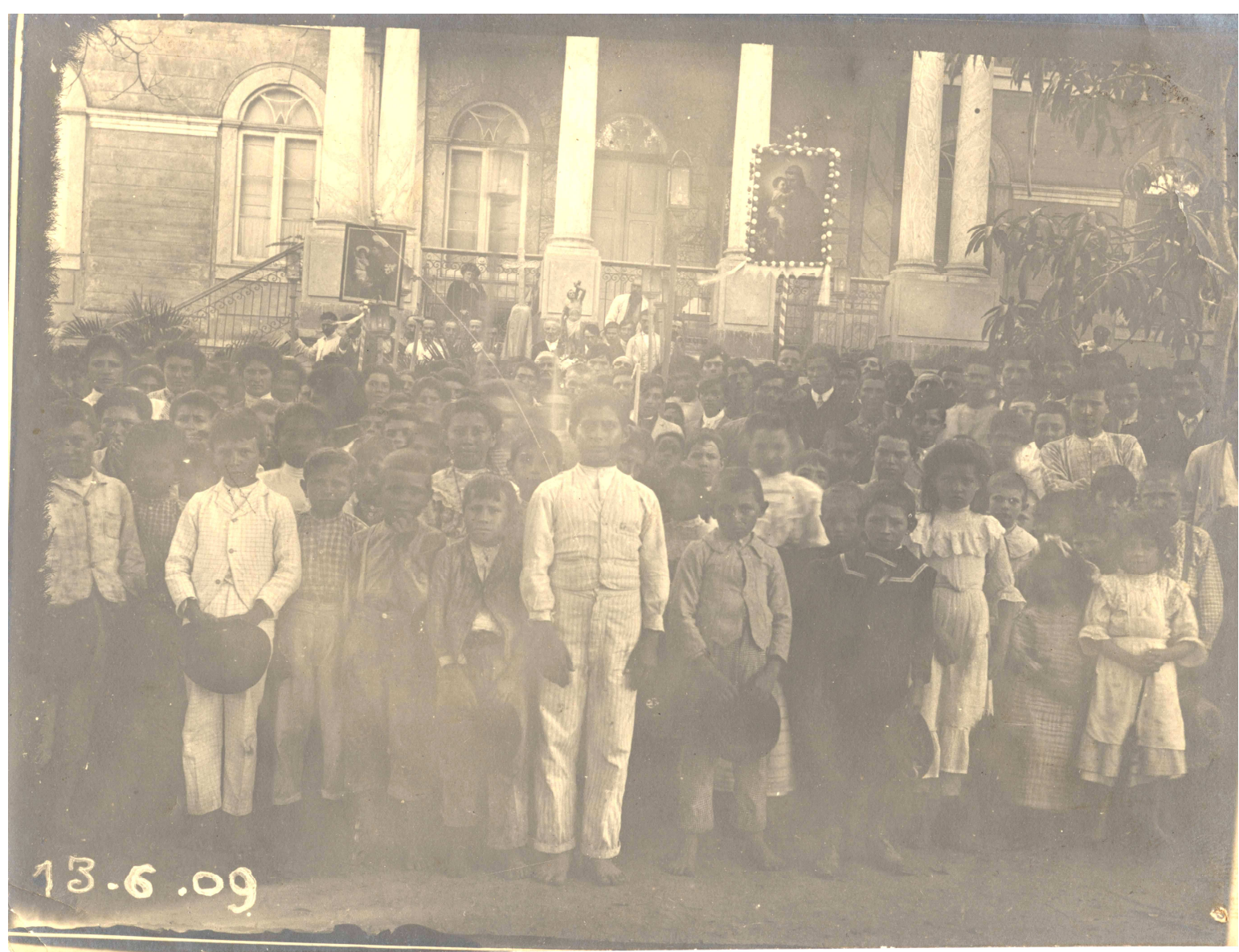

Figura 18: Filhos de colonos reunidos em dia santo em frente à sede da fazenda Pau d' Alho, em 1909, mesmo período em que conviveram, no mesmo local, filhos de ex-escravos.

\subsubsection{Atuação da mão de obra livre na indústria de edificação}

Como sempre acontece, em decorrência dessa intensificação da expansão industrial, também o trabalho experimenta uma crescente especialização na sua divisão técnica e social. Por outro lado, com a crescente complexidade que as atividades humanas vão assumindo, impõe-se necessária uma maior racionalidade operativa em sua realização. O ensino profissional engaja-se nesse espírito, pretendendo, dessa forma, protagonizar uma nova realidade no contexto da produção industrial.

Antes de aparecerem as escolas de aprendizagem profissional, o ensino de ofícios era efetuado nas corporações, nas formas próprias que tomaram no Brasil: como

\footnotetext{
${ }^{133}$ As origens das principais influências para a adoção do neoclássico em São Paulo, conforme defendem Anita Salmoni e Ema Debenedetti, em seu livro sobre a arquitetura italiana em São Paulo, teriam sido todas estabelecidas por imigrantes, italianos e alemães. Ver SALMONI, Anita e DEBENEDETTI, Emma. Arquitetura italiana em São Paulo. São Paulo, Perspectiva, 1981, p.33.
} 
vimos, essas corporações associavam o trabalho livre ao trabalho escravo e não se comportavam segundo os códigos que regiam o funcionamento da corporação europeia. Tratava-se, apenas, de um negócio, de um investimento para obtenção de renda com a venda do trabalho escravo através de seu aluguel. Mas é dessas corporações que ficaram, como herança, o título de mestre-artesão, oficial e aprendiz. Esses "agrupamentos" de trabalhadores para a prática de ofícios vigoraram desde os tempos coloniais até a Independência. Eram compostos por mestres da mesma especialidade que possuíam oficinas, onde empregavam trabalhadores, manufaturavam seus artefatos e realizavam a instrução dos aprendizes, pelos quais eram responsáveis (matérias elementares, desenvolvimento de caráter e ensino de seu ofício) ${ }^{134}$. Já versamos um pouco sobre o assunto, nas primeiras partes deste capítulo.

Com a chegada dos imigrantes, chegaram também ideias e ideários políticos como o anarquismo, propagado rapidamente entre a nova classe operária em formação. A situação na Itália, especificamente entre os camponeses do norte (Lombardia), contribuiu significativamente para o desenvolvimento do pensamento anarquista italiano. No Brasil, o anarquismo está relacionado com o pensamento libertário, na tentativa de enfrentar a racionalidade burguesa, além de promover intensa campanha contra a igreja. Tinha como alvo a consciência libertária das massas exploradas para destruição do sistema dominado por exploradores ${ }^{135}$. Por aqui, contudo, sua presença é mais fraca que em toda a América Latina. Apesar de o anarco-sindicalismo ter voltado seu discurso para os trabalhadores manuais, nem por isso privilegiou o proletariado como classe revolucionária. Ainda assim, é consenso afirmar que os sindicatos reverberam o discurso anarquista dessa época.

Para Simão ${ }^{136}$, os imigrantes não inseriram, na estrutura dos sindicatos, os padrões corporativos de seu país de origem, pois já formavam, desde o início, uma associação de assalariados (exceto mestres e contramestres). Ele analisa que outros tipos de associações é que devem ser assim consideradas, como as sociedades de socorro mútuo, que auxiliavam os operários imigrantes ${ }^{137}$. Nos padrões do sindicalismo, em termos estritos, as primeiras organizações operárias no Brasil reuniam operários de distintos ofícios e indústrias, e tinha como objetivo a melhoria dos salários e diminuição da jornada de trabalho.

\footnotetext{
134 CONDEPHAAT, Relatórios de Processo de Tombamento. Colégio Técnico de Campinas, agosto/1983 (Centro de Memória Unicamp), p. 43.

135 PEREIRA, Paulo Cesar Xavier. São Paulo, a construção da cidade, 1872-1914. São Carlos: Rima Editora, 2004, p. 104.

${ }^{136}$ SIMÃO, Azis. Sindicato e Estado. São Paulo: Dominus, USP, 1966, p. 149 a 152.

137 As primeiras surgiram em 1872, entre os imigrantes alemães e, mais tarde, muitas outras, já agremiando os imigrantes italianos.
} 
Paulo César Xavier Pereira ${ }^{138}$ afirma que, no contexto do período que analisa (entre 1872 e 1914), enquanto outros ramos industriais, como o fabril, cresciam vigorosamente por articularem melhores condições de concorrência, o mesmo não ocorria com a construção. O autor considera dois motivos possíveis para explicar o atraso: a mão de obra pouco qualificada e a especulação imobiliária. Quanto aos imigrantes, estes assumiram a fama de detentores de habilidades com qualidades superiores às do trabalhador nacional na atividade da construção, mas tiveram que lutar muito para obter melhores condições de trabalho. No final do século, são os italianos que predominam nos canteiros de obras paulistanos, superando os números indicados pelo recenseamento de 1872: no final do século, os trabalhadores estrangeiros nas edificações correspondiam a $30 \%$ e os brasileiros, a 60\%; em 1913, os italianos já eram $4 / 5$ dos ocupados na construção civil. A suposta superioridade técnica do italiano nos canteiros de obras, para Pereira, é mais ideológica que real, constituindo apenas argumento necessário para o adequado ajustamento dos valores salariais entre operários de fábricas - também predominantemente italianos -, trabalhadores nacionais e custo da mão de obra aplicada na construção civil.

A figura do empreiteiro aparece, no período, como essencial para o crescimento do setor: é ele que atua como mediador entre o proprietário da obra e o trabalhador do canteiro, viabilizando a transferência de parte da valorização imobiliária auferida pelo proprietário para o trabalhador do canteiro. Para ocupar essa posição de intermediador, o empreiteiro era responsável pela obra e cuidava desde dos materiais e instrumentos de trabalho até da disciplina do trabalhador, organizando e controlando toda a produção no canteiro $^{139}$.

Apesar do sucesso do imigrante italiano com sua desenvoltura técnica, não foram eles os responsáveis pelo estabelecimento de uma conjuntura favorável ao desempenho de suas habilidades, mas as condições que lhe foram propiciadas (oportunidades de trabalho), que também dependiam muito da produção imobiliária e da dinâmica do mercado de terras e obras.

O trabalho de construir edifícios, em 1893, foi classificado como atividade artística (indústria manufatureira), o que poderia indicar um campo de produção social em que a expropriação do conhecimento técnico ainda não se havia instalado. A assimilação da tecnologia estrangeira estava apenas iniciando, principalmente com a fundação das primeiras escolas de engenharia e dos liceus de artes e ofícios ${ }^{140}$. Por outro lado, é um fato importante de se examinar o que ocorreu no período, em termos de apropriação do

\footnotetext{
${ }^{138}$ PEREIRA, Paulo César Xavier. São Paulo, a construção da cidade, 1872-1914. São Carlos: Rima Editora, 2004 , p. 98.

139 Idem, p. 93.

${ }^{140}$ Ibidem, p. 103.
} 
conhecimento técnico pela indústria: ali, o operário, recém investido da condição de "moderno" - que desconhecia o processo de produção do qual participava, diferente do antigo artesão que conhecia em detalhes as etapas de produção do que fazia - via-se instado a estabelecer outros caminhos para assegurar seu aprendizado de ofício. As relações entre ensino e trabalho foram radicalmente modificadas. À medida que

a escola se propõe a substituir a oficina (...) se abrem os caminhos para 0 desenvolvimento das técnicas em nível mais alto que a tradição empírica e da transmissão pessoal e direta do saber fazer. Ë a partir daí que se pode falar, com propriedade, em tecnologia $^{141}$

Mas, assim como Gorz ressalta, é essencial reunificar a hierarquia escolar e a do trabalho, uma vez que "ensino e produção, formação e trabalho foram separados porque a teoria e o conhecimento estavam separados da prática, os operários separados dos meios de produção, da cultura e da sociedade civil”142.

\subsubsection{Quem eram}

Muitos artistas, artesãos, escultores e mestres de fachada destacaram-se pelas belíssimas obras e amplo domínio técnico, manifestos nas grandes construções ecléticas e neoclássicas realizadas no período, muitas delas de autoria de Ramos de Azevedo ${ }^{143}$. A grande maioria - pode-se afirmar com toda segurança - imigrantes.

Podemos organizar esses artífices imigrantes em três grupos principais: os artistas-artesãos, os escultores e os arquitetos e engenheiros ${ }^{144}$. Todos os três grupos são identificados apenas nas obras paulistanas de Ramos de Azevedo.

Segundo o estudo de Macambira, no primeiro grupo podemos classificar como artistas-artesãos os frentistas, modeladores, fundidores, pintores, decoradores de interiores, mestres-de-obras e capomastri, "aptos a executar qualquer projeto"145. Teriam aprendido seu ofício no país de origem, porém muitos também teriam aperfeiçoada sua

\footnotetext{
141 Gama apud PEREIRA (2004).

142 GORZ, André. "Técnica, técnicos e a luta de classe" In Crítica da divisão do trabalho. São Paulo, Martins Fontes, 1996, p. 247.

${ }^{143}$ Ramos - que estava sempre em contato com estes artistas - contribuiu para o aprimoramento das técnicas operadas por eles, incentivando o aprendizado de tais técnicas no Liceu de Artes e Ofícios paulistano, requisitando seus serviços em suas edificações e promovendo concursos e eventos de cunho cultural.

144 MACAMBIRA, Yvoty de Macedo Pereira. Os Mestres da fachada: artistas-artesãos. São Paulo, Brasil, Centro Cultural São Paulo, Divisão de Pesquisas, 1985, p. 32.

145 TOLEDO, Benedito de Lima e DANON, Diana Dorothea. São Paulo: "Belle Époque". Companhia Editora Nacional, Editora da Universidade de São Paulo, 1974, p. 13.
} 
técnica aqui no Brasil, em oficinas particulares e, principalmente, no Liceu de Artes e Ofícios de São Paulo.

Dentre os conhecidos artistas-artesãos que trabalharam com Ramos de Azevedo estão Pascoal Forlenza ${ }^{146}$, que foi seu mestre-de-obras e trabalhou na obra do Teatro Municipal de São Paulo e Calixto Fiammignhi ${ }^{147}$, que trabalhou como frentista nas obras do Teatro Municipal e, também, no Palácio da Justiça, no Banco de São Paulo e no Jockey Clube. Outro que provavelmente tenha trabalhado na execução de ornamentos é Gerolamo Joo, que, segundo dados de sua filha, teria trabalhado com Ramos de Azevedo no Teatro Municipal. Gerolamo tinha uma oficina de ornamentos na Av. Liberdade no 96, em São Paulo, em sociedade com Pelliciotti, segundo registro da época, ali instalada em 1882.

No segundo grupo, os artistas escultores - menos envolvidos com as lidas edílicas e mais com o meio artístico e acadêmico - são os mais conhecidos. Destacaramse nas obras paulistanas pelo elevado conhecimento técnico, adquiridos em seu país de origem ou através de constantes contatos com ateliês e artesãos locais. Buscaram permanentemente o aperfeiçoamento de suas técnicas, ou retornando ao país de origem para alguma atualização, participando de concursos ou mesmo atuando como educadores - muitos foram professores do Liceu de Artes e Ofícios de São Paulo. Dentre os principais, destacamos aqui: Amadeo Zani, ettore ximenes, Luigi Brizzolara, Galileo Emendabili, Riccardo Cipicchia e Irmãos Incerpi ${ }^{148}$.

Amadeo Zani, escultor italiano, foi o autor de "Glória Imortal aos Fundadores de São Paulo", instalado no Pátio do Colégio em 1925 - é sua obra mais famosa. Com 25,85 metros de altura, o monumento apresenta uma figura feminina, que simboliza a cidade, tendo nas suas mãos um ramo de louros, uma foice e uma tocha, representando a glória, o trabalho e o fogo simbólico da religião e da cultura. A parte central é decorada por pequenos grupos de figuras ocupadas em preparar o solo, fundar alicerces e carregar materiais. São também retratadas cenas do início da colonização, como a primeira missa, a defesa da vila pelo índio Tibiriçá e a Guerra dos Tamoios. As peças do monumento foram executadas em Roma e aqui ajustadas sob a direção de Zani.

Zani veio ao Brasil pela primeira vez em 1887, frequentou escritório do engenheiro Gaudenzio Bezzi, no Rio de Janeiro, que estava construindo o edifício do Ipiranga, e voltou à Europa. Veio novamente ao Brasil em 1909, dessa vez fixando-se na capital

\footnotetext{
146 Idem, p. 44.

147 Ibidem, p. 44.

148 As referências sobre os artistas Zani, Ximines, Brizzolara, Emendabili, Cipicchia e Irmãos Incerpi encontram-se, sem numeração de páginas, na seguinte fonte: CONSULADO Geral da Itália. Artistas italianos nas praças de São Paulo. São Paulo, s.d.
} 
paulista, onde exerceu magistério no Liceu de Artes e Ofícios aos 27 anos, a convite de Ramos de Azevedo. Ao lado de outros professores do Liceu, como o arquiteto Domiciano Rossi e os pintores Pedro Alexandrino, Túlio Mugnaini e Oscar Pereira da Silva, entre outros, fez parte do grupo fundador da Academia de Belas-Artes de São Paulo. Em 1934, Amedeo Zani obteve medalha de ouro no I Salão Paulista de Belas-Artes. Dentre suas obras, destacam-se os monumentos: o túmulo do escritor Eduardo Prado em Art Nouveau e em arte tumular no Cemitério da Consolação, em São Paulo em 1901; a obra "Álvares de Azevedo", na Praça da República, com peça em bronze e pedestal em granito e bronze em 1907; a obra "Cesário Mota", na Praça da República, com peça em bronze e pedestal em granito em 1909; a escultura "Verdi", acantonada no Vale do Anhangabaú, com 5,23m de altura, realizada em 1916 e considerada a favorita do artista; a obra "Alfredo Maia", na Praça Júlio Prestes, uma peça em bronze e granito, criada em 1926; o túmulo do Conde Alexandre Siciliano, uma bela capela em estilo assíriobabilônico, no Cemitério da Consolação, desenhada em 1927; e a obra "Caetano de Campos," na Praça da República, com peça em bronze e pedestal em granito bege.

Ettore Ximenes, italiano de Palermo, escultor, pintor e professor, destacou-se por ter sido autor do projeto vencedor de um concurso internacional para a construção do "Monumento à Independência do Brasil", erguido no bairro do Ipiranga, em São Paulo. Na Itália, Ximenes estudou pintura em Nápoles e desenho em Florença. Chegando no Brasil em 1919. Só retornou definitivamente para a Itália em 1926, ano de sua morte. Também executou o "Monumento à Amizade Sírio-Libanesa", em São Paulo, por ocasião das comemorações do primeiro centenário da Independência do Brasil.

Luigi Brizzolara é outro italiano que também participou do concurso para o monumento comemorativo da independência, em 1919, quando veio ao Brasil. Classificou-se em segundo lugar. Nascido em Chiavari, dedicou-se desde jovem à escultura e transferiu-se, com a idade aproximada de vinte anos, para Gênova, matriculando-se na Academia Linguística de Belas Artes, aperfeiçoando-se na escola do escultor G. Scanzi, de quem foi o discípulo predileto. Em São Paulo, deixou outras obras em destaque como: o mausoléu da família Matarazzo, no cemitério da Consolação, que pelas suas proporções é ainda hoje um dos maiores monumentos fúnebres do mundo; outros monumentos fúnebres, como o da família Machado; o brasão de armas de Ermelino Matarazzo no Hospital Matarazzo; e diversas estátuas para particulares. Fez o monumento Carlos Gomes e a escultura "Poesia e Musica" na Praça Ramos de Azevedo. Brizzolara esculpiu também duas estátuas no Museu da Independência, na colina do Ipiranga, à direita e à esquerda do peristilo, com três metros e meio de altura, reproduzindo Antonio Raposo Tavares e Fernão Dias Paes Leme. Também fez uma 
estátua de Fernão Dias Paes em pedra, quase idêntica à do museu, no Jardim Público da Avenida Paulista.

Galileo Emendabili foi o escultor que ficou mais famoso ao ganhar o concurso internacional para a execução do "Monumento a Ramos de Azevedo', inaugurado, em 1934, na Avenida Tiradentes (posteriormente transferido para a Cidade Universitária). Ítalo-brasileiro, nascido em Ancona, apaixonou-se pela arte do entalhe em madeira, compartilhando o ofício de seu pai, Ludovico, que era proprietário de uma serraria. $A$ partir dessa aproximação com o entalhe, foi estimulado a trabalhar com escultura no ateliê do surdo-mudo Clementi, um exímio ebanista. Com seu lado republicano numa Itália monarquista e sem liberdade para exercer seu trabalho, mesmo em seu ateliê na sua cidade natal, decidiu deixar seu país com sua esposa Malvina Manfrini, em 1923, num navio cujo destino final era Buenos Aires. Emendabili desembarcou em Santos estabelecendo-se na cidade de São Paulo, onde tornou-se rapidamente um dos artistas mais conhecidos desse grupo de italianos. Venceu diversos concursos, trabalhou como entalhador no Liceu de Artes e Ofícios e tem diversas obras em mausoléus do Cemitério da Consolação e do Araçá, na Pinacoteca do Estado de São Paulo e muitos monumentos públicos na cidade de São Paulo, como o "Obelisco Mausoléu ao Soldado Constitucionalista de 1932" (1954), no Parque Ibirapuera, e aquele dedicado ao cientista Dr. Luís Pereira Barreto (1927), pelo qual ganhou prêmio em concurso internacional, na confluência da avenidas Angélica e São João. Passou a ter seu próprio ateliê na Rua das Flores, atual Praça Clóvis Bevilácqua, em 1924, e na Rua Bela Cintra, em 1929. A partir de 1933, passou a trabalhar com a colaboração de Fulvio Pennacchi, que elaborava os desenhos para alguns de seus projetos.

Ricardo Cipicchia, nascido em Roma em 1885, trabalhou muitos anos em circo, até se envolver com esculturas de madeira. Segundo relato de Menotti Del Picchia, registrado em fonte do Consulado Italiano, assim referia-se a Cipicchia:

esculpir em madeira é uma das artes mais difíceis... recorta-se a imagem que se tem na imaginação. É obra direta. Só os grandes escultores conseguem arrancar diretamente da matéria as criações que se engendram ${ }^{149}$

Cipicchia participou da inauguração do I Salão de belas Artes organizado no Palácio das Indústrias (ver item 2.1.3. No Brasil: Exposições, feiras e eventos) com uma estátua de madeira que chamou a atenção de Del Picchia, em meio às obras de mármore e bronze, de um garoto com "barriga de bandolim". Mais tarde, por muitos anos, dedicou-

\footnotetext{
${ }^{149}$ CONSULADO Geral da Itália. Artistas italianos nas praças de São Paulo. São Paulo, s.d.
} 
se ao ensino na Escola de Aprendizes e Artífices de São Paulo, como professor de ebanística.

Já os irmãos Incerpi, Tito, Amos e Dumas, eram brasileiros, filhos de italianos, tinham firma de cantaria no Bom Retiro. Aprenderam o ofício da construção com pedra com o pai, que veio de Incerpi, região muito conhecida pela técnica milenar. Os irmãos trabalharam no "Monumento às Bandeiras", na construção da Catedral da Sé, dos monumentos à Independência, a Ramos de Azevedo, à Fundação São Vicente e ao Duque de Caxias. Também fizeram trabalhos menores, em capelas e fachadas de prédios, como a do Banco do Brasil, na Rua Líbero Badaró.

No terceiro grupo desses imigrantes estão os engenheiros e arquitetos. Segundo Salmoni e Debenedetti, Ramos inicialmente empregou mão de obra italiana somente ocupando cargos mais modestos, como é possível observar na relação de funcionários de sua firma: pedreiros, carpinteiros e mestre-de-obras - entre os mais conhecidos, estavam Ambrogi, Giacometti e Beltrami. Mais para frente, entre seus colaboradores mais imediatos e ocupantes de cargos mais altos da empresa, não se verifica uma maioria italiana, à exceção de Claudio Rossi e Domiciano Rossi (que não eram parentes). Passaram por ali outros imigrantes famosos, como o francês Victor Dubugras, 0 português Ricardo Severo e os alemães Hehl e $\mathrm{Krug}^{150}$. Ao assumirem o papel de colaboradores, esses estrangeiros assumiram importância significativa na firma de Ramos de Azevedo, desenhando a grande maioria das obras que o engenheiro-arquiteto agenciava e empreendia: após alguma discussão de um croqui e alguma explanação geral, eram eles alguns dos principais responsáveis pela condução de todo o trabalho de desenvolvimento e detalhamento dos projetos.

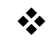

Retomando a meada que orienta este estudo, na Campinas do final do século XIX, ainda antes do período de imigração subvencionada, é preciso destacar que os ofícios ligados à construção civil, tanto aqueles aplicados na construção de edifícios como na realização de obras de infraestrutura urbana, constituíam um saber fazer local que vinha sendo praticado, desde muito tempo, pela mão de obra escrava. Isso significa que haveria já alguma especialização de ofícios, procurando atender os diferentes setores da construção civil, conforme recrudescia a expansão urbana da cidade.

150 SALMONI, Anita e DEBENEDETTI, Emma. Arquitetura italiana em São Paulo. São Paulo, Perspectiva, 1981, p.78. 
Ainda antes da primeira leva de imigrantes subsidiada pelo governo, um expressivo número de imigrantes italianos, contratados para atuar em uma grande obra da cidade, conviveu por um tempo razoável com a mão de obra escrava e livre local, provavelmente promovendo, no mínimo, uma espécie de diversificação da produção do conhecimento técnico local.

Essa situação provoca algumas questões que não inspiram respostas fáceis: por que o Diretório que administrava a obra preferiu um grupo de mais ou menos 80 italianos conduzidos por um engenheiro italiano em detrimento da mão de obra local? Por que Ramos de Azevedo, ao receber a administração da obra das mãos de Bonini, preferiu manter não só as mesmas soluções construtivas, como também integralmente o mesmo grupo de operários? Para onde foram esses italianos após a conclusão das obras na Catedral? Até que ponto esse grupo interferiu na produção do conhecimento técnico local? São questões que esta dissertação pretende apenas tangenciar, procurando mais iluminar as lacunas do que preenchê-las, propondo um veio de investigação que nos permita melhor compreender a história das mãos que se dedicam às obras de personagens como Ramos de Azevedo.

\subsection{Construção e linguagem de estilo no contexto campineiro e azevediano}

As obras realizadas por Ramos de Azevedo no início de sua carreira - em Campinas, entre 1879 e 1886, logo após o retorno da Bélgica - não são muitas, se comparadas às inúmeras produzidas na capital paulista, após transferir sua residência para a capital paulista, em 1886. Todavia, tratava-se de um número de obras bastante significativo, se comparado à produção de outros colegas na mesma época - lembre-se que, só naquela cidade, contavam-se 26 obras que lhe são atribuídas, a maior parte delas projetadas e erguidas no período em que ali viveu. Após esse período, o número de obras é menor e foram realizadas em intervalos de tempo mais espaçados.

A partir do nosso relato sobre a indústria da construção civil local, realizado em capítulos anteriores, foi possível montar um panorama geral - apresentado a seguir - de como foram produzidas as principais obras de Ramos de Azevedo em Campinas, destacando a predominância de alguns materiais, estilos e processos construtivos, sempre tendo em vista o diálogo com o contexto estudado. Esta análise, embora breve e aqui organizada em ordem cronológica, propõe comparações com outras obras locais e entre as próprias obras do engenheiro-arquiteto, traçando uma linha do desenvolvimento tecnológico experimentado, evidenciando as estratégias construtivas utilizadas e preparando a abordagem analítica das técnicas praticadas no período, só que com maior 
ênfase na sua aplicação, no capítulo seguinte, com o estudo da nova sede da fazenda Pau d' Alho, ampliada e reformada por Ramos em 1885.

Data de 1846 o surgimento de um dos primeiros sobrados em Campinas: o sobrado de Mascarenhas, que ganhou destaque por ter hospedado o Imperador Dom Pedro II. No mesmo ano foi construído um segundo sobrado, de Dona Teresa Miquelina do Amaral Pompeu, irmã do Visconde de Indaiatuba, onde também se hospedou o Imperador em visita à cidade, décadas mais tarde, em 1875. O sobrado de Dona Miquelina é descrito como uma edificação imponente, "com sacadas em toda a frente e

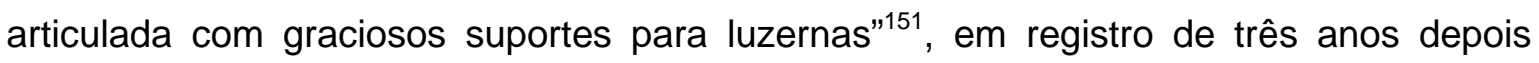
(Figura 19).

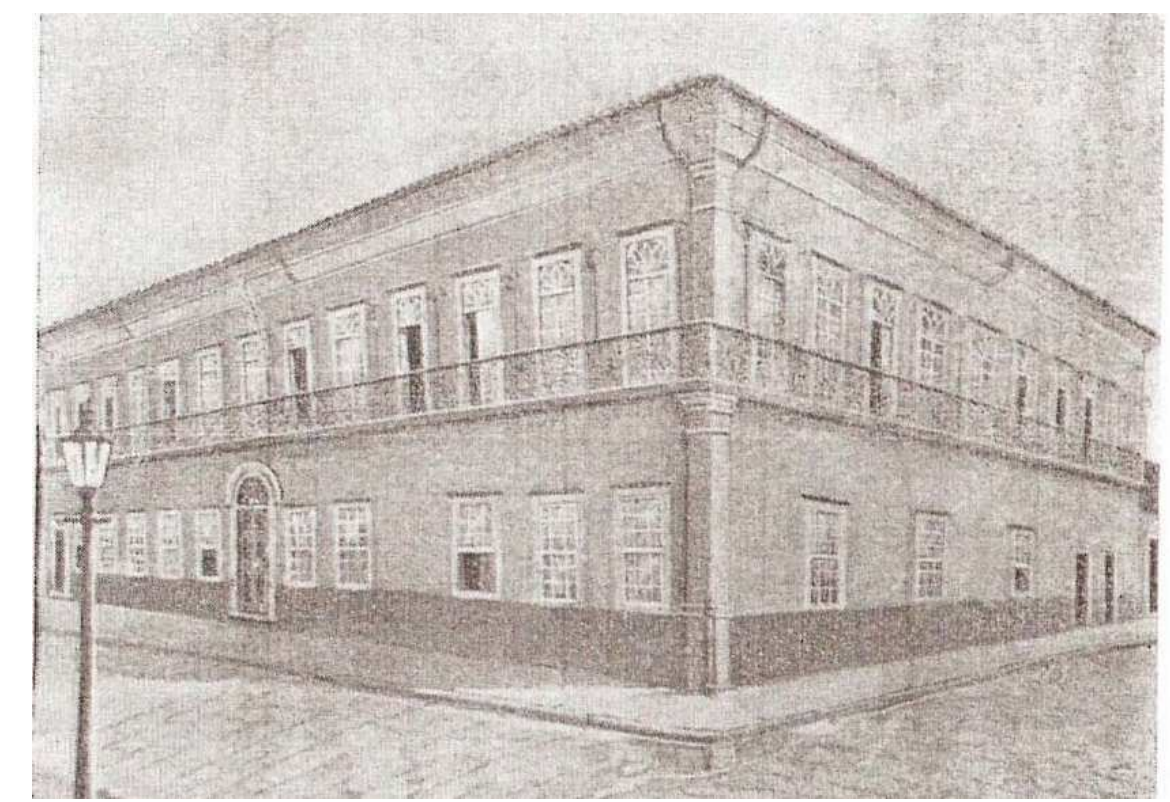

Figura 19: Um dos primeiros sobrados da cidade, de Dona Miquelina do Amaral Pompeu ${ }^{152}$

Conforme essa mesma fonte, o professor Celso Maria de Mello Pupo, ressalta-se que, pouco antes, "acabara de surgir na cidade uma serralheria modesta para suporte de luzernas, que logo passou a produzir belas e grandiosas grades"153. Teria sido este um dos primeiros indícios inequívocos dos primeiros traços levemente neoclássicos da cidade, desde o começo do uso do gradil de ferro, que entrara no Brasil em 1838.

\footnotetext{
${ }^{151}$ Luzernas são candeeiros ou lampiões. PUPO, Celso Maria de Mello. Campinas, seu berço e juventude, Campinas: Publicações da Academia Campinense de Letras, 1969, no 20, p. 187.

152 Figuras 19 a 21: PUPO, Celso M. de M. Campinas, seu berço e juventude, Campinas: Publicações da Academia Campinense de Letras, 1969, 188 a 193.

${ }^{153}$ Idem, p. 183.
} 
Contudo, cabe lembrar que grande parte dos produtos de ferro era importada - como os que seriam aplicados na finalização da Catedral, nas sacadas e nas obras de arte de serralheria importadas da França. Pouco era produzido aqui, a maior parte do material consistindo em acabamentos para serralheria e fundição.

A taipa e o pau-a-pique ainda predominavam na fase de transição entre o açúcar e o café, mas já se podiam ver algumas técnicas tradicionais sendo abandonadas. Abandono comprovado, inclusive, com a utilização de vergas ligeiramente curvas: dentre os primeiros casos de verga curva que apareceram nesse período, é digno de nota a Capela Santa Cruz, obra em que Celso Pupo ressalta que foi necessária uma certa preparação técnica para realizar a construção utilizando a novidade ${ }^{154}$. Entretanto, a verga reta ainda predominou por um certo tempo, mesmo com o surgimento dos novos sobrados - como a casa de Antonio Carlos de Sampaio Peixoto, de taipa e pau-a-pique, que é um exemplo do uso de vergas retas em edifícios de proporções maiores (Figura $20)^{155}$.

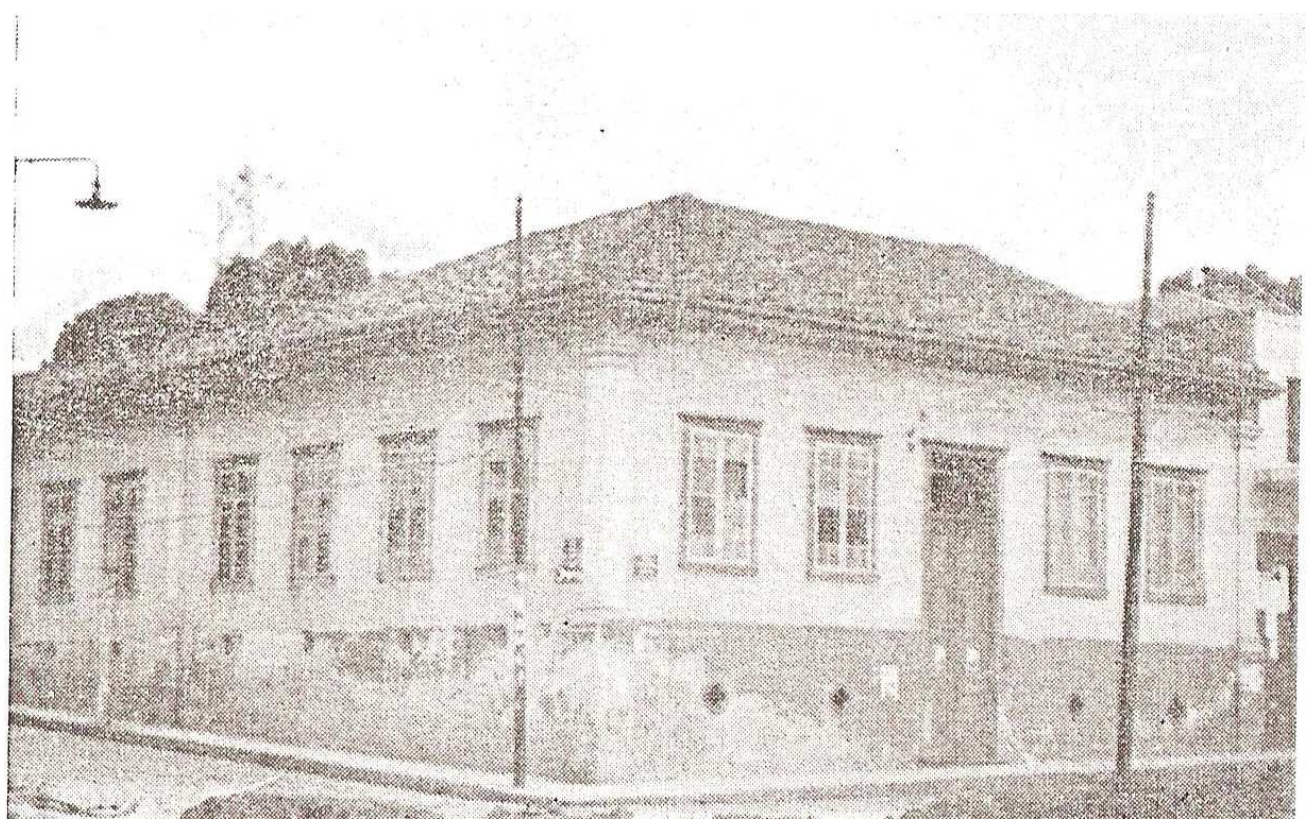

Figura 20: Casa de Sampainho, demolida

Porém, outra ocorrência de verga curva podia ser observada no sobrado de Francisco Pompeu do Amaral, além de uma sacada com três aberturas, recurso ainda pouco comum. Muitas reformas, dedicadas a atender às novas concepções de forma e desenho arquitetônico, foram realizadas - como no próprio sobrado pioneiro de Mascarenhas, reformado em 1867, para eliminar o beiral e substituí-lo pela platibanda. Como as paredes externas eram construídas com tijolo, não havia mais a necessidade de

\footnotetext{
154 Ibidem, p.180.

155 lbidem, p. 186.
} 
grandes beirais, indispensáveis para proteger a antiga taipa, dando lugar à platibanda um recurso de desenho que se tornou praticamente obrigatório depois de 1875, quando foi exigido o uso de calhas nas fachadas das casas.

Até essa data, prevaleceu a cultura do uso da terra crua nas edificações, período conhecido como o ciclo do pau-a-pique. Mas é no ano de 1875 que se iniciou a produção do tijolo Clayton, na olaria de propriedade do citado Sampainho (Antonio Peixoto, o dono da primeira olaria do estado e do casarão de taipa e pau-a-pique com vergas retas) que, por exibir as armas do Império, logo ganhou o título de "Tijolo Imperial". É curioso notar que, na construção das primeiras residências que fizeram uso do tijolo, este era reservado apenas para a elevação das paredes internas, enquanto que os vedos externos ainda eram erguidos com pau-a-pique ou taipa. Aos poucos, a terra crua perderia definitivamente seu posto, mas não deixa de ser curioso o fato dela subsistir, ainda que por curto período de tempo, justamente numa situação construtiva que nos motivaria imaginar o contrário. Cabe-nos apenas formular algumas conjeturas, imaginando o descrédito inicial na capacidade estanque do material ou mesmo em seu desempenho estrutural.

Já a casa de Francisco de Paula Bueno - na Rua Barreto Leme, próximo à R. Dr. Quirino, no qual residiu por muito anos a família Castro Mendes, e em cuja platibanda registrou-se a data de 1867 - foi construída utlizando-se o tijolo nas paredes mestras e o pau-a-pique para elevação das secundárias, ao contrário do costume campineiro, segundo nos relata Pupo ${ }^{156}$. Próximo a essa residência, no trecho médio da Av. Francisco Glicério, a casa de José de Sousa Campos, construída em 1868, é também uma das primeiras residências com detalhes neoclássicos, exibindo janelas encimadas por vergas em semi-circulo e adornadas com bandeiras de ferro. Em sua construção, foi utilizado tanto o pau-a-pique quanto tijolo Clayton. Essa mistura de técnicas construtivas tornou-se comum na execução dos sobrados campineiros na época, com o tijolo também sendo utilizado na execução das fundações, nas abobadilhas de sustentação de piso apoiadas em perfis de ferro e, é claro, em paredes.

Mesmo assim, os casarões iam surgindo aos poucos e o tijolo ainda era presença inexpressiva. Apesar de poucos, os edifícios já chamavam bastante a atenção, tanto pelas características sóbrias e detalhes adereçados e originais como pelas grandes dimensões. É o caso, por exemplo, da residência do Barão de Ataliba Nogueira, na Regente Feijó, que, apesar de térrea, já exibia uma sóbria platibanda e porta monumental. Em 1879, com a construção de um vistoso sobrado na Avenida. Francisco Glicério, o detalhe original era a água-furtada (Figura 21), sucessora da camarinha -

\footnotetext{
${ }^{156}$ PUPO, Celso Maria de Mello. Campinas, município no Império: fundação e constituição, usos familiares, a morada, sesmarias, engenhos e fazendas, São Paulo: Impr. Oficial, 1983, p. 56.
} 
como citado anteriormente, era um cômodo inicialmente utilizado como extensão de instalações comerciais e aparecia agora nas residências. Esta composição volumétrica e o desenho das aberturas passou, então, a ditar uma nova tendência.

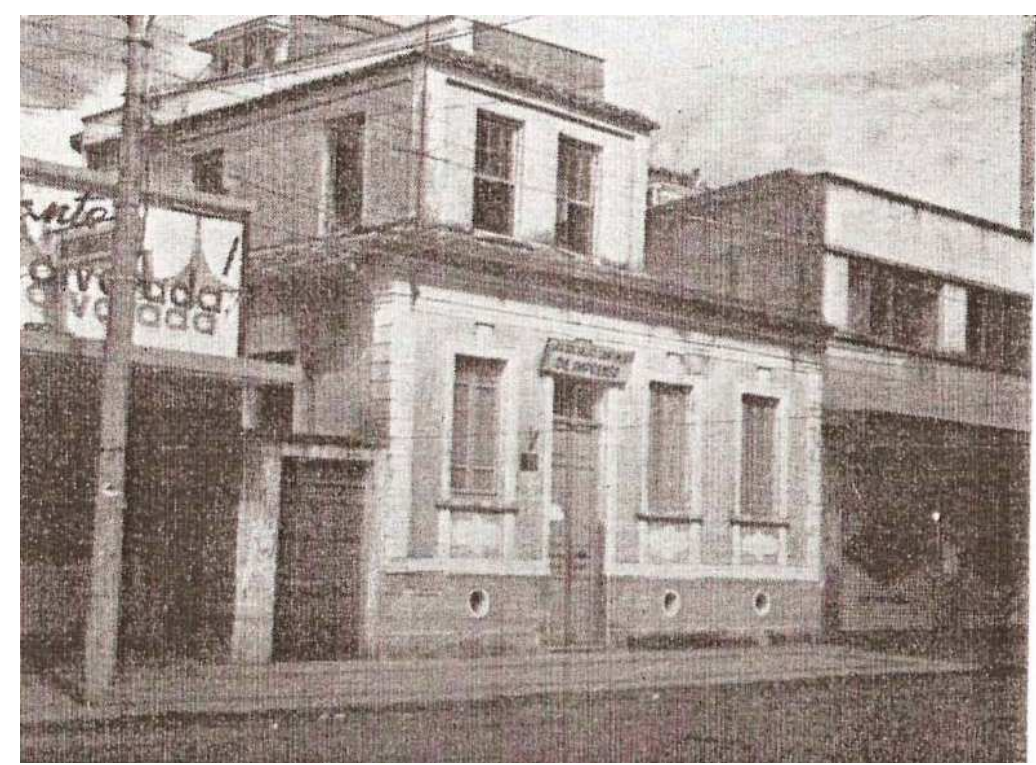

Figura 21: Residência com água furtada na Av. Francisco Glicério

Nesse mesmo ano a cidade viu ser construído o Solar do Barão de Itapura, em estilo renascentista italiano, agora fazendo as alvenarias, todas erguidas com tijolos, funcionarem como um autêntico sistema portante. Com colunas jônicas na fachada principal, as janelas foram abertas em arco pleno no pavimento inferior e, no superior, foram encimadas por vergas retas e pequenos frontões triangulares ${ }^{157}$.

Evidentemente, tratava-se de instituir um novo padrão de edificação urbana, pelo menos para uma cidade com o porte de uma Campinas do final do século XIX. Considerando algum comportamento conservador da população campineira, pode-se avalizar, com alguma segurança, a hipótese de que não eram todos os proprietários, prestes a construir suas residências, que se empolgavam com tais novidades. Assim, a presença de uma burguesia minimamente informada, certas aspirações europeias e algum capital acumulado eram condições essenciais e interdependentes para a disseminação desse novo padrão. Como tais condições não eram, de modo algum, distribuídas amplamente entre a maioria dos cidadãos campineiros; e uma vez que a presença da aristocracia cafeeira nas estruturas de poder local promovia esse entrecruzamento entre expectativas sócio-culturais e capacidade de investimento, parece plausível afirmar que seria a produção da edificação pública que conseguiria reunir -

\footnotetext{
${ }^{157}$ SCARANO, Julita e ARMOND, Angela Cristina. Lista de Bens Tombados do Condephaat: Solar Barão de Itapura, Site da Secretaria de Cultura do Governo do Estado de São Paulo http://www.cultura.sp.gov.br/portal/site/SEC/menuitem.a943691925ae6b24e7378d27ca60c1a0/?vgnextoid=c8 8fcf75c7e9b110VgnVCM100000ac061c0aRCRD\&cpsextcurrchannel=1.
} 
como ocorre até hoje, inclusive - as brechas políticas, as referências culturais e o suporte financeiro adequado para a experimentação de uma nova linguagem, tanto estilística como construtiva.

Segue um exemplo dessa afirmação: Ramos construiu um bela residência para o comendador Joaquim Ferreira Penteado, o Barão de Itatiba, e seu filho, Ignácio Ferreira de Camargo Andrade, o Palácio dos Azulejos. Erigido numa esquina, a residência era composta de dois edifícios geminados, cada um com seu portal. Na fachada de azulejos portugueses, até a platibanda recebeu louça branca. Os gradis de ferro fundido podem ser vistos no balcão do segundo pavimento e na porta de acesso principal, também se destaca a claraboia com vidros coloridos. Ora, o comendador já havia trabalhado com Ramos e conhecia, com alguma propriedade, os recursos de linguagem e construção operados pelo jovem engenheiro-arquiteto, quando a ele encomendou sua primeira obra na cidade: a Escola Ferreira Penteado.

Como já visto no capítulo introdutório, no início da década de 1880, a cidade já contava com uma certa infra-estrutura, dispondo de transporte de bondes movidos a tração animal, iluminação a gás, fábricas importantes para a produção agrícola, fundições de ferro e bronze, fábricas de cerveja, gelo, sabão e chapéus, marcenarias, carpintarias a vapor, curtumes etc. Ramos de Azevedo já estava instalado na cidade, recém-chegado da Bélgica, desde 1879. Foi então que o comendador, provavelmente a partir da recomendação de alguém do estreito círculo de relações com o qual mantinha vínculos, encomendou a primeira obra de Ramos a ficar pronta na cidade, a Escola Ferreira Penteado. Atendendo um pequeno programa, orientado para o atendimento de crianças pobres, a escola foi inaugurada em maio de 1880. Construída toda em alvenaria de tijolos, pelos poucos registros que foram encontrados sobre a construção original e as parcas informações sobre a construção na cidade, esse pequeno edifício, juntamente com o Solar do Barão de Itapura, deve seguramente fazer parte do conjunto das primeiras obras, em Campinas, que emprega exclusivamente esse material. A construção, de $81,35 \mathrm{~m} 2$, possui uma planta quase quadrada, recuada onze metros do passeio e com empenas laterais cegas, demonstrando os prováveis limites do estreito lote de oito metros onde se assentava. Segundo a análise de Monteiro ${ }^{158}$, devido à pequena testada do lote, talvez não tivesse sido possível trabalhar a volumetria da fachada com maior desenvoltura: quase plana, a fachada projetava apenas um pequeno avanço de alguns centímetros do seu terço central, destacando ligeiramente a entrada ${ }^{159}$.

\footnotetext{
158 MONTEIRO, Ana Maria Reis de Góes. Ramos de Azevedo: Presença e atuação profissional em Campinas: 1879-1886. Dissertação apresentada à Faculdade de Arquitetura e Urbanismo da PUC-Campinas para a obtenção do grau de Mestre, 2000, p. 47.

159 Os corpos avançados passariam a ser muito comuns nas obras posteriores de Ramos, que começaram a aparecer expressivamente a partir de 1897, como no projeto da Cadeia e do Fórum.
} 
$\mathrm{Na}$ entrada de acesso ao lote, portão e grade de ferro ornamentado. A cobertura é formada por um telhado de duas águas, uma delas voltada para frente e a outra para os fundos do lote, contidas por uma pequena platibanda - o que implica a adoção de calha embutida e condutores de águas pluviais na fachada. A entrada do edifício, acessada pela escada externa de mármore, é feita por uma porta de madeira almofadada, instalada sob um portal em arco, ocupando praticamente toda a saliência que sobressaía da fachada. Essa saliência era arrematada na parte superior por um frontão interrompido um recurso bastante incomum, pelo fato de não ser nem clássico (triangular), nem curvo, mas recortado, emoldurando os dizeres: "Ao povo - consagra J. Ferreira Penteado, fez erigir em 1880". As janelas laterais são duplas, emparelhadas sob dois arcos plenos interceptados e emoldurados por frisos e pingentes. Uma coluna central, adornada com folhas de acanto ${ }^{160}$ no capitel, acompanhando o formato da porta, separa uma janela da outra (Figura 22). Abaixo da platibanda, na extensão da cornija, os frisos são sobrepostos à superfície parietal ${ }^{161}$, numa técnica também ainda pouco utilizada. Esse seria o neoromântico, uma novidade de estilo, segundo Monteiro ${ }^{162}$.

É pelo menos intrigante a dissonante combinação entre uma implantação tradicional, herança dos tempos do casario colonial - empenas cegas e montadas sobre os limites laterais do lote, cumeeira paralela à rua, porta central ladeada pelas janelas dos cômodos que confinam a entrada principal e águas de telhado para frente e para os fundos do lote - e a proposição de um estilo neo-romântico para uma edificação escolar com pouco mais de $80 \mathrm{~m} 2$ em Campinas. Sem dúvida, há um grau bastante elevado de experimentação construtiva, tendo em conta o porte do edifício e, principalmente, se levarmos em conta as dificuldades intrínsecas ao trabalho de aplicação de frisos, de recortes nos revestimentos, de moldagem e instalação de capitéis etc. - isto é, os elementos materiais de uma linguagem de estilo.

\footnotetext{
160 Planta espinhosa originária da Grécia e utilizada frequentemente na decoração dos templos gregos pela sua folha ornamental larga e de recortes simétricos.

${ }_{161}$ Parietal, adj. Relativo à parede, segundo Dicionário Aurélio.

162 MONTEIRO, Ana Maria Reis de Góes. Op.cit. (2000) p. 48.
} 

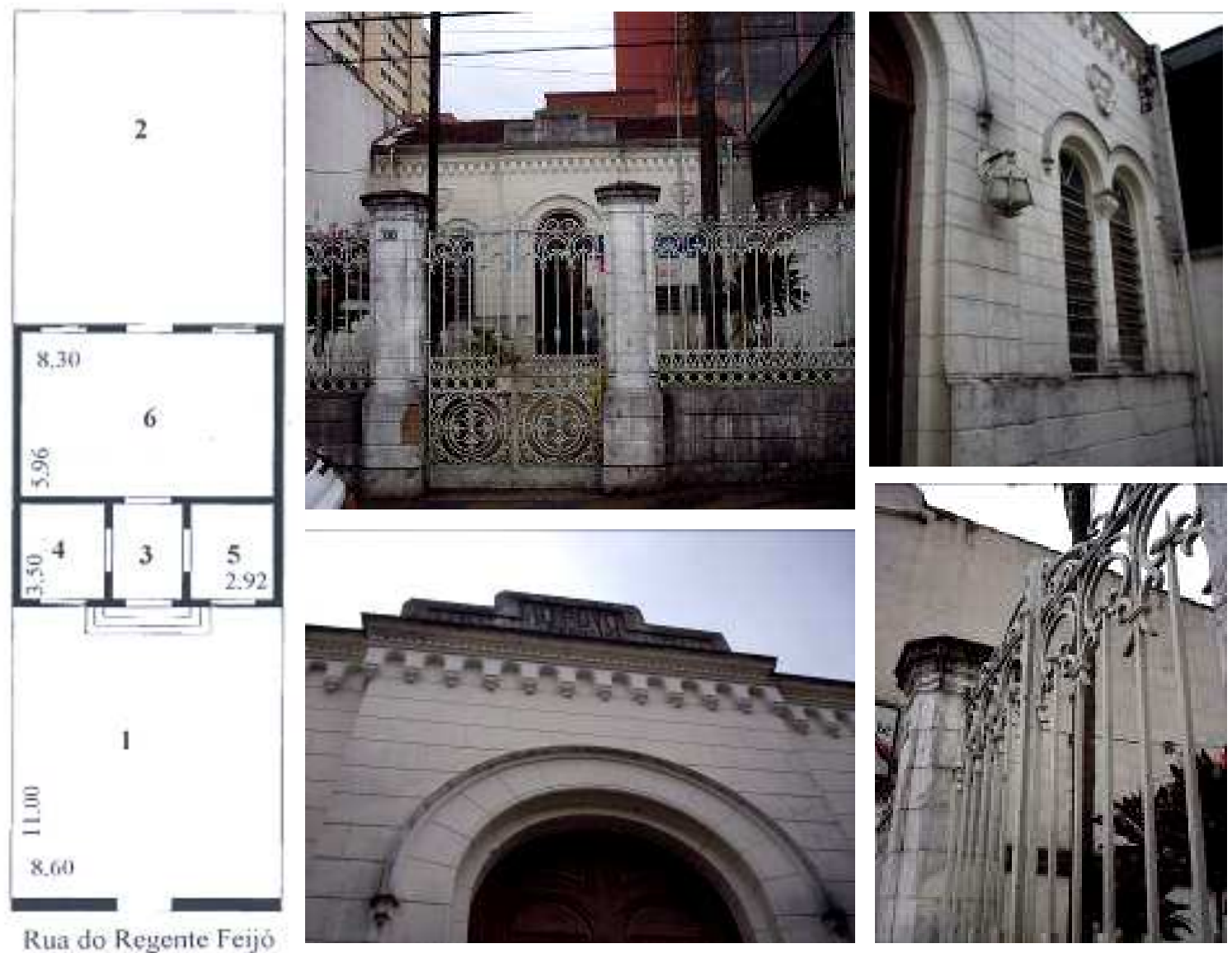

Figura 22: Planta da Escola, com recuo frontal (1) e posterior (2), vestíbulo (3), locutório (4), vestiário (5) e sala de aula (6). Imagens: fachada da escola e detalhe das aberturas ${ }^{163}$

Também destinado a um uso público, porém restrito - teria sido, originalmente, projetado para abrigar restaurante, bailes e jantares comemorativos ${ }^{164}$-, o Chalet do Bosque dos Jequitibás foi o projeto seguinte do engenheiro-arquiteto, já na esteira de um bem sucedido trabalho com seus clientes anteriores. Com obras iniciadas em 1880, o chalé foi erguido em frente a uma pequena praça e inaugurado em setembro de $1881^{165}$. Essa pequena construção de tijolos tem as empenas voltadas para os lados, no sentido oposto ao adotado até então (inclusive, diferentemente da solução de implantação dada para a Escola Ferreira Penteado). O detalhe na cumeeira, uma travessa no beiral próximo a cumeeira, será uma marca registrada de Ramos de Azevedo, presente em suas outras obras campineiras, como a sede da fazenda São Vicente. Observando a única foto antiga do chalé que obtivemos, percebe-se que, antes das janelas basculantes de ferro, instaladas em vãos emoldurados pelos montantes da estrutura de madeira, ali

\footnotetext{
163 Planta: MONTEIRO, A. M. R. G. Ramos de Azevedo: Presença e atuação profissional em Campinas: 1879-1886. Dissertação apresentada à Faculdade de Arquitetura e Urbanismo da PUC-Campinas para a obtenção do grau de Mestre, 2000, pp. 46; e fotos: tiradas pela autora. As fotos apresentadas nesta dissertação foram tiradas pela autora no período de junho de 2006 a setembro de 2009.

164 BULHÕES, Nice. Casarão do bosque vai ser reaberto. Correio Popular, Campinas, 3 mai. 2003

165 MONTEIRO, Ana Maria Reis de Góes. Op.cit. (2000) p. 111.
} 
existiam venezianas, também de madeira, com folhas articuladas abrindo para fora, permitindo plena iluminação e ventilação do interior. Com quatro salas e duas alcovas, o projeto também traz um novo estilo: o de chalé suíço. (Figura 23).

O ensaio de uma outra e bastante distinta opção construtiva - não se tratava apenas de uma questão de estilo ou puro formalismo, mas de uma opção que implicava, antes de tudo, uma outra solução estrutural - em projeto imediatamente posterior ao elaborado para a Escola do comendador, novamente denota a disposição de Ramos - e a condescendência de seus clientes - para a experimentação das diversas possibilidades construtivas que aprendera em seu período na Europa. Parecem realmente constituir ensaios construtivos e formais que somariam experiência para aplicação - ou rejeição em projetos futuros.
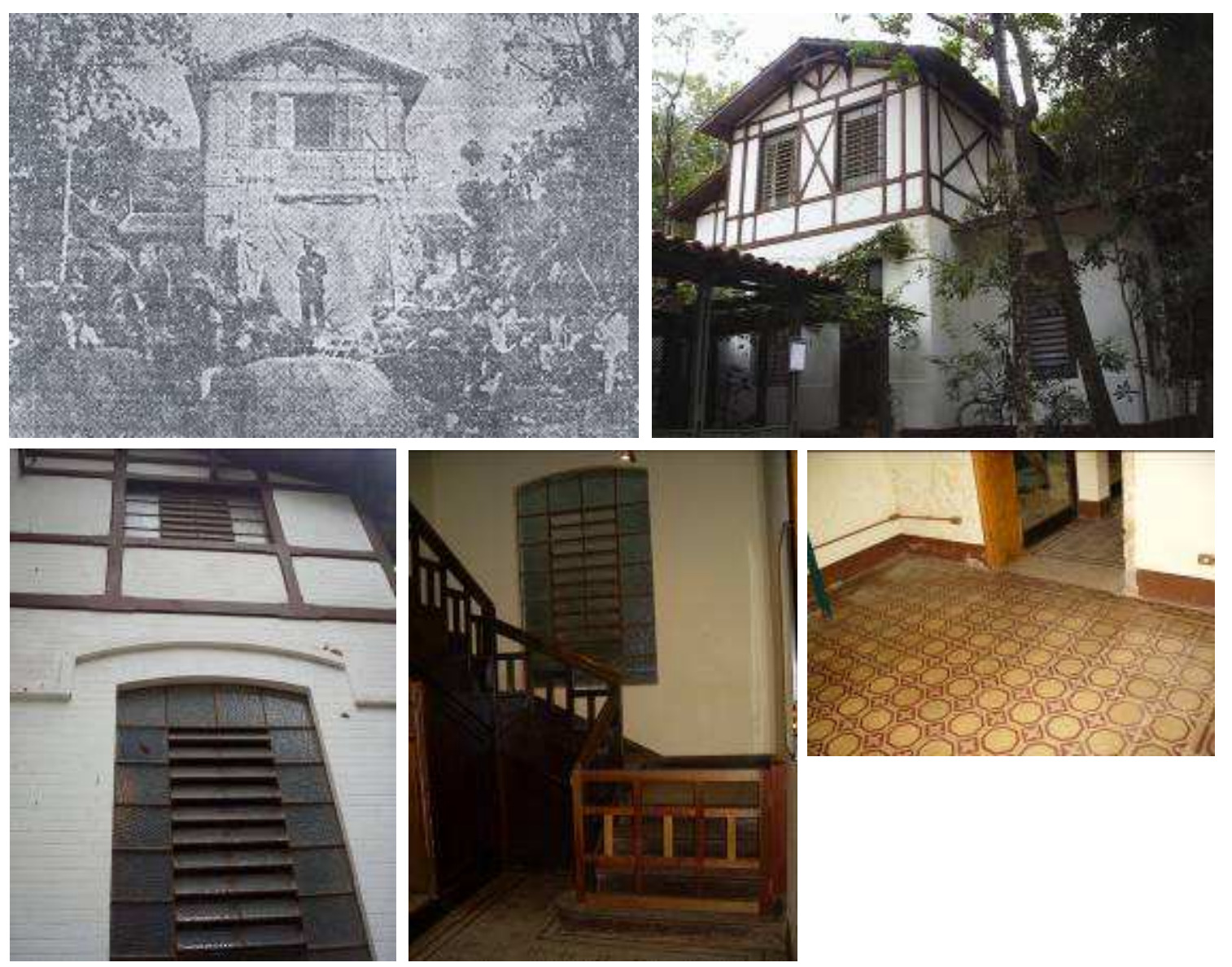

Figura 23: Foto de época, de jornal, mostrando recital em frente ao Chalet. Foto da fachada, detalhe da janela e detalhes da escada e do piso ${ }^{166}$

${ }^{166}$ Imagem em preto e branco: Correio Popular, Campinas, 14 jul. 1974. 
Em 1883 foram finalizadas as obras da Igreja Matriz de Campinas, conduzidas por Ramos de Azevedo. Como já comentado na Introdução, o projeto original para a fachada da Igreja Matriz de Campinas não é dele: coube a ele apenas dar sequência e concluir os serviços conduzidos inicialmente pelo administrador anterior, o engenheiro italiano Cristovam Bonini. A edificação - iniciada em 1807, como já vimos - ganhava, com a nova fachada proposta por Bonini, um jogo de volumetria mais trabalhado, articulado verdadeiramente como uma "composição acadêmica"167 - que, em absoluto, não se harmonizava com o corpo existente, construído

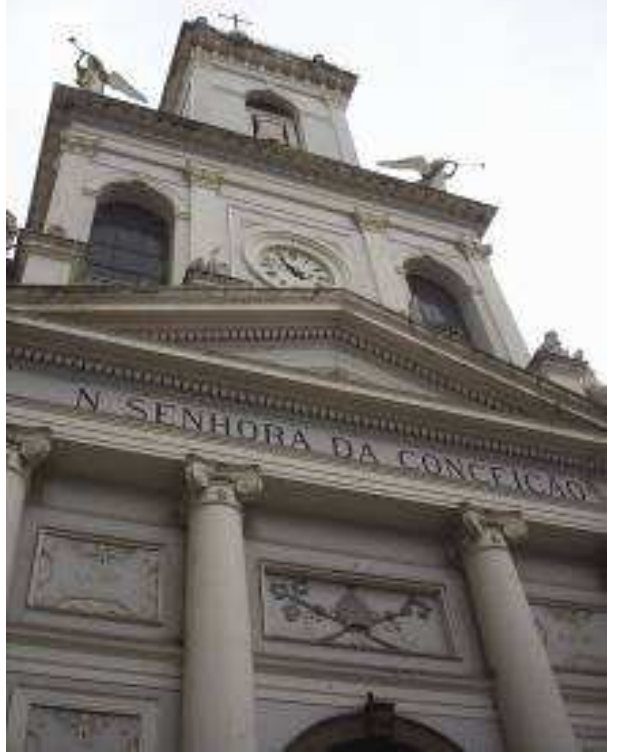

Figura 24: Fachada da catedral e os elementos neoclássicos em taipa de pilão. Composta de três corpos sobrepostos, a fachada estrutura-se em forma de torre assiriana, decorada em estilo clássico. O primeiro corpo é de ordem Jônica, com a parte central saliente e coroada por um frontão triangular. As três entradas são encimadas por quadros em relevo onde estão gravadas as principais datas históricas da catedral. O segundo corpo é de ordem Coríntia composta, onde está instalado o relógio que separa duas janelas em arcadas. O terceiro corpo é, justamente, a parte da obra finalizada por Ramos de Azevedo, incluindo a torre e sua cobertura. Conforme Lemos, Ramos teria introduzido algumas modificações no desenho original de Bonini, procurando imprimir mais leveza ao conjunto, mas sem alterar significativamente a proporção da volumetria original: seria de sua autoria a substituição da cobertura da torre, trocando a meia cúpula encimada por uma cruz, conforme proposto pelo italiano, por uma esguia torre octogonal. O terceiro corpo se assenta sobre uma base quadrada, envolvido por um largo passeio, emoldurando apenas a janela onde se instala o sino principal. Sobre esse corpo, instala-se a pirâmide de coroamento da torre, encimada por uma cruz de ferro.

Para executar os ornamentos e apliques decorativos nesse terceiro corpo da fachada, Ramos teria mantido a mesma opção de material que Bonini utilizou nos primeiros corpos, procurando manter cor, textura e características dos ornamentos já executados: provavelmente argamassas de cimento, com agregados finos e compósitos para tratamento da superfície acabada ${ }^{168}$. Muitos foram os elementos importados, não só

\footnotetext{
${ }^{167}$ CONDEPHAAT: Relatório de Tombamento, p. 15, citação de Carlos Lemos.

${ }^{168}$ LEITE, Ricardo. Catedral Metropolitana de Campinas: um templo e sua história. Campinas, Komedi, 2004, p. 34.
} 
equipamentos como o relógio e o sino, como materiais básicos, tais como ferro, aço, cal e até tijolos. Da mesma forma, também a mão de obra, qualificada para o tratamento e acabamentos pretendidos, era constituída de trabalhadores estrangeiros: um grande número de italianos, razoavelmente qualificados, divididos em pedreiros, canteiros, serralheiros e carpinteiros.

Uma das hipóteses desta dissertação é que, apesar da pequena participação no projeto e mesmo na condução das obras, o trabalho de Ramos na fachada da Igreja Matriz de Campinas parece contribuir sobremaneira para a compreensão do desenvolvimento profissional do engenheiro-arquiteto. As razões dessa inferência serão tratadas com maior cuidado nas Considerações Finais. A participação de Ramos na obra citada, provavelmente, deve ter repercutido positivamente na consolidação de sua credibilidade como construtor: uma igreja matriz de uma cidade que, para a época, não era pequena; uma obra que se arrastava já quase há cem anos, gerando desgaste político e indisposições entre seus administradores; inúmeros equívocos de condução técnica e erros construtivos; e, por fim, quando tudo parecia equacionado, algum desentendimento faz ruir a última esperança, depositada num engenheiro italiano e em seu grupo de operários conterrâneos. Tudo isso parece confluir para a criação de um contexto tão intrincado que só um sujeito muitíssimo habilidoso poderia desembaralhar nem que fosse apenas para colocar a cruz no topo da igreja. Mas esse é um assunto que pretendemos reservar para as conclusões deste trabalho.

No projeto do Circolo Italiani, realizado em parceria com o engenheiro italiano Samuele Malfatti e inaugurado em 1885, Ramos parece ampliar um pouco mais a presença dos referenciais neoclássicos em seus projetos - se tomarmos como referência o quanto eles aparecem no projeto para a Escola do comendador Ferreira Penteado e no chalé do Bosque dos Jequitibás. Talvez porque associado a um italiano, talvez porque projetando para italianos, o certo é que o projeto do Circolo agrega uma quantidade significativa de elementos neoclássicos - o que nos faz imaginar que, nessa obra, Ramos sentia-se mais à vontade para lidar com tais referências. Inicialmente, o projeto constituía-se apenas de um salão nobre com quatro salas adjacentes. Mas, já nos primeiros estudos, ganhava outra dimensão: originalmente concebido para abrigar o estudo da língua italiana, suas instalações deveriam comportar mais de 100 alunos ${ }^{169}$. Inaugurado pela sociedade italiana em maio de 1886, o prédio erigia-se sobre altos porões e exibia uma ornamentação típica do neo-renascimento. Essa inauguração contava apenas com o corpo central da edificação, construída numa primeira etapa de

169 MONTEIRO, Ana Maria Reis de Góes. Ramos de Azevedo: Presença e atuação profissional em Campinas: 1879-1886. Dissertação apresentada à Faculdade de Arquitetura e Urbanismo da PUC-Campinas para a obtenção do grau de Mestre, 2000, p. 121. 
obras. Só posteriormente a ala direita e, em seguida, a esquerda foram erguidas, e somente em 1924 foram inauguradas as duas alas superiores, dedicadas à instalação de um hospital, finalizando a implantação de todo o conjunto.

De qualquer forma, é nessas situações que o ensaio das soluções de desenho parecem acompanhar de perto os ensaios de opções construtivas. Não deixa de ser curioso que essa sequência de projetos demonstra uma espécie de afinação de instrumentos, como se a conjugação ideal entre técnica, estratégia construtiva e linguagem de estilo estivesse sendo sistematicamente buscada em cada nova obra.
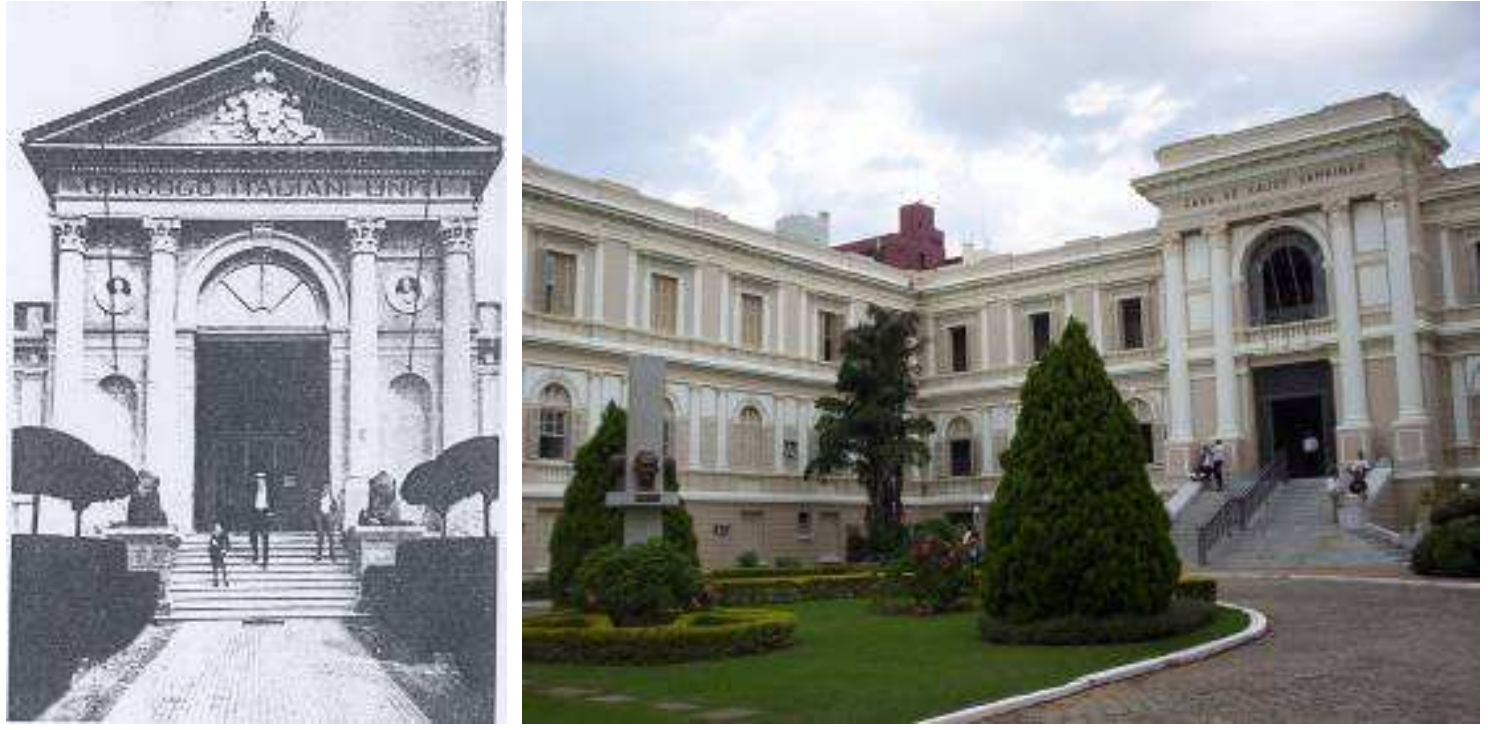

Figura 25: Fachada central do Circolo Italiani, ainda com frontão triangular e foto atual do edifício ${ }^{170}$

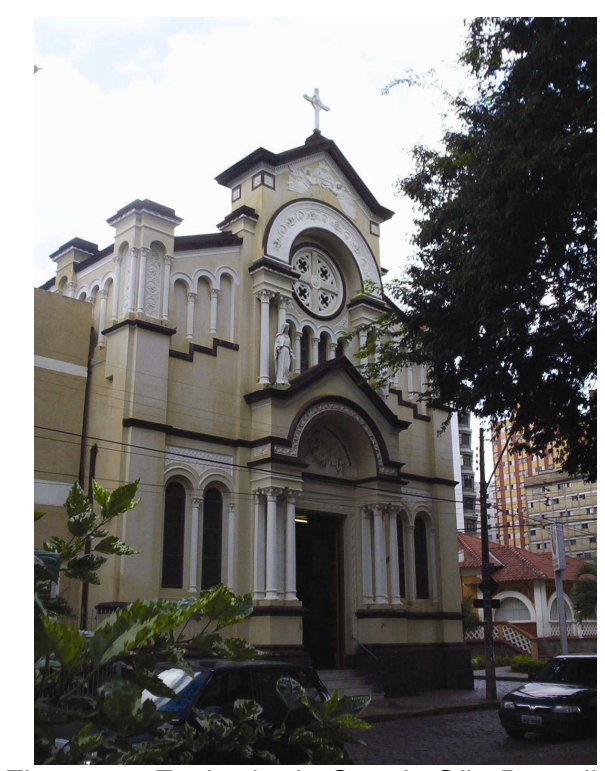

Figura 26: Fachada da Capela São Benedito
Concomitante ao projeto do Circolo Italiani é o projeto da fachada neo-romântica para a Capela São Benedito, iniciado em 1885. Ali, a ornamentação aparece mais densa e rica, fazendo jus à condição de capela. O edifício existente, com características e padrão construtivo coloniais ${ }^{171}$, foi inteiramente reformado, mantendo-se apenas sua estrutura e proporções originais, pretendendo assegurar a manutenção da harmonia alcançada pelo desenho original. É nesse edifício que serão utilizadas as técnicas construtivas mais modernas

\footnotetext{
${ }^{170}$ Imagem em preto e branco: LEMOS, Carlos A. C. Ramos de Azevedo e seu Escritório. São Paulo, Pini, 1993 , p. 29

171 MONTEIRO, Ana Maria Reis de Góes. Ramos de Azevedo: Presença e atuação profissional em Campinas: 1879-1886. Dissertação apresentada à Faculdade de Arquitetura e Urbanismo da PUC-Campinas para a obtenção do grau de Mestre, 2000, p. 117.
} 
e introduzidos novos elementos arquitetônicos. A entrada tem um corpo avançado, com frontão independente e imagens também avançadas, e um conjunto de duas colunas de ordem jônica e duas pilastras de ordem coríntia de cada lado, recebidas por uma escada externa perpendicular de mármore, ladeada por um guarda-corpo de ferro ornamentado. As janelas laterais, duplas e emparelhadas ao lado do volume de entrada, lembram as janelas da Escola Ferreira Penteado - arcos plenos duplos, intermediados por colunas de ordem jônica, talvez uma linguagem adotada em fachadas de largura estreita. No corpo superior da capela, uma série de colunas de ordem igualmente jônica e arcos plenos acompanham o frontão inferior, dando destaque a um belo óculo ornamentado.

No Cemitério da Saudade, um projeto realizado no século XX, quando Ramos já estava morando em São Paulo, o engenheiro-arquiteto desenhou, além de algumas pequenas edificações - como a capela e uma pequena construção destinada à administração e descanso dos familiares dos mortos -, todo o traçado, parcelamento e o portal principal do cemitério (datado da década de 1910).
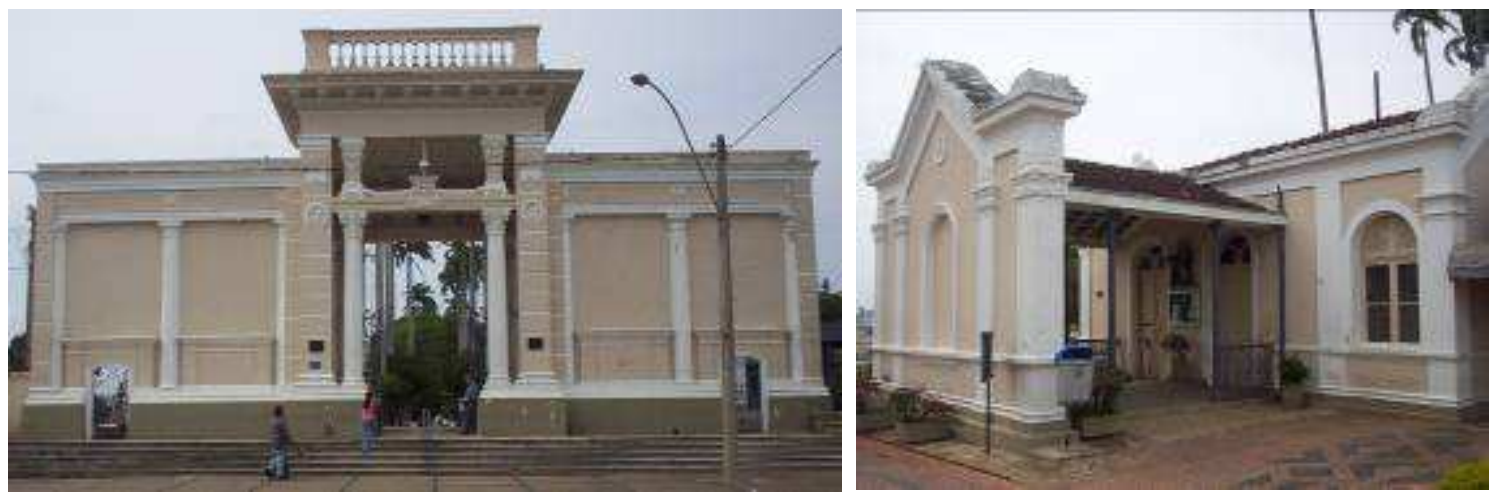

Figura 27: Portal de entrada do cemitério e pequena construção destinada à administração e descanso dos familiares dos mortos

A casa da administração era dividida em dois corpos, unidos por uma varanda junto ao portão de acesso. Há uma referência, em Monteiro ${ }^{172}$, que Emílio Drausfene, engenheiro da Câmera Municipal e responsável pela direção técnica das obras, teria realizado algumas modificações no interior daquela edificação - mas que, para todos os efeitos, não interferiram, aparentemente, no aspecto geral da obra.

Aqui, assim como na sede da fazenda Pau d'Alho (como veremos mais adiante), os elementos neoclássicos são usados intensivamente, de forma explícita e muito vigorosa, com as colunas e o entablamento do portal (atualmente com seus vãos preenchidos por questões de segurança) plenamente comprometidos com as ordens e proporções clássicas. Podemos dizer que, ao utilizar esses elementos com tal

172 MONTEIRO, Ana Maria Reis de Góes. Ramos de Azevedo: Presença e atuação profissional em Campinas: 1879-1886. Dissertação apresentada à Faculdade de Arquitetura e Urbanismo da PUC-Campinas para a obtenção do grau de Mestre, 2000, p. 235. 
intensidade, Ramos pode ter sido influenciado pelo projeto e detalhes propostos e executados na fachada da Matriz campineira. Foram usadas as colunas coríntias e métopas e foi repetida a bossagem utilizada nas pilastras do portão de acesso da Escola Ferreira Penteado. Na parte superior central, Ramos de Azevedo usou, pela primeira vez, a balaustrada e, no interior, um mural com anjos de gesso. Na parte central, acima do relevo datando "1913", uma luminária adornada de ferro. Aqui também começa a usar o ferro fundido de modo mais expressivo: no monumental portão da entrada, nas esbeltas colunas e nos gradis da casa administrativa.

Com novas medidas sanitárias tomadas devido às epidemias, os edifícios públicos construídos nesse período ganharam novos programas, além de diversas soluções técnico-construtivas inéditas.

Ramos de Azevedo já não mais residia na cidade, após ter se mudado para São Paulo em 1886. Ramos só voltaria à cena campineira com o projeto do prédio onde Ataliba Nogueira instalou sua residência. Em estilo neo-renascentista, o edifício teria sido construído em 1891 ou em 1896 - há controvérsias quanto à data exata ${ }^{173}$. Quanto aos estilemas, agora não há novidades: as janelas de vergas retas são ornamentadas com apliques e dão para varandas com balaustradas. Em toda a fachada há vincos horizontais e friso na platibanda. Na parte central, um frontão interrompido em cima e abertura de verga reta ornamentada em arco pleno, com pilastras coríntias nas laterais. Apesar dos ornamentos serem os mesmos utilizados por Ramos em inúmeros outros projetos, essa é uma obra mais madura, com técnicas e processos construtivos mais apurados e abastecidos por uma indústria civil mais consolidada. A estrutura aparece aqui em destaque, com paredes portantes de alvenaria de tijolos e "trilhos de trem" que reforçam as interfaces entre o térreo e o primeiro andar. Segundo o arquiteto João Baccelar ${ }^{174}$ que realizou a reforma do prédio em 1991 - o que mais impressiona no projeto de Ramos de Azevedo são as cintas de aço que envolvem todo o sobrado, protegendo-o da trepidação gerada pelo tráfego da rua em frente ${ }^{175}$. Nas paredes estruturais foi utilizada argamassa de cimento e cal para assentamento das alvenarias, e estuque em treliça de madeira nas paredes internas secundárias; madeira serrada e aparelhada foi aplicada

\footnotetext{
173 PRANDI, Daniela. Centro Cultural Victória abre suas portas: Centro terá duas salas de cinema, livraria, locadora e bar e abre ao público amanhã. Correio Popular, Campinas, 08 nov. 1991.

${ }_{174}$ CINECLUBE moderno em prédio antigo. Jornal de Domingo, Campinas, 10 nov. 1991.

175 COSTA, Maria Teresa. Condepacc tomba Hotel Vitória. Diário do Povo, Campinas, 14 jul. 1990.
} 
nos acabamentos, na estrutura do entrepiso e no telhado, revestido com telhas cerâmicas importadas $^{176}$.

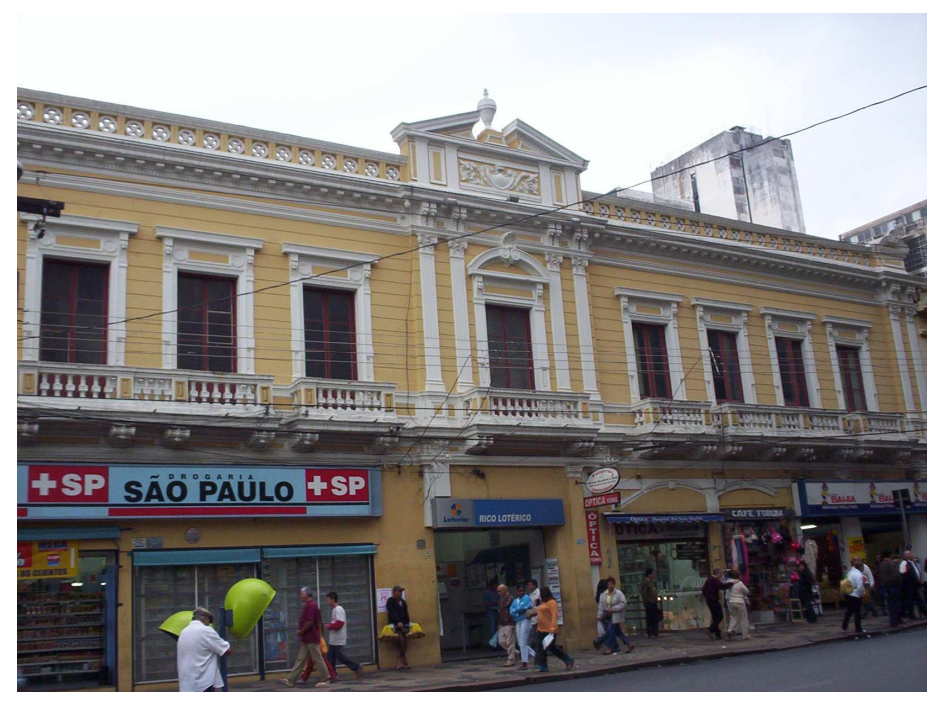

Figura 28: Fachada do antigo Solar Ataliba Nogueira

O projeto de Ramos para a cadeia pública de Campinas - finalizado apenas em 1896 - teve sua obra dirigida pelo engenheiro Antonio Raffin ${ }^{177}$. A nova cadeia substituía a antiga edificação destinada para esse fim, bastante simplória e com capacidade defasada $^{178}$. Ramos promoveu uma profunda readequação do programa, propondo cômodos bem distribuídos e arejados ${ }^{179}$, tanto na parte dos prisioneiros como nas salas do Fórum. Suas paredes internas foram revestidas de argamassa especial, feita com pó de mármore, segundo um relato da época. No centro do salão central foi instalado um enorme lustre. As pinturas, imitando o mármore - conhecida como 'marmorização' -, seria outra técnica muito utilizada por Ramos - nesse caso, demonstrando alguma inventividade para a reprodução falseada do requinte do período cafeeiro, numa circunstância que não recomendava a aplicação do material real. Com dois corpos avançados $^{180}$ que se projetam nas fachadas frontal e posterior, esse recurso passará a ser mais comum em suas obras. No andar térreo, foram projetados os espaços de

176 O projeto para a sede da Fazenda Alpes data provavelmente desse mesmo período - 1890. Diferentemente da Fazenda Pau d'Alho - tomando como exemplo de projeto para uma construção em meio rural - e da residência Ataliba Nogueira - como referência do trabalho de Ramos neste período -, essa construção não aparenta requinte algum. Pelo contrário, segue um padrão estritamente rural, mantendo a tipologia original de sede de fazenda. Os acabamentos são muito simples, a volumetria pouco trabalhada e seu aspecto é absolutamente sóbrio - o que chama a atenção.

177 CARVALHO, Maria Cristina Wolff de. Ramos de Azevedo. São Paulo, Editora da Universidade da São Paulo, 2000, p. 156.

178 ABRAHÃO, Fernando Antonio (Mestre em História pelo IFCH /Unicamp, O Ajustar das Contas: Uma Análise dos Discursos Sobre o Sistema Carcerário em Campinas na Virada do Século XX, site .www.centrodememoriaunicamp.br/arqhist/artigos.htm.

179 MONTEIRO, Ana Maria Reis de Góes. Ramos de Azevedo: Presença e atuação profissional em Campinas: 1879-1886. Dissertação apresentada à Faculdade de Arquitetura e Urbanismo da PUC-Campinas para a obtenção do grau de Mestre, 2000, p. 219.

180 CARVALHO, Maria Cristina Wolff de. Ramos de Azevedo. São Paulo: Editora da Universidade da São Paulo, 2000, p. 159. 
distribuição e uso comum: o vestíbulo ${ }^{181}$, o hall central e a escadaria monumental. As formas clássicas mantiveram-se fortes, assim como o detalhamento, numa linguagem arquitetônica mais compatível. Predominam as aberturas de arco pleno, sendo que apenas as aberturas laterais, no andar superior, são encimadas por vergas retas e ornamento triangular. $\mathrm{Na}$ parte superior central, colunas duplas de ordem dórica em relevo e varanda baixa de balaustrada, repetida no coroamento do entablamento, com frontal interrompido e encimado curvo.
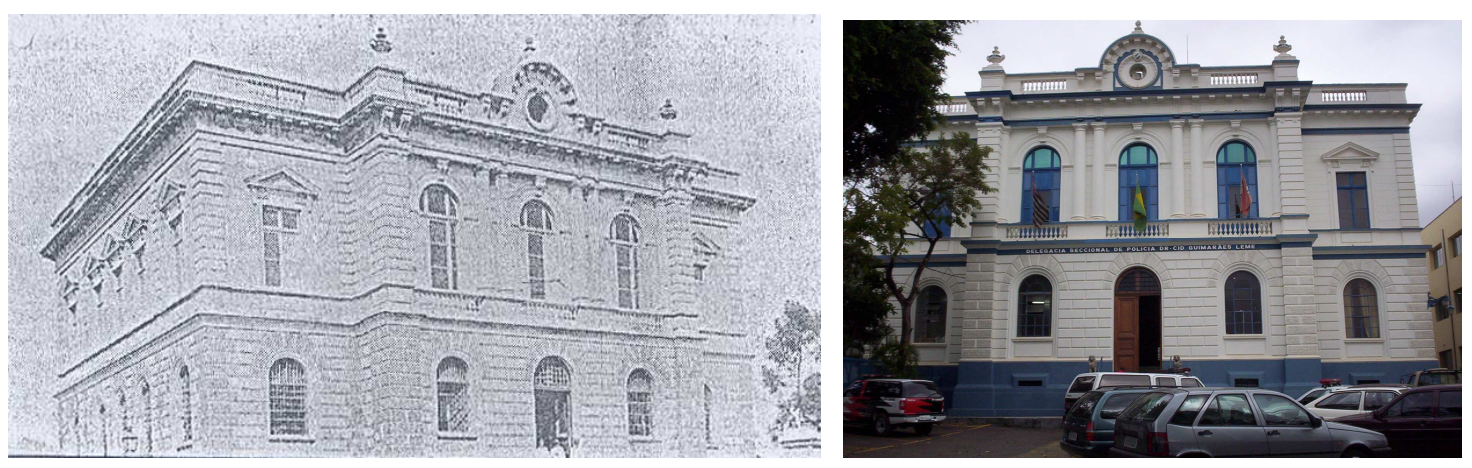

Figura 29: Foto da Cadeia Nova quando foi inaugurada e foto recente ${ }^{182}$

Ainda nesse período, Ramos inaugurou a Escola Francisco Glicério, em fevereiro de 1897. O prédio caracteriza-se por uma arquitetura eclética, fugindo do padrão usualmente operado pelo engenheiro-arquiteto, com elementos neo-renascentistas, porém com forte influência neo-gótica, demonstrada através dos apliques ogivais, do frontão triangular mais agudo e a presença de pináculos. As duas alas térreas, independentes, foram construídas depois, em 1903 - criando a ilusão dos corpos avançados. Dispostas de cada lado do bloco principal para atender as necessidades do novo sistema educacional - que exigia 10 salas de aula e seguindo os padrões da Escola Modelo $(1890)^{183}$ - as edificações que as abrigavam tinham portas altas e paredes esbeltas.

\footnotetext{
${ }^{181}$ LEMOS, Carlos Alberto C. Alvenaria Burguesa: Breve história da arquitetura residencial de tijolos em São Paulo a partir do ciclo econômico liderado pelo café. São Paulo, Nobel, 1985, p. 53.

182 Imagem em preto e branco: Correio Popular, Campinas, 27 abril 1993.

183 MONTEIRO, Ana Maria Reis de Góes. Ramos de Azevedo: Presença e atuação profissional em Campinas: 1879-1886. Dissertação apresentada à Faculdade de Arquitetura e Urbanismo da PUC-Campinas para a obtenção do grau de Mestre, 2000, p. 223.
} 

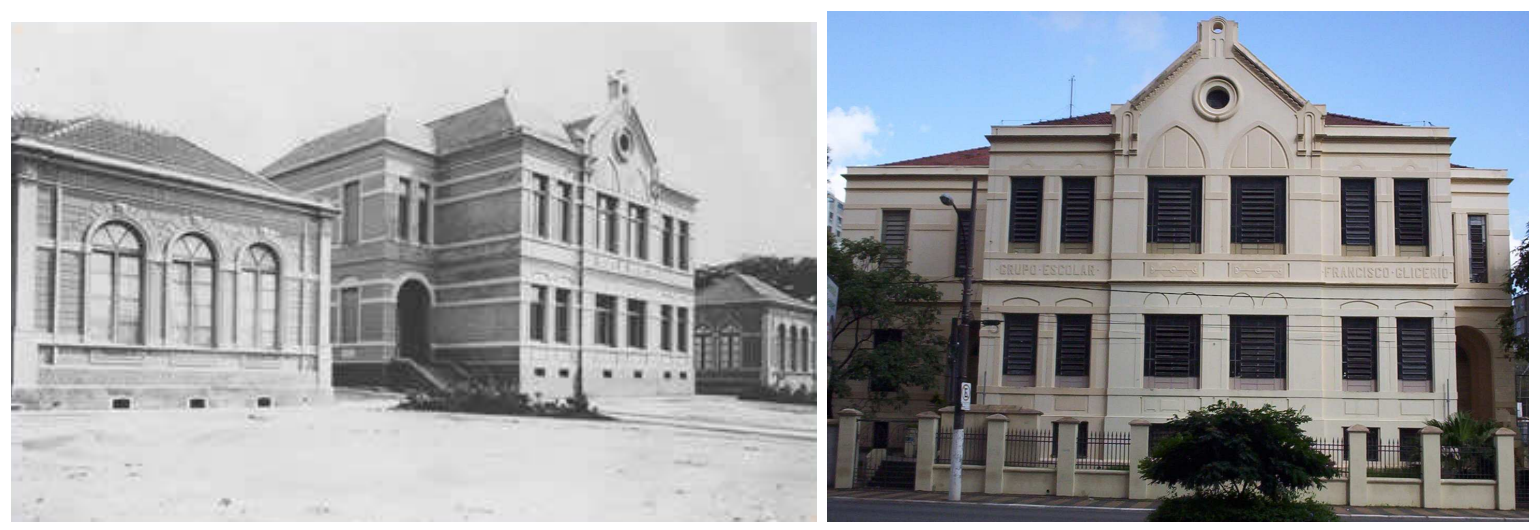

Figura 30: Foto tirada entre 1903 e 1905 e foto recente da Escola Francisco Glicério ${ }^{184}$

No final do século, Ramos projetou três residências em Campinas ${ }^{185}$. Uma delas foi demolida. As outras duas foram projetadas para Azurem Costa ${ }^{186}$ e para Horacio Antonio da Costa. O palacete de Azurem Costa ostenta estilo eclético, possui rica ornamentação em ferro fundido e pilares de sustentação da varanda feitos com o mesmo material. Verifica-se, na fachada, adornos neo-renascentistas, como frontões acima das janelas, vincos na argamassa da fachada, nos cunhais e nos balaústres na varanda. Infelizmente, o telhado original, que caracterizava o edifício, com traços franceses, foi substituído pelo acréscimo de um andar totalmente inexpressivo ${ }^{187}$. Na residência de Horacio da $\operatorname{Costa}^{188}$, também de dois andares, e situado numa esquina com portão lateral, são observados os mesmos recursos de acabamento dos revestimentos (argamassa vincada).

\footnotetext{
184 Imagem em preto e branco: Coleção Particular Mํㅡ Luíza Pinto de Moura.

185 LEMOS, Carlos A. C. Ramos de Azevedo e seu Escritório. São Paulo, Pini, 1993, p. 18.

186 BATTISTONI FILHO, Duílio. Alguns Aspectos da Arquitetura Urbana de Campinas. Campinas, Komedi, 2002 , pp. 51 e 52.

${ }^{187}$ CONDEPACC: Abertura do Estudo de Tombamento, Abril de 2001/ Residência Azurem Costa.

188 Artigo O Engenheiro Architecto F. P. Ramos D'azevedo em Campinas, sob coordenação Geral de Cássia Denise Gonçalves e Flávia Larneiro Leão, do site www.unicamp.br/cmu/iconografia/ menu/ exposicoes/ramnos azevedo.htm.
} 

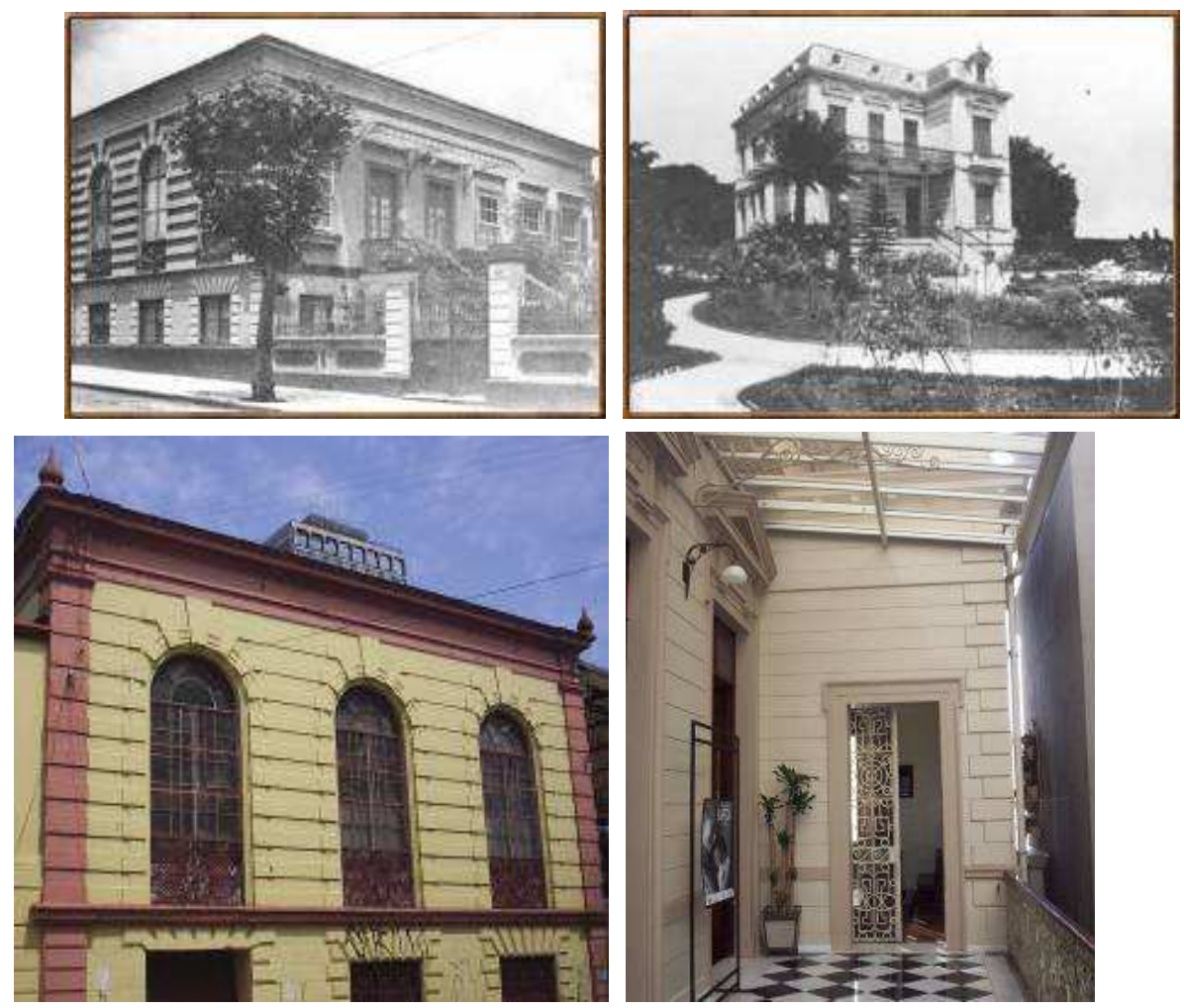

Figuras 31: Foto antiga e recente da residência Azurem Costa e Horácio da Costa, respectivamente ${ }^{189}$

No início do século XX, Ramos de Azevedo se envolveu com apenas mais duas obras na cidade - já bastante ocupado com as inúmeras obras da capital: o projeto do Mercado Municipal, que ficou pronto em 1908, e o projeto - e talvez a construção - do Instituto Profissional Bento Quirino, finalizado dez anos depois.

O projeto para o Mercado Municipal é um projeto diferenciado, tanto pelo estilema que apresenta quanto pela técnica construtiva: com forte influência da arquitetura muçulmana ${ }^{190}$, o prédio tem estrutura de concreto armado - uma opção até então inédita nas obras campineiras de Ramos $^{191}$. Na parte interna, há um sistema de revestimento que, devido à impermeabilidade do material utilizado, substituía com vantagem os velhos e bons azulejos. $\mathrm{O}$ arco abobadado da entrada e alguns enfeites foram confeccionados artesanalmente. Construído por Augusto Fried $^{192}$, sua planta retangular foi desenvolvida em três naves no sentido longitudinal, com iluminação através de aberturas localizadas na altura da linha dos beirais. $O$ uso do concreto era um expediente ainda pioneiro e casou bastante bem com os novos e diferentes tipos de elementos ornamentais aplicados na obra.

\footnotetext{
189 Imagens em preto e branco: Coleção fotos avulsas CMU.

190 PRÉDIO foi quase demolido. Diário do Povo, Campinas, 14 jul. 1982.

191 MERCADÃO todo remodelado será entregue ao público no dia 20. Correio popular, Campinas, 07 de julho de 1973.

192 CONDEPACC: Relatório de estudo de tombamento, 1972, p. 29.
} 

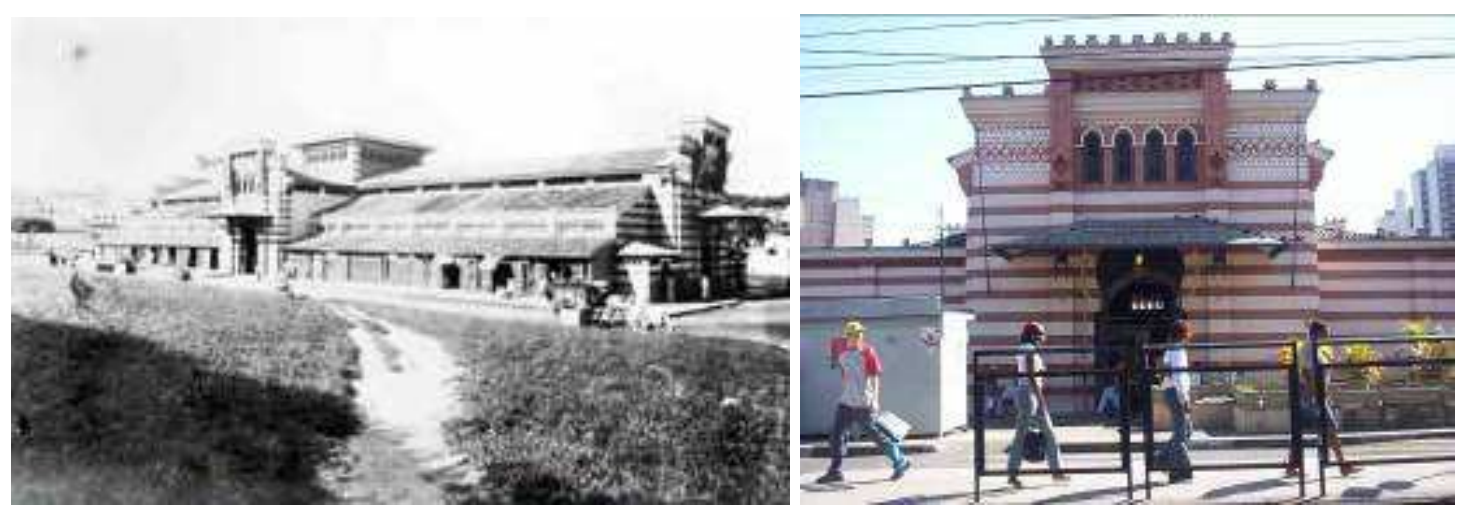

Figura 32: Foto recente de uma das fachadas do mercado ${ }^{193}$

Em 1918, Ramos projetou a sua última obra na cidade, o Instituto Profissional Bento Quirino ${ }^{194}$.

Nesse ano, em São Paulo, todos os programas de necessidades passaram por uma profunda revisão, desde aqueles que orientavam projetos para estabelecimentos comerciais, indústrias, hospitais e cemitérios, como também residências e tudo o mais que se pudesse construir. As dependências deveriam ter dimensões mínimas de 2,00 metros e a área, nunca menor que $8,00 \mathrm{~m}^{2}$. Os porões, surgidos para afastar a umidade dos pisos e proteger o madeiramento do piso com algum pé direito, seriam aceitos só a partir de 2,50 m, contanto que não fossem usados para comércio, oficinas ou dormitórios (Código de 1911). Os pés direitos tiveram suas medidas reduzidas para 3,00m e passaram a ser exigidas venezianas nos dormitórios, para garantir uma constante renovação do ar. As garagens passaram a ser permitidas, dividindo o mesmo telhado da habitação. Tudo passou a ser regulamentado, inclusive os pátios internos e escadas, pretendendo tornar as moradias mais salubres e seguras (Serviço Sanitário de 1917).
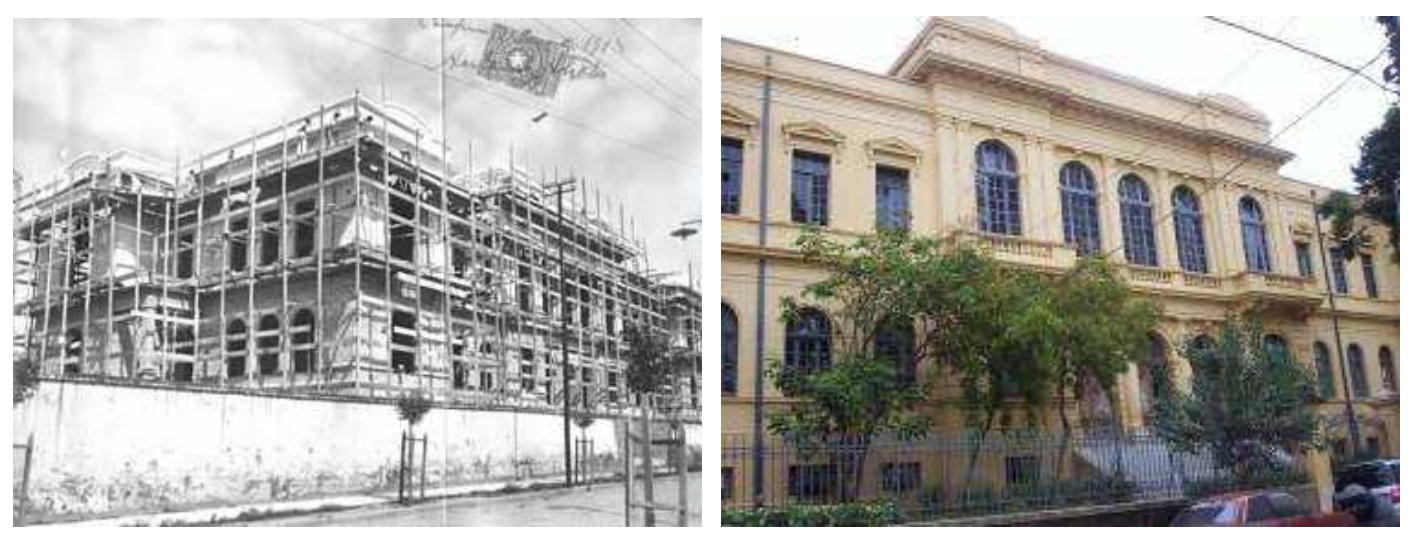

Figura 33: Foto da construção e foto recente da parte central da fachada do Instituto Bento Quirino ${ }^{195}$

\footnotetext{
193 Imagem em preto e branco: Coleção Particular Mํㅡ Luíza Pinto de Moura.

194 MONTEIRO, Ana Maria Reis de Góes. Ramos de Azevedo: Presença e atuação profissional em Campinas: 1879-1886. Dissertação apresentada à Faculdade de Arquitetura e Urbanismo da PUC-Campinas para a obtenção do grau de Mestre, 2000, p. 263.

195 Imagem em preto e branco: Fundo Tribunal de Justiça de Campinas/CMU.
} 
O projeto para o prédio do Instituto Bento Quirino procurou agregar todas as novidades edilícias surgidas com a nova legislação e os novos programas de necessidades. Procura compatibilizar, entretanto, as questões higiênicas regradas pelas nova normativa, monumentalidade e a funcionalidade de um edifício que deveria abrigar uma escola nos moldes do Liceu de Artes e Ofícios ${ }^{196}$. O prédio apresenta três pavimentos, um deles, um porão utilizável, com plantas distintas entre si e simétricas em relação ao seu eixo transversal. O movimento da sua elevação principal é dado pela existência de corpos salientes, pequenas sacadas e diferentes modelos de esquadrias. Podemos considerar o Instituto, dentre as obras azevedianas em Campinas, como sendo um dos mais expressivos projetos de Ramos, agregando e condensando toda a experiência profissional que havia adquirido ao longo de quase quarenta anos de atividade profissional.

Antes da realização dessas últimas obras campineiras, o modus operandi de Ramos de Azevedo já estava bem estabelecido. Seu escritório técnico, reestruturado em 1906, contava com uma grande equipe de profissionais: engenheiros, arquitetos e artesãos, e um sem número de clientes e fornecedores. A abrangência de nosso estudo não daria conta, é certo, de iluminar todas as intrincadas relações entre o aparato técnico instituído por Ramos de Azevedo e aquele que se erigia no contexto de uma expansão econômica vertiginosa, como aquela experimentada pela cidade e pelo estado de São Paulo. No entanto, seria plausível afirmar que o desenvolvimento do aparato técnico instituído por Ramos apenas alcançou a impressionante capacidade operacional que lhe permitiu realizar tudo o que realizou, porque articulou, a um só tempo: conhecimento técnico especializado, tanto de projeto e construção como de finanças, administração, estrategia política, comércio etc.; agenciamento adequado da força de trabalho, compondo de forma equilibrada capital variável e capital fixo; e a melhor condição material possível, implicando, por vezes, construir as condições de produção do recurso material necessário.

Nos termos desta dissertação, é isso que nos interessa chamar de aparato técnico.

${ }^{196}$ TOMBADA oficialmente a Escola Bento Quirino. Diário do Povo, 27 de outubro de 1984. 


\section{O PROCESSO E A TÉCNICA}

\subsection{Uma sede, um partido arquitetônico novo: a Fazenda Pau d'Alho}

Como vimos desde o começo deste estudo, a ligação do Barão de Anhumas com Ramos de Azevedo era claramente próxima. Embora não haja provas ou indícios do contrato de Ramos para reformar a sede da fazenda, o histórico da Pau d'Alho revela uma estreita relação entre proprietários da fazenda e a família de Ramos: três irmãs suas casaram-se com três filhos dos antigos proprietários. Além disso, o Barão também estivera muito próximo de Ramos quando envolvido com as obras da Catedral Metropolitana, na qual o engenheiro-arquiteto atuara como dirigente de obras na etapa final da sua construção. A única confirmação que se tem sobre o envolvimento de Ramos com as obras de reforma da sede da fazenda é a afirmação do neto do Barão de Anhumas, Carlitos Aranha - quando era o proprietário da fazenda no final dos anos 1940 - à atual proprietária, Marguerite Dutilh, como nos conta sua filha Julie. É importante lembrar que a assinatura da autoria de projetos e construções não era comum naquela época: esse registro só se tornaria corriqueiro a partir da segunda década do século XX. Quanto à data da reforma, como sabemos que o Barão de Anhumas já era proprietário da fazenda em 1885 e pelas notícias que saíram no jornal local neste ano - no qual lemos o relato de que o terreiro de secagem de café já era atijolado -, cremos que a reforma teria terminado nesse mesmo ano.

\subsubsection{Agenciamento do café}

As fazendas que foram se instalando e se estruturando na região campineira ao longo século XIX - assim como as de todo o estado paulista - antecederam o desenvolvimento industrial do núcleo central da cidade, agenciando inúmeros recursos dedicados à produção cafeeira e abrigando diversas edificações e equipamentos que representam uma arquitetura específica, construída para essa finalidade. Localizada em sítio favorável ao plantio de café, na região do Anhumas, pela excelência da terra e de sua adequação para a lavoura de café - a chamada "terra roxa" - e a presença de árvores pau-d'alho (Figura 01) - que são indícios importantes que evidenciam essa fertilidade -, além da proximidade de um curso d'água significativo, a implantação da fazenda Pau d' Alho seguia todos os pré-requisitos necessários para tal finalidade. 
$\mathrm{O}$ agenciamento cafeeiro trouxe um novo partido para esse tipo de instalação rural, ao voltar o conjunto sede, senzala, edifícios para beneficiamento do café (casa de máquinas e tulhas) e edifícios de apoio para o terreiro de café, que estava situado no núcleo central. Tratava-se de uma tipologia de fazenda que começava a se consolidar, em

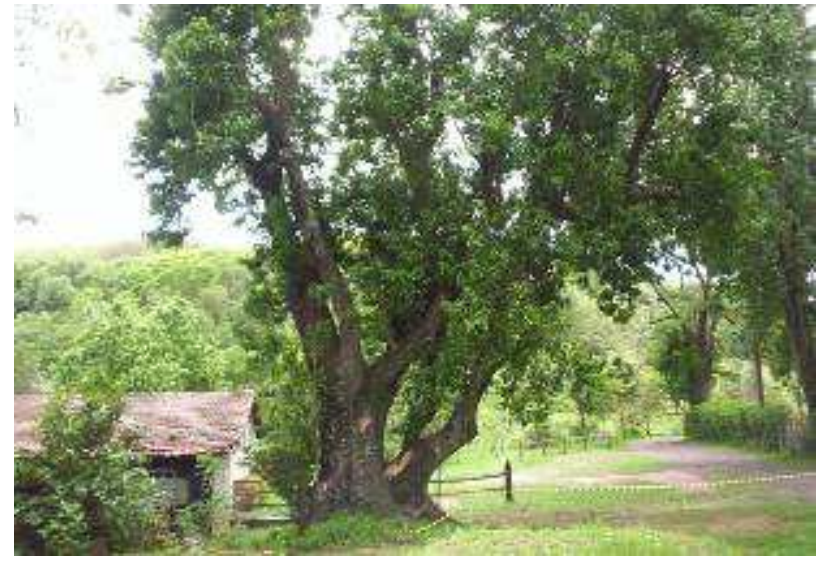

Figura 01: Exemplar de pau-d'Alho na fazenda, um indício de terra boa para o plantio de café substituição àquele perpetrado pelo engenho de cana-de-açúcar. São muito raras as edificações remanescentes do sistema canavieiro na região campineira. De qualquer forma, não seria correto ignorar que, antes da economia cafeeira, foi na economia da cana-de-açúcar que se principiou a instalação de uma base industrial local: ainda que rústica, tal base era composta por edificações e equipamentos, construídos e instalados tanto para atender a fazenda - desde sua subsistência, passando pelo abate de gado e produção de farinha, milho, feijão e até tecido para roupas dos escravos, por exemplo -, quanto para todas as etapas da produção canavieira. Com a crise desse sistema e, como vimos, o enriquecimento advindo com o café, as relações comerciais se intensificaram e a fazenda cafeeira foi se abrindo para novos costumes, principalmente sociais e culturais, com a ascensão de uma nova elite, a dos barões de café.

Não sabemos se a fazenda Pau d' Alho chegou a ser produtora de açúcar. Sabese apenas que o antigo proprietário, Antonio Benedito Cerqueira Leite, foi registrado como um dos 51 senhores de engenho de Campinas em 1851'. Mesmo já sendo registrado como engenho, é possível que ainda não funcionasse como tal, pois a formação de toda a estrutura de produção de um engenho levava muito tempo. Com a morte do dono da sesmaria, o sr. Cerqueira Leite, em 1861, já vimos que a fazenda Pau d'Alho originou-se a partir do fracionamento das terras promovido em 1874, com uma fração da antiga sesmaria. É provável que o agenciamento de café da Pau d'Alho - o qual conhecemos hoje pelos resquícios e imagens antigas - fora construído no início da década de 1860. Contudo, é certo que em 1874, data do fracionamento das terras, as principais edificações do sistema cafeeiro da fazenda Pau d' Alho já tinham sido implantadas. $\mathrm{Na}$ imagem mais antiga da fazenda - uma gravura, feita provavelmente por volta dos anos de 1860, e que hoje pertence ao acervo da fazenda Pau d'Alho e da qual não se conhece a autoria (Figura 02) -, podemos ver que, pela disposição das

\footnotetext{
1 ZAKIA, Silvia Palazzi. Fazenda Pau d' Alho. Pesquisa histórica - arquiteura. Campinas, 2008, p. 3.
} 
edificações, a composição refere-se ao momento inicial da implantação do sistema cafeeiro - ainda que claramente influenciado pelo sistema canavieiro, com as construções simplórias e rústicas que lhe são características. Na gravura, podemos compor essa tipologia: uma sede comprida à esquerda, ladeada por um jardim e com o pomar atrás da residência; ao centro do conjunto, o terreiro; numa extremidade da sede, fica o acesso à senzala, que se articulava em quadra, uma solução típica da região; e, no canto esquerdo da imagem, as edificações para o beneficiamento do café. No primeiro plano, vemos o estábulo, próximo ao rio e, nos fundos, em terreno alto e íngreme, vemos o cafezal. Ali o terreiro de café se destaca no centro do conjunto.

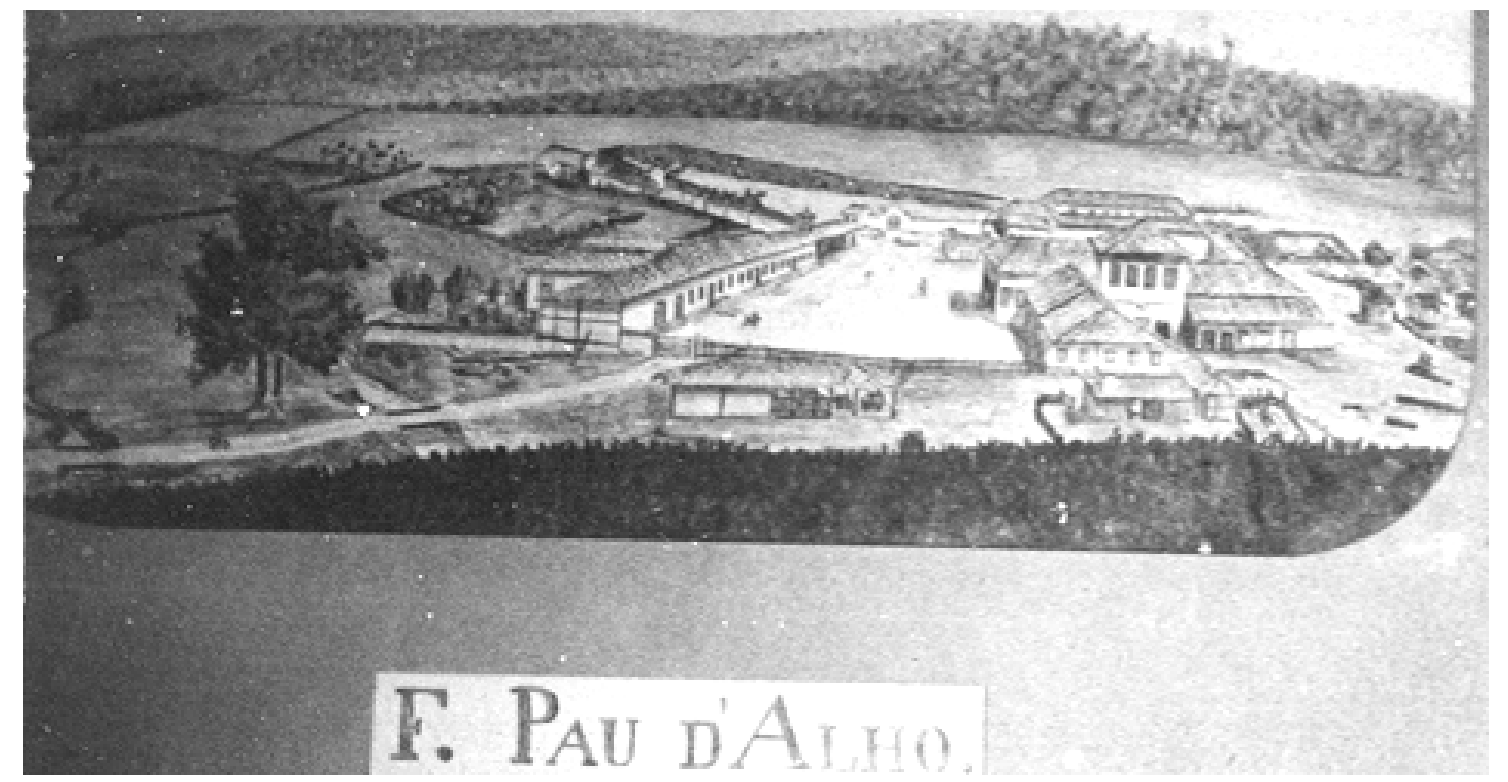

Figura 02: A imagem mais antiga da fazenda Pau d'Alho, indicando o agenciamento da produção cafeeira ${ }^{2}$

A partir dessa imagem, fizemos uma ilustração da implantação da fazenda naquela época, conforme exposto na Figura 03. Silvia Zakia, autora do estudo histórico no qual foi baseado o tombamento da fazenda, levanta três hipóteses para o conjunto arquitetônico $^{3}$, referindo-se a três períodos importantes da fazenda no auge cafeeiro, após a reforma de Ramos: o primeiro, em que vemos fotos com o terreiro próximo à sede; o segundo período, apresentando o terreiro mais afastado da sede; e o terceiro, no qual não aparece mais o estábulo e, no lugar do terreiro, encontra-se um grande jardim frontal. O desenho de implantação que aqui apresentamos aproxima-se do croqui de

\footnotetext{
${ }^{2}$ Gravura cedida por Julie Dutilh. As imagens antigas referentes à fazenda Pau d'Alho nessa dissertação apresentadas foram cedidas pela atual proprietária, Julie Dutilh, a quem agradecemos imensamente pela contribuição.

${ }^{3}$ Idem, p. 27.
} 
Zakia e refere-se à primeira reconstituição hipotética do conjunto, em período mais próximo da data da reforma - que é o objeto deste estudo ${ }^{4}$.

Já em 1885, ficamos sabendo, pela notícia de jornal relatada por Pupo ${ }^{5}$, que a fazenda, pertencente ao então Comendador Manuel Aranha, dispunha de máquina de benefício de café acionada a água e terreiros atijolados. Como vimos, é provável que nesse ano tivesse sido concluída a reforma da sede: primeiro, porque sabemos que, na época da reforma, o terreiro já estaria sendo atijolado; segundo, porque a reforma não apenas se estendeu à edificação da sede, mas também ao depósito ao lado da sede e à casa do administrador que, erigido com técnicas construtivas mais antigas, ganhou apliques ornamentais novos. Como é possível verificar na imagem reproduzida na Figura 02, o terreiro ainda não era atijolado. Pela amplitude da reforma, podemos inferir que o terreiro ganhou o piso atijolado no mesmo período da reforma das outras edificações.

\footnotetext{
${ }^{4}$ Os croquis originais das três reconstituições hipotéticas feitos por Zakia podem ser conferidos no Anexo 4 , Imagens 1 a 3.

5 PUPO, Celso Maria de Mello. Campinas, município no Império: fundação e constituição, usos familiares, a morada, sesmarias, engenhos e fazendas. São Paulo, Impr. Oficial, 1983, p. 186.
} 


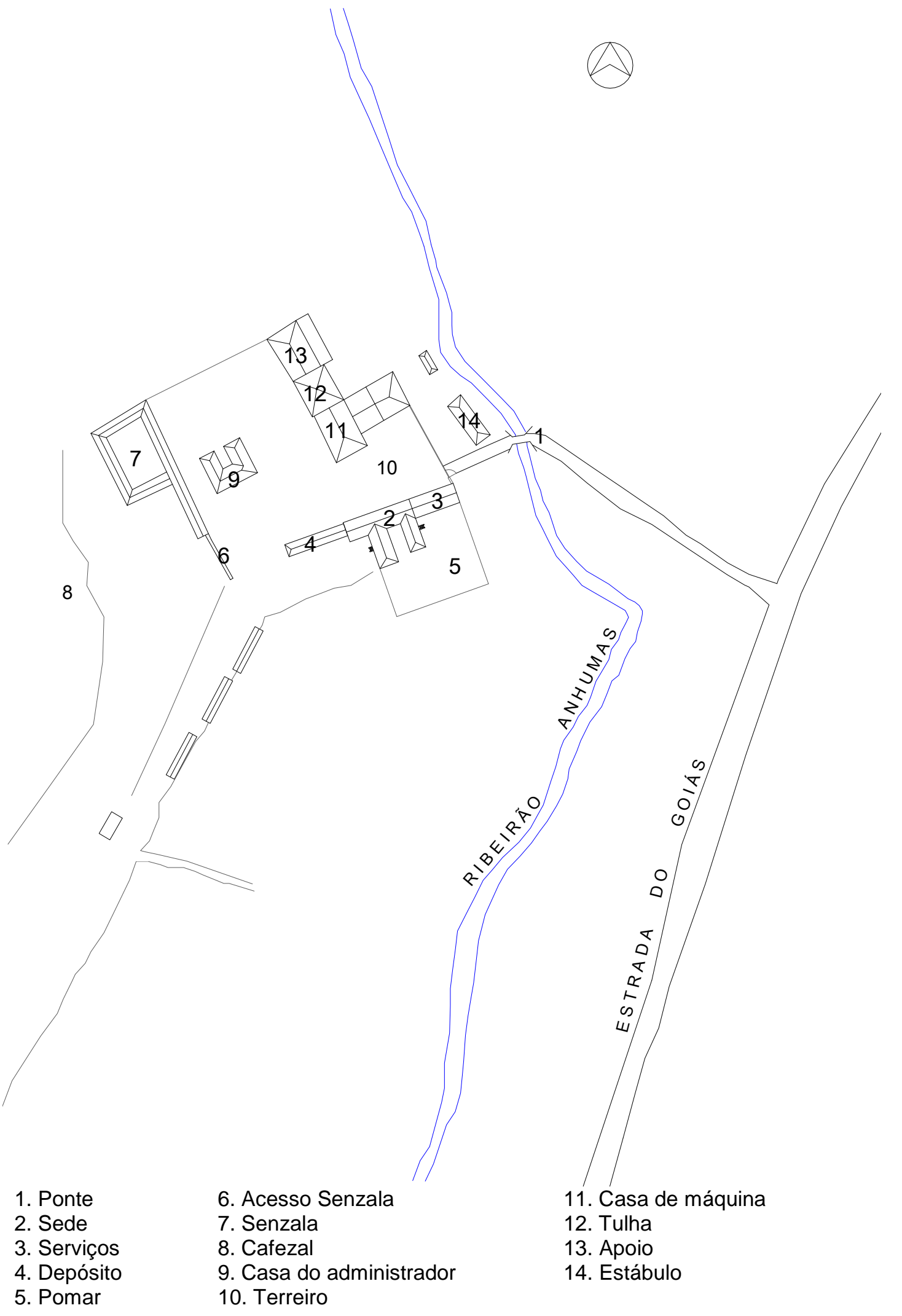

Figura 03: Desenho hipotético do momento da implantação do sistema cafeeiro na fazenda Pau d'Alho, em 1874 , data do fracionamento das terras que originou a fazenda ${ }^{6}$

6 Levantamento realizado pela autora baseado no levantamento existente de 1947. Os levantamentos gráficos apresentados nessa dissertação foram levantados pela autora nos meses de setembro e outubro de 2009. 
O terreiro de café, que a princípio era de terra batida, deveria ser implantado em área quase plana, necessária para a secagem dos grãos. Próximo ao terreiro, e numa parte mais elevada do terreno, situavam-se os lavadores, tanques de água que escoavam por declividade por um sistema de canais. Ainda hoje é possível identificar os canais (Figura 07), agora com partes faltantes e cercados de grama: por eles os grãos percorriam desde a parte posterior ao acesso da senzala (parte mais alta) até a frente da casa do administrador, próximo à casa de máquinas - que não mais existe (provavelmente demolida no início dos anos 1940, dela resta apenas o embasamento de pedra - Figura 08). Depois de lavados, os grãos de café eram levados para o beneficiamento na casa de máquinas e estocados na tulha - também não mais existente, demolida na mesma época em que foi demolida a casa de máquinas.

A casa de máquinas, que abrigava os equipamentos para beneficiamento do café, e a tulha, grande edificação onde era armazenado o café em coco, geralmente eram contíguas: aqui seguem, portanto, a tradição, aparecendo juntas e, como em muitos casos no interior paulista ${ }^{7}$, com a tulha erigida em dois pavimentos, provavelmente construída inteiramente de tijolos - conforme podemos inferir pela imagem da Figura 05 , equipada com as típicas grandes janelas, exigência imprescindível para a adequada ventilação do interior. Já no caso da senzala e da casa do administrador - que ainda se encontram preservados -, a construção é de taipa de pilão. $\mathrm{Na}$ imagem ainda aparecem outras edificações térreas acopladas, provavelmente destinadas também ao beneficiamento do café ou à instalação de oficinas de serralheria e carpintaria, como ocorreu em algumas fazendas da região - essas instalações situam-se próximas à tulha. Como não existem mais, pouco podemos falar sobre elas.

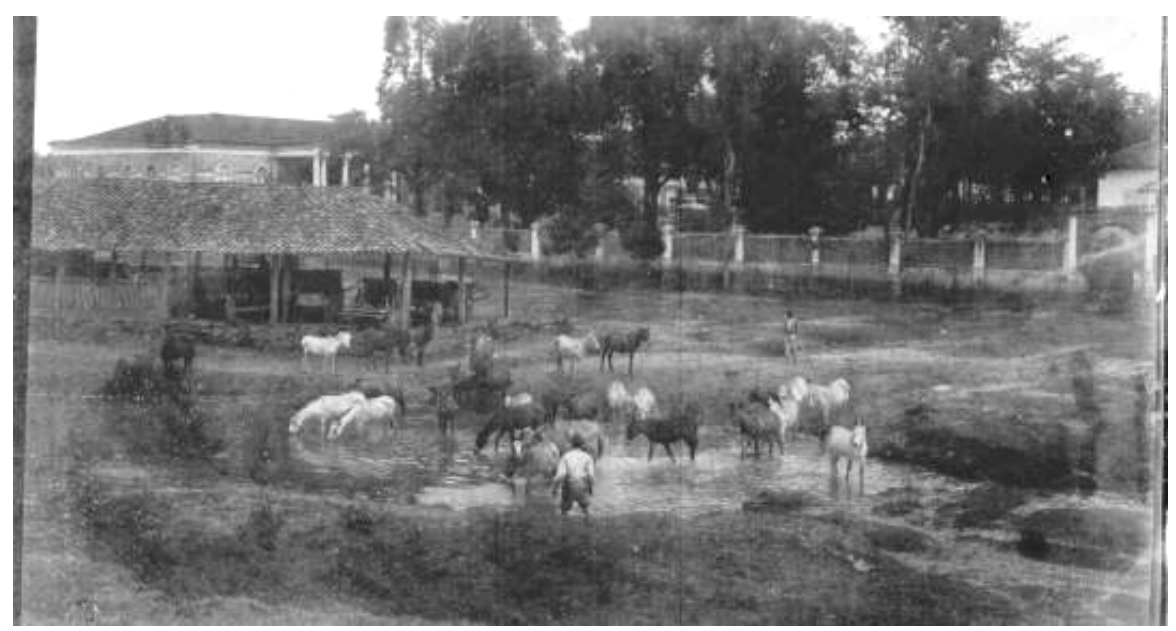

Figura 04: Estábulo e bebedouro próximo ao rio, início do século XX

\footnotetext{
${ }^{7}$ BENINCASA, Vladimir. Velhas Fazendas: Arquitetura e Cotidiano nos campos de Araraquara 1830 -1930. São Carlos: EdUFSCar, 2003, p 150.
} 


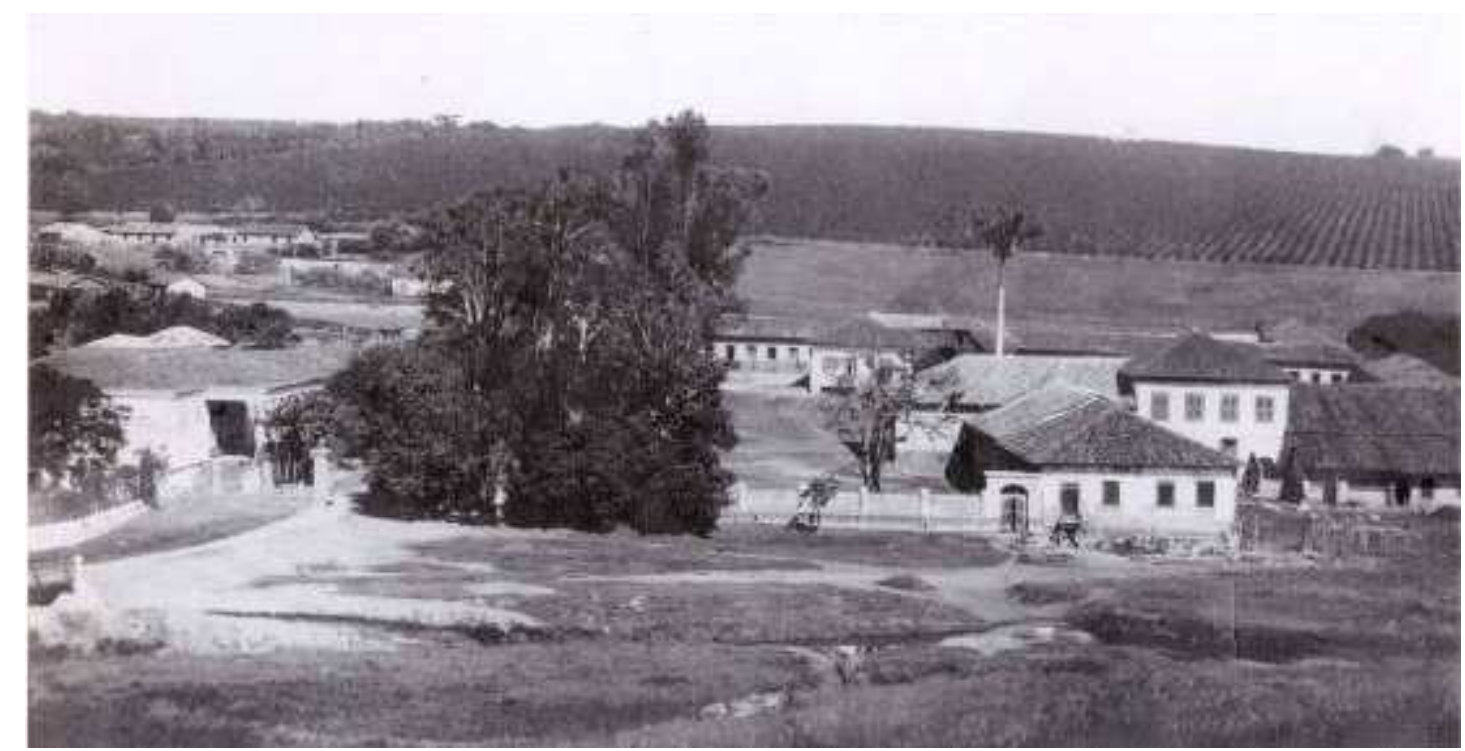

Figura 05: Casa de máquinas e tulha à direita, parcialmente preservados no início do século XX

Sabe-se que a fazenda, antes de ser fracionada, contava também com uma olaria, provavelmente onde estava situada a vizinha fazenda Anhumas, depois da divisão das terras. A olaria, distando aproximadamente $1,5 \mathrm{~km}$ da sede da Pau d'Alho, contava com uma infraestrutura capaz de atender toda a região, com enxugadouro (grandes áreas livres para secagem dos tijolos), extensos galpões de mais de $100 \mathrm{~m}$ de comprimento, um forno e quatro altas chaminés enfileiradas, de aproximadamente 20 metros, e uma outra chaminé um pouco mais baixa do outro lado do galpão (Figuras 06, 09 e 10). Acreditamos que ali foram produzidos os tijolos da reforma da sede da Pau d'Alho, com a inscrição "BA" na cunha dos tijolos, em referência ao Barão de Anhumas, além de outros tijolos prensados comuns. O funcionamento da produção de tijolos numa olaria naquela época será analisado um pouco mais adiante, no item referente à construção com tijolos. Em péssimo estado, os galpões já se encontram em ruínas, restando apenas as chaminés mais ou menos preservadas. Contudo, segundo moradores da região, o que restou já está com os dias contados, prestes a ser demolido, para atender a um projeto com área de lazer para os moradores das redondezas.

Pelo tamanho da fazenda e porte de sua capacidade de produção, é possível que outras tantas edificações tenham existido para atendê-la, inclusive para abrigar o grande número de escravos de propriedade do Barão, edificações que poderiam ser pequenas fábricas de sabão e vela, ou de farinha e produtos farmacêuticos para consumo local. De qualquer forma, é desse conjunto de instalações voltadas para a produção cafeeira composta pelo terreiro, lavadores, casa de máquinas, tulhas e oficinas - que irão surgir as primeiras bases industriais que sustentarão a expansão econômica da região: os modernos equipamentos importados; a modernização dos sistemas construtivo 
empregados nas construções; as novas dinâmicas dispostas pela força de trabalho, com o fim da escravidão e a presença do imigrante; novas modalidades de relações comerciais; enfim, uma conjuntura completamente nova que exigiu um outro aparelhamento e conhecimento técnico para lidar com a produção e reprodução das condições de existência que viriam alterar radicalmente o modo de vida vigente. 


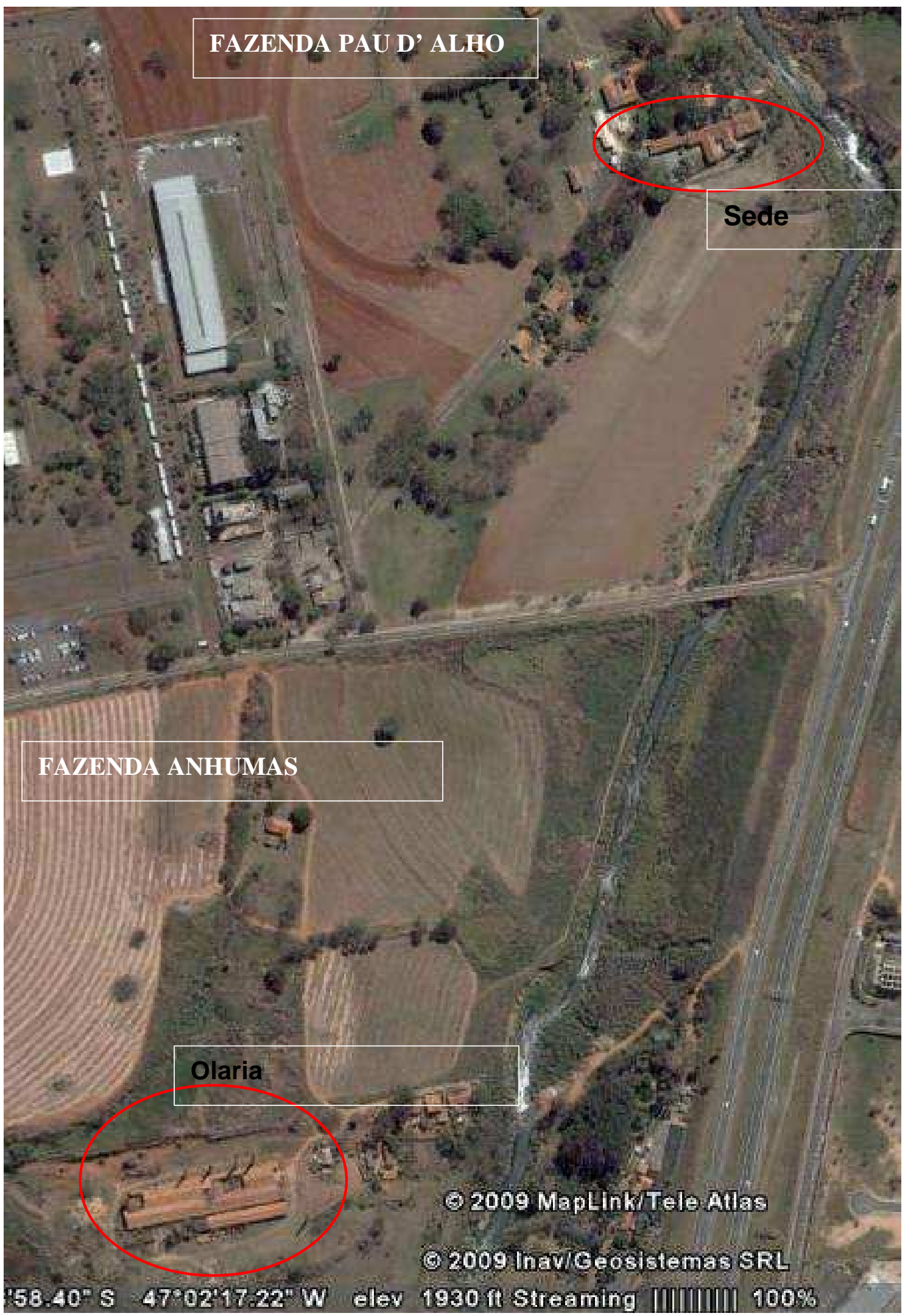

Figura 06: Foto aérea, de 2005, em aparece a sede da fazenda Pau d’Alho, ao norte, e da olaria ao sul, já dentro da área da Fazenda Anhumas (em círculos). 

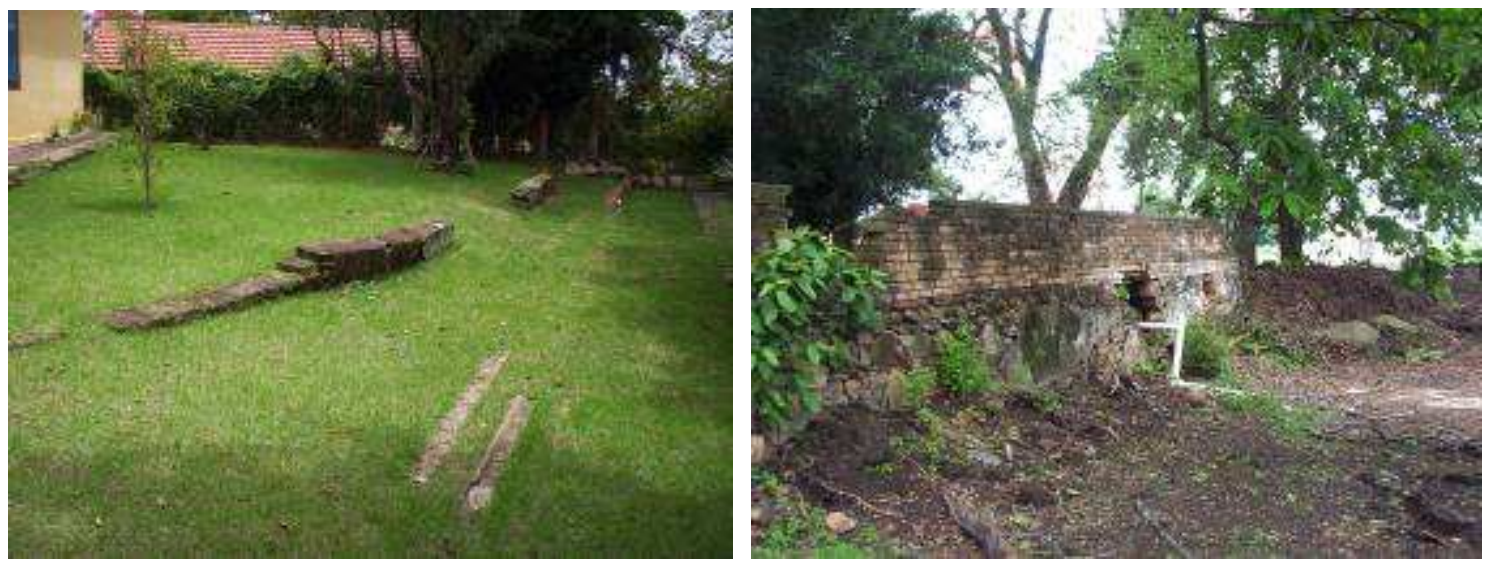

Figuras 07 e 08: Resquícios dos canais para escoamento dos grãos após lavagem do café, próximo à casa do administrador, e do embasamento de pedra da casa de máquinas, com as primeiras fiadas de tijolo
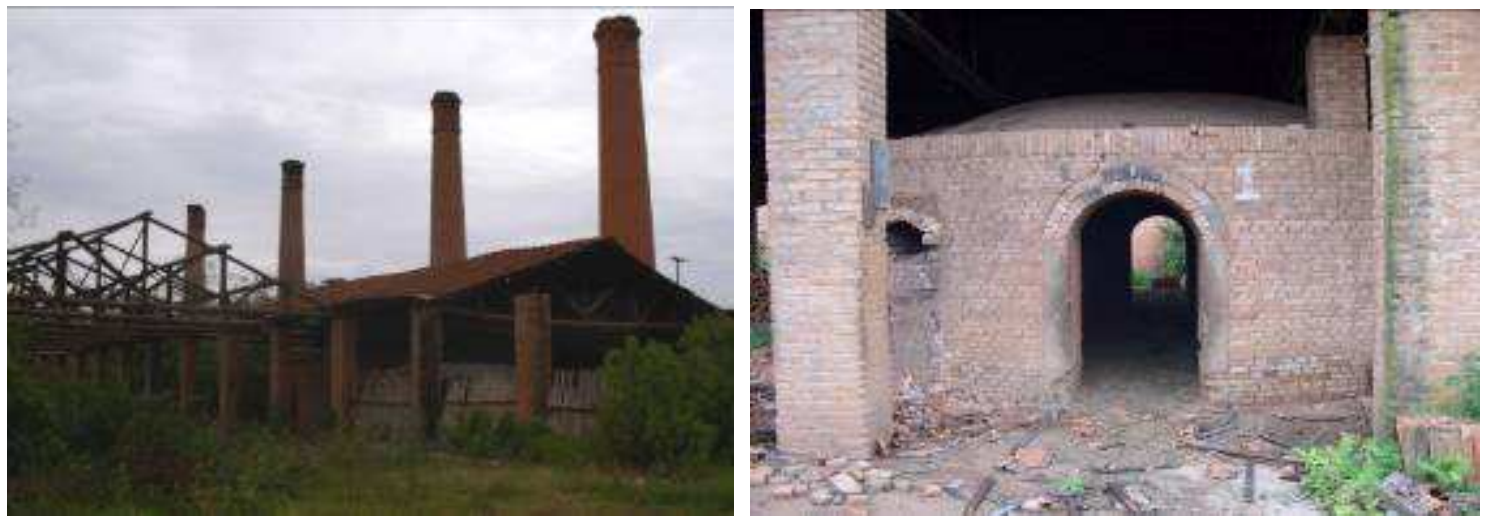

Figura 09 e 10: Situação atual dos fornos da olaria, onde possivelmente foram produzidos os tijolos utilizados na reforma da sede da fazenda Pau d'Alho

\subsubsection{A sede}

A sede da fazenda Pau d' Alho, como aparece na imagem da Figura 02, foi implantada em terreno à meia encosta e construída com estrutura de madeira aparente a chamada "gaiola", uma antiga técnica utilizada pelos mineiros -, com fundação de pedra e vedação de taipa de mão. Acreditamos que seja uma construção do início da década de 1860, contemporânea ao início da produção cafeeira, ainda no tempo em que a fazenda era propriedade de Antonio Benedito Cerqueira.

Já nas fotos do início do século XX, datadas de $1909^{8}$, é visível a grande reforma promovida na sede, em que toda a vedação foi encamisada com tijolos, revestida e adereçada com apliques e ornamentos neoclássicos. Literalmente, é como se a velha casa de fazenda colonial vestisse roupa nova, já com os adereços dos novos tempos e de sua nova condição sócio-econômica.

Devemos lembrar, entretanto, que esse processo de encamisamento em alvenaria

\footnotetext{
${ }^{8}$ Ver uma parte do conjunto após reforma de Ramos de Azevedo (1885) na Imagem 4 do Anexo 4.
} 
de tijolos foi bastante difundido na região campineira: tratava-se de um recurso 'modernizante', adotado na reforma de muitas sedes de fazendas da região, que então passariam a exibir feições ecléticas, escondendo as velhas construções erigidas no esquema citado acima ${ }^{9}$. Como vimos, esse sistema também foi utilizado na finalização da fachada da Catedral Metropolitana de Campinas, ainda no período em que as obras eram dirigidas por Bonini, antes de passar o cargo a Ramos de Azevedo, que deu continuidade aos trabalhos - e que, provavelmente, aprendeu rapidamente como resolver o problema do encamisamento de paredes de taipa com alvenarias de tijolos.

Com a reforma da sede da fazenda Pau d' Alho, a construção na extremidade esquerda, com duas grandes entradas - destinadas provavelmente aos serviços masculinos (consertos em geral) - foi ampliada: a implantação à meia encosta foi aproveitada e, com o acréscimo de um alpendre e um porão habitável - para onde foi transferida a antiga área de serviços -, tornou-se uma edificação assobradada, passando a ser chamada de "sede alta, diferenciando-se da construção à direita, que se manteve no mesmo nível, térrea, que passou a ser chamada de "sede baixa".

Quanto a desenhos e plantas da sede da fazenda Pau d'Alho - que poderiam auxiliar, porventura, na recuperação da cronologia dos eventos -, são conhecidas apenas duas.

A primeira - uma planta com perspectiva, baseada na gravura antiga que conhecemos - foi elaborada pelo arquiteto Antonio Luis Dias de Andrade, o Professor Janjão, para o levantamento preliminar das fazendas campineiras realizado pelo Condephaat em 1973 (Figura 12) ${ }^{10}$. Nessa planta, o arquiteto destacou, em um círculo, a reforma numa parte da sede, ampliada posteriormente, a qual atribuímos a Ramos de Azevedo. Não sabemos se a planta desenhada por Dias de Andrade foi baseada em outra original, mas é possível afirmar que não está completa, talvez devido à interrupção do estudo, pelo Condephaat, da fazenda Pau d'Alho para se dedicarem a outras fazendas.

Outra planta que se tem conhecimento foi publicada pelos alunos de uma disciplina de especialização de restauro da PUCCAMP, que promoveu o estudo das fazendas campineiras. O estudo da fazenda Pau d'Alho foi baseado na planta de Janjão e seus registros gráficos foram conferidos in loco.

Como estes estudos - tanto o de Janjão como o dos alunos do curso da PUC não registravam as dimensões dos cômodos, vãos e espessuras, realizamos um outro

\footnotetext{
${ }^{9}$ Estas sedes são retratadas em várias aquarelas de José Castro Mendes. Para consultá-las - além de uma relação de fazendas campineiras, tipos de sede e vida cotidiana - ver: PUPO, Celso Maria de Mello. Campinas, município no Império: fundação e constituição, usos familiares, a morada, sesmarias, engenhos e fazendas. São Paulo, Impr. Oficial, 1983.

${ }^{10}$ ANDRADE, A. L. D. Levantamento preliminar das fazendas. São Paulo, Condephaat, 1973.
} 
levantamento, in loco, e constatamos algumas diferenças significativas, relevantes para a compreensão do processo de reforma da sede. Essa nova planta é apresentada no final deste capítulo, nas Figuras 20 e 24 (cuja ampliação compõe o Anexo 3).

$\mathrm{Na}$ construção à direita da sede (que inclui tanto a sede baixa como a alta) está o que chamamos de "depósito", implantado no mesmo embasamento e, provavelmente, construído na mesma época de construção da sede. Era um anexo independente, abrigando três cômodos, ligados apenas externamente entre si, com somente uma ligação interna com a própria sede. O cômodo do meio, com $15,15 \times 5,85$ m poderia ser mais um compartimento de serviço, para armazenagem, ou mesmo apoio para os cavalos utilizados no transporte a charrete ${ }^{11}$. Um dos cômodos, na extremidade do anexo - o único com janela cercada com grades aparentes - acredita-se ser a antiga cadeia dos escravos. Com área pequena, medindo 5,85X5,95m, seu acesso encontra-se muito próximo ao portão que liga à senzala. A configuração isola, contudo, a cadeia da área de convívio dos escravos.

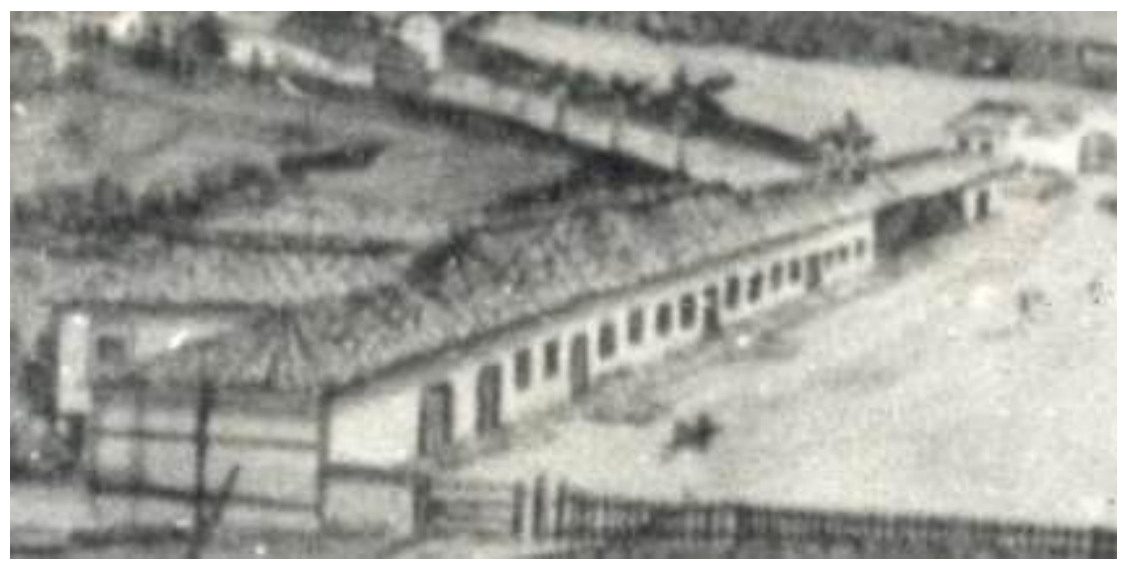

Figura 11: Ampliação da gravura, destacando a antiga sede antes da reforma e, ao fundo, o depósito

O conjunto de edificações que configurava a sede, antes da reforma de Ramos, era acessada por três entradas: portas médias, intercaladas por janelas, todas essas aberturas encimadas por vergas retas (Figura 11). A entrada principal da sede, antes da reforma - quando o alpendre ainda não existia -, devia ser feita pela porta média da esquerda, que dava acesso ao grande salão. Essa área - que citamos como sendo a sede baixa - não está pintada de azul na planta em "U" desenhada por Janjão (Figura 12). Quanto à área que acreditamos ser destinada a serviços masculinos, acreditamos que não era relacionada com a moradia do senhor da fazenda, nem que tivesse acesso interno a ela. A a sede alta, destacada em azul na planta de Janjão, passou a funcionar como uma continuação da sede baixa, interligada a esta por três acessos internos com escada. As duas grandes entradas deram lugar a uma única nova entrada externa - cujo

\footnotetext{
${ }^{11}$ Ver fotos de charretes, com as senhoras nos jardins em frente à sede na Imagem 5 do Anexo 4.
} 
acesso passou a se dar pelo novo alpendre. Esse acesso era feito por uma única porta maior, acompanhada por seis janelas, agora com vãos mais estreitos.

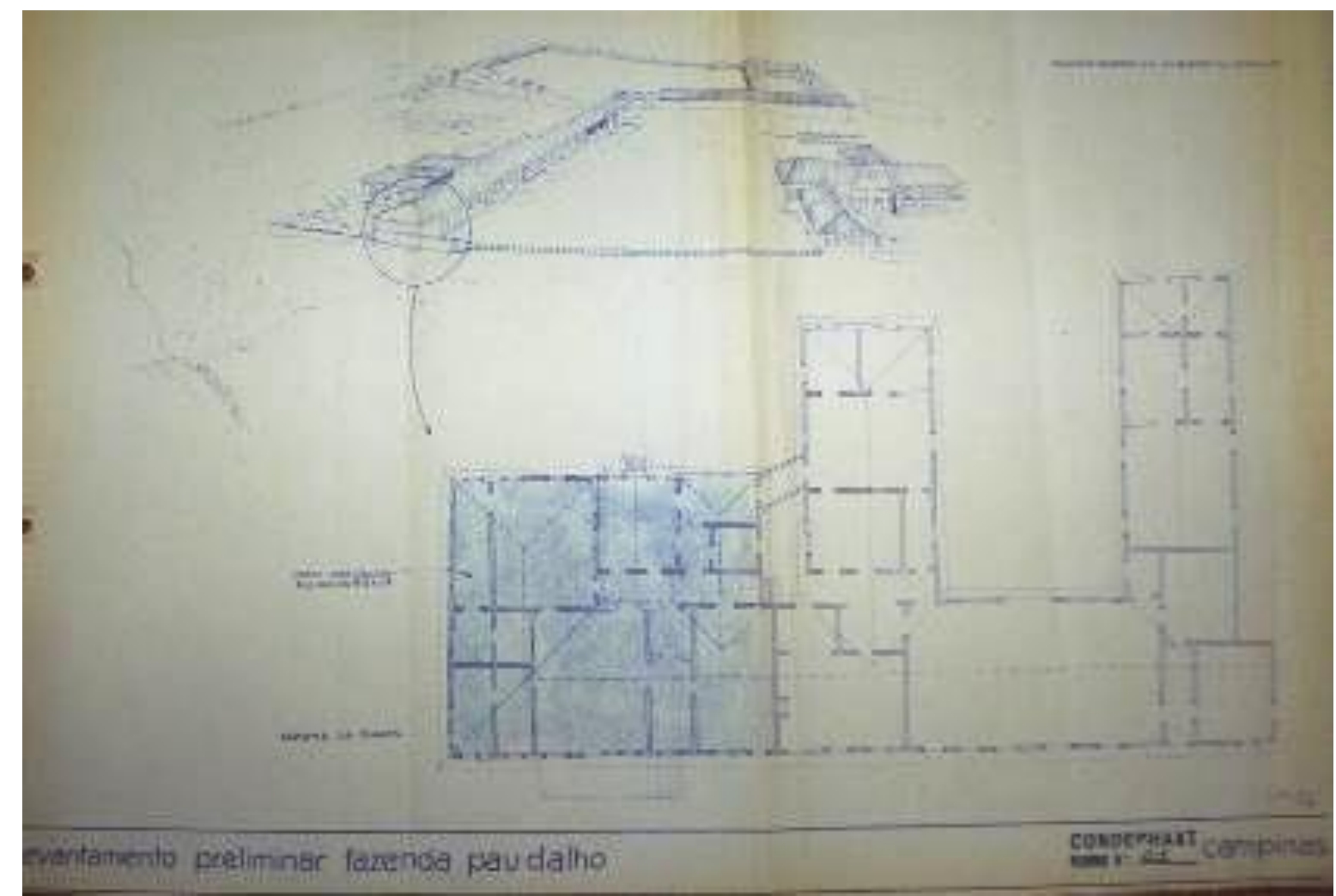

Figura 12: Desenho feito pelo arquiteto Antonio Luis D. Andrade (Janjão) para levantamento do Condephaat, no qual destaca no círculo a área da reforma, $1973^{12}$

${ }^{12}$ Foto do levantamento feito por Janjão tirada pela autora na sede do Condephaa em setembro 2007. 


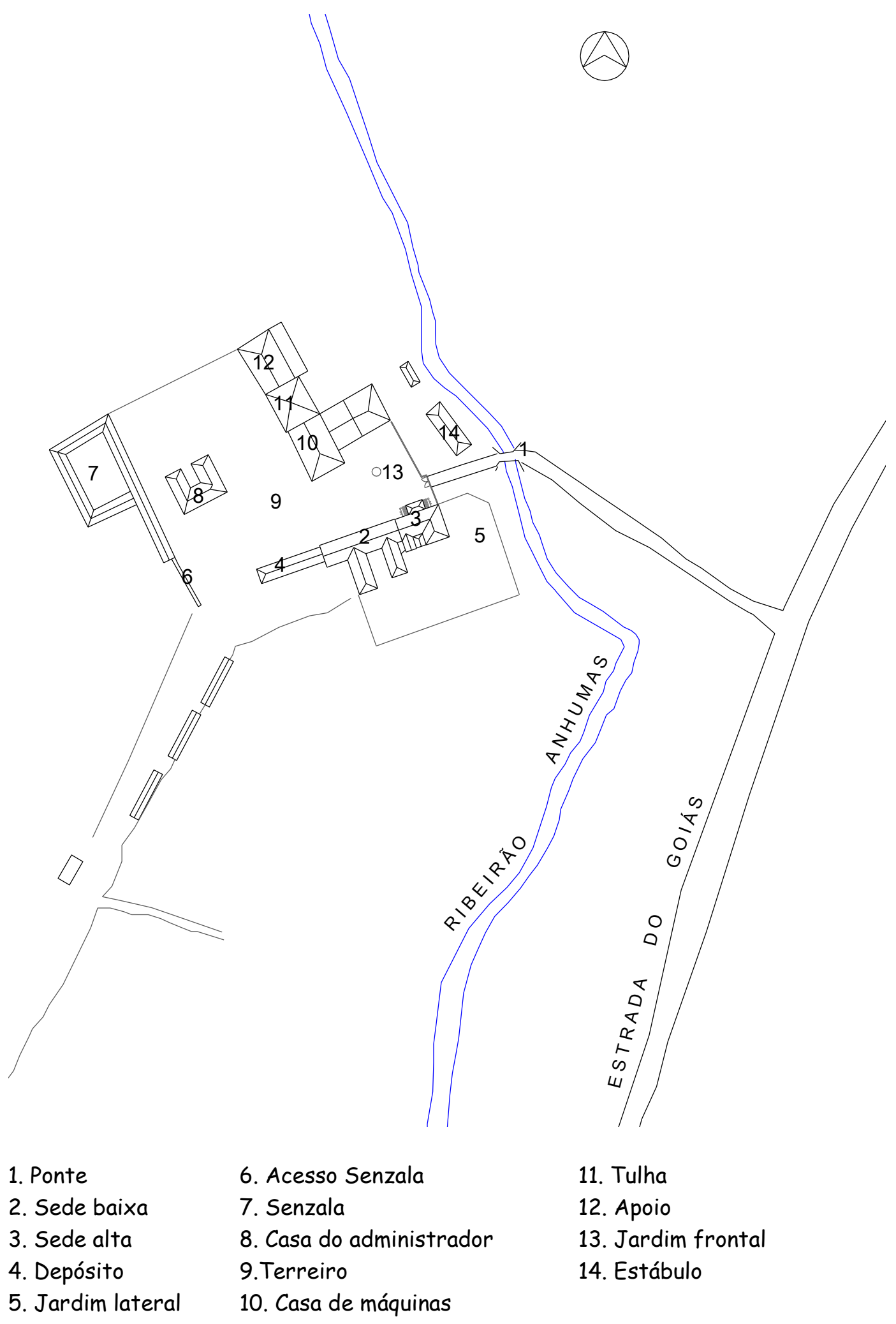

Figura 13: Desenho hipotético da implantação da sede após reforma de Ramos de Azevedo em 1885 
Para melhor compreendermos o que ocorreu ali no final do século XIX - as mudanças de técnicas construtivas e a atuação de Ramos de Azevedo naquela reforma precisamos entender como se estruturava a tipologia por sobre a qual se justapôs o novo padrão. As sedes dos antigos engenhos, construídos com técnicas construtivas muito simples e rudimentares, preocupavam-se em assegurar, pelo menos, um bom funcionamento, pouco importando alguma aspiração estética mais elaborada: possuíam alpendres profundos, proporcionais à altura, para proteger do sol, tornando o ambiente agradável e fresco, de onde o fazendeiro tinha visão privilegiada da fazenda. $\mathrm{Na} \mathrm{Pau}$ d'Alho, contudo, vemos que a sede baixa não tinha alpendre e que sua entrada abria-se direto para o grande salão, de quase dez metros de largura - o que não era muito comum na região, apesar de constarem registros dessa ocorrência nos engenhos mais antigos, onde aconteciam as grandes festas e bailes.

Com implantação em "U" - um desenho ainda próximo das tradicionais implantações em "L" -, a sede baixa da Pau d'Alho, assim como muitas outras sedes de café da região, herdaram a lógica de distribuição interna da casa do engenho: as salas sociais na frente, alcovas e quartos de dormir no parte central, aos fundos a cozinha e instalações de apoio (refeições e despensas) e, numa das pernas do "U", ao nível do solo, compartimentos de serviços. Aqui, assim como nas antigas plantas em "L", os serviços ficavam na parte alongada, dando para o pomar nos fundos. Na parte frontal e lateral situavam-se os jardins, grandes e planejados, novidade que acompanhava o requinte cafeeiro: provavelmente implantado no início do século $X X$ - quando os grandes jardins entraram na moda-, o jardim frontal também abrigava um poço.

Entrando no salão, à esquerda, ficava a capela interna, que consistia em um oratório particular para a família - uma funcionalidade doméstica comum nas sedes de engenhos mais antigos que persistiu até meados do século XIX na região campineira, segundo Pupo ${ }^{13}$. Não há resquícios do altar na Pau d'Alho de hoje, uma pequena área de 10,00m2, sucedida de um cômodo maior de aproximadamente $35,00 \mathrm{~m} 2$, que seria por onde a sede baixa ligar-se-ia com a ala nova reformada por Ramos: à esquerda, no fundo do salão, esse cômodo dava acesso à porta externa da esquerda. São diversos os relatos das cerimônias de casamentos e batizados que ocorriam nessas pequenas capelas, quando o convívio familiar era ainda muito limitado à fazenda, isolada - tanto geográfica como socialmente falando -, antes da popularização do café na região. $\mathrm{A}$ proximidade com o salão era necessária para facilitar o acesso às festas. Pupo também relata que era comum emprestarem as capelas para casamentos de outros que não os seus moradores.

13 PUPO, Celso Maria de Mello. Campinas, município no Império: fundação e constituição, usos familiares, a morada, sesmarias, engenhos e fazendas. São Paulo, Impr. Oficial, 1983, p. 68. 
À direita da entrada do salão ficavam alguns compartimentos, provavelmente utilizados como dormitórios: há algumas fotos do início do século $X X^{14}$ que mostram a entrada, vista da fachada, onde aparece uma parede interna que hoje não existe mais, comprovando que havia pelo menos um dormitório dentro dessa área - uma vez que, através da abertura, é possível identificar uma veneziana na foto, diferente de outras aberturas sem venezianas na área contígua ao salão. Esse cômodo, após a reforma de Ramos, pelas fotos de 1909, poderia ser um dormitório para as amas, filhas de escravos, ou ainda ex-escravas, que cuidavam dos filhos pequenos dos fazendeiros. As paredes que ainda hoje têm uma pequena parte conservada, em forma de três pilares alinhados à parede, seguindo a viga existente - provavelmente eram de taipa de mão, levando-se em conta os indícios explicitados pelos furos na face inferior da tesoura, indicando por onde passariam os roliços da gaiola da taipa de mão.

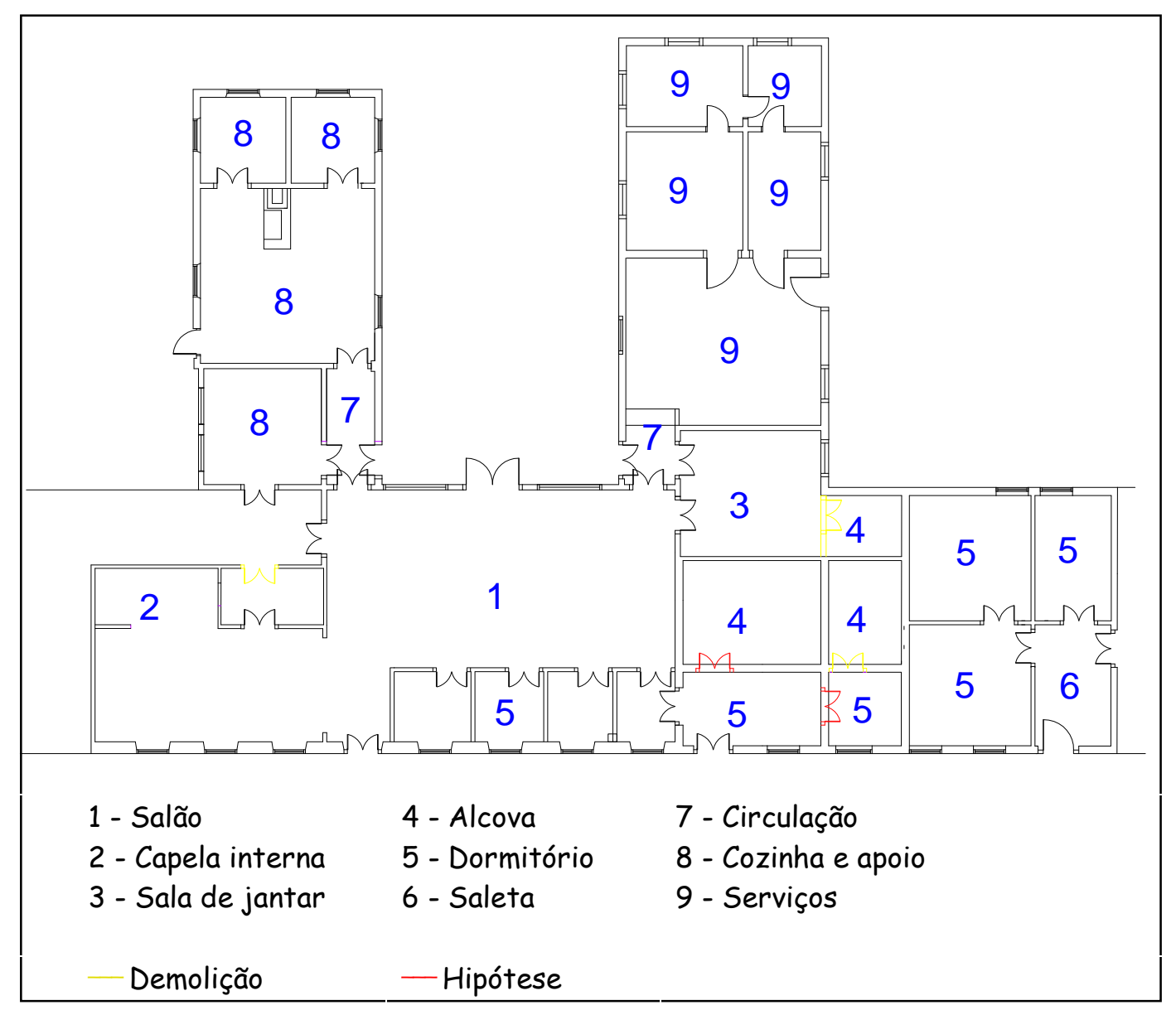

Figura 14: Planta hipotética da sede baixa em 1885

\footnotetext{
${ }^{14}$ Observar parede interna, vista através da porta externa da sede baixa, nas gravuras da Imagem 6 do Anexo 4.
} 

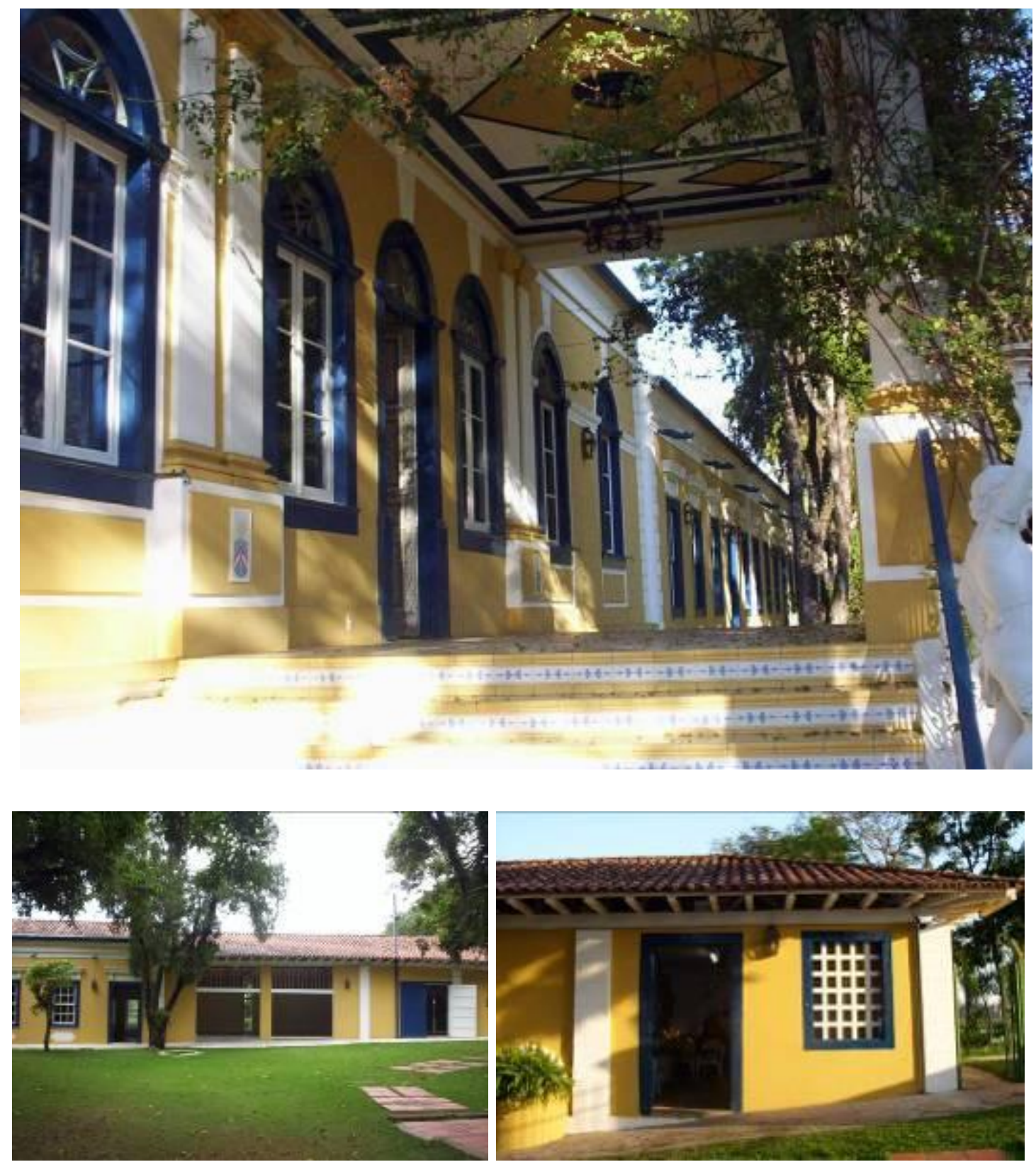

Figura 15: Vista do embasamento da sede: sede alta em primeiro plano, sede baixa e depósito ao fundo; Figura 16: Vista do depósito; Figura 17: Vista da cadeia dos escravos, ao lado do depósito

À direita do salão situavam-se a sala de jantar, a sala íntima, dormitórios e alcovas. Do salão, nesse lado, abriam-se dois acessos: um para a sala de jantar ligada a uma alcova - provavelmente para hóspedes, por estar ligada à sala de jantar - e uma outra porta, que acessava um dormitório - este também tinha acesso externo, por uma das portas principais da sede baixa. Tal dormitório era ligado a um pequeno cômodo e uma alcova (dormitório sem janelas), e o outro dormitório era ligado à outra alcova. $\mathrm{A}$ ligação do dormitório com as duas alcovas são suposições nossas, conforme o costume local. Procuramos evidenciar essa suposição, realçando, na planta da Figura 14, as portas em cor vermelha e a ligação entre as alcovas em cor amarela - que, segundo a atual proprietária da fazenda, ainda existia até 2004. A sala de jantar, além da ligação 
com o salão, ligava-se também a um pequeno corredor que daria para a área de serviços.

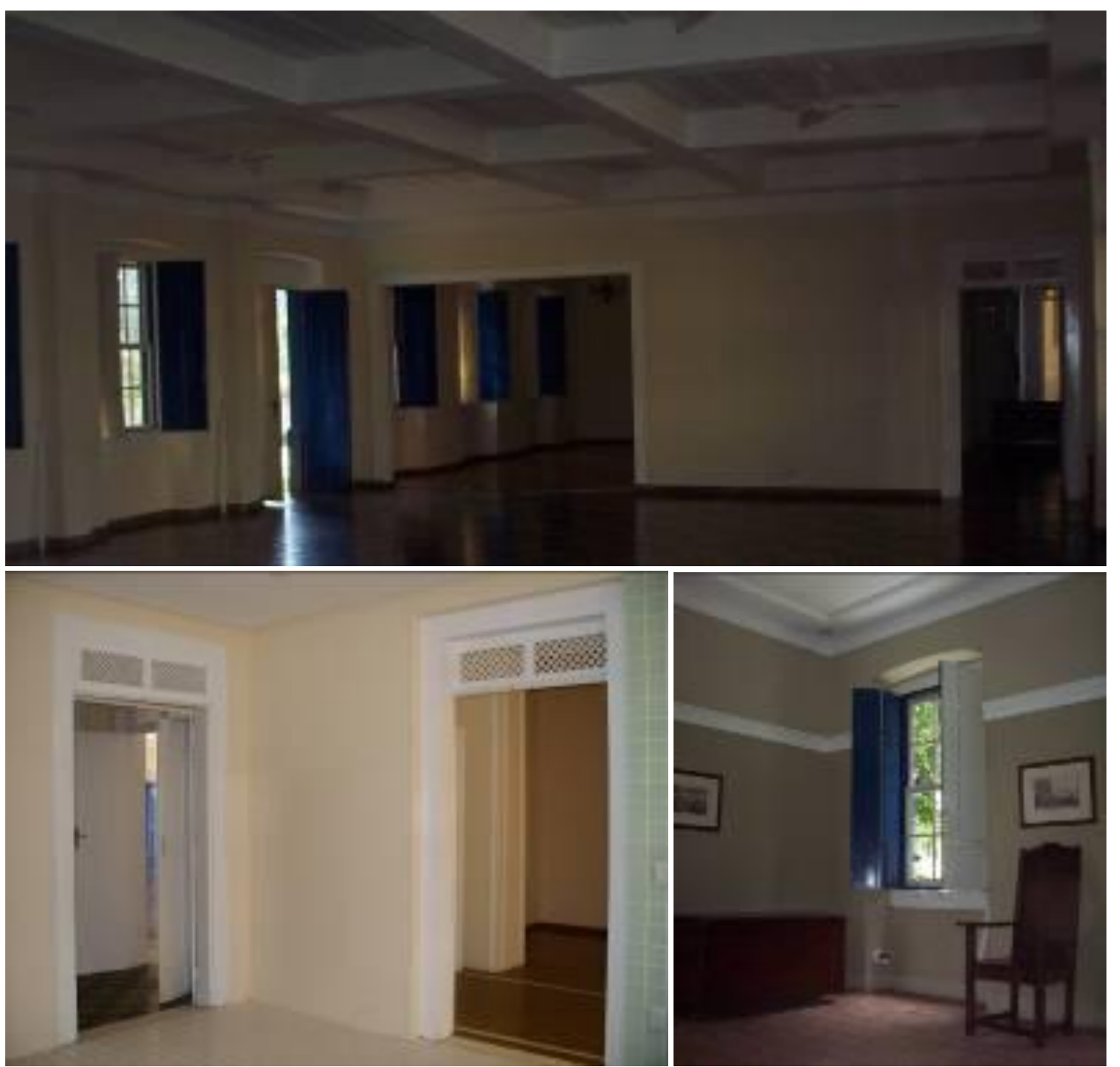

Figuras 17: vista do salão para a antiga capela; Figura 18: portas dos cômodos que antecedem a cozinha; Figura 19: dormitório do bloco com acesso externo

Ao lado desse bloco de alcovas e dormitórios, havia outro bloco independente com três dormitórios, também com acesso externo, antecedido de uma pequena saleta, que dá para dois dormitórios. Um destes dá para um terceiro dormitório. Da saleta também se tem acesso ao depósito. Os cômodos para dormir totalizam dois dormitórios e três alcovas, uma delas ligadas à sala de jantar, no primeiro bloco; e três dormitórios e uma saleta no outro bloco - o que poderia indicar a presença da família do senhor da fazenda em uma ala e, na outra ala, independente, a presença da família dos filhos do senhor, netos e muitos agregados - uma estratégia sócio-familiar que vem desde a época do açúcar. Os dormitórios, como era o costume, eram providos de camas com cabeceiras ou de armação (apoio para as cortinas), arcas, baús, cômodas e armários, 
todos de madeira entalhada, além do urinol, geralmente feito de metal ou porcelana. Nos pisos e paredes, os acabamentos eram mais simples: lajotas, paredes caiadas e forro de madeira simples ${ }^{15}$.

No bloco posterior ao salão, capela, dormitórios e saletas, desenvolvem-se dois blocos: as "pernas" da implantação em "U". Nesses blocos ficavam as áreas de serviços: no bloco esquerdo, um cômodo antecedendo a cozinha com fogão e, ao fundo, dois cômodos menores de apoio. O primeiro cômodo deveria ser uma dispensa e era ligado à cozinha pelo corredor que vinha do salão. Os outros compartimentos de apoio, ligados diretamente à cozinha através de portas e generosamente ventilados, deviam ser utilizados para serviços diferenciados, como o preparo de carnes - inclusive o abatimento de animais - e o outro para preparo de refeições com farinha, já que na época esses cômodos eram separados por tipo de serviço. A cozinha era o único cômodo de serviços dessa ala com uma ligação externa, dando para o pomar. Já no bloco direito, outros cômodos eram destinados para outros serviços: um pequeno corredor dava acesso a um grande cômodo, com ligação externa. A partir deste, acessava-se mais dois cômodos, por sua vez interligados a outros dois. Esses cinco cômodos deviam ser usados para serviços de lavanderia e outros serviços de apoio para a fazenda, separados da cozinha ${ }^{16}$.

Dessa forma, a sede da fazenda assemelhava-se a uma pequena fábrica, com um grande número de cômodos, escrupulosamente dedicados a atividades específicas, que impediam o conflito e o entrecruzamento de serviços e serviçais, cuidadosamente designados, orientados e conduzidos pela esposa do senhor para o atendimento de um grande contingente de moradores, tanto para sua acomodação como alimentação. Era ela que seria a responsável pela boa condução e o sucesso das inúmeras atividades domésticas: supervisionar a atividade de diversos serviçais em diversos cômodos, providenciar refeições tanto para a família como para os escravos e cuidar de todas as entregas que chegavam na casa ${ }^{17}$. Se somarmos essa intensa dinâmica doméstica às atividades de produção, não seria muito afirmar que a fazenda, como um todo, articula, em escala compacta, praticamente todos os elementos da cadeia de produção que a grande indústria viria sistematicamente parcelar.

\footnotetext{
${ }^{15}$ PUPO, Celso Maria de Mello, Campinas, município no Império: fundação e constituição, usos familiares, a morada, sesmarias, engenhos e fazendas. São Paulo, Impr. Oficial, 1983, p. 80.

${ }_{16}$ Ver foto da grande área de serviços com acesso externo na Imagem 7 do Anexo 4.

17 LEMOS, Carlos A. C. Casa Paulista - história das moradias anteriores ao ecletismo trazido pelo café. São Paulo, EDU USP, 1999, p. 208.
} 
Ramos de Azevedo, quando chegou à fazenda, convidado para fazer a reforma, encontrou uma típica sede de fazenda de meados do século XIX: uma estrutura de madeira aparente, vedada com taipa de mão e com aberturas simples de verga reta. Provavelmente, ali teria sido um campo bastante amplo para estender os conhecimentos aprendidos no exterior e a experiência que já acumulara com suas outras obras na cidade, tendo como argumento a concessão de um ar modernizador para a fazenda. Com a técnica do tijolo aprendida na Europa e a experiência da obra que herdara de Bonini - a fachada da Catedral -, a sede baixa e a antiga área de serviços masculinos ganharam um encamisamento de tijolos que subiu acima do nível do telhado, ganhando assim uma platibanda e calhas, que também suportava os novos apliques ao redor das janelas e portas. Os ornamentos da platibanda seguem uma linha contínua até a área que foi ampliada - a sede alta - onde essa linha, um pouco mais acima, se repete. As vergas retas da sede baixa, porém, foram mantidas, assim como a assimetria das entradas, enquanto a sede alta ganhou uma nova linguagem, com aberturas em arco pleno, organizadas num desenho que apresenta um certo rigor geométrico e rigidez simétrica. As duas sedes são diferenciadas pelas aberturas e gabaritos diferentes - harmonizandose, contudo, pelos ornamentos contínuos.

Como já vimos, a sede alta passou a ser assobradada e ganhou um novo alpendre ${ }^{18}$. Porém, nesse caso, o alpendre de $8,00 \times 4,60 \mathrm{~m}$, mais largo que profundo, ladeado pelas escadas, não serviria para a ventilação nos moldes das antigas moradas da época do açúcar: a inclusão desse alpendre teria sido uma introdução deliberada do ecletismo na zona campineira, fato ressaltado por Lemos ${ }^{19}$. O alpendre é sustentado por seis colunas dóricas e todo cercado de corrimão de madeira, com pequenos portões laterais de ferro e forro finamente trabalhado (Figura 15): todo esse cuidado demonstraria a explícita intenção eclética defendida por Lemos.

Da sede alta, só há uma entrada central pelo piso do alpendre, com vista para o jardim frontal ${ }^{20}$, ladeada por três janelas de cada lado. Essa entrada dá acesso a uma sala de visitas de quase 25,00m2. As dimensões estabelecidas para esse cômodo já demonstram a preocupação em receber pessoas de fora do convívio familiar - uma novidade trazida com a expansão da sede, uma vez que na sede baixa não existia uma

\footnotetext{
${ }^{18}$ Ver foto do alpendre no início do século na Imagem 8 do Anexo 4.

${ }^{19}$ LEMOS, Carlos A. C Casa Paulista - história das moradias anteriores ao ecletismo trazido pelo café. São Paulo, EDU USP, 1999, p. 221.

${ }^{20}$ Ver imagens dos jardins na época em estudo: a proprietária, Maria, no jardim frontal com o poço e, no jardim lateral usando uma sombrinha - Imagens 9 e 10 do Anexo 4.
} 
sala com tal finalidade, apenas o salão para ocasiões especiais. Pelas laterais dessa sala, abrem-se os acessos para uma bateria de dormitórios e alcovas. À esquerda da sala, a circulação leva a um pequeno dormitório - ou uma sala de conversas - e a uma saleta, de convívio mais pessoal, o qual dá acesso a uma alcova e a um dormitório. À direita da sala de visitas, um dormitório ou um possível escritório, e, nesse lado, encontram-se mais três alcovas e uma pequena saleta, que dá acesso à sede baixa através de uma escada interna. Na parte posterior da sede alta, encontramos a sala de jantar, ainda com grandes proporções como na sede baixa -, geralmente, sempre um dos maiores cômodos nas casas, para as principais refeições, cuja mesa de jantar era rodeada de sofás, marquesas, poltronas e cadeiras de balanço encostadas às paredes. $\mathrm{A}$ sala de jantar também é chamada de varanda para alguns autores, enquanto a varanda, nessa sede, ao lado da sala de jantar, é chamada de sobrevaranda, para refeições menores $^{21}$. $\mathrm{O}$ acesso a essa varanda se dá pelo corredor, que também faz ligação com as alcovas da ala direita. No final do corredor, outro acesso interno à sede baixa através de escada.

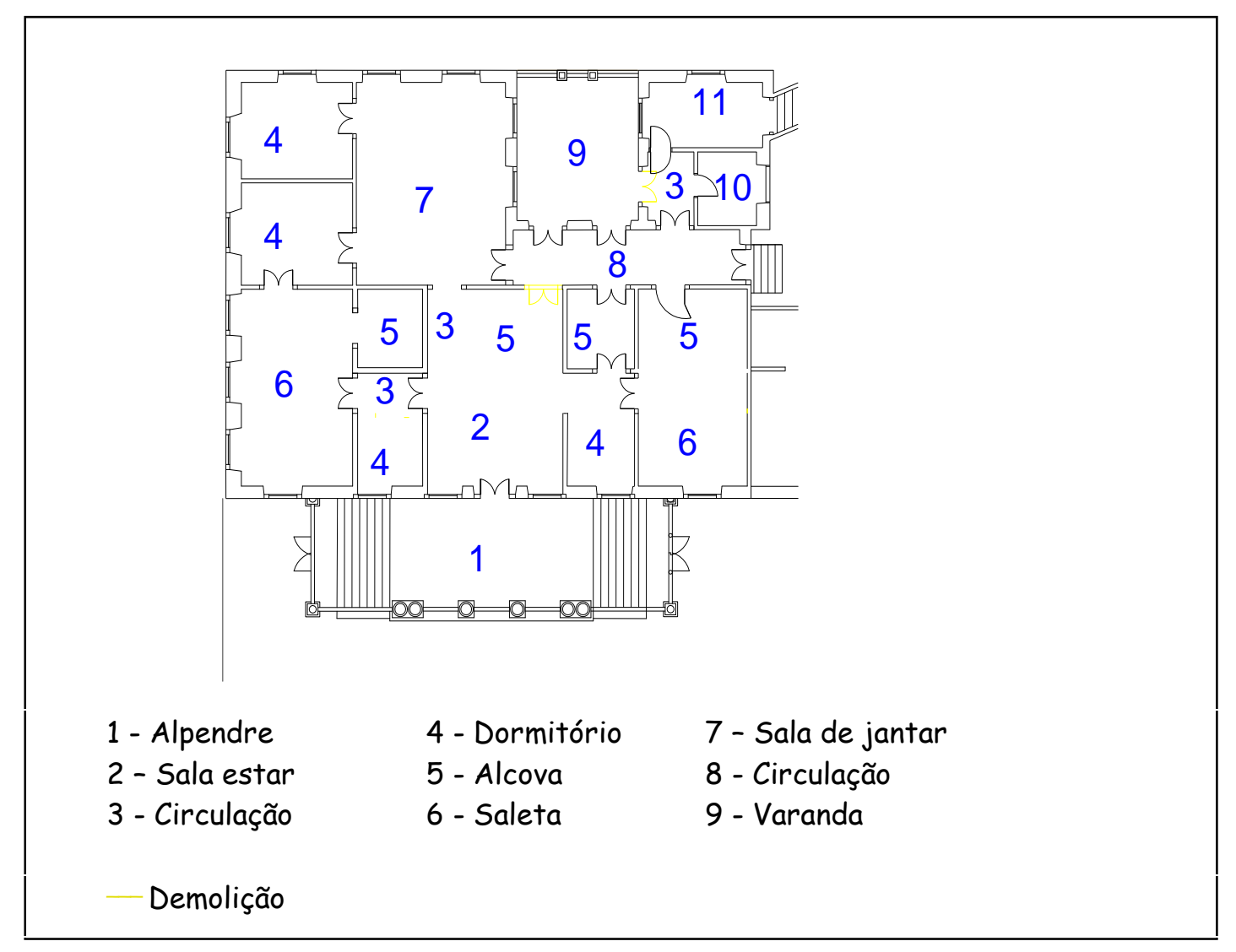

Figura 20: Planta hipotética da sede alta em 1885

${ }^{21}$ PUPO, Celso Maria de Mello. Campinas, município no Império: fundação e constituição, usos familiares, a morada, sesmarias, engenhos e fazendas. São Paulo, Impr. Oficial, 1983, pp. 93. 
A varanda é um cômodo aberto, com acesso pelo corredor interno. Era um ambiente íntimo da família, para refeições menores como café da manhã e lanches, que tem os fundos voltados para o pomar, acessado através de um pequeno portão e uma escada externa. O cômodo também se liga à dispensa e ao apoio da cozinha e tem acesso à sede baixa por uma escada interna.

No porão, sem acesso interno, encontravam-se os compartimentos para serviços masculinos. Com acessos na lateral e nos fundos, com três portas externas em cada fachada, ali guardavam-se as ferramentas para pequenos serviços e obras - como é possível constatar numa foto de um operário trabalhando na construção da ponte, em frente a uma das portas do porão ${ }^{22}$. Ali, diferente dos cômodos de serviços ligados à cozinha e à lavanderia, as mulheres não entravam. Após 1950, por conta das enchentes do rio, a sede alta perdeu o porão habitável para proteger a estrutura: o embasamento foi rebocado e as aberturas foram trocadas por seteiras, tornando o porão inutilizável.

$\mathrm{Na}$ sede alta, constatamos que a planta quadrada é bastante sóbria. Dispõe, contudo, de ambientes bem ventilados e pé-direito alto, além de soalhos de madeira e forros de madeira trabalhados, pisos arrematados com altos rodapés e ornamentos aplicados na borda de cima. Ao mesmo tempo em que o ecletismo aparece com bastante vigor, identificamos ainda alguns elementos bastante tradicionais - como as alcovas, a tipologia da sala de receber na frente e da sala íntima nos fundos e os dormitórios ligados entre si e entre alcovas. Por outro lado, o sobrado separou os compartimentos de serviços para níveis diferentes, antes localizados na parte posterior, agora passando para o porão. De qualquer forma, trata-se, nessa região, de um período de transição para o ecletismo, o qual aparece mais nos ornamentos da fachada do que na planta arquitetônica. Veremos, nas obras futuras de Ramos, a diminuição das salas de receber, as quais ganhariam vestíbulos para distribuir os espaços na entrada e interligações com a sala de jantar.

Com a presente descrição das edificações que compõem a sede da fazenda Pau d'Alho e considerações aqui articuladas, pretendemos estabelecer alguma condição mínima de apropriação dos espaços edificados e, posteriormente, aprofundar o estudo das técnicas construtivas aplicadas na sua reforma - particularmente na reforma da sede alta, que ganhou novos acabamentos, novos materiais e uma nova linguagem de estilo.

\footnotetext{
${ }^{22}$ Ver Imagens 11 a 13 do Anexo 4: foto da ponte ao lado da sede, foto da fachada lateral e foto da fachada posterior com porão habitável, ainda intacto.
} 


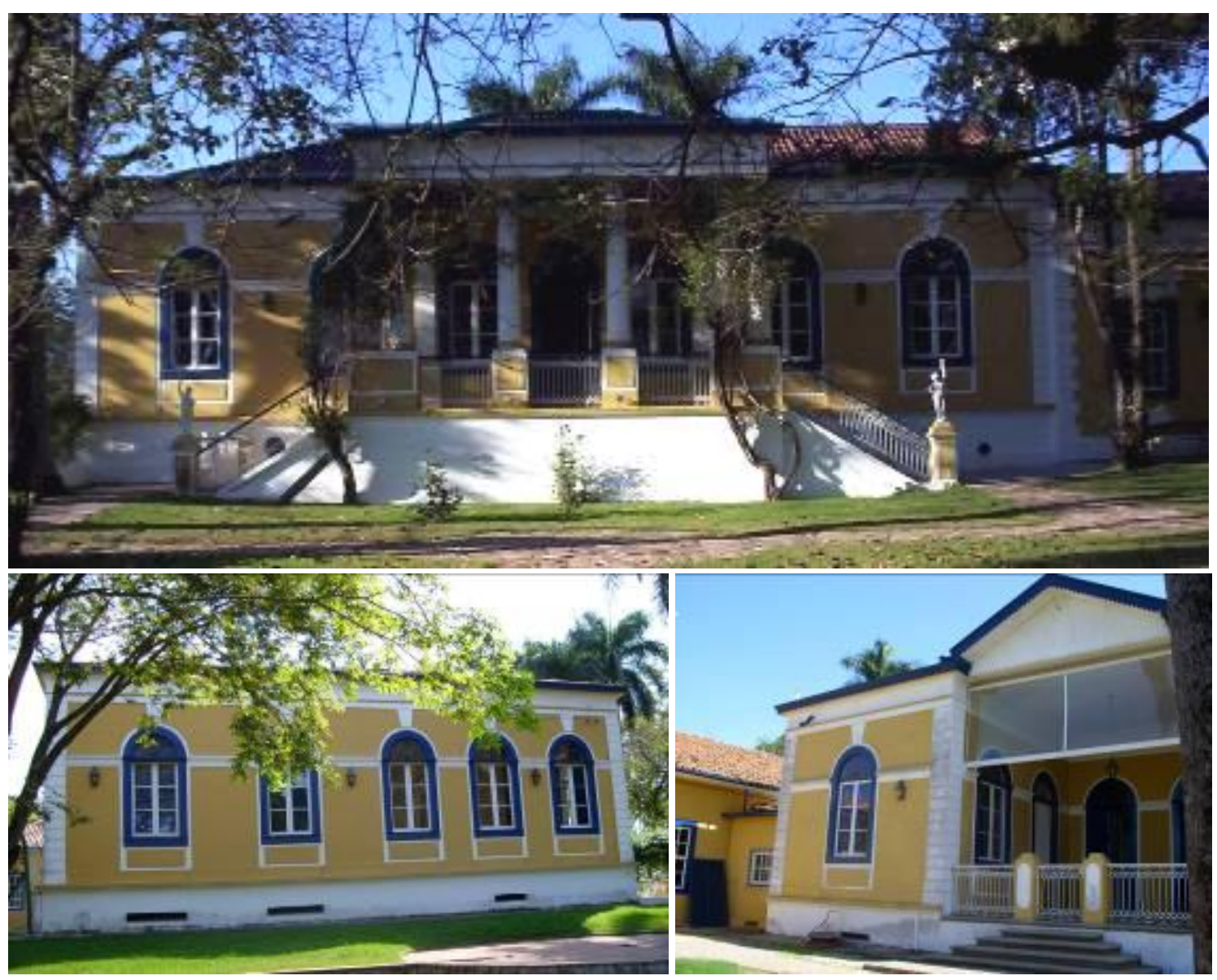

Figuras 21: Situação atual da fachada frontal da sede alta com alpendre; Figura 22: Fachada lateral; Figura 23: fachada posterior, mostrando a ligação com a sede baixa 


\subsection{Técnicas construtivas na fazenda Pau d'Alho}

Nesta seção, passaremos ao estudo das técnicas construtivas praticadas no período observado através da análise da construção na sede da fazenda Pau d'Alho. Condizentes com as técnicas construtivas da época, as opções adotadas para a reforma de 1885 seguem a lógica dos processos de produção em construção civil que se consagraram desde então. Cabe salientar, entretanto, que, apesar desses processos parecerem-nos hoje operações corriqueiras, trata-se aqui do momento em que estão sendo instituídos - e por isso a relevância que pretendemos ressaltar para um estudo como o que se apresenta: o que buscamos é promover algumas conexões entre técnicas e cultura construtivas, história da arquitetura, história econômica e social e o debate sobre preservação da memória construída e de suas implicações no contexto da preservação do patrimônio histórico e social.

Este item divide-se conforme os estabelecimentos do edifício - ou subsistemas, como são conhecidos na literatura mais recente: fundações ${ }^{23}$, estruturas, alvenarias, diferentes materiais usados como madeira, ferro e pedra, até os acabamentos, ornamentos e revestimentos: analisaremos suas aplicações, as principais opções técnicas praticadas e o processo de sua aplicação na reforma em estudo. Por fim, cabe alertar que, além da reforma de 1885, a sede passou por mais duas outras reformas no século XX, uma em 1950 e outra em 2004, que também deixaram marcas visíveis na história construtiva de tal edifício.

\subsubsection{Fundação e alicerces}

A fundação de uma edificação era feita conforme a natureza do terreno: se tivesse resistência, podia ser o próprio terreno e, dependendo do seu comportamento: se sem coesão (areias e pedregulhos), coesivos (argila), silte inorgânico ou de solo orgânico (argila e silte de materia orgânica), sendo os últimos mais resistentes. Se o solo firme estivevesse a uma pequena profundidade, só havia uma solução, a fundação direta, onde se abre vala ou poço. Se o solo firme estivesse a grande profundidade, dependia, além da natureza do terreno (seco ou lodoso), da carga transmitida pelo edificio (pequena ou grande), restando quatro soluções possíveis: fundação direta, flutuante, artificial ou indireta.

\footnotetext{
${ }^{23}$ Não nos dedicaremos ao estudo das terraplenagens, pois não serão relevantes para a presente pesquisa.
} 
A fundação direta ocorria em casos de terrenos secos, e a escavação pode ser em valas, poços ou abrangendo toda a construção, com sapatas corridas, sapatas individuais e "radiers" (sapata constínua que abrange toda a superfície do edifício) ou sapata geral para toda a construção.

A fundação flutuante ocorria em casos de terrenos secos, consistindo em retirar um volume de terra com peso aproximadamente igual ao da carga que será aplicada e, em seguida, com a execução do alicerce por meio de "radier", conferindo uniformidade de pressão. Uma fundação flutuante também podia ser formada por uma série de tubulões que se apoiavam sobre uma camada mais resistente e recebiam a

carga dos alicerces, executados no fundo da escavação, correspondente ao peso do edifício.

A fundação artificial ocorria em terrenos secos, consistindo em escavar até certa profundidade, sem atingir o solo pouco compressível, e apisoar o terreno - com macaco, seja mecânico ou manual - ou cravar estacas de consolidação.

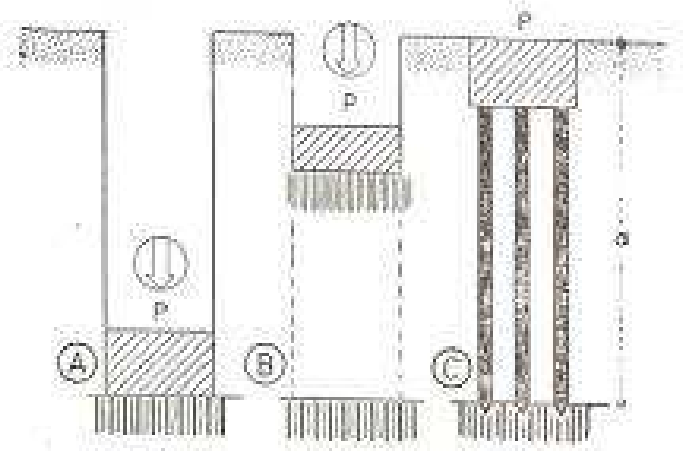

Figura 25: Representação de fundação direta $(\mathrm{A})$, artificial $(\mathrm{B}) \mathrm{e}$ indireta $(\mathrm{C})^{24}$

A fundação indireta ocorria em terrenos secos e lodosos e consistia em fincar estacas, sem escavar, ou executar tubulões, até alcançar solo firme, e sobre essas estacas ou tubulões, estabelecer os alicerces. As estacas podiam ser de madeira com pontas e argolas metálicas (Figura 28) e, no início do século XX, já podia ser de concreto pré-moldado e concreto fundido no local (Figura 29A), cravadas através de bate-estacas, estrutura de madeira ou aço, que sustém as guias do macaco e as polias para os cabos (Figura 29B).
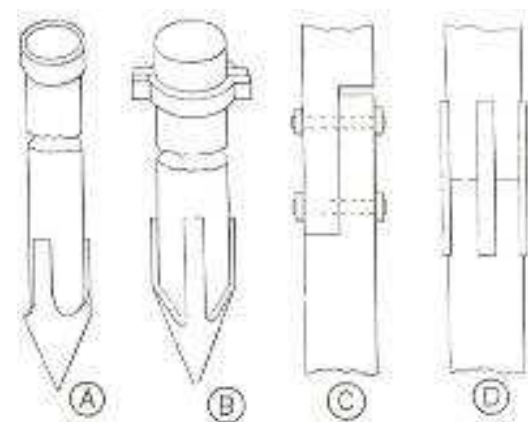

Figura 26: Estaca com ponta e argola metálica (A e B), e reforçada com taleiras e parafusos ( $C$ e D)

${ }^{24}$ Figuras 25 à 29: ALBUQUERQUE, A. Construções Civis. São Paulo: Empresa Gráfica da Revista dos Tribunais, 1952, p. 151, p. 57, p.57, p.67, p. 68 respectivamente. 

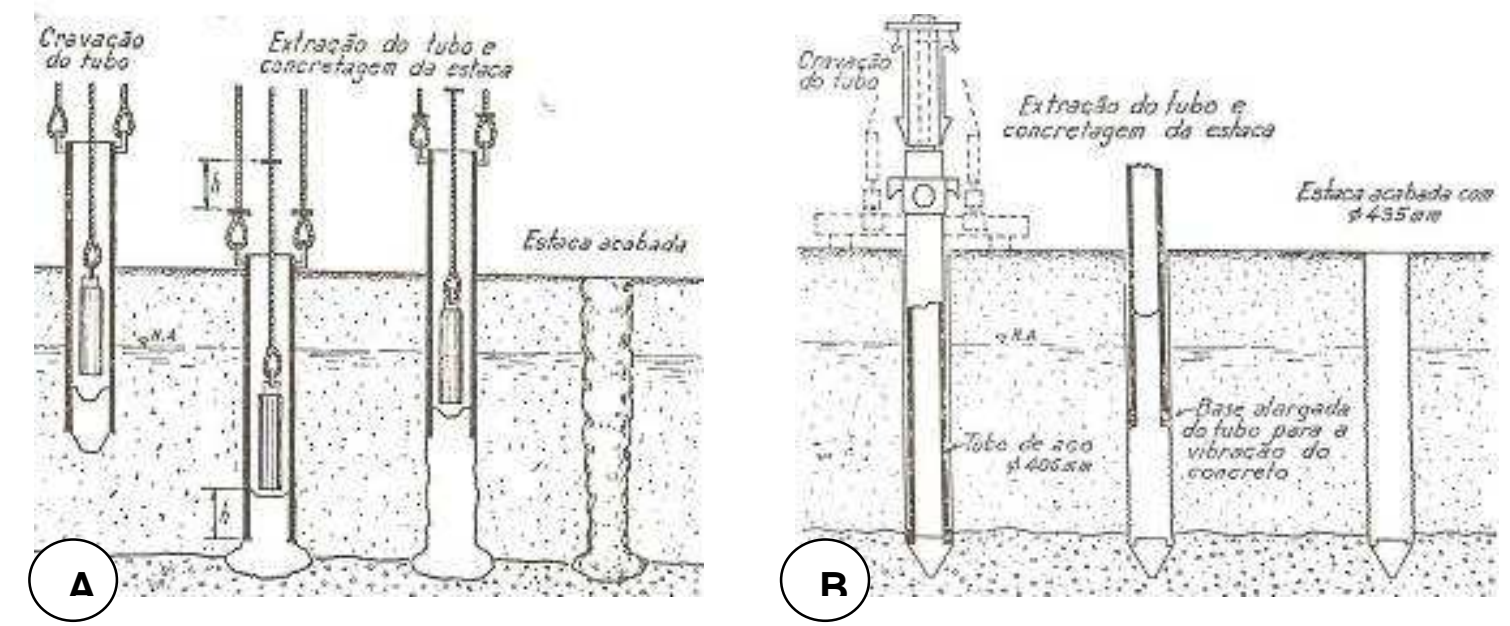

Figura 27: Cravação do tubo de aço fundido no local (A) e cravação de estacas por meio de bate-estacas (B)

Depois da preparação das fundações, eram feitos os alicerces. Os alicerces eram corridos ou em pares: no primeiro caso, tanto fundação quanto alicerces eram contínuos; no segundo, eram executados em situações separadas. O alicerce era composto de duas partes: a sapata, parte inferior de alvenaria, com largura maior, que se apoia diretamente sobre a fundação e o alicerce em si (Figura 30). Estes podiam ser: alicerces de pilares (Figura 31A e 31B), alicerces mistos (corridos e em pilares), alicerces de degraus - em terrenos muito inclinados (Figura $31 \mathrm{C}$ ) e alicerces à beira de barrancos ${ }^{25}$.

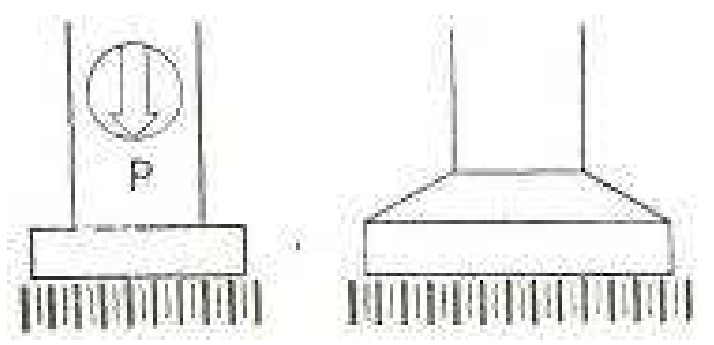

Figura 28: Alicerce com parte inferior de alvenaria

${ }^{25}$ Para referência aos tipos de fundações utilizados na época e alicerces, ver ALBUQUERQUE, p. 151. 

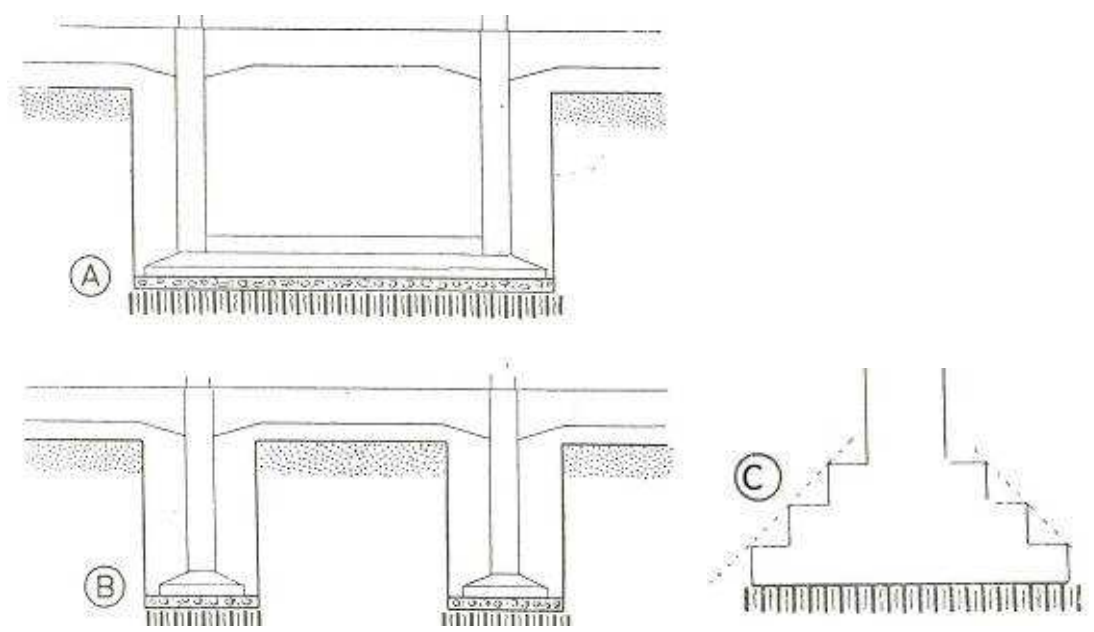

Figura 29: Alicerce de pilares com sapata contínua (A) e isoladas (B), e alicerce de degraus (C)

Na fazenda Pau d'Alho, podemos constatar que toda a sede foi assentada sobre embasamento de pedra, à meia encosta, assim como a construção vizinha da sede - o depósito - e a área de serviços masculinos, situado do outro lado. Já na reforma de 1885, a parte da edificação que abrigava a antiga área de serviços - que foi ampliada tanto na parte da fachada posterior como frontal, com o acréscimo do alpendre -, situada no mesmo nível da sede baixa, ganhou um novo pavimento, aproveitando o trecho de maior desnível da meia encosta. Esse desnível permitiu um bom aproveitamento do embasamento de pedras, tornando-se a nova área de serviços masculinos da sede, agora assobradada $^{26}$, denominada, após a reforma, de sede alta.

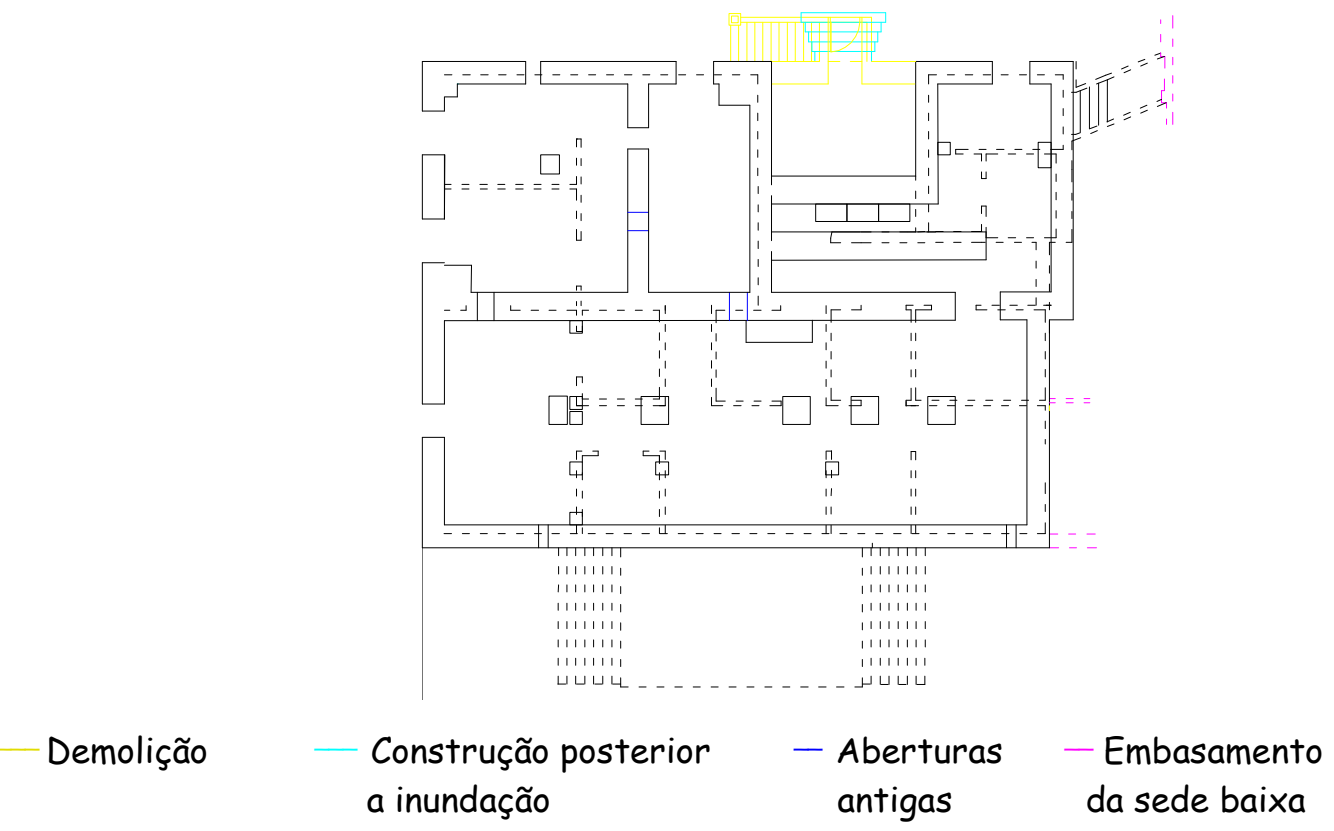

Figura 30: Planta do porão na sede alta com embasamento de pedras, construído com a reforma

${ }^{26}$ Ver foto do embasamento de pedra na elevação posterior da sede baixa na Imagem 14 do anexo 4 . 


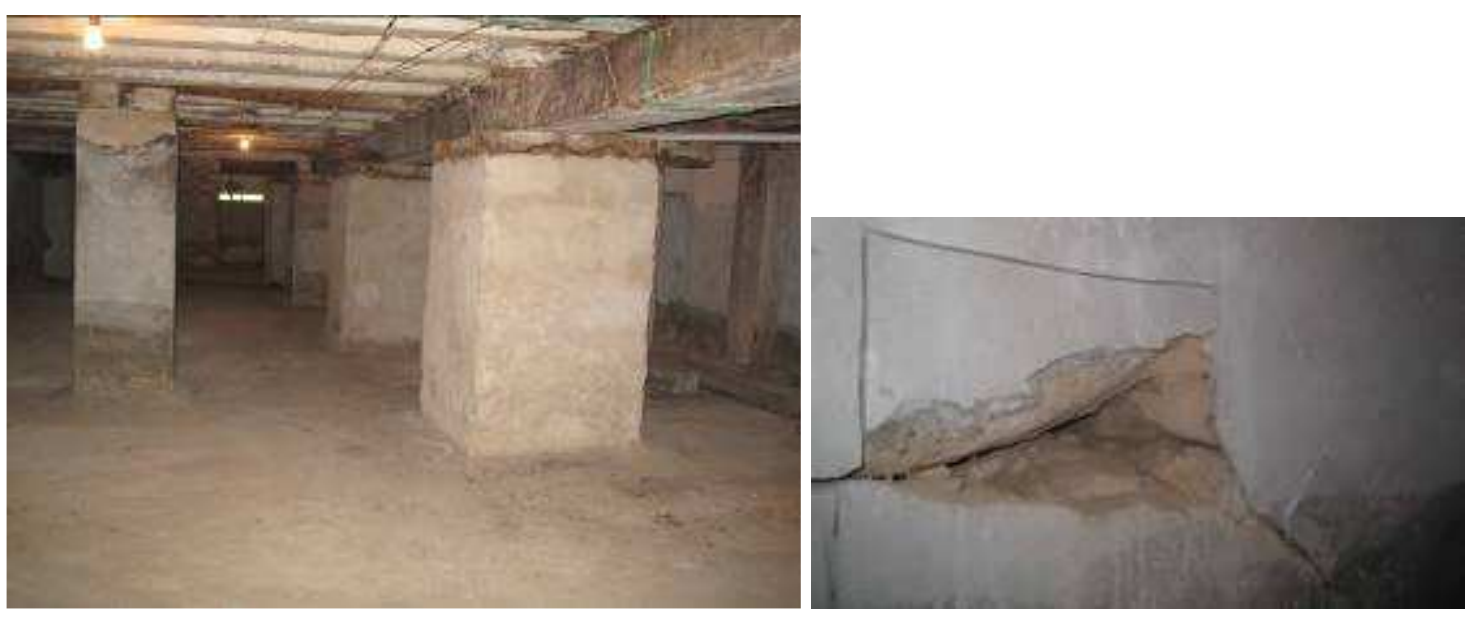

Figura 31: Foto do porão atual (sede alta) com pé-direito reduzido, pilares e paredes rebocados; detalhe (foto à direita): parte da parede rebocada expondo a pedra original

Porém, em 1950, o porão, que antes era habitável, foi fechado e teve seu pédireito diminuído por conta da inundação do rio ali próximo, portanto, não podemos analisar exatamente como foi feito o alicerce. A parte inferior do porão foi aterrada para proteger a casa de futuras inundações, ficando um pé direito de apenas $1,70 \mathrm{~m}$ e as antigas portas viraram pequenas janelas, as seteiras. Nessa ocasião, as paredes e os pilares do porão foram rebocados por cima das pedras, apresentando espessuras que variam de 0,70 a 0,92m, com o dobro de largura das paredes no andar superior. Não foi possível analisar os alicerces também devido ao curto período para o estudo, pois são obras de alvenaria executadas abaixo do nível do terreno, que recebem a carga do edifício e transmitem-na à fundação. O que se pode afirmar é que, provavelmente, a fundação - de acordo com a maneira que era feita, na segunda metade do século XIX deve ser direta, pela proximidade com o rio e pela característica de solo firme a pouca profundidade.

Sob a fundação e o alicerce, vinham as estruturas, como veremos a seguir. Elas podiam ser compostas por estrutura de madeira, alvenaria de tijolos, alvenaria de pedra ou estrutura metálica.

\subsubsection{Estruturas}

\subsubsection{Estrutura de madeira}

Até o século XVIII, as estruturas de madeira eram as mais usuais. Denominadas de "gaiolas", predominaram nas edificações mineiras. O esqueleto de madeira era constituído de pés direitos, beldrames, frechais e peças de contraventamento. Os pés direitos eram madeira de esquadria reforçada, enterrada no solo e colocada nos cruzamentos das paredes ou outros pontos intermediários. Os beldrames eram peças horizontais, fixadas nos pés-direitos, à altura do piso, e isoladas do solo para melhor 
conservação. Os frechais eram peças horizontais, à altura do telhado, e sobrepostas aos pés direitos. Finalmente, o contraventamento completava a gaiola: constituído de pontaletes, era reforçado pelas portas, janelas, vigamento e tesouras do telhado. Essa estrutura de madeira era utilizada em conjunto com as paredes de taipa de pilão e taipa de mão, técnicas à base de barro; a primeira, apiloada horizontalmente e, a segunda, aglutinada num trançado de madeira preso à estrutura de madeira.

$\mathrm{Na}$ fazenda Pau d'Alho, sob o embasamento de pedra, tanto na sede baixa quanto na alta, foi construída uma estrutura de madeira, conforme a Figura 02 do item 3.1 - única imagem que se tem conhecimento de antes da reforma - em que podemos ver, na fachada lateral, os pés-direito, beldrame e uma viga intermediária. A utilização desse tipo de estrutura também pode ser vista no portão de entrada. Tal estrutura, mais frágil, passou a perder força no século XX, pois já no final do século XIX só eram utilizadas em construções rurais ou em edificações provisórias. Além disso, foram muito usadas em feiras e exposições que começaram a despontar no período.
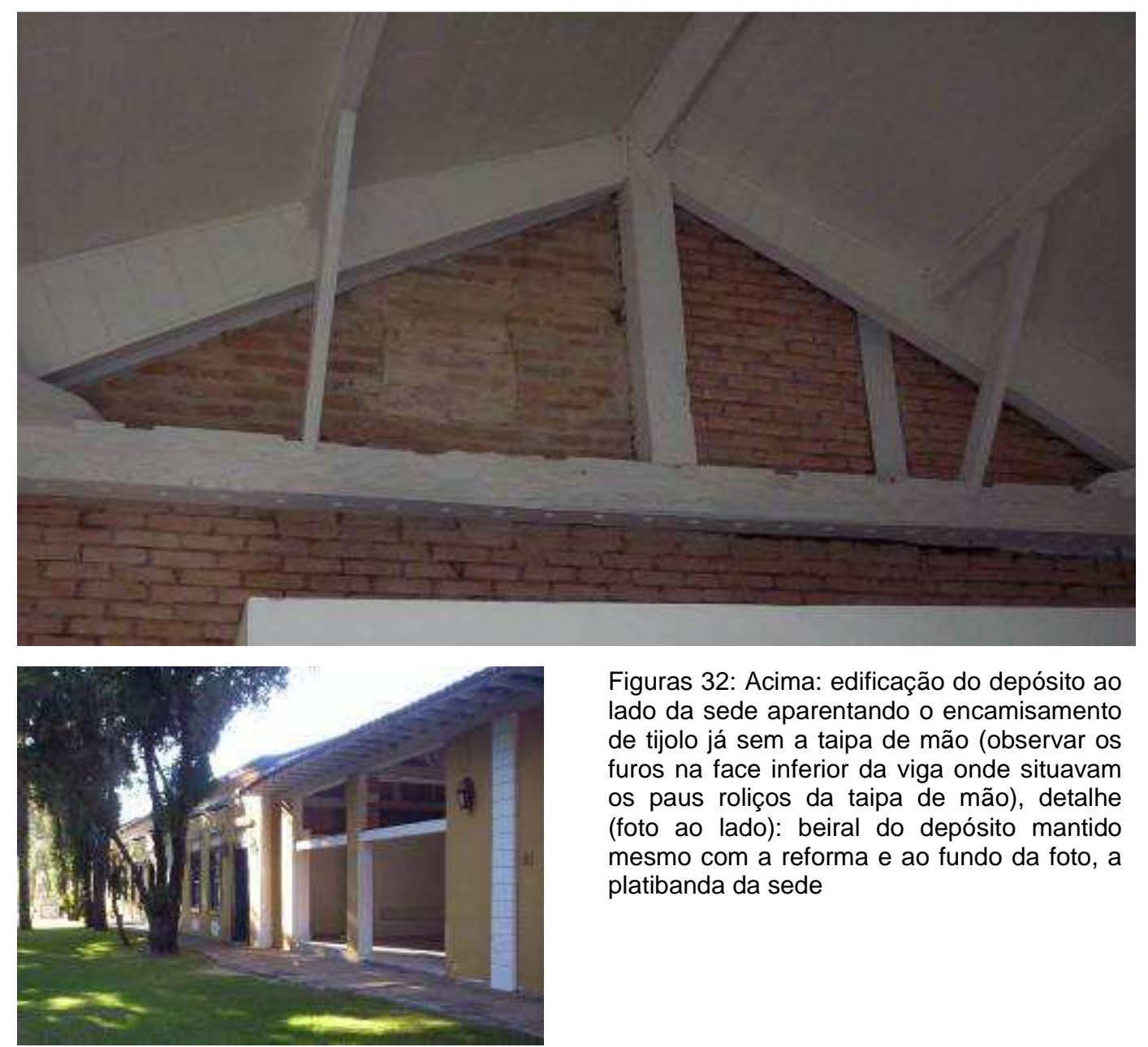

Figuras 32: Acima: edificação do depósito ao lado da sede aparentando o encamisamento de tijolo já sem a taipa de mão (observar os furos na face inferior da viga onde situavam os paus roliços da taipa de mão), detalhe (foto ao lado): beiral do depósito mantido mesmo com a reforma e ao fundo da foto, a platibanda da sede

Em 1885, com a reforma de Ramos de Azevedo, e a estrutura de madeira já em desuso, toda a sede construída em estrutura de madeira e taipa de mão ganhou um 
reforço de tijolos, que começava a se popularizar, e foram introduzidos elementos neoclássicos. Essa técnica é chamada de encamisamento, e praticamente foi um processo natural da fase de transição do açúcar para o auge cafeeiro. Ocorreu em muitas sedes de fazenda da região entre as décadas de 1860 e 1880, ocorrendo até mesmo em uma grande obra como a Catedral Metropolitana, que foi construída em taipa de pilão e reforçada com estrutura de pedra, passando a ser encamisada no final da década de 1860 (Figura 33).

O depósito, a edificação situada ao lado da sede, próximo à sede baixa construída no mesmo período, com o mesmo embasamento de pedra - também foi construído com taipa de mão e encamisado com tijolo, porém, em muitas partes, não se encontra mais a taipa de mão, apenas o tijolo (Figura 32). Devemos observar que, nessa edificação, o encamisamento não ultrapassou a altura do telhado, mantendo-se o antigo beiral, enquanto que, na sede, o encamisamento ultrapassou a altura do telhado, formando-se a platibanda (detalhe Figura 32). O motivo disso talvez esteja no fato de que Ramos quisesse manter as feições originais numa edificação de finalidade que não fosse a moradia, como o depósito. No item a seguir, veremos sobre a utilização da alvenaria de tijolos, que passou a predominar nas construções desse período, além do encamisamento como estrutura para as novas construções.

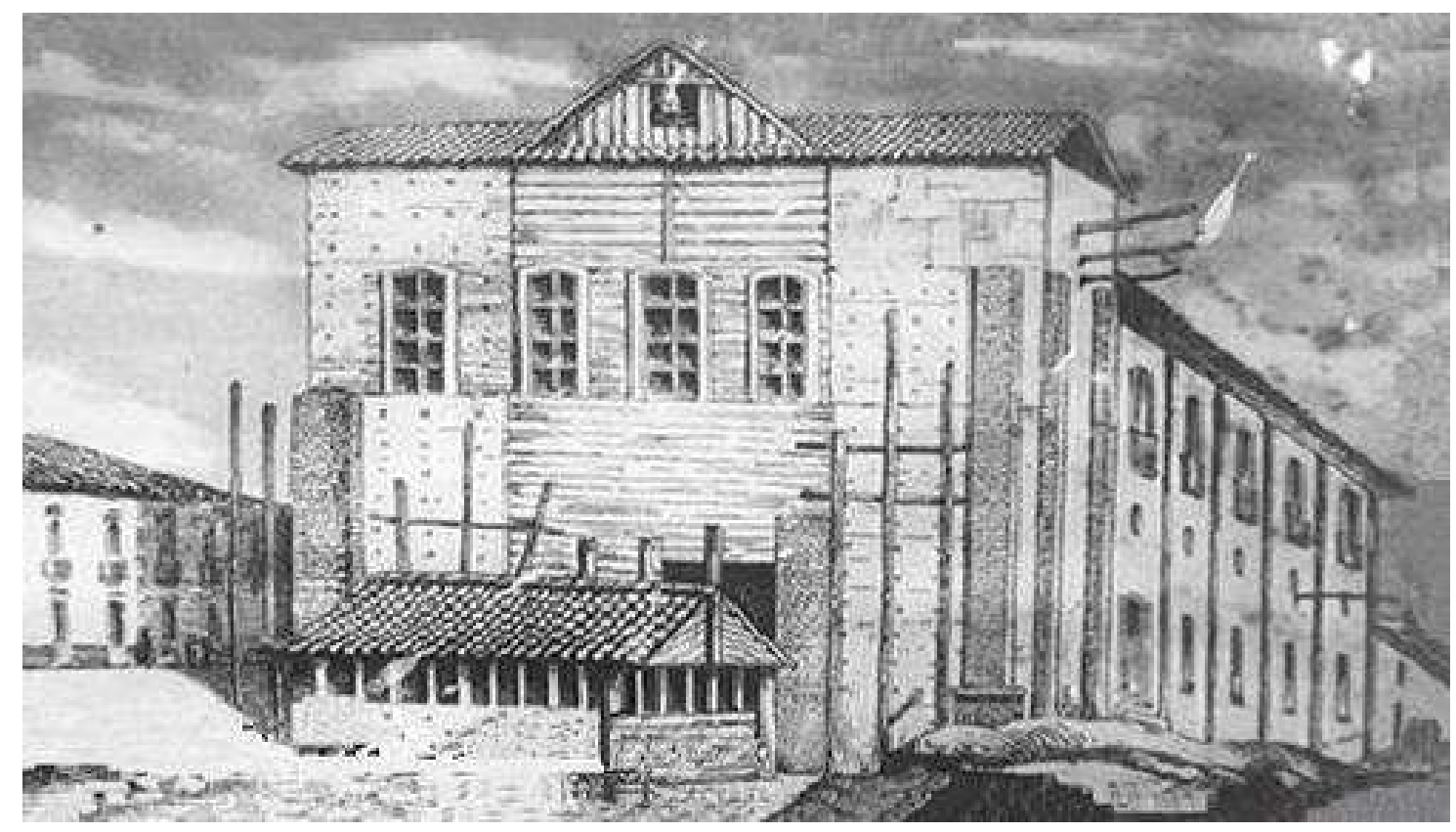

Figura 33: Encamisamento de tijolos na Catedral Metropolitana de Campinas, iniciado na gestão de Bonini, em 1869, dez anos antes de passar o cargo a Ramos de Azevedo. Observar furos da taipa de pilão e tijolos subindo nos cunhais 


\subsubsection{Alvenaria de tijolo}

Sabemos que a origem do tijolo é muito antiga e, até o final do século XIX, tinha função tanto estrutural como de vedação. Ao longo dos tempos e, de acordo com as civilizações que o produziram, foi adquirindo vários tipos de faces - triangular, quadrada, retangular, sextavada, etc, mas a retangular prevaleu sobre as demais. Em função da variação da espessura, o tijolo também adquiriu muitas feições volumétricas: cúbico, paralelepípedo e chapa de barro de pequena espessura (para ladrilhamento). As dimensões foram modificando-se de acordo com as necessidades e conforme os arranjos ornamentais. Passou a substituir o adobe devido a suas vantagens, pois, com 0 cozimento, adquiria características físicas e químicas interessantes, como o isolamento acústico e térmico, em função de sua porosidade e rugosidade. Sua matéria-prima básica, a argila, compunha-se essencialmente de caolino e de outros elementos como silicatos, carbonatos, sulfuretos, matérias betuminosas e carbonosas, dentre outros, em proporções variáveis, que conforme a predominância desses elementos, ia adquirindo características físicas e químicas diferenciadas, assim como cores diversas (branca, amarela, vermelha $)^{27}$.

As olarias remontam desde a Antiguidade e eram compostas por um extenso terreno livre, denominado enxugadouro ou eira, para secagem dos tijolos antes da queima, e de uma área coberta ou galpão para a instalação de fornos e chaminés, com a configuração necessária para atender sequência de confecção de tijolo: armazenamento do barro extraído das barreiras, preparação da pasta, moldagem, secagem e queima ${ }^{28}$. Inicialmente, a produção de tijolos era manual, entretanto, com a industrialização advinda do desenvolvimeto técnico europeu do final do século XVII e inicio do XX, foram criadas máquinas para o seu fabrico, aumentando sua produção. É a partir desse século que as máquinas foram exportadas para o Brasil. Porém, esse avanço da indústria oleira não modificou a busca pela qualidade da argila. D'Alambert cita a recomendação de João Emílio Segurado ${ }^{29}$

“...o barro empregado no fabrico de tijolo deve ser isento de carbonato de calcáreo, o qual aumenta a sua fusibilidade e sua decomposição pode produzir fendas; não deve conter pirites ou outros compostos sulfurosos, na ocasião da cozedura, podem fendê-lo; do mesmo modo será insento de pederneira que rachando sob a ação do tijolo..."

${ }^{27}$ D'ALAMBERT, Clara Correia. Tijolo nas construções paulistanas do século XIX. São Paulo: s.n., 1993, p. 27.

28 Ibid., pp. 28 a 30.

29 SEGURADO, João Emílio dos Santos. Alvenaria e cantaria. 4. ed. Lisboa, Bertrand, Biblioteca de Instrução Profissional. 19-?. 
e a de Rainville ${ }^{30}$, quanto às características do barro ideal para fabricação de tijolo de boa qualidade. Esse autor afirma que

“...pondo-se água no barro, para obter uma massa maleável, que com facilidades se possa por nas formas, deve o barro deixar-se trabalhar bem com os dedos, sem rachar, se o barro estiver rico ou gordo demais, não dará bons tijolos, porque a forma enverga no secar e racha no queimar...do mesmo modo o barro não deve ser magro e arenoso demais, porque no queimar sofre uma contração muito grande, e fica fundido, poroso e arruinado...".

Segundo D'Alembert, pelos comentários do engenheiro Antonio de Paula Freitas, em 1884, os conselhos de Rainville eram seguidos com frequência pelos oleiros brasileiros. Em São Paulo, havia grande dificuldade na escolha de um barro adequado para a confecção de tijolos, pois o solo da capital paulista era bastante pobre em argila de boa qualidade, por isso barrento, pouco plástico e de difícil cozimento, produzindo tijolos porosos e de pouca resistência às cargas. Na feitura de tijolo, quando a argila disponível era muito maleável, acrescentava-se areia na mistura, "o melhor anti-plástico existente".

Após escolha correta do material, iniciava-se a preparação da pasta, amassando o barro com certa quantidade de água - nem pouca nem excessiva - até formar uma massa com consistência homogênea. Era costume deixar o barro "apodrecer" durante o inverno para purificar. Depois de preparada a pasta, começava a moldagem de tijolos, manual ou mecanicamente. O modo manual era mais utilizado em pequenas olarias, mais simples e de baixo custo, empregando-se o molde de madeira, caixa de madeira sem tampa nem fundo, com as dimensões, de preferêcia, maior que o tijolo pronto, porque no cozimento as peças sempre diminuíam em função da perda de água. Depois de moldado, o tijolo era levado, ainda dentro da forma, para o enxugadouro (ou eira de enxugo), onde era retirado do molde e permanecia descansando até secar completamente, por um tempo variável de 5 a 10 dias, o que evitava deformações nos tijolos durante o cozimento devido à rápida perda de água.

Já a moldação mecânica era feita por moldadores de pressão ou por máquinas de fieira, e não era necessária a secagem, pois os tijolos já saíam da máquina bem prensados, prontos para serem queimados. Depois de secos naturalmente, eram enfornados, cozidos, resfriados e desenformados. A queima de tijolos podia ser feita em medas, em fornos intermitentes - que eram feitos em ciclos de queima (Figura 34) -, em fornos semi-contínuos ou contínuos, e exigia altas temperaturas, em torno de 1000 gaus.

30 RAINVILLE, Cesar. O Vinhola Brasileiro. Eduardo e Henrique Larmmert, Rio de Janeiro, 1880. 
Com o cozimento, o tijolo sofria alteração de cor, passando do pardo para vermelho ou amarelo, dependendo da composição da argila e da chama do combustível. O tempo de permanência de tijolos no forno devia ser suficiente para que toda a água fosse eliminada de maneira uniforme, resultando em tijolos bem cozidos e compactos. O resfriamento das peças era feito pela injeção lenta de ar frio no forno até que estivessem prontos para desenformar. Os tijolos destinados à confecção de alvenaria aparente exigia mais cuidado na aparência das peças, e eram alisados, logo após serem desenformados, para adquirirem regularidade ${ }^{31}$. A produção do tijolo na região da fazenda Pau d' Alho provavelmente era manual, pela dimensão dos galpões para secagem dos tijolos, porém foram utilizados, como vimos, tijolos mais trabalhados, gravados com as iniciais do Barão de Anhumas, sendo provável que nessa olaria também tivesse máquinas para produção mecânica.

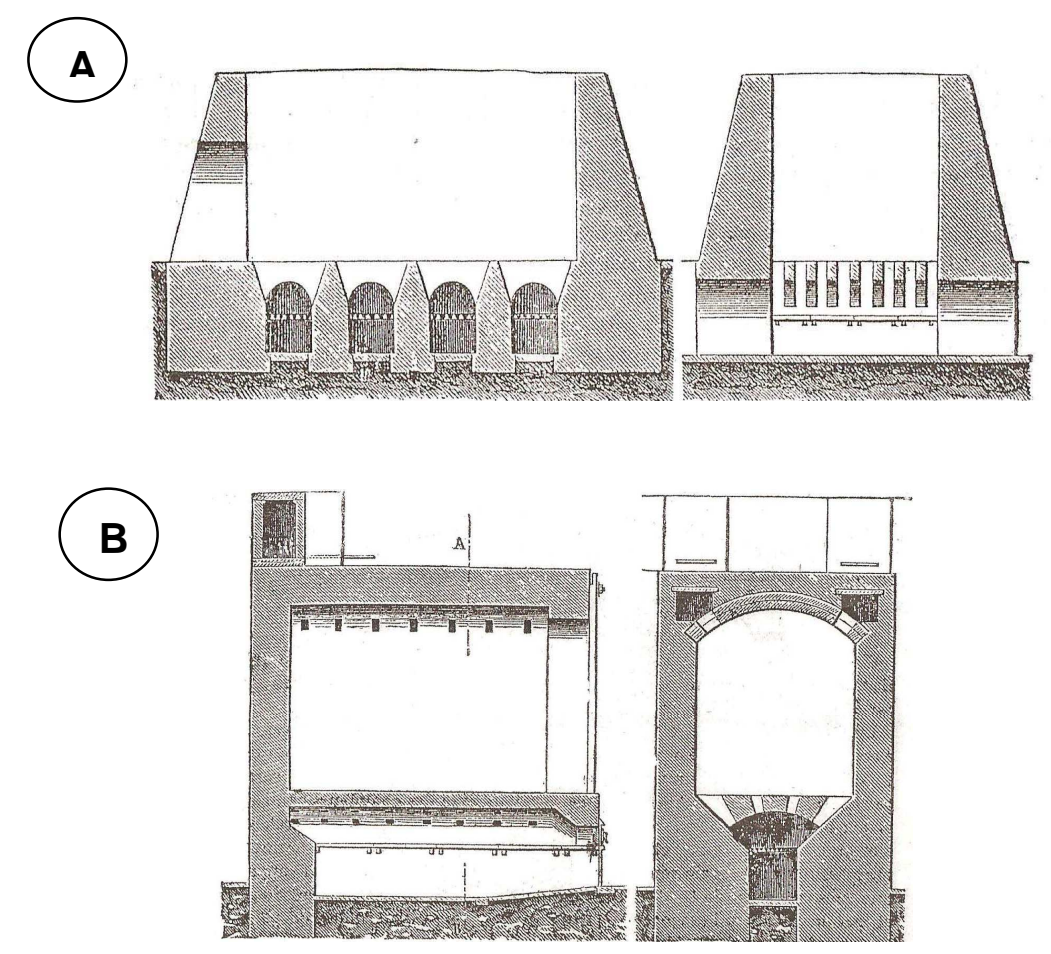

Figura 34: Forno intermitente para tijolo $(A)$ e forno intrmitente coberto para tijolo $(B)^{32}$

Para o bom acabamento do tijolo, devia ser considerada a resistência das alvenarias, que dependia da inter-relação entre seus dois componentes, o tijolo e a

31 D'ALAMBERT, Clara Correia. Tijolo nas construções paulistanas do século XIX. São Paulo: s.n., 1993, pp. 31 a 38.

32 SEGURADO, J. E. S. Materiais de construção. Biblioteca de Instrução Profissional, Livraria Bertrand, Volume I, 19-?, pp. 52 e 53. 
argamassa. Esta devia ser preparada nas proporções recomendadas, o que geralmente se dava pela experiência de pedreiros e mestres de obras.

No século XIX, a grossura das paredes variavam em função de seu fim construtivo e da carga que deveriam suportar. Eram dispostas em arranjos definidos de aparelho, nos quais a colocação de fiadas obedecem uma ordem rigorosa, para que as juntas verticais não fossem contínuas. Nas paredes mais delgadas, o tijolo era assentado segundo o seu comprimento, e chamava-se pano de tijolo de cutelo, ou ao alto ou à galga. Esse tipo era empregado em divisões internas, tabique ou construções de caráter provisório. As fiadas eram colocadas desencontradas: se na primeira fiada colocava tijolo inteiro, na segunda, devia começar com meio tijolo, e assim por diante.

Pano de meia vez tijolo (ou parede singela) era a denominação dada às paredes em que o tijolo era colocado sobre sua face de baixo, de forma que a largura da parede correspondia à largura de cada peça. Esse tipo de parede era constantemente utilizado em divisões de construções térreas e andares superiores de sobrados. Nesse aparelho, o aspecto é o mesmo, com juntas verticais interrompidas, distinguindo-se um do outro pela parte do tijolo visível no paramento ${ }^{33}$.

Nas paredes de vez tijolo ou nas paredes dobradas, a espessura da alvenaria equivalia ao comprimento do tijolo ou a duas larguras. Eram, em geral, empregadas em panos externos de construções térreas e sobrados, suportando maior carga que as paredes internas e divisórias.

São vários os aparelhos usuais, conforme Figura 35, mas esses eram os mais recomendados por Alburquerque. Utilizava-se também, ocasionalmente, paredes de vez e meia (com espessura igual à soma do comprimento e da largura do tijolo), de duas vezes tijolo (equivalente a duas vezes o comprimento do tijolo) e de espessuras até superiores. Segundo Leitão, a espessura variava de acordo com o número de andares de edificios e grandeza de divisões internas.

Segurado ${ }^{34}$ também se refere a outras aparelhagens como sistema inglês (Figura 36A), sistema flamengo (Figura 36B) e sistema em losango (Figura 36C). Quanto à produção de um pedreiro, o mesmo autor diz, no referido livro, que um pedreiro com o seu servente pode fazer, em 10 horas de trabalho, cerca de 8 a 9 metros quadrados de parede e, em 8 horas diárias, apenas 6 a 7 metros quadrados.

O tijolo vulgarmente usado na construção de paredes, burro -este mais antigo ou furado, tinha, em média, $0,23 \mathrm{~m}$ de comprimento $X 0,11 \mathrm{~m}$ de largo $X 0,07 \mathrm{~m}$ de grosso,

\footnotetext{
${ }^{33}$ ALBUQUERQUE, Alexandre. Construções Civis. São Paulo: Empresa Gráfica da Revista dos Tribunais, 1952, p.104.

${ }^{34}$ SEGURADO, João Emílio dos Santos. Alvenaria e cantaria. 4. ed. Lisboa, Bertrand, Biblioteca de Instrução Profissional, 19-?, pp. 74 a 78.
} 
e a espessura da junta não devia exceder um centímetro, devendo a argamassa ser um pouco consistente e preencher completamente o intervalo entre os tijolos. Devia haver o máximo de cuidado em conservar as juntas horizontais e os paramentos verticais, fazendo uso do cordel e prumo para tal fim.
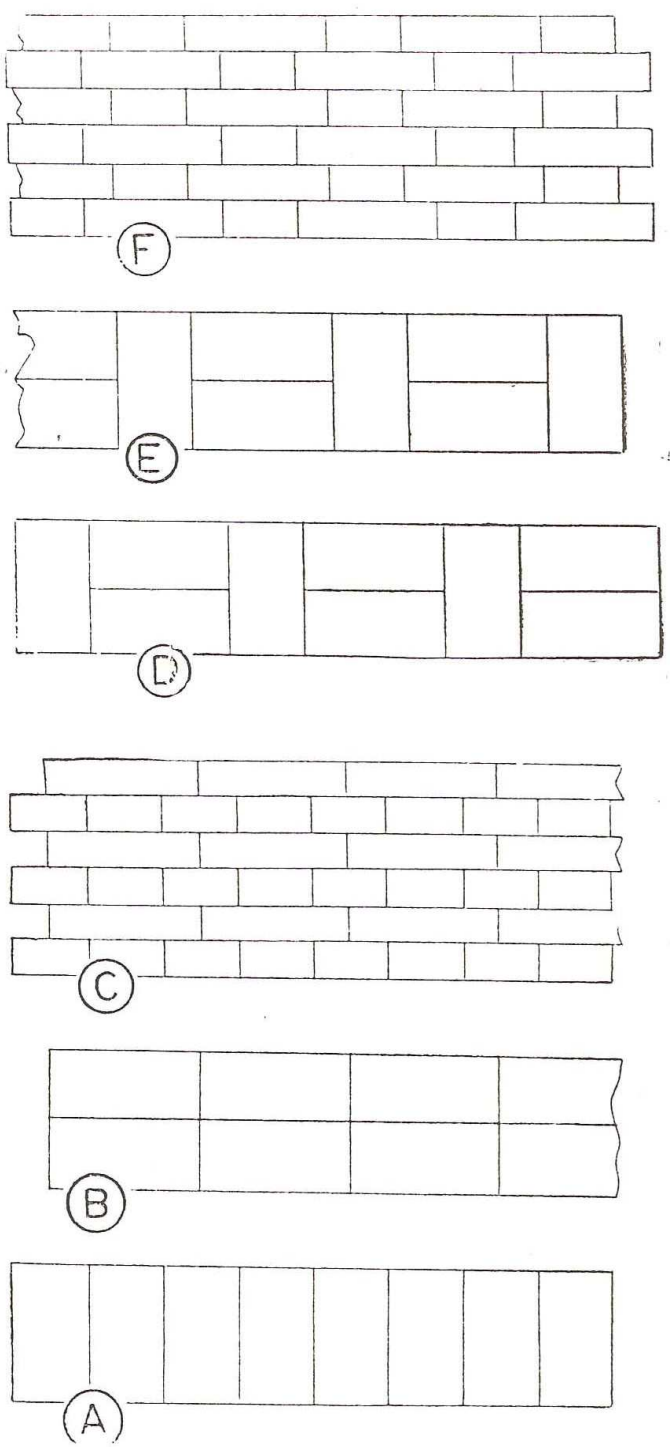

Figura 35: Diversos aparelhos de tijolo cheio ${ }^{35}$
Outras medidas dos tijolos mais comuns, produzidos em Portugal e no Rio de Janeiro, podem ser conferidas na tabela publicada por Segurado ${ }^{36}$ (ver Figura 37).

Além dos tijolos maciços e de alvenaria (mais finos que os de burro para melhor aproveitamento na aparelhagem), começava a ser mais constante, por aqui, o uso do tijolo furado. Os tijolos furados podiam ser de seis, oito ou nove canais; de alvenaria, curvo para chaminés, macho e fêmea para tabique, cheios para cimalhas, furados para cimalhas ou furado para corrimão (ver Figura 38).

Outros tipos de tijolos produzidos eram os ladrilhos, de dimensões finas, cores variadas e diversos desenhos. Seu modo de fabrico era idêntico ao de outros tijolos, usando as mesmas máquinas dos tijolos e acrescentando a pasta de materiais corantes de origem mineral. Podiam ser: ladrilho mosaico cerâmico, cozido com cores variadas, e ladrilho mosaico hidráulico ou cimento, moldado nas formas de prensa de parafusos (Figuras 39 e 40).

\footnotetext{
${ }^{35}$ Fonte: ALBURQUERQUE, A. Construções Civis. São Paulo: Empresa Gráfica da Revista dos Tribunais, 1952, p. 104.

${ }^{36}$ SEGURADO, J. E. S. Alvenaria e cantaria. 4. ed. Lisboa, Bertrand, Biblioteca de Instrução Profissional. 19?, p. 61 .
} 


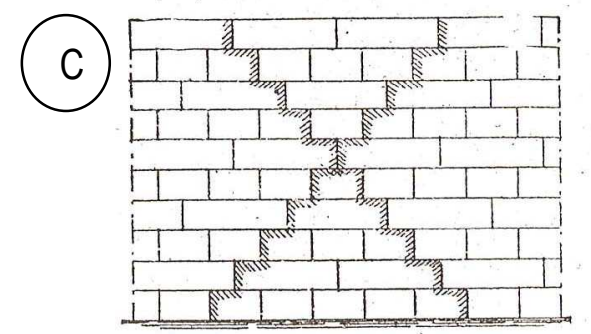

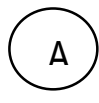
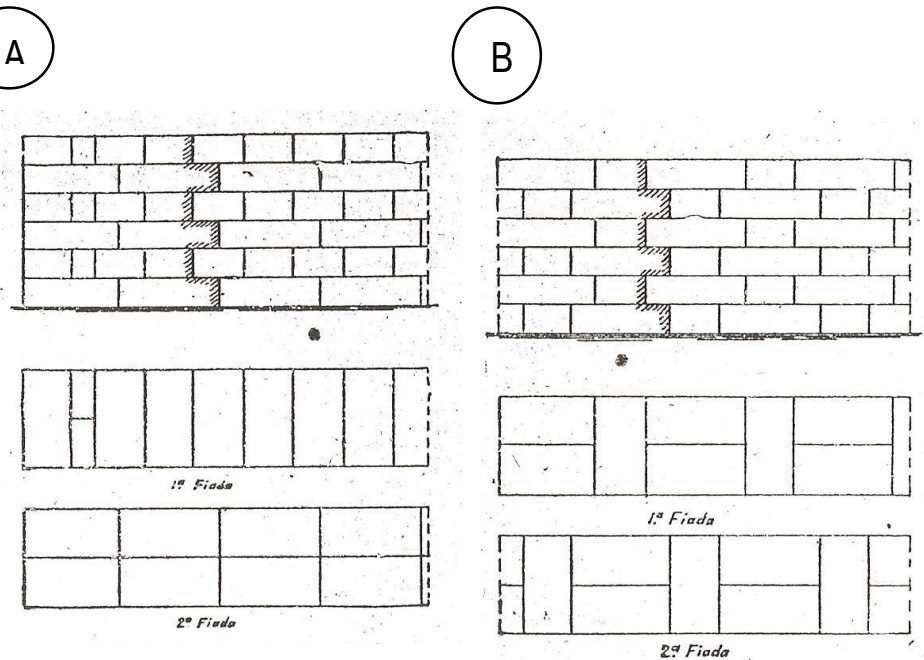
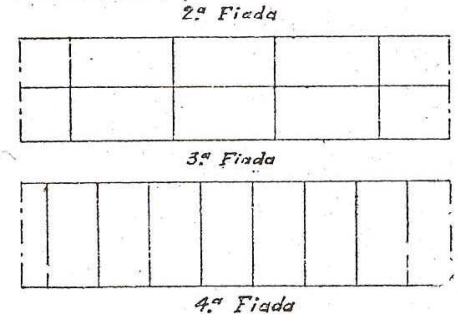

Figura 36: Pano de uma vez tijolo: aparelho inglês (A), aparelho flamengo (B) e aparelho losango $(C)^{37}$

Dimensões e pesos dos pxincipaes typos de tijolos

\begin{tabular}{|c|c|c|c|c|c|c|c|}
\hline \multirow{2}{*}{ 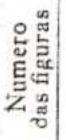 } & \multirow{2}{*}{\multicolumn{3}{|c|}{ Nomes }} & \multicolumn{3}{|c|}{ Dimensóes } & \multirow{2}{*}{$\begin{array}{c}\text { Peso } \\
\text { por tijolo }\end{array}$} \\
\hline & & & & Comprimento & Largura & Altura & \\
\hline & & & . & $\mathrm{m}_{0,230}$ & ${ }_{0,110}^{\mathrm{m}}$ & $\stackrel{\mathrm{m}}{\theta, 070}$ & $k$ \\
\hline $\begin{array}{l}38 \\
39\end{array}$ & Tijolo & $\begin{array}{l}\text { burro } \ldots . . \\
\text { prensado. }\end{array}$ & 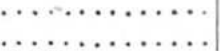 & $\begin{array}{l}0,250 \\
0,230\end{array}$ & 0,110 & 0,065 & 3,060 \\
\hline- & $\Rightarrow \quad 1$ & rebatido or & drilho......... & 0,300 & 0,150 & 0,030 & 2,200 \\
\hline - & D & " & $\quad \ldots \ldots \ldots \ldots$ & 0,260 & 0,140 & 0,035 & 2,000 \\
\hline 40 & & d'alvenaria & $\ldots \ldots \ldots \ldots \ldots$ & (), 230 & 0,110 & 0,035 & $1, i 65$ \\
\hline$n$ & . & , & $\ldots \ldots \ldots \ldots \ldots$ & 0,230 & 0,110 & 0.030 & 1,400 \\
\hline 46 & " & eurvo, de $r$ & variavel. .... & 0,230 & 0,120 & 0,070 & 3,000 \\
\hline 41 & $n$ & furado de? & iracos.......... & 0.230 & 0.110 & 0,075 & 2,680 \\
\hline$n$ & n & » & $" \quad \ldots \ldots \ldots \ldots$ & 0,250 & 0,120 & 0.070 & - \\
\hline - & ” & $"$ & $» \quad \ldots \ldots \ldots \ldots$ & 0,230 & 0,130 & 0,050 & 1,600 \\
\hline - & " & » & $\quad \ldots \ldots \ldots$ & 0,250 & 0,120 & 0.035 & 1,400 \\
\hline 42 & ” & 》 & $n \quad \ldots \ldots \ldots$ & 0.230 & 0,110 & 0,100 & 3,750 \\
\hline ” & $n$ & $-\infty$ & $n \quad \ldots \ldots \ldots \ldots$ & 0,230 & 0,110 & 0,070 & 2.680 \\
\hline 43 & - & ” & $" \quad \ldots \ldots \ldots \ldots$ & 0250 & 0,250 & 0.120 & 9,000 \\
\hline- & $D \quad c$ & d'alvenaria & rado 2 canaes. . & 0230 & 0,110 & 0,035 & 1,700 \\
\hline 45 & $"$ & , & $\triangle 3$ & 0,230 & 0,110 & 0,040 & 1,460 \\
\hline ఎ & » & para tabiqu & macho e femea. & 0,360 & 0.190 & 0055 & 4,680 \\
\hline 51 & Corrim & não para ba & stres........ & 0,400 & 0,330 & 0,120 & - \\
\hline 48 & Tijolo & para cimal & $\ldots \ldots \ldots \ldots \ldots \ldots$ & 0,220 e 0,150 & 0,110 & 0070 & - \\
\hline 50 & & $"$ & & $0,230^{\circ}$ & 0,110 & - & - \\
\hline 52 & Tijolo & burro silic & aleareo ......... & 0,230 & 0.110 & 0,070 & 3,400 \\
\hline 53 & $\because p$ & para cimalt & ilico calcareo. & 0,220 e 0,150 & 0,110 & 0.070 & 2.620 \\
\hline 54 & & » & $"$ & 0.23 e 0.130 & 0.120 & 0,070 & 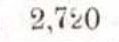 \\
\hline
\end{tabular}

Figuras 37: Tabela com dimensões de tijolos 


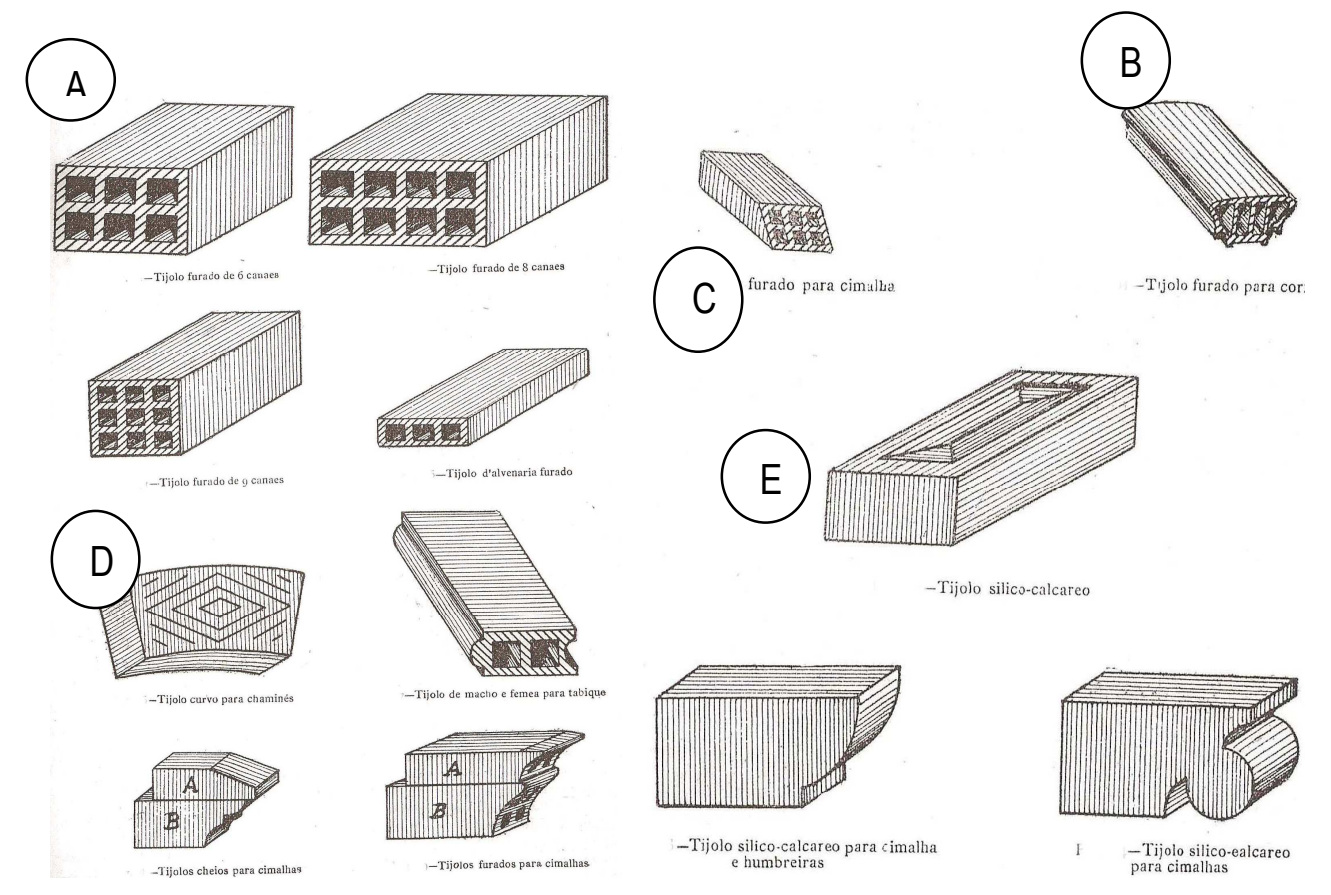

Figura 38: Vários tipos de tijolos: tijolos maciços - de burro, prensado e alvenaria (A), tijolos furados - 2, 6, 8, 9 e 3 canais (B), tijolos ornamentais - para cimalha e para corrimão (C), tijolos tipo sílico-calcáreo - comum e para cimalhas (D), e outros tijolos ornamentais - curvos para chaminé, para tabique e para cimalhas $(E)$

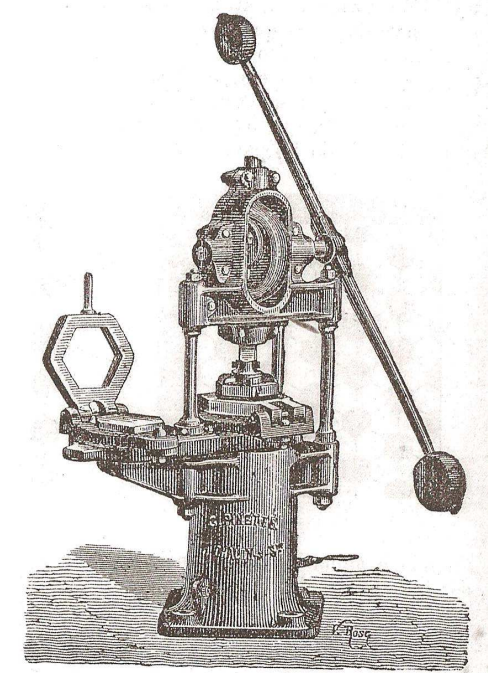

Figura 39: Prensa de parafuso para moldar ladrilhos
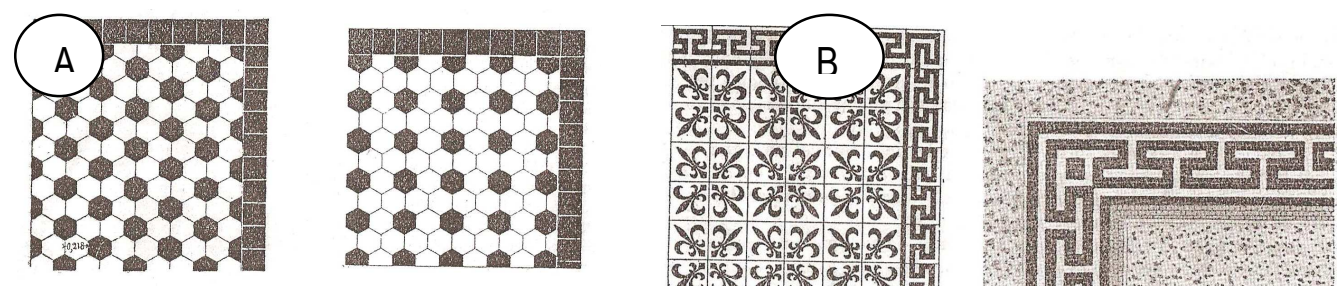

Figura 40: Modo de dispor ladrilhos: hexagonais $(A)$ e quadrados (B)

${ }^{37}$ Figuras 36 a 40: SEGURADO, J.E.S. Alvenaria e cantaria. 4. ed. Lisboa, Bertrand, Biblioteca de Instrução Profissional.1908, 19-?, pp. 75, 61, 58, 69 e 70 respectivamente. 
Vale lembrar que, no final do século XIX, em São Paulo, construíam-se paredes com largura exagerada, em grande parte devido à inexperiencia construtiva e à desconfiança dos construtores paulistanos com a nova técnica da alvenaria de tijolos.

$\mathrm{Na}$ sede da fazenda Pau d'Alho, observamos que a alvenaria de tijolo do encamisamento, por conta da reforma (visto acima do forro - único local onde podemos avistá-la) apresenta-se em aparelho irregular, porém muito próximo do aparelho losango que vimos (Figura 41). Os tijolos ali são prensados, com medidas iguais aos antigos, conforme vimos na tabela, apenas um centímetro mais comprido: $0,24 m \times 0,11 m \times$ $0,07 \mathrm{~m}$. Oustros tijolos de barro possuem a insígnia "B.A.", muito provavelmente em referência ao proprietário Barão de Anhumas.

As paredes externas da sede possuem dimensões que variam entre 0,37 e 0,61m no total (Figura 42), sendo que a parte de tijolo ocupa $0,15 \mathrm{~m}$ de largura, mesma largura das aberturas das janelas e portas. A medida restante, portanto - e variável -, corresponde à taipa de mão, situada no lado interno da parede. Já as paredes internas são constituídas de tijolos de barro maciço.

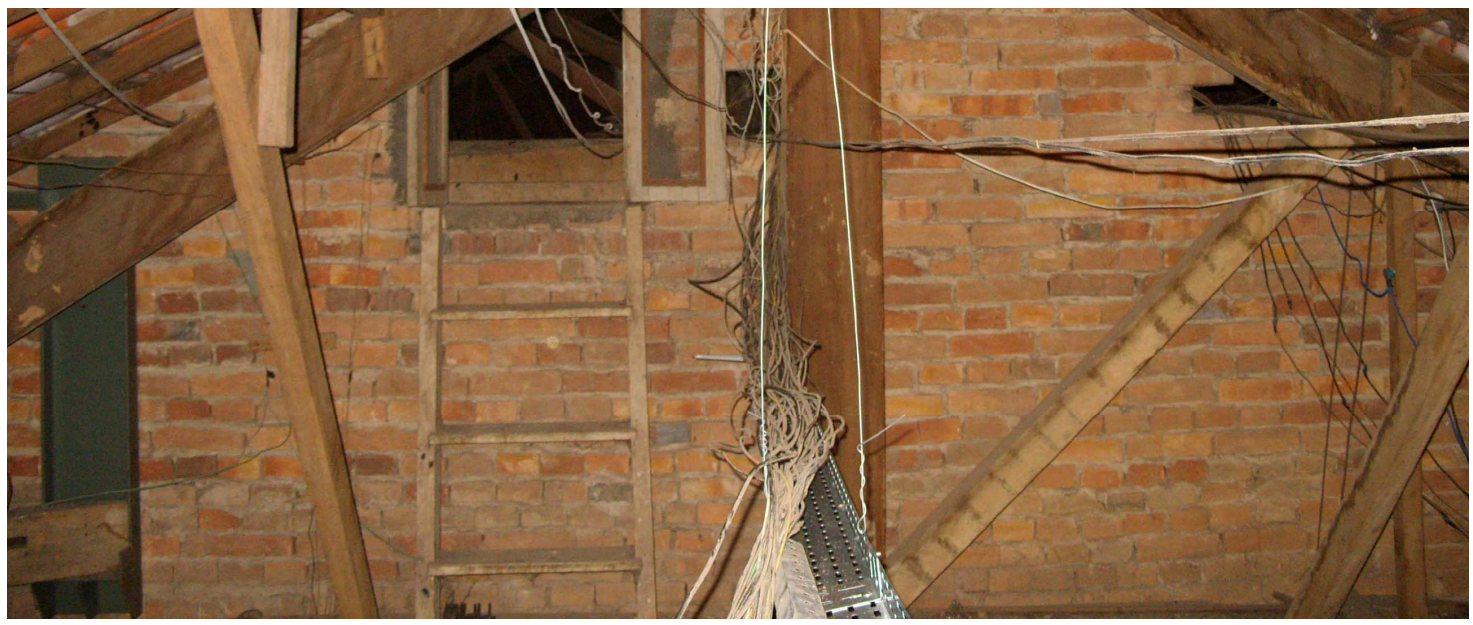

Figura 41:Parede de tijolos na sede fazenda Pau' Alho, visto acima do forro: aparelho flamengo

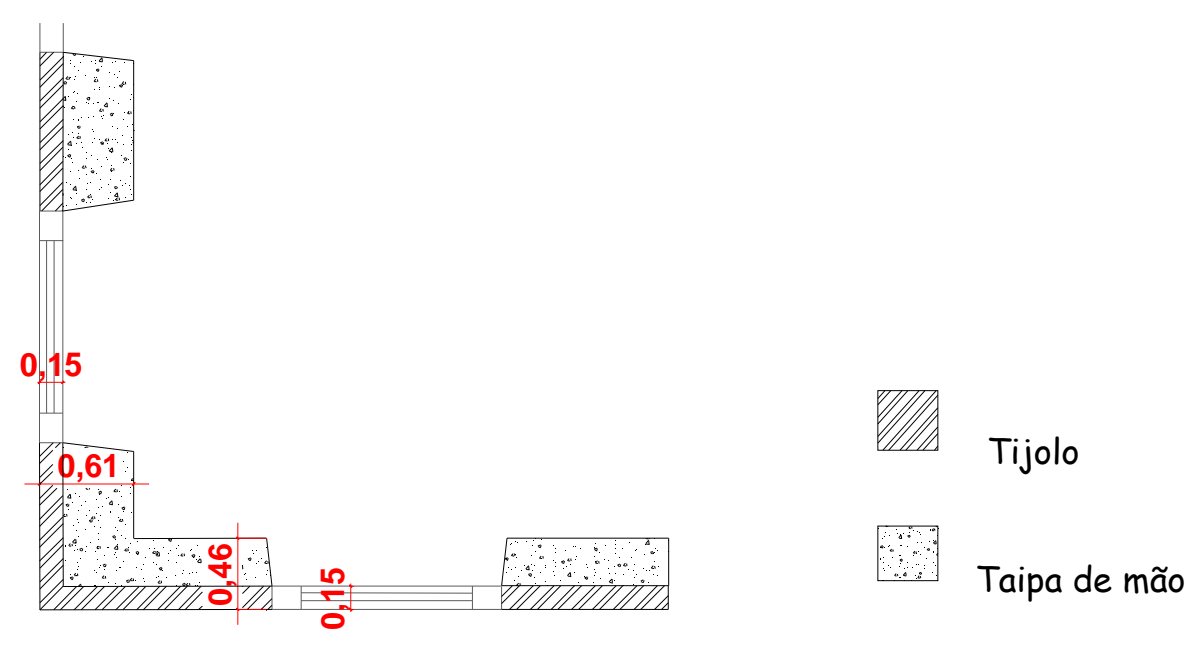

Figura 42: Detalhe da parede externa atualmente composta de taipa de mão e tijolo 
Quanto aos pisos, na sede baixa da fazenda Pau d' Alho encontramos, na maioria dos cômodos e, principalmente nos dormitórios, saletas e alcovas, lajotas simples de barro, de 0,20 X 0,20m (ver Figura 43), conforme fotos antigas do acervo da atual proprietária. Material semelhante foi usado no alpendre - construído no final do século XIX na sede alta - assim como na varanda e dispensa. Com o decorrer do tempo, esse piso foi mantido em parte da sede baixa, no dormitório e na saleta, enquanto na sede alta não existe mais, foi substituído por ladrilhos modernos na ocasião do evento "Campinas Decor 2004".

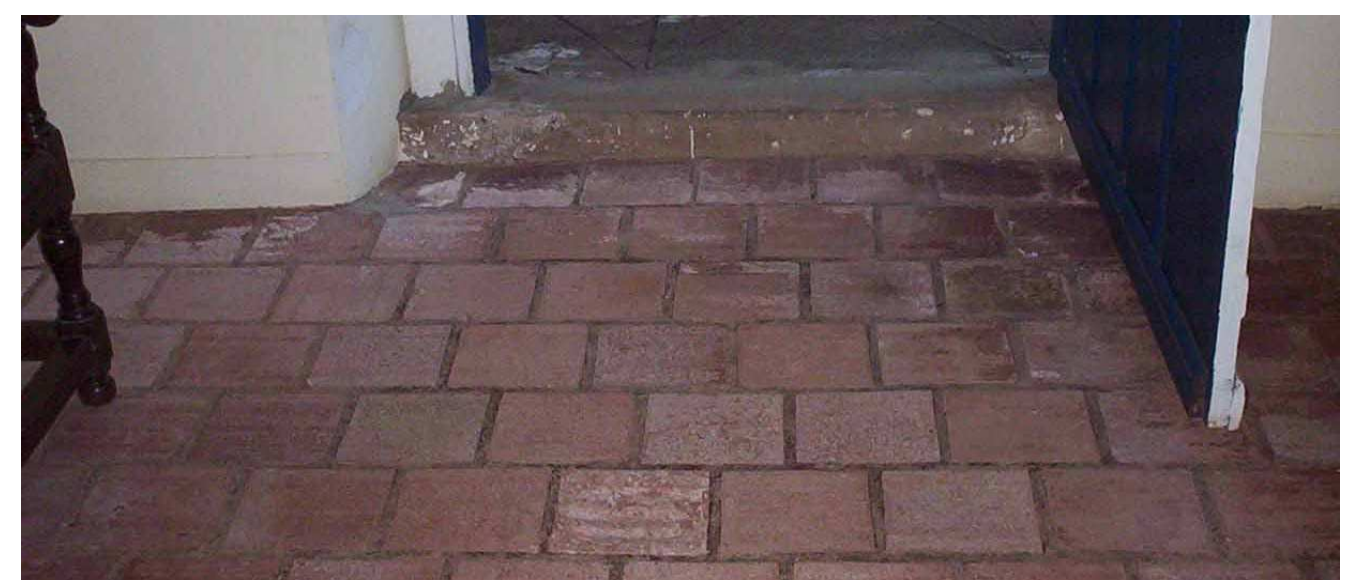

Figura 43: Lajotas de barro que foram mantidas na sede baixa da fazenda Pau d'Alho

Não foram apenas as estruturas de madeira que passaram a ser menos utilizadas quando o tijolo começou a se popularizar, as alvenarias de pedra também foram perdendo seu espaço, sendo mais aconselhadas para alicerces, muro de arrimo e revestimento, como veremos a seguir.

\subsubsection{Alvenaria de pedra}

A alvenaria de pedra tem origem muito antiga, desde o período colonial, e sua utilização foi mais constante no litoral, onde as pedras eram abundantes.

No assentamento, as pedras eram mergulhadas na argamassa, sem deixar vazios. A argamassa devia ser preparada com cal rica em areia não muito grossa, porque o seu fim é encher os intervalos e juntas, e não para unir e segurar as pedras. A segurança das pedras era obtida com o seu peso e a sua espessura ${ }^{38}$.

\footnotetext{
${ }^{38}$ RAINVILLE, Cesar. O Vinhola Brasileiro. Eduardo e Henrique Larmmert, Rio de Janeiro, 1880, p.131.
} 


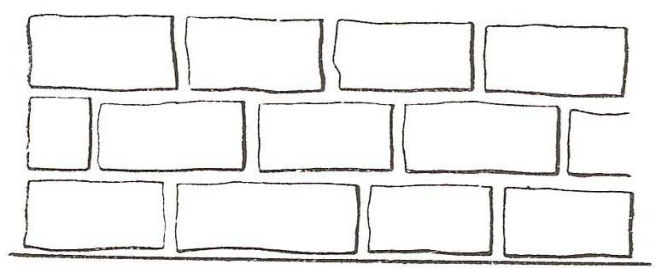

(A)

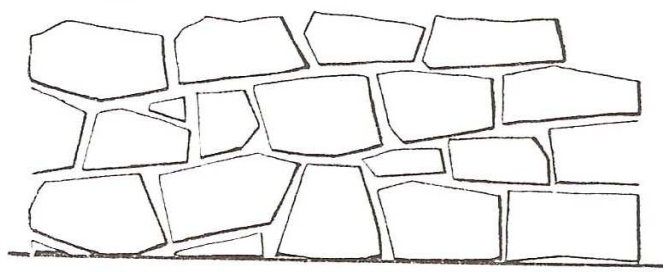

(B)

Figura 44: alvenaria de pedra retangular $(\mathrm{A})$ e irregular $(\mathrm{B})^{39}$
Apesar de as pedras serem irregulares, o serviço devia ser feito em fiadas, em camadas sucessivas de 0,40 a 0,50m cada uma, segundo Albuquerque ${ }^{40}$. Para melhor amarração, deviam-se intercalar pedras pequenas com grandes. A alvenaria de pedra também podia ser executada para ficar aparente, a chamada alvenaria de pedra aparelhada, geralmente com blocos de forma retangular (Figura 44A). Os blocos também podiam ser usados assim como saíam da pedreira, o chamado aparelho irregular (Figura 44B). Dependendo da ferramenta utilizada, o aparelho de pedra era designado, como por exemplo, cantaria de picão, cantaria de picola, cantaria de escoda ${ }^{41}$, etc - ver algumas ferramentas na Figura 45.
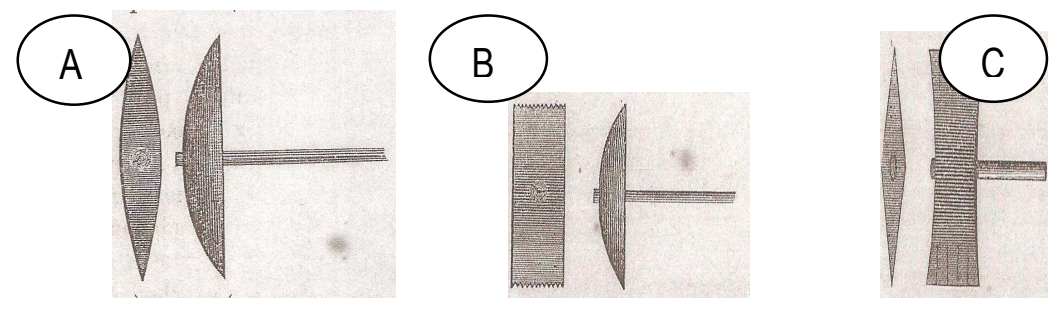

Figura 45: Ferramentas para trabalho de pedra: picão $(A)$, picola $(B)$ e escoda $(C)^{42}$

$\mathrm{Na}$ região de Campinas, a alvenaria de pedra foi muito pouco utilizada, pois dependia da presença das pedras nas proximidades ou dentro das fazendas. Na fazenda Pau d' Alho, a pedra foi utilizada apenas no embasamento da sede para a taipa de mão, quando foi construída nos anos de 1860, como vimos no início do subitem 3.2, referente às fundações. Em outras edificações na fazenda, foram utilizadas essa mesma técnica, tanto com paredes de taipa quanto com paredes de tijolos. Com a reforma, a técnica perdeu totalmente seu valor, não sendo mais utilizada.

\footnotetext{
${ }^{39}$ ALBUQUERQUE, Alexandre. Construções Civis. São Paulo: Empresa Gráfica da Revista dos Tribunais, 1952, p. 97.

40 Idem., p. 97.

41 LEITÃO, Luiz Augusto. Curso Elementar de Construções. Lisboa, Imprensa Nacional, 1986, pp. 15 a 17.

42 idem., pp. 15 e 16.
} 
Enquanto o tijolo ocupava cada vez mais o lugar das estruturas de madeira e alvenarias de pedra, no início do século XIX, na Europa, já era comum o uso da estrutura de ferro reforçando a alvenaria de tijolo. Adentraremos nesse assunto a seguir.

\subsubsection{Estrutura metálica}

Na Europa, os primórdios de casos das colunas de ferro são citados por Villalba, que relata seu uso em naves de igrejas e também de arco misto atirantado ${ }^{43}$. Em 1776, já se fundiam os primeiros perfis industriais para elementos estruturais (Figura 46). Já na metade do século XIX, com o advento do forjado metálico, foi introduzido um novo conceito de estrutura metálica, as vigas, graças a avanços de cálculos da engenharia estrutural. No final do referido século, as peças de ferro passaram a ser importadas, através de numeração, e montadas, em partes, na capital paulistana, prosseguindo para o interior. Em Campinas, essas estruturas seriam muito usadas mais tarde, nos coretos de praças, como o do antigo Passeio Público (atual centro de Convivência Cultural) e o da Praça Carlos Gomes, reformada por Ramos de Azevedo no início do século XX, e em outras suas obras, principalmente públicas e, inclusive, em sede de fazendas, como a fazenda São Vicente (Campinas) e Ibaté (próximo a São Carlos), sustentando os alpendres. Na sede da fazenda Pau d' Alho, o ferro foi utilizado como ferro fundido ornamentado no gradil e no portão do alpendre na sede alta, o que se repete na grande porta, com duas folhas que dão acesso ao quintal, na sede baixa.
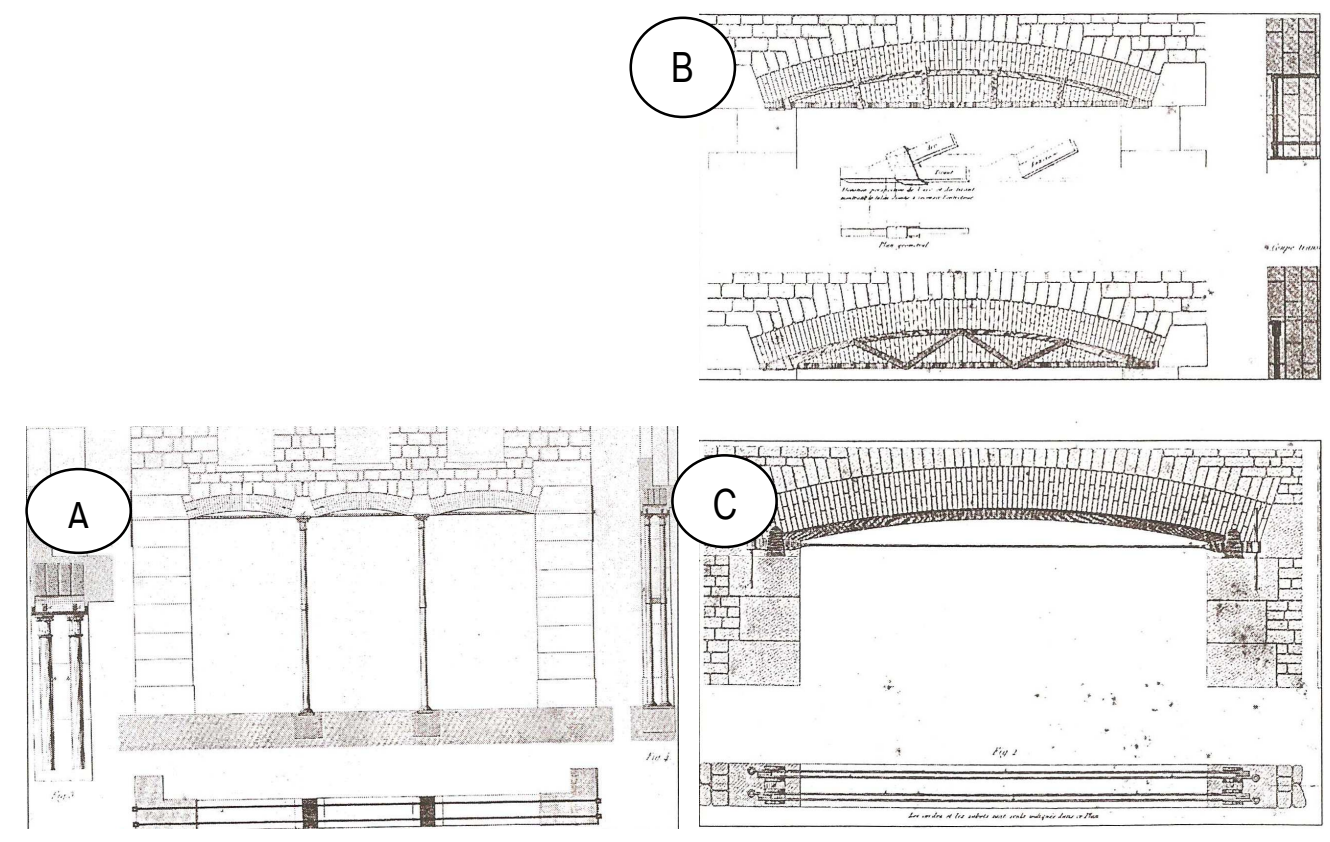

Figura 46: Exemplos de arcos mistos atirantados: colunas de ferro $(A)$ e vigas curvas $(B \text { e } C)^{44}$

\footnotetext{
${ }^{43}$ VILLALBA, Antonio Castro. História de la construcción arquitectónica. Edicions UPC, pp. 308 a 324.

44 Idem para figuras 46 e 48, pp. 308, 310 e 316 respectivamente.
} 


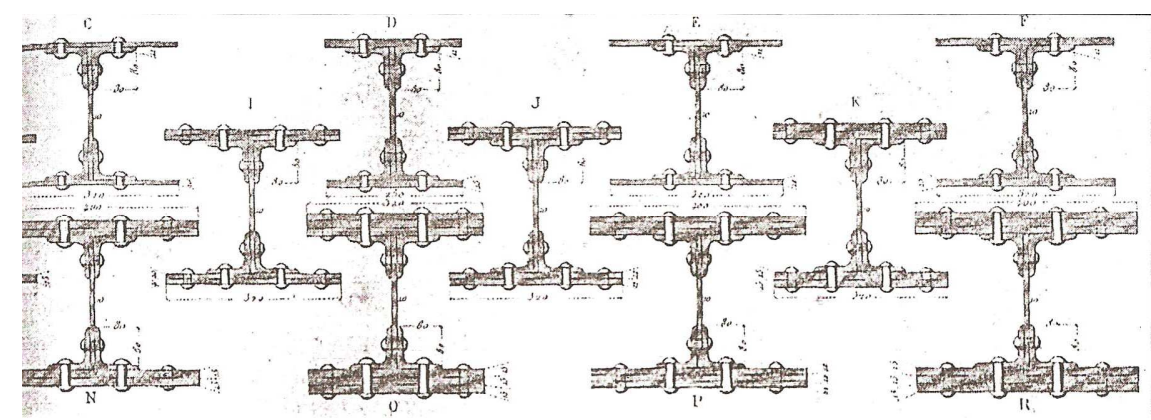

Figura 47: Primeiros perfis estruturais, início do século XIX

Os perfis mais usados eram os de viga armada, com a finalidade de suportar grandes cargas. A viga armada era sempre a combinação de um certo número de barras laminadas perfiladas e de largas barras chatas, largas em todo o comprimento da viga, ou seja, de alma cheia. As vigas também podiam ter almas descontínuas, que eram mais leves, com almas ligadas por barras verticais e cantoneiras, como os exemplos da Figura 49 abaixo.
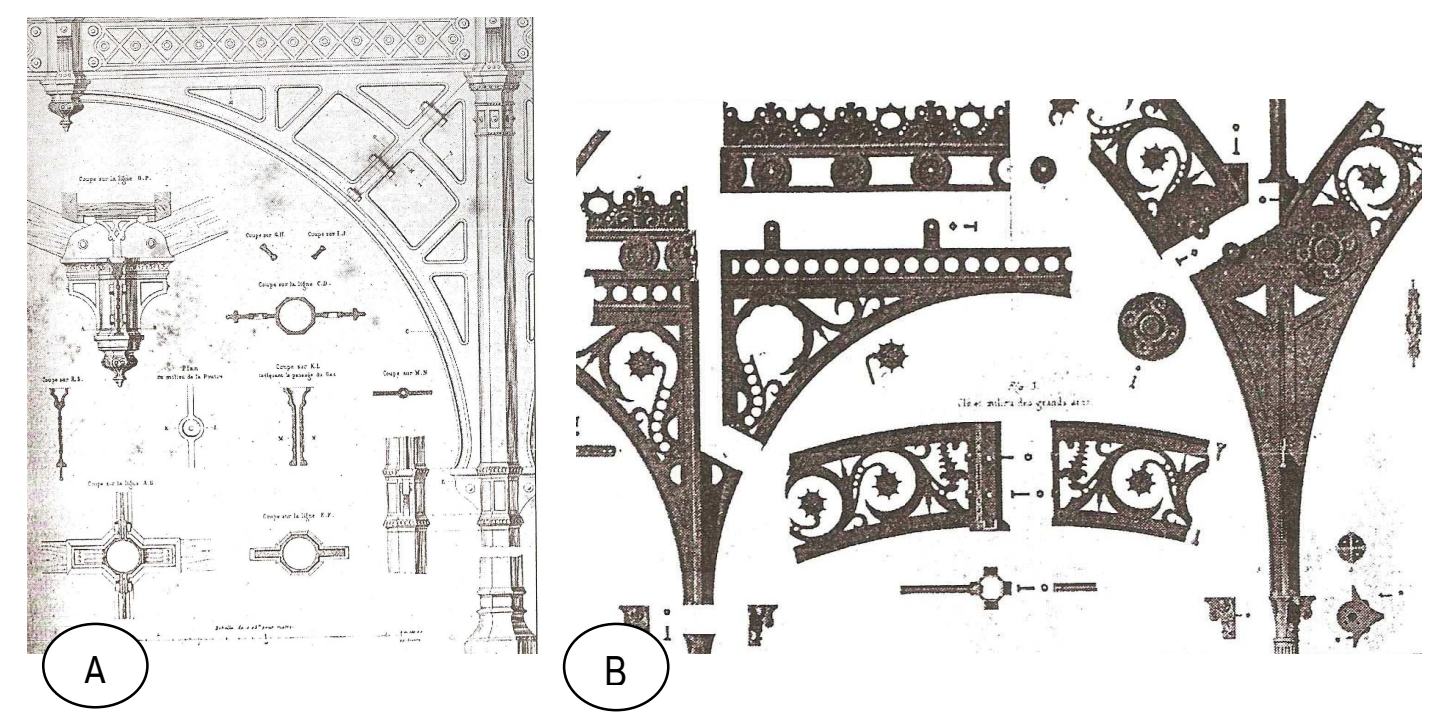

Figura 48: União de viga e coluna de fundação $(A)$ e detalhes de armaduras de ferro ornamentadas (B)
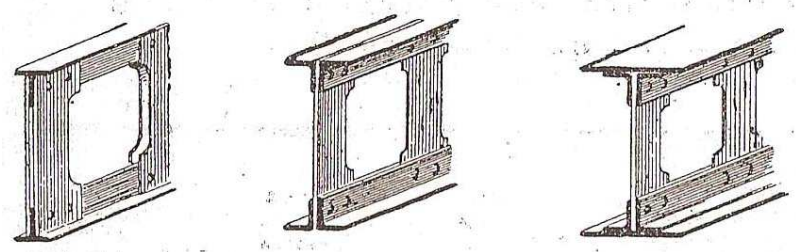

Figura 49: Vigas de almas descontínuas ${ }^{45}$

45 SEGURADO, J. E. S. Construção Civil: Materiais de construção. Biblioteca de Instrução Profissional, Livraria Bertrand, 19-?, Volume I, pp. 52. 
Até o início do século XX, quando se começou a utilizar o cimento armado em São Paulo, a função do esqueleto de ferro era separada da vedação de tijolos, até então as paredes tinham ambas as funções. Nesse período, era costume ainda executar edifícios com um ou dois pavimentos em paredes de tijolos e, nos edifícios de três ou mais pavimentos, já se utilizavam as estruturas de ferro.

Na reforma da sede da fazenda Pau d' Alho, não sabemos se o ferro foi utilizado na estrutura. É possível que tenha sido, em meio às paredes de tijolos, pois há ocorrências dessa técnica em obras posteriores de Ramos, de maneira não muito evidente, por não se saber dessa especificação nos seus projetos. Contudo, há essa probabilidade, uma vez que a estrutura de ferro estava começando a ser utilizada na época.

Encerrando o estudo das estruturas, entraremos no estudo das argamassas, utilizadas tanto para o assentamento e impermeabilização das alvenarias como para revestimento e decoração. A seguir, veremos o seu estudo para assentamento e, em subitem mais adiante, referente aos acabamentos, veremos sobre sua outra finalidade.

\subsubsection{Argamassas}

As argamassas eram constituídas de aglomerantes, agregados miúdos e água. Os agregados miúdos podem ser pó de pedra ou areia, sendo essa mais comum. Quanto aos aglomerantes, podem ser cal, cimento ou gesso. A seguir veremos sobre cal e cimento, mais utilizados para assentamento de alvenaria.

\subsubsection{Cal}

A cal - resultado da calcinação de pedras calcárias carbonatadas - era geralmente branca, com sabor cáustico e solúvel na água, obtida no estado pastoso, juntamente com a areia.

A cozedura era feita em diferentes fornos: medas (Figura 50A), fornos intermitentes (Figura 50B), fornos contínuos (Figura 50C), fornos de gás ou a carvão ${ }^{46}$. Depois da cozedura, as pedras de cal eram separadas em três classes: as "inteiramente cozidas", que aspergidas com água formavam uma pasta homogênea sem deixar resíduo; as "semi-cozidas", que depois de apagadas deixavam resíduos duros; e as "recozidas", cuja cozedura era feita em temperatura muito elevada. Por fim, a cal era extinta, isto é, hidratada, através de diferentes modos - fusão, imersão, aspersão e espontâneo - passando na água, de preferência de chuva, que tem menos ácido

46 SEGURADO, João Emilio dos Santos. Materiais de construção. Biblioteca de Instrução Profissional, Livraria Bertrand, 19-?. Volume I, pp. 72 a 84. 
carbônico. Só então a cal era reduzida a pó, sendo peneirada, para extrair as substâncias estranhas, e, em seguida, ensacada para transpor grandes distâncias.
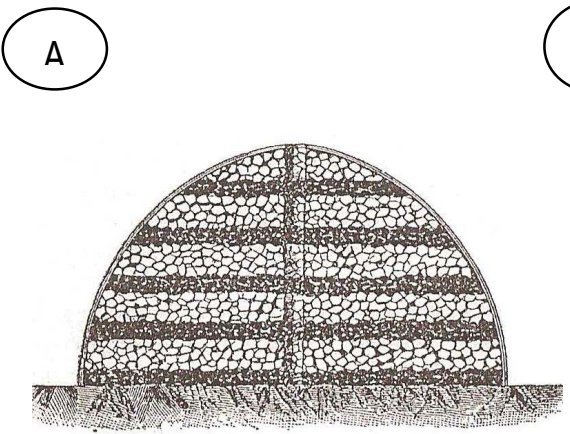
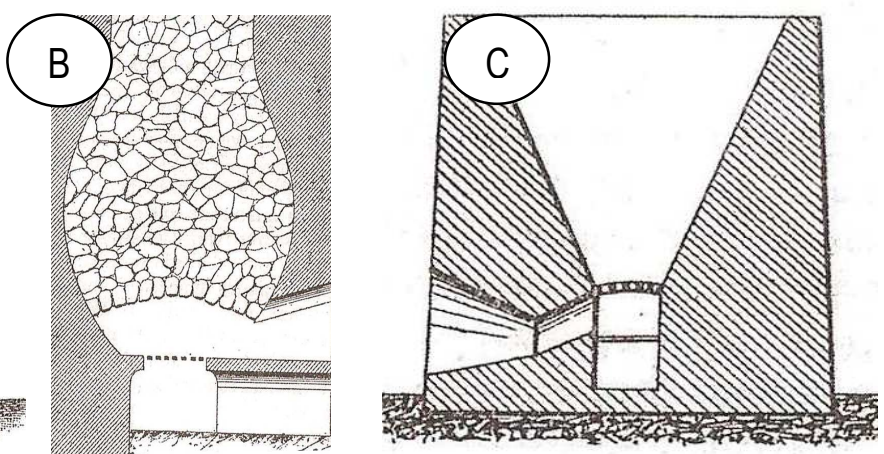

Figura 50: Cozedura de cal em medas (A), em fornos intermitentes (B) e em fornos contínuos (C)

O calcário, quando continha uma certa quantidade de argila antes de ser aquecido, produzia cal hidráulica, com resistência intermediária maior que a cal. Sabe-se que, em São Paulo, no início do século XX, comprava-se a cal virgem, em pequenas partidas e queimadas imediatamente, e fazia-se a extinção no próprio canteiro, alguns dias antes do seu emprego.

A cal utilizada nas construções em Campinas, provavelmente, era importada da região, vemos, nas folhas de pagamento encontradas na Catedral Metropolitana de Campinas, que há registro de frete de sacos de cal vindas de São Paulo nos primeiros anos da década de 1880, o que não deveria ser diferente no caso das fazendas campineiras, inclusive a Pau d'Alho. Certamente, nessa época, o componente da argamassa utilizada no assentamento dos tijolos do encamisamento na sede da fazenda foi a cal, enquanto o cimento ainda não era muito comum.

Mais tarde, sabemos que alguns dos fornos de cal viriam a ser produzidos no estado, na região de Sorocaba, sendo construídos pelo Banco União em 1894, quando Ramos de Azevedo, já instalado na capital, chefiava a Carteira Imobiliária do banco (Figura 51).

\subsubsection{Cimento}

Já os calcários que produziam de 20 a 40\% de argila, com a cozedura, davam origem aos cimentos, tendo resistência maior que a cal hidráulica. $\mathrm{Na}$ época, o cimento era classificado em dois grupos principais: o cimento romano, de presa rápida (em meia hora), e o Portland, de presa lenta (em vinte quatro horas $)^{48}$.

\footnotetext{
${ }^{47}$ Ibid., p. 76.

48 Ibid., pp. 84 a 96.
} 


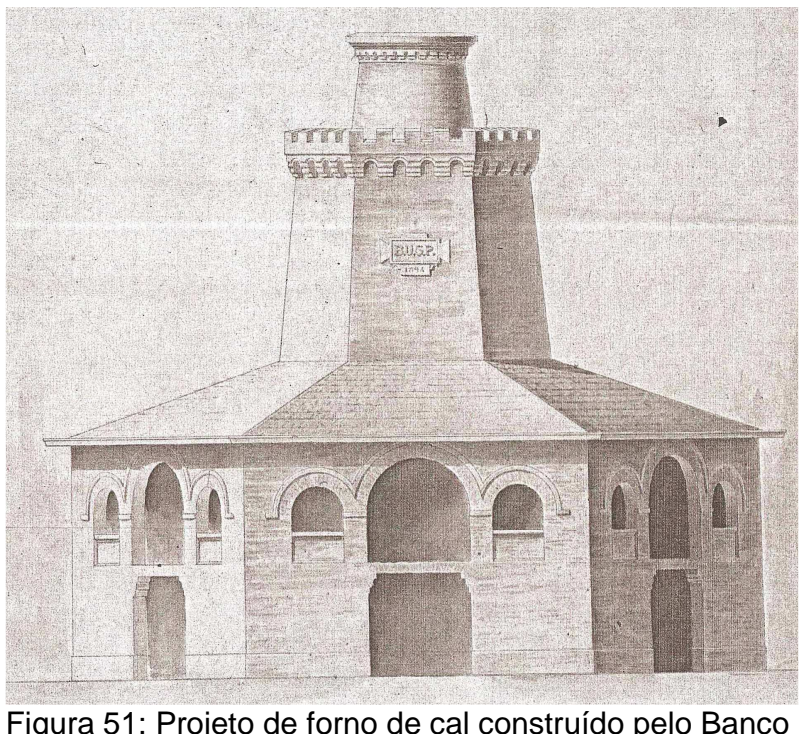

Figura 51: Projeto de forno de cal construído pelo Banco União em $1894^{49}$
O cimento romano referia-se ao antigo uso da argamassa pelos romanos. Quando aplicado após a saída do forno, fazia presa instantaneamente, sendo recomendável ficar exposto ao ar para facilitar o seu manuseio. 0 cimento fazia pasta com a água, diminuindo seu volume, ao contrário da cal. Após a presa, sua resistência variava, sendo considerada alta, assim como a dureza e a impermeabilidade, aderindo muito bem a todos os materiais. Porém, sensível na variação de temperaturas, se a temperatura subia, a presa era mais rápida, se descia, era mais lenta. $\mathrm{O}$ cimento romano era muito empregado, especialmente, nas construções hidráulicas, nas molduras delicadas revestidas de estuque, no refechamento das cantarias e na fabricação de tubos de gás e água.

O cimento Portland, que deriva dos primeiros cimentos fabricados na Inglaterra, no início do século XIX, que se assemelhava a pedra "Portland", já era o mais usado no final do século $X I X$, apresentando todas as vantagens que o romano não apresentava na questão do manuseio após a presa. Aquele era, geralmente, um cimento artificial, obtido da mistura da cré e da argila. Depois de expurgado das impurezas do cimento, misturavam-se calcário e argila reduzidos a pó, e amassava-se com água, moldando-se tijolos. Estes, depois de bem secos, eram levados ao forno, e depois triturados, reduzidos a pó fino. $\mathrm{O}$ uso de cimento Portland era muito grande, desde revestimento de canos de esgoto, cisternas, reservatórios de água, fundações em terrenos úmidos, nas abóbadas, alvenarias e construções do chamado cimento armado.

O cimento armado, um outro tipo classificado por Segurado, já era comum na Europa no início do século XX. Constituído de esqueleto metálico e argamassa de cimento, era muito empregado em pilares, paredes, colunas, pavimentos, abóbadas planas, coberturas e canalização de água e esgoto. Já se faziam edifícios completos de cimento armado, que logo seriam o que chamamos hoje de construções de concreto armado.

Como dissemos antes, provavelmente o cimento não foi empregado nas argamassas utilizadas na fazenda Pau d' Alho, contudo, o estudo não é em vão, pois

${ }^{49}$ LEMOS, C. A. C. Ramos de Azevedo e seu escritório. São Paulo, Pini, 1993. 
sabemos que essa também pode ser uma outra probabilidade que,e devido ao curto espaço de tempo, não foi possível levar a cabo essa análise em laboratório. Mesmo com a não obtenção de uma certeza, vemos na fazenda a utilização, em meio das técnicas modernas para a época, de muitos componentes tradicionais. Familiarizar-se com as técnicas existentes, para Ramos de Azevedo, não é motivo de parar no tempo, mas um impulso para o desenvolvimento das técnicas construtivas.

Findo o estudo das fundações e estruturas, vamos partir para o estudo dos telhados.

\subsubsection{Telhados}

As coberturas podiam ser de telhados apresentados como de platibanda ou de beiral. O beiral era utilizado no período colonial, e a platibanda começou a ser utilizada com a popularização do tijolo e, consequentemente, do ecletismo.

No caso da platibanda, ficava escondido atrás do ático, as águas eram captadas pelas calhas e levadas para fora pelos condutores ou gárgulas. No caso do beiral, era visível, formando balanço sobre o prumo da parede, e as águas escorriam livremente, sem precisar de calhas e condutores. Porém, no caso da platibanda, apesar de mais moderna, tinha a desvantagem do não funcionamento das calhas ou condutores, pois podiam ser obstruídos facilmente pela ação do vento e entrada de sujeiras, podendo entrar água no interior do edifício. No segundo caso, a desvantagem - menor - ficava por conta das telhas, que podiam se levantar, também com a ação do vento. Nesse caso, podia ser com caibro aparente ou revestido.

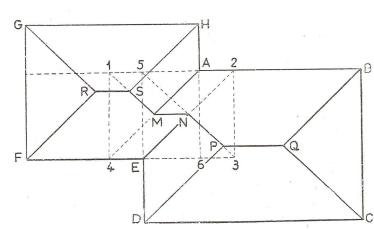

Figura 52: Telhado tipo marselhês ${ }^{50}$

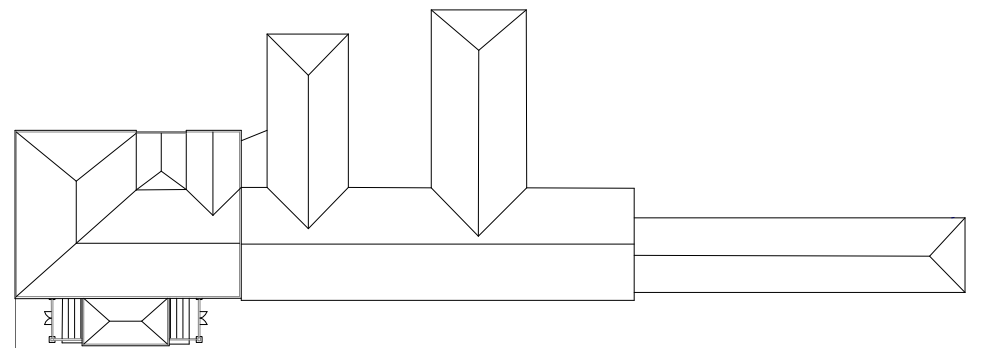

Figura 53: Telhado da sede fazenda Pau d' Alho: à direita e ao centro telhado mais simples de duas águas, à esquerda, na sede alta, telhado recortado

Como vemos na primeira gravura da sede da fazenda Pau d' Alho, os telhados apresentam os beirais usados nos tempos do Brasil colônia, associado à taipa, em toda a sua cobertura; já no final do século XIX, com a adoção da linguagem neoclássica na

\footnotetext{
${ }^{50}$ ALBUQUERQUE, Alexandre. Construções Civis. São Paulo: Empresa Gráfica da Revista dos Tribunais, 1952, p. 158.
} 
reforma de 1885 , o beiral da fachada frontal da sede baixa foi deixado de lado, e a cobertura ficou escondida na platibanda. Porém, na fachada posterior e em toda a elevação do depósito - cujo telhado se encontra em altura mais baixa -, o beiral se manteve, ganhando novos elementos como forro e condutores. A sede alta ganhou uma nova cobertura, encoberta por platibanda um pouco mais alta que da sede baixa. Com a adoção do novo estilo, os telhados ganharam mais diversidade de águas, que até então era comum de uma ou duas águas, ou até quatro águas, possibilitando, também, pelos avanços da estrutura, diversos ângulos. É o caso do tipo marselhês, de telha Marselha importada, que passou a ser o mais comum, conforme Figura 52. Na figura seguinte, podemos ver o telhado da sede baixa ao centro da figura, em duas águas, com dois puxados posteriores, separados com três águas cada, assim como do depósito à direita. $\mathrm{Na}$ sede alta, à esquerda, temos um telhado mais trabalhado: aqui, as duas águas do eixo central da sede baixa foram mantidas - estas mais altas em relação à sede baixa porém com um recorte na ponta, além de puxados de duas águas colados na outra. $E$, na parte frontal, um pequeno telhado independente para o alpendre, com quatro águas ${ }^{51}$.
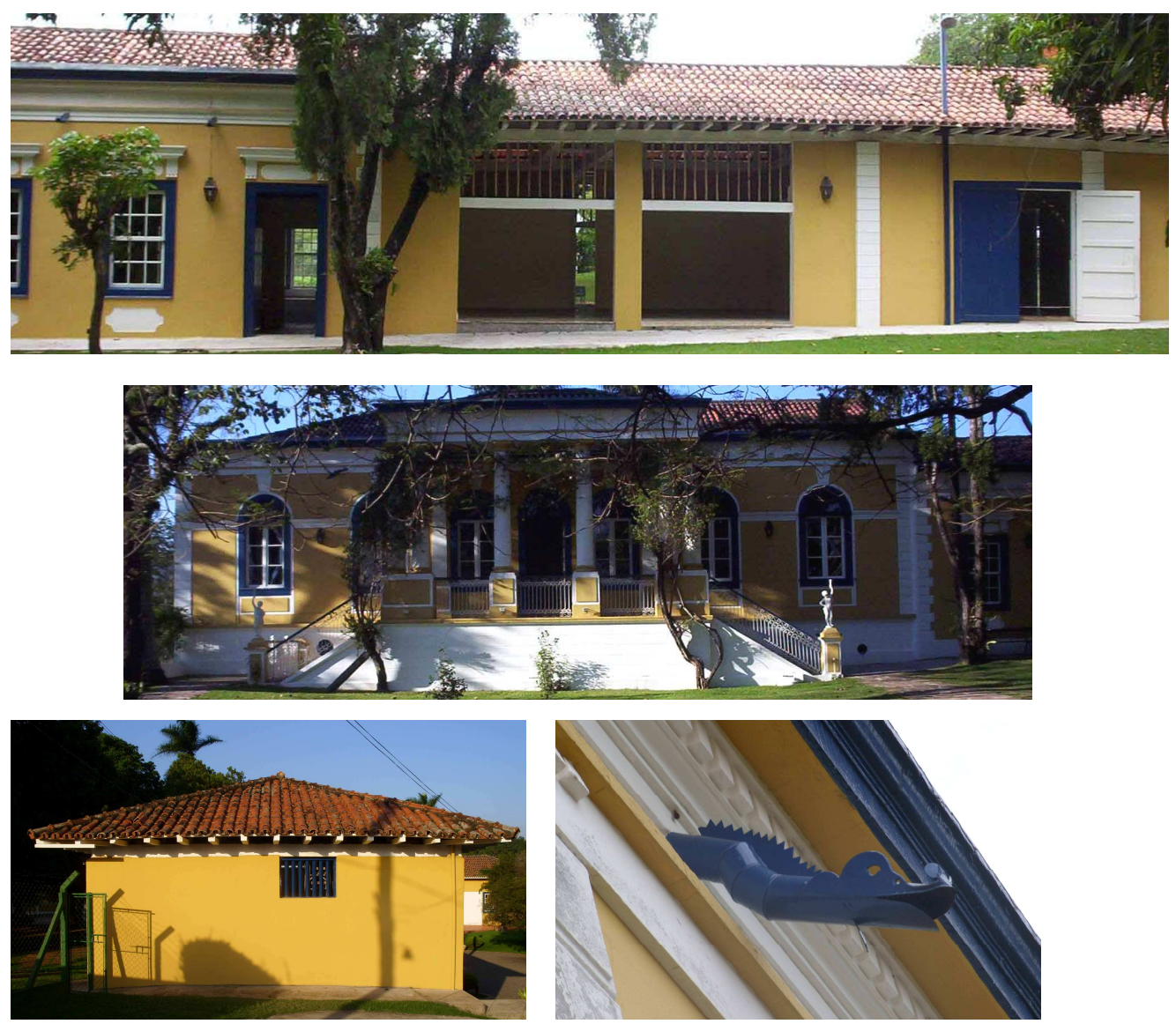

Figura 54: Vista frontal da sede baixa e do depósito, no qual vemos as diferenças de gabarito e cobertura; Figura 55: Vista frontal da sede alta, em que podemos ver a cobertura do alpendre; Figura 56: Vista lateral do depósito apresentando beiral; Figura 57: Detalhe da gárgula

\footnotetext{
${ }^{51}$ Ver disposição do telhado na ampliação da foto aérea tirada em 1951 na Imagem 15 do anexo 4.
} 
Em toda a fachada frontal da sede foi colocada a gárgula, um elemento para desaguar, afastada da parede. Foi trazida da Europa, sendo muito utilizada em catedrais góticas, em forma de animais e figuras monstruosas, aqui na forma aproximada de cabeça de dragão. As gárgulas são outro elemento que une a sede alta com a sede baixa, situadas ao longo da cornija da platibanda em ambas as sedes.

Os telhados podem ter estrutura de madeira ou metálica, cobertos com telha ou cobertura metálica, como veremos a seguir.

\subsubsection{Estrutura de madeira}

A estrutura de madeira era constituída por uma série de tesouras, compostas pelas empenas (peças inclinadas), unidas pelo tensor (peça horizontal) e apoiadas pelo pendural (peça central vertical). As escoras (peças diagonais) e os pontaletes (peças verticais) eram peças secundárias que auxiliavam no apoio das empenas e das escoras, respectivamente. Por cima, para o sustento das telhas, iam as terças (horizontalmente, por cima das empenas); no sentido contrário, por cima, os caibros; e, enfim, as ripas, filetes de madeira no mesmo sentido das terças. Por cima do tensor, ia o contra-frechal (terça inferior). A mão-francesa completava a estabilidade dessa armadura, evitando a flexão da cumeira e das terças. Essa estrutura pode ser vista na Figura 58A e as tesouras de madeiras mais usuais podem ser vistas na Figura 58B.

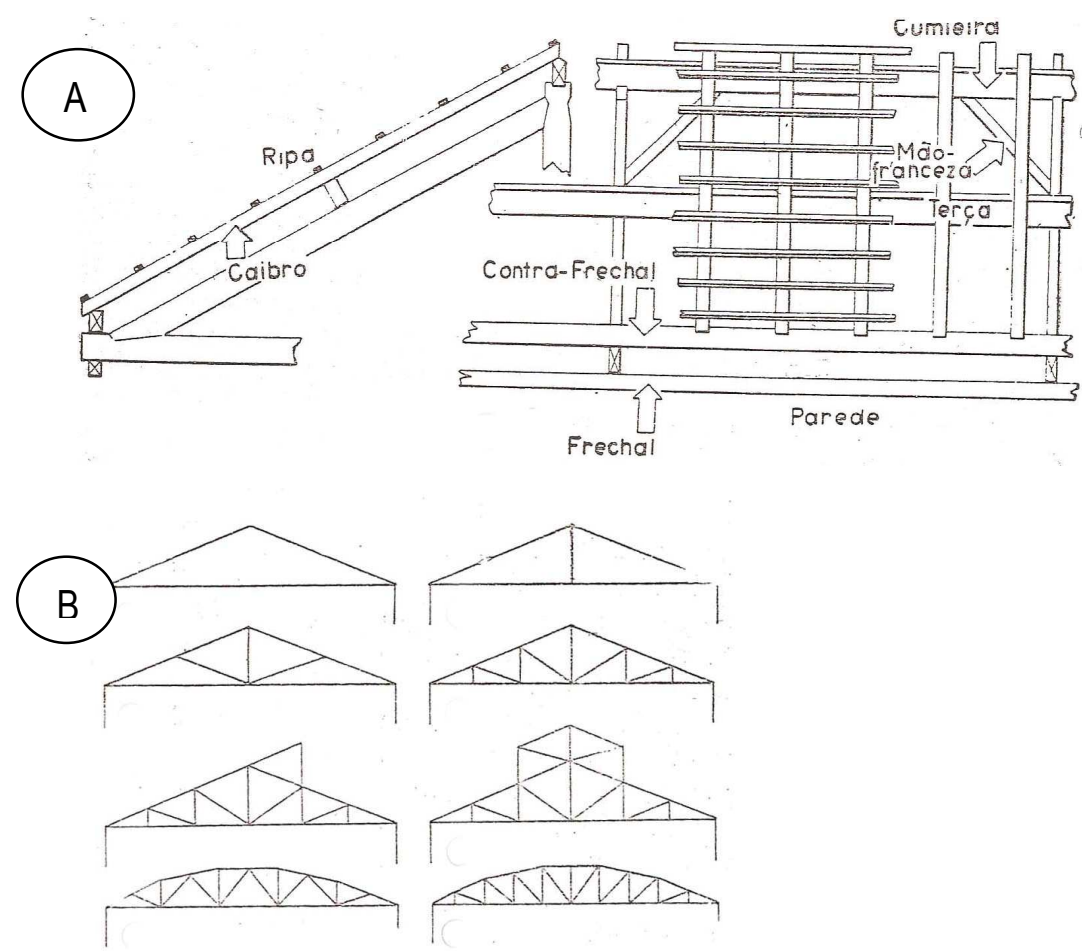

Figura 58: Representação de partes constituintes a estrutura de madeira $(A)$ e tesouras de madeira mais usuais $(B)^{52}$

52 ALBUQUERQUE, Alexandre. Construções Civis. São Paulo: Empresa Gráfica da Revista dos Tribunais, 1952, pp. 159 e 163. 
Na sede da fazenda na Pau d' Alho, constatamos a estrutura de madeira em toda a cobertura, tanto na sede como no depósito, com seus componentes tradicionais. Há indícios de outras madeiras, provavelmente de reformas posteriores à de 1885. Sabe-se, pela atual proprietária, que houve uma renovação do telhado no ano de 1950.

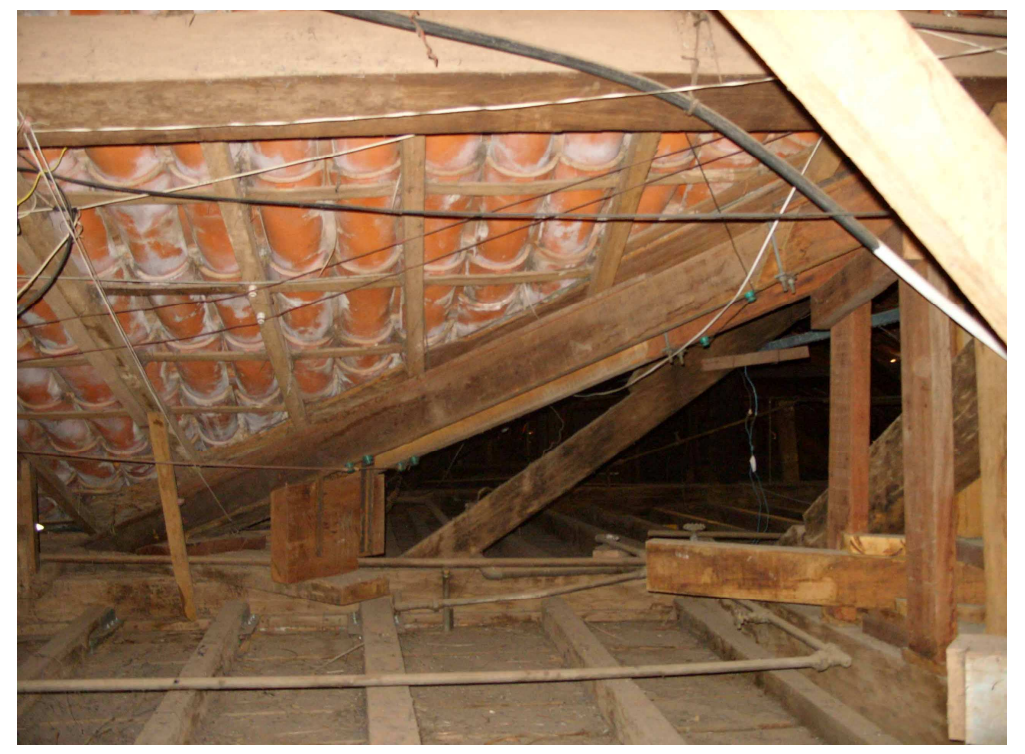

Figura 59: Tesoura de madeira na sede baixa da Pau d' Alho

\subsubsection{Estrutura metálica}

As estruturas de ferro nas coberturas, novidade na época, podiam ser tesouras, arcos, treliças ou pórticos, indicados para grandes vãos. Outra vantagem, além dos grandes vãos, era a sua desmontagem e montagem no local da obra, com parafusos e porcas. Já sua desvantagem estava no risco de incêndios. Nos encontros das peças metálicas também eram utilizadas chapas especiais, para que não fosse necessário cortar as peças no local. Esse material também permitia muita flexibilidade na união de estrutura de edifícios com a estrutura de telhados. Essas coberturas só iriam se popularizar, de fato, no início do século XX.

Embora não haja nenhum sinal da presença desse tipo de cobertura na fazenda Pau d' Alho, é importante ressaltarmos, para o estudo das técnicas construtivas locais que, nesse período, esse tipo de cobertura já estava despontando, inclusive em fazendas, nos galpões. 


\subsubsection{Telhas cerâmicas}

Os tipos de telhas mais comuns, utilizadas com estrutura de madeira, eram: as curvas - Romana ou Canudo - com 0,40m de comprimento (Figura 60A); a Holandesa (Figura 60B); as chatas - Marselha com 0,42X0,25m e Progresso (Figura 60C); o Telhão - com 0,55X0,14m (Figura 60D); e a de Escama - com 0,26X0,14m. Estas últimas, típicas do ecletismo, viriam a cobrir os sobrados, na cidade, ainda no final do século XIX.
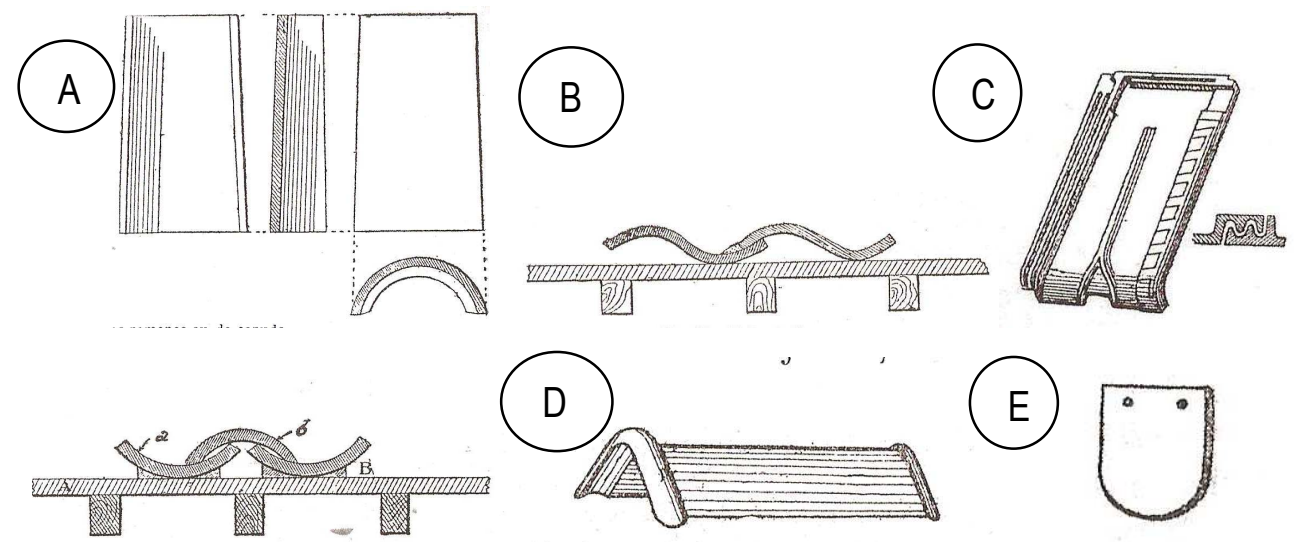

Figura 60: Telha Romana (A), Holandesa (B), Marselha (C). Telhão (D) e Escama (E) ${ }^{53}$

Em geral eram moldadas em fôrmas; depois de preparada a pasta e colocada num molde plano, era passada para um molde curvo. Para telhas chatas, usava-se mais prensa de parafuso. No fabrico da telha de Marselha, era muito usada a prensa rotativa denominada Prensa Revolver. A produção dessas telhas ainda não era comum aqui, por muito tempo foram importadas.

Apesar dos novos ares neoclássicos e o recorte da cobertura, foram utilizadas em toda a sede as telhas tipo capa e canal, próprias para o estilo anterior, mantendo um padrão colonial antigo. Essas telhas não são as mesmas que se encontram atualmente, pela reforma que houve em 1950, sendo trocadas por outras do mesmo modelo no século $X X$.

\subsubsection{Cobertura metálica}

As coberturas metálicas consistiam em chapas laminadas lisas e estriadas ou galvanizadas lisas e onduladas, sendo a última a mais usada para tal fim, principalmente quando curva. As chapas tinham dimensões variadas e serviam para outras funções, como as estriadas, que podiam ser usadas para varandas, escadas, tampas, etc.

53 SEGURADO, J. E. S. Construção Civil: Materiais de construção. Biblioteca de Instrução Profissional, Livraria Bertrand, 19-?. Volume I, pp. 62 a 64. 

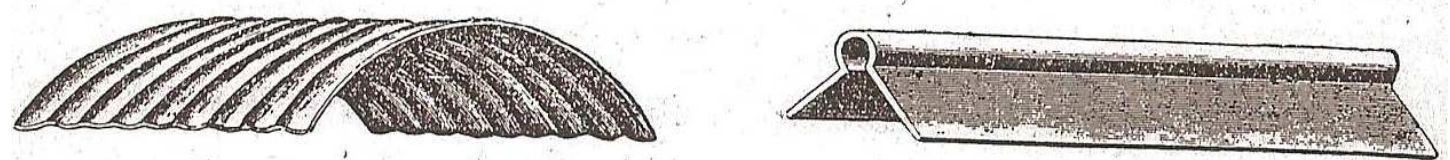

Figura 61: Chapa ondulada curva e chapa de ferro galvanizada ${ }^{54}$

As coberturas metálicas não estão presentes na sede da fazenda Pau d'Alho, assim como vimos no caso da estrutura metálica dos telhados, porém já era usadas nas fazendas.

Encerrando o estudo da estrutura de um edifício que envolve a fundação, estrutura e cobertura, passaremos agora a explicitar os elementos construtivos como escadas, aberturas e acabamentos. Ainda que não ocupem grande parte numa edificação, muitas vezes foram esses elementos que definiram o estilo e a construção de uma época.

\subsubsection{Escadas}

A classificação das escadas em externas e internas dependiam do tipo de material, elas podiam ser constituídas por pedras, tijolos, madeira ou ferro.

\subsubsection{Escadas de pedras e tijolo}

Apesar das diferenças de preparo técnico nas escadas de tijolos e de pedra, era necessário empregar argamassa hidráulica, de preferência, e preencher todas as juntas verticais cuidadosamente, para evitar a introdução de água da chuva. Em escadas mais apuradas, faziam-se degraus com focinho saliente - ver Figura 63 -, com saliência moldurada ${ }^{55}$. Em escadas cujos degraus não podiam ter lagura superior a $24 \mathrm{~cm}$, conseguia-se torná-las mais cômodas talhando as pedras em trapézio retângulo, cuja maior base forma o piso e, o lado inclinado, o espelho do degrau (Figura 62B).

A disposição de ambas as escadas, em planta, eram paralelas à fachada, a primeira em ambos lados, a segunda, em um lado apenas. Outras disposições que se podiam adotar eram escadas perpendiculares à fachada do edifício e curvas - ver Figura 64. As escadas exteriores pouco diferiam das empregadas no interior dos edifícios.

\footnotetext{
54 Idem, p. 48.

55 SEGURADO, João Emílio dos Santos. Alvenaria e cantaria. 4. ed. Lisboa, Bertrand, Biblioteca de Instrução Profissional, 19-?, pp. 216 a 219.
} 
(B)

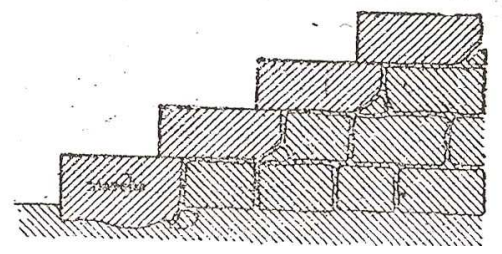

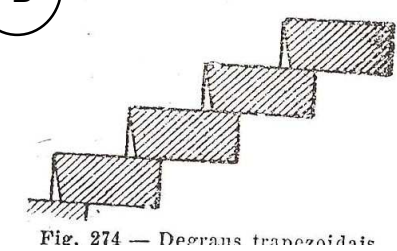

(C)

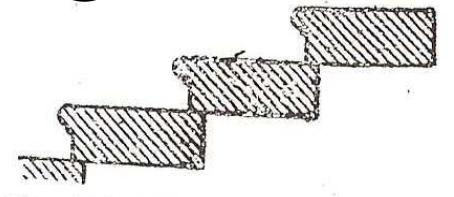

Figura 62: Degraus em ângulo reto (A), degraus trapezoidais (B) e degraus com focinhos $(C)^{56}$
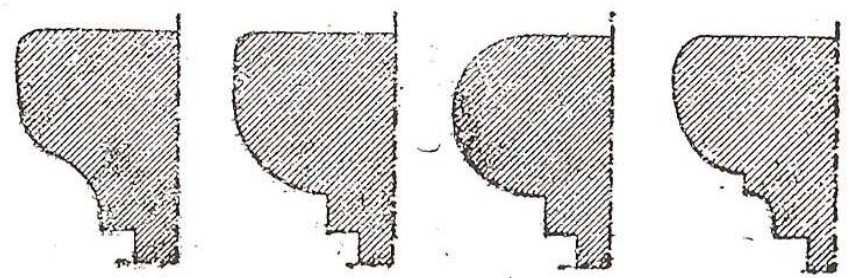

Figura 63: Tipos de perfis de focinhos de degraus ${ }^{57}$
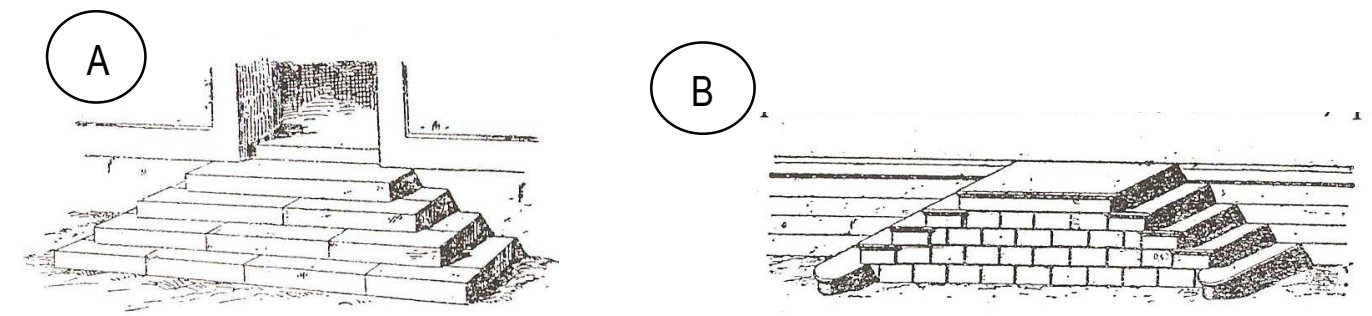

(C)

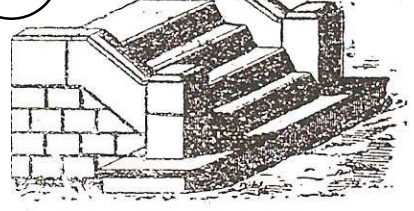

(D)

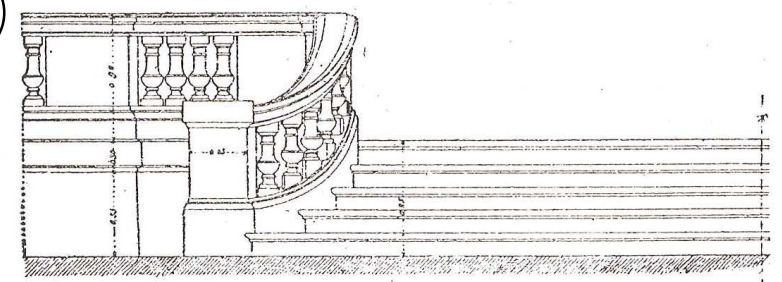

Figura 64: Escada perpendicular à fachada (A), escada paralela à fachada (B), escada entre muros paralelos (C) e escada curva (D) ${ }^{58}$

\subsubsection{Escadas de madeira}

A parte construtiva de uma escada de madeira compunha-se de pernas, degraus e corrimãos. Os degraus apoiavam-se em peças de madeira inclinadas, denominadas "pernas", entalhadas inferior e superiormente. Nesse caso, uma ou ambas as pernas podiam ser fixadas ou encostadas na parede ${ }^{59}$. Elas podiam ser entalhadas para degraus, recortadas, rebaixadas ou galgadas, conforme Figura 65 abaixo.

\footnotetext{
56 Idem, p. 217.

57 Idem, p. 218.

58 Idem, pp. 220 e 223.

59 Idem, pp. 294 a 314.
} 


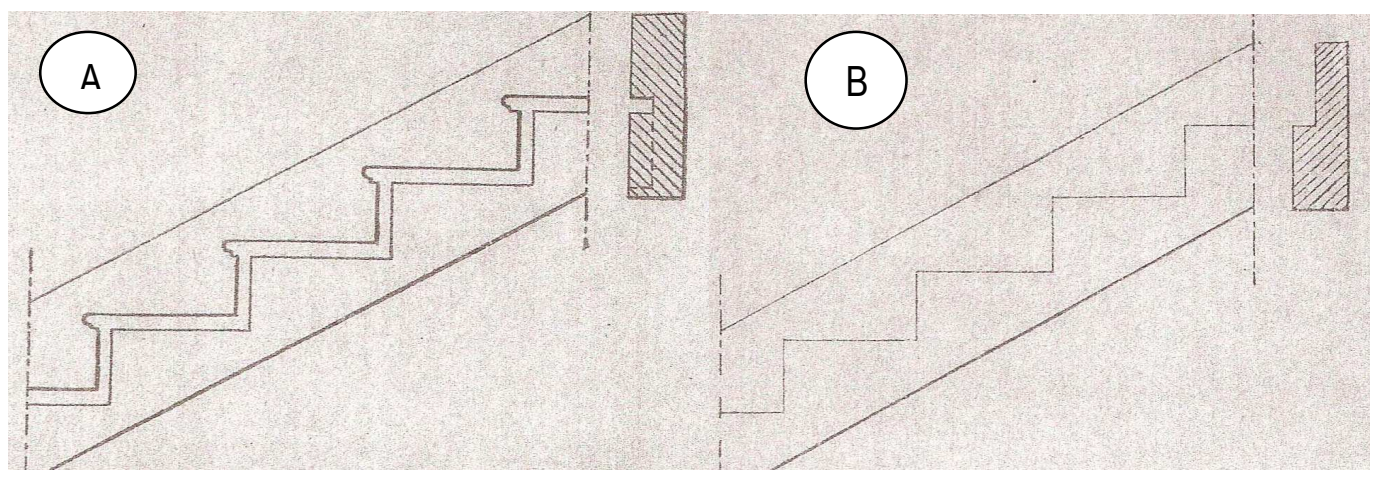

Figura 65: Escada com perna com entalhe para os degraus (A) e com perna rebaixada $(B)^{60}$

O degrau era constituído de duas partes, a horizontal, piso ou "cobertor", e a vertical, espelho ou "pé": a primeira geralmente faz saliência sobre o segundo, formando o "focinho", constituindo variadas molduras a depender do encaixe entre o espelho e o piso - ver Figura 66.

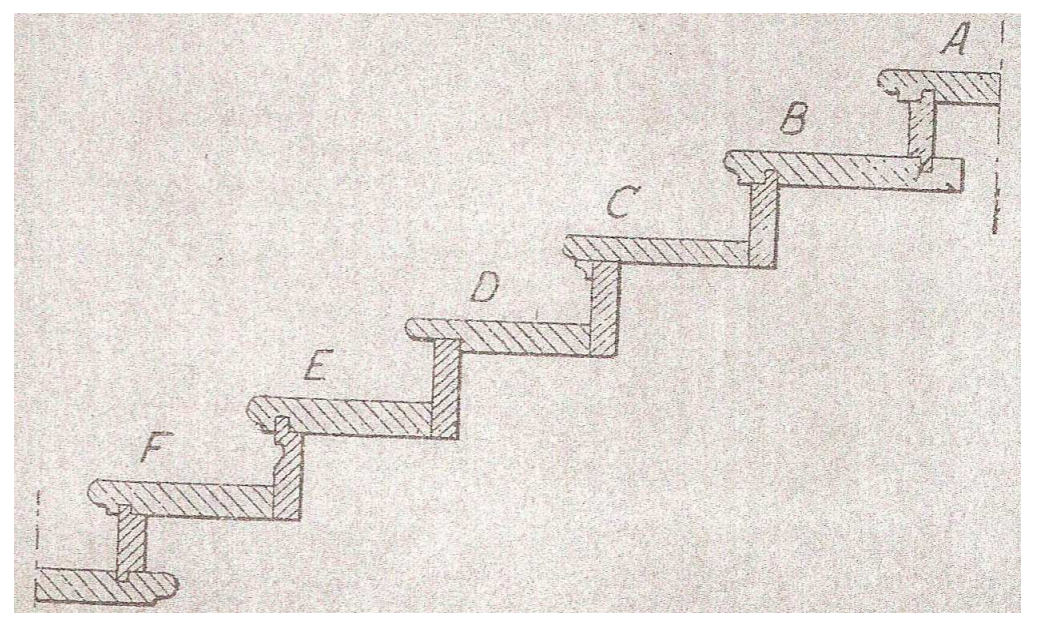

Figura 66: Diferentes tipos de degraus ${ }^{61}$

O corrimão, o apoio colocado a um ou dois lados da escada, era assentado nas paredes, sobre balaústre ou gradeamento apropriado. O balaústre podia ser fixado diretamente sobre o degrau, sendo pouco comum. $O$ recomendado era o gradeamento de ferro aparafusado nas pernas. Esse gradeamento geralmente começa com uma coluna mais ornamentada.

\subsubsection{Escadas de ferro}

Escadas ainda incomuns eram as escadas de ferro, que podiam ser das mais simples, para oficinas, ligadas com alvenaria ou com madeira, curvas e de ferro fundido ${ }^{62}$.

\footnotetext{
60 SEGURADO, J. E. S. Construção Civil: trabalho de carpintaria. Biblioteca de Instrução Profissional, Livraria Bertrand, 19-?, pp. 296 e 297.

61 Idem, p. 218.

62 SEGURADO, João Emíio Santos. Construção Civil: trabalho de serralharia civil. Biblioteca de Instrução Profissional, Livraria Bertrand, 19-?, pp. 154 a 162.
} 
As mais simples, "ligeiras", eram bem inclinadas, não recomendadas para habitações, e eram constituídas de duas pernas de viga "U", duas cantoneiras e degraus com chapas de ferro estriadas - ver Figura 67A. As escadas de ferro ligadas com alvenaria eram mais indicadas para ambientes exteriores, constituídas de pernas de viga "I", ligadas por tirantes aparafusados, com degraus de tijolo e focinhos de ferro - ver Figura 67B. As escadas de ferro ligadas com madeira eram muito usadas em interiores das habitações, sendo constituídas de pernas de ferro com barra chata, espelhos e cantoneiras de ferro e degraus de madeira. Os degraus podiam estar encaixados entre as pernas ou dispostos sobre elas, ficando salientes na lateral - ver Figura 67C.

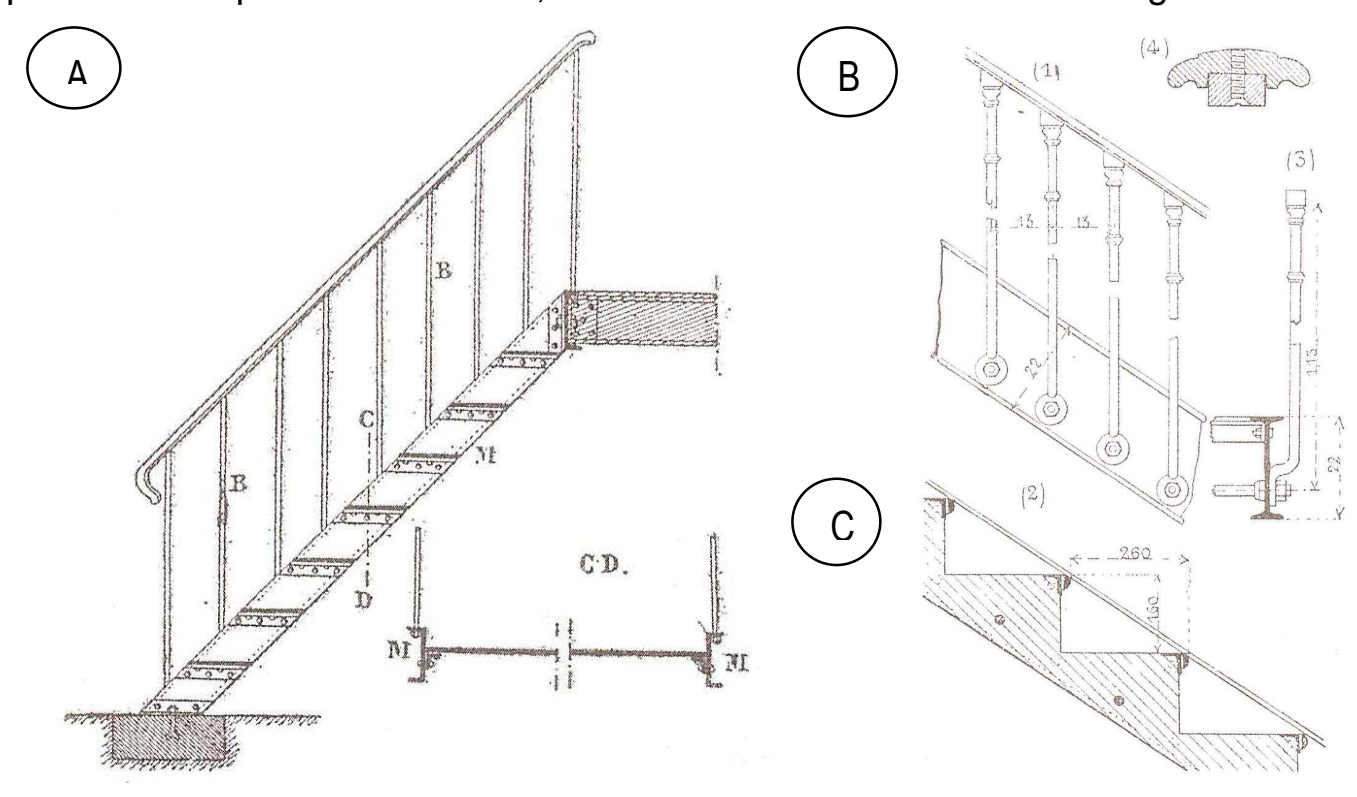

Figura 67: Escada simples de ferro (A) e escada de ferro e alvenaria (B), escada de ferro e madeira (C) ${ }^{63}$

Já as escadas curvas de ferro eram constituídas de chapas de ferro ou barras viradas, que eram as pernas, sendo suspensas (apoiando no solo e nos pavimentos) ou encostadas nas paredes - Figura 73A. Essas escadas também podiam ser em forma de caracol, com uma coluna central, geralmente um tubo laminado chumbado no solo Figura 73B.

${ }^{63}$ Idem, p. 154. 


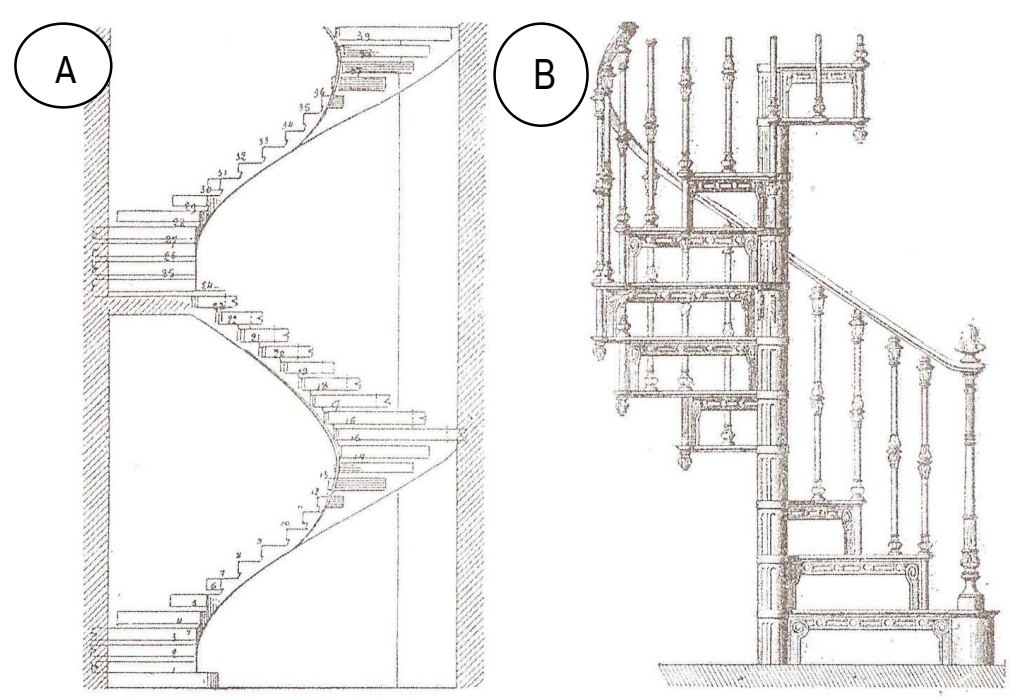

Figura 73: Escada curva de ferro $(A)$ e escada de caracol $(B)^{64}$

As escadas de ferro fundido serviam tanto para lanços retos como curvos, porém são incomuns em grandes larguras. O tipo mais simples era o de degraus fundidos numa só peça e encaixado nas paredes ou encaixado nas pernas de barra de ferro chata, conforme Figura 74A. Os degraus eram fixados entre si por meio de parafuso, sem auxílio das pernas, como a Figura 74B.
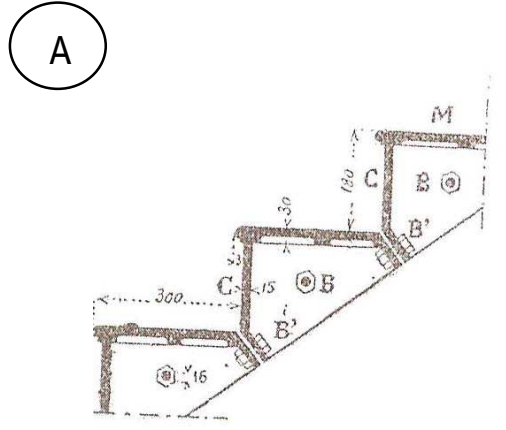
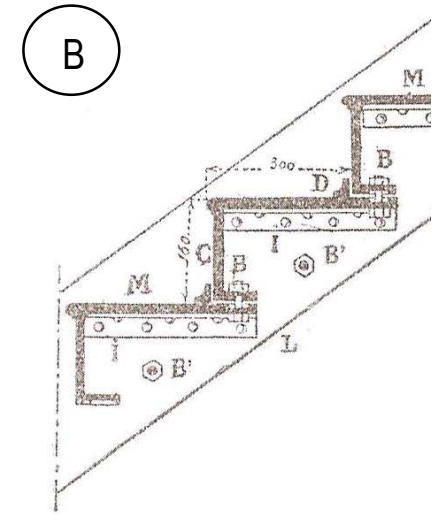

Figura 74: Escada de ferro fundido numa só peça $(A)$ e com parafusos $(B)^{65}$

Antes da reforma de 1885, a sede baixa não possuía alpendre e seu acesso se dava às três portas frontais com degraus irregulares, que seguiam a inclinação do terreno: a porta esquerda com dois degraus, a central com apenas um e a da direita sem degraus. Na fachada posterior da sede baixa, as escadas que encontramos atualmente foram colocadas quando da realização de novas aberturas, anos depois da reforma. Com a nova entrada pelo alpendre através da nova sede, a sede alta - por conta da reforma -

\footnotetext{
64 Idem, p. 158.
}

65 Idem, p. 160. 
ganhou uma escadaria ${ }^{66}$ com dois acessos laterais e um mesmo patamar (Figuras 75 e 76). Na fachada posterior da sede alta, foi feita uma escada que ligava o exterior à varanda (Figura 77), porém esta já não existe mais, por conta da já citada reforma de 1950 - restando-nos apenas fotos. Na reforma, o porão teve seu pé-direito diminuído para evitar alagamento na parte interior da edificação, sendo substituída por uma outra escada. É muito provável que ambas as escadas originais, com embasamento de pedra, foram construídas com tijolos, juntamente com o encamisamento de tijolos ao redor da edificação. A alvenaria de pedra já não se usava com muita frequência, e as escadas de pedra exigiam um preparo técnico maior que o do tijolo, além de bons alicerces para evitar desnivelamento dos degraus e fraturas.
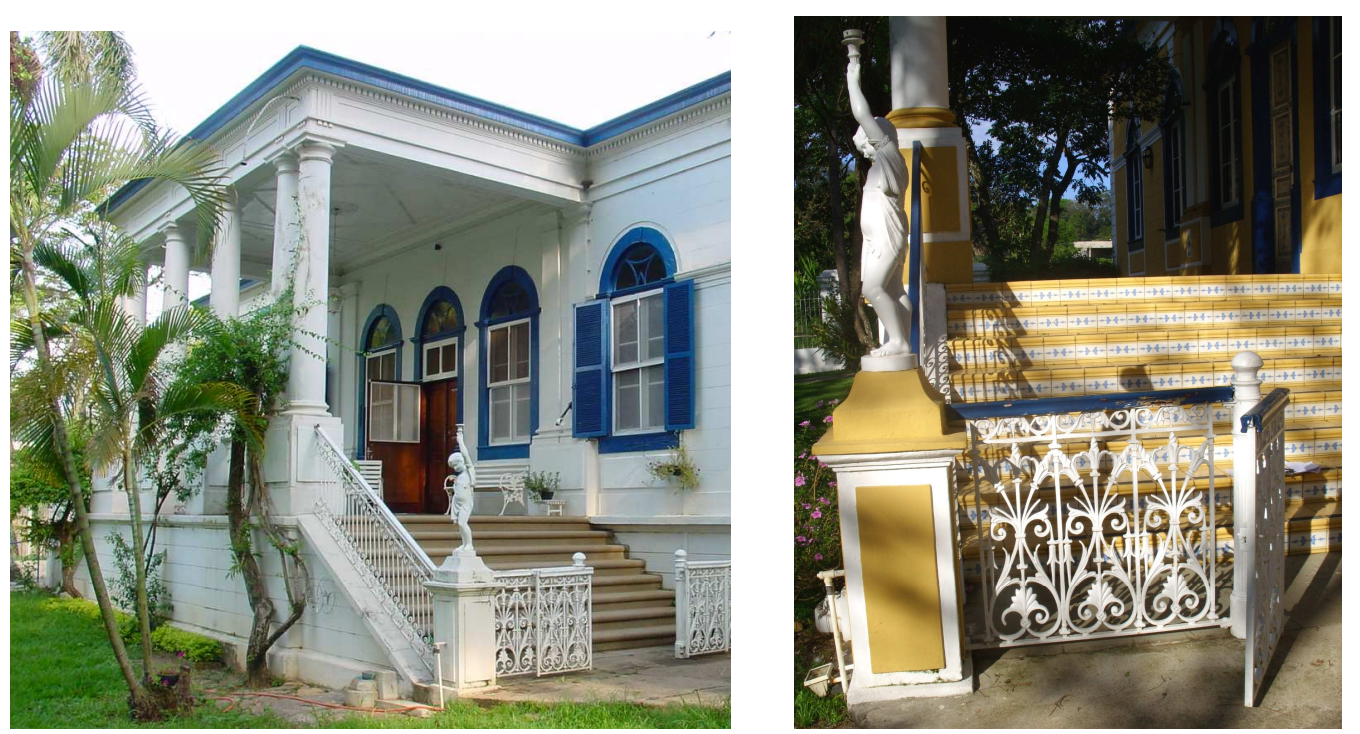

Figuras 75 e 76: Escada da fachada frontal da sede alta: acesso lateral do alpendre antes e depois da intervenção do Campinas Decor, em que o degrau ganhou revestimento de ladrilho. Notar, na primeira foto, a saliência dos degraus antes da intervenção ${ }^{67}$

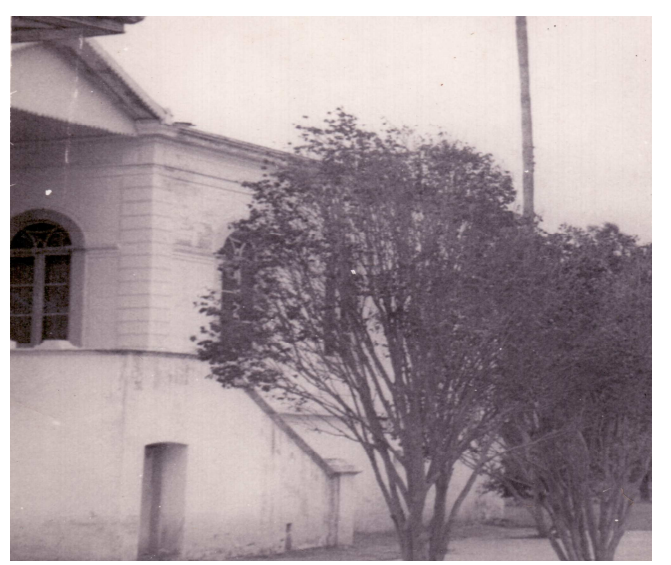

Figura 77: Escada da fachada posterior da sede alta: uma das raras imagens mostrando a escada original, demolida com a reforma de 1950 , em que o porão teve pé-direito diminuído

\footnotetext{
${ }^{66}$ Foto da escada da fachada frontal com os dois acessos laterais, ver Imagem 16 do Anexo 4.

${ }^{67}$ Figura 75: foto cedida por Julie Dutilh.
} 
No interior da sede, a ligação interna entre a parte baixa e a parte alta é feita por três escadas, a que liga o apoio da cozinha na sede alta à cozinha situada na sede baixa é de alvenaria de tijolo, as outras duas, ligações entre áreas sociais das duas partes, são de madeira. Essas pequenas escadas de cinco degraus são assentadas em base de pedra e não possuem corrimão. Uma delas já não existe mais, desde a intervenção do Campinas Decor ${ }^{68}$.
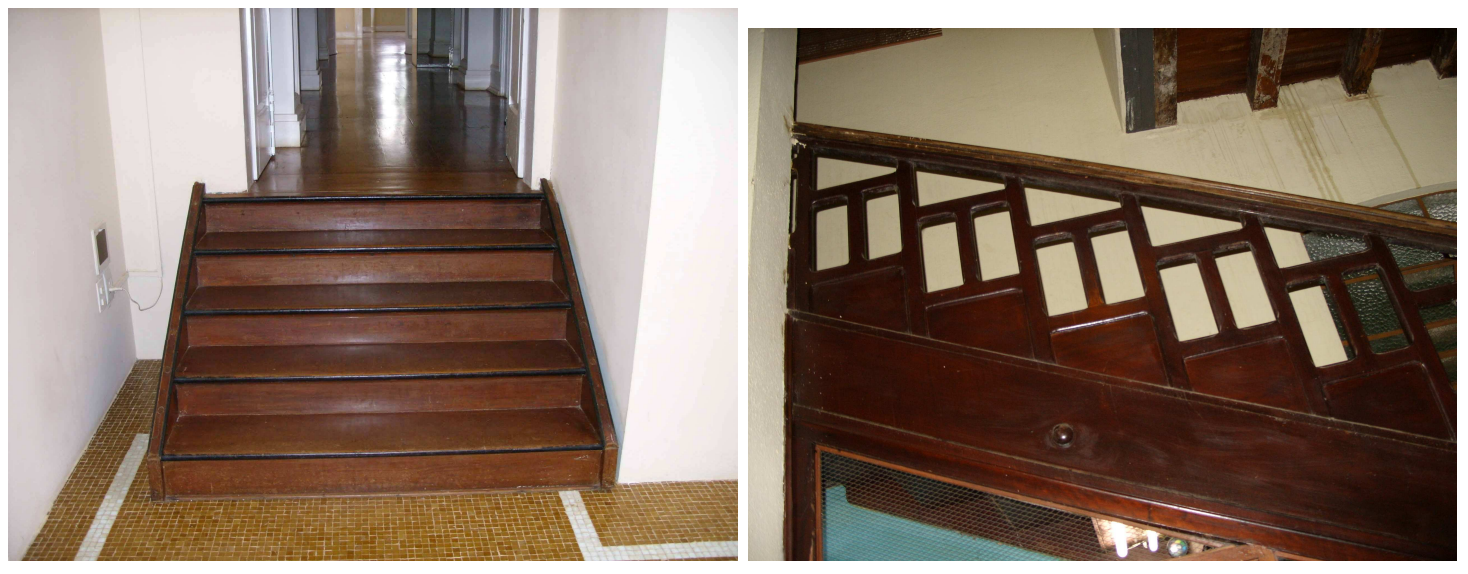

Figuras 78 e 79: Escada de madeira sem corrimão que liga corredor da sede alta ao salão da sede baixa da Pau d' Alho; à direita, escada de madeira do Chalet do Bosque dos Jequitibás, projetado por Ramos de Azevedo dois anos antes, apresentando corrimão de madeira

\subsubsection{Aberturas}

As aberturas são divididas em portas e janelas, e cada espécie será estudada pelo tipo de material: de madeira ou de ferro. Veremos como eram constituídas cada uma dessas portas e janelas que evidenciam as diferenças construtivas de antes e depois da reforma.

\subsubsection{Portas de madeira}

As portas eram compostas de batentes, guarnição no qual as folhas são suspensas, conforme planta de régua de batente da Figura 74, e pelas folhas em si. Estas, quanto à sua construção, podiam ser de travessa à cola (ou de calha), rilhadas (ou entaleiradas), engradadas, almofadadas ou envidraçadas ${ }^{69}$.

\footnotetext{
${ }^{68}$ Foto da escada de madeira que liga a sede alta a baixa que não existe mais pode ser vista na Imagem 17 do Anexo 4, idêntica à outra escada existente.

69 Ibid, pp. 176 a 182.
} 


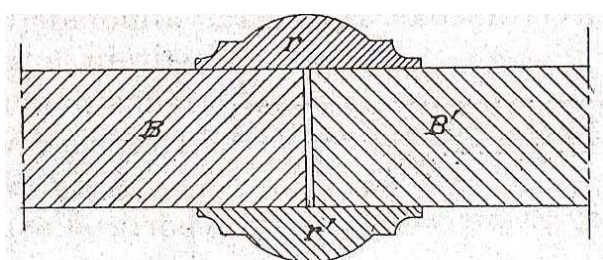

Figura 74: Planta de régua de batente ${ }^{70}$

As portas de travessa à cola ou de calha eram seguras, de custo baixo, com aspecto rústico: consistiam em um tabuado vertical de ranhuras, contraventado com auxílio de travessas horizontais, conforme Figura 76A e 76B. O tabuado apresentava uma pequena moldura que evidenciava a junta, conforme Figura 76D. As travessas podiam estar sobrepostas às tábuas ou ligeiramente embutidas, por entalhe em malhete, para que as travessas ficassem bem encaixadas através do serrote de cola, conforme a Figura $75 \mathrm{C}$ e $75 \mathrm{E}$.

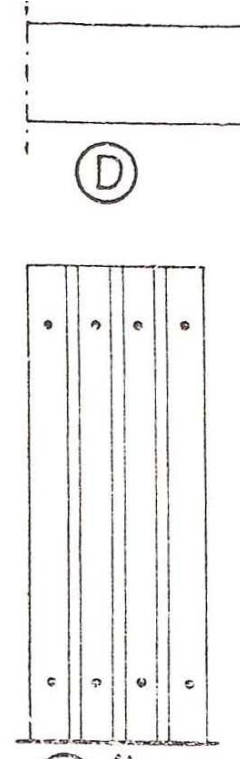

(A)
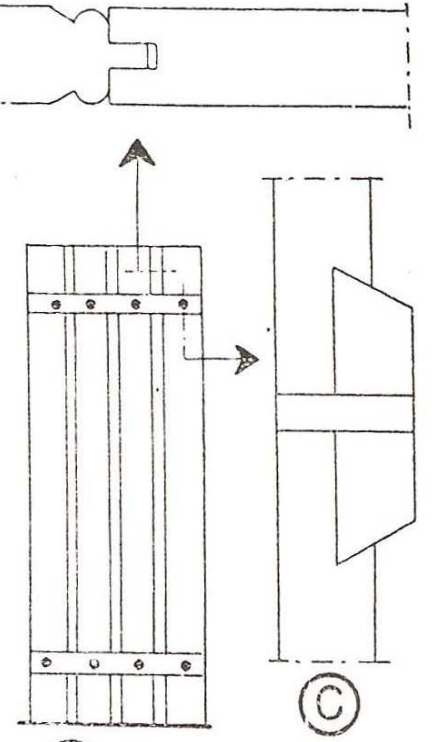

(B)

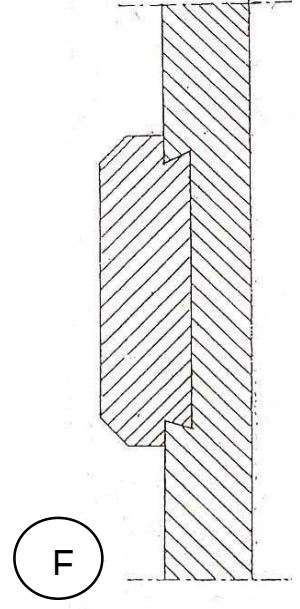

Figura 75: Tabuado de ranhura $(A)$, porta de travessa à cola $(B)$, e sua moldura $(D)$, travessa embutida com sambladura $(C)$

As portas rilhadas ou entaleiradas eram constituídas de tábuas grossas, de quatro a cinco centímetros de espessura, ligadas a macho e fêmea e atravessadas por "taleiras" ou travessas em forma de cunha. Eram inseridas numa caixa retangular das tábuas, ficando ocultas - ver Figura 76.

\footnotetext{
70 Imagens das figuras 74 a 83:SEGURADO, J. E. S. Construção Civil: trabalho de carpintaria. Biblioteca de Instrução Profissional, Livraria Bertrand, 19-?, pp. 176 a 186.
} 


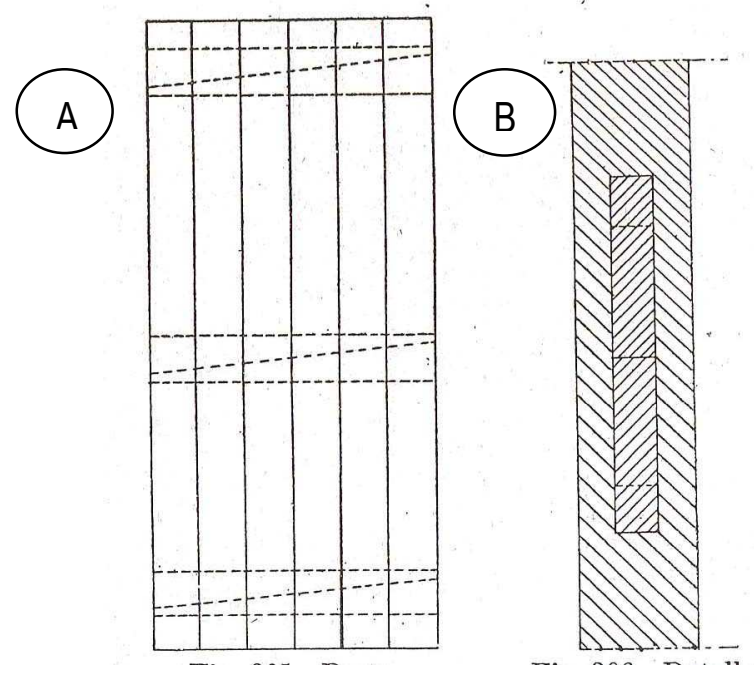

Figura 76: Porta entaleirada $(A)$ e detalhe do encaixe da travessa (B)

As portas engradadas eram mais sólidas e recomendadas: formadas por uma grade, eram constituídas por duas "couceiras" - ver detalhe na Figura 77A - e três travessas, que alojavam as tábuas, ligadas a macho e fêmea, conforme Figura 77B.

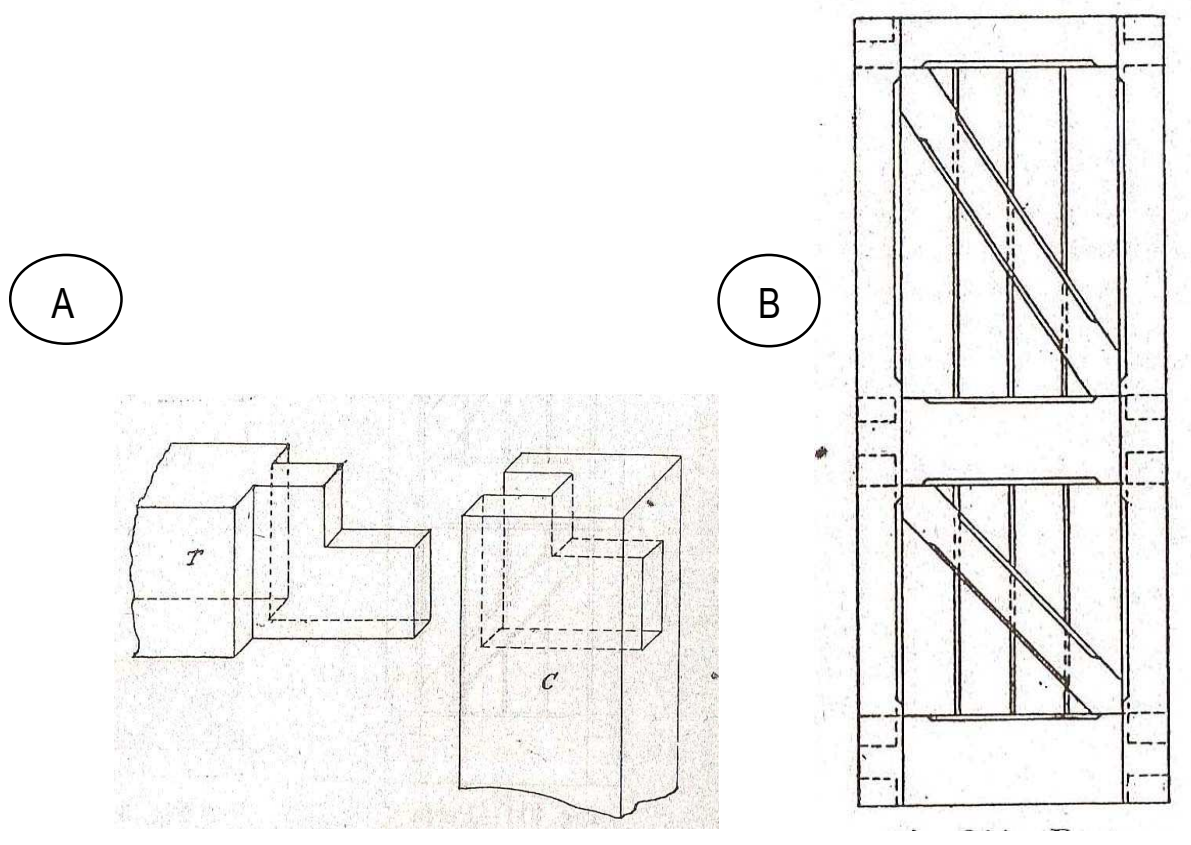

Figura 77: Encaixe da couceira (A) e porta engradada (B)

As portas almofadadas eram portas engradadas cujos vãos, deixados entre as couceiras, e travessas eram guarnecidos de almofadas ou painéis moldurados, conforme Figura 78A. Quando as portas eram estreitas, usavam-se só duas couceiras, e as almofadas eram fixadas por meio de macho e fêmea, conforme Figura 79A. Quando as portas eram mais largas, empregava-se uma couceira intermediária no meio das almofadas duplas, conforme Figura 78B. 

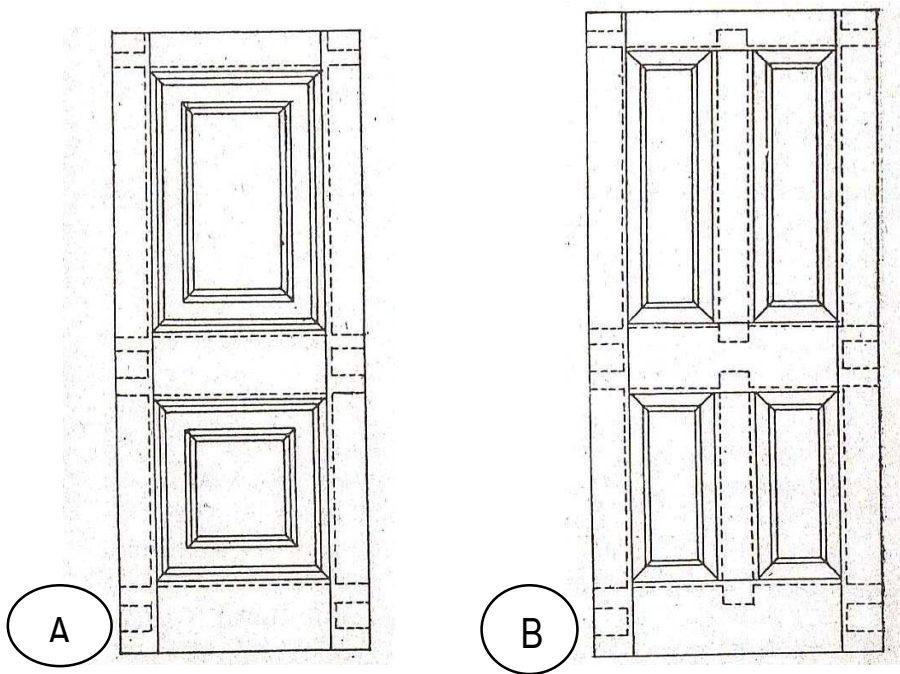

Figura 78: Porta almofadada (A) e porta com duplas almofadas (B)

Albuquerque apresenta alguns tipos de decoração de portas com almofadas ${ }^{71}$. As mais econômicas eram as almofadas encaixadas no montante liso e, depois de armada a porta, o marceneiro colocava por cima das almofadas duas molduras, conforme Figura 79A. A moldura do montante podia ser rebaixada ou saliente. A rebaixada era mais econômica, devido à menor espessura da madeira, o que pode ser visto na Figura 79C. Também podia ser preparada em duas partes, conforme Figura 80B. As trinchas eram tapadas pelo mata-junta, peça postiça pregada com pequenos pregos no paramento do montante (Figura 79E). O mata-junta podia ser fixado com parafuso na espessura da porta, dando um melhor acabamento (Figura 80F) e a porta também podia ser completamente lisa, como as entaleiradas, e ter as molduras imitando as almofadas, pregadas à face, conforme a Figura 80.

As portas envidraçadas eram portas almofadadas em que se substituía a almofada por caixilhos que receberiam a vidraça. A Figura 81, de Segurado, representa bem a composição de uma porta envidraçada: com dupla almofada inferior "PP"; caixilho "V" pra quatro vidros; bandeira envidraçada "C"; duas couceiras laterais e uma central "O"; e quatro travessas (inferior, média, a da bandeira "T" e a curva que limita a bandeira na parte superior).

\footnotetext{
${ }^{71}$ ALBUQUERQUE, Alexandre. Construções Civis. São Paulo: Empresa Gráfica da Revista dos Tribunais, 1952, pp. 277 e 278.
} 


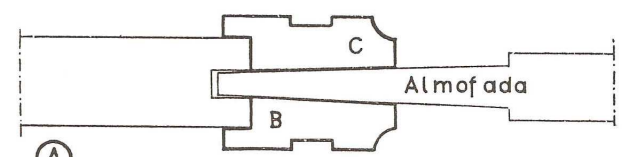

(A)
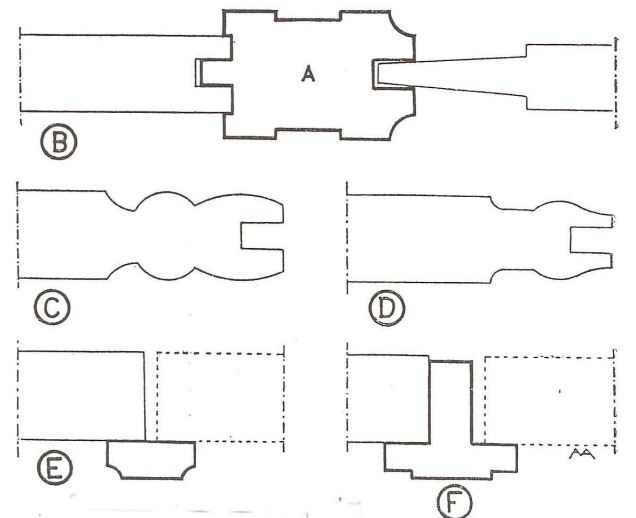

Figura 79: Almofada com duas molduras (A), almofada encaixada em uma peça (B), molduras rebaixadas ( $C$ e D) e com mata junta nas trinchas ( $E$ e $F$ )

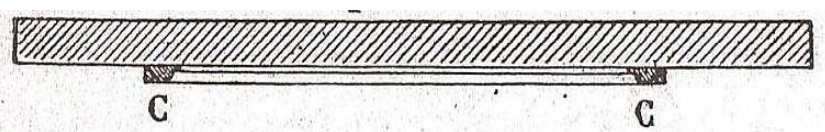

Figura 80: Molduras pregadas na porta.
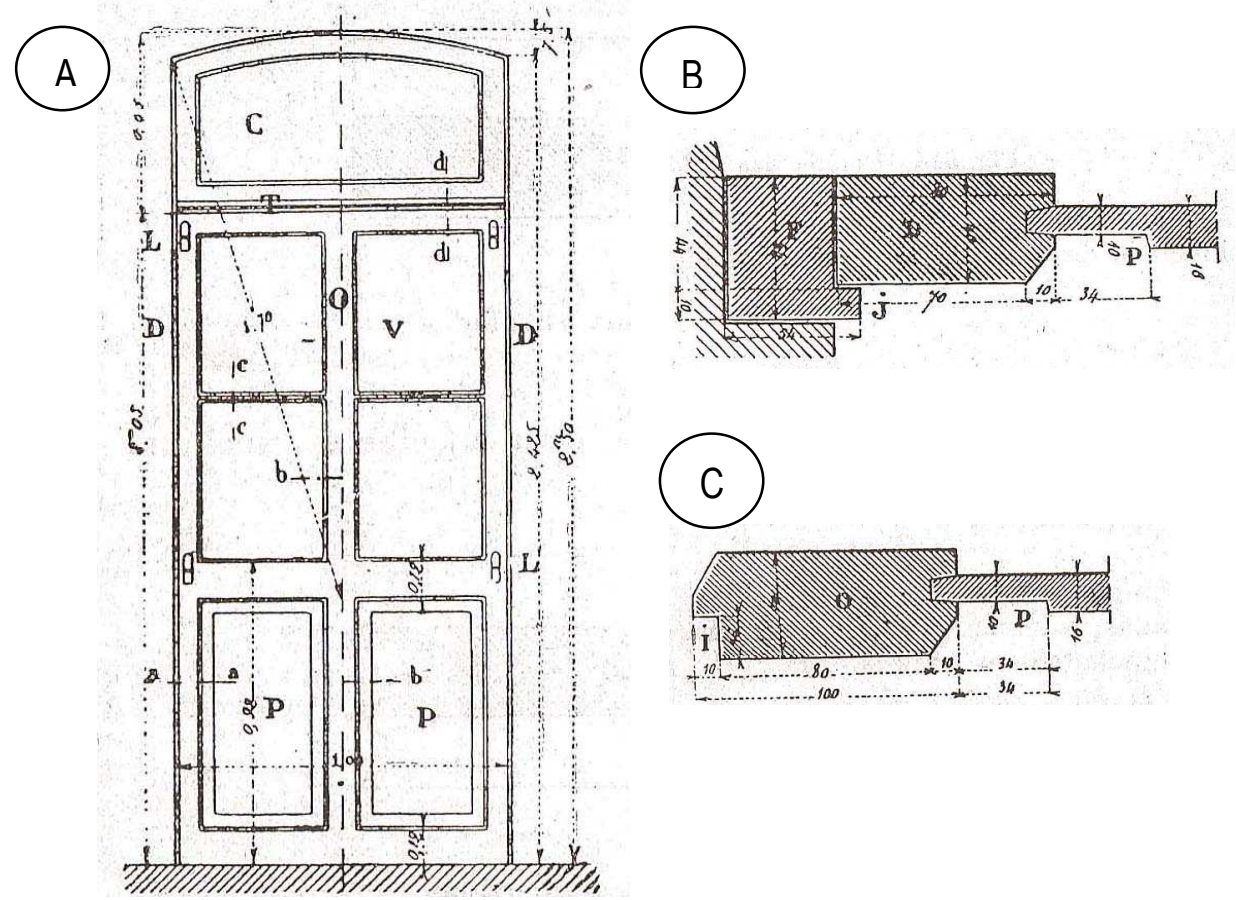

Figura 81: Porta envidraçada (A), corte $A A(B)$ e Corte BB (C). 


\subsubsection{Portas de ferro}

As portas de ferro eram usadas em vãos maiores, porém com folhas não muito largas, pois exigiam ferragens de articulação reforçadas. Ainda incomuns por aqui, usava-se mais as portas de ferro de abrir, as de correr ainda não eram comuns, sendo mais usadas para vãos maiores ainda, principalmente para salas e terraços ${ }^{72}$. No caso de portas pesadas, podia-se apoiar, além dos umbrais, nas soleiras, através de arcos de metal resistente e embutidos no piso.

Os vãos das janelas acompanham o formato do vão das portas externas: as janelas na sede baixa também foram mantidas com as vergas retas, assim como as portas, com a reforma, e ganharam novos ornamentos em cima do vão, idênticas às das portas; na sede alta os vãos das janelas têm os mesmo arcos plenos das portas com bandeira de vidro e o detalhe de vidro azul (Figuras 96 e 97).

\subsubsection{Janelas de madeira}

As janelas eram compostas pelo aro de pedraria, fixo à alvenaria, e pelo caixilho, móvel $^{73}$. O caixilho era fixo, às vezes, quando se destina apenas a dar luz, como no caso das bandeiras de portas e janelas. $\mathrm{O}$ aro de pedraria se diferia das portas por ter a travessa inferior, o peitoril, do qual fazia parte a pingadeira, para proteger as paredes da ação das águas pluviais. O caixilho podia ser de um ou mais batentes, conforme a Figura 82.

Segurado classifica os tipos caixilho em: de janela em corrediça ${ }^{74}$, de balanço e de persianas. Os tipos de janela corrediça consistiam em dois ou mais caixilhos verticais deslizando entre as ranhuras do aro e deixando parte do vão aberto. No exemplo dado na Figura 94A abaixo, à esquerda, o caixilho superior mantém-se fixo.

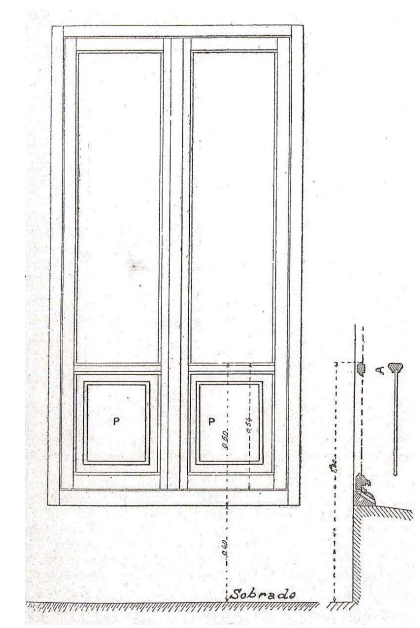

Figura 82: Janelas com dois batentes

\footnotetext{
72 ALBUQUERQUE, Alexandre. Construções Civis. São Paulo: Empresa Gráfica da Revista dos Tribunais, 1952 , p. 280.

73 SEGURADO, João Emílio dos Santos. Construção Civil: trabalho de carpintaria. Biblioteca de Instrução Profissional, Livraria Bertrand, 19-?, pp. 182 a 188.

${ }^{74}$ Ver janela corrediça com vidros originais na Imagem 16 do Anexo 4.
} 
As janelas de balanço, ou basculantes, empregadas mais em hospitais e escolas, consistiam em caixilhos retangulares móveis segundo o eixo médio horizontal, tendo o cuidado da amplitude da janela, ao abrir-se, ser limitada pela ranhura do aro, para não correr água da chuva para dentro, conforme Figura 83B.
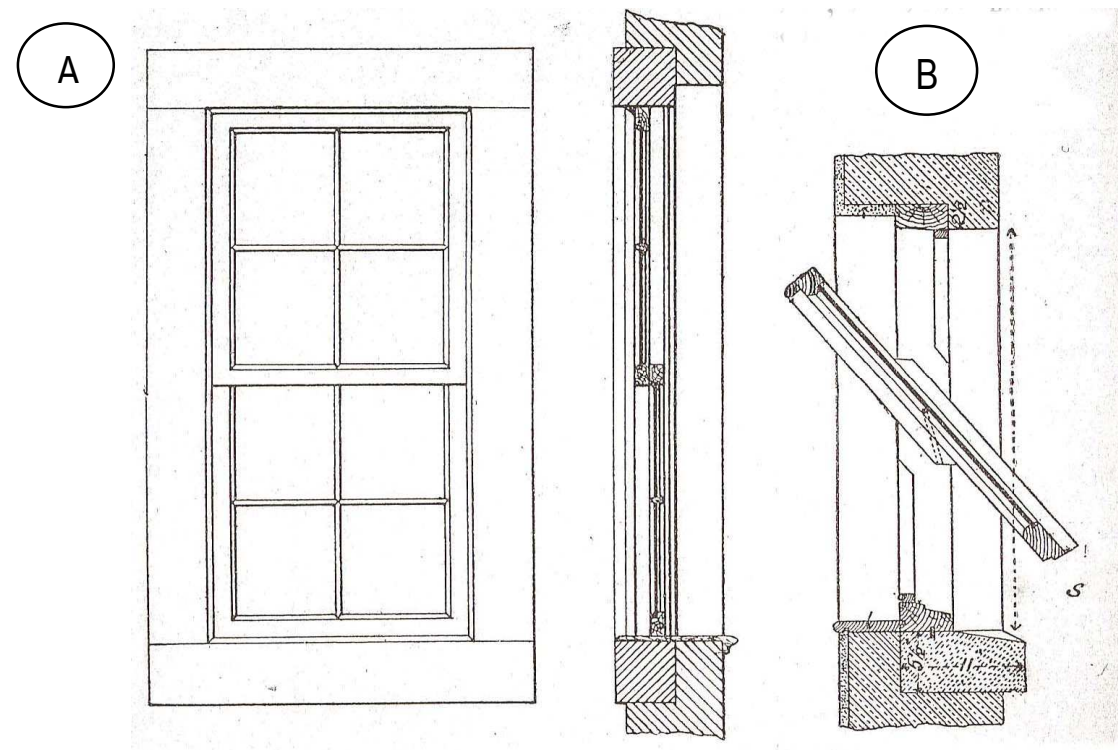

Figura 83: Janela de corrediça $(A)$ e janela de balanço $(B)$

As persianas eram caixilhos em que os vidros são substituídos por tabuinhas inclinadas, que se fixavam pela parte de fora da vidraça e abriam para o exterior. Eram em geral de dois batentes, podendo ser de dobrar sobre si, alojando na aduela da janela (conforme Figura 84B) ou podendo ligar-se por meio de respiga com postigos, conforme Figura 84A.

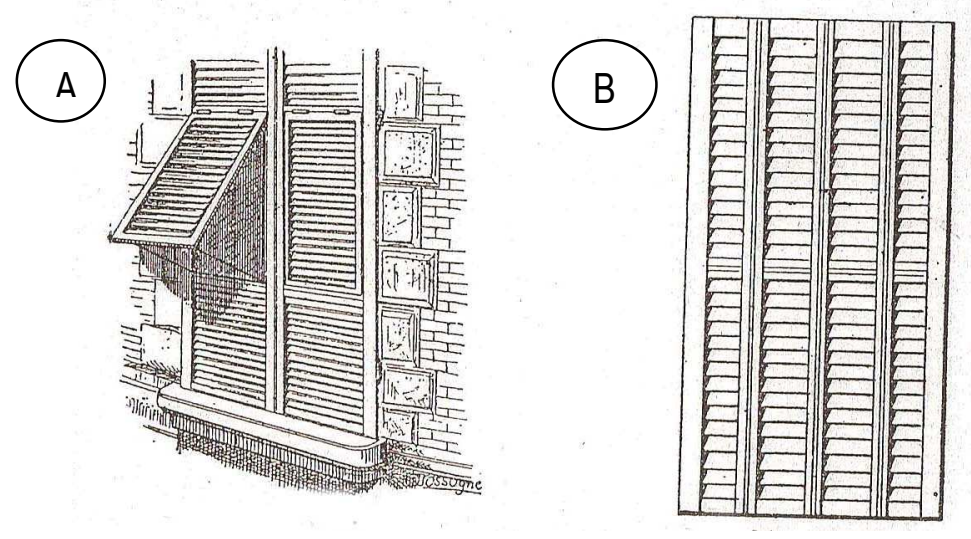

Figura 84: Janelas com postigos (A) e janelas de dobrar (B) $)^{75}$

\footnotetext{
${ }^{75}$ SEGURADO, J. E. S. Construção Civil: Trabalho de carpintaria. Biblioteca de Instrução Profissional, Livraria Bertrand, 19-?, p. 87.
} 


\subsubsection{Caixilhos de ferro}

Os caixilhos de ferro ainda não eram muito usados. Há duas janelas na fazenda com esse material, mas não sabemos se são as originais, e é possível que sejam, pois pertencem à área que foi ampliada na sede alta. Apesar do custo elevado, tinham vantagem sobre os de madeira por causa dos grandes vãos; sua desvantagem era a ferrugem, implicando maior cuidado na conservação, lembrando que, aqui, os caixilhos de alumínio ainda não eram comuns. Os caixilhos de ferro podiam ser fixos ou móveis, este sendo de correr, basculantes, de abrir ou guilhotina ${ }^{76}$. Em lugares próximos a varandas ou com fácil acesso ao exterior, usavam-se os caixilhos fixos, com muitas subdivisões, que são os caixilhos mais comuns.

Os caixilhos de correr eram providos de trilhos na parte superior e possuíam rolamentos esféricos. Em alguns casos, possuem parte superior basculante para melhor ventilação. No caso de hospitais, escolas e escritório, era aconselhável o uso de janelas com básculas na parte baixa, com eixo na parte inferior, dirigindo a corrente de ar para cima - Figura 85A. O mais comum, no caso de cozinhas e banheiros, era com a folha girando em torno do eixo horizontal a meia altura - Figura 85B, 85C e 85D.

Os caixilhos de abrir eram os que ventilavam melhor, porém, quando fechados, eram inconvenientes. Em vãos maiores que 1,50m, eram geralmente empregados os de guilhotina, que eram munidos de mola, como na Figura 86.

${ }^{76}$ ALBUQUERQUE, Alexandre. Construções Civis. São Paulo: Empresa Gráfica da Revista dos Tribunais, 1952, pp. 291 e 296. 

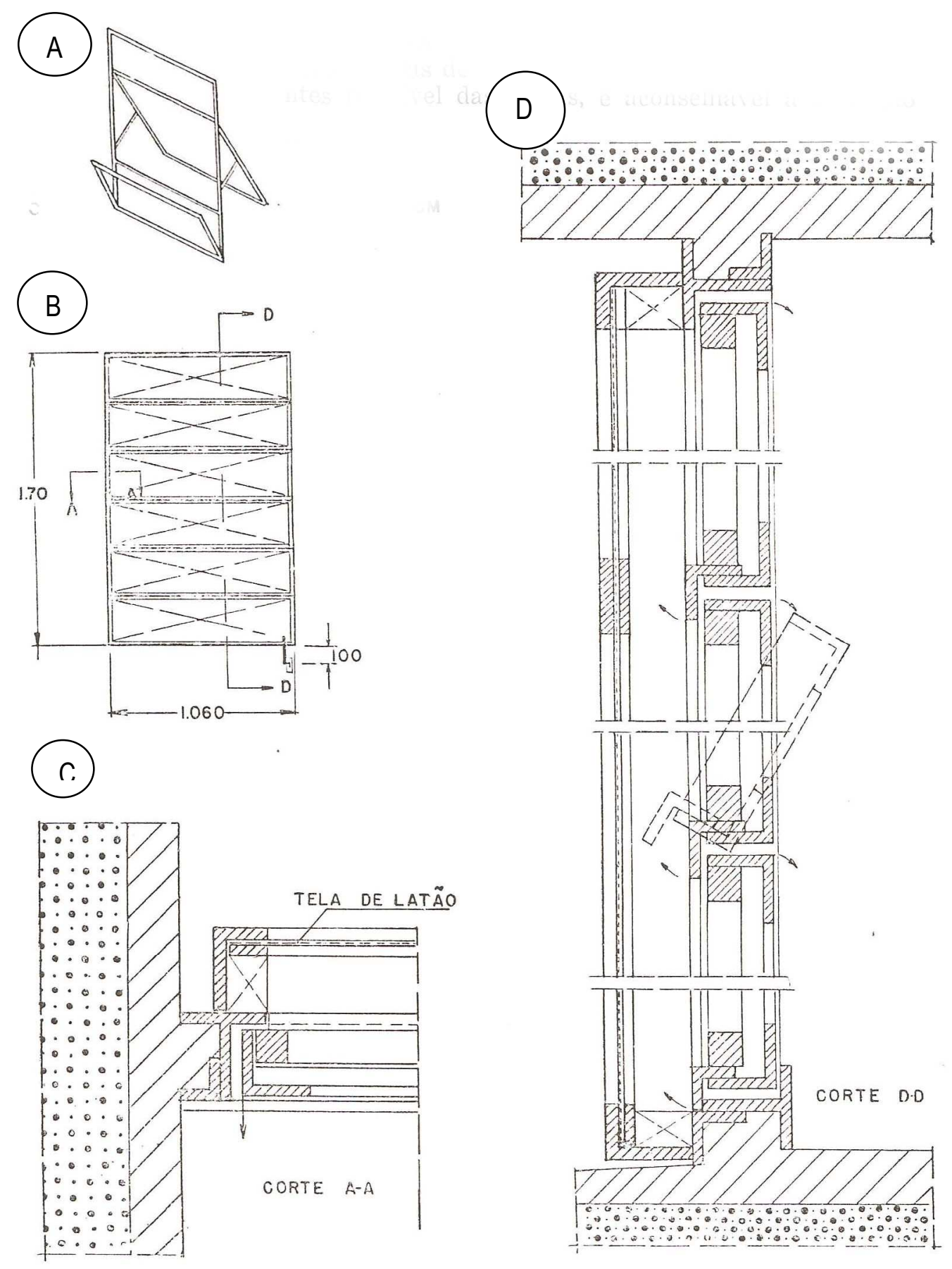

Figura 85: Janela basculante com eixo na parte inferior $(A)$ e na parte central e cortes $(B, C \text { e } D)^{77}$ 

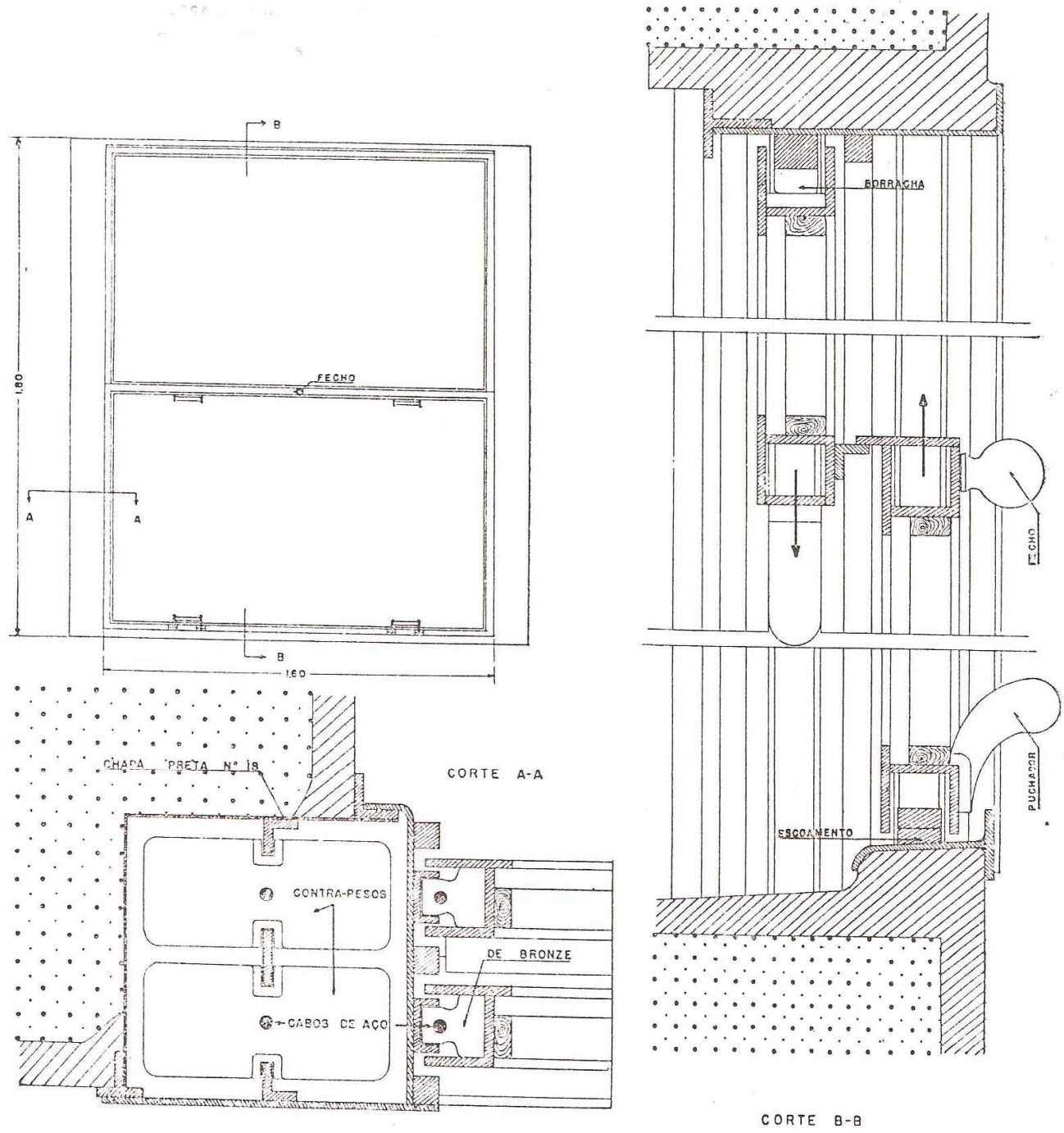

Figura 86: Janela com caixilho de abrir ${ }^{78}$

Na fazenda Pau d'Alho, na sede baixa, todas as antigas aberturas externas, portas e janelas mantiveram o antigo padrão colonial de antes da reforma de 1885 , com vergas retas, passando a ser molduradas por conta da reforma de Ramos de Azevedo com novos apliques; já na sede alta, todas as aberturas foram construídas, nessa ocasião, em arco pleno; em ambas sedes, as janelas e portas são providas de madeira. Já interiormente, as aberturas, tanto da sede alta como da baixa, são de verga reta com duas folhas, com pouca diferença de altura e vão: enquanto na sede baixa o vão é $1,16 \mathrm{~m}$, na sede alta é de $1,14 \mathrm{~m}$. A diferença entre as portas das sede alta e baixa consiste no tipo de material e construção, tanto no que diz respeito às portas internas como externas: na sede baixa, o batente e as folhas são de madeira nacional pintados, de branco nas internas (Figura 87) e de azul nas externas (Figura 93) e, na sede alta, foram aplicadas madeiras importadas: batentes de peroba com painéis do nosso citado 
pinho-de-riga, moldura de cedro envernizados nas internas (Figura 89) e pintadas de azul - igual as da sede baixa - nas externas -, porém hoje as portas internas são pintadas de branco. Quanto à construção, todas as folhas das portas da sede baixa são entaleiradas, e as internas possuem bandeiras vedadas com treliça. Enquanto na sede alta todas as folhas de portas são almofadadas com bandeiras de vidro, as externas em arco pleno, com detalhe em vidro azul acompanhando as janelas e as bandeiras das portas internas, são retas.

Algumas portas da sede baixa aparentam ser mais antigas que outras, essas são de travessa à cola e sem bandeiras (Figura 87). Na sede alta encontramos ainda uma porta diferente das demais: imponente em arco pleno sem folhas, talhada à mão, marca a entrada principal que dá acesso à sala de jantar através da sala de visitas (Figura 91). Outras duas portas diferenciadas são as do cômodo de apoio à cozinha, também na sede alta, sem bandeiras e com vidro no lugar da almofada superior (Figura 92), para dar visibilidade á chamada copa. Apenas a porta da fachada posterior da sede baixa, que dá acesso externo do salão, é de ferro (Figura 90).
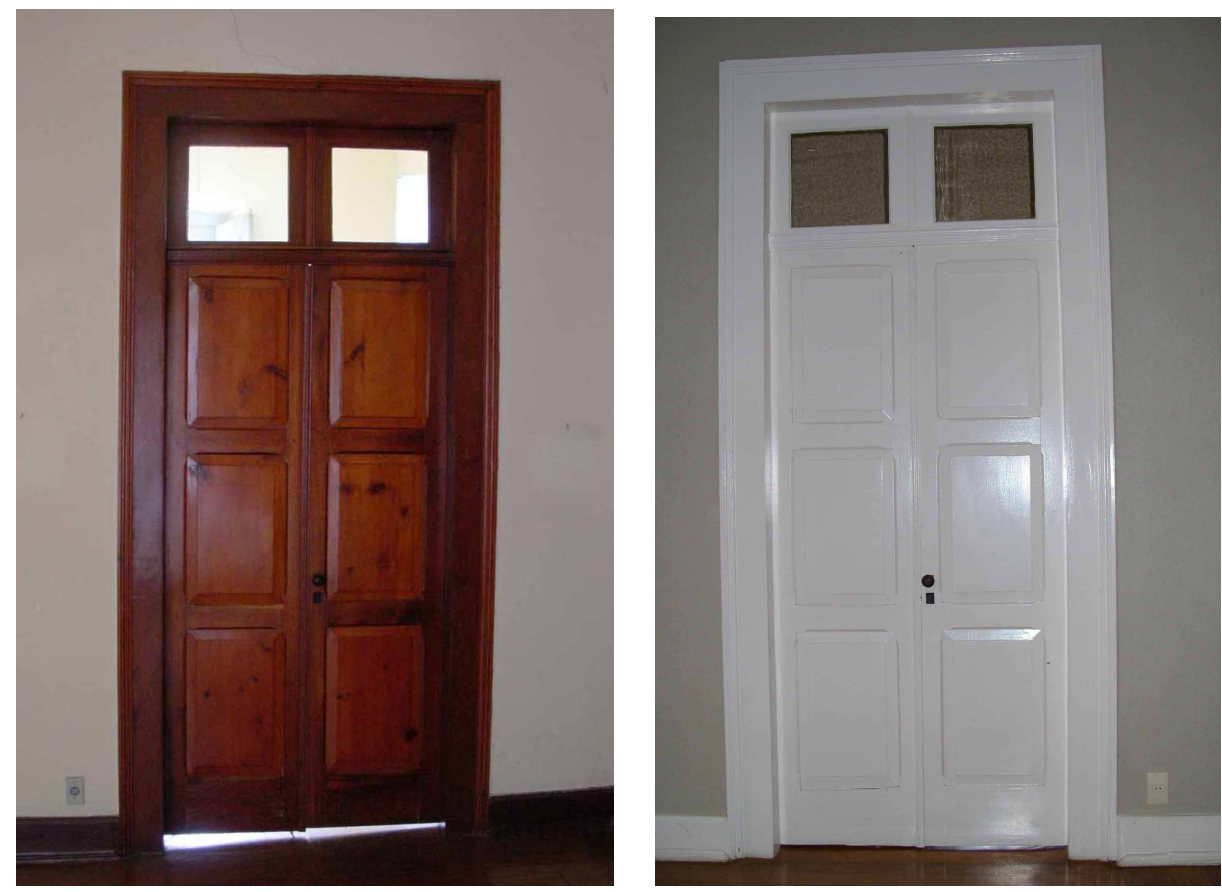

Figuras 87 a 90: Acima, portas da sede baixa: à esquerda, porta de travessa à cola e À direita, porta entaleirada com bandeira vedada de treliça; abaixo, porta da sede alta: à direita, porta envernizada antes da intervenção do Campinas Decor e o mesmo modelo de porta pintado de branco após intervenção

${ }^{78}$ Idem, p. 294. 

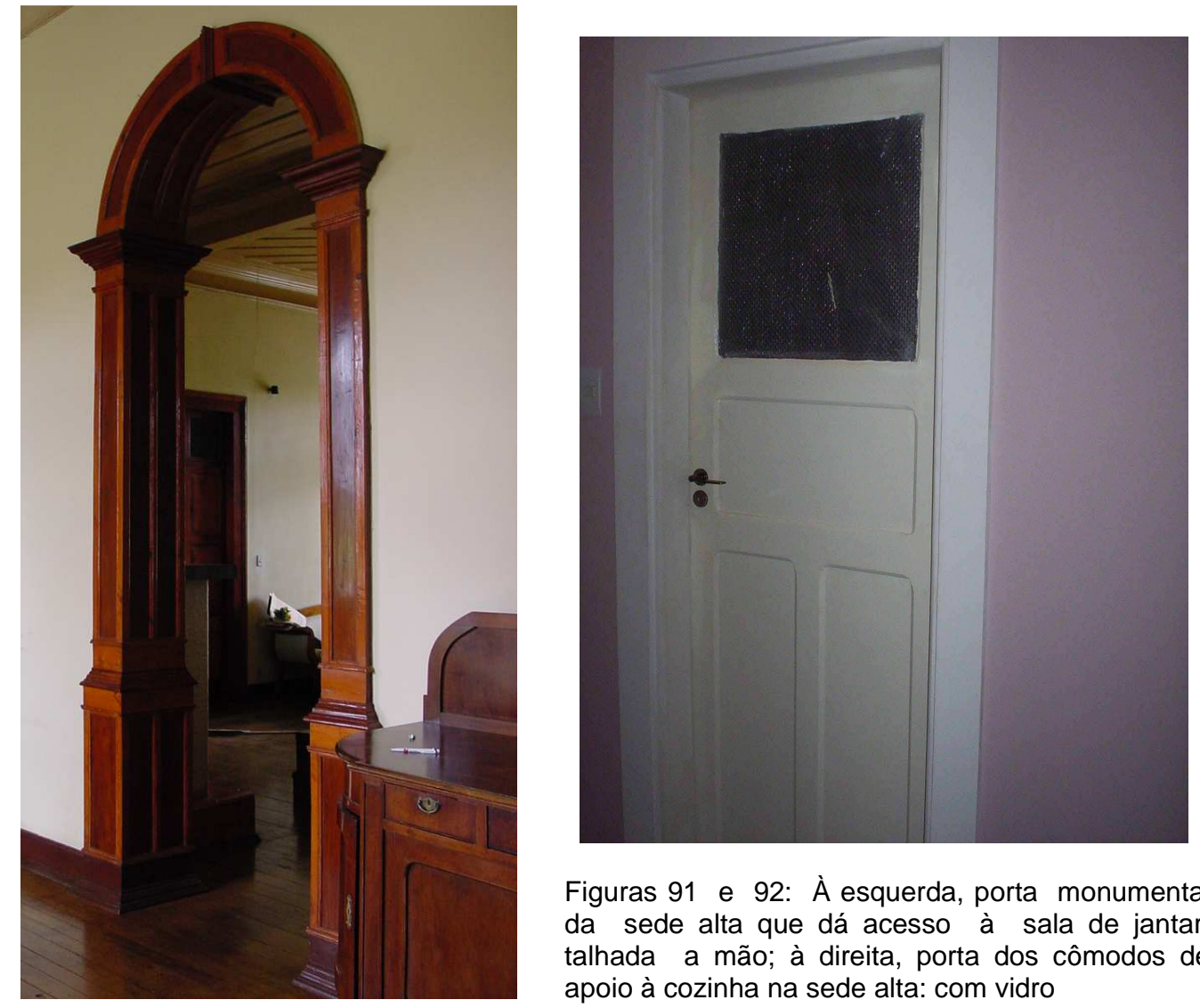

Figuras 91 e 92: À esquerda, porta monumental da sede alta que dá acesso à sala de jantar: talhada a mão; à direita, porta dos cômodos de apoio à cozinha na sede alta: com vidro
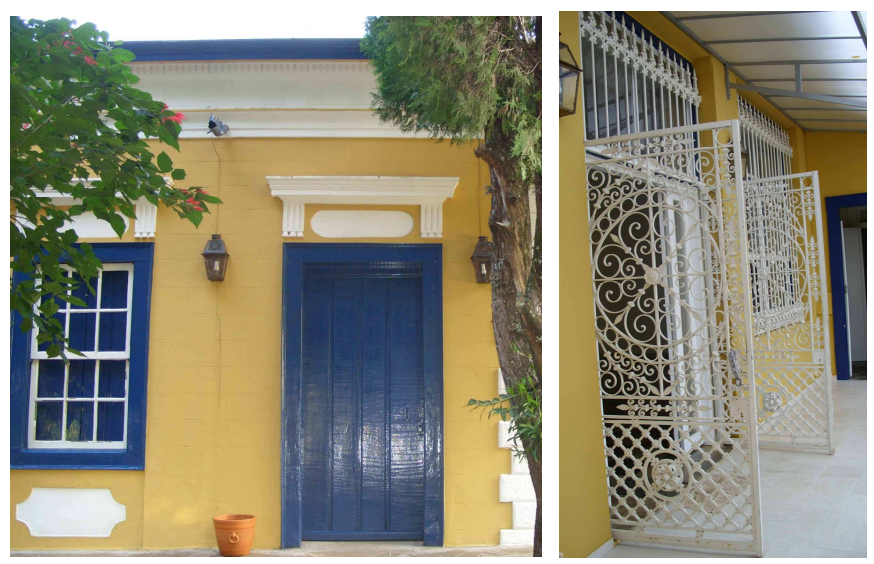

Figuras 93 e 94: Portas externas da sede baixa: porta na fachada frontal em verga reta e folha entaleirada da sede com ornamentos colocados por conta da reforma e porta na fachada posterior com gradil de ferro 


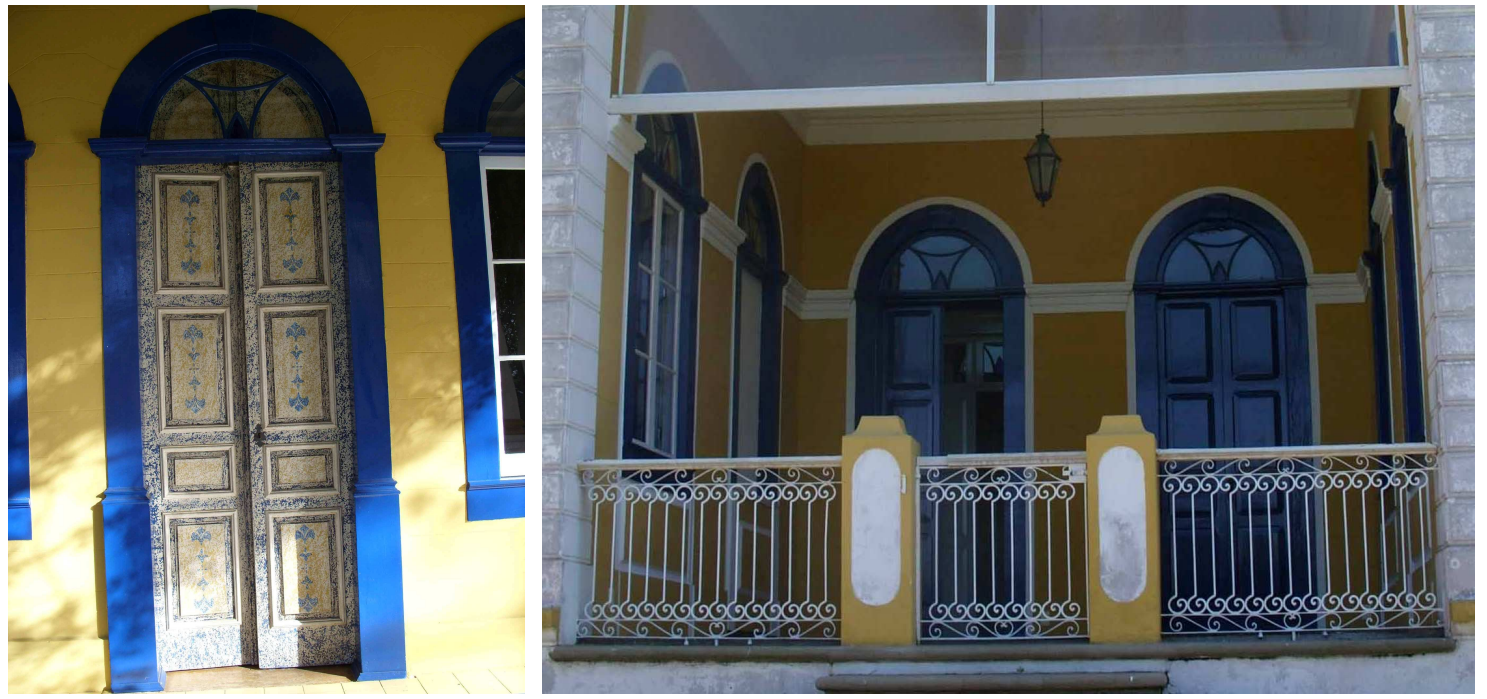

Figura 95 e 96: Portas da sede alta na fachada frontal em arco pleno com bandeira e na fachada posterior portas igualmente em arco pleno e com bandeira
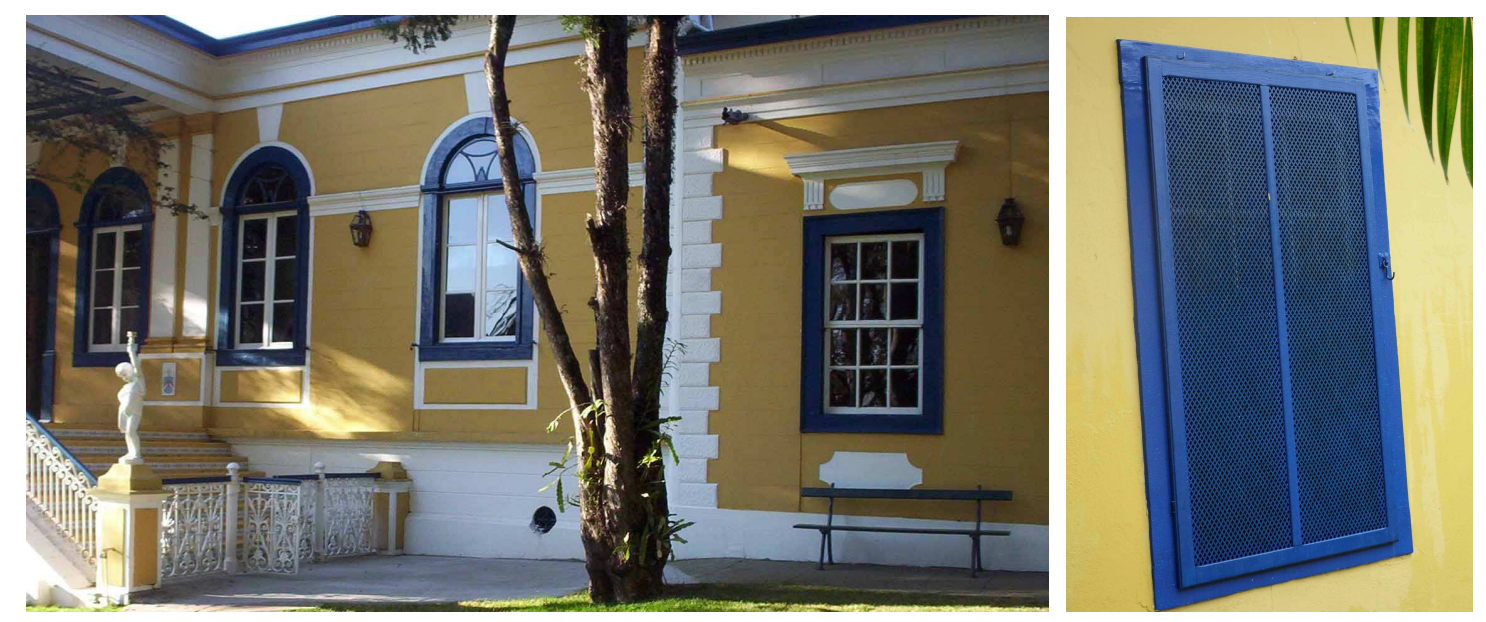

Figuras 97 e 98: À esquerda, janelas de arco pleno da sede alta; ao centro, janelas de verga reta da sede baixa e, à direita, janela da sede baixa com treliça, na cozinha

Quanto às janelas: na sede alta, elas são com batente e corrediças de madeira com vidro e folhas internas de abrir para dentro de madeira; nos dormitórios, essas janelas apresentavam venezianas externas, que hoje não existem mais por conta da reforma de 2004 com o Campinas Decor. A maioria das janelas da sede alta é idêntica, apenas duas janelas são diferenciadas pelo material e formato, o ferro, que fica na ligação entre a sede baixa e sede alta. Na sede baixa, a maioria das janelas também é idêntica, algumas, nos cômodos referentes à cozinha, apresentam treliças externas removíveis, mesma técnica dos muxarabis ${ }^{79}$ do período colonial. $\mathrm{E}$ as duas janelas do

\footnotetext{
${ }^{79}$ Muxarabis são janelas de influência árabe que foram muito comuns no período colonial, podem ser vistos em muitas edificações mineiras como Ouro Preto e Diamantina. Tinham a finalidade de controlar a claridade do ambiente e manter as mulheres escondidas dos passantes na rua nos cômodos internos, através do qual elas poderiam enxergar o exterior.
} 
salão são de ferro, acompanhando o formato da única porta de ferro externa que dá para a parte posterior (Figuras 99 e 100).
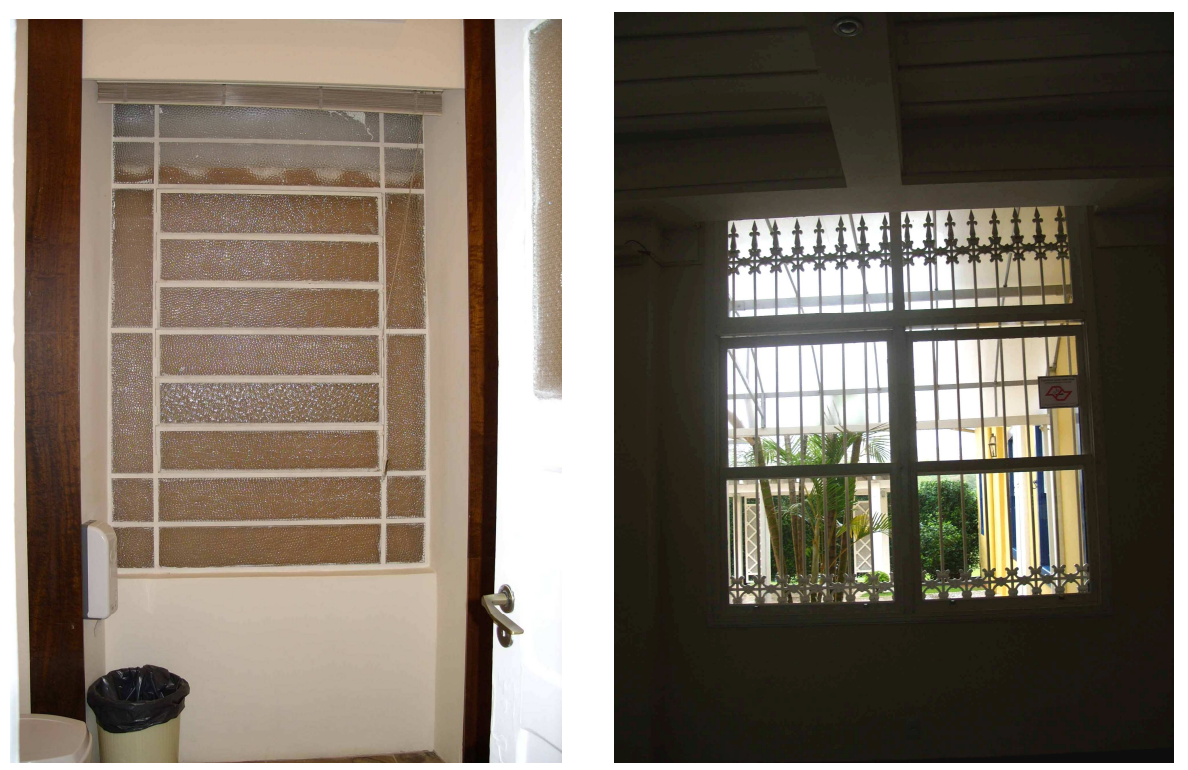

Figuras 99 e 100: Janela com caixilhos de ferro: da dispensa, na sede alta, e janela com gradil de ferro ornamentado, no salão da sede baixa

\subsubsection{Acabamentos}

Neste último item do capítulo, veremos primeiramente sobre os tipos de decoração arquitetônica, a seguir veremos os acabamentos pelos diferentes tipos de material: argamassa, rebocos e estuques, madeira, ferro, tijolo, tintas e vernizes.

\subsubsection{Decoração arquitetônica}

Segundo o engenheiro-arquiteto Alexandre Albuquerque, os elementos que compunha os revestimentos da decoração arquitetônica eram envasamento, molduras, cornijas e áticos, paredes de oitão, arcadas e padieiras e os peitoris ${ }^{80}$. Além dos elementos arquitetônicos citados, Segurado se refere a outros elementos como envasamento ou soco, fachas, cunhas e pilastras como aplicações das ordens arquitetônicas $^{81}$. Estes elementos serão brevemente analisados aqui, os perfis das molduras e outros elementos decorativos devem ser apropriados para cada tipo de

${ }^{80}$ ALBUQUERQUE, Alexandre. Construções Civis. São Paulo: Empresa Gráfica da Revista dos Tribunais, 1952 , pp.132 a 138.

${ }^{81}$ SEGURADO, João Emilio dos Santos. Construção Civil: Edificações. Lisboa: Bertrand, 19-?, pp. 72 a 82. 
material, se for gesso, madeira ou ferro, portanto, serão apresentados conforme os respectivos materiais.

Os envasamentos consistiam num pedestal de ordem que propiciava um conjunto harmonioso a um ou mais andares, com o último andar constituído pelo entablamento. Às vezes, chegava a preencher todo o primeiro andar, mas o correto era compreender parte da fachada entre o solo e o nível de rez de chão. Quando o edifício era de um só andar, possuía só o soco, uma pequena saliência junto ao solo, sem apresentar cornija.

Com a reforma de Ramos de Azevedo, em 1885, a velha fachada lisa de taipa foi substituída por uma nova, aplicada sob uma camada de tijolos em toda a fachada frontal da sede baixa e da sede alta, que também ganhou um alpendre de seis colunas a uma nova área na fachada posterior, com as mesmas técnicas construtivas, o encamisamento de tijolos fechado por uma cobertura de duas águas, cuja empena é formada pela continuação do forro da varanda.

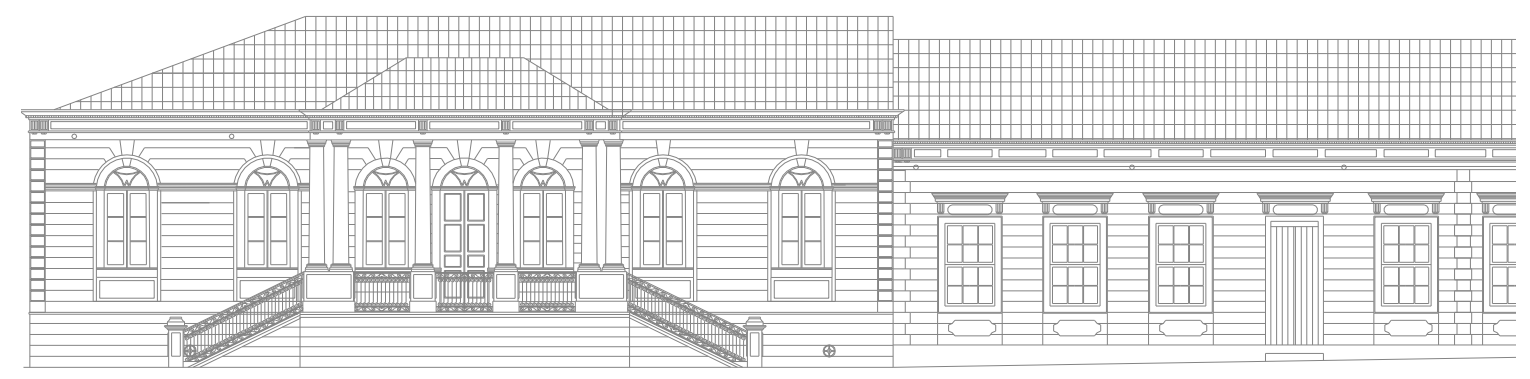

Figura 101: Nova fachada neoclássica após a reforma de Ramos de Azevedo: sede alta à direita e parte da sede baixa à esquerda 
$\mathrm{Na}$ sede baixa não foi feito o tipo de envasamento clássico, pois mantiveram 0 pé-direito original. Adicionaram apenas uma camada lisa de reboco na parte inferior, acompanhando o desnível do terreno. $\mathrm{Na}$ sede alta, o envasamento é formado até a altura do piso do alpendre na fachada frontal - o rez do chão - correspondendo à parte do porão que era habitável na época, com acesso na parte posterior. $O$ envasamento é constituído por vincos horizontais, com as aberturas circulares na fachada frontal e aberturas retas na lateral e nos fundos. Na Figura 102, pode ser conferido um Figura 102: Exemplo de envasamento completo ${ }^{82}$ exemplo de envasamento completo, abarcando do solo ao rez de chão e o seu perfil.

Acima do envasamento vinham as molduras, um dos principais elementos, pois estas serviam para caracterizar as divisões principais e contornar a aberturas de portas e janelas, não tendo, exclusivamente, fim decorativo. Nessa sede, as molduras são o destaque: moldam as portas e janelas de verga reta, na sede baixa, e ligam as aberturas em arco pleno da sede alta. As molduras tinham várias denominações de acordo com o respectivo perfil - ver Figura 103 - sendo as principais: de dupla curvatura, as chamadas "Gola" ou "Gula", sendo reversa (103C e 103F) ou direita (103D e 103E); as chatas, chamadas "Faixa" ou "Filete" (103G e 103H), cavadas entre dois filetes; e feitas com dois quarto de círculo, chamada "Escócia" (103B).

82 SEGURADO, J. S. E. Construção Civil: Edificações. Lisboa: Bertrand, 19-?, p. 74. 


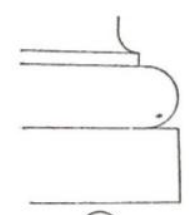

(A)

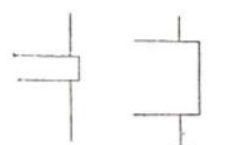

(G)

(H)

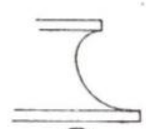

(B)

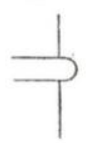

(1)

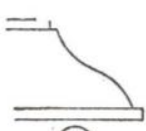

(C)

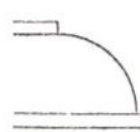

(1)

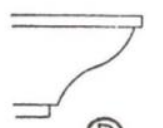

(D)

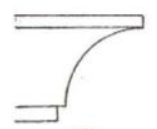

(

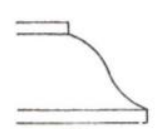

(E)

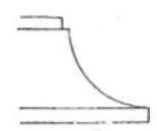

(L)

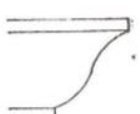

(F)

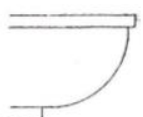

(M)

Figura 103: Molduras "Gola” ou "Gula" reversa (C e F), Direita (D e E),"Faixa” ou "Filete" (G e H) e "Escócia" (B) ${ }^{83}$

As molduras também estão presentes nas bases e capitéis das

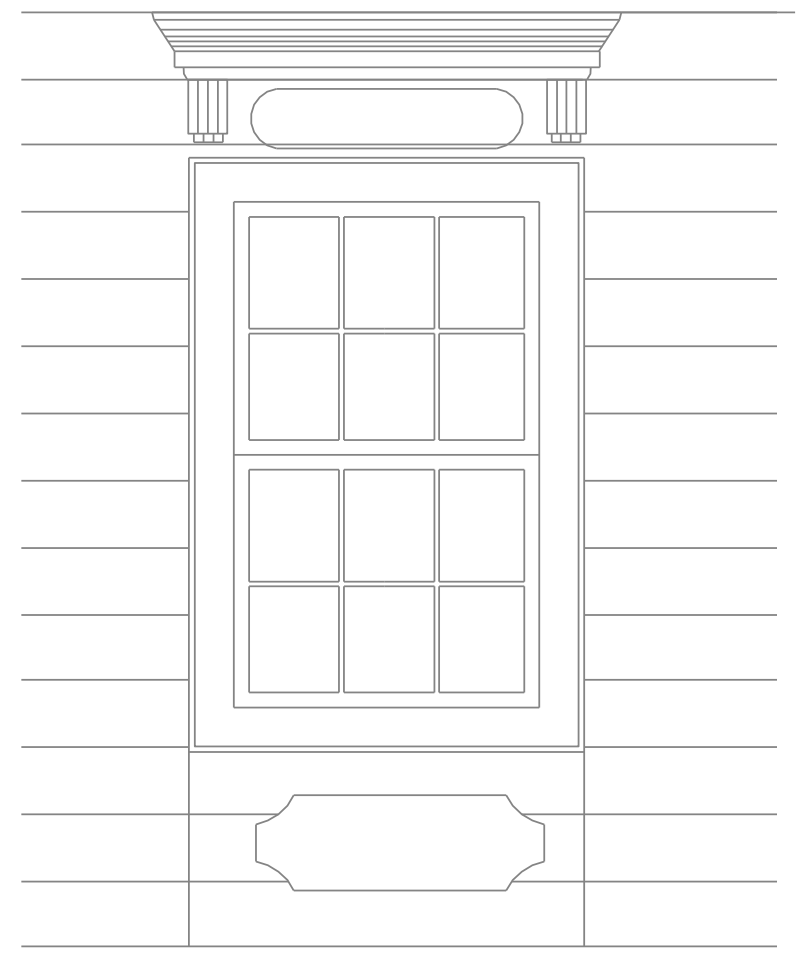

Figura 104: Presença de moldura escócia e moldura direita na parte superior das janelas da sede baixa seis colunas e pilastras do alpendre. As colunas, como visto na Figura 106, também podiam ter suas bases decoradas com soco (sapata), como no item $A$, ou soco estilizado (106B, 106C e 106D).

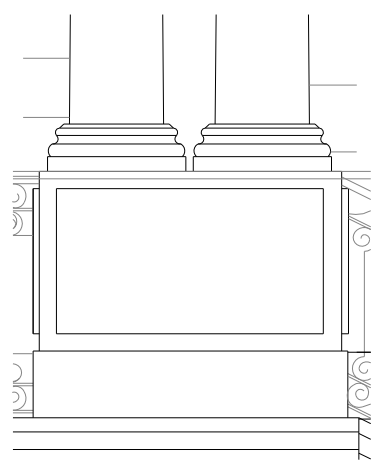

Figura 105: Base da coluna dórica no alpendre da sede alta da Pau d' Alho

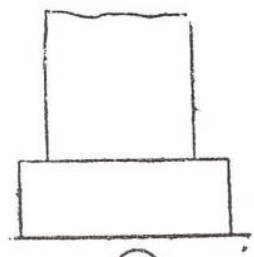

(A)

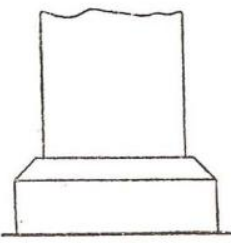

(B)

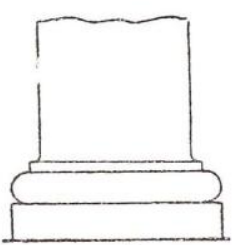

(C)

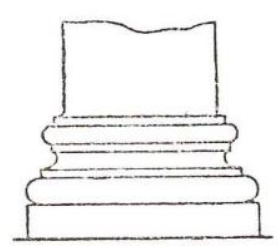

(i)

Figura 106: Bases de coluna decorada com soco simples $(A)$ e estilizado (B, C e D) $)^{84}$

${ }^{83}$ ALBUQUERQUE, Alexandre. Construções Civis. São Paulo: Empresa Gráfica da Revista dos Tribunais, 1952, p. 132.

84 Idem, p. 133. 
Outro elemento decorativo muito usado era a cornija, que era a moldura que coroava a parede, marcando o telhado, com a função de afastar as águas pluviais e evitar que estas escorram pela parede, como visto na Figura 107C. Eram acompanhadas de frisos e arquitraves, faziam parte do entablamento - Figura 107A e eram decoradas com mísulas, modilhões ou tríglifos. A cornija segue por toda a sede baixa e se repete da mesma forma na sede alta, situando-se acima da linha final do entablamento - conjunto onde a cornija está localizada - da sede baixa (Figura 108).

O ático era outro elemento de importância semelhante às cornijas, colocado por cima destas, escondia o telhado e era decorado de forma que a fachada ficasse uniforme. Segurado ${ }^{85}$ apresenta dois tipos de ático, o italiano, conforme Figura 109, com a cobertura aparecendo, e o típico francês, encobrindo o telhado e arrematado por balaustrada, conforme Figura 110.

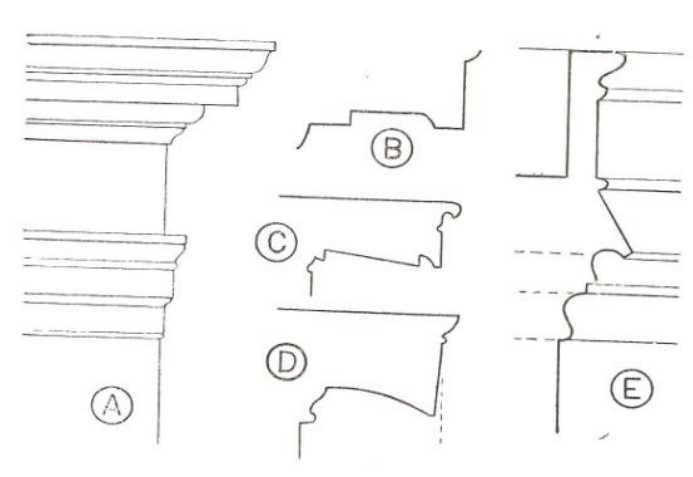

Figuras $107^{86}$ e 108: Acima cornija no entablamento $(A)$, diferentes perfis $(B, C$ e $D)$ e perspectiva (E); ao lado cornija na Pau d' Alho: fim do entablamento da sede alta à direita coincide com começo do entablamento da sede baixa à esquerda

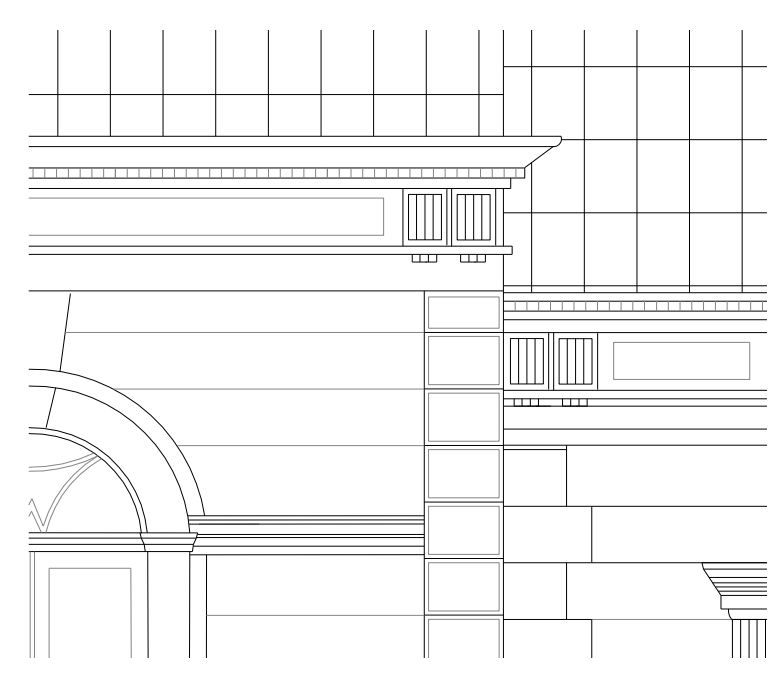

Segurado também apresenta as cimalhas como cornijas do ático, sempre com um lacrimal e de diversos modelos, como o de Vignola, de Paladio, de Bramante, cimalhas com mísulas, com mútulos e com modilhões.

\footnotetext{
${ }^{85}$ SEGURADO, J. S. E. Construção Civil: Edificações. Lisboa: Bertrand, 19-?, pp. 69.

${ }^{86}$ ALBUQUERQUE, Alexandre. Construções Civis. São Paulo: Empresa Gráfica da Revista dos Tribunais, 1952, p. 134
} 

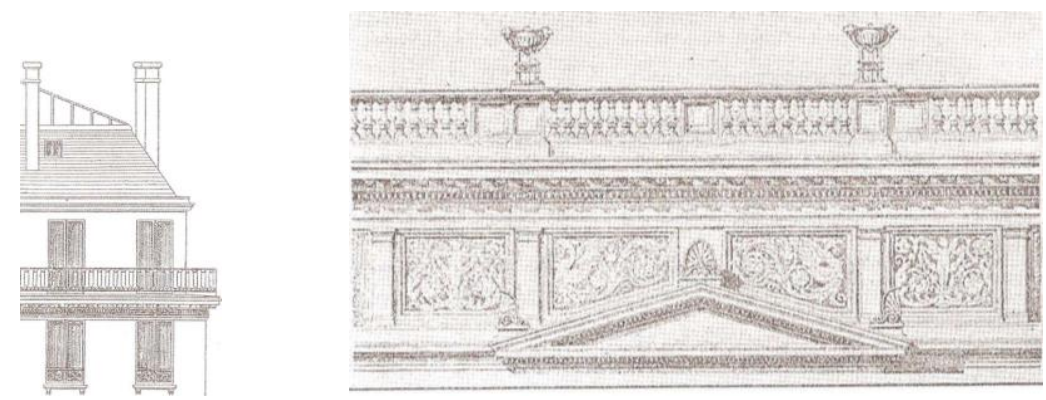

Figura 109 e 110: Ático italiano $(A)$ e ático francês $(B)^{87}$

Assim como o ático, um elemento importante na composição das fachadas são os frontões, que eram usados como coroamento das fachadas e tinham altura de um terço a um sexto da largura. Tinham função construtiva na época dos gregos; no final do século XIX, sua função era decorativa, passando a perder o uso com o advento do concreto armado. Os frontões também podiam ser interrompidos ou curvos, como mostra Segurado ${ }^{88}$ na Figura 111 abaixo. Esses elementos não foram utilizados na Fazenda Pau d' Alho, mas foram usadas em outras obras campineiras, algumas de autoria de Ramos de Azevedo, como o frontão do Circolo Italiani Uniti, construído um ano depois da sede da fazenda, e o ático francês adotado no portal do Cemitério da Saudade, alguns anos depois.

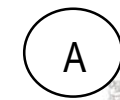

A
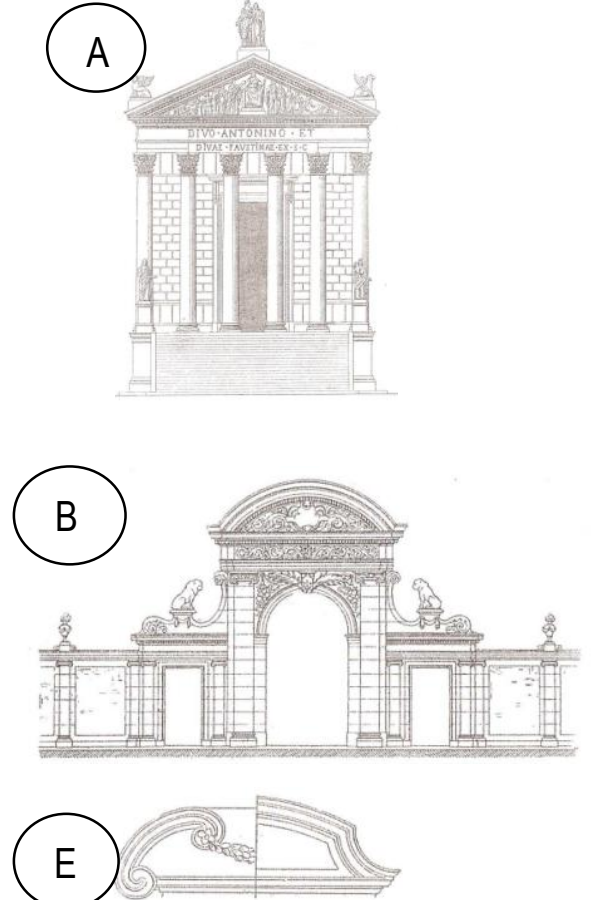

\section{E}
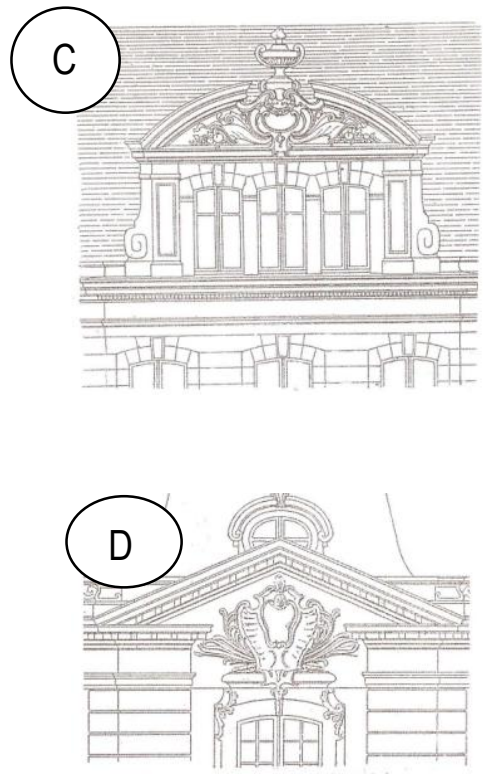

Figura 111: Frontão clássico (A), frontão curvo (B), frontão interrompido em cima (C), frontão interrompido em baixo (D), frontão da Renascença $(E){ }^{89}$

\footnotetext{
87 SEGURADO, J. E. S. Construção Civil: Edificações. Lisboa: Bertrand, 19-?, pp. 66, 67 e 68. 88 Ibid., pp. 67 e 68.

${ }^{89}$ SEGURADO, J. E. S. Construção Civil: Edificações. Lisboa: Bertrand, 19-?, pp. 66, 67 e 68.
} 
Um método muito comum na parede de oitão, em edifícios com parede triangular, que não era tão usada, era construir algumas fiadas de tijolos sobrepostas às telhas, a fim de evitar a captação de águas pluviais junto ao vizinho - ver Figura 112. Porém, na sede da Pau d' Alho, essas paredes, que se encontram na fachada posterior da edificação, mantiveram a platibanda na sede alta e o antigo beiral na sede baixa, não foi adotado tal sistema, dando destaque para a empena com a continuação do forro de madeira da varanda e para o adornado de lambrequim de madeira (Figura 113). A adoção desse detalhe na empena seria uma característica comum nas obras de Ramos de Azevedo, tanto na região como em todo o estado.

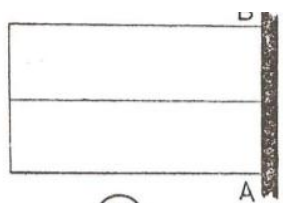

(B)

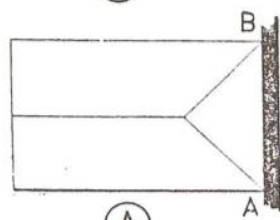

(A)

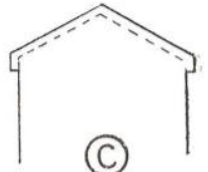

(C)

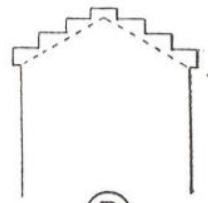

(D)

Figura 112: Parede de oitão: com três águas $(A)$, com duas águas $(B)$ e com fiadas sobrepostas $(C \text { e D })^{90}$

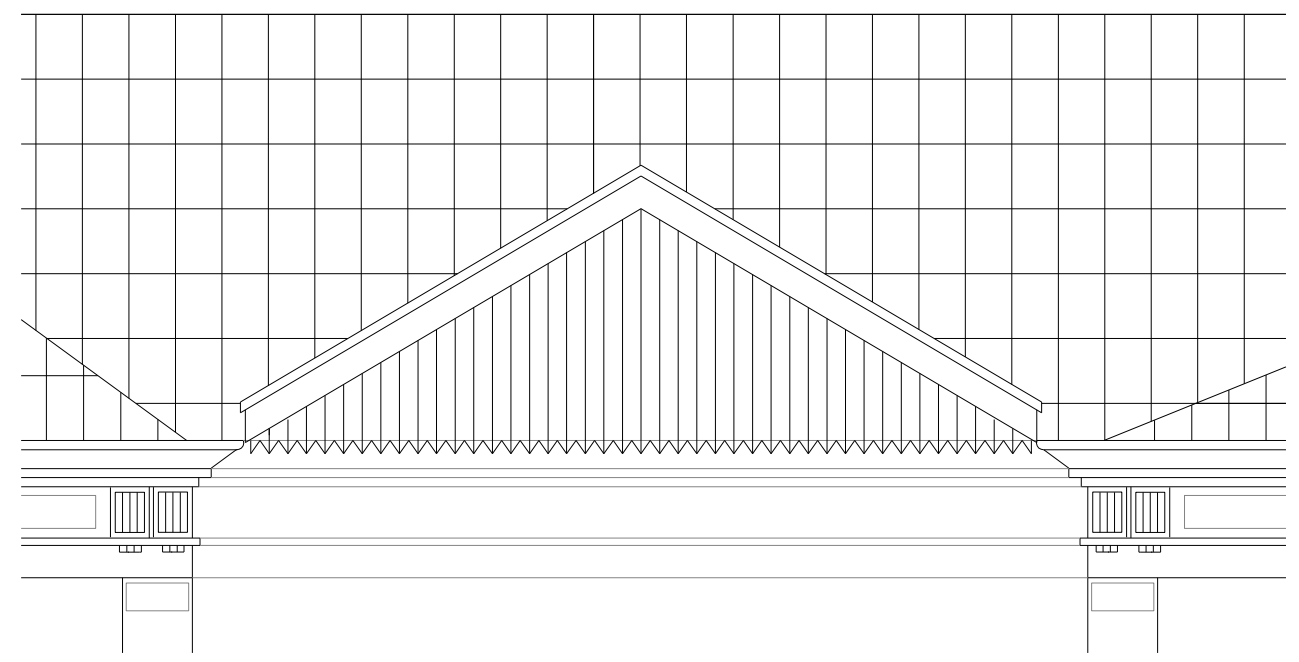

Figura 113: Detalhe de empena na fachada posterior: continuação do forro de madeira da varanda e lambrequim de madeira

90 ALBUQUERQUE, Alexandre. Construções Civis. São Paulo: Empresa Gráfica da Revista dos Tribunais, 1952, p. 137. 
Outro elemento muito utilizado nas fachadas eram as arcadas, constituídas por uma série de arcos apoiados em pés-direitos isolados, formando galeria coberta. Esse elemento também não foi utilizado na sede da fazenda Pau d' Alho. No século XIX, foram muito usadas as arcadas fingidas, geralmente de diâmetro reduzido, com função decorativa, as chamadas "arcaturas". Segurado ${ }^{91}$ argumenta que as arcadas eram o meio mais comum empregado na decoração de edifícios e apresenta vários tipos de arcadas, conforme Figura 114.

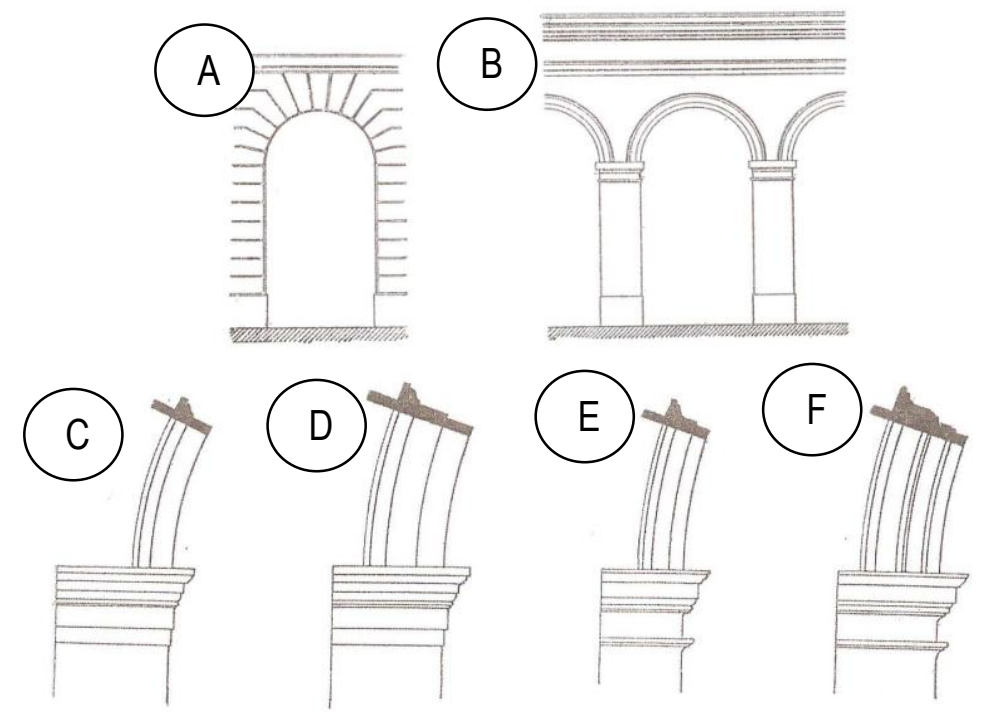

Figura 114: Arcada decorada sem moldura (A), arcada com moldura sobre pilastra retangular (B), arcada jônica sem pedestal ( C), arcada jônica com pedestal (D), arcada coríntia sem pedestal (E), arcada coríntia com pedestal (F)

A janela é o principal elemento que diferencia as sedes quanto à técnica construtiva, como já vimos, sendo em verga reta na sede baixa e arco pleno na sede alta, e também quanto à decoração. Na sede baixa, as janelas são encimadas por uma moldura sustentada por um tríglifo com métopas em cada extremidade, imitando o tríglifo da cornija. Nesta, os tríglifos se apresentam nas extremidades, em duplas, e, na parte inferior, as janelas receberam bossagem, imitando uma almofada de pedra.

$\mathrm{Na}$ sede alta, as janelas em arco pleno, que pela sua própria técnica construtiva exerceu também função decorativa dispensando molduras superiores, também receberam as bossagens na parte inferior.

Ambos tipos de janelas foram desprovidas de padieiras, que eram outros elementos construtivos que se tornaram decorativos nas janelas. As padieiras e peitoris, coroamento em linhas horizontais protegendo a janela contra a ação das chuvas, não eram tão comuns no final do século XIX, mas tinham grande importância - ver Figura 115.

91 Ibid., pp. 59 a 65. 

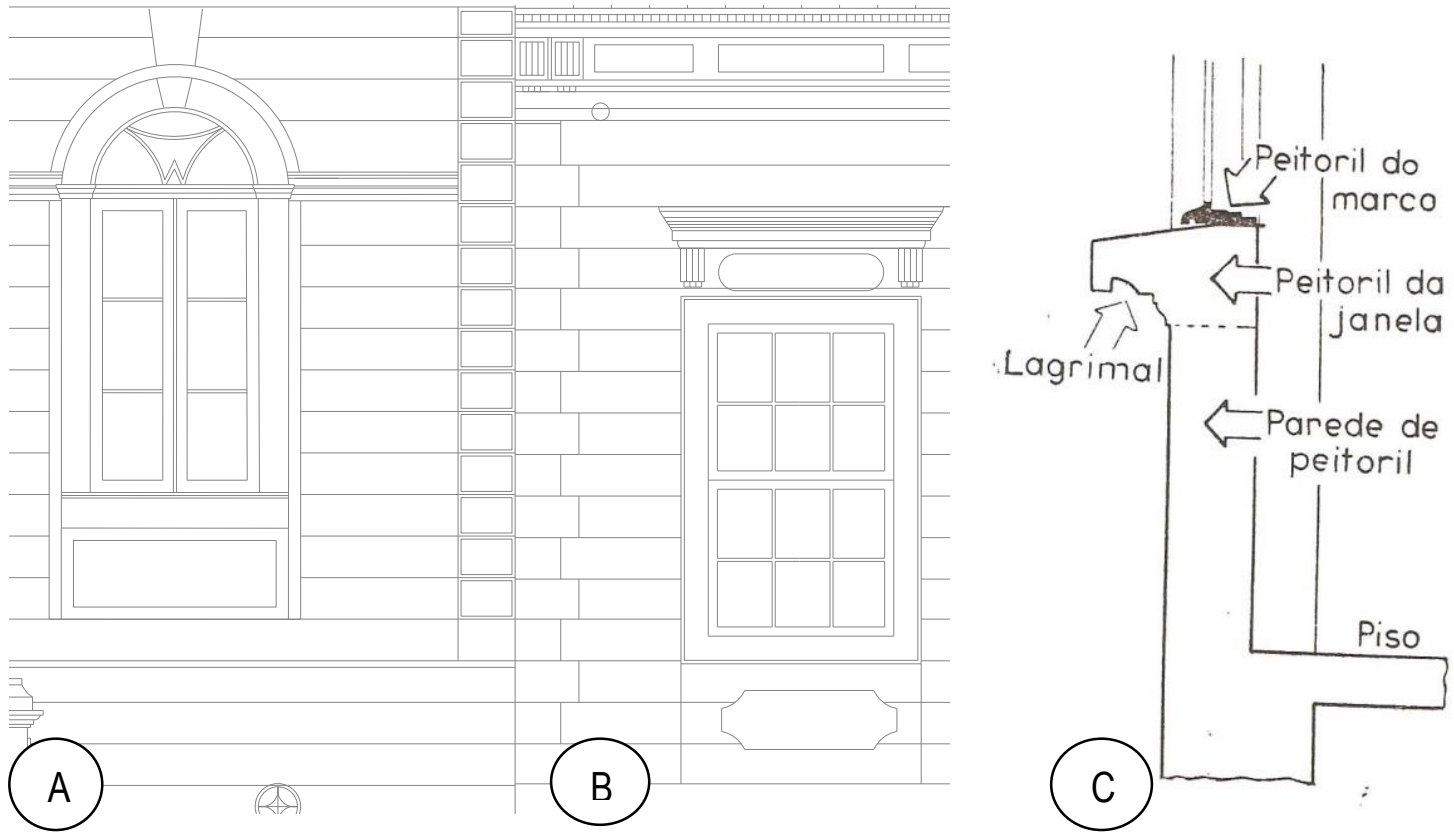

Figura 115: À esquerda: janela da sede alta em arco pleno (A), à direita: janela da sede baixa em verga reta (B).Composição de peitoril (C) ${ }^{92}$

Em caso de diversos pisos, eram utilizadas as fachas que serviam para separar os pisos e evitar a queda da água da chuva pela parede abaixo. Possuíam diversas formas, desde modelos simples, clássicos, góticos, românticos com lacrimal para proteger as paredes (Figura 116), especialmente de alvenaria de tijolo, e sem lacrimal (Figura 117).

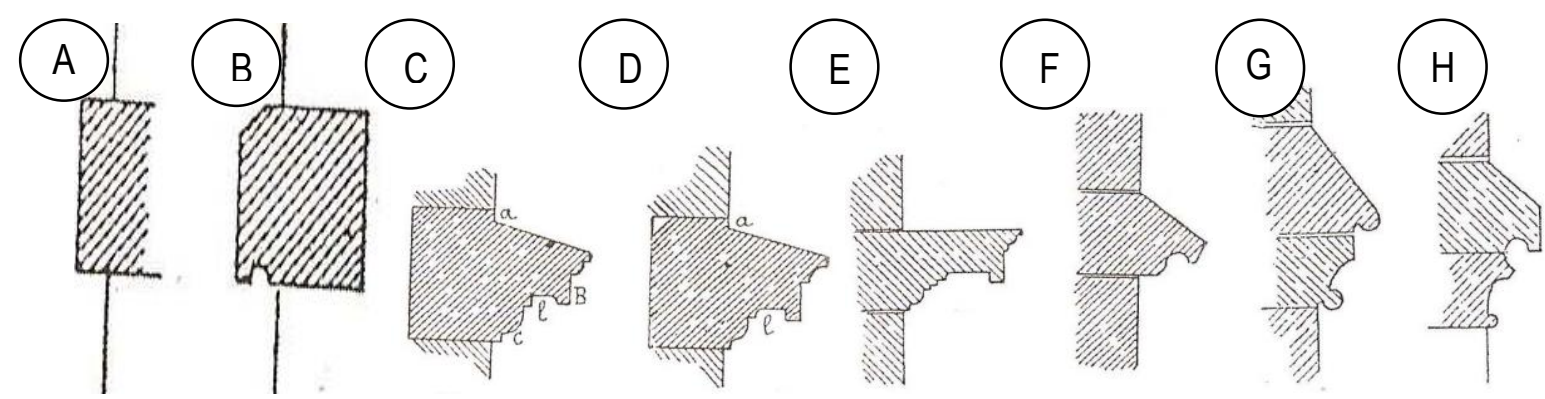

Figura 116: Fachas simples (A e B) com lacrimal (C e D), facha clássica $(E)$, facha gótica $(F)$, e facha romântica $(\mathrm{G}$ e $\mathrm{H})$

92 Ibid., pp. 138. 

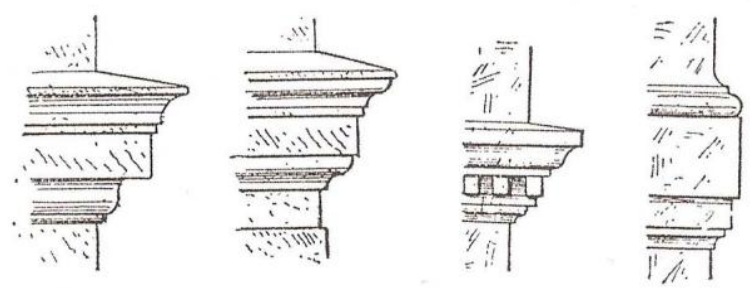

Figura 117: Fachas clássicas sem lacrimal

Por fim, os cunhais e pilastras revestiam, verticalmente, do envasamento até a cimalha e as pilastras, do começo ao fim ou alternadas, conforme Figura 119. O detalhe na fachada mais marcante nas obras de Ramos de Azevedo são os cunhais, o chamado cunhal guarnecido, imitando bossagem de pedra. Na sede alta, os cunhais estão em todos os cantos e, na sede baixa, entre as portas, temos uma versão de bossagem imitando os cunhais para separar as entradas.
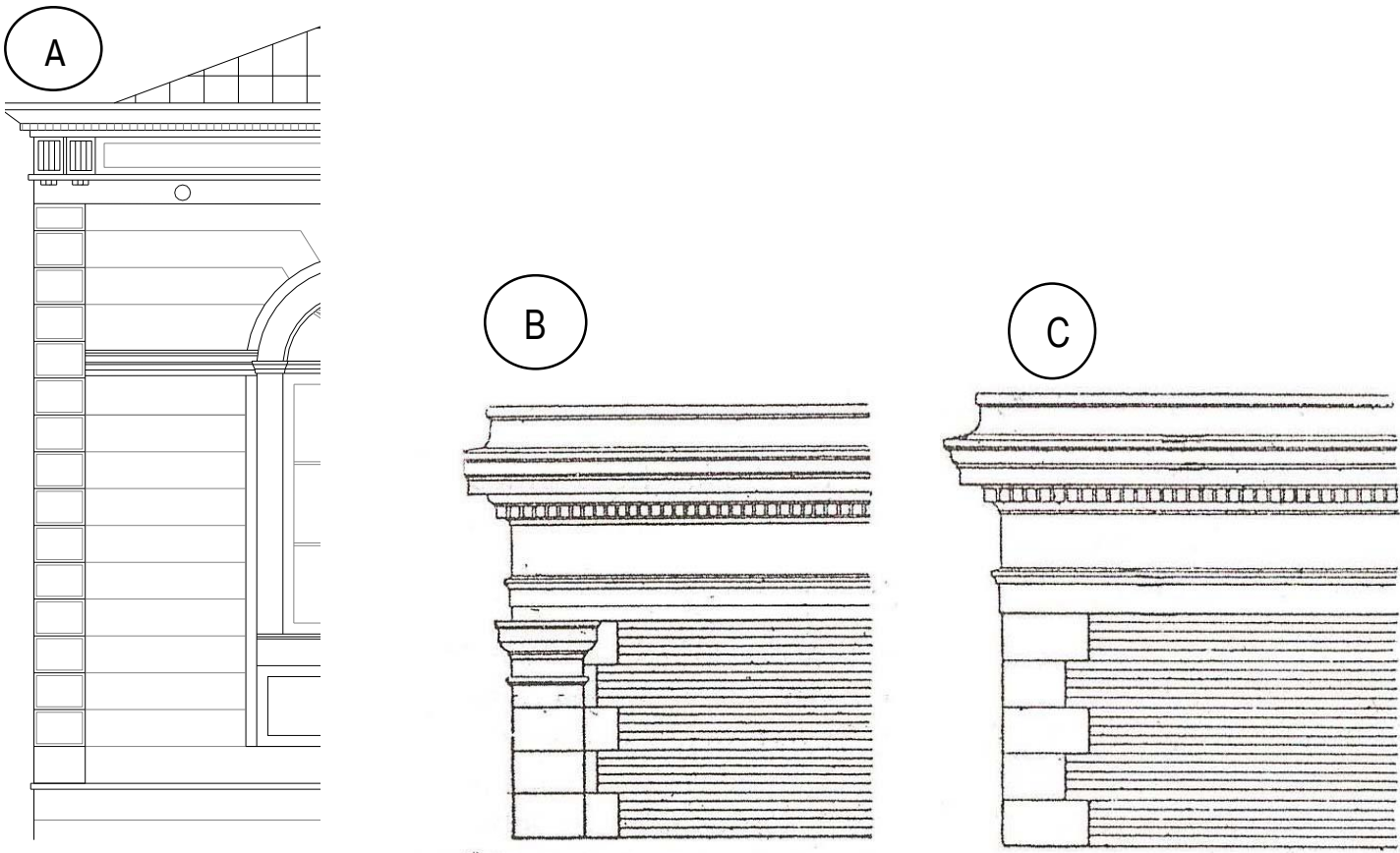

Figura 118 e 119: Cunhal da sede alta na fachada frontal da fazenda Pau d' Alho (A) e exemplos de cunhal com pilastra $(B)$ e cunhal guarnecido $(C)^{93}$

\subsubsection{Argamassas, rebocos e estuques}

A argamassa, além de ser usada como acabamento das paredes, com função de protegê-las, foi um elemento muito importante na decoração, fortalecendo o

\footnotetext{
${ }^{93}$ SEGURADO, J. E. S. Construção Civil: Edificações. Lisboa: Bertrand, 19-?, pp. 66, 67 e 68.
} 
ecletismo e, no caso aqui investigado, os traços neoclássicos. Além de revestir a alvenaria, podia revestir frontais, e internamente, tabiques e tetos.

O acabamento das paredes também podia ser feito com argamassa hidráulica, de cimento e areia, ou com gesso amassado com água. O revestimento de argamassa hidráulica podia ser feito diretamente sobre a alvenaria ou sobre uma primeira camada de argamassa ordinária. Já o revestimento de gesso, fazia-se necessário ser colocado sobre uma camada de argamassa ordinária, não devendo ser usado em paramentos exteriores, pois se alterava com a umidade.

Os frontais, tabiques e tetos, depois de revestidos de argamassa, podiam receber decoração fasquiada, uma série de fasquias ou réguas paralelas separadas a uma distância para segurar o reboco da argamassa, precedidos do "enchimento". As fasquias de madeiras possuíam bases de dez e dezoito milímetros de largura e altura de doze milímetros, e eram dispostos em linhas horizontais, distando de dois a três centímetros, com a base maior das fasquias voltadas para o exterior para prender melhor a argamassa do reboco. Nos tetos e sancas, era necessário aproximar mais o fasquiado para reter mais facilmente a argamassa. Também se aplicava o fasquiado sob os degraus das escadas para formar o teto do andar abaixo.

O "emboço" ou "chapado" era a aplicação da primeira camada de argamassa ordinária às paredes de alvenaria, obtendo-se uma superfície plana, mas muito áspera, e sobre este se aplica a segunda camada, o "reboco", deixando a superfície bem regular. Este é também chamado de "enchimento a pardo", quando é misturado à argamassa ordinária para apressar a secagem. Para conseguir o reboco perfeito, usavam as mestras ou superfície de referências como guia para o pedreiro. Para fazer a mestra, chapavam na mesma prumada uns botões de argamassa, fixando pedaços de fasquias com o rabo da colher até ficarem bem aprumados. A mestra se formava entre esses botões de argamassa, uma facha vertical de doze a dezesseis centímetros de largura, desempenando-a com a régua que se esfrega sobre a superfície, e podiam-se fixar mestras com gesso também. Depois de secas, as mestras rebocavam os espaços entre elas, chapando a argamassa à colher e roçando com a régua entre duas mestras, tirando a argamassa em excesso e, em seguida, o reboco era alisado com desempenadeira. 
O revestimento com argamassa hidráulica podia constituir um reboco liso ou áspero, chamado de "crespido". Neste, a argamassa era embebida na vassoura que ia chapando a parede por igual, sendo usado em muros e envasamento de edificações, mas não muito recomendado devido ao acúmulo de poeira nas cavidades. Sobre o reboco ou enchimento, aplicava-se o "estuque", podendo ser moldurado ou não, branco ou colorido. Nas paredes externas, onde não se podia usar o gesso, aplicavase o "guarnecimento", argamassa de cal e areia, numa primeira camada, e de cal em pasta na segunda, podendo ser branco ou colorido.

O estuque, além de ser usado como decoração mesmo nas casas mais simples como revestimento liso, era muito utilizado para o conforto da casa. Obtido pela cozedura da pedra de gesso, o pó, quando misturado com água, endurecia rapidamente, facilitando o trabalho. A cal para estuque empregada pelo estucador devia ser extinta com antecedência, por imersão. Depois de fria, muitos estucadores utilizavam os pêlos (de boi, de cabra, crina) para dar mais consistência à pasta. As ferramentas utilizadas pelos estucadores eram: o metro (régua de madeira), fio de prumo (cone de metal com cordel fino), níveis (bolha de ar), compasso, cintel e esquadros. Também utilizavam ferramentas de pedreiros, como a picadeira, colher de pedreiro, colherim, ferro de canto, ferro de corte, ganchetas, desempenadeira, talochas, réguas de canto, entre outros - ver Figura 120. 


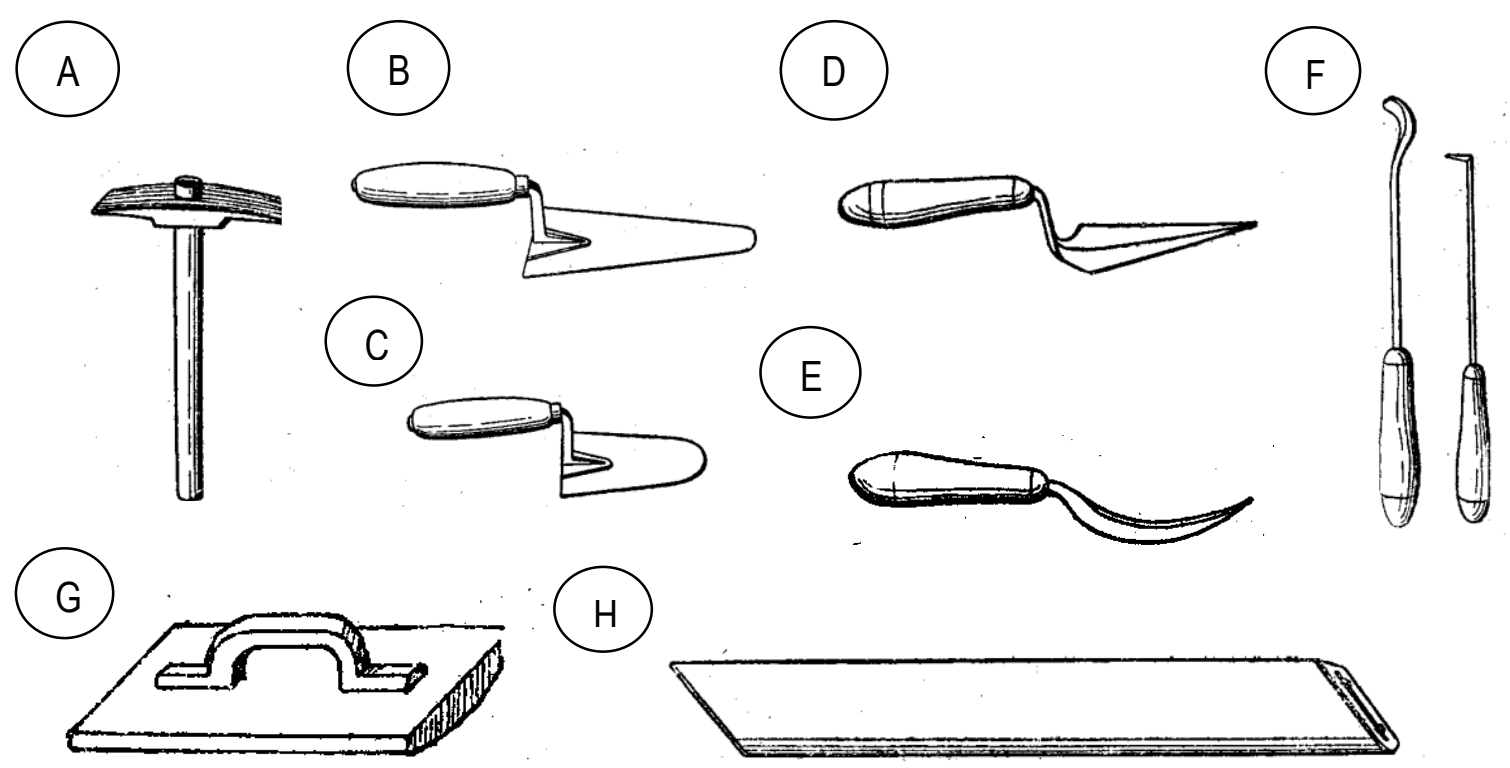

Figura 120: Ferramentas utilizadas pelo estucador: picadeira $(A)$, colher de pedreiro $(B)$, colherim $(C)$, ferro de canto $(D)$, ferro de corte $(E)$, ganchetas $(F)$, talocha $(G)$ e régua de canto $(H)^{94}$

O revestimento das paredes podia ser ornamentado com molduras, que podiam ser feitas in loco ou serem postiças $^{95}$. Para fazer as molduras no local definitivo, era necessário aplicar o molde, uma chapa de ferro com perfil da moldura, recortada e pregada em tábua com o mesmo perfil aproximadamente, mas deixando a chapa metálica um pouco proeminente. O molde era munido de guias "D", que corriam sobre outras iguais "G" (Figura 121A), fixadas nas paredes com auxílio de escápulas (Figura 121B) e munido de "pegas", para que o estucador pudesse manejar adequadamente.

Antes de correr a moldura, devia-se executar seu esqueleto com tijolos devidamente recortados com placas de concreto ou o esqueleto podia ser feito com ripas pregadas em cambotas, que eram embutidas nas paredes. Sobre o esqueleto, 0 operário atirava a argamassa com a colher e corria o molde, fixando-o nas guias correspondentes. Repetia esse processo em várias passadas, até que o reboco ficasse grosso e, depois que secava, fazia uma segunda camada, com o acabamento desejado, granulado ou liso. Para ficar bem liso, aplicava-se à moldura leite de cal, passando o molde e retocando, se necessário, com auxílio de colher ou espátula. Por fim, o acabamento dos ângulos, que não dava para ser feito com o molde, era terminados à mão por operários especializados.

\footnotetext{
94 Ibid., pp. 131 a 149.

95 ALBUQUERQUE, Alexandre. Construções Civis. São Paulo: Empresa Gráfica da Revista dos Tribunais, 1952, pp. 201 a 203.
} 

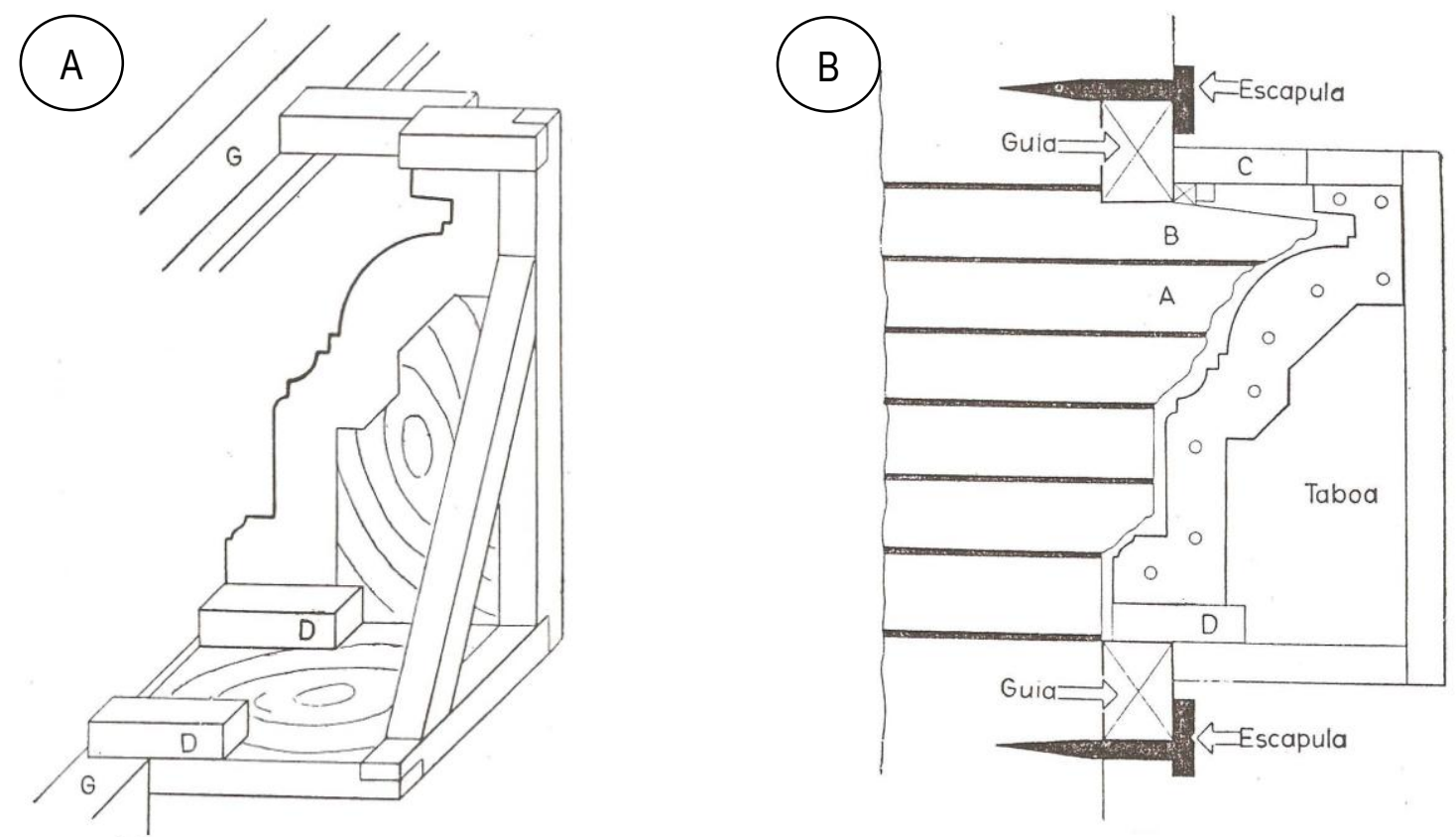

Figura 121: acima à esquerda: exemplo de molde aplicado em revestimentos internos $(A)$, à direita: exemplo de molde com guias par correr sobre as guias fixadas com escápula (B): ${ }^{96}$

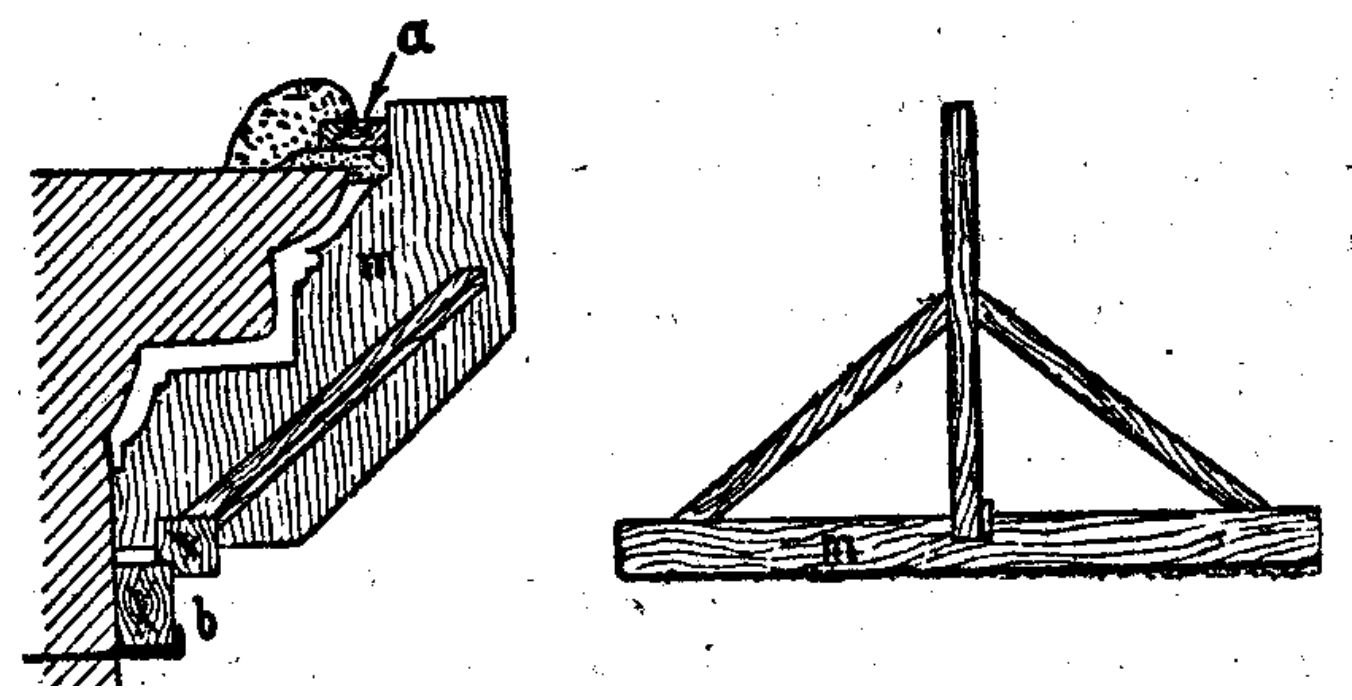

Figura 122: Exemplo de um dispositivo utilizado para a aplicação de molduras em fachadas $^{97}$

Já as molduras postiças, que eram executadas em oficinas especializadas pelo sistema de fundição e, posteriormente, fixadas à parede, ofereciam mais vantagem devido ao melhor acabamento. Quando as molduras eram ornamentadas, este era o único recurso, pois o ornato não podia ser obtido com o molde. Depois de tirado o negativo em cola, do molde de barro ou gesso, essas molduras postiças podiam ser

\footnotetext{
96 Ibid., pp. 201.

${ }^{97}$ SEGURADO, João Emílio Santos. Construção Civil: acabamentos de construções. Lisboa: Bertrand, $19-?$, pp.121 a 132.
} 
reproduzidas em grande número de cópias. As molduras eram fundidas em gesso e reforçadas com fios de aniagem, facilitando seu transporte, sua serragem e fixação nas paredes e tetos com parafusos envolvidos em estopa e colocados em banho de gesso, e então a moldura era finalizada com retoques nas emendas.

Não foram só os elementos de decoração arquitetônica como molduras, cornijas, tríglifos e colunas que transformaram a sede da fazenda Pau d'Alho numa sede moderna, vigente do neoclassicismo, aqui a argamassa teve um papel muito importante. A argamassa foi utilizada em toda a fachada da sede, tanto alta como baixa, unidas pelos mesmos vincos horizontais, como podemos ver na Figura 123.

Sem ornamentos com motivos animais ou infantis como era costume, na fazenda Pau d' Alho os ornamentos consistem basicamente em todo o entablamento, pilastras, cunhas, molduras, fachas e bossagens, como vimos, sendo aplicados esses métodos. Além das gárgulas, peças de ferro para escoar água no formato de cabeça de dragão, outra imagem que se tem são duas estátuas de anjos situadas no pedestal dos acessos laterais das escadas do alpendre, que são de ferro e foram importadas, tendo a inscrição de sua origem marcada em local próximo ao pedestal.

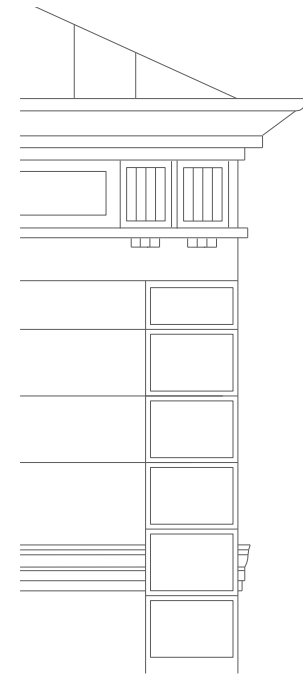

Figura 123: Detalhe das métopas e molduras de argamassa na sede da fazenda Pau d' Alho

\subsubsection{Madeira}

Em geral, o trabalho com madeira requeria vários instrumentos de carpinteiro como: esquadro, serras, sargentos, machados, enxós, maços, bedames, brocas, garlopas, plainas e muitos outros. Segurado ${ }^{98}$, em seu livro de Carpintaria Civil, relata

98 SEGURADO, João Emílio dos Santos. Construção Civil : trabalho de carpintaria. Biblioteca de Instrução Profissional, Livraria Bertrand, 19-?, pp. 4. 
que os carpinteiros civis classificavam o trabalho de madeira em "tosco" ou "limpo". "Tosco" era o trabalho de madeira apenas serrado, sem apresentar outro aparelho, e não ficava à vista, como o esqueleto de casa, frontais, tabique, vigamentos e outros. $O$ trabalho "limpo" ou "carpintaria de obra branca" era o trabalho que tinha acabamento mais cuidado, para ficar à vista, como o trabalho de portas, janelas, alizares, rodapés, soalhos, vigamentos e tetos de madeira, e escadas, que aqui serão apresentados, relacionados ao presente item de ornamentos arquitetônicos.

Externamente, a madeira foi utilizada apenas nas janelas, tanto da sede alta como da baixa, e no corrimão do alpendre, internamente, este material será usado com abundância nos soalhos, forros, revestimentos e detalhes.

\subsection{Soalhos}

Os soalhos mais comuns eram de mecha e encaixe, estes eram chamados por Segurado ${ }^{99}$ de "soalho à portuguesa", preparados com auxílio de plainas mecânicas e sua fixação ao vigamento era feita com prego oculto, segundo Albuquerque ${ }^{100}$ - ver Figura 124A. A mecha não tinha comprimento igual ao da ranhura para o soalho ficar bem justaposto - Figura 124B. Outros tipos de juntas longitudinais utilizavam meia madeira, chamado por Segurado de "soalho à inglesa", mas menos usado - Figura $124 \mathrm{C}$ e 124D. As tábuas de soalho não deviam ser muito largas, as mais comuns são de dez centímetros. Para reduzir o custo de mão-de-obra, utilizavam tábuas mais largas, de quatorze a vinte centímetros e, para diminuir os defeitos, costumavam aplainar com um ou dois chanfros na parte inferior - Figura 124E e 124F.
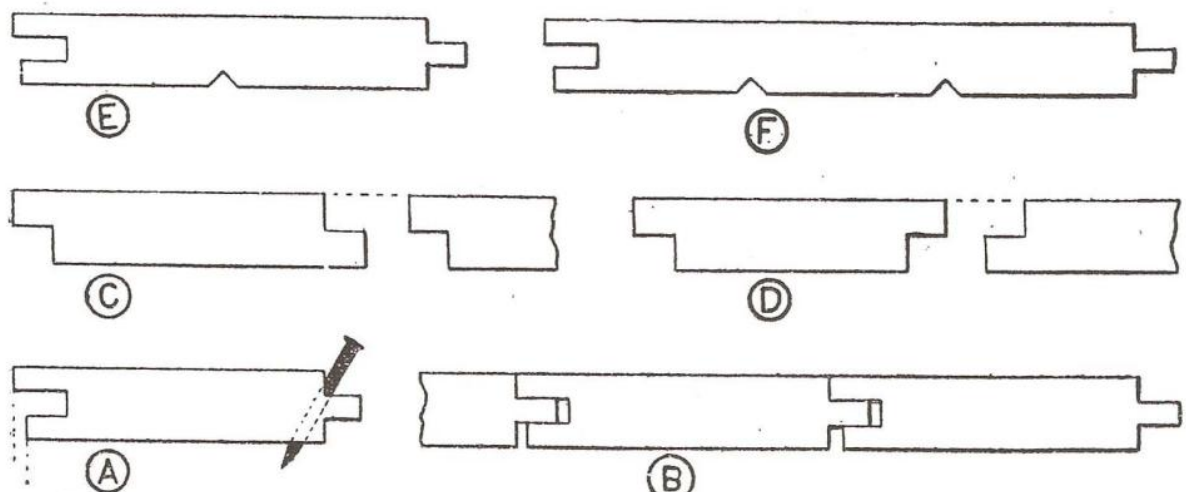
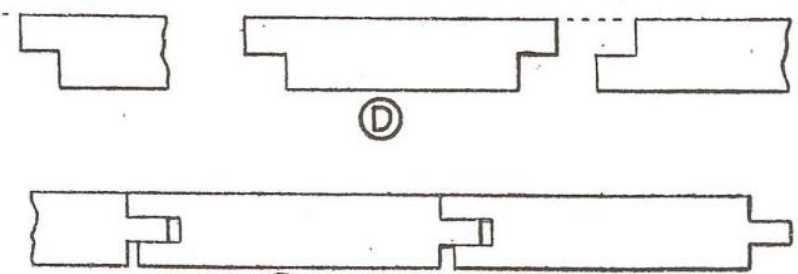

(B)

Figura 124: Soalho tipo mecha e encaixe: com prego oculto $(A)$, encaixe $(B)$, com meia madeira $(C$ e D) e com chanfros (E e F)

99 SEGURADO, João Emílio dos Santos. Construção Civil: Materiais de construção. Biblioteca de Instrução Profissional, Livraria Bertrand. Volume II, pp. 27.

100 ALBUQUERQUE, Alexandre. Construções Civis. São Paulo: Empresa Gráfica da Revista dos Tribunais, 1952, pp. 234 a 242.

101 lbid., pp. 234 
As tábuas de soalhos eram pregadas formando desenhos, sendo que o tipo mais econômico era o soalho paralelo. Eram pregadas paralelamente às paredes mais compridas e ao barrote perpendicular. Outro tipo de soalho era o diagonal, com barrotamento igual, com diversos desenhos (Figura 125A a 125C). Para um melhor aspecto dos soalhos, utilizavam-se de tabeiras (Figura 125D a 125G), uma cercadura de tábuas paralelas em todas as paredes e sua largura dependia da largura da sala, valorizando o soalho central.
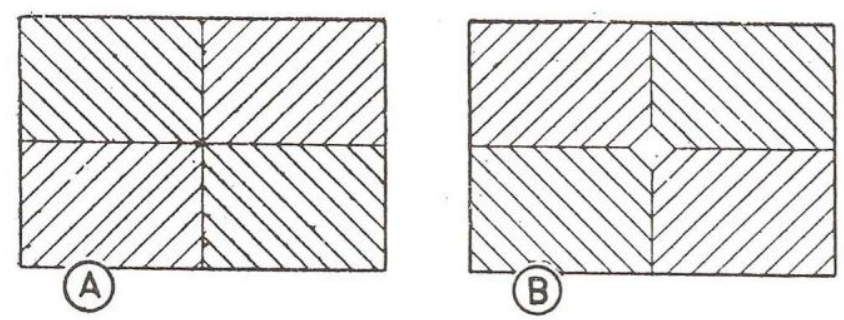

(B)

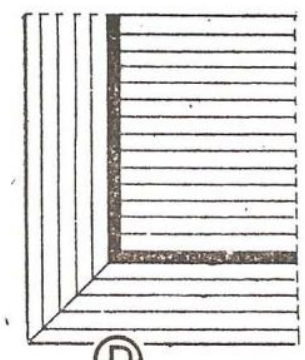

(D)

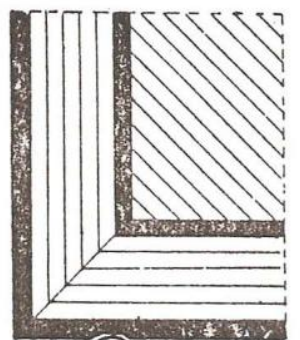

(E)

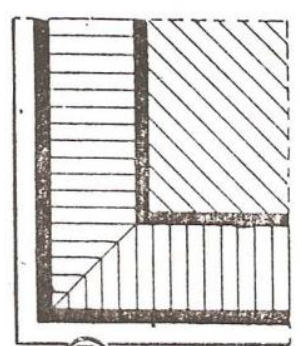

(E)

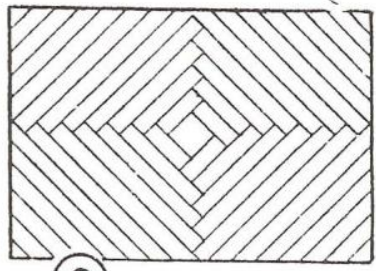

(C)

Figura 125: Soalho diagonal $\left(A, B\right.$ e C) e com tabeiras $\left(D, E, F\right.$ e G) ${ }^{102}$

Outro tipo de soalho que também se usava eram os soalhos de tacos, chamados por Segurado de "parquets", com rica variedade de desenhos (Figura 128). Em geral tinham largura de 0,07 a 0,09 m e comprimento de 0,15 a 0,20 m. Pronta a laje, assentava-se com argamassa e pouca água. Era aconselhável colocar os tacos em posição diagonal e sem tabeira. Por fim, deviam ser igualmente raspados e encerados. Para os tacos, o ipê era a madeira mais recomendada. 

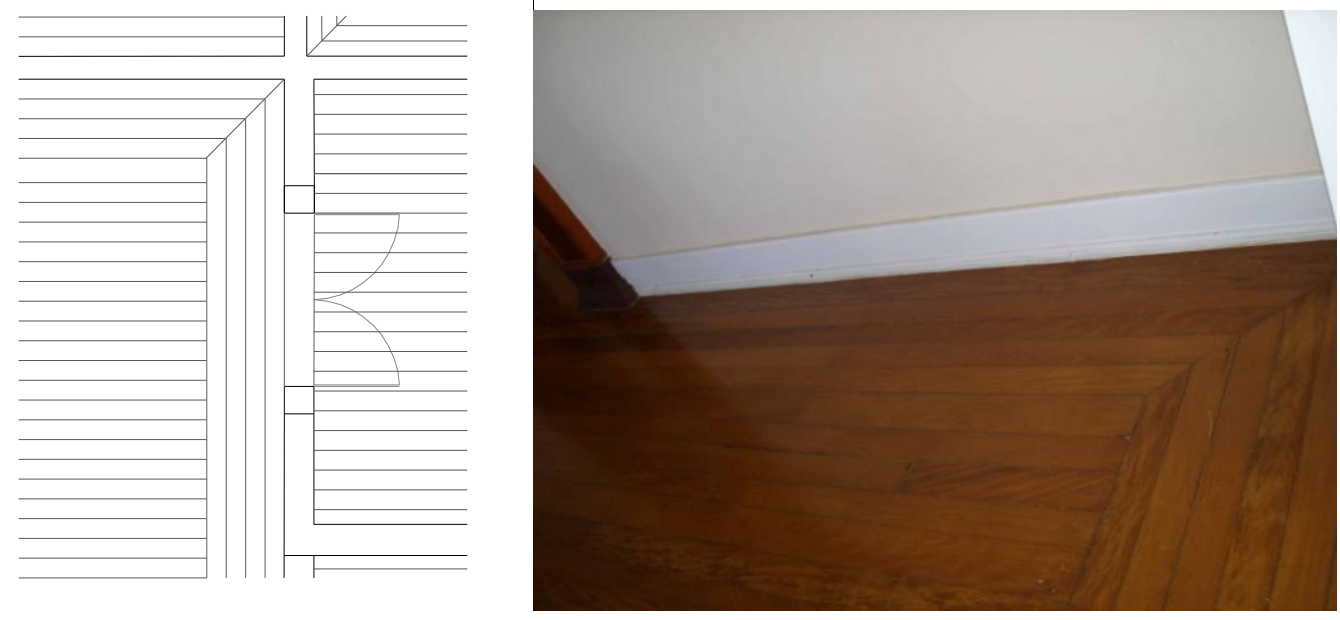

Figuras 126 e 127: Desenho da tabeira cercando piso da sala na sede alta da fazenda Pau d' Alho e sua foto

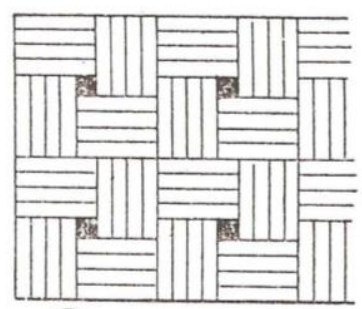

(A)

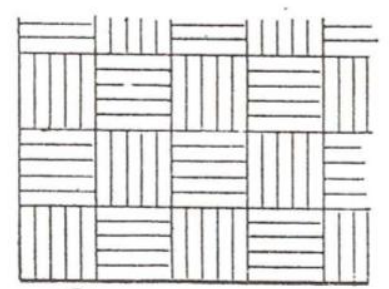

(D)

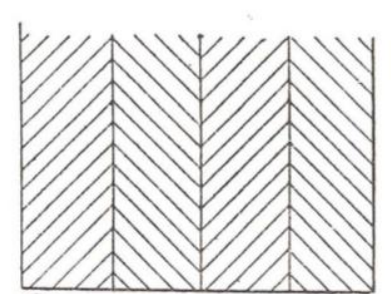

(B)

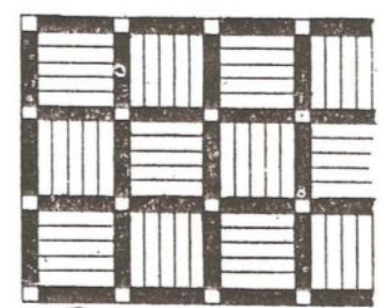

(e)

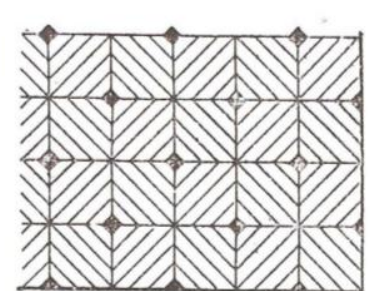

(C)

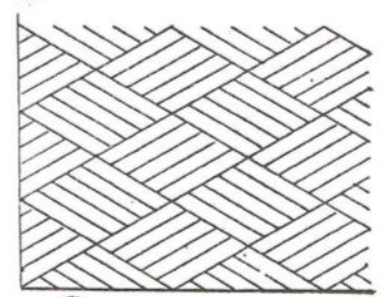

(F)

Figura 128: Diversos desenhos de parquets

No interior dos cômodos da sede alta, os pisos das salas e dormitórios da Pau d' Alho são tabuados de madeira do tipo mecha e encaixe, mais empregados em São Paulo. Já os soalhos de taco não foram usados na Pau d'Alho. As tabeiras foram utilizadas nas salas e saletas da sede alta, como sala de visitas, sala de jantar e saletas íntimas, diferenciando-as dos dormitórios, que não apresentavam tabeira ${ }^{103}$. As soleiras também deviam combinar com o soalho, sendo, de preferência, uma só tábua. Por fim, o soalho era raspado, manual ou eletricamente, pronto para receber pintura de cera. As madeiras mais usadas para tal fim, em São Paulo, eram de perobas e canelas.

\footnotetext{
${ }^{102}$ Figuras 127 e 128: Ibid, pp. 237 e 239.

${ }^{103}$ Ver detalhe de todos pisos de madeira na sede alta na ampliação da planta no Anexo 3.
} 


\subsection{Rodapés}

Os rodapés constituíam complemento de revestimento aos pisos de madeira: são tábuas de 0,05 a 0,015 m de altura, fixadas na parte inferior da parede, junto ao piso. Eram fixados com pregos em tacos e demarcados pelo pedreiro. Para aumentar seu efeito decorativo, usavam-se rodapés duplos. A madeira mais usada para rodapés era a peroba. Na sede alta, os rodapés são mais altos, com $0,17 \mathrm{~m}$ - essa altura foi muito utilizada nas obras de Ramos de Azevedo em Campinas, como podemos constatar, por exemplo, no Bosque dos Jequitibás, na Escola Ferreira Penteado e até na Catedral Metropolitana.

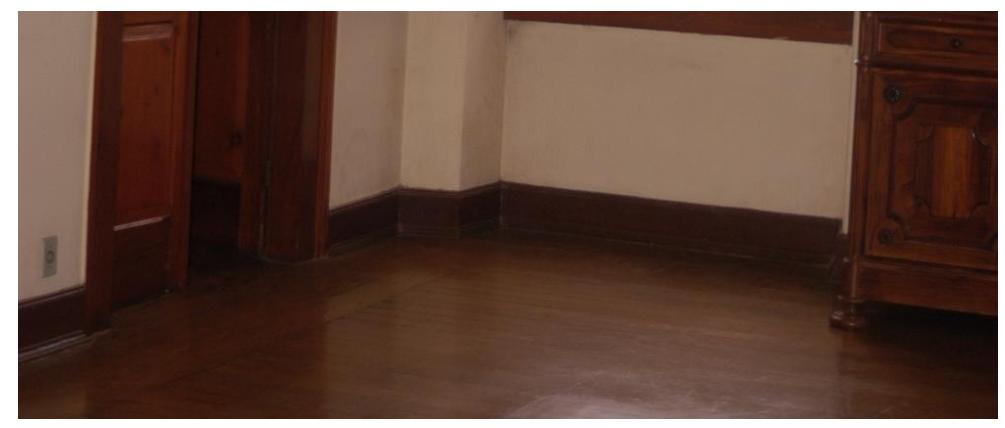

Figura 129: rodapés de madeira da saleta

\subsection{Forros e vigamentos}

Os casos comuns de sobrados de madeira eram constituídos de vigamento, recebendo, de um lado, o soalho e, de outro, o teto - Figura $131 \mathrm{~A}$-, porém menos recomendado, outros casos eram dois vigamentos independentes - Figura 131B mais seguro e menos sonoro. O vigamento também podia ser aparente, nesse caso, o barrotamento devia ser aparelhado com muito apuro, aumentando o custo de mão-deobra e também a sonoridade - Figura 131C. Para evitar essa sonoridade, podia-se usar forro e enchimento com material isolante, muito caro - Figura 131D ${ }^{104}$.

104 ALBUQUERQUE, Alexandre. Construções Civis. São Paulo: Empresa Gráfica da Revista dos Tribunais, 1952, pp. 244 à 248. 

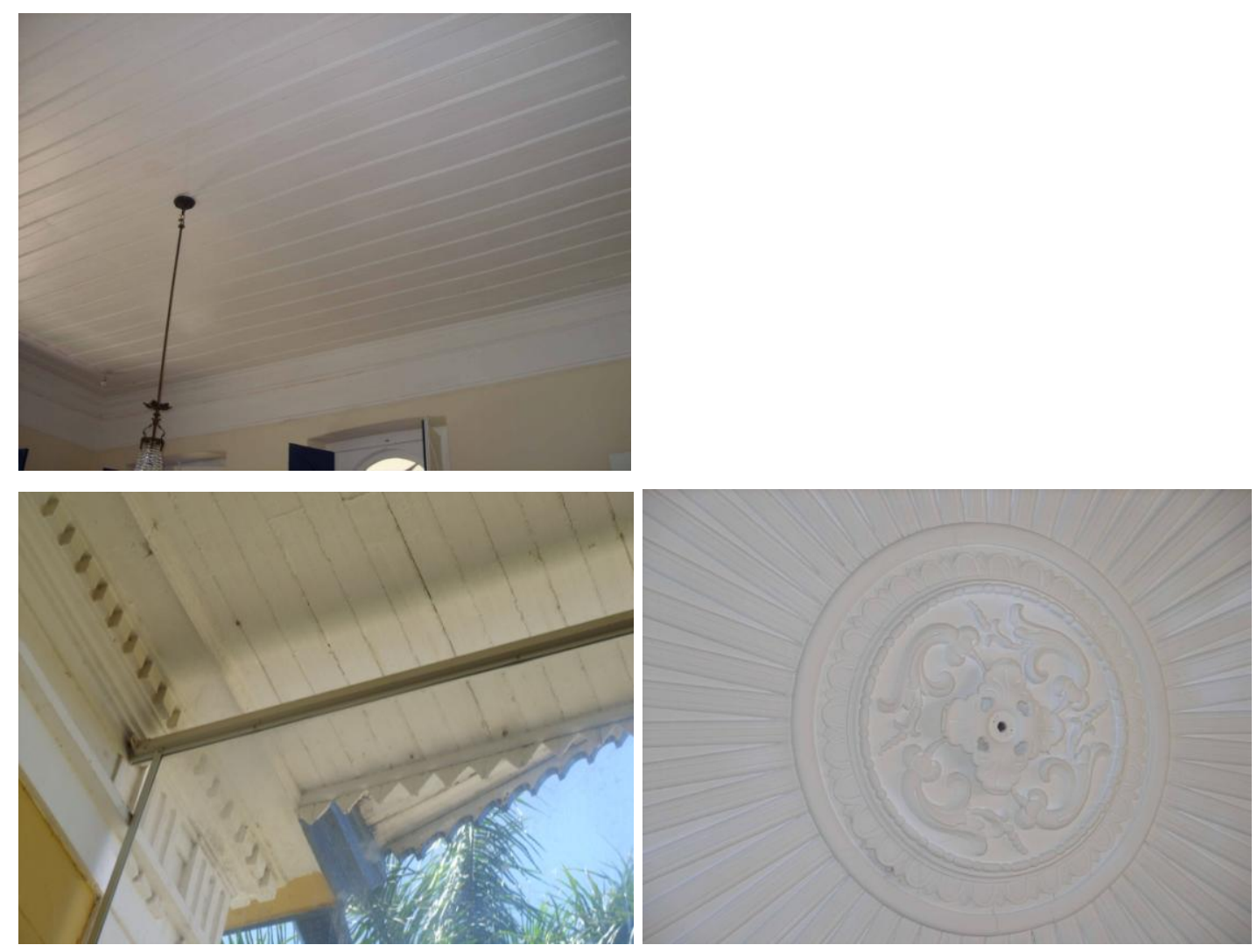

Figura 130: Forro tipo mecha-e-encaixe: na saleta, na varanda com cornija, e na saleta com motivos florais 


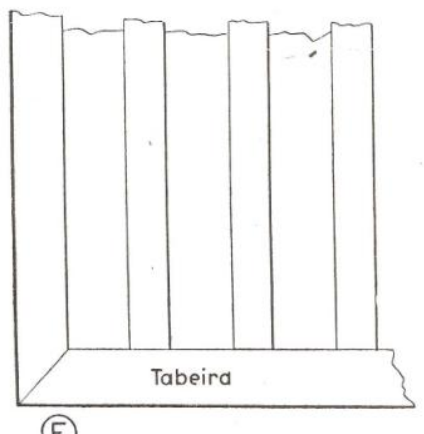

(F)
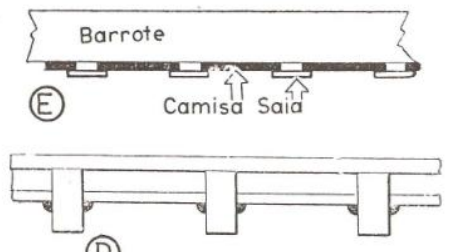

(D)
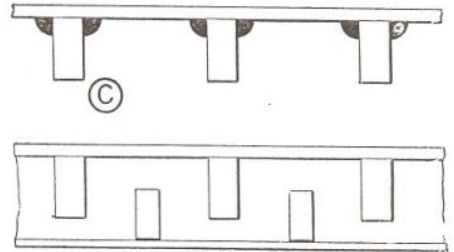

(B)

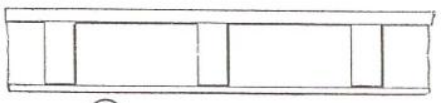

(A)

Figura 131: Soalho com vigamento comum (A), independente (B), com barrotamento sofisticado (C), acústico (D), saia e camisa (E) e com tabeira (E) ${ }^{105}$
Os tetos de madeira podiam ser tábuas sobrepostas, também chamadas "saia e camisa", processo mais antigo e prático, ou de mecha e encaixe, mais moderno, que foi utilizado na fazenda Pau d'Alho, em todos os ambientes da sede alta e na maioria dos ambientes da sede baixa (Figura 130), passando a ser usado depois que as serrarias dispuseram de máquinas especiais para aplainar as tábuas. No teto de "saia e camisa", as camisas eram as tábuas pregadas diretamente no barrotamento, deixando entre elas espaço vazio, onde eram pregadas sobrepostamente às saias, tábuas de largura mais reduzida que as camisas - Figura 131F. Para um melhor acabamento, colocava-se um quadro ao redor, a tabeira.

Nos tetos de mecha e encaixe, o sistema era semelhante aos pisos de soalhos, não sendo necessário paramento liso, porém, como era difícil esconder as juntas, mantinham-nas visíveis e com uma moldura, conforme Figura 132A e 132B. Os desenhos do teto também eram semelhantes aos soalhos de tábuas de madeira, conforme Figura 132C a 132F.
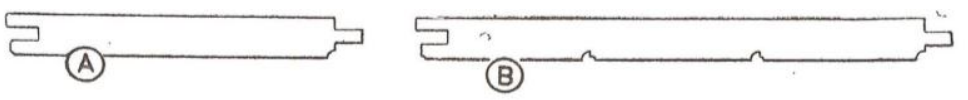

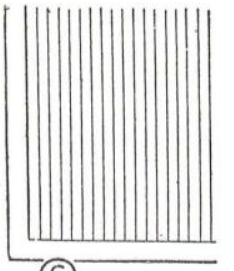

(C)

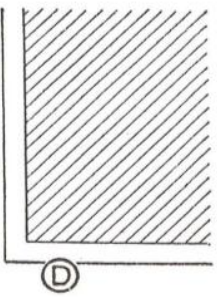

(D)

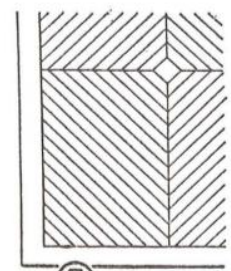

(E)

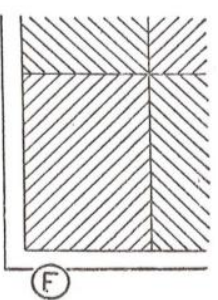

(F)

Figura 132: Teto de mecha e encaixe (A e B) e diferentes desenhos (C, D. E e F)

105 Ibid, pp. 245. 
Os soalhos podiam ser arrematados com "aba e cimalha", cuja cimalha era pregada no teto e na aba, uma tábua de madeira fixada na parede, fazendo a ligação entre teto e parede. Para arrematar, pregava a arquitrave na parte inferior da aba e, após isso, o pedreiro retocava o reboco - ver Figura 133. Esse tipo de acabamento não foi encontrada na sede da Pau d' Alho.

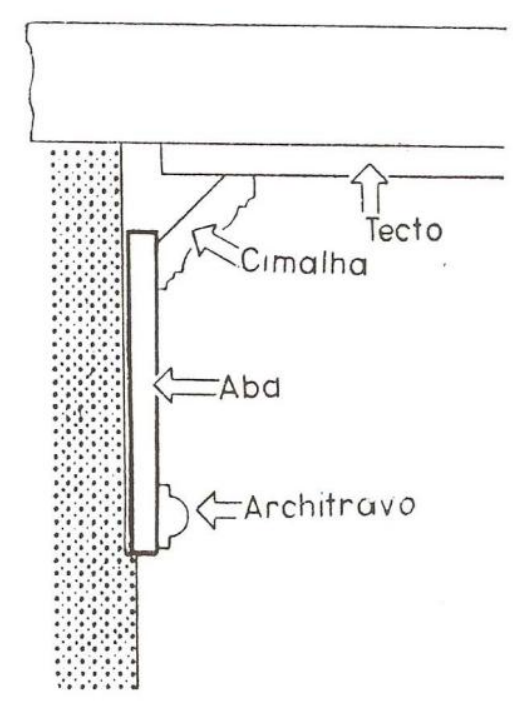

Figura 133: Arremate de soalho com arquitrave, aba e cimalha ${ }^{106}$

\subsection{Alizares}

Os alizares de madeira eram revestimentos de paredes internas que, em geral, chegavam à altura de 1,5 a 2,3 metros, podendo também revestir até o teto. Existiam dos mais simples com rodapé (Figura 134A) e moldura superior, aos mais sofisticados, com almofadas (Figura 134B) ${ }^{107}$. O alizar era sempre fixado com auxílio de parafusos e tacos de madeira, que eram embutidos nas paredes no momento em que o marceneiro inicia o assentamento e o pedreiro abre o buraco e encaixa os tacos com argamassa. E os parafusos ficavam ocultos para receber o verniz.

Esse foi um acabamento que não foi aplicado na Pau d'Alho, onde os acabamentos interiores com ornamentos ficaram por conta do piso, forro e portas, que passaram a ser muito comuns nos sobrados.

\footnotetext{
106 Ibid. pp. 247.

107 Ibid., pp. 214 a 216.
} 

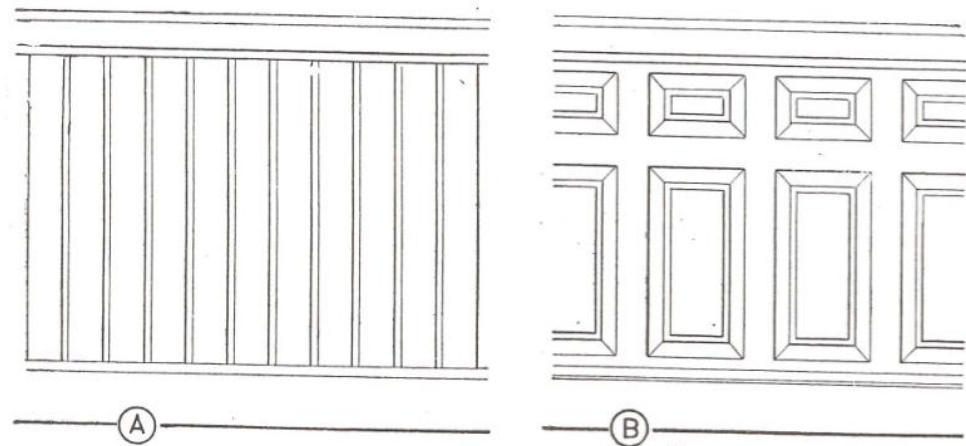

Figura 134: Alizar mais simples com rodapé $(A)$ e alizar com almofadas $(B)^{108}$

\subsection{Ornamentos}

Outros ornamentos utilizando madeira, na época, eram geralmente elementos internos que podiam ser balaústre, colunas, bases, corrimãos, fustes, e muitos outros. Estes eram entalhados à mão pelos escultores de pequenas oficinas, a maioria deles imigrantes italianos. Mais tarde, no início do século XX, o Liceu de Artes e Ofícios foi responsável pela maioria das esculturas de madeira na capital.

Os corrimãos e balaústres de madeira já eram pouco usados, segundo Segurado, devido à facilidade e economia do ferro fundido e forjado. Os ornamentos de madeira passaram a ser usados como molde para estes últimos - ver Figura 135.

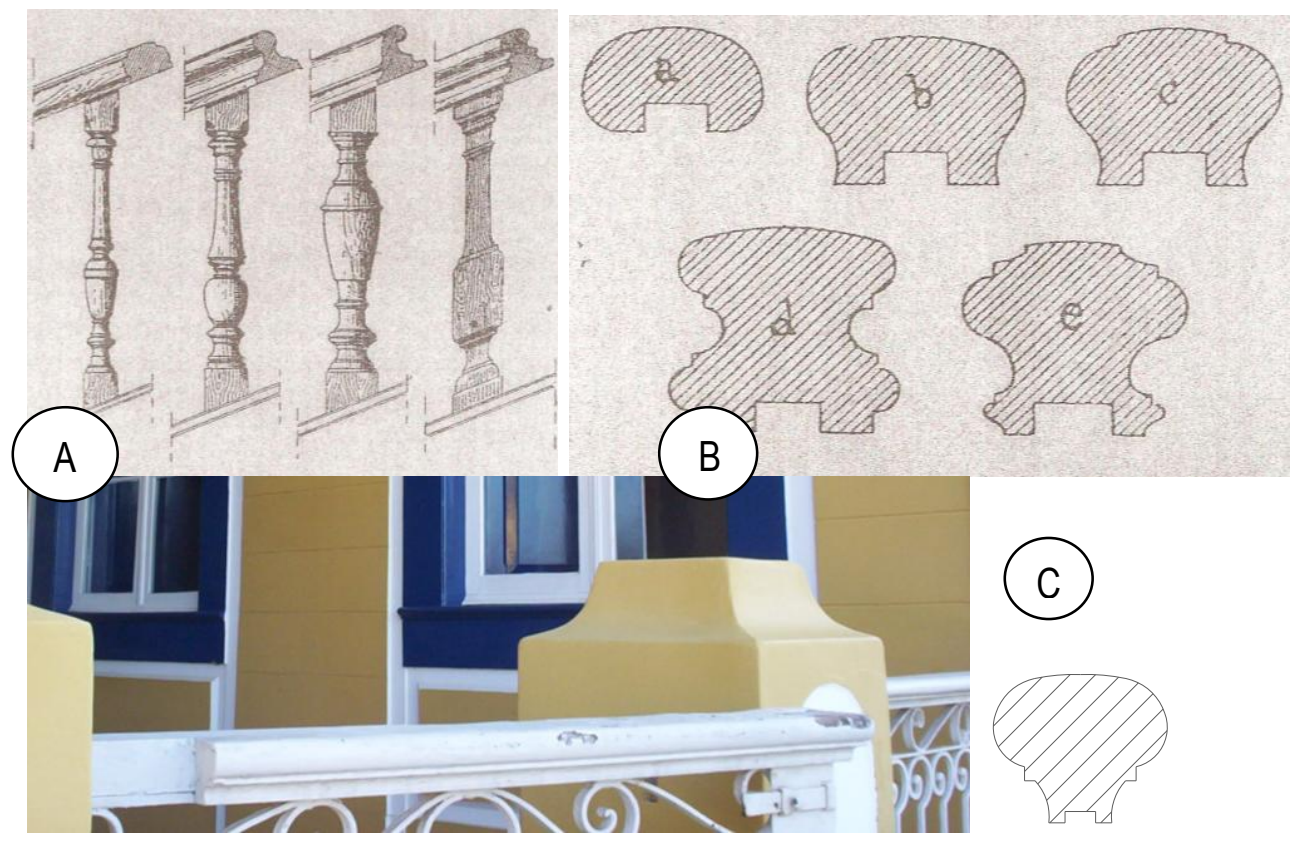

Figura 135: Escadas de madeira - diversas balaustradas $(A)$ e corrimãos $(B)$, foto do corrimão da varanda na sede alta da fazenda Pau d' Alho e desenho do corrimão correspondente $(C)^{109}$

\footnotetext{
108 Ibid., pp. 215.

109 SEGURADO, João Emílio Santos. Construção Civil: acabamentos de construções. Lisboa: Bertrand, 19-?, pp. 121 a 132.
} 

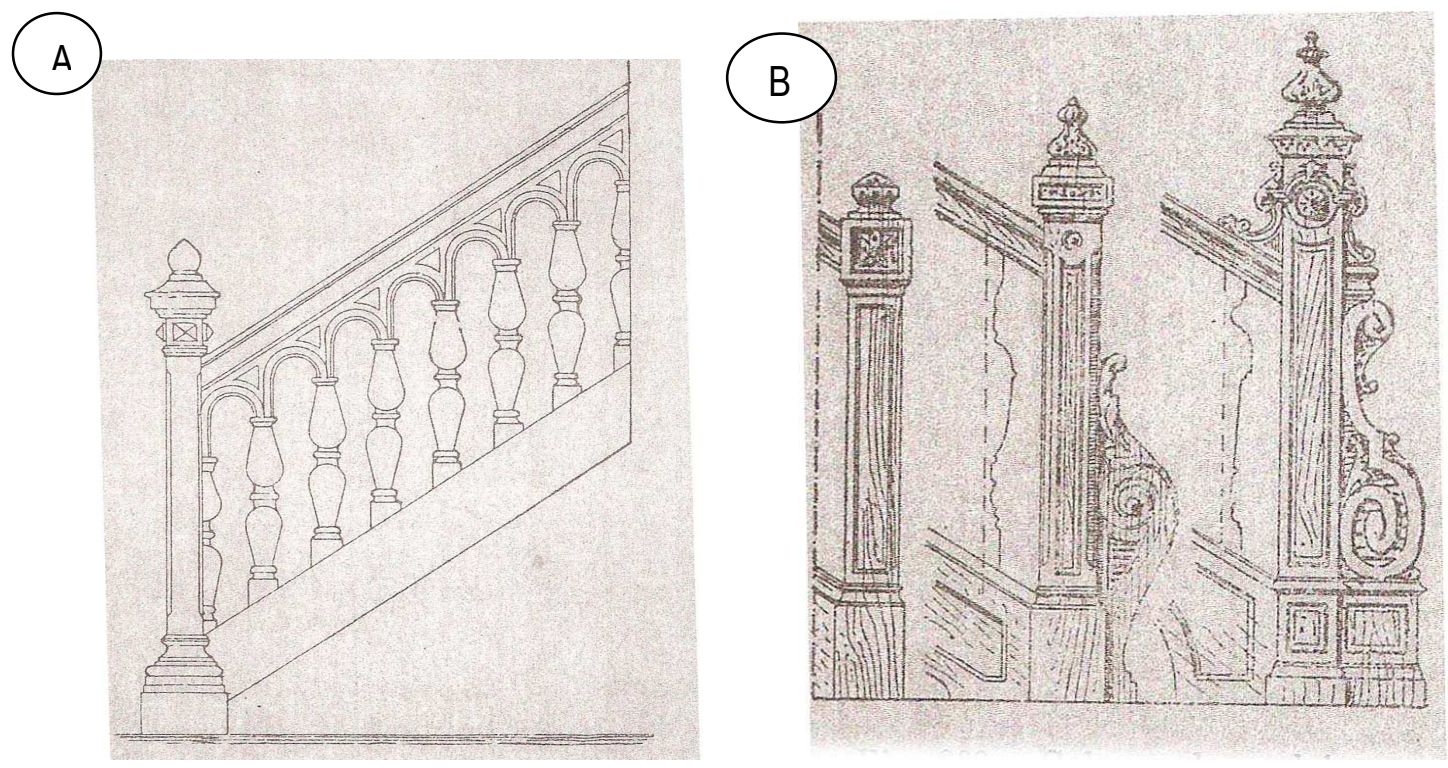

Figura 136: Escada com balaustrada e coluna $(A)$ e exemplos de colunas $(B)^{110}$

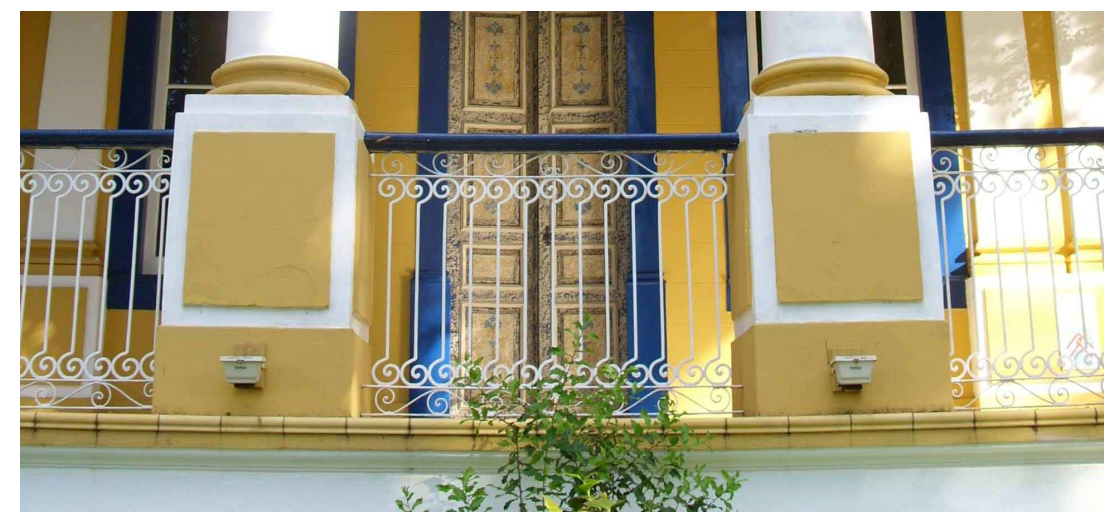

Figura 137: Corrimão de madeira com gradil de ferro no alpendre na sede alta

Além da argamassa e da madeira, outro material que se destacou nos acabamentos das construções, no período em que o ecletismo ganhava força por aqui, foi o ferro, como logo mais veremos.

\subsubsection{Ferro}

O ferro começava a ganhar mais flexibilidade na função estrutural, como já vimos, passando muitas vezes a ser agregado à função decorativa. Devido as suas propriedades, esse material, depois do tijolo e da argamassa, foi o que mais correspondeu à linguagem eclética. O ferro era empregado em três estados: laminado ou forjado, fundido ou coado, e como aço. No Brasil, no último quartel do século XIX, foram usados especialmente os laminados e fundidos, de maior variedade, já o aço passou a

\footnotetext{
110 SEguRADO, J. E. S. Construção Civil: trabalho de carpintaria.Biblioteca de Instrução Profissional, Livraria Bertrand, 19-?, p. 87.
} 
ser empregado posteriormente, no lugar do ferro, com as mesmas dimensões dos perfis de ferro, porém mais leves. Entre os elementos que são analisados na sede da fazenda Pau d'Alho, são as escadas, os perfis, os tubos, e os parafusos, pregos e dobradiças ${ }^{111}$.

\subsection{Tubos}

Os tubos de ferro laminado eram usados na canalização de água ou gás, no centro da cidade, e eram muito raros nas fazendas, que ainda não usufruíam desse abastecimento, pois nesse momento começava a instalação dos primeiros banheiros.

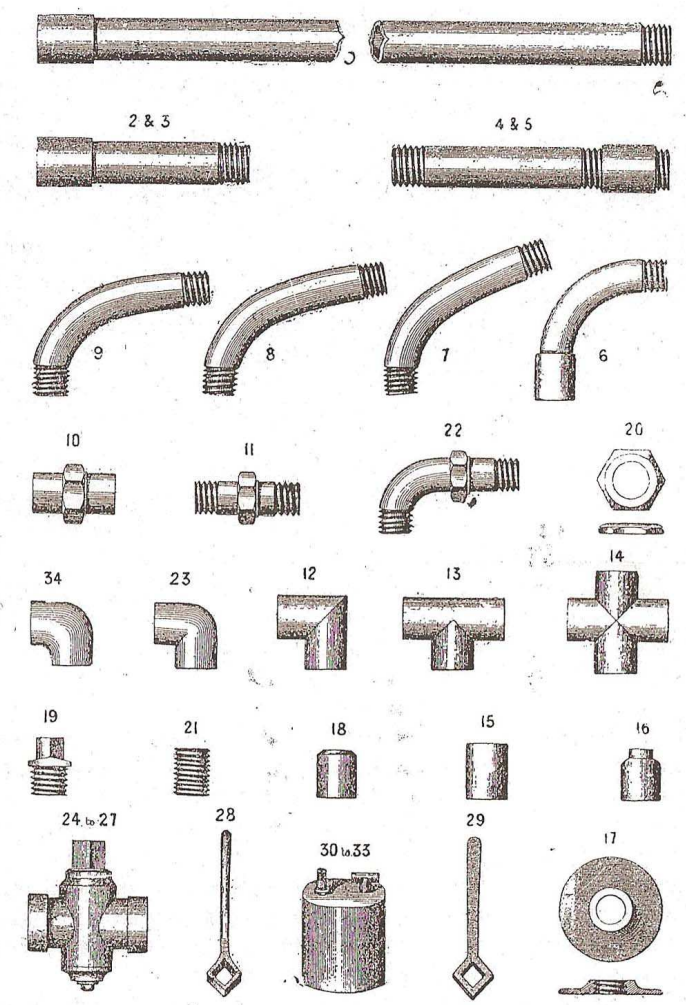

Figura 138: Diferentes formatos de tubos de ferro ${ }^{112}$

Uma outra opção que já existia eram os tubos de ferro fundido, de resistência maior, porém também não há ocorrência desses tubos nas sedes de fazendas que foram reformadas no período, pois eram utilizados nos sobrados que estavam começando a surgir da cidade. Esses tubos eram mais comuns em forma de colunas de ferro fundido, geralmente ornamentadas, com capitel, soco e fuste - como podemos ver na Figura 139. Foram usados em alguns projetos de Ramos de Azevedo, inclusive em seus projetos de sede de fazendas, como nos casos da sede da fazenda São Vicente, em Campinas, e da

\footnotetext{
${ }^{111}$ SEGURADO, João Emílio dos Santos. Construção Civil: Materiais de construção. Biblioteca de Instrução Profissional, Livraria Bertrand. Volume II, 19-?, pp. 46 a 60.

112 SEGURADO, J. E. S. Construção Civil: Materiais de construção. Biblioteca de Instrução Profissional, Livraria Bertrand, 19-?, Volume I, pp. 54.
} 
fazenda Ibaté, próxima a São Carlos, contudo não há essa ocorrência de colunas ornamentadas na Pau d' Alho. Porém, o ferro fundido foi usado ali em gradis, como guarda-corpo, tanto no alpendre como na varanda, com os motivos dos ornamentos combinando com os motivos da porta externa do salão, na sede baixa, e com os gradis das janelas ao lado dessa porta.
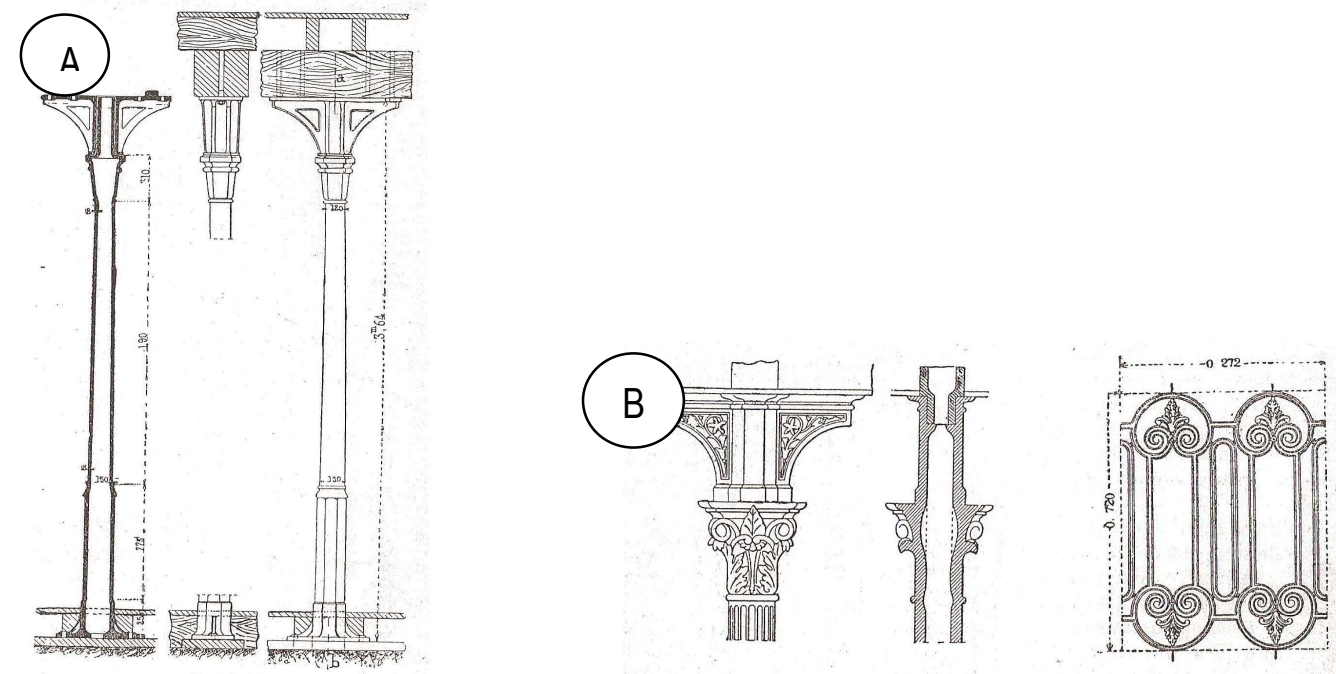

Figura 139: Exemplos de colunas de ferro ornamentadas $(A)$ e capitel $(B)^{113}$

No caso da sede fazenda Pau d' Alho, não foi diferente: os tubos em colunas de ferro foram muito utilizadas. Esses tubos, usados na cidade, podiam ser "pretos" ou "galvanizados", podendo ser retos ou curvos, com diferentes formatos e dimensões, como podem ser vistos na Figura 138.
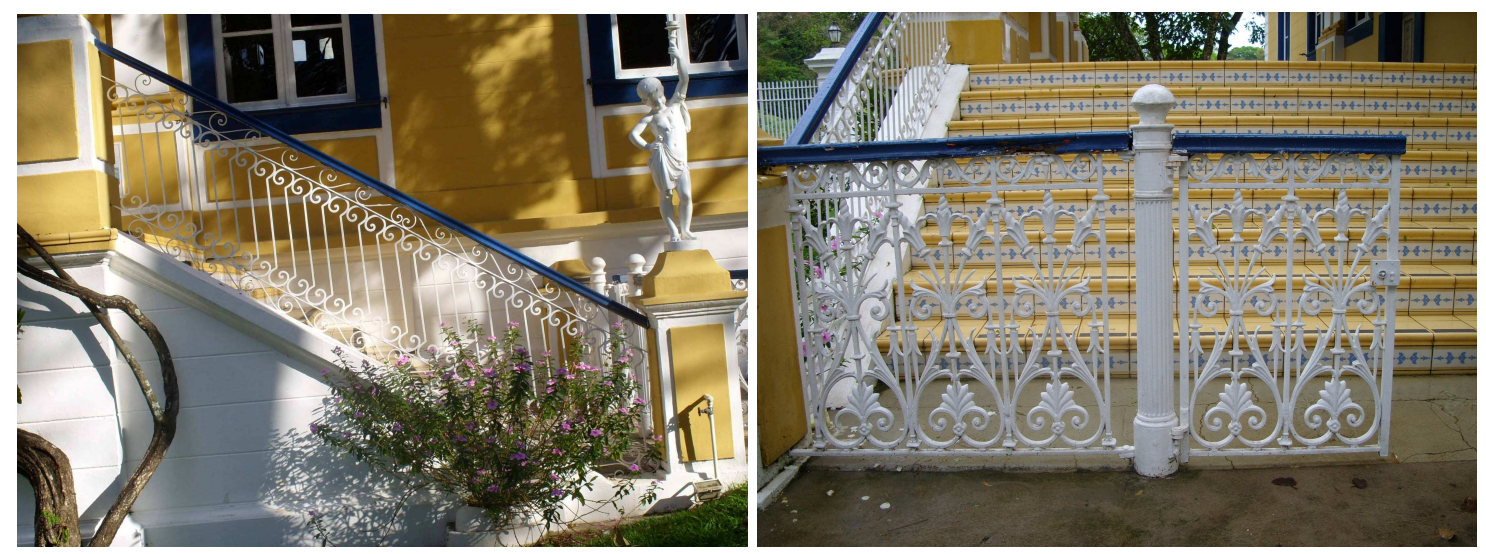

Figuras 140 e 141: Sede alta - gradil da escada lateral do alpendre ornamentado e porta de acesso à escada, de ferro fundido

${ }^{113}$ Idem, pp. 56 e 58. 

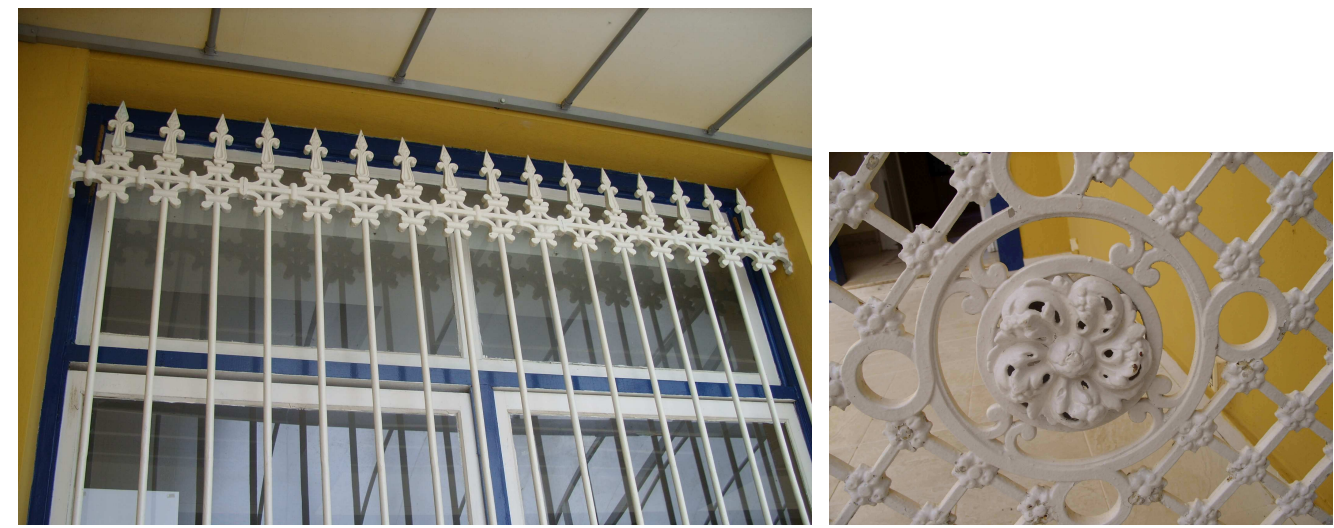

Figuras 142 e 143: Sede baixa - gradil da janela do salão com setas que se aproximam do formato do gradil da portinha de acesso ao alpendre; detalhe da folha de ferro fundido da porta do salão

\subsection{Ferragens}

As ferragens mais comuns eram os de cabeça e porca, os de fenda e os de cabeça sextavada - Figura 144. As ferragens já estavam presentes nas portas e janelas mais antigas - situadas na sede baixa, e abrangiam variados formatos e funções. As mais comuns eram os parafusos, pregos, dobradiças, ferrolhos, fechos de correr e fechaduras. Os parafusos tinham dimensões variadíssimas e eram muito usados para ligar as vigas de ferro.

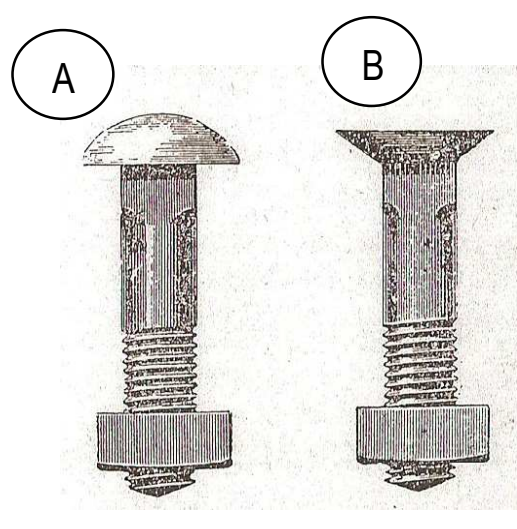

Figura 144: Parafuso de cabeça de tremoço com arreigada e porca quadrada (A), e parafuso com porca e cabeça contrapunçoada $(B)^{114}$

\footnotetext{
${ }^{114}$ SEGURADO, J.E.S. Construção Civil: trabalho de serralharia civil. Biblioteca de Instrução Profissional, Livraria Bertrand, 19-?, p. 35.
} 
Os pregos podiam ser de ferro forjado ou de arame; o primeiro era feito manualmente e mais incomum, o segundo, feito mecanicamente, era o mais usado. Essas peças eram numeradas conforme grossura e 0 comprimento. Os de arame podem ser quadrados também, preferíveis na ligação com a madeira.

Outra ferragem muito usada e essencial eram as dobradiças e os fechos de correr, que eram constituídos de chapas aparafusadas, com função de articular e trancar, respectivamente. Alguns dos variados modelos de dobradiças são representados na Figura 146 abaixo, sendo os mais comuns munidos de rolamento de esfera (146B, 146C e 146D). Outra ferragem muito usada eram os gonzos, mais flexíveis ver Figura 145 ao lado.
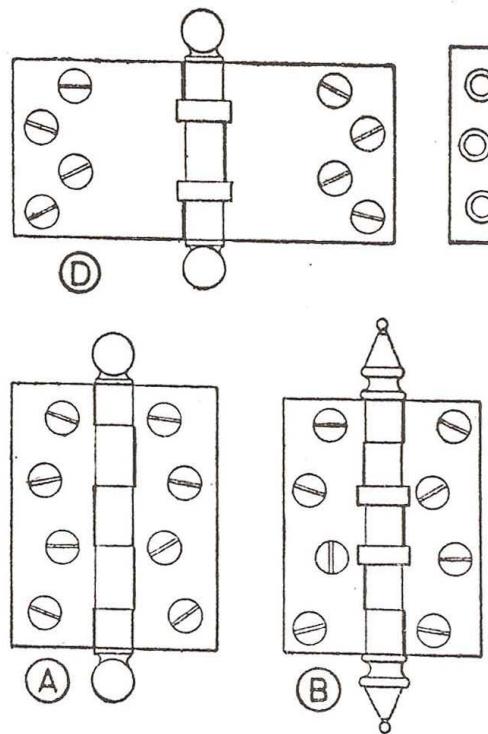

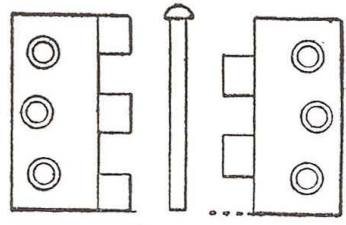

(E)
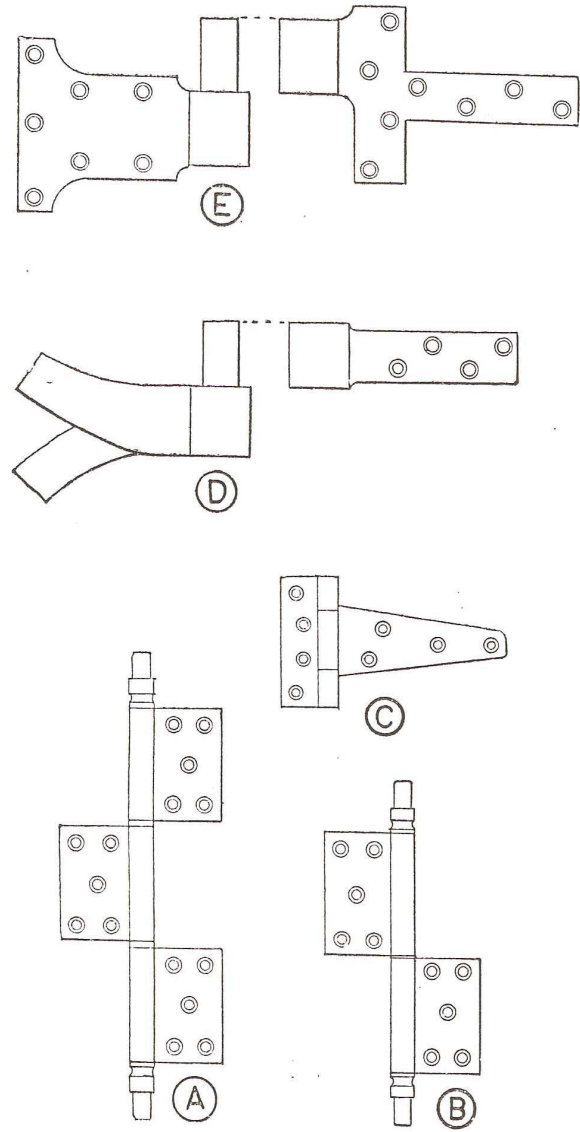

(C)

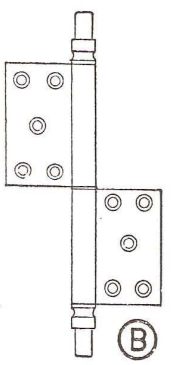

Figura 145: Diversos tipos de gonzos ${ }^{115}$

Figura 146: Diversos tipos de dobradiça

\footnotetext{
${ }^{115}$ Figuras 145 e 146: ALBUQUERQUE, A. Construções Civis. São Paulo: Empresa Gráfica da Revista dos Tribunais, 1952, pp. 304 e 305.
} 


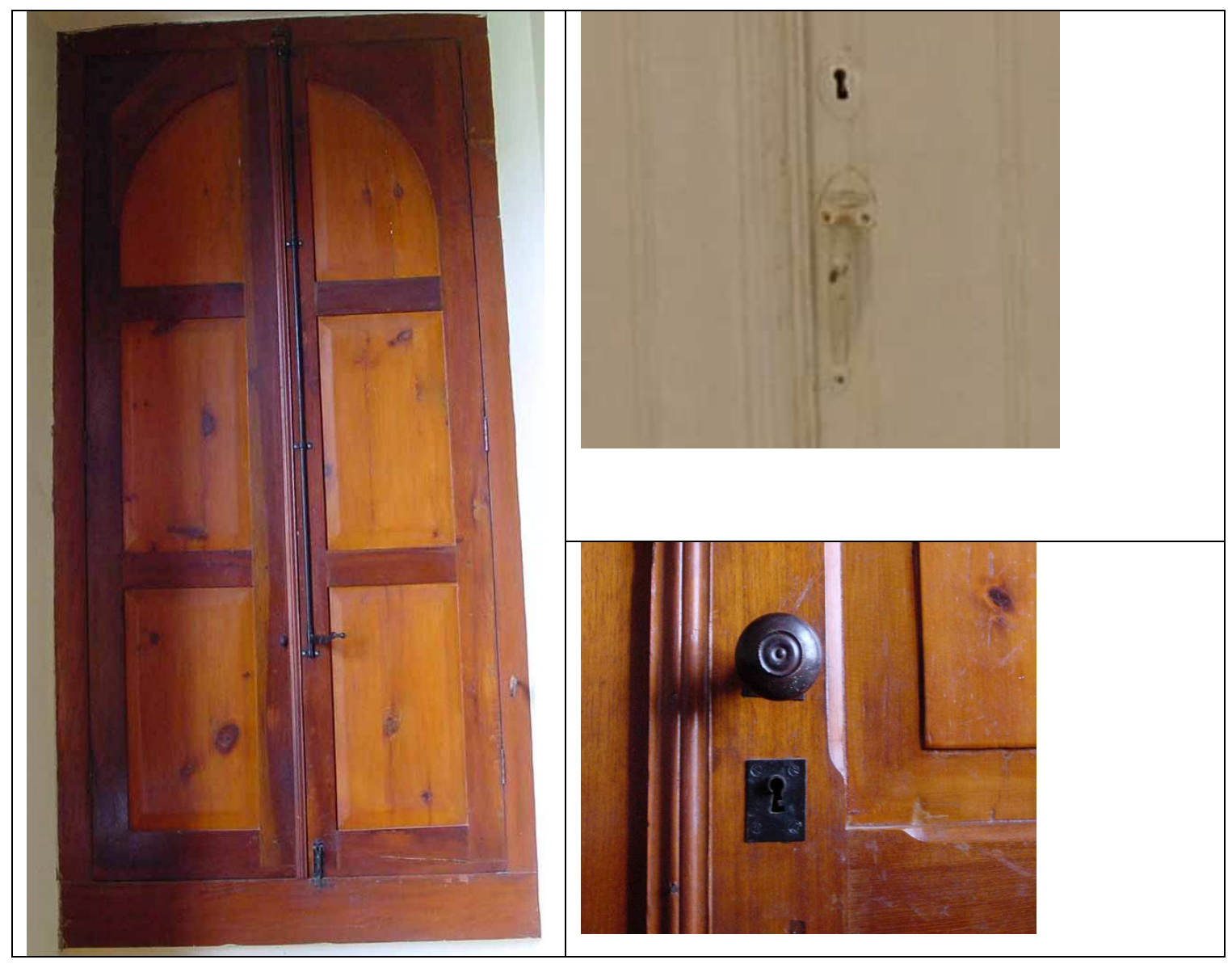

Figuras 147 e 148: Dobradiça e ferrolho das janelas da sede alta. À direita, detalhe das fechaduras; Acima, fechadura da porta mais antiga, situada na sede baixa; Abaixo, fechadura de maçaneta redonda, situada na sede alta, ainda antes da intervenção do Campinas Decor ${ }^{116}$

Com a reforma de Ramos de Azevedo, em 1885, a novidade ficou por conta das fechaduras com maçaneta redondas nas portas novas da sede alta.

Encerra-se aqui o item relativo a ferro, e segue-se com a abordagem de um componente que era fabricado nas olarias juntamente com os tijolos, os tubos cerâmicos.

\subsubsection{Tijolo}

Já vimos anteriormente o funcionamento de uma olaria tradicional. Aqui vemos um elemento que também era produzido ali, com fins principalmente decorativos.

\subsection{Tubos}

Os tipos de tubos eram de pasta de argila plástica não lavada, em cantoneira, sifão e variados formatos, como visto na Figura 149. Os ornamentos variavam entre telha de chaminé, ornato para espigão de telhado e balaústres, como na Figura 150.

\footnotetext{
${ }^{116}$ Imagens cedidas por Julie Dutilh.
} 

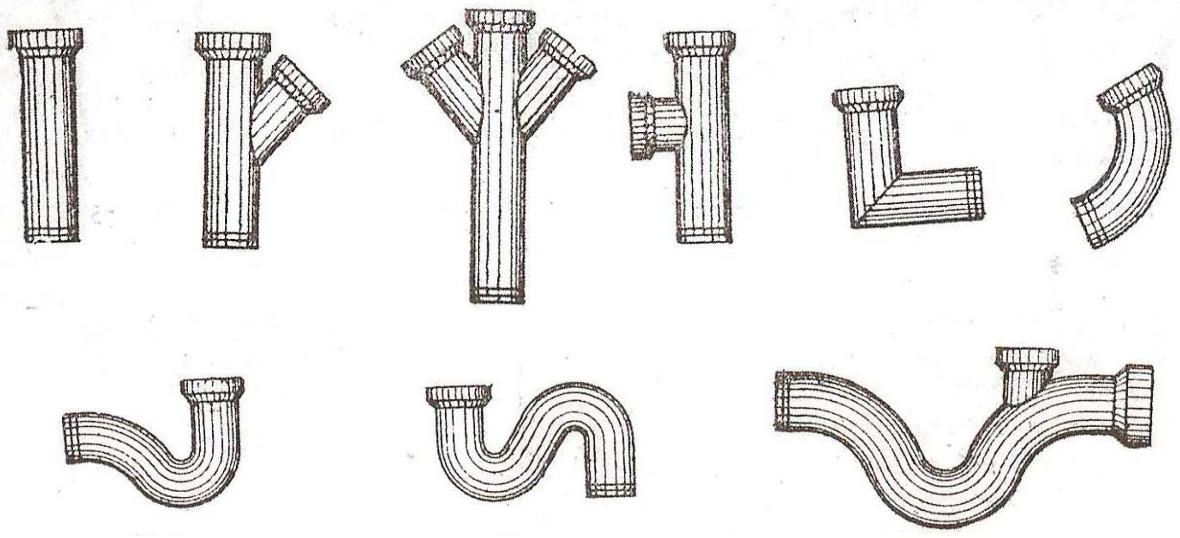

Figura 149: Variados tipos de tubos ${ }^{117}$

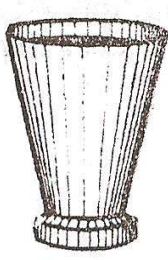

Fig. 74

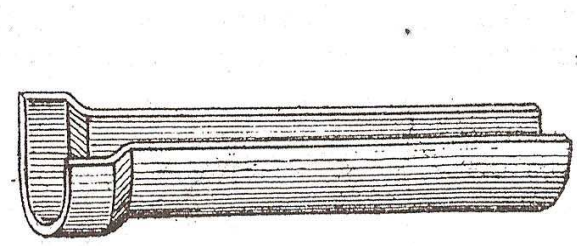

Fig. 76 - Telhăo de algeróz

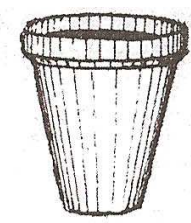

Fig. 75

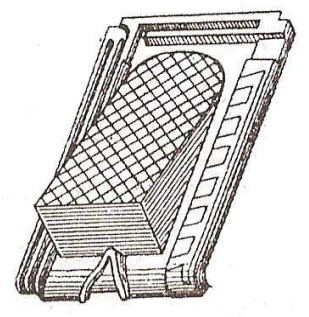

Fig 77-Telha de passadeira

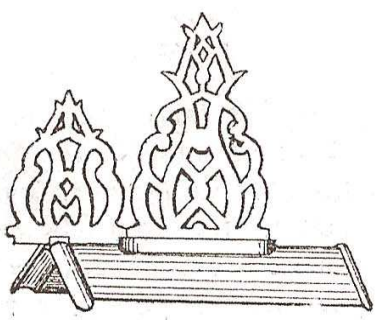

Fig. 8o-Ornato para espigăo de telhado

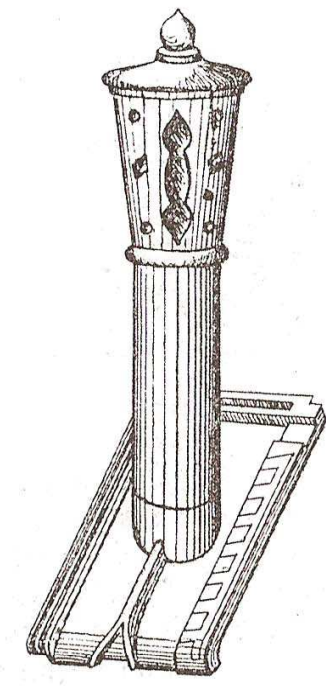

Fig. 78 -.Telha de chaminé

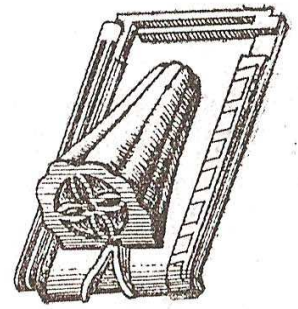

Fig. 79-Telha de ventilador

Figura 150: Variados tipos de ornamentos

117 Figuras 149 a 150: SEGURADO, J. E. S. Construção Civil: Materiais de construção. Biblioteca de Instrução Profissional, Livraria Bertrand, 19-?. Volume I, pp. 67 e 68. 


\subsubsection{Tintas e vernizes}

A pintura, que tinha por fim proteger os materiais das construções, dependia da natureza do material, variando seu modo de aplicação. As tintas compunham-se de uma parte sólida e outra líquida, a primeira era o pó, que constituía a cor, e a segunda era o dissolvente, como água, cola, verniz, etc. Segundo a natureza dos líquidos, denominavase "pintura a cola" ou "têmpera", e "pintura a óleo"118.

As pinturas de cola, mistura de água e cola animal, só podiam ser usadas no interior dos edifícios e sobre reboco. Também se usava pintura de cal com cola, extinguindo-se a cal, juntando aguarrás, têmpera com cola e água, além do pó colorido. A pintura de cal era mais recomendada para reboco em paredes exteriores ${ }^{119}$.

A pintura de verniz, formada de líquidos viscosos por causa dos solventes, não era aconselhável para exteriores ${ }^{120}$.

As principais ferramentas para o pintor eram as brochas para a aplicação das tintas, com formas e dimensões variadas - ver Figura 151 abaixo.
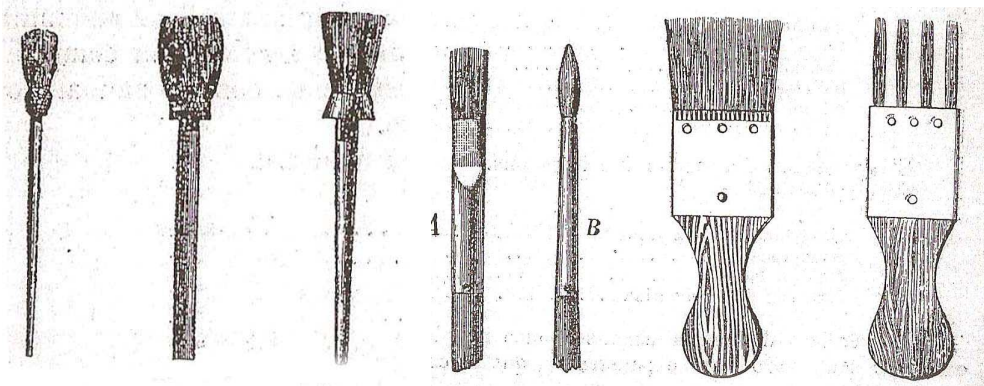

Figura 151; Alguns tipos de brochas ${ }^{121}$

Nas fotos mais antigas da fazenda Pau d'Alho, podemos ver que a pintura, em toda a superfície da sede, inclusive nas colunas do alpendre, tanto na sede alta como na baixa, foi aplicada com efeito marmorizado ${ }^{122}$, uma prática recorrente de Ramos de Azevedo. Já nos ambientes internos, não se sabe se houve faixas ou apliques florais. Em algumas fotos, podemos ver paredes lisas na sala de jantar e, na saleta ${ }^{123}$, a parede aparece com uma pintura trabalhada em todo o cômodo.

\footnotetext{
118 SEGURADO, João Emílio dos Santos. Construção Civil: Materiais de construção. Biblioteca de Instrução Profissional, Livraria Bertrand, 19-?, Volume I, p. 67.

${ }_{119}$ RAINVILLE, Cesar O Vinhola Brasileiro. Eduardo e Henrique Larmmert, Rio de Janeiro, 1880, p. 210.

120 ALBUQUERQUE, Alexandre. Construções Civis. São Paulo: Empresa Gráfica da Revista dos Tribunais, 1952, pp. 291 e 296. pp. 344 a 346.

121 SEGURADO, J. E. S. Construção Civil: Materiais de construção. Biblioteca de Instrução Profissional, Livraria Bertrand, 19-?, Volume I, p. 74.

122 Ver Imagens 19 e 20 do Anexo 4, com a proprietária Maria sentada nos bancos da fachada frontal.

${ }^{123}$ Para observar as paredes da sala de jantar, ver Imagem 21 do Anexo 4 e, para as paredes da saleta, ver Imagem 22 do Anexo 4.
} 


\section{CONSIDERAÇÕES FINAIS}

A análise da construção em Ramos de Azevedo é um pretexto. Por intermédio dela, procuramos compreender o modo como se estruturou o aparato técnico que se constituiu como contexto tecnológico num determinado período da história relativamente recente deste país, indispensável para a realização da obra azevediana. Pelo pretexto, pretendíamos chegar ao contexto.

Tomando como pretexto a análise das técnicas construtivas praticadas por Ramos de Azevedo em seu início de carreira, fizemos um esforço de considerar, com alguma profundidade, o contexto da construção civil em Campinas e no estado de São Paulo, perpassando desde as técnicas construtivas locais - aquelas que a tradição passa através de gerações - até o conhecimento ilustrado das técnicas aplicadas na construção civil. Mas, se apenas partirmos do âmbito geral em direção ao particular, como acessar o 'contexto tecnológico de um determinado período histórico do país' apenas versando sobre técnicas aplicadas na reforma e ampliação da sede de uma fazenda, numa cidade do interior de São Paulo, no final do século XIX? A técnica construtiva, entendida como aparato, envolve mais do que a aplicação desse saber fazer num determinado local: é preciso conhecer as mãos que manusearam e operaram tais técnicas, por que estavam ali, qual o seu passado e as condições de sua reprodução naquele dado momento, além de entender esse momento, na amplitude de seu âmbito econômico, político e histórico, assim como todas as condições estruturais que condicionavam a produção vigente. A hipótese desse trabalho é que o estudo da técnica em si e em seu processo de desenvolvimento, num dado momento e local e operada por personagens identificáveis, abre as chaves para a compreensão mais precisa do amplo contexto em que é praticada - esta é a motivação desse estudo.

Vimos que, em Campinas, quando Ramos de Azevedo chegou à cidade para ali instalar seu escritório e iniciar sua atividade profissional, a mão de obra predominante ainda era escrava - o que condizia com as mecânicas da produção cafeeira então vigentes e, apesar de se encontrar em seu auge, já se faziam perceptíveis os sinais da decadência que estava por vir. Fazendeiros de café buscavam investir nos escravos, tentando manter o negócio rentável - o que incluía o aprimoramento técnico dessa mão de obra, inclusive oferecendo estudos para os escravos pequenos, como no caso pioneiro do Barão de Anhumas.

Sem que seja necessária alguma confirmação de Ramos neste sentido, é certo que voltara da Europa pleno de convicções de ofício e o desejo de realizar as doutrinas estéticas e as novidades construtivas que aprendera em Gante. É significativa, nesse sentido, a compatibilização que o engenheiro-arquiteto promove entre implantação 
tradicional e linguagem de estilo na pequena Escola Ferreira Penteado, uma de suas primeiras obras em Campinas (ver, no Capítulo 2, o item 2.8. Construção e linguagem de estilo no contexto campineiro e azevediano). Contudo, para construir efetivamente ao modo eclético, era necessária uma mão de obra especializada - que aqui não se encontrava - para lidar com os materiais importados. Ramos teve que trabalhar, de alguma forma, com essa dificuldade e limitação: imagine-se um profissional, relativamente jovem (entre 27 e 28 anos), recém-formado e inexperiente, orientando os artesãos locais ao mesmo tempo em que orientava o trabalho dos artífices qualificados estrangeiros. Apesar de sua consistente bagagem acadêmica e das boas relações pessoais, políticas e comerciais que dispunha, sem dúvida alguma é necessária muita habilidade, perspicácia e autoridade para lidar com aquela conjuntura, no mínimo, tensa.

Essa habilidade em lidar com tal situação - capacidade de trabalhar com profissionais de diferentes formações e com negócios relacionados (porém cada um com sua especificidade) no ramo da construção civil - se refletiria mais tarde, numa promissora carreira, a qual se efetivara na capital paulista já no início do século XX. Pode-se afirmar, com alguma segurança, que sua intervenção, no momento de constituição de todo um setor produtivo no país - a indústria da construção civil -, tanto direta como indiretamente, contribuiu decisivamente para sua consolidação e desenvolvimento. Com seus projetos e obras ou atuando no ramo da produção de materiais de construção, participando de instituições financeiras de fomento à indústria ou como educador, participando da reformulação do Liceu de Artes e Ofícios e na Escola Politécnica - que praticamente inauguraram a formação técnica profissional e superior no país -, Ramos sem dúvida contribuiu para o aprimoramento das dinâmicas de comércio exterior, para o crescimento industrial, para a especialização da mão de obra, para a formação do engenheiro, para a instituição da construção em tijolos no país etc. - para além de trazer o neoclássico e o ecletismo para o país.

Por outro lado, o conhecimento técnico e científico ampliava-se e aperfeiçoava-se a partir do esforço de inúmeros agentes, fazendo avançar a amplitude dos processos de produção investidos na indústria, em geral, e na construção civil em particular. Foram inúmeros engenheiros e arquitetos que se associaram a Ramos, foram inúmeras as contribuições desse sem número de colaboradores. Além disso, a intenção de relatar as diversas composições daquilo que vimos chamando de aparato tecnológico voltado para a construção civil - conhecimento técnico, dinâmica da força de trabalho e disponibilidade de condições materiais - tem por objetivo demonstrar o quanto as condições infraestruturais determinaram o contexto que então se formava. Pode-se afirmar que, pela via 
inversa, também o momento e a conjuntura eram oportunos: esse era o contexto positivo que tornava promissor o futuro do jovem Ramos.

E a situação em Campinas foi o campo paradoxalmente favorável para que o engenheiro-arquiteto pudesse iniciar sua carreira com ventos a favor: ainda que registrando pioneirismo em diversas áreas industriais, a carência de mão de obra dedicada à construção civil campineira era grande frente à demanda que se avolumava, abrindo um vasto caminho para o desenvolvimento de um mercado de trabalho específico, agora regulado pelo afluxo da mão de obra estrangeira. A crise, as epidemias de febre amarela e a imigração subvencionada tardiamente contribuíram para protelar o desenvolvimento industrial na cidade. Mas o deságue de grandes montantes de recursos financeiros, excedentes da produção cafeeira local, configuravam o capital necessário para o investimento massivo, não só na indústria como também na construção civil e no transporte ferroviário. A constituição de uma elite endinheirada, capaz de alimentar aspirações modernizantes e de um estilo de vida europeu, também estabelece outro patamar de expectativas em termos de linguagem formal e de vida urbana. Parece-nos necessário ressaltar que esse foi o campo de partida de Ramos de Azevedo.

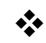

Contudo, o fato mais interessante - e intrigante - para as considerações finais dessa dissertação, acabam escapando do âmbito estrito da fazenda Pau d'Alho, enquanto estudo de caso: trata-se da forma como se deu sua entrada e atuação na administração das obras da Matriz de Campinas - e como daí decorre todo o agenciamento de sua inserção na Pau d'Alho e nas inúmeras obras que realizou na cidade.

Quando chegou em Campinas, a conclusão da reforma da igreja era, muito provavelmente, a primeira obra pela qual se responsabilizava como profissional. Aceitava a empreitada a convite de um velho conhecido seu, o Visconde de Parnaíba, com quem trabalhara, em 1872, na Cia. Mogiana de Estradas de Ferro, ainda antes de partir para a Bélgica. Ramos de Azevedo assumiu as obras da Catedral Metropolitana substituindo o engenheiro Cristovam Bonini, contratado pelo Diretório das Obras - um braço ad hoc da Câmara Municipal, composto por alguns notáveis (o Barão de Anhumas, entre eles), exclusivamente dedicado à gestão das obras de construção da igreja -, na esperança de por fim à epopeia daquela obra que se arrastava por quase 70 anos (lembrando que o início das obras datava de 1807). Mas, por algum motivo desconhecido, Bonini seria substituído pelo moço engenheiro-arquiteto, recém-chegado da Bélgica e que sabia do 
que se tratava as opções técnicas e construtivas encaminhadas pelo italiano. O que levou a essa substituição, como dissemos, não nos foi dado saber. É possível que tenha sido por divergências com o Diretório das Obras, ou porque já findava o período de contrato determinado para Bonini.

A estrutura administrativa que este assumira havia sido concebida no período de administração das obras conduzida pelo Dr. Antonio de Joaquim Sampaio Peixoto, pai de Sampainho - aquele proprietário da primeira olaria na cidade e que, como o pai, também viria administrar as obras da catedral, anos mais tarde. Nomeado administrador de obras em 1848 ${ }^{1}$, formado em Direito pela Academia de São Paulo e residente em Campinas desde 1834, o Dr. Sampaio - certamente com algum tino para os negócios - buscou aumentar a receita para a construção da Catedral, contando com a ajuda de alguns importantes nomes da cidade: encabeçados pelo Barão de Anhumas - que doou a quantia equivalente à receita do ano de 1849 (4:742\$000) - foram esses notáveis que se imbuíram no esforço de conclusão da matriz campineira. Em 1850, ainda nessa administração, foi composta uma turma de operários para o trabalho, formando ali um corpo de aprendizes. Porém o dinheiro para pagamento dos novos funcionários voltaria a escassear. O administrador, Dr. Sampaio, tomou então a iniciativa de criar a lei dos impostos locais destinados às obras da Matriz Nova, votada em março de 1854, mas logo depois deixou a condução das obras e outros administradores, nomeados pela Câmara Municipal, passaram a administrá-la: eram políticos, pequenos industriais e fazendeiros em sua maioria - certamente os capitalistas de então, pessoas influentes e com uma grande renda acumulada, proveniente da economia cafeeira.

As obras, na administração de Bonini, na década de 1870, já contavam, portanto, com uma estrutura bem definida, com um ritmo de trabalhos que, aparentemente, seguia um curso regular. Foi quando transferiu suas atribuições para Ramos que, antes de assumir oficialmente a tarefa, acompanhou e assistiu o italiano durante alguns meses, desde o convite, pouco tempo após sua chegada da Bélgica (maio de 1879), até outubro de 1879, quando Bonini assina o último relatório de pagamento da "feria" dos operários. Pelo que podemos observar nos relatórios seguintes, já assinados exclusivamente por Ramos a partir de novembro de 1879, percebe-se que o engenheiro-arquiteto manteve fielmente aos procedimentos adotados pelo antecessor, inclusive no que se refere ao projeto arquitetônico. Apenas uma intervenção tópica, como vimos, ajustando a solução para a cobertura da torre.

\footnotetext{
${ }^{1}$ CÂMARA MUNICIPAL DE CAMPINAS. Monografia da Catedral de Campinas. Campinas, Comissão de Direitos Humanos e Cidadania, 2ª edição, 2007, p. 22.
} 
Os relatórios mencionados, documentos originais achados na Catedral Metropolitana em recente trabalho de reforma ${ }^{2}$, são preciosos não só pela sua raridade como pelo tanto que nos esclarece - ao nos colocar inúmeras questões - sobre uma atividade sempre carente de registros. Demonstram o cuidado minucioso que engenheiro Cristovam Bonini dispensava a cada detalhe: os relatórios eram elaborados mensalmente e indicavam as datas de pagamentos de cada funcionário; traziam as respectivas folhas de pagamentos mensais; reuniam os comprovantes de compra de materiais, adquiridos nas mais variadas localidades, tanto no Brasil quanto no exterior, custos de transportes, carreto, armazenagem e despesas com agências despachantes; além de, obviamente, relatar o acompanhamento das obras e ocorrências. Nas diversas folhas de pagamento, é constatado que quase todo o material para construção da catedral era importado ou trazido de outras cidades e estados, desde parafusos, ferro, aço, mármore, madeira, tinta, cimento, cal virgem, couro, óleo de linhaça, pólvora, lima, estopim, carvão, azeite, cola, sabão, papel e tijolo de diferentes lugares do país, inclusive vindo do Rio de Janeiro.

\footnotetext{
2 Uma pequena parte do relatório de Ramos de Azevedo foi publicada em um livreto pela Câmara Municipal de Campinas: Monografia da Catedral de Campinas. Campinas, Comissão de Direitos Humanos e Cidadania, $2^{\mathrm{a}}$ edição, 2007. Agradecemos o acesso à documentação aqui reproduzida ao arquiteto Ricardo Leite, responsável pela catalogação do acervo.
} 

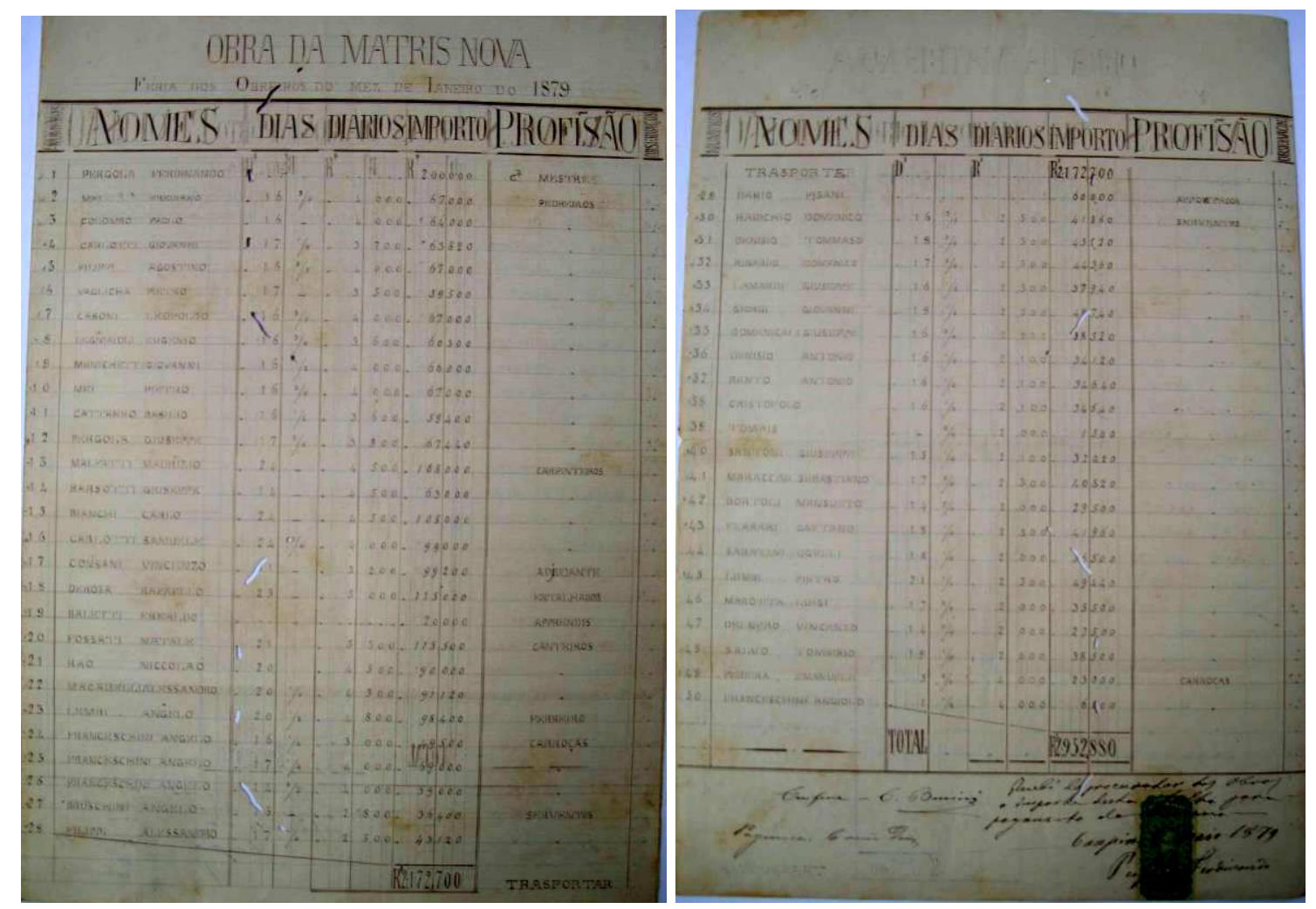

Figura 01: Partes do relatório de Bonini, registrando a "feria" de funcionários do mês de janeiro de 1879 , assinado por ele em maio de 1879
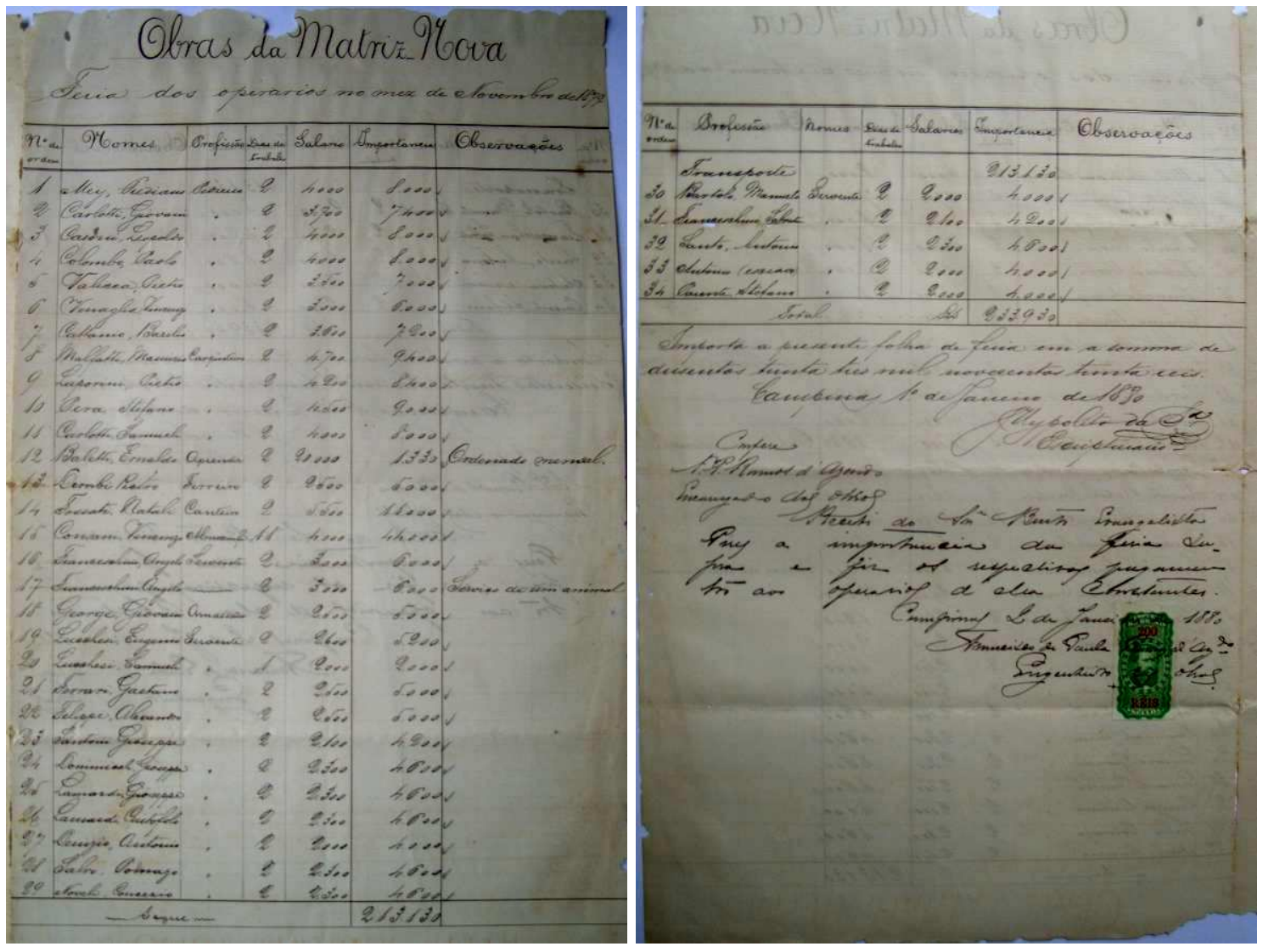

Figura 02: Partes do relatório de Ramos de Azevedo, registrando a "feria" de funcionários do mês de novembro de 1879, seguindo o mesmo padrão de seu antecessor, assinado em janeiro de 1880 


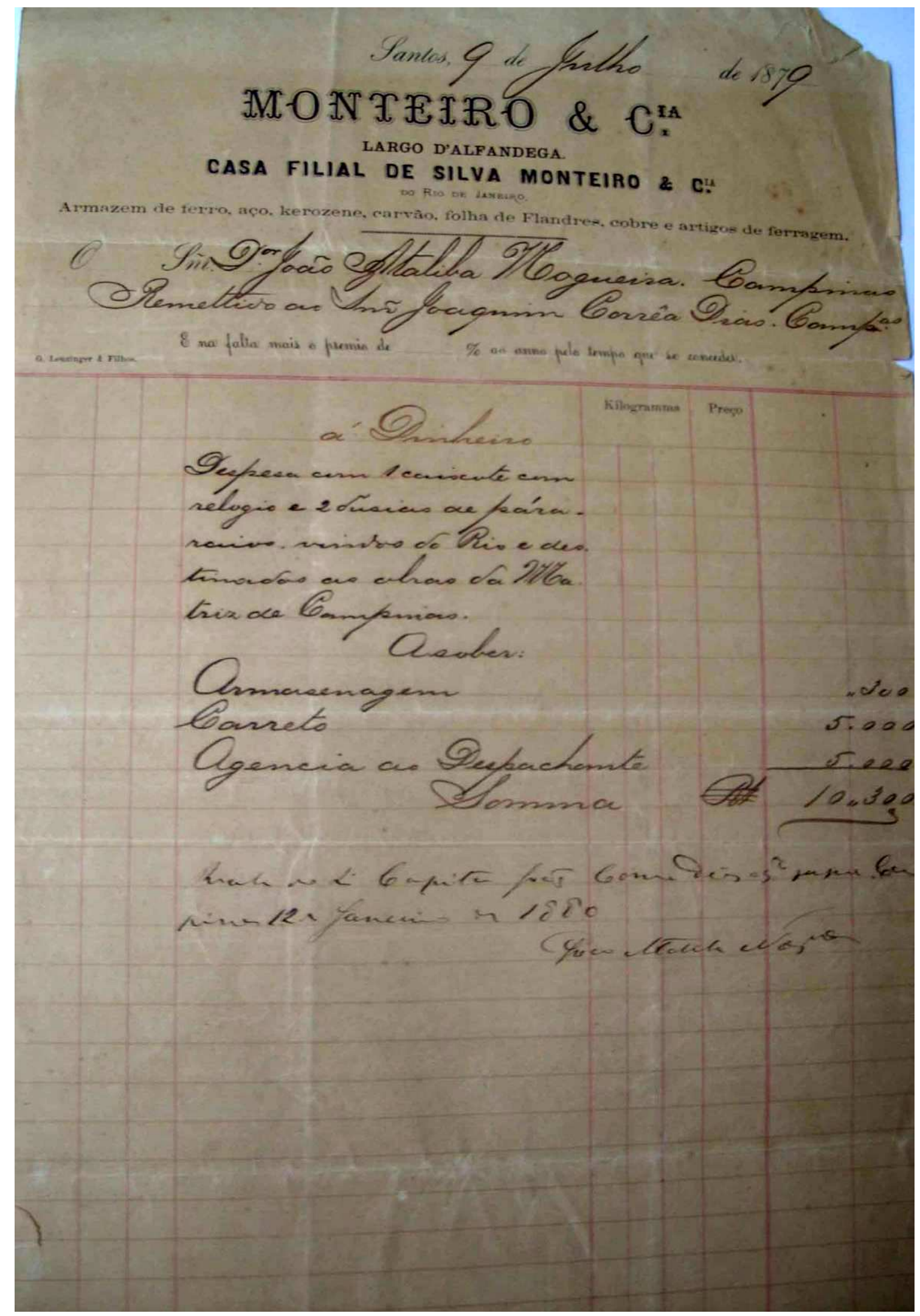

Figura 03: Comprovante de pagamento de despesa com o envio (armazenagem, carreto e despachante), pela Monteiro \& Cia, de Santos (filial da Casa Silva Monteiro e Cia., do Rio de Janeiro) de relógio e duas dúzias de pára-raios, trazidos do Rio, para a Matriz de Campinas 


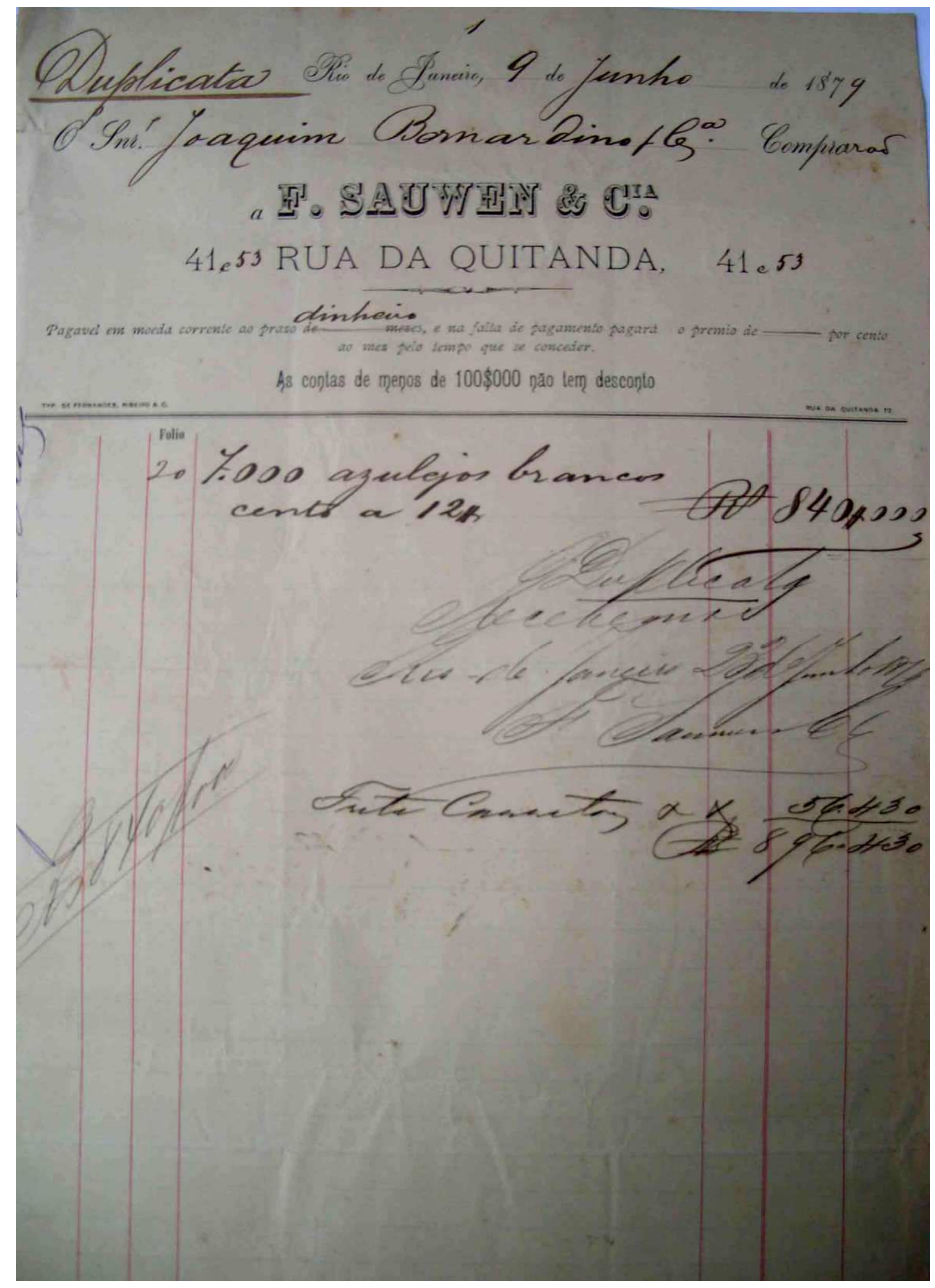

Figura 04: Comprovante de pagamento de compra a F. Sauwen. 


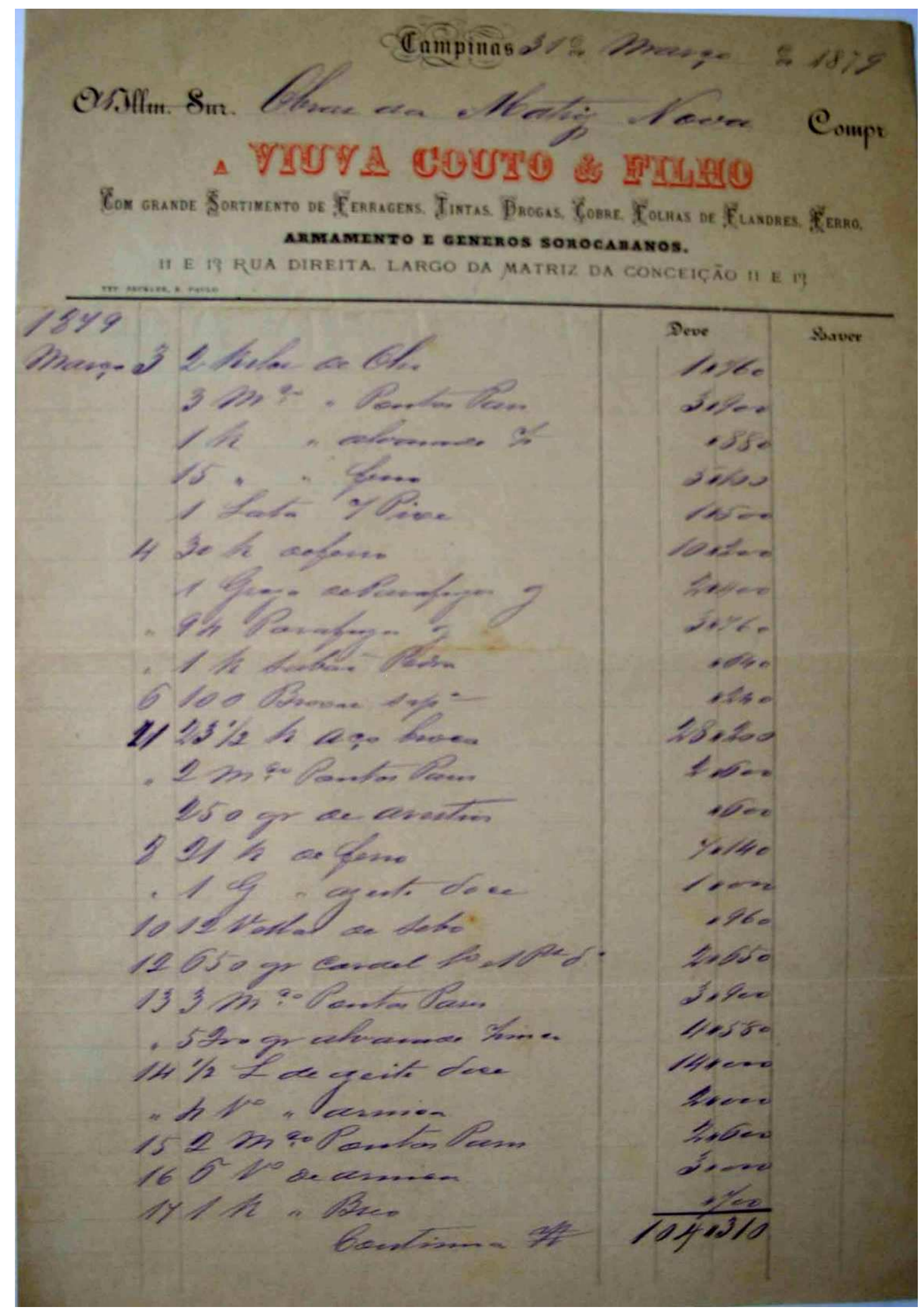

Figura 05: Comprovante de pagamento, com data de 31 de março de 1879, de compra, à Viúva Couto e Filho para a Catedral de Campinas: ferragens, tintas, drogas, folhas de flandres e ferro 


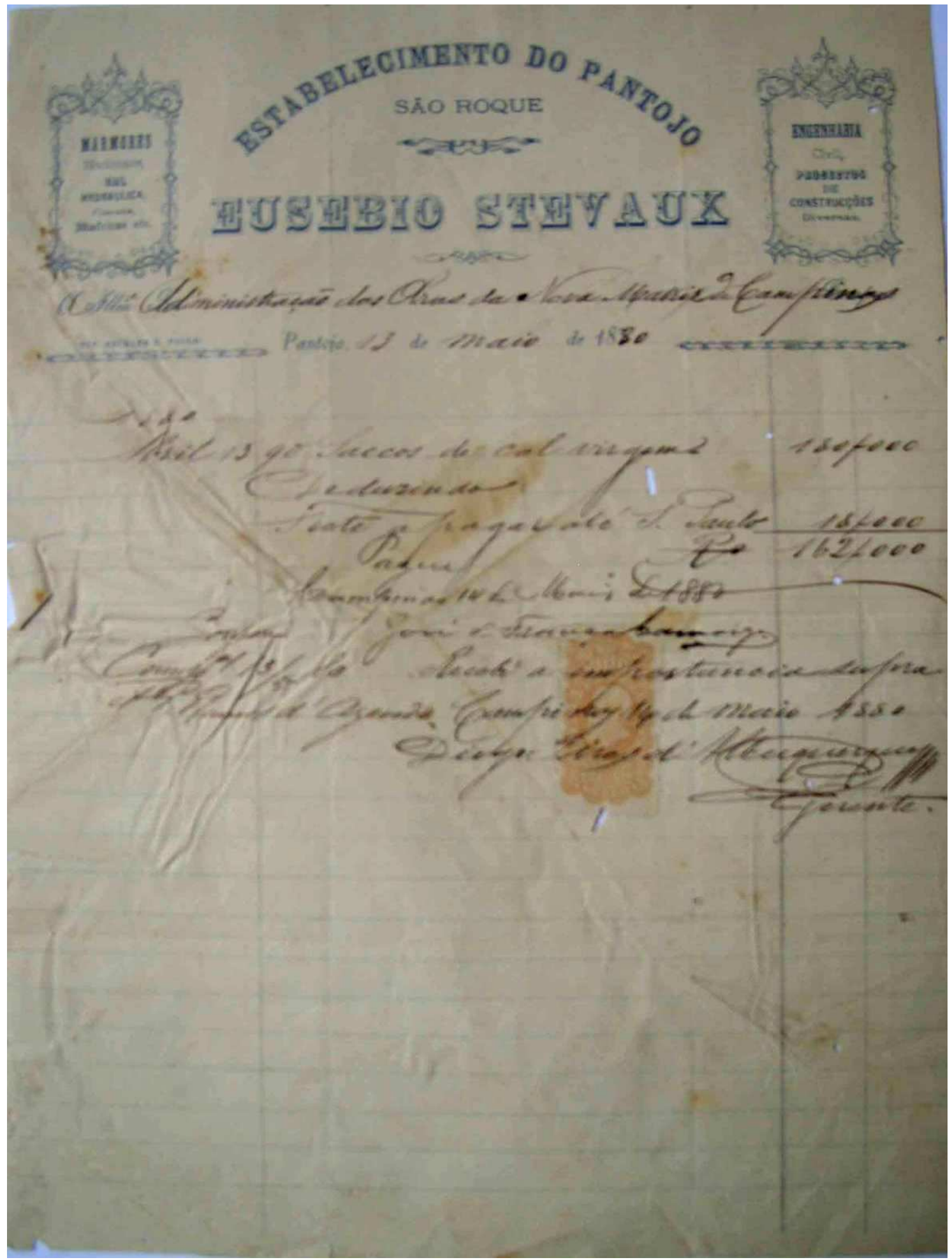

Figura 06: Comprovante de pagamento de $162 \$ 000$ réis, referentes à compra de cal virgem e respectiva dedução de frete (provavelmente pago à parte), da Eusébio Stevaux, emitido em 13 de maio de 1880, a favor da "Administração das Obras da Nova Matriz de Campinas" 
Dada a dimensão da obra da Catedral Metropolitana, tanto pelo seu tamanho como pela utilização de novos materiais - como o tijolo nos anos de 1870 -, a especificidade da mão de obra envolvida - em torno de 80 trabalhadores italianos, entre oficiais e serventes - e as novas modalidades de relações comerciais, envolvendo casas bancárias, importadoras e fazendeiros - a base de sustentação que financiava a construção da matriz campineira, mantida pela renda dos barões do café - é certo que Ramos de Azevedo encontrou ali oportunidade ímpar para adquirir uma experiência profissional qualificada.

Finalmente inaugurada, com muito sucesso, três anos e meio depois de sua posse, parece-nos possível imaginar que o trabalho da matriz acabou the rendendo um certo prestígio: já no período das obras da igreja, trabalhara em outros projetos e obras ${ }^{3}$ antes de ir para a capital: com alguma certeza, podemos afirmar que ali, na obra da Catedral campineira, Ramos teria lançado as bases do método de gerenciamento que levaria por toda a sua vida profissional. O que nos leva intuir essa asserção foi a tentativa de responder uma das questões que formulamos no item 2.7 do Capítulo 2: por que Ramos de Azevedo, ao receber a administração da obra das mãos de Bonini, preferiu manter não só as mesmas soluções construtivas, como também, integralmente, o mesmo grupo de operários? Talvez porque seja necessário admitir que o jovem Ramos, ao chegar recém-formado a Campinas, não chegara 'profissionalmente acabado', isto é, apesar de toda sua inquestionável habilidade, complementar sua formação e acumular alguma experiência custou-lhe bastante trabalho e aprendizado.

Daí decorrem as considerações a seguir.

Em uma de suas primeiras obras campineiras - a reforma da sede da fazenda Pau d'Alho - pudemos ver como Ramos soube aproveitar as oportunidades que lhe eram oferecidas, ao mesmo tempo que articulava o conhecimento adquirido em sua estada na Bélgica com as técnicas construtivas tradicionais locais, rompendo com a linguagem colonial e inserindo harmonicamente uma nova cultura construtiva e formal.

Contudo, muito da memória de todo esse processo foi perdida.

Com a edição de 2004 do Campinas Decor no local - evento que mostra as tendências da moda arquitetônica e da decoração regional -, fizeram-se necessárias algumas adequações nos espaços existentes, quando muitas partes da construção foram descaracterizadas. Isto significa que não só os elementos físicos que constituem a história daquele processo foram suprimidos, mas toda sua identidade social foi reescrita em um caminho inverso. É certo que essa memória não pode ser mantida integralmente ${ }^{4}$,

\footnotetext{
${ }^{3}$ Ver, no Capítulo 2, o item 2.7. Construção e linguagem de estilo no contexto campineiro e azevediano.

${ }^{4}$ ORTIZ, Renato. Cultura brasileira e identidade nacional. São Paulo-Brasil, Brasiliense, 1985, p.132.
} 
diante de formas diferentes de valores, absorvidas através das gerações. Contudo, reescrever uma história por cima de outra é apagar o que já foi escrito, propiciando uma efetiva alienação do presente em relação à memória construída e ao patrimônio imaterial: é direito do indivíduo, como cidadão, ter pleno acesso às informações de seu passado, pois é do conhecimento que fazemos o futuro.

Por outro lado, pode parecer exagero abordarmos a questão por este ângulo, uma vez que, com a real dificuldade de o poder público assumir a preservação dessa memória construída, parece plausível ajustar essa providência com o apoio da iniciativa privada.

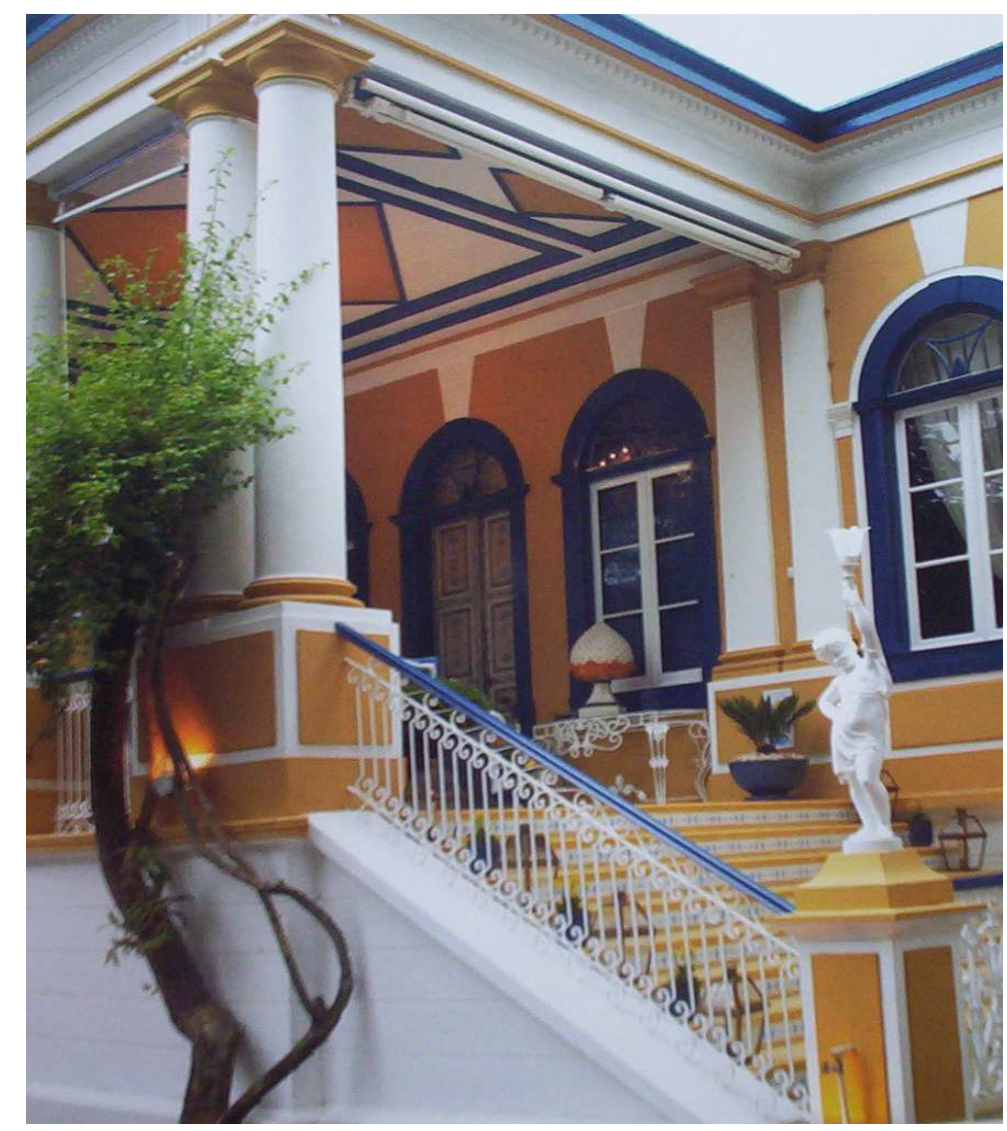

Figura 07: Foto de parte da fachada frontal da fazenda Pau d' Alho em 2004, ocasião do Campinas Decor ${ }^{5}$

A impressão que nos resta - e com ela concluímos esta dissertação - é que a responsabilidade pelo fato de parecer justo - e de certa forma louvável - intervenções como o Campinas Decor numa edificação como sede da fazenda Pau d'Alho, é a forma como contamos nossas histórias. Talvez seja necessário despessoalizar os personagens de nossas histórias, impedindo o esvaziamento de sentido que, por vezes, o caminho do relato virtuoso pode favorecer: a constituição de uma personalidade, na verdade, é fruto de vários fatores e injunções de uma época determinada.

\footnotetext{
${ }^{5}$ Revista Campinas Decor, 2004, p. 55.
} 
O argumento que nos leva a questionar quanto ao 'modo como contamos nossas histórias' se sustenta a partir de que, ao rastrearmos toda a conjuntura que fez Ramos de Azevedo ser o personagem que é, parece ocorrer a seguinte operação: 1. Muitas vezes, por uma razão metodológica, parece ocorrer uma desvinculação - ainda que não intencional - entre personagem e contexto; 2. Tal desvinculação permite uma certa 'hibridação' do personagem, mostrando-o como um ser em si, desligado de todas as contingências cotidianas, permitindo a construção da história como a história do "personagem"; 3. Dessa operação resulta que a memória construída perde terreno para a memória personificada: parece que delegamos ao personagem toda a responsabilidade pela preservação da memória como patrimônio; 4. Assim, destituída de carne e dos aromas cotidianos, a memória construída passa a ser considerada com certa permissividade, uma vez que o que importa já está destacado, "de terno limpo e alma lavada", como diz Boris Fausto, ao referir-se ao negro Arias de Oliveira, o principal acusado do crime no restaurante chinês, um fato que mobilizou os paulistanos no período do carnaval e da Copa de 1938. Por isso, pareceria normal e absolutamente aceitável a realização do Campinas Decor na sede da fazenda Pau d'Alho.

No livro em que se conta a história desse crime bárbaro, Fausto situa a "forma de fazer história" que orienta sua concepção: a "micro-história". Segundo o autor

Seus objetivos básicos podem ser assim resumidos: a) reduzir a escala de observação do historiador, a fim de apreciar ações humanas e significados que passam despercebidos quando se lida com grandes quadros; b) concentrar essa escala em pessoas comuns e não em grandes personagens, buscando ouvir sua voz; c) extrair de fatos aparentemente corriqueiros uma dimensão sociocultural relevante; d) apelar para o recurso da narrativa, ao contrário da história das grandes estruturas, sem entretanto confundir-se - dado seu conteúdo e seu estilo - com as narrativas tradicionais, predominantes no século XIX; e) situar-se no terreno da história, o que significa apoiar-se nas fontes, delimitando-se assim, claramente, a obra ficcional ${ }^{6}$.

É claro que sabemos que esta dissertação não tem a pretensão de realizar, sequer em parte, os objetivos citados por Fausto. Trazemos essa citação apenas para explicar o porquê da "exumação" dos processos construtivos praticados no final do século XIX, numa fazenda de uma cidade interiorana do estado de São Paulo.

Mas Boris Fausto ainda adverte:

\footnotetext{
${ }^{6}$ FAUSTO, Boris. O crime do restaurante chinês: carnaval, futebol e justiça na São Paulo dos anos 30 . São Paulo: Companhia das Letras, 2009, p. 9. Agradecemos à arquiteta e professora Maria Cristina Wolff de Carvalho pela indicação desta obra, no exame de qualificação desta dissertação.
} 
Entre os riscos em que o gênero tem incorrido ao longo dos anos, figura em destaque o de tomar por objetivo uma história curiosa, mas irrelevante. Acredito que o livro não incide nesse problema, na medida em que o episódio central é a chave de abertura de caminhos mais amplos, sejam eles, entre outros, o funcionamento do aparelho policial e judiciário, o racismo, a discussão da natureza da criminalidade, do perfil dos infratores etc. ${ }^{7}$

Acreditamos que a forma como Ramos de Azevedo assumiu a obra da Catedral não é "irrelevante". Tampouco irrelevante o modo como orientou os trabalhos de reforma da sede da Pau d'Alho. Acreditamos que esses "episódios" são "a chave de abertura de caminhos mais amplos", que esta dissertação apenas propõe iniciar.

E Fausto termina assim suas considerações sobre o assassinato, o julgamento e a respectiva absolvição de Arias de Oliveira: "Para que se importar com o passado, se depois de tanto barulho e trabalho tudo dera em nada?"8

\footnotetext{
7 Idem, p. 11.
}

8 Ibidem, p. 210. 


\section{REFERÊNCIAS BIBLIOGRÁFICAS}

ABATE, Pedro Trucolo. O estudo das transformações ocorridas na arquitetura da Fazenda Pau Dalho no final do Século XIX e no Século XX Inventário e análise das técnicas construtivas. Monografia apresentada como exigência para graduação de Licenciatura Plena no Curso de História sob orientação do Mestre Professor Roberto Pastana Teixeira Lima, Faculdade de Ciências e Letras Plínio Augusto do Amaral, Amparo, 1998.

ALBERNAZ, Maria Paula e LIMA, Cecília Modesto de. Dicionário Ilustrado de Arquitetura. $2^{\underline{a}}$ edição, São Paulo, ProEditores, 2000.

ALBUQUERQUE, Alexandre. Construções Civis. São Paulo, Empresa Gráfica da Revista dos Tribunais, 1952.

ALVIM, Zuleika e GOULART, Silvana. Escola Politécnica: Cem anos da tecnologia brasileira. São Paulo, Grifo Projetos Históricos e editoriais, 1994.

ALVIM, Zuleika. Brava gente!: os italianos em São Paulo, 1860 -1920. São Paulo, Brasiliense, 1986.

AMARAL, Leopoldo. Campinas Recordações. São Paulo, Secção de Obras d' O estado de São Paulo, 1927.

ANDRADE, A. L. D. Levantamento preliminar das fazendas. São Paulo, Condephaat, 1973.

ANELLI, Renato Luis Sobral. Arquitetura e Cidade na obra de Rino Levi. Tese de Doutorado, FAU/ USP, 1995.

ARAÚJO, Juliana Borges de. A indústria da Construção Civil em São Paulo e a indústria da tecnologia de concreto: da experiência do gabinete de resistência dos materiais ao laboratório de ensaios dos materiais, 1899-1934. Monografia para Graduação em Economia, Pontifícia Universidade Católica de Campinas, 1992.

ARGAN, Giulio Carlo. Arte Moderna. São Paulo, Companhia das Letras, 1992.

ARGOLLO, André Ferrão. Arquitetura do Café. Campinas, Editora da Unicamp, Imprensa Oficial, 2004.

ASALAN, Nicola. Uma Radiscopia da Maçonaria para candidatos e cunhadas. Londrina, Editora Maçônica “ A Trolha " Ltda, 1997.

BADARÓ, Ricardo de Souza Campos. Campinas, o despontar da modernidade. Campinas, CMU/ UNICAMP, 1996.

BAENINGER, Rosana. Espaço e tempo em Campinas: migrantes e a expansão do pólo industrial paulista. Campinas, CMU/ UNICAMP, 1996.

BANDECHI, Brasil. A Bucha, a Maçonaria e o Espírito Liberal. São Paulo, Editora Parma, 1982.

BANDEIRA JR. A Indústria do Estado de São Paulo em 1901. São Paulo, Diário Oficial, 1901.

BANHAM, Reyner, Teoria e Projeto na Era da Máquina. São Paulo, Perspectiva, 1979. 
BARBUY, Heloísa. Museu Paulista: um monumento no Ipiranga, história de um edifício centenário e de sua recuperação. São Paulo, Imprensa Oficial, 1999.

BARCELLOS, Henrique. Almanach do Correio de Campinas para 1886. Campinas, Typographia da Gazeta de Campinas, 1886.

BARDY, Pietro Maria. Engenharia e Arquitetura na Construção. Banco Sudameris Brasil AS, 1985.

BARROS, Álvaro Paes de. O Liceu de Artes e Ofícios e seu fundador: depoimento histórico no primeiro centenário da grande instituição / Rio de Janeiro, 1956.

BASBAUM, Leoncio. Historia sincera da Republica. 4ํㅡㄹ edição. São Paulo, Alfa-Omega, 1985-86.

BATTISTONI FILHO, Duílio, 1937 Alguns aspectos da arquitetura urbana em Campinas. Campinas, Komedi, 2002.

Aspectos Culturais da História de Campinas. Campinas, Mousinho, 1983.

BEGUIN, François. As maquinarias inglesas do conforto. Revista Espaço e DebatesCidades e Histórias, Revista de Estudos Regionais e Urbanos, nº 34, ano XI, 1991, pp. 39-54.

BELLIA, Antônio Carlos. Fazendas do Ciclo do Café. Região de Campinas. Cadernos de Fotografia 5. São Paulo, Imprensa Oficial do Estado, s.d.

BENEVOLO, Leonardo. Historia da arquitetura moderna. São Paulo, Perspectiva, 1976.

BENINCASA, Vladimir. Velhas Fazendas: Arquitetura e Cotidiano nos campos de Araraquara 1830 -1930. São Carlos, EdUSCar, 2003.

BENJAMIN, Walter. "A obra de arte na era de sua reprodutibilidade técnica" in Magia e técnica, arte e política: ensaios sobre literatura e história da cultura. São Paulo, Brasiliense, 1994.

BORTOLUCI, Maria Ângela Pereira. Moradias urbanas construídas em São Paulo no período cafeeiro. São Paulo, [s.n.], 1991.

BOTACINI, Vicente. História de Campinas e história da Imigração Italiana. Campinas, Hortograph Produções Gráficas.

BRADASCHIA, Clóvis. A escola politécnica e o desenvolvimento de ensino na técnica de fundição em São Paulo. São Paulo, USP/POLI, 2002.

BRESCIANI, Maria Stella Martins. Lógica e dissonância - Sociedade de trabalho: lei, ciência e resistência operária. São Paulo: Revista Brasileira de História, vol. 6, no 11, setembro de 1985/ fevereiro de 1936.

BRITO, Jolumá. História da cidade de Campinas. Campinas, Saraiva, 1956 -1959, 26 volumes.

BRUAND, Yves. Arquitetura Contemporânea no Brasil (original: L'architecture Contemporaine au Brésil), p.74- 83; 1981, Editora Perspectiva, São Paulo, Brasil.

BRUNO, Ernani Silva. História e Tradições da Cidade de São Paulo. José Olympio Editora, São Paulo, 1954. 
CÂMARA Municipal de Campinas. Monografia da Catedral de Campinas. Campinas, Comissão de Direitos Humanos e Cidadania, 2ª edição, 2007.

CAMILLO, Ema Elisabete Rodrigues. Guia Histórico da Indústria Nascente em Campinas (1850-1887). Campinas, CMU/Mercado de Letras, 1998.

CAMPANELLA, Christian. Obras de recuperação e restauro arquitetônico. Lisboa, Câmera Municipal de Lisboa, 2003.

CAMPOS, Eudes. Arquitetura Paulistana sob o Império. Tese de doutoramento na FAUUSP, 1997.

CANO, Wilson. Raízes da concentração industrial em São Paulo. Rio de Janeiro, Difel, 1998.

CARDONA, Francisco, e ROCHA, José. Almanhach de Campinas (literário e estatístico) 1892. Campinas, Typographia Cardona, primeiro anno, 1892.

CARMO, Vitu. Chão fecundo: 100 anos de historia do Instituto Agronômico de Campinas. São Paulo, Marprint Editora, 1987.

CARNIER Junior, Plínio. A imigração para São Paulo - a viagem, o trabalho, as contribuições. São Paulo, 1999.

CARPINTEIRO, Antonio Carlos Cabral. Momento de ruptura: as transformações no centro de Campinas na década de cinqüenta. Campinas, Área de Publicações CMU, 1996.

CARVALHO, José Murillo de. Os Bestializados: o Rio de Janeiro e a Republica que não foi. São Paulo, Companhia de Letras, 1997.

CARVALHO, Maria Cristina Wolff de. Ramos de Azevedo. São Paulo: Editora da Universidade da São Paulo, 2000

CASTELANI, José. Os maçons que fizeram a história no Brasil. Gazeta Maçônica, 1991. A maçonaria e o movimento republicano brasileiro. Traço Editora, 1989.

CESAROLI, Josiane. A grande cruzada: os engenheiros e as engenharia de poder. Tese de Mestrado, Unicamp, 1998.

CHALOUB, Sidney. Cidade Febril: cortiços e epidemias na cidade imperial. São Paulo, Companhia das Letras, 1996.

COMPANHIA Industrial de São Paulo. Almanach do Estado de São Paulo para 1891. São Paulo, Editora Companhia Industrial de São Paulo, oitavo anno, 1891.

CONSELHO Superior LAO. LAO - Liceu de Artes e Ofícios - 120 anos. São Paulo, LAO, 1993.

CONSULADO Geral da Itália. Artistas italianos nas praças de São Paulo. São Paulo, s.d.

COSTA, Cacilda da. O Sonho e a Técnica: a Arquitetura do Ferro no Brasil. São Paulo, EDUUSP, 1994.

COSTA, Emilia Viotti da. Da monarquia à república: momentos decisivos. São Paulo, Fundação Editora da UNESP, 1999. 
CUNHA, Luiz Antonio $O$ ensino profissional na irradiação do industrialismo. São Paulo, Brasília, UNESP/ Flacso, 2000.

D'ALAMBERT, Clara Correia. Tijolo nas construções paulistanas do século XIX. São Paulo, s.n., 1993.

D'AlESSNDRO, Alexandre. A Escola Politécnica de São Paulo (Histórias de sua História), São Paulo: Revista dos Tribunais, 1943-1944.

DEAN, Warren. A industrialização de São Paulo (1880-1945). São Paulo, Difusão Européia do Livro, 1971.

DIÉGUES Junior, Manuel. Imigração, Urbanização e industrialização. Rio de Janeiro, Centro brasileiro de Pesquisas Educacionais, 1964.

DE BONI, Luis Alberto (org.). A Presença Italiana no Brasil, Volume II. Porto Alegre, Torino/ Escola Superior de Teologia, Fondazione Giovanni Agnelli, 1990.

DIVISÃO de Preservação / DPH - Seção Técnica de Crítica e Tombamento Prefeitura São Paulo. Palácio da Indústria Memória e Cidadania. O restauro para a nova Prefeitura de São Paulo. São Paulo, Editora Método, 1992.

EGINGER, Cláudio \& CAVALCANTI, Pedro. São Paulo, a Construção da Cidade. São Paulo, DBA, 1999.

ELLIS Junior, Alfredo. A economia paulista no século XVIII: O ciclo do muar, o ciclo do açúcar. São Paulo, Academia Paulista de Letras/ Sangirard, 1979. Populações Paulistas. São Paulo, Nacional, 1934.

EMENDABILI, Galileo. Monumento a Ramos de Azevedo - Jornal das exposições Pinacoteca do Estado. São Paulo, Pinacoteca do Estado, 1997.

ESCOLA Politécnica: 100 anos, São Paulo, Expressão Cultura, 1993.

ESCOSTEGUY, Jorge. Escola Politécnica de São Paulo, 100 anos de Tecnologia Brasileira, São Paulo, EPUSP 1994.

ESPIRITO SANTO, Jose Marcelo do. Palácio das indústrias. S.I.: s.n., 1987.

FABRIS, Annateresa (org.). Ecletismo na Arquitetura Brasileira. São Paulo, Nobel, Editora da Universidade de São Paulo, 1987.

Mercado das Letras, 1997.

Monumento a Ramos de Azevedo: do Concurso ao exílio. Campinas:

FARAH, Ana Paula. A produção do engenheiro-arquiteto Francisco de Paula Ramos de Azevedo na província de São Paulo, dissertação de Mestrado Universidade de São Paulo/ Escola de Engenharia de São Carlos, 2003.

FAUSTO, Boris. Trabalho urbano e conflito social (1890-1920).Rio de Janeiro, Bertrand Brasil, 2000 (Corpo e alma do Brasil).

FERRARI, Alfonso Trujillo. Influencia da industrialização na região rural de Campinas. Campinas, Conselho Indiginista Missionário, 1972. 
FERREIRA, Carlos, e SILVA, Hypolito da. Almanach Popular para o anno de 1879. Campinas: Typographia da Gazeta de Campinas, segundo anno.

FERRO, Sérgio. Arquitetura e trabalho livre. São Paulo, Cosac Naify, 2006.

FISCHER, Sylvia. Ensino e Profissão: O Curso de Engenheiro Arquiteto da Escola Politécnica de São Paulo, São Paulo, 1989.

FLYNN, Maria Helena de Barros. Ramos de Azevedo, I -Fase Campineira, trabalho disciplinar do curso de Pós-graduação da FAU. Março de 1990. Monumento do Ipiranga, 1876, 1 Concurso de Anteprojeto de escultura, Arquitetura e Urbanismo, trabalho disciplinar do curso de Pós-graduação 1989. Concursos de Arquitetura, Província de São Paulo - 1870 - 1890, trabalho programado, curso de Pós-graduação da FAU, junho de 1991, dois volumes.

FONSECA, Celso Suckow da. História do ensino industrial no Brasil, Rio de Janeiro, 1962.

FRAMPTON, Kenneth. História Crítica da Arquitetura Moderna. São Paulo, Martins Fontes, 1997.

FRASCISCO, Rita de Cássia. Estudo sobre a linha férrea Campinas-Jaguariúna e proposta de intervenção com vistas à conservação de suas Estações. São Paulo, FAUUSP, 2001

FREHSE, Fraya. O tempo das ruas na São Paulo de fins do império. São Paulo, Edusp, 2005.

FREYRE, Gilberto. Sobrados e Mucambos. Rio de Janeiro, Record, 1991.

GIEDION, Sigrist. Espaço, Tempo e Arquitetura. São Paulo, Martins Fontes, 2004.

GITAHY, Maria Lucia Caira "Qualificação e urbanização em São Paulo: a experiência do Liceu de Artes e Ofícios (1873-1934)", In Trabalhadores Urbanos e Ensino Profissional. Campinas: Unicamp, 1986, pp 19-118.

GITAHY, Maria Lucia Caira, PEREIRA, Paulo Cesar Xavier (org). O complexo industrial da construção e a habitação econômica moderna, 1930-1964.

GORDINHO, Margarida Cintra (org). Liceu de Artes e Ofícios de São Paulo: Missão Excelência. Marca D’água, São Paulo, 2000.

GORZ, André. Crítica da divisão do trabalho. São Paulo, Martins Fontes, 1996.

GOULART, Edmo. Campinas, ruas da época imperial. Campinas, Maranata,1983.

GUIMARÃES, Alaor Malta. Campinas: dados históricos e estatísticos (contendo um guia completo de ruas). Campinas, Livraria Brasil, 1953.

HOLANDA, Sergio Buarque de. A contribuição para a formação italiana do Brasil. Florianópolis, NUT/ NEIITA/ UFSC, 2002.

HOLLOWAY. Thomas H. Imigrantes para o café: café e sociedade em São Paulo, 18861934. Rio de Janeiro, Paz e Terra, 1984.

HABERMAS, Jürgen. "Técnica e Ciência como 'Ideologia'" in como "ideologia". Lisboa: Edições 70, 1997 (original de 1968). Técnica e ciência 
HOMEM, Maria Cecília Naclério. Exposição Vila Penteado. São Paulo, USP, 1976.

O Prédio Martinelli: a ascensão do imigrante e a verticalização de São Paulo. São Paulo, Projeto Editores, 1984.

O Palacete Paulistano e Outras Formas de Morar da Elite Cafeeira: 18671918. São Paulo, Martins Fontes, 1996.

IANNI, Octavio. O ABC da classe operaria. São Paulo, HUCTEC, 1980.

KOVAL, Boris. História do proletariado brasileiro. 1857 a 1967. São Paulo, Editora Alfa e Omega, 1982.

KUHL, Beatriz Mugayar. O tratamento das superfícies arquitetônicas como problema teórico de restauração, Anais do museu Paulista, 2004, v 12, pp 309-330.

Arquitetura do ferro e arquitetura ferroviária em São Paulo, reflexões sobre a sua preservação. São Paulo, Ateliê, SEC, FAPESP, 1998.

LADEIRA, José M. e OCTAVIO, B. Almanach de Campinas para 1908. Campinas, Typhographia e Stereotyp. da Casa Mascotte, 1908.

LAPA, José Roberto do Amaral. A Cidade: os Cantos e os Antros; Campinas 1850 1900, EDUSP, 1996.

LEITÃO, Luiz Augusto. Curso Elementar de Construções. Lisboa, Imprensa Nacional, 1986.

LEITE, Ricardo. Catedral Metropoiitana de Campinas: um templo e sua história. Campinas, Komedi, 2004.

LEMOS, Carlos A. C. Arquitetura Brasileira. São Paulo, Melhoramentos, Editora da Universidade de São Paulo, 1979.

. Alvenaria Burguesa: Breve história da arquitetura residencial de tijolos em São Paulo a partir do ciclo econômico liderado pelo café. São Paulo, Nobel, 1985.

. Casa Paulista - história das moradias anteriores ao ecletismo trazido pelo café. São Paulo, EDU USP, 1999.

Ramos de Azevedo e seu escritório. São Paulo, Pini, 1993.

LISBOA, José Maria. Almanak de Campinas para 1871. Campinas, Typographia da Gazeta de Campinas, 1870. Campinas, 1871.

Almanak de Campinas para 1872. Campinas, Typographia da Gazeta de

LOBO, Pelágio. Velhas Figuras de São Paulo. São Paulo, Academia Paulista de Letras, 1977.

LOPES, João Marcos de A. Em memória das mãos: o desencantamento da técnica na arquitetura e no urbanismo. Tese de Doutorado apresentada ao Departamento de Filosofia do Centro de Educação e Ciências Humanas da Universidade Federal de São Carlos - UFSCar, abril 2006. 
LOUREIRO, Maria Amélia Salgado. A evolução da casa paulistana e a arquitetura de Ramos de Azevedo. São Paulo, Voz do Oeste e Secretaria de Estado da Cultura, 1981.

LUNÉ, Antonio José Baptista de; FONSECA, Paulo Delfino da. Almanak da Província de São Paulo para 1873. São Paulo, Imprensa Oficial do Estado, 1985.

MACAMBIRA, Yvoty de Macedo Pereira. Os Mestres da fachada: artistas-artesãos. São Paulo, Brasil] : Centro Cultural São Paulo, Divisão de Pesquisas, 1985.

MARAM, Sheldon L. Anarquistas imigrantes e o Movimento Operário Brasileiro, 18901920.

MARCOVITCH, Jacques. Pioneiros \& Empreendedores - A Saga do Desenvolvimento no Brasil. Volume 1. São Paulo, EDUSP 2003.

MARCUSE, Herbert. "Algumas implicações sociais da tecnologia moderna" in Praga revista de estudos marxistas. São Paulo, Jinkings Editores Associados, 1997 ( $\mathrm{n} \times 1$ set/dez 1996 - original de 1941).

. "Industrialização e capitalismo na obra de Max Weber" in MARCUSE, Herbert. Cultura e sociedade - vol. II. Rio de Janeiro, Paz e Terra, 1998, pp. 113 a 136.

MARIANO, Júlio. Campinas de ontem e ante-ontem; quadros históricos menos conhecidos da Cidade Princesa, que se traçaram tendo por base documentos inéditos do Arquivo da Câmera Municipal de Campinas. Campinas, Editora Maranata, 1970.

MARTINS, Ana Luiza. Império do Café: a grande lavoura do Brasil de 1850 a 1890. São Paulo, Atual, 1990.

MARTINS, José de Souza. O Cativeiro da Terra. São Paulo, Livraria Editora Ciências Humanas, 1979.

MARTINS, José Pedro. Campinas do Matto Grosso: da febre amarela a cólera dos rios. Campinas, 1997.

MATEUS, João C. O. M. Técnicas Construtivas Tradicionais de Construção de Alvenarias. A literatura técnica de 1750 a 1900 e seu contributo para a conservação de edifícios históricos. Lisboa, Horizonte, 2002.

MATOS, Odilon Nogueira de, Maria Lucia de Souza Rangel Ricci. Um pouco da historia de Campinas. Campinas, PUC, Departamento de História, 1985.

Café e ferrovias: a evolução ferroviária de São Paulo e o desenvolvimento da cultura cafeeira. $3^{\circ}$ Edição; São Paulo, Edições Arquivo do Estado, 1981.

MARX, Karl. O capital: crítica da economia política, livro 1, vol. 1. Rio de Janeiro, Civilização Brasileira, 2002.

. "Trabalho Estranhado e Propriedade Privada" In Manuscritos econômicofilosóficos. São Paulo, Boitempo, 2004.

MARX, Karl e ENGELS, Friedrich. A ideologia alemã. São Paulo, Martins Fontes, 1998.

MEDRANO, Lilia Inês Zanotti de e GODOY, João Miguel Teixeira de (org). Campinas Visões de sua história. Campinas, Editora Átomo, 2006. 
MEILLER, João Luiz e SILVA, Francisco I. de Araújo. Meio século de tecnologia 18991949. São Paulo: Instituto de Pesquisas Tecnológicas, 1949, pp. 32.

MENDES, Jose de Castro. Efemérides campineiras: 1739-1960. Campinas, Gráfica Palmeiras, 1963.

Retratos da velha Campinas. São Paulo, Departamento de Cultura, 1951.

MONBEIG, Pierre. Pioneiros e fazendeiros de São Paulo. São Paulo, Hucitec-Polis, 1998.

MONTEIRO, Ana Maria Reis de Góes. Ramos de Azevedo: Presença e atuação profissional em Campinas: 1879-1886. Dissertação de Mestrado, Faculdade de Arquitetura e Urbanismo da PUC-Campinas, 2000.

MUMFORD, Lewis. A Condição do Homem: Uma análise dos propósitos e Fins do Desenvolvimento Humano. Tradução V. de Miranda Reis. RS, Editora Globo, 1952.

NASCIMENTO, Teresinha Aparecida Quiaotti Ribeiro do. Memórias da educação; Campinas (1859 - 1960), Campinas, Editora da UNICAMP, CMU, 1999, Coleção Campiniana, ํㅡㄹ. 20.

NEGRI, Barjas. Concentração e desconcentração industrial em São Paulo (1880-1990). Campinas, SP, UNICAMP, 1996.

OCTAVIO, Benedito e MELILLO, Vicente. Almanach Histórico e Estatístico de Campinas 1912. Typhographia Casa Mascotte, 1911.

OLIVEIRA, Helena Donaria. A interiorização da indústria e a dinâmica regional paulista: bases históricas do desenvolvimento econômico da região de Campinas. 1991.

OLIVEIRA, Maria Coleta F.A. de. Questões demográficas no período cafeeiro em São Paulo. Campinas, NEPO, UNICAMP, 1985.

OLIVEIRA, Mario Mendonça. Tecnologia de Conservação e Restauração: Materiais e Estruturas - Roteiro de Estudos. Salvador, Mestrado em Arquitetura e Urbanismo da UFBA/ PNUD/ UNESCO, 1995.

ORTIZ, Renato. Cultura brasileira e identidade nacional. São Paulo-Brasil, Brasiliense, 1985.

PEREIRA, Paulo César Xavier. Espaço, técnica e construção. São Paulo, Nobel, 1988.

2004. São Paulo, a construção da cidade, 1872-1914. São Carlos, Rima Editora,

PESSOA, Ângelo Emilio da Silva (Org.). Conhecer Campinas numa perspectiva histórica. Campinas: Secretaria Municipal de Educação, 2004.

PETRONE, Maria Thereza S. A lavoura canavieira em São Paulo: expansão e declínio (1765-1851) São Paulo, Difusão Européia do Livro, 1968.

PEVSNER, Nikolaus. As origens da Arquitetura Moderna e do Design. São Paulo, Martins Fontes, 1996.

PINHEIRO, Maria Lucia Bressan. Sobre a casa de Dona Yayá. São Paulo, EDUSP, 1999. 
PINTO, Alfredo Moreira. Campinas - Impressões de Viagem. Rio de Janeiro, Companhia Typográfica do Brasil, 1898.

PORTA, Paula (org). História da cidade de São Paulo - A cidade no Império 1823-1889, volume 2, São Paulo, Paz e Terra 2004.

PRADO, Antonio da Silva. Relatorio de 1901 apresentado a Câmara Municipal de São Paulo. São Paulo, Typ de Vanorden \& Co, 1902.

Relatorio de 1902 apresentado a Câmara Municipal de São Paulo. São Paulo, Typ de Vanorden \& Co, 1903.

Relatorio de 1906 apresentado a Câmara Municipal de São Paulo. São Paulo, Typ de Vanorden \& Co, 1907.

PUPO, Celso Maria de Mello. Campinas, seu berço e juventude, Campinas, Publicações da Academia Campinense de Letras, 1969, ㄲo 20.

Campinas, município no Império: fundação e constituição, usos familiares, a morada, sesmarias, engenhos e fazendas. São Paulo, Impr. Oficial, 1983.

RAINVILLE, Cesar O Vinhola Brasileiro. Eduardo e Henrique Larmmert, Rio de Janeiro, 1880.

REDONDO, Garcia. Revista de Engenharia, 1880.

REIS FILHO, Nestor Goulart. Quadro da Arquitetura no Brasil. São Paulo, Perspectiva, 1970.

Aspectos da história da engenharia civil em São Paulo: 1860-1960. São Paulo, Companhia Brasileira de Projetos e Obras - CBPO e Livraria Kosmos Editora.

. "Campinas e suas estações: de onde partia o progresso". In: São Paulo e outras cidades: produção social e degradação dos espaços urbanos. 1994.

São Paulo. Reparticao de Estatistica e Archivo do Estado. Divisão

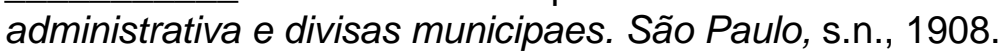

J. Bignardi, 1953.

Apontamentos para a história da fábrica de ferro do Ipanema. São Paulo,

SAIA, Luis. Morada Paulista. São Paulo, Perspectiva, 1972.

SAINT-HILAIRE, A de. Viagem à província de São Paulo. São Paulo, Martins,1972.

SALGADO, Ivone. Urbanismo Sanitarista em Campinas no final do séc. XIX Campinas, 1992. Projeto Integrado $\mathrm{CnPq}$ "A evolução Urbana de Campinas", Relatório Final, Faculdade de Arquitetura e Urbanismo, Pontifícia Universidade Católica de Campinas, 1992.

SALMONI, Anita e DEBENEDETTI, Emma. Arquitetura italiana em São Paulo. São Paulo, Perspectiva, 1981.

SANTOS, Antonio da Costa. Campinas, das origens ao futuro: compra e venda de terra e água e um tombamento na primeira sesmaria da Freguesia da Nossa Senhora da Conceição das Campinas do Mato Grosso de Jundiaí (1732-1992). 
SANTOS, Maria Cecília Loschiavo dos. Escola Politécnica da Universidade de São Paulo, Reitoria da Universidade de São Paulo, 1985.

SECKLER, Jorge. Almanach Administrativo, Commercial e Industrial da Província de São Paulo para o anno de 1886. São Paulo, Editores Proprietários Jorge Secker \& C., quarto anno, 1886.

Almanach do Estado de São Paulo para o anno de 1890. São Paulo, Editores Proprietários Jorge Secker \& Comp., setimo anno, 18889.

SECRETARIA de Economia e Planejamento. Aspectos estruturais do desenvolvimento da economia paulista: construção civil. São Paulo, A Secretaria, 1978.

SECRETARIA Municipal de Cultura de São Paulo Signos de um novo tempo: a São Paulo de Ramos de Azevedo. São Paulo, Revista Cidade - Revista do Departamento do Patrimônio Histórico, Jan 98.

SEGURADO, João Emílio dos Santos. Acabamento de construções: estuques, pinturas, etc. Lisboa: Bertrand, 19-?.

Profissional.1908.

Alvenaria e cantaria. 4. ed. Lisboa, Bertrand, Biblioteca de Instrução . Construção Civil: acabamentos de construções. Lisboa, Bertrand, 19-?. . Construção Civil: edificações. Lisboa, Bertrand, 19-?.

- Construção Civil: materiais de construção. Biblioteca de Instrução Profissional, Livraria Bertrand. Volume I.

- Construção Civil: materiais de construção. Biblioteca de Instrução Profissional, Livraria Bertrand. Volume II.

- Construção Civil: terrapanagens e alicerces. Biblioteca de Instrução Profissional, Livraria Bertrand.

- Construção Civil: trabalho de carpintaria civil. Biblioteca de Instrução Profissional, Livraria Bertrand.

- Construção Civil: trabalho de serralharia civil. Biblioteca de Instrução Profissional, Livraria Bertrand.

SEGAWA, Hugo. Arquitetura no Brasil, 1900-1990. São Paulo, Edusp, 1997.

Prelúdio da Metrópole - Arquitetura e Urbanismo em São Paulo na passagem do século XIX ao XX. São Paulo, Ateliê Editorial, 2000.

SEMEGHINI, Ulysses C. Do café a indústria: uma cidade e seu tempo. Campinas, UNICAMP, 1991.

SERVIÇO GRÁFICO BRASILEIRO DE GEOGRAFIA E ESTATÍSTICA, Monografia História do Município de Campinas. Rio de Janeiro, 1952.

SEVERO, Ricardo. Liceu de Artes e Ofícios de São Paulo - Histórico, estatuto, regulamento, programas e diplomas. 1934. 
SILVA, Áurea Pereira. Engenhos e fazendas de café em Campinas (Séc. XVIII - Séc. XX) Anais do Museu Paulista, 2006, jun/ vol. 14, São Paulo, Universidade de São Paulo, pp. 81-119.

SILVA, Geraldo Gomes da. Arquitetura do ferro no Brasil. São Paulo, Ed. Nobel, 1987.

SILVA, Hypolito da. Almanach Popular para o anno de 1878. Campinas, Typographia da Gazeta de Campinas, Primeiro anno, 1877.

SIMÃO, Aziz. Sindicato e Estado. São Paulo, Dominus USP, 1966.

SIMMEL, George. "A metrópole e a vida mental" em VELHO, Otávio. O Fenômeno Urbano. São Paulo, Zaar, 1979.

SIMONDON, Gilbert. Du mode d'existence des objets techniques. Paris, Aubier, 1989.

STAHLBERG, Altino. A presença dos imigrantes italianos em Limeira. Limeira, memória Limeirense, 1998.

STEIN, S. J. Grandeza e decadência do café no Vale do Paraíba. São Paulo, 1961.

TELLES. Augusto Carlos da Silva. Arquitetura eclética - Perda e Preservação. Revista Barroco, Belo Horizonte, n 17, pp. 283-28, 1993/6.

TELLES, Henrique Vichnewski. As indústrias Matarazzo no interior paulista: arquitetura fabrile patrimônio industrial (1920-1960). Dissertação de Mestrado, Departamento de História do Instituto de Filosofia e Ciências Humanas da Unicamp.

TELLES, Pedro Cardoso da Silva. História da engenharia no Brasil (séc XVI - XX). Rio de Janeiro, Livros Técnicos e Científicos Editora, 1984.

TOLEDO, Benedito de Lima e DANON, Diana Dorothea. São Paulo: "Belle Époque". Companhia Editora Nacional, Editora da Universidade de São Paulo, 1974.

VASCONCELLOS, Sylvio. Arquitetura do Brasil - Sistemas Construtivos. Belo Horizonte, Escola de Arquitetura da UFMG, 1958.

VARGAS, Milton (org). Contribuições para a história da engenharia no Brasil. São Paulo, EPUSP, 1994. - História da técnica e da tecnologia no Brasil. São Paulo, Unesp, 1994.

VAUTHIER, L. L. Casas de residências no Brasil. In Arquitetura Civil I, FAUUSP e MECIPHAN, São Paulo, 1975.

VILLABA, Antonio Castro. Historia de la construcción arquitectónica. Edicions UPC.

ZAKIA, Silvia Palazzi. Fazenda Pau d'Alho. Pesquisa histórica - arquiteura. Campinas, 2008. 


\section{ANEXOS}

Anexo 1: Quadros de indústrias e mão de obra por ano em Campinas

\begin{tabular}{|l|c|}
\hline \multicolumn{2}{|c|}{ QUADRO 1 - 1870 } \\
\hline Lojas de ferragens & 14 \\
\hline Depósito de cal & 2 \\
\hline Carpinteiros e mestres de obras & 16 \\
\hline Depósito de ferro e zinco & 2 \\
\hline Depósito de madeira & 5 \\
\hline & 1 \\
\hline Arquiteto & 2 \\
\hline Entalhadores DE OBRA & 2 \\
\hline Olarias & 3 \\
\hline Ferrarias & 10 \\
\hline Ferreiros e serralheiros & 2 \\
\hline Fundições de ferro & 3 \\
\hline Fundidores & 13 \\
\hline Marceneiros & 5 \\
\hline Ferradores \\
\hline Pedreiros e mestres de obra & 5 \\
\hline Pintores & 3 \\
\hline Torneiros de ferro e metais & \\
\hline Torneiros de madeira & \\
\hline Vidraceiros \\
\hline & \\
\hline \multicolumn{2}{|c|}{} \\
\hline
\end{tabular}




\begin{tabular}{|l|c|}
\hline \multicolumn{2}{|c|}{ QUADRO 2 - 1871 } \\
\hline \multicolumn{2}{|c|}{ A INDÚSTRIAS } \\
\hline Depósito de madeira & 7 \\
\hline Depósito de cal & 2 \\
\hline Depósito de ferro e zinco & 2 \\
\hline Casas de importação e commissões & 8 \\
\hline Lojas de ferragens & 17 \\
\hline Olarias & 7 \\
\hline Fundições de ferro e bronze & 2 \\
\hline B - MÃO DE OBRA & 17 \\
\hline Arquiteto & 13 \\
\hline Engenheiro agrimensor & 3 \\
\hline Carpinteiros e mestres de obras & 32 \\
\hline Ferradores & 4 \\
\hline Ferreiros e serralheiros & 13 \\
\hline Fundidores de metais & \\
\hline Marceneiros & 1 \\
\hline Pedreiros e mestres de obras & \\
\hline Pintores & \\
\hline Torneiros em ferro e metais & \\
\hline Torneiros em madeira & \\
\hline Vidraceiros & \\
\hline Entalhadores & \\
\hline
\end{tabular}




\begin{tabular}{|l|c|}
\hline \multicolumn{2}{|c|}{ QUADRO 3 - 1878 } \\
\hline A - INDÚSTRIAS \\
\hline Depósitos de madeira & 6 \\
\hline Lojas de ferragens & 11 \\
\hline Olarias & 2 \\
\hline Fundição & 2 \\
\hline Marcenarias B - MÃO DE OBRA \\
\hline \multicolumn{2}{|c|}{} \\
\hline Engenheiro agrimensor & 1 \\
\hline Torneiros & 2 \\
\hline Marmorista & 1 \\
\hline Ferradore & 1 \\
\hline
\end{tabular}

\begin{tabular}{|l|c|}
\hline \multicolumn{2}{|c|}{ QUADRO 4 - 1879 } \\
\hline \multicolumn{2}{|c|}{ A - INDÚSTRIAS } \\
\hline $\begin{array}{l}\text { Oficinas de carpinteiros e mestre de } \\
\text { obras }\end{array}$ & 2 \\
\hline Oficinas de ferreiros e serralheiros & 11 \\
\hline $\begin{array}{l}\text { Fundição de ferro, bronze e } \\
\text { galvanizadores de metais }\end{array}$ & 2 \\
\hline Oficina de funileiros e latoeiros & 4 \\
\hline Fábricas de móveis & 12 \\
\hline Olarias & 3 \\
\hline Serrarias a vapor & 2 \\
\hline \multicolumn{1}{|c|}{ BÃO DE OBRA } \\
\hline Marmoristas & 3 \\
\hline Pintores
\end{tabular}




\begin{tabular}{|l|l|}
\hline \multicolumn{2}{|c|}{ QUADRO 5 - 1886 } \\
\hline A - INDÚSTRIAS \\
\hline Oficina de mármore & 3 \\
\hline Ferragens & 8 \\
\hline Olarias & 3 \\
\hline Fundições & 3 \\
\hline Depósito de móveis & 3 \\
\hline Depósitos de madeira & 3 \\
\hline Marcenarias e oficinas de móveis & 7 \\
\hline Papéis pintados e vidros & 3 \\
\hline \multicolumn{1}{|c|}{ B- MÃO DE OBRA } & 2 \\
\hline Ferradores & 9 \\
\hline Ferreiros & 3 \\
\hline Marmoristas & 4 \\
\hline Marceneiros & 1 \\
\hline Mestres de obra1 & 3 \\
\hline Commerciantes importadores (ferragens) & \\
\hline Engenheiros & \\
\hline
\end{tabular}

\begin{tabular}{|l|c|}
\hline \multicolumn{2}{|c|}{ QUADRO 6 - 1892 } \\
\hline \multicolumn{2}{|c|}{ A - INDÚSTRIAS } \\
\hline Marcenaria e carpintaria & 1 \\
\hline Oficina de marcenaria e depósito de móveis & 1 \\
\hline Armazém vidros, cristais, louças e outros & 1 \\
\hline Marcenarias & 10 \\
\hline Olarias B- MÃO DE OBRA & 8 \\
\hline \multicolumn{2}{|c|}{} \\
\hline Marmoristas
\end{tabular}




\begin{tabular}{|l|c|}
\hline \multicolumn{2}{|c|}{ QUADRO 7 - 1908} \\
\hline \multicolumn{2}{|c|}{ A - INDÚSTRIAS } \\
\hline Olarias & 7 \\
\hline \multicolumn{2}{|c|}{ B- MÃO DE OBRA } \\
\hline \multicolumn{2}{|c|}{} \\
\hline Marceneiros e carpinteiros & 4 \\
\hline Empreiteiros-construtores & 29 \\
\hline Marmoristas & 3 \\
\hline Ferreiros & 21 \\
\hline
\end{tabular}




\section{Anexo 2: Quadros de indústrias e mão de obra por ano em São Paulo}

\begin{tabular}{|c|c|}
\hline \multicolumn{2}{|c|}{ TABELA 1 - 1886} \\
\hline $\begin{array}{l}\text { Pintor de casas (fingimento de mármore e } \\
\text { madeiras) e vidraceiro }\end{array}$ & Conrado Sorenicht, rua Brigadeiro Raphael Tobias no 5 \\
\hline Empreiteiro de obras & Pacoli Hehl, rua dos Protestantes $n^{\circ} 27$ \\
\hline Casa de importação de ferragens & $\begin{array}{l}\text { Bullow \& Company, rua Direita, no } 43 \text { (e madeira) } \\
\text { Eduardo Prates - Casa Importadora, rua de S. Bento, n } \\
81 \text { (e cimento) } \\
\text { Alberto Kuhlmann, rua S. Caetano, № } 44\end{array}$ \\
\hline Serraria e depósito de Madeira & José Faccini e Matheus Hussler (arquiteto) \\
\hline $\begin{array}{l}\text { Depósito de papéis para forrar casas e } \\
\text { vidros para vidraça }\end{array}$ & Pedro P. Binttecourt \& C, rua São Bento n 36 \\
\hline $\begin{array}{l}\text { Compra e venda por conta de terceiros, } \\
\text { entre outros, casas e terrenos }\end{array}$ & $\begin{array}{l}\text { Agencia Central Publio Mendonça, Travessa da } \\
\text { Quitanda } n^{\circ} 5 \mathrm{~A}\end{array}$ \\
\hline \multirow{4}{*}{ Oficina de funilaria } & $\begin{array}{l}\text { Miguel Coiro \& Irmão, rua da Imperatriz n } 48 \\
\text { (encanamentos, cobre e ferro) }\end{array}$ \\
\hline & Zerrenner, Bulow \& Comp, rua Direita no 43 \\
\hline & Rempe \& Cia, rua de S, Bento ํo 41 \\
\hline & Eduardo Prates, rua S. Bento $n^{\circ} 81$ \\
\hline
\end{tabular}

\section{TABELA 2 -1890}

\begin{tabular}{|l|l|}
\hline $\begin{array}{l}\text { Empreiteiros e construtores, ornamentação, } \\
\text { escultura e arquitetura (monumento Ypiranga) }\end{array}$ & $\begin{array}{l}\text { Martinelli \& Irmão, Alameda do Triunpho n 6, } \\
\text { (fundada em 1872) }\end{array}$ \\
\hline Depósito de madeira & $\begin{array}{l}\text { Bettoi Santos \& Comp. (soalho de canella } \\
\text { parda, forro, vigotas, ripas e telhas), rua da } \\
\text { Concordia }\end{array}$ \\
\hline Marmorarias & $\begin{array}{l}\text { Marmoraria Central (Carrara)/ Falmiro Conti \& } \\
\text { Francesco Valenti, rua da Boa Vista n 62 } \\
\text { Antiga Marmoraria Imperial - Martinelli \& Irmão, } \\
\text { Alameda do Triunpho no 6 }\end{array}$ \\
\hline Funilaria & $\begin{array}{l}\text { Antonio Columbus- fabricação de objetos em } \\
\text { ferro, zinco e latão (banheiras, ornamentos, } \\
\text { encanamentos), rua Brigadeiro Raphael Tobias } \\
\mathrm{n}^{\circ} \text { 24 }\end{array}$ \\
\hline Carpintaria e serraria & $\begin{array}{l}\text { Serraria Americana (soalho e ferro, pinho } \\
\text { nacional e estrangeiro, peroba), rua Duque de } \\
\text { Caxias no 20 }\end{array}$ \\
\hline
\end{tabular}


Anexo 3: Fazenda Pau d'Alho - planta e elevações

Legenda:

Reforma / acréscimo

Demolição 


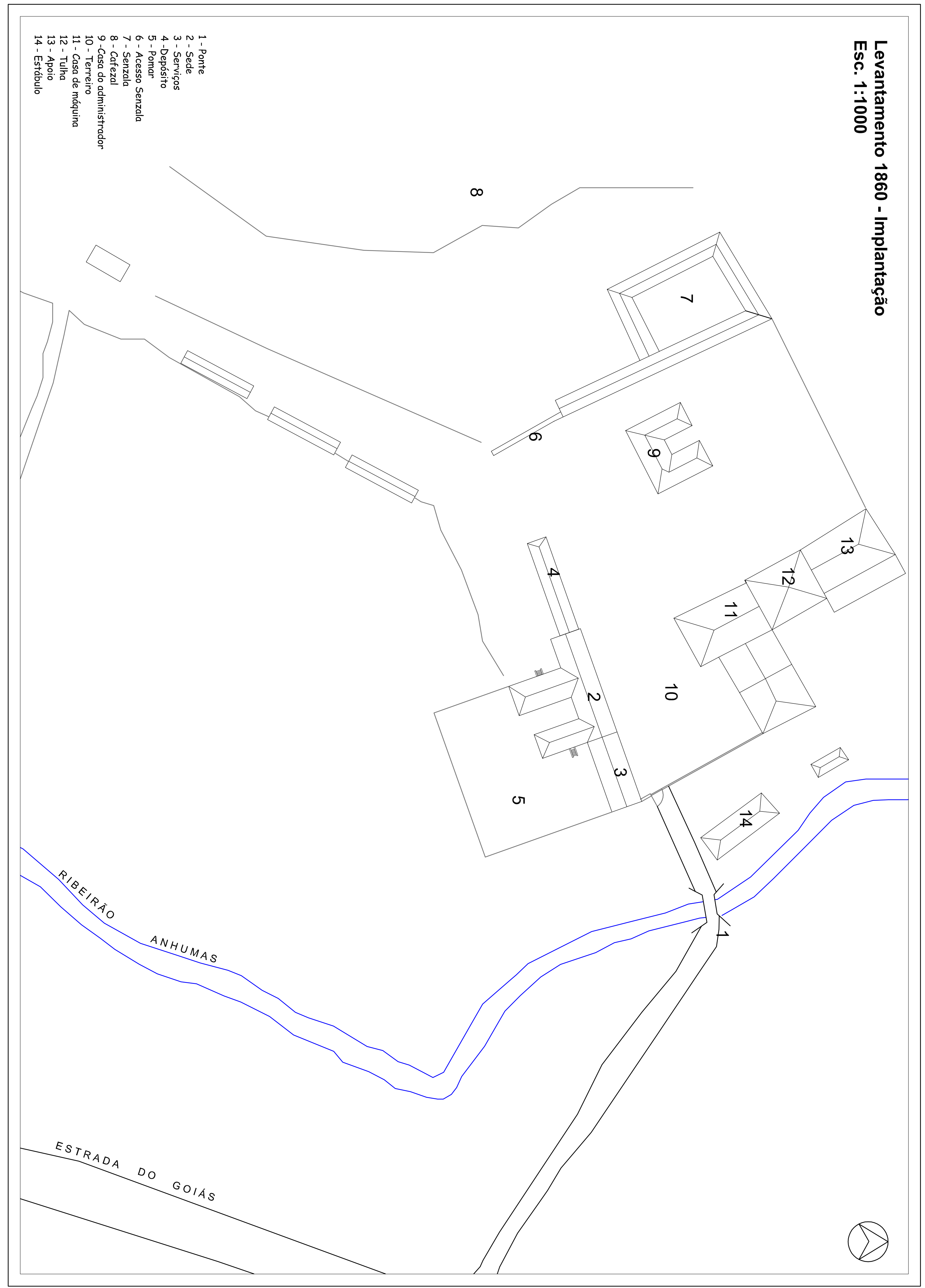




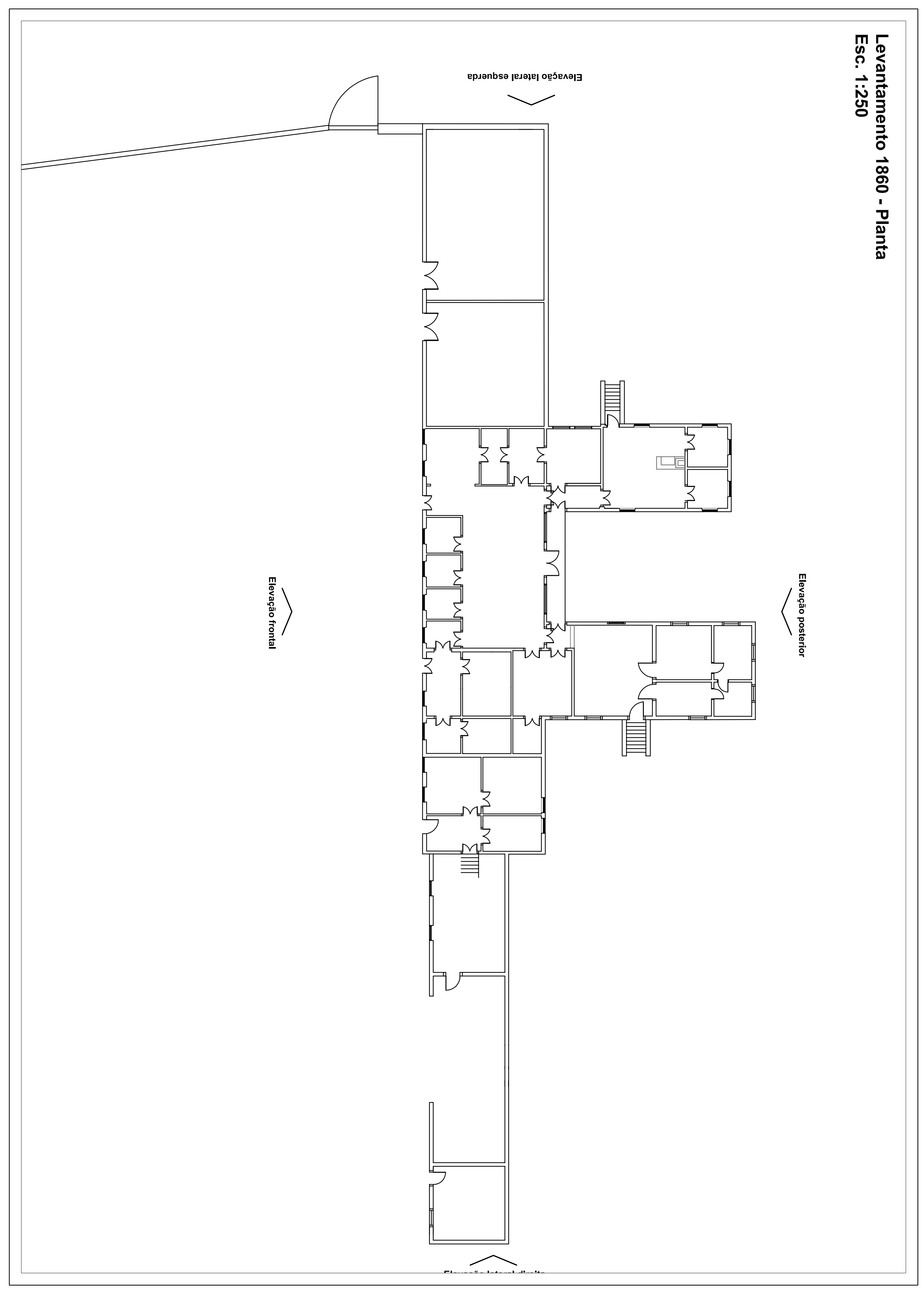




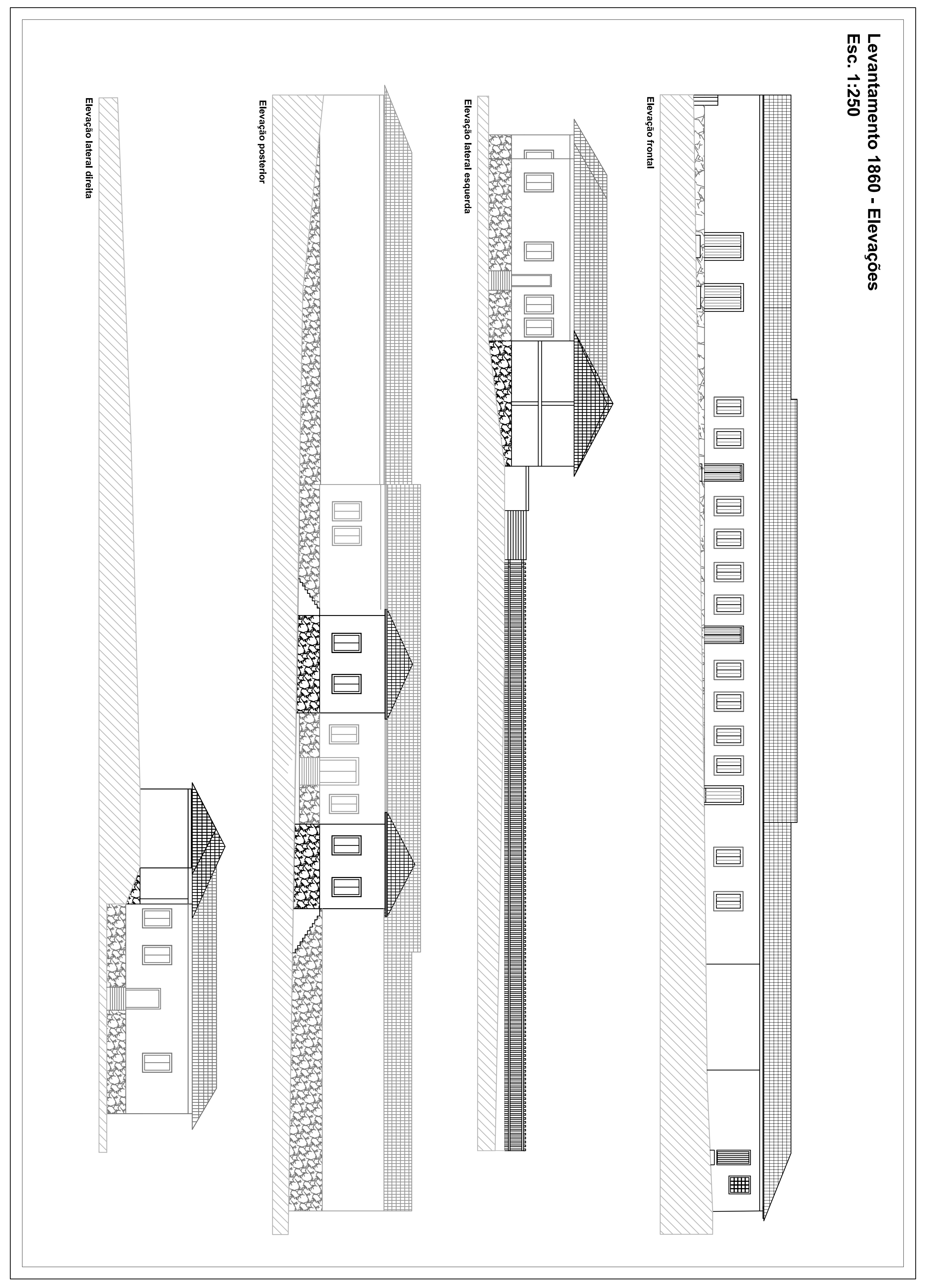




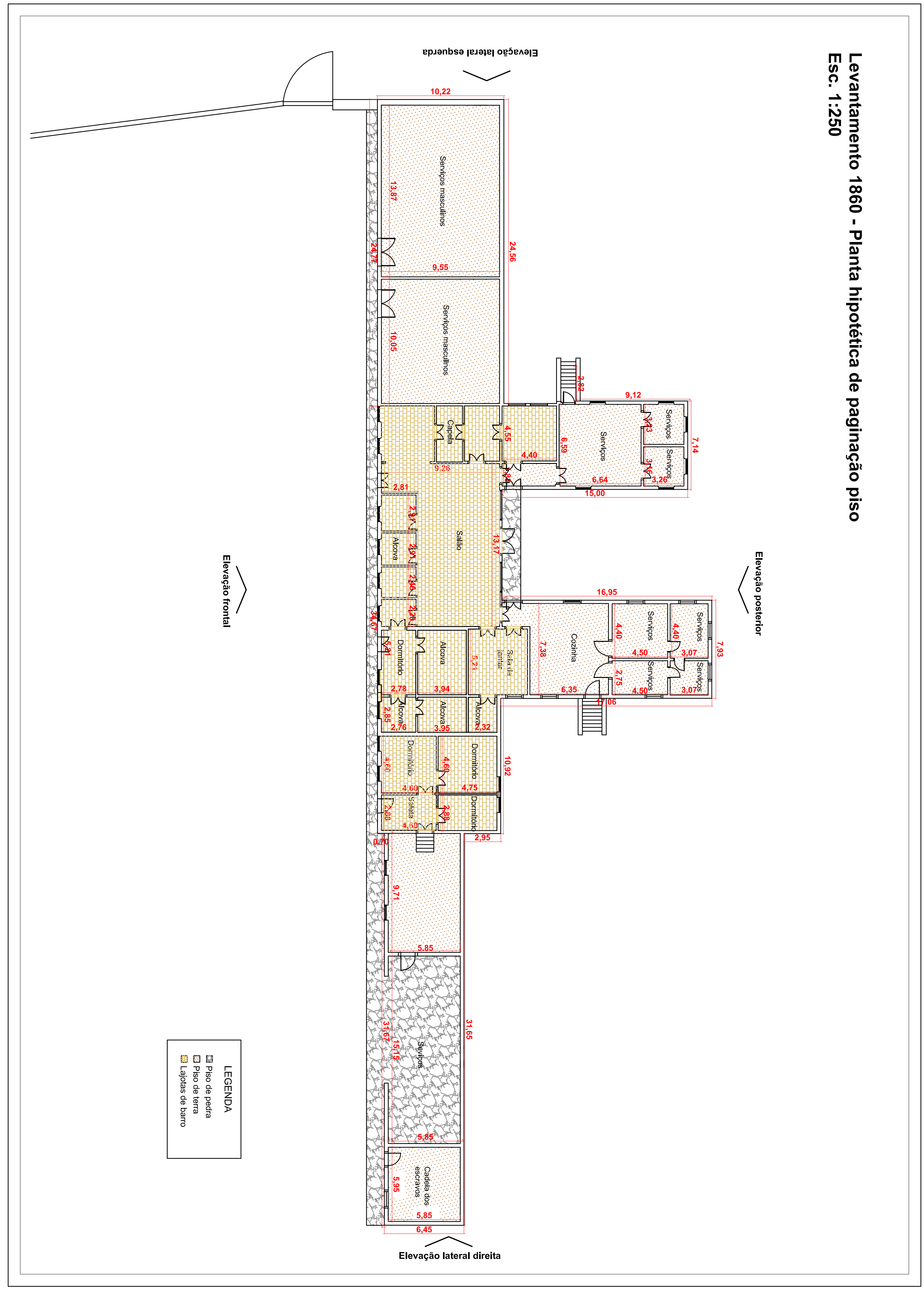




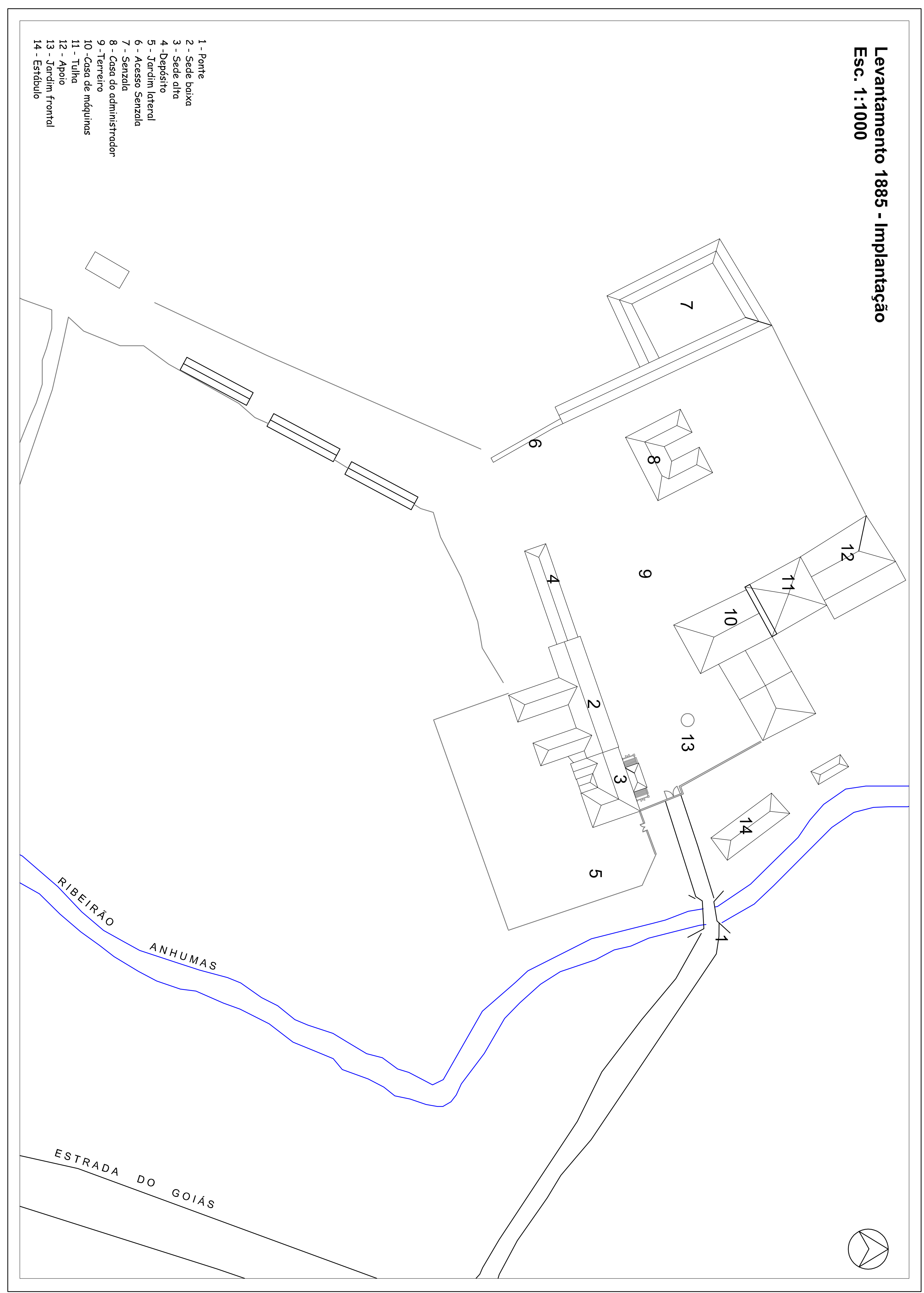




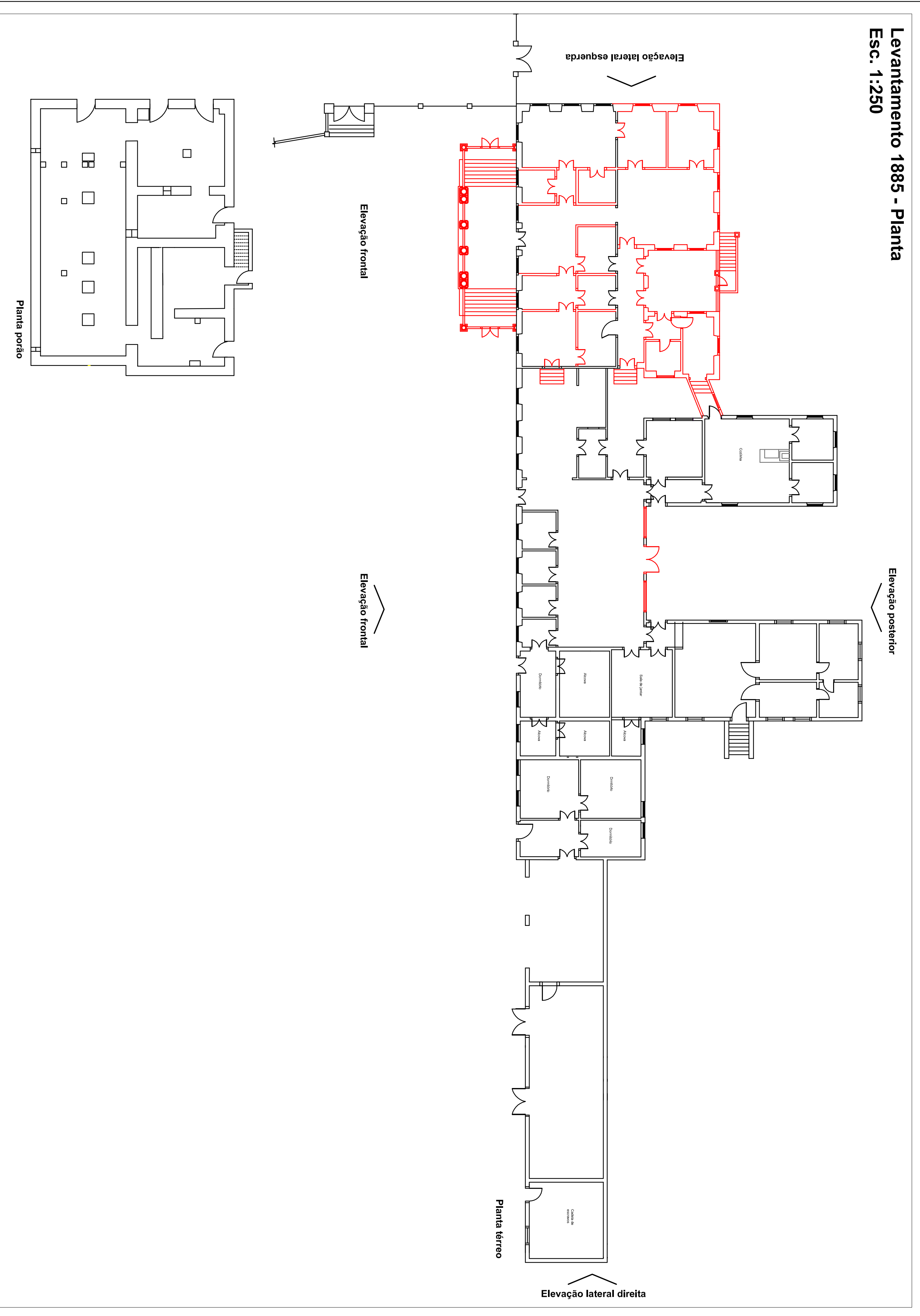




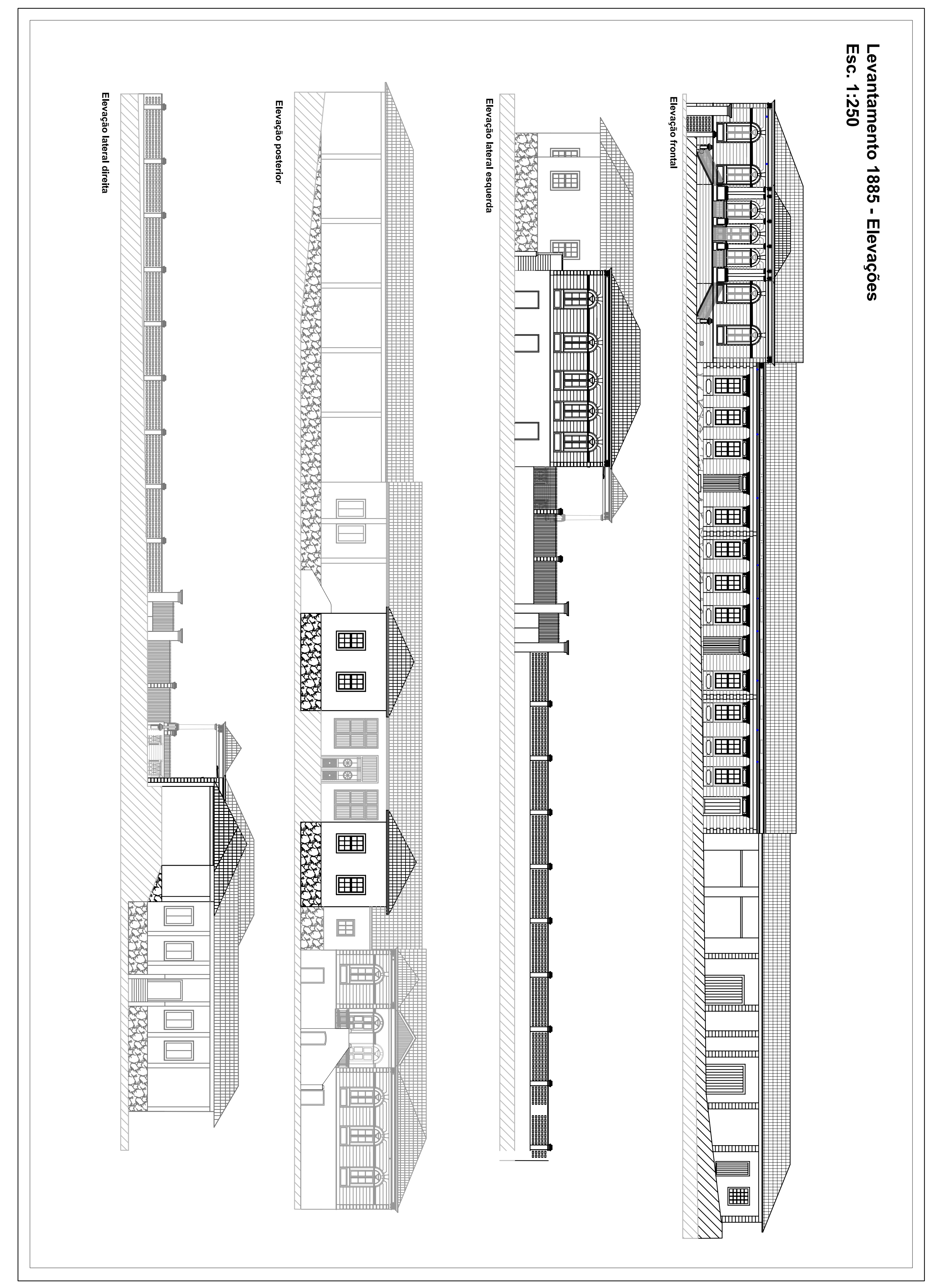




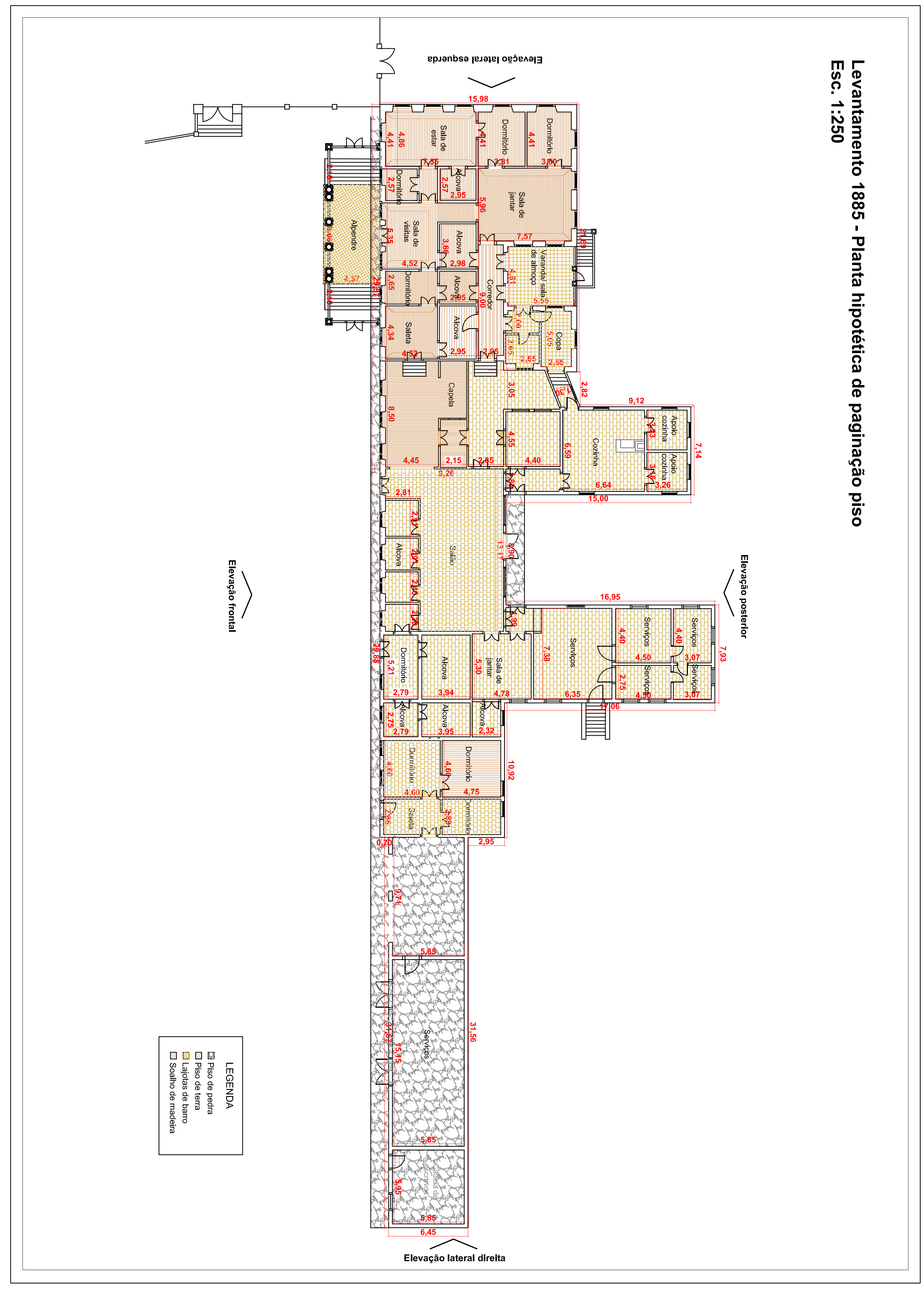




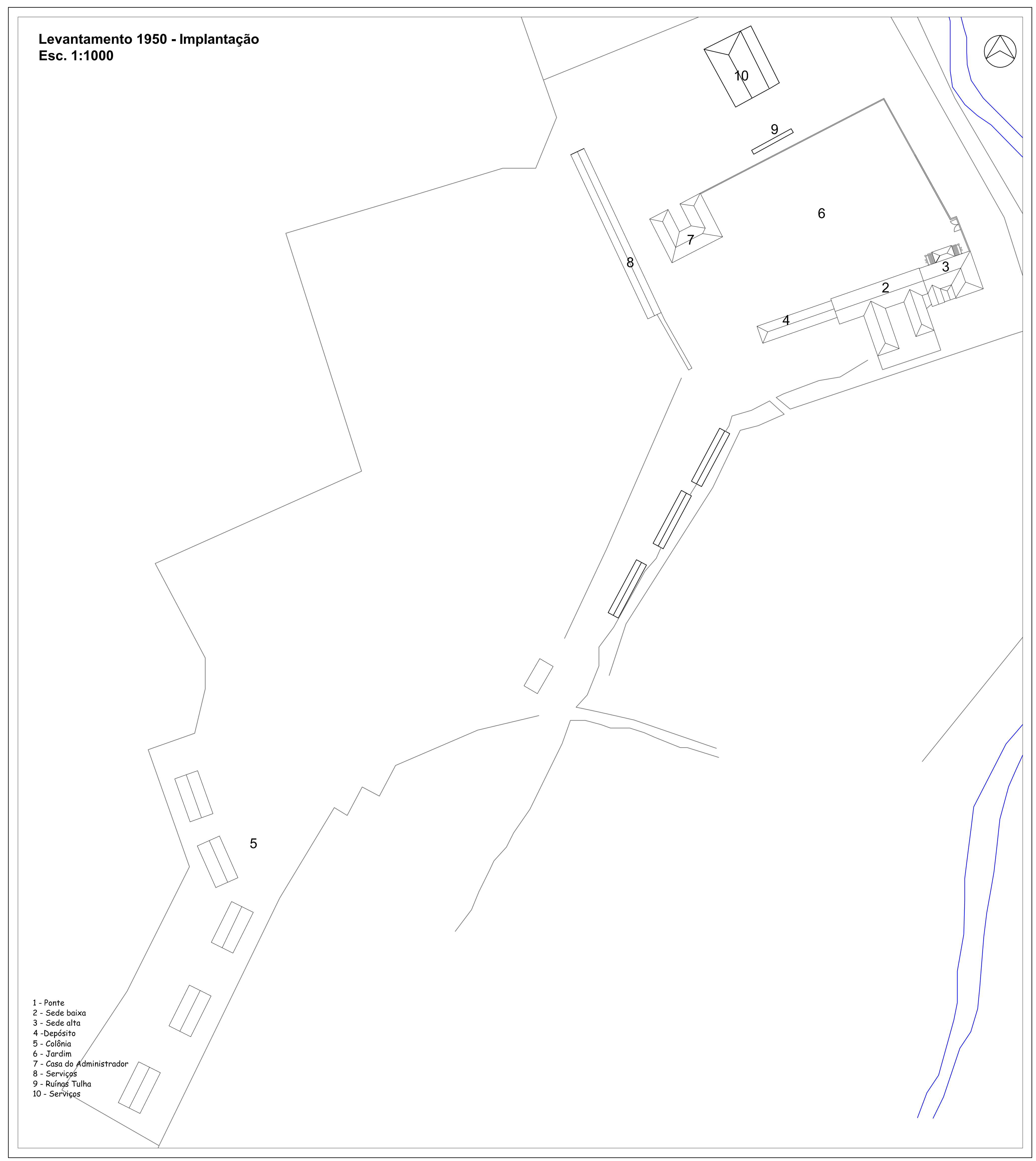




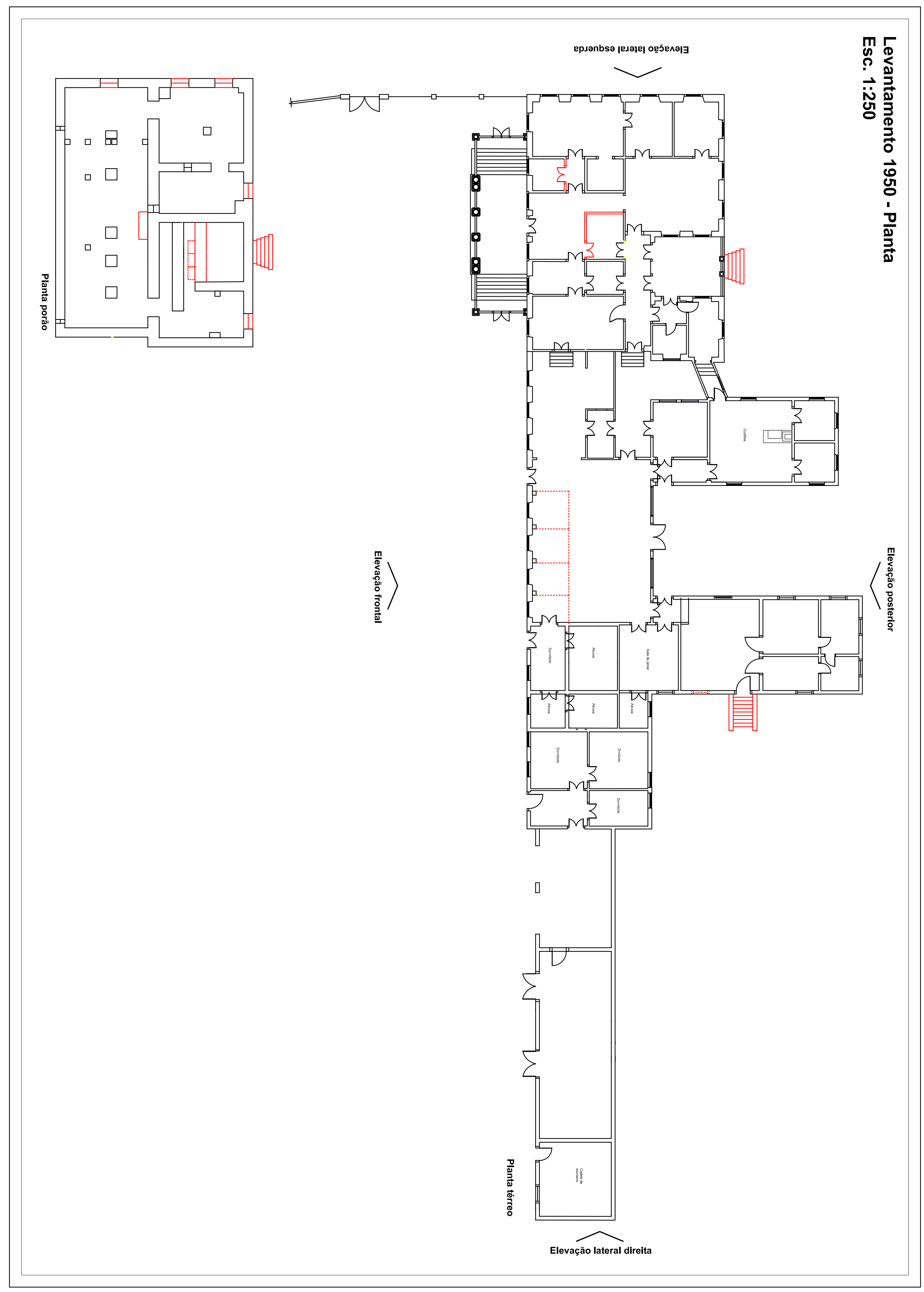



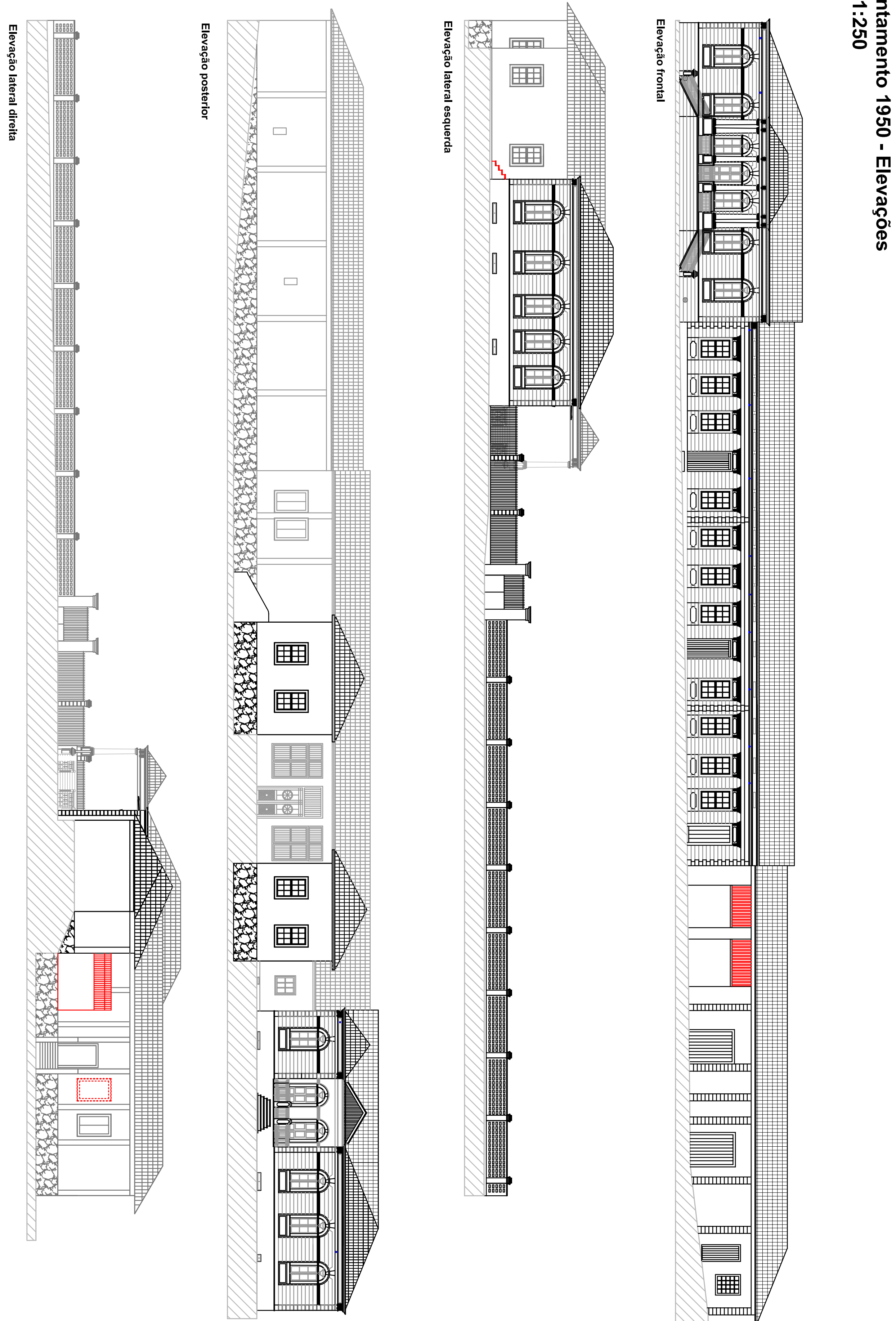


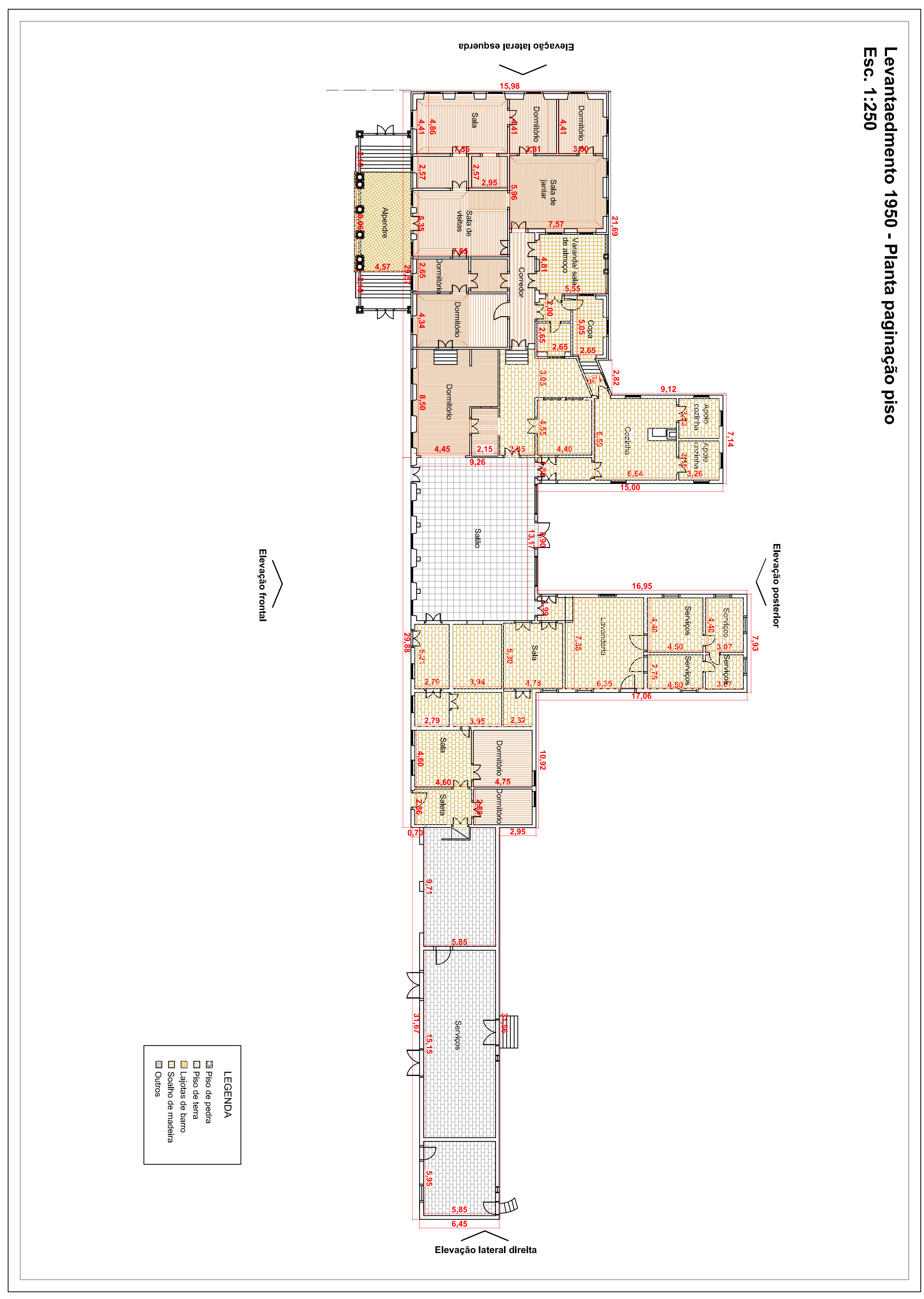




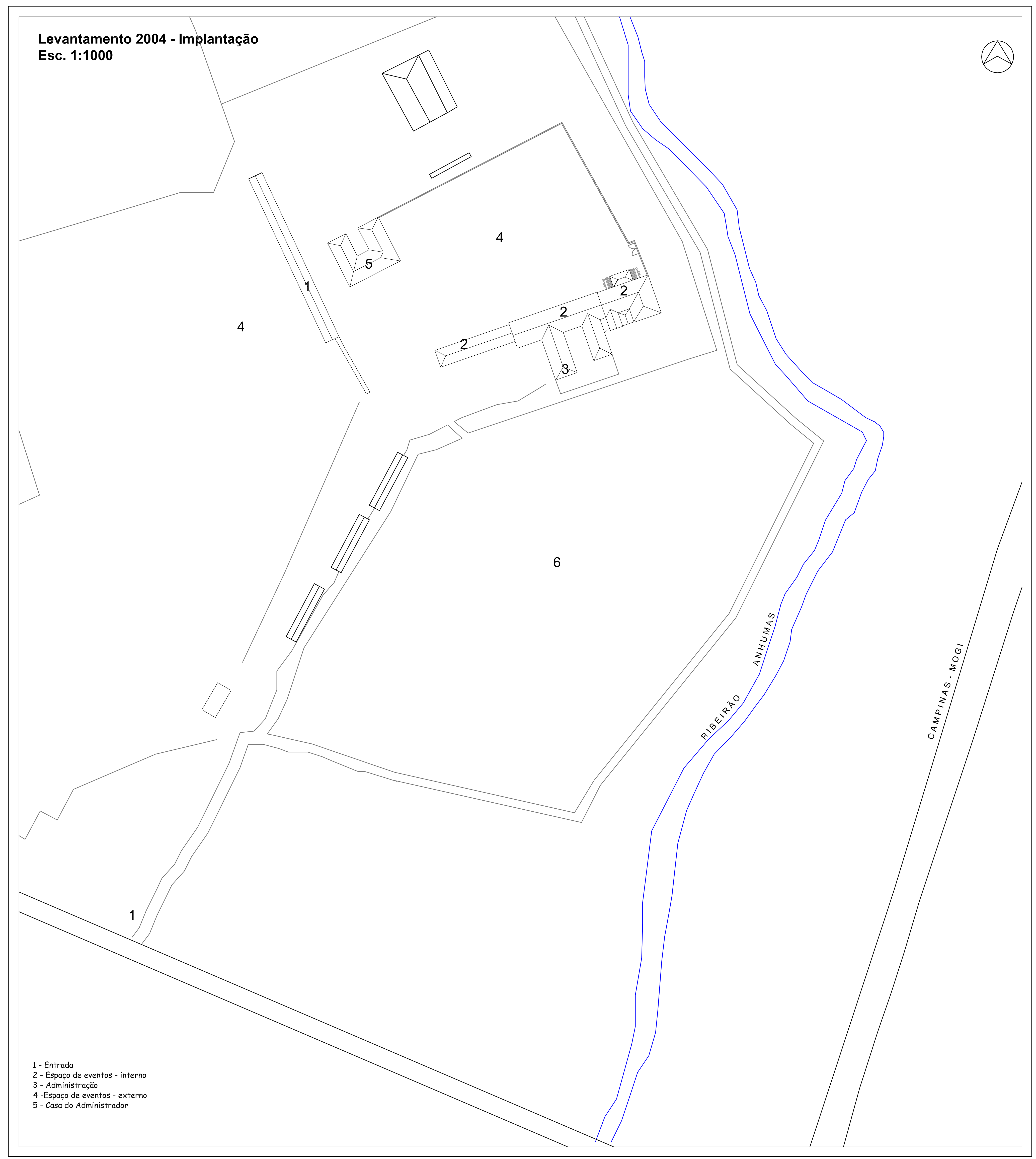




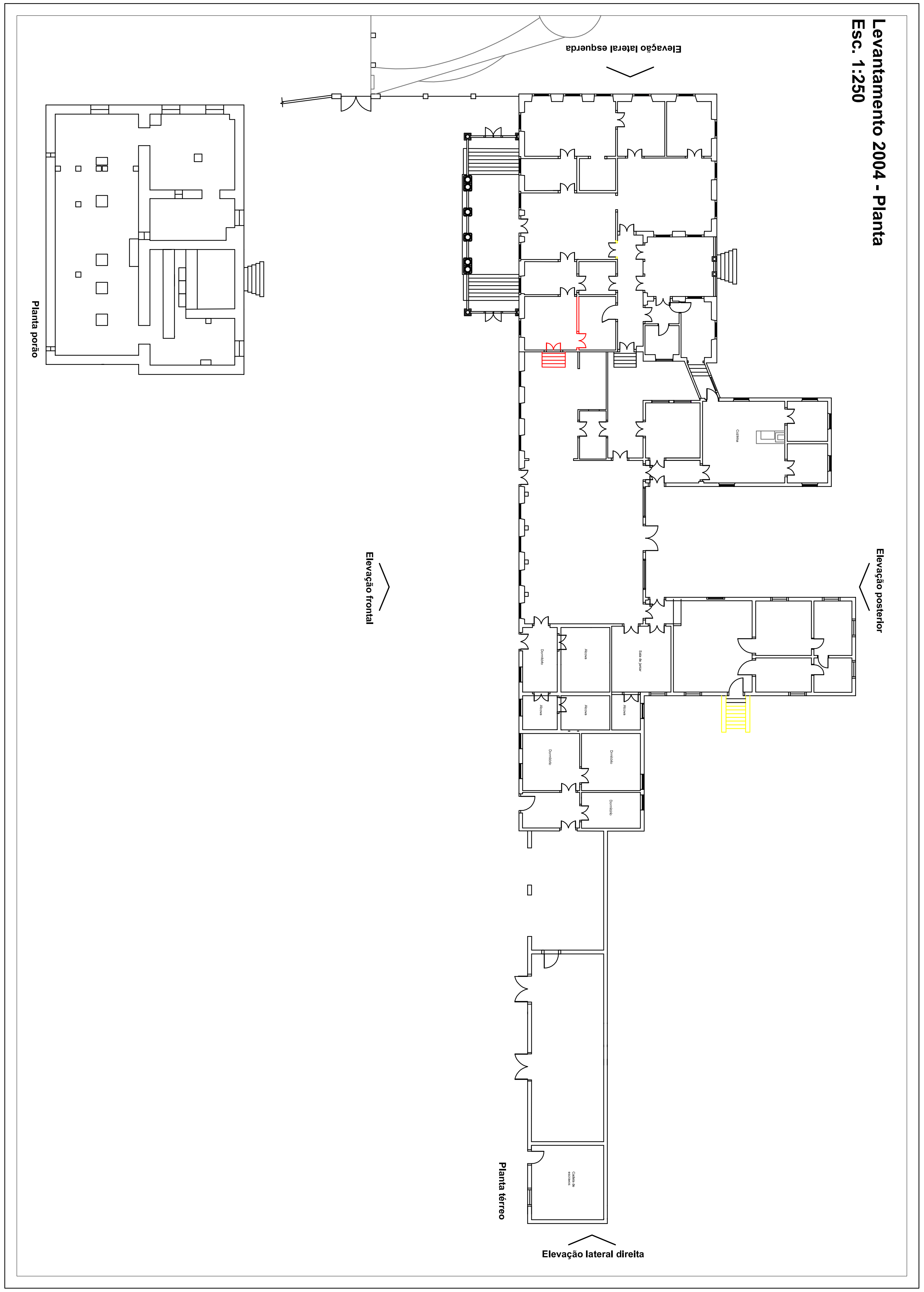




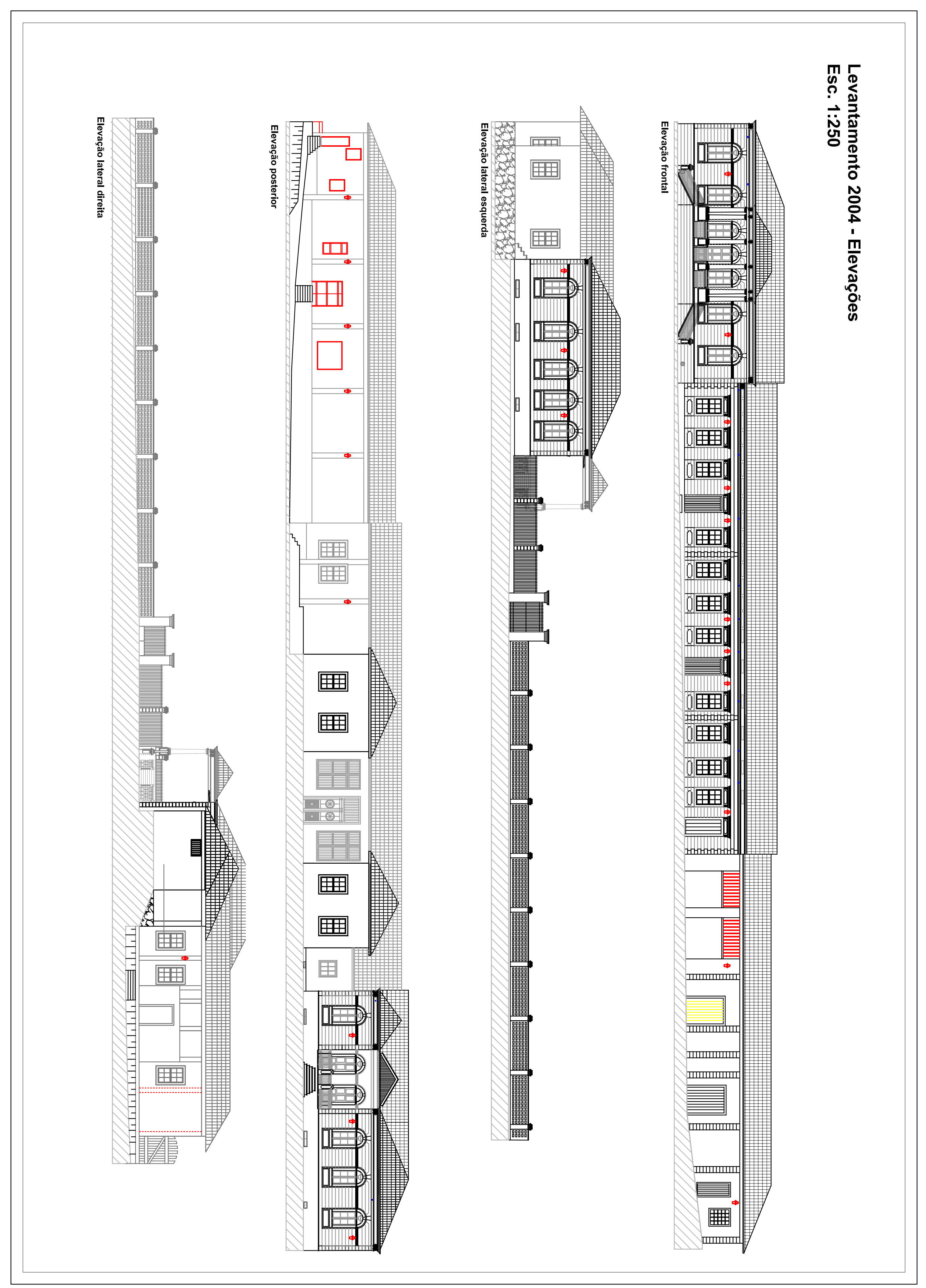




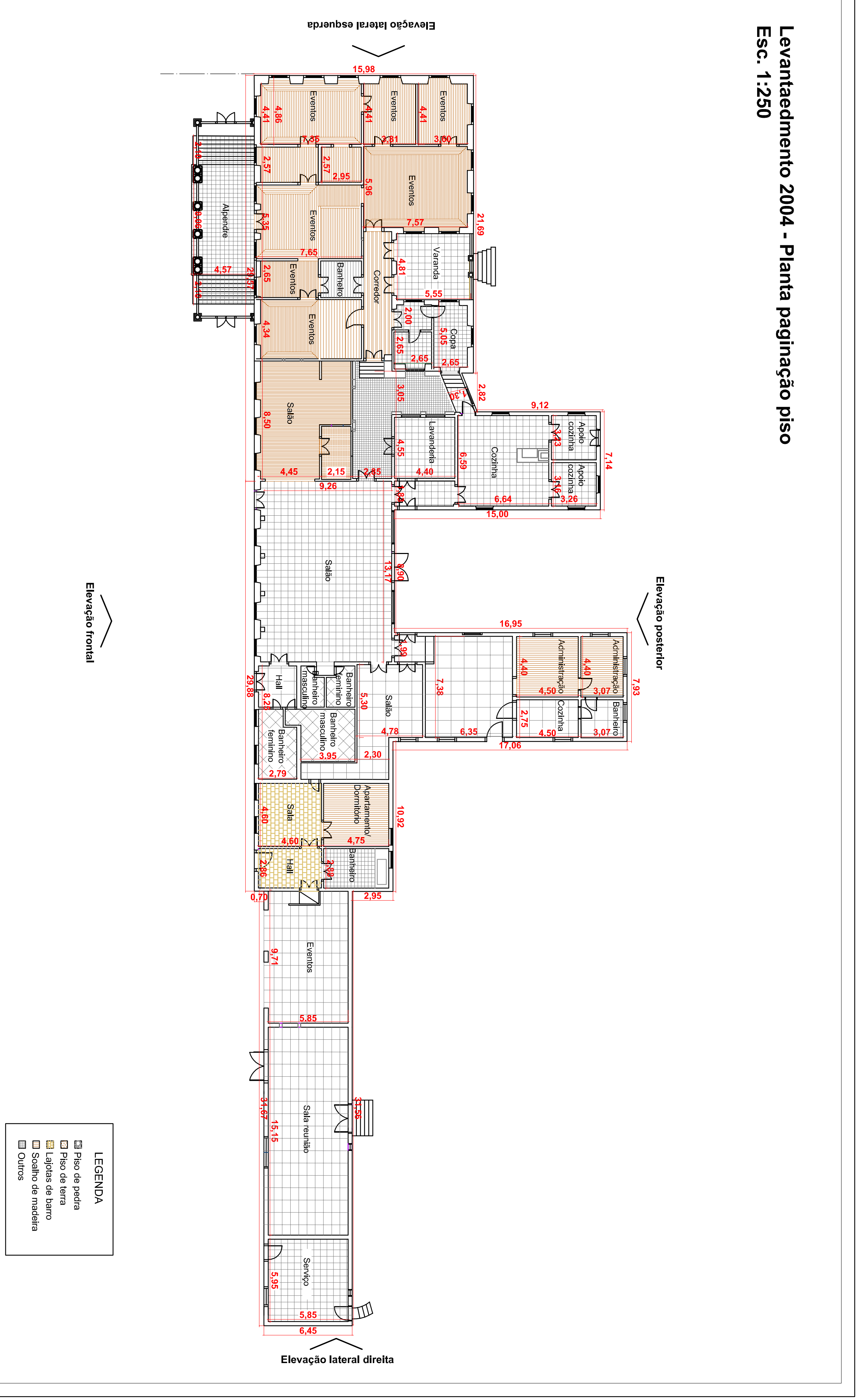




\section{Anexo 4: Fazenda Pau d'Alho - Imagens}

\section{Imagem 1}

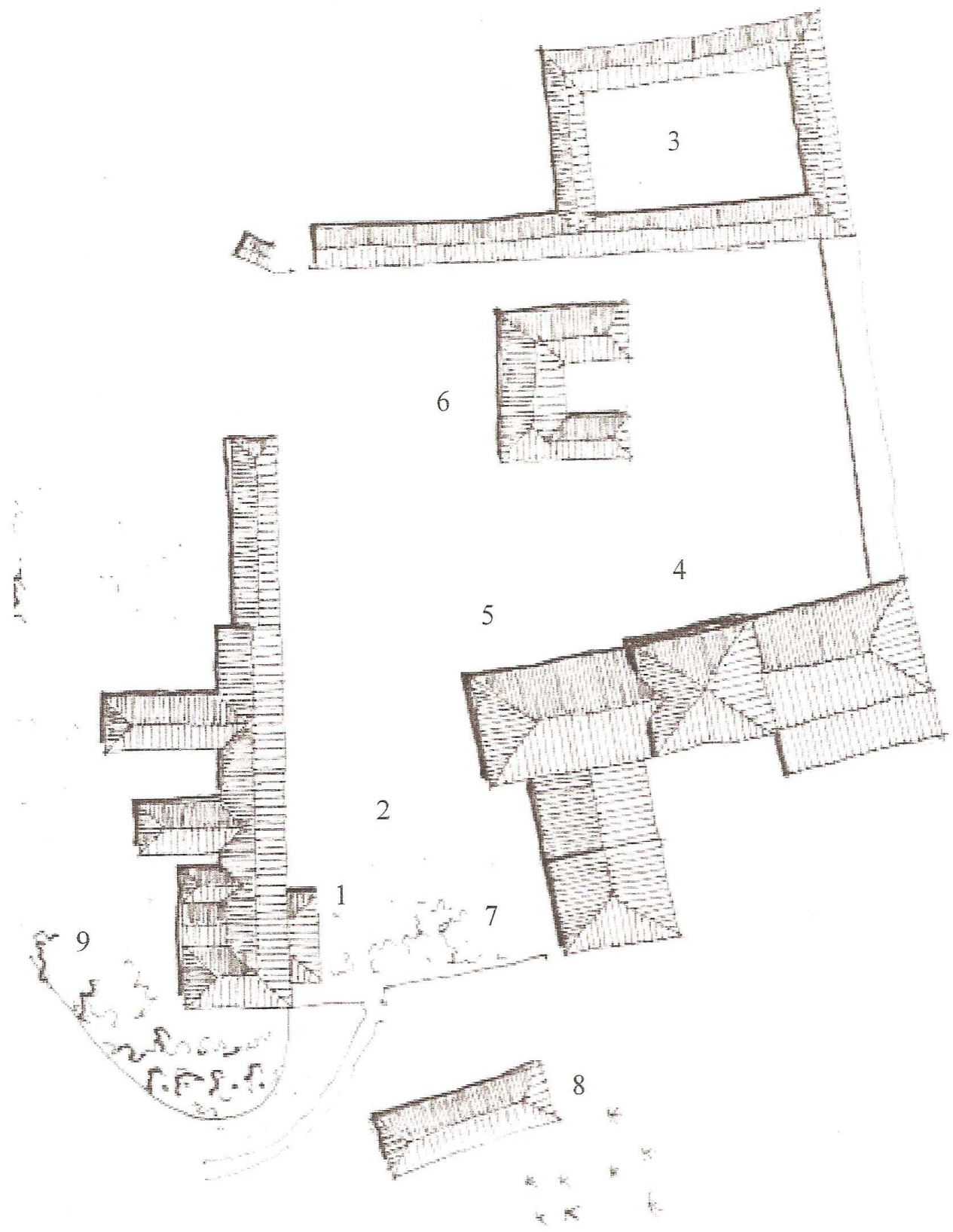

Planta de reconstituição hipotética do conjunto arquitetônico $\mathbf{A}$ (sem escala)
1. sede
2. terreiro
3. sengala
4. tullha
5. casa de máquinas
6. escola/habitação
7. jardim
8. estábulo
9. pomar 


\section{Imagem 2}

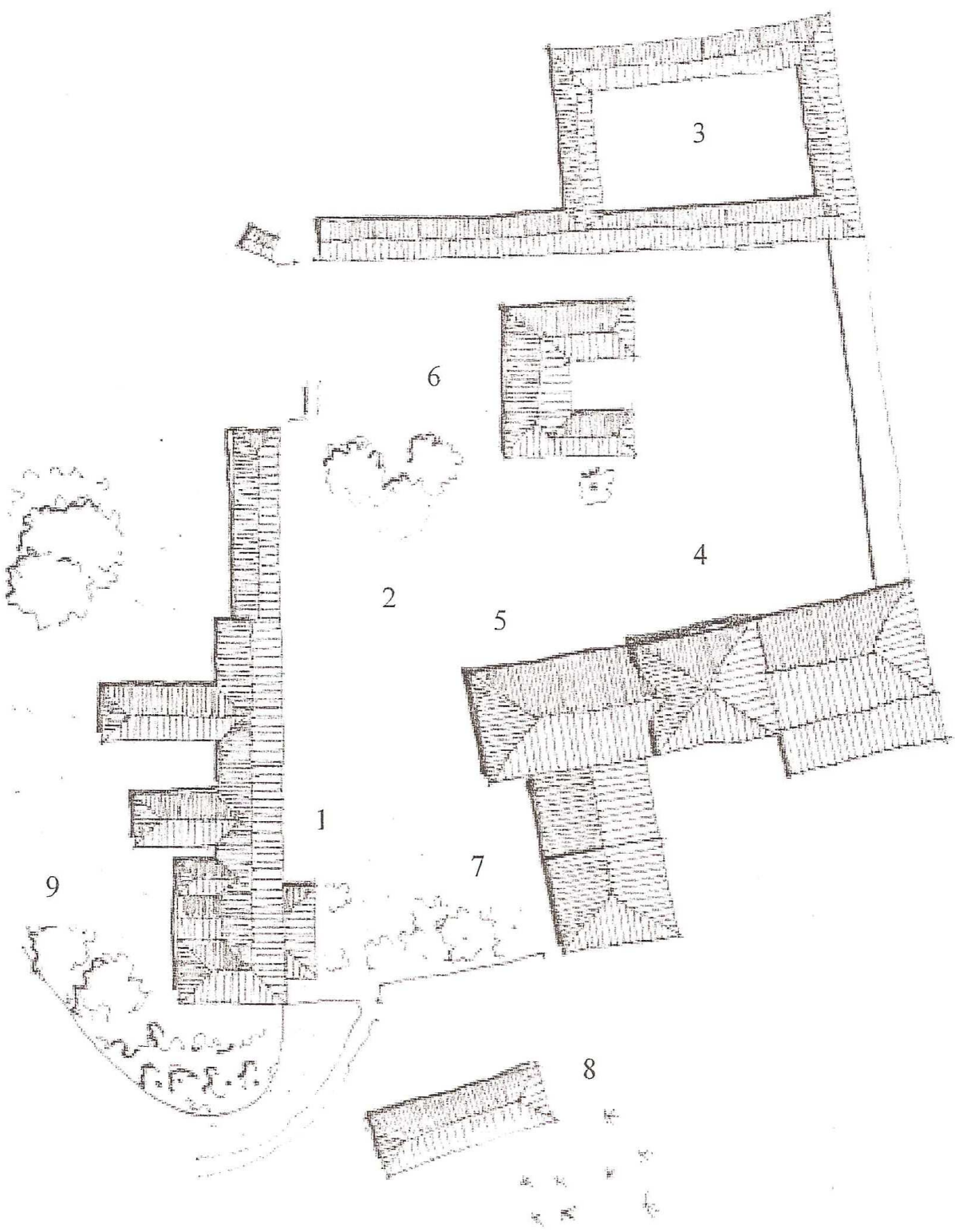

Planta de reconstituição hipotética do Conjunto Arquitetônico B (sem escala)

1. sede

2. terreiro

3. senzalla

4. tullha

5. casa de máquinas

6. escola/habilação

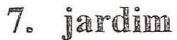

8. estábulo

9. pomar 


\section{Imagem 3}

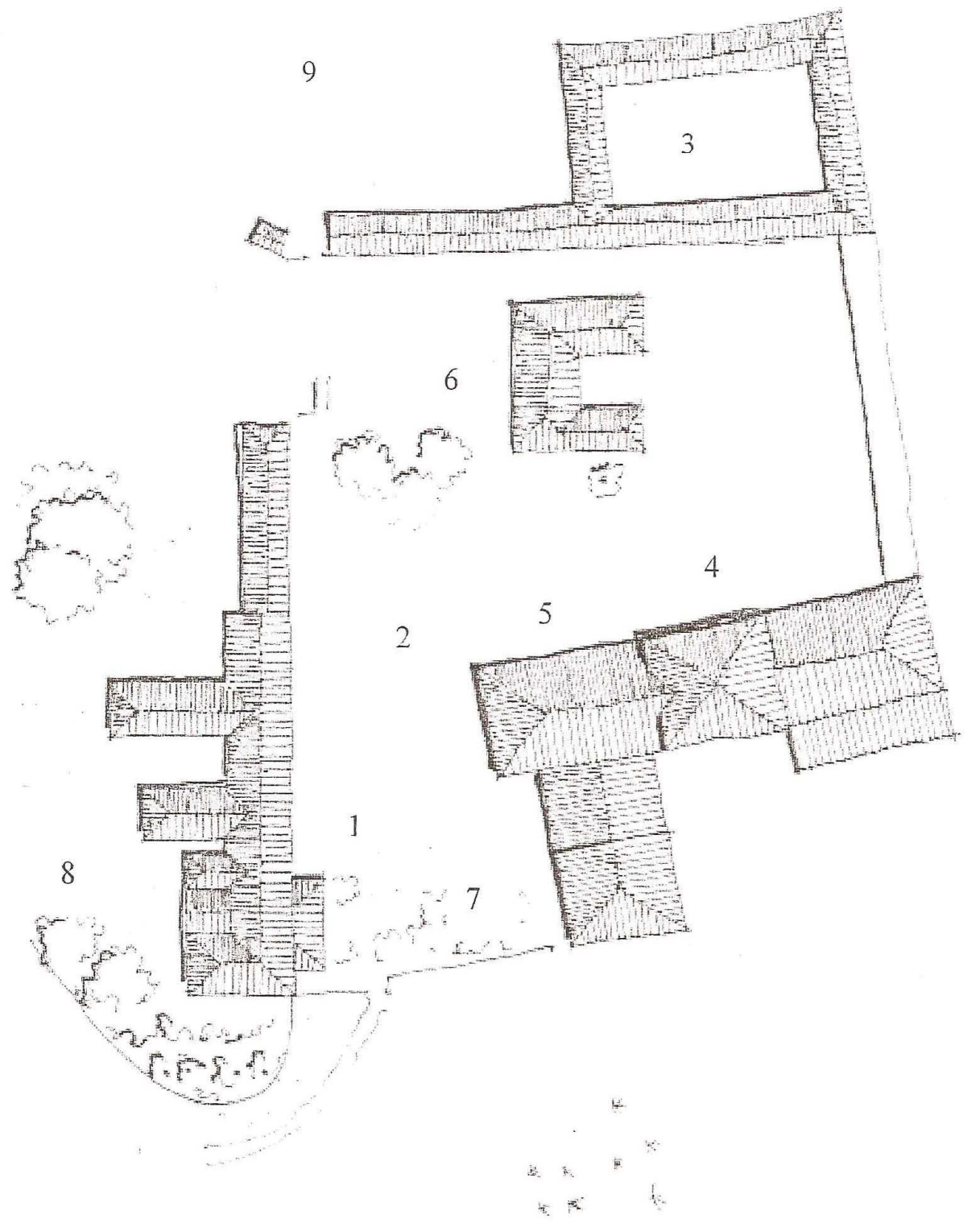

Planta de reconstituiẹão hipotética do conjunto arquitetônico C (sem escala)
1. sede
2. terreiro
3. senzala
4. turlha
5. casa de máquinas
6. escolla/habitaçã̃
7. jardin
8. pormat
9. movos terreiros 


\section{Imagem 4}

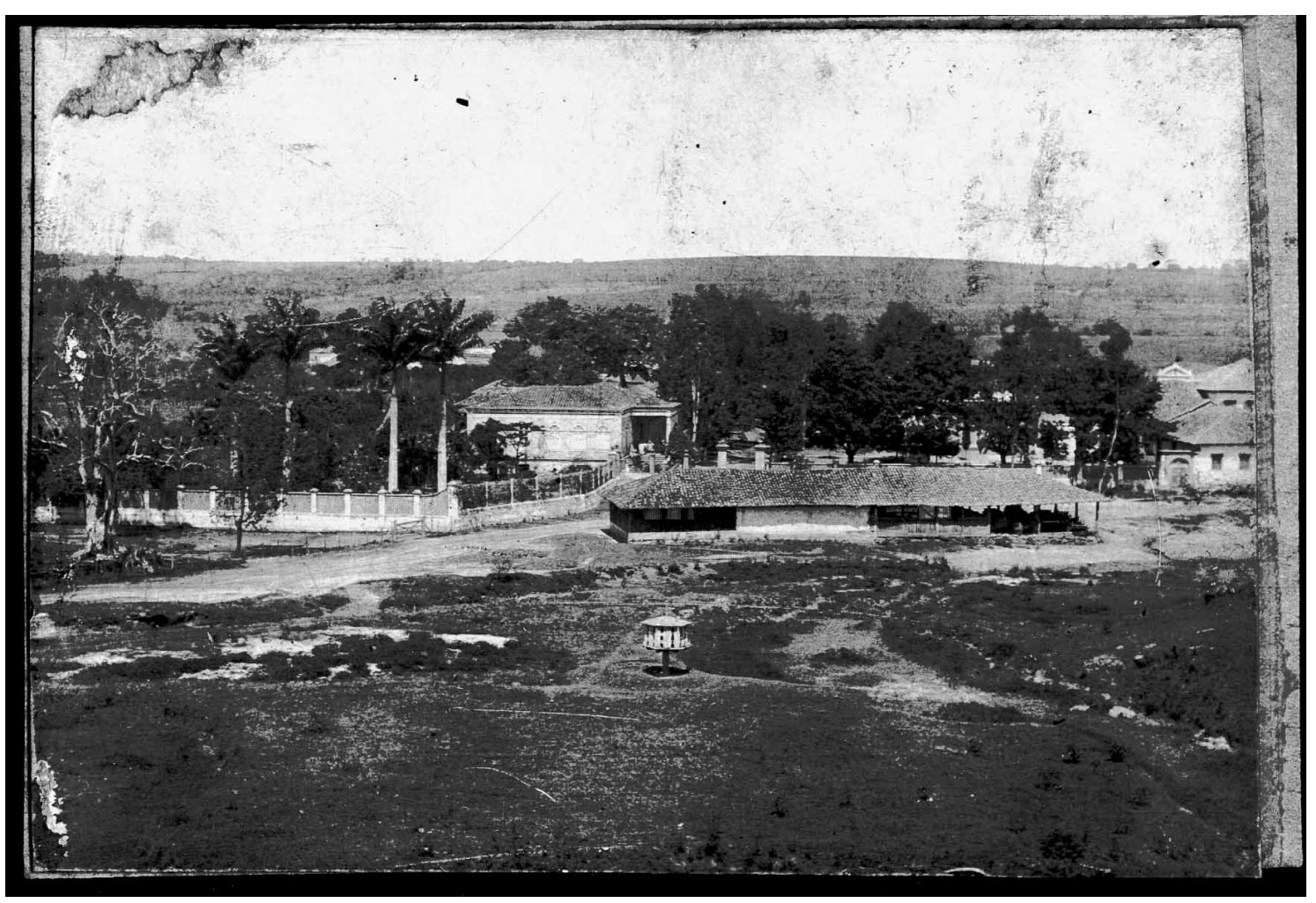

Imagem 5
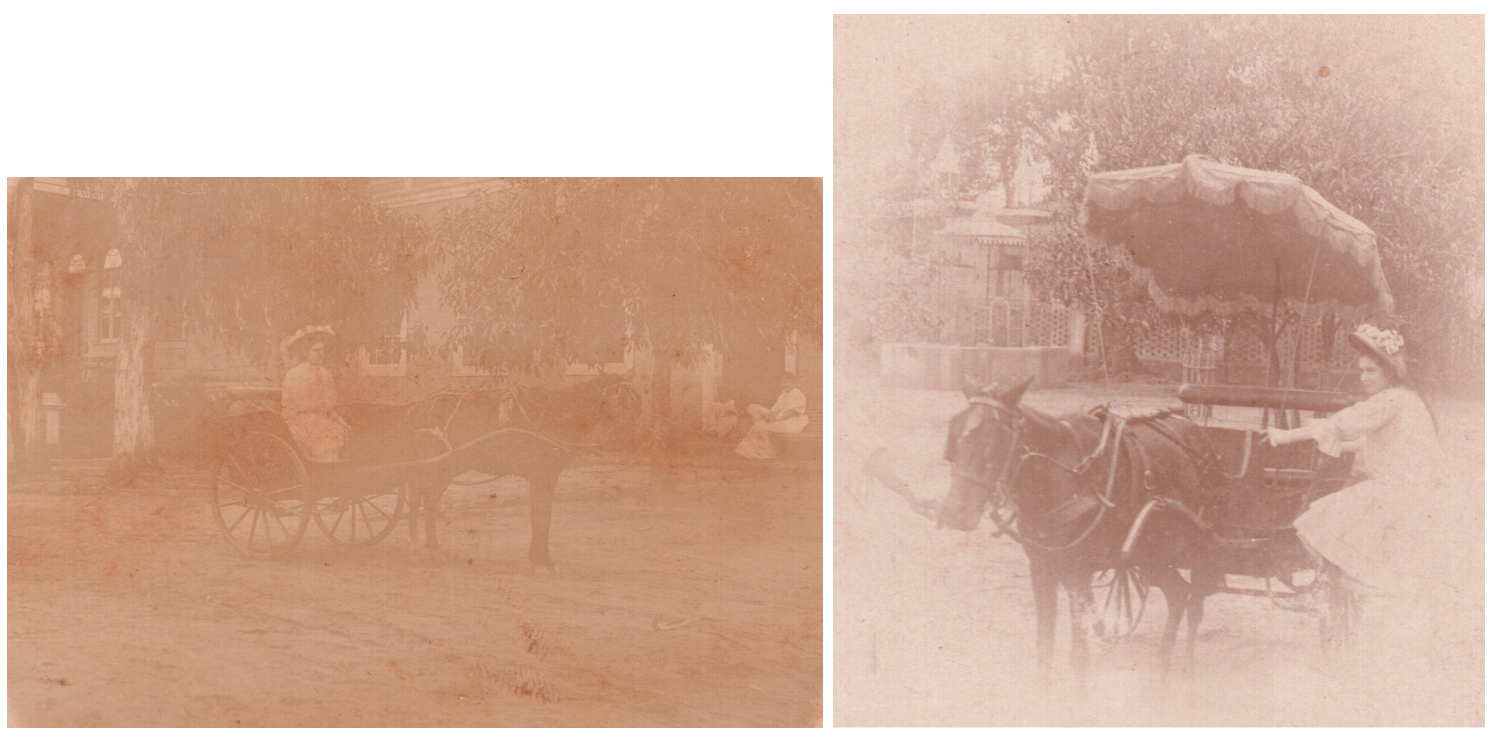


\section{Imagem 6}

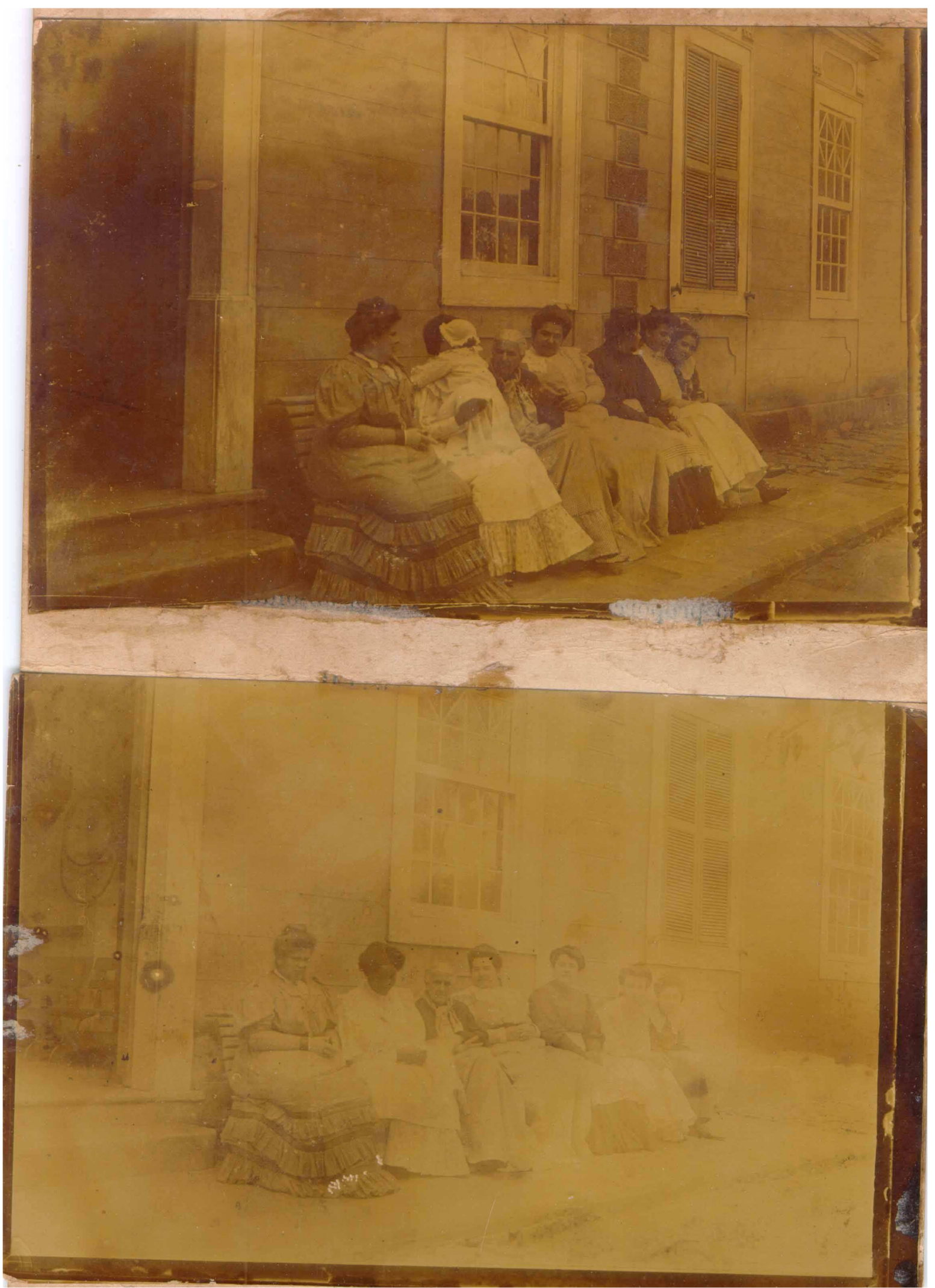




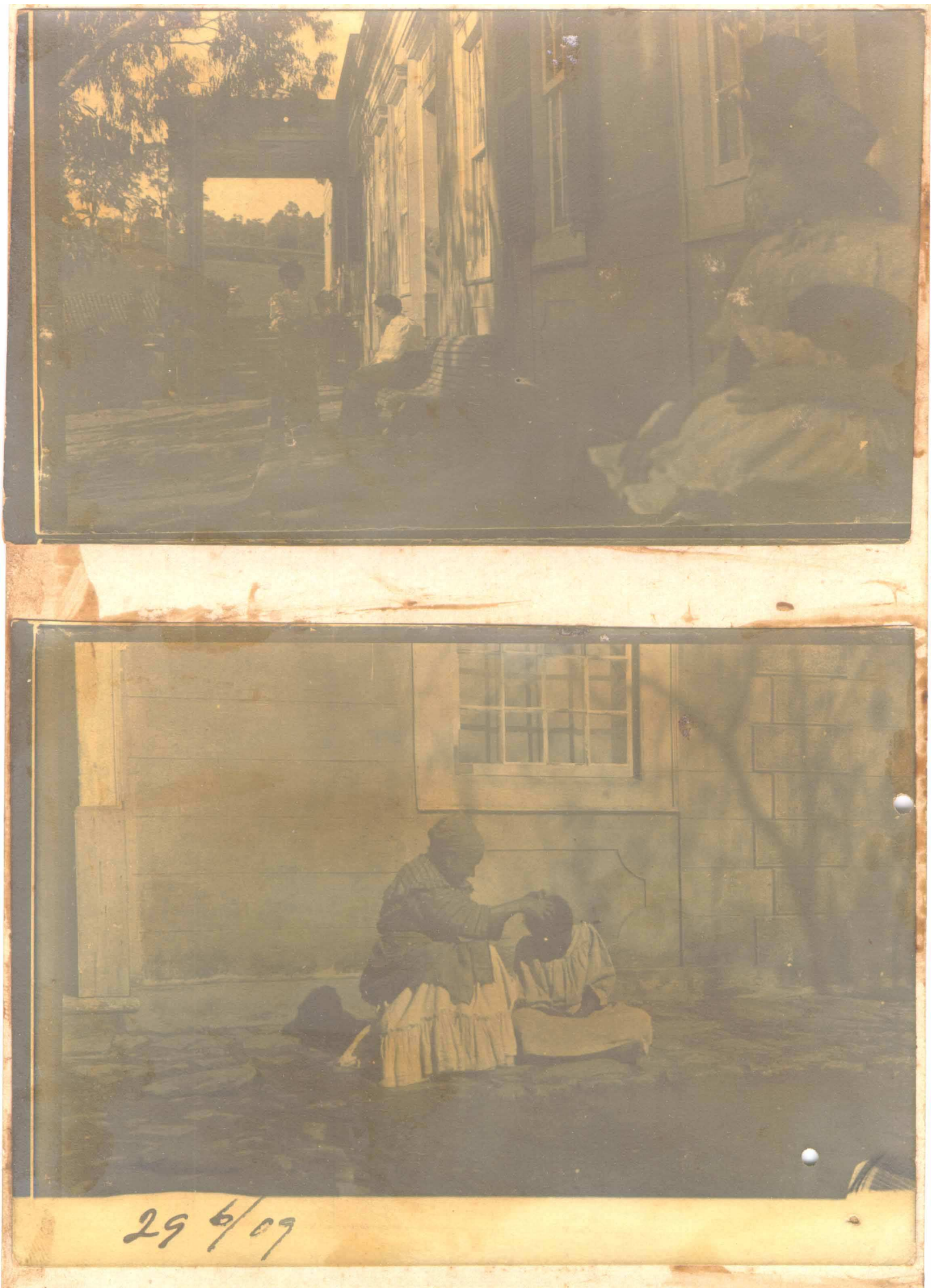




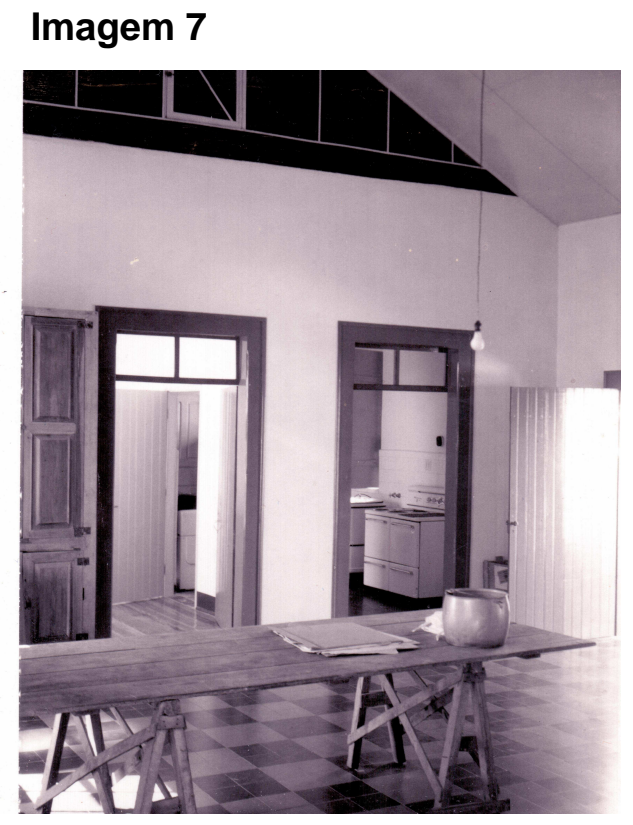

Imagem 8

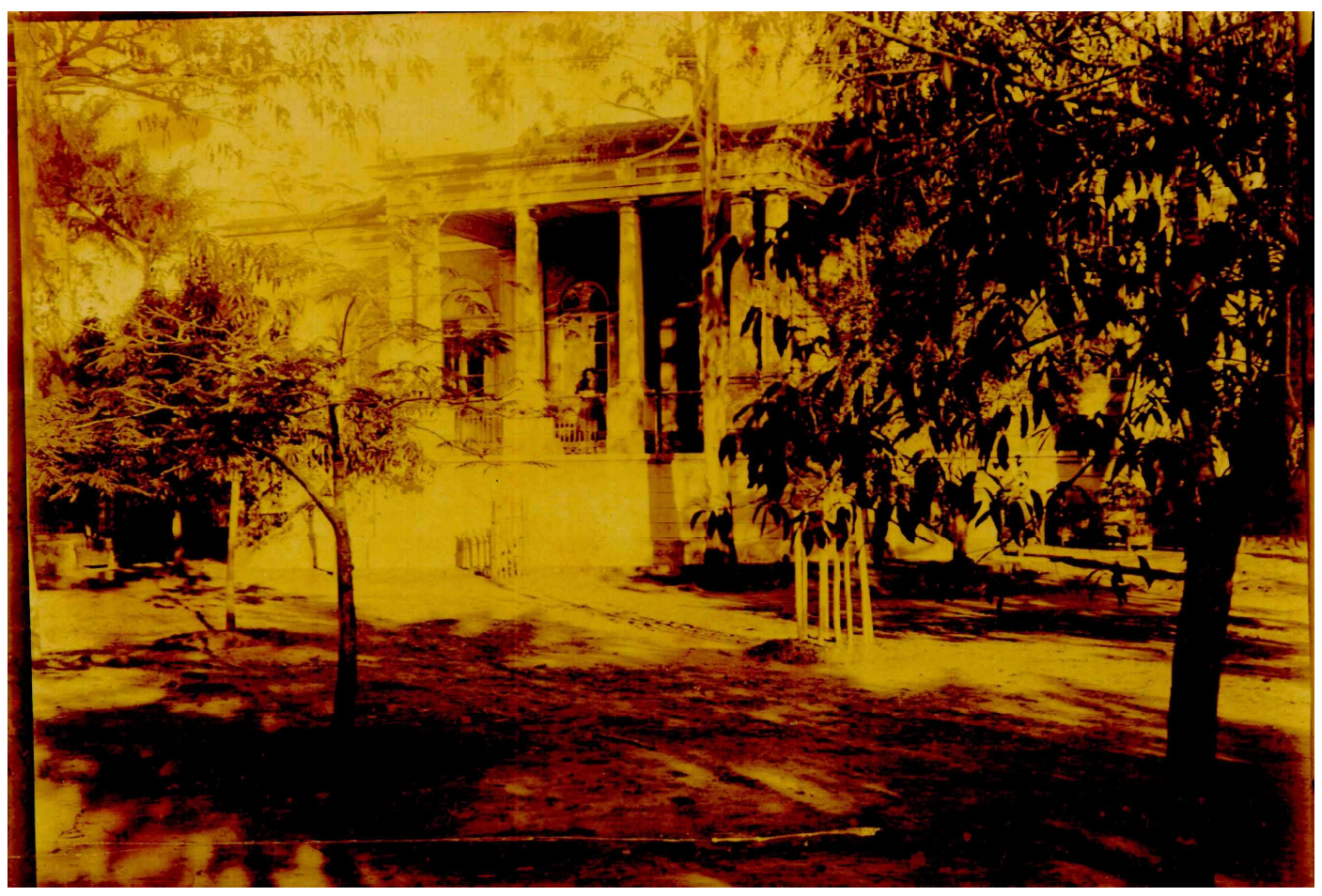




\section{Imagem 9}

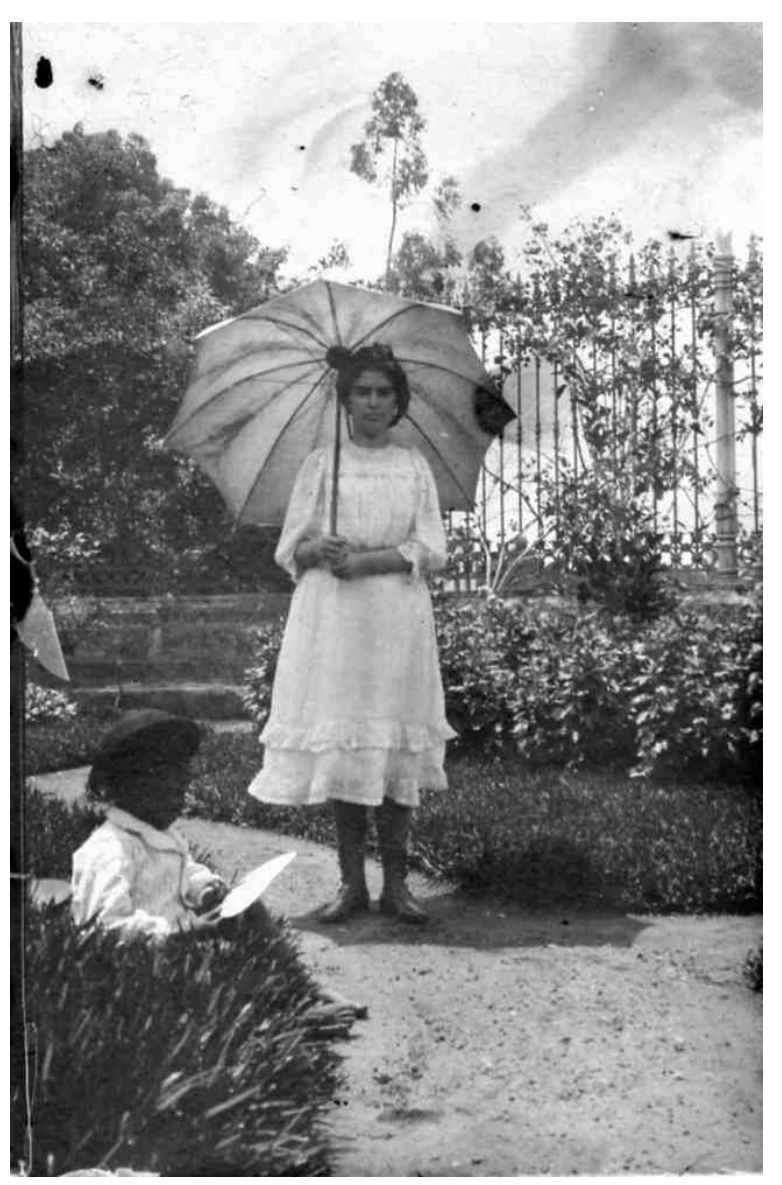

\section{Imagem 10}

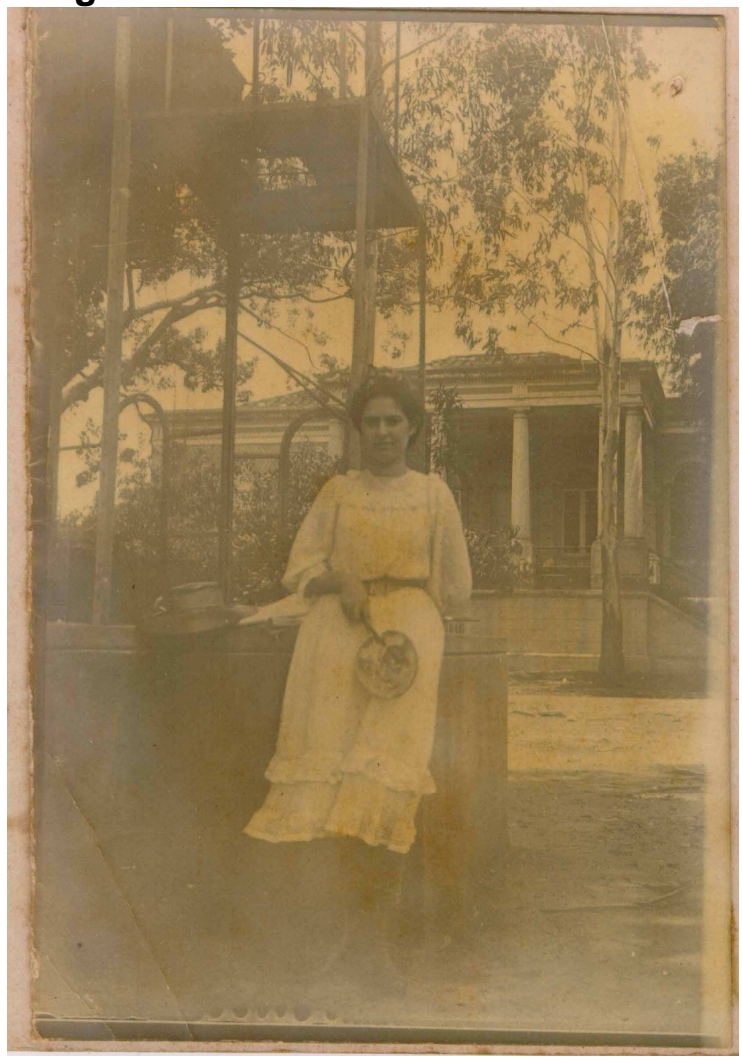


Imagem 11

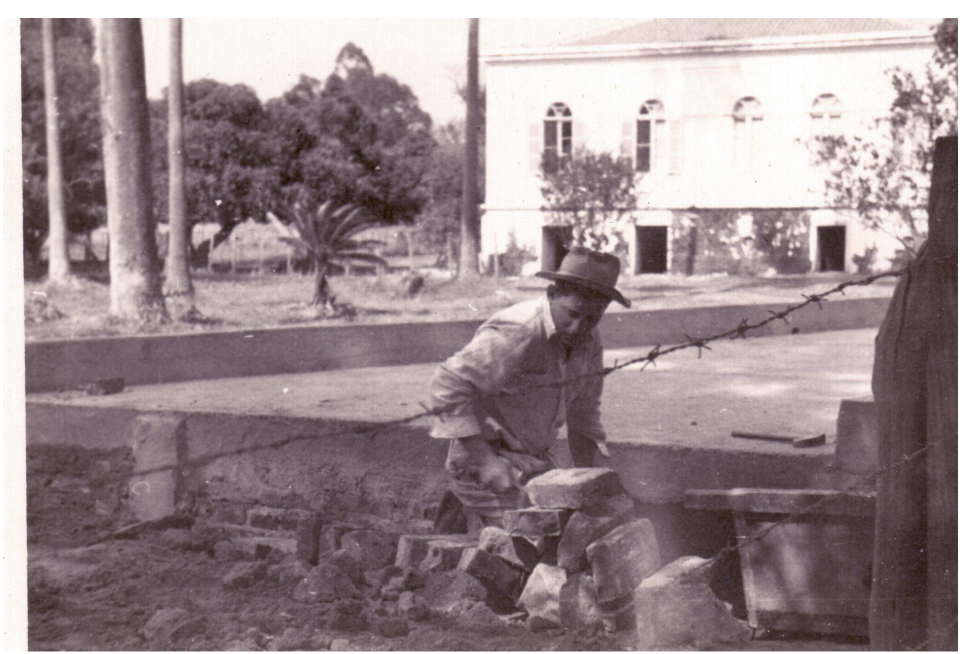

Imagem 12

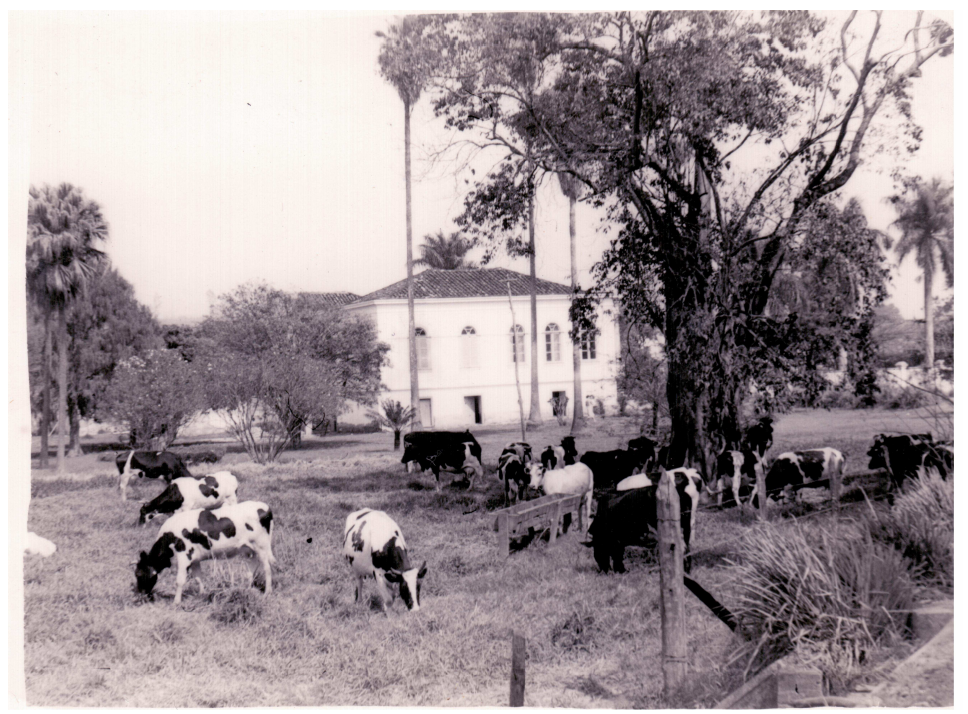

Imagem 13

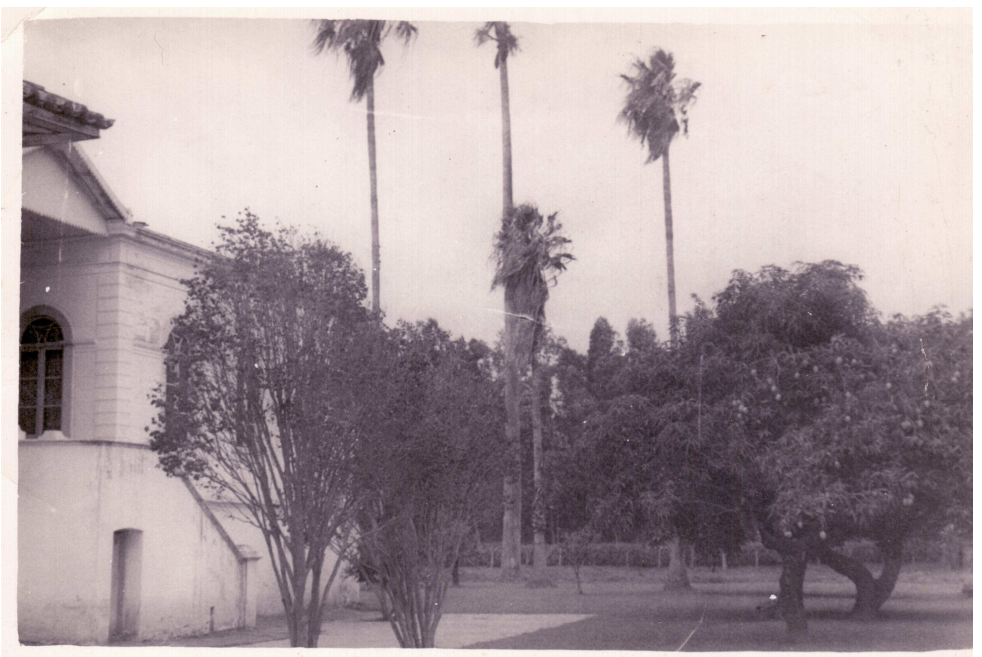




\section{Imagem 14}

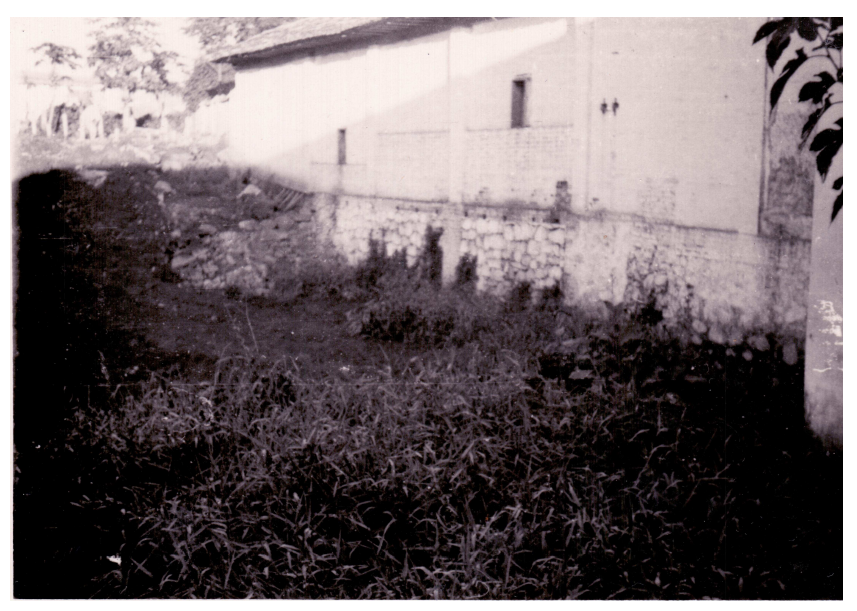

\section{Imagem 15}

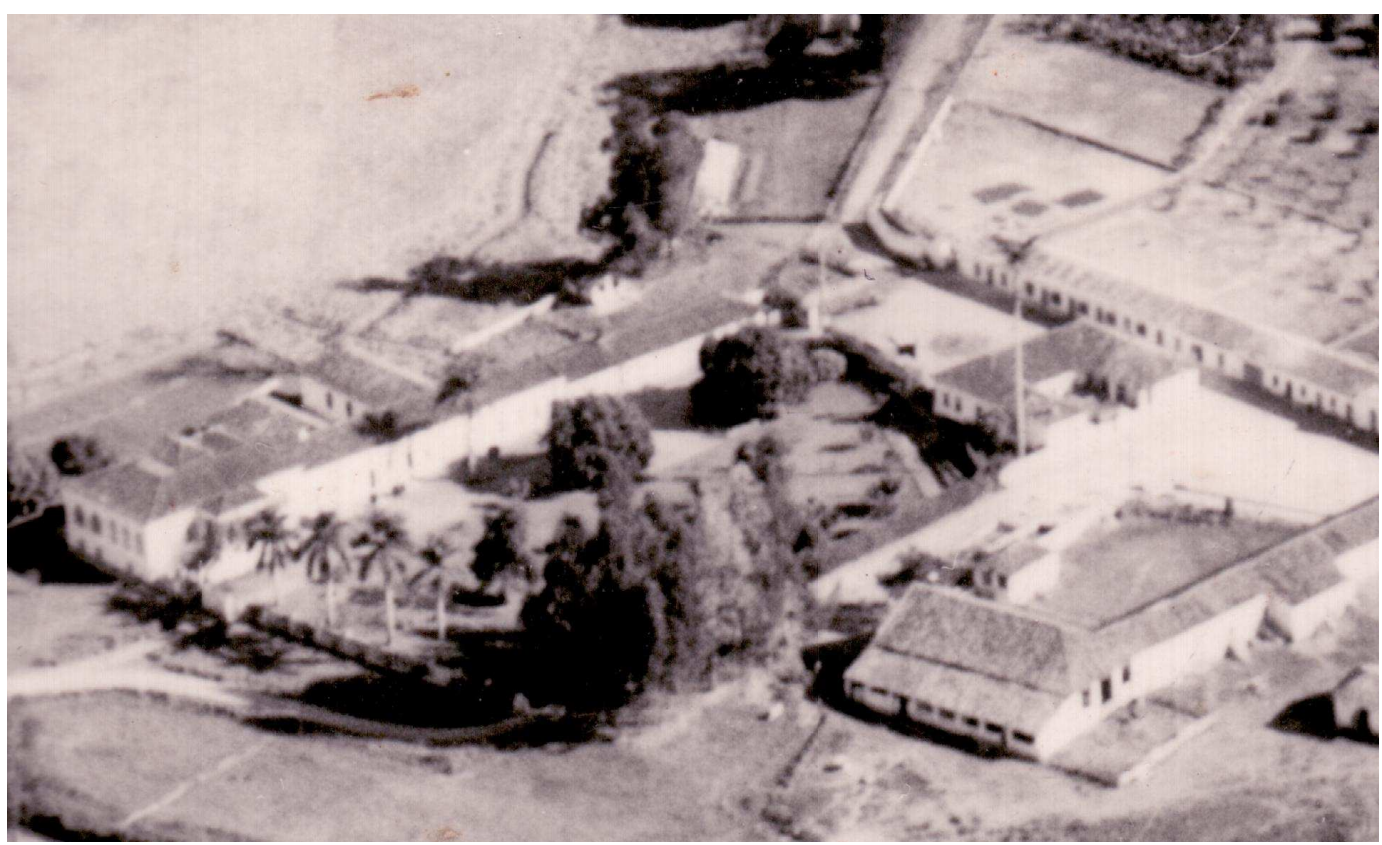

\section{Imagem 16}

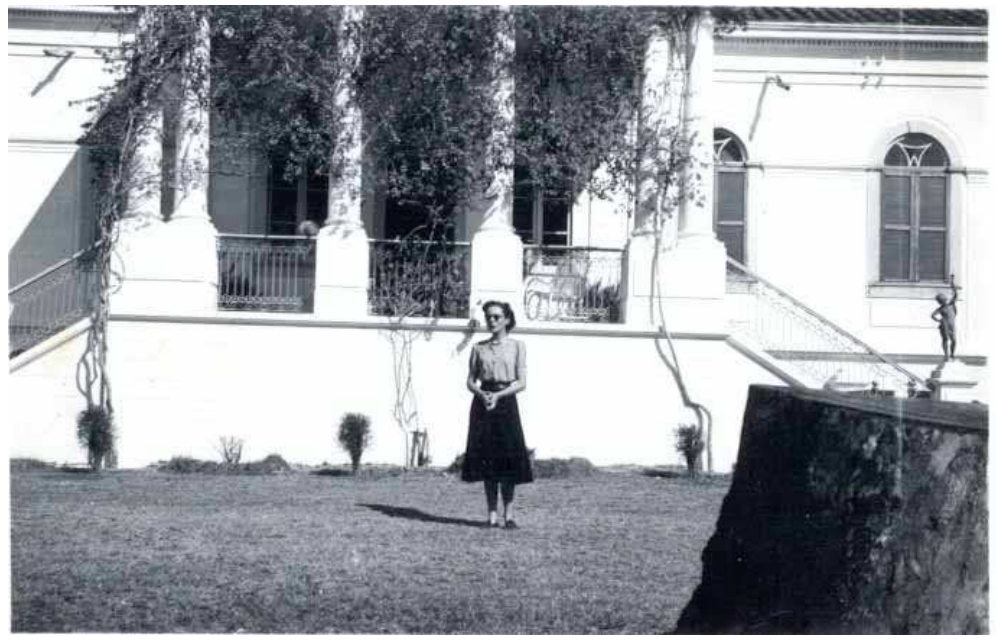




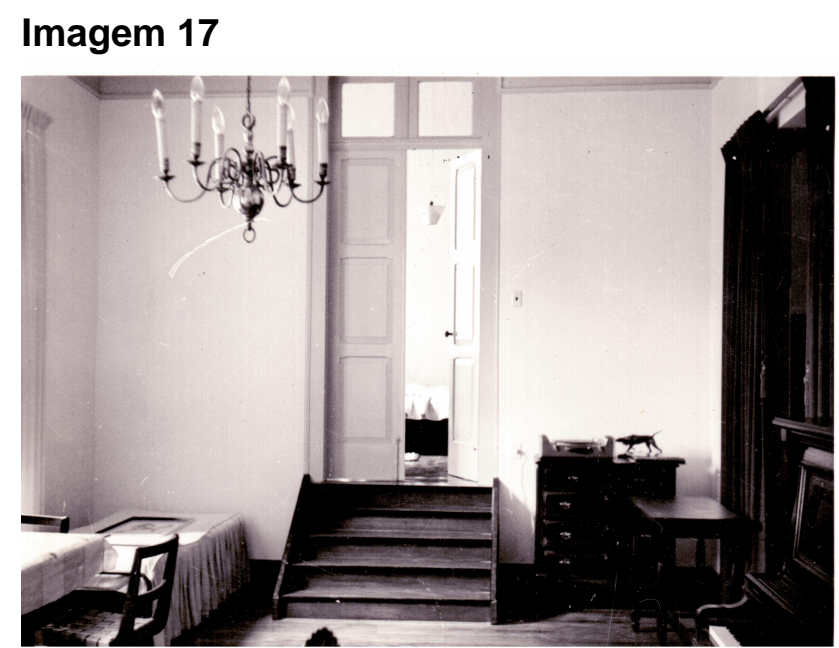

Imagem 18

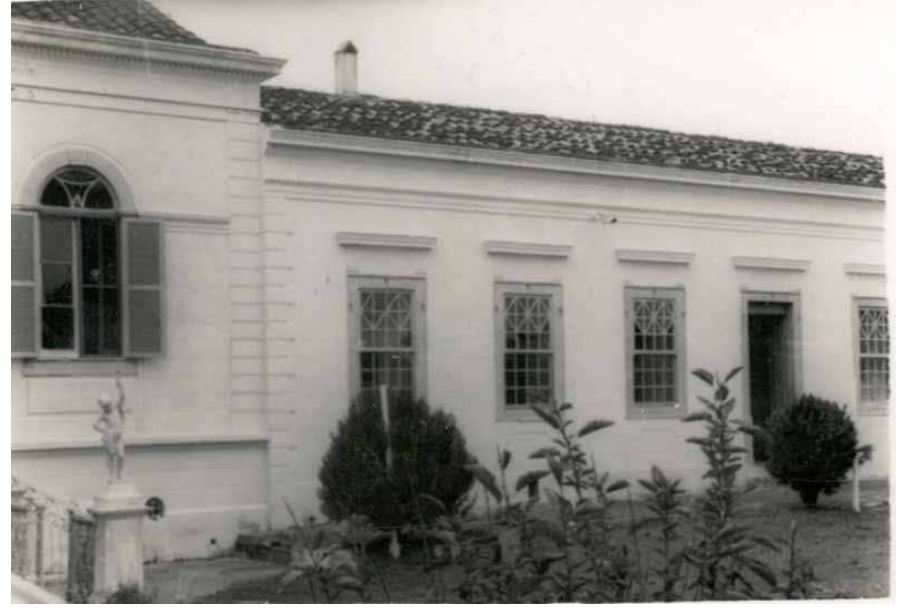

\section{Imagem 19}

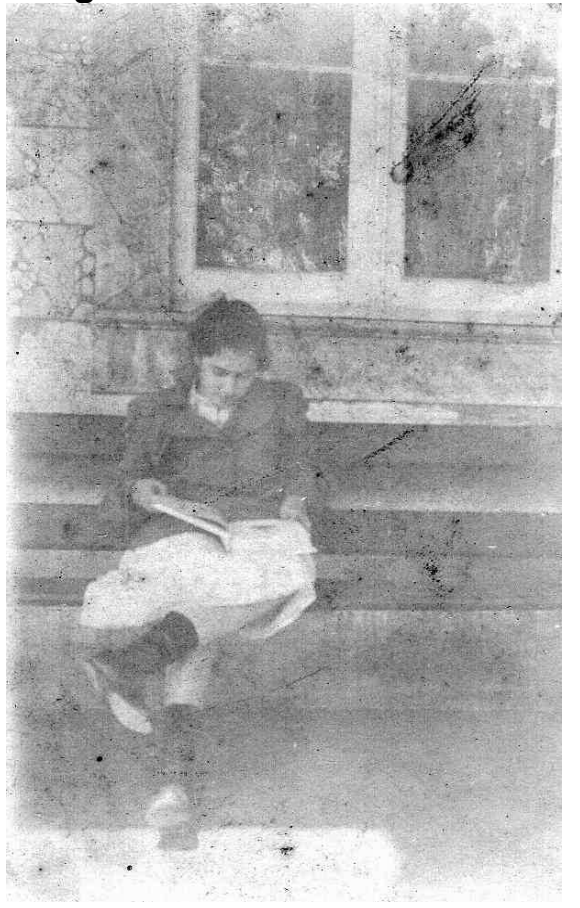




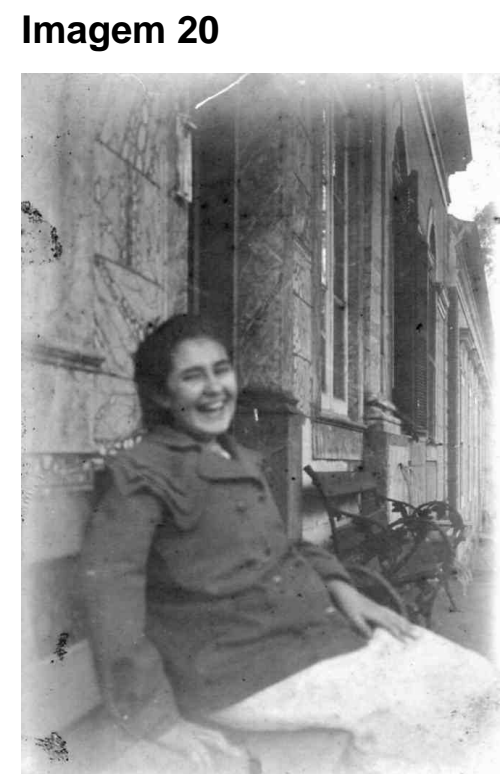

Imagem 21

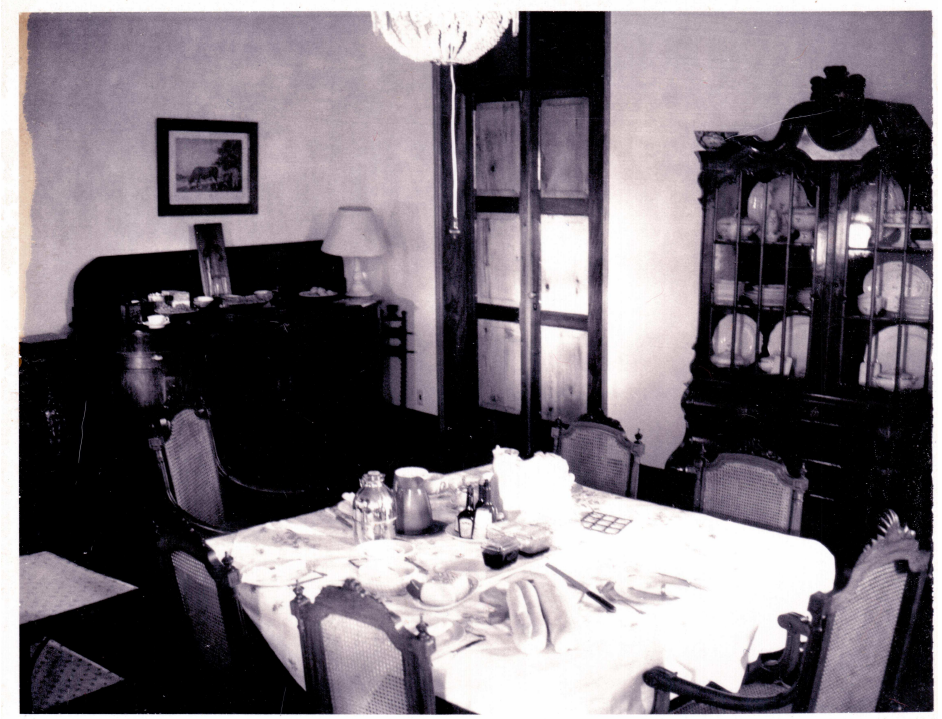

Imagem 22

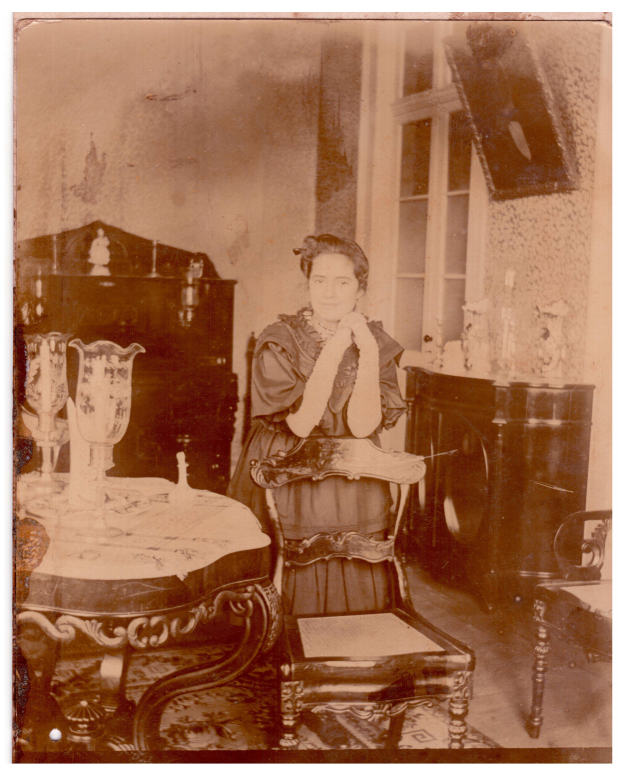

